UNIVERSIDAD NACIONAL DE LA PLATA

FACULTAD DE HUMANIDADES Y CIENCIAS DE LA EDUCACIÓN

SECRETARÍA DE POSGRADO

\title{
AVATARES DEL HISPANISMO: CANON Y ESTUDIOS LITERARIOS EN LA ARGENTINA (1949-1973)
}

\section{Marisa Eugenia ELIZALDE}

Tesis para optar por el grado de Doctora en Letras

Directora: Dra. Melchora Romanos (Universidad de Buenos Aires)

Co-directora: Dra. María Mercedes Rodríguez Temperley (Universidad Nacional de La Plata)

La Plata, 10 de junio de 2016 


\section{Resumen}

Los procesos de configuración del hispanismo en la Argentina fueron adquiriendo modulaciones ideológicas particulares en distintos momentos del devenir intelectual en el país, desde las posiciones antagónicas iniciales del siglo XIX hasta su conformación como espacio disciplinar autónomo y sus estrategias de legitimación a lo largo del siglo XX. Desde las primeras décadas de este siglo se asiste a la consolidación del hispanismo en el ámbito académico, a partir de los aportes críticos y metodológicos producidos en el seno de institutos y centros de investigación, que se visibilizaron en publicaciones académicas, revistas y ediciones de obras y estudios vinculados con la lengua y la cultura españolas. Estas producciones condujeron a operaciones de revisión, reformulación y/o ampliación del canon hispánico, definido como un espacio de tensiones y negociaciones entre tradición e innovación. En tal sentido, la revisión crítica de los modos de apropiación y resignificación del canon hispánico por parte de los intelectuales argentinos a través de las publicaciones académicas y de sus conexiones con el campo editorial ofrece una mirada sobre los procesos de construcción de una tradición propia de estudios hispanistas situada en las coordenadas ideológico-culturales de mediados del siglo XX.

Palabras clave: hispanismo - canon literario - literatura española -publicaciones académicas- 


\section{Agradecimientos}

Hay algo que aprendí tan pronto me embarqué en esta tarea de hacer una tesis: que es un camino apasionante, arduo, a veces hostil y siempre enriquecedor. Un camino hacia el conocimiento, no sólo académico, sino —y tal vez esto sea lo más importante-, hacia el conocimiento de uno mismo. Pero es como todo lo trascendente de la vida: una meta que uno se (im)pone y que le permite ponerse a prueba en cada decisión, en cada duda, en cada inicio y en cada cierre.

Y además, es un camino que permite el encuentro con gente valiosa, abierta, generosa, incondicional. A ellos es que quiero dedicar estas líneas de agradecimiento.

- A mi directora, la Dra. Melchora Romanos, porque me recibió un día desde la lejana Pampa, me albergó en el Instituto de Filología y aceptó guiarme en esta tarea con su experiencia, sus conocimientos, su palabra justa y la disposición necesaria.

- A mi co-directora, la Dra. María Mercedes Rodríguez Temperley, por su generosidad, su ejemplo de trabajo, su afán por la investigación y la docencia y por la pasión que sabe transmitir.

- A mi colega y maestra en muchos sentidos, la Dra. Graciela Salto, quien creyó en mí antes que yo misma.

- A la Dra. Analía Gerbaudo, quien con su pasión y compromiso con el saber me contagió su entusiasmo y su energía.

- A mis compañeros de docencia, de trabajo y de experiencias compartidas en todos estos años en la Facultad de Ciencias Humanas de la UNLPam: Aldo Reda, Dora Battiston, Marta Urtasun, José Maristany, Diana Moro, Nora Forte y Carolina Domínguez, por las charlas, las lecturas, los estímulos oportunos. Por 
haber estado siempre y haberme mostrado tantas veces el camino. Y a la querida memoria de Nancy Sad, por el ejemplo de vida y de lucha.

- A mis colegas más jóvenes, ex alumnos algunos de ellos, por demostrarme el valor del esfuerzo y de la superación en todos los ámbitos: Sonia Bertón, Vicky González, Cecilia Gaiser, Eugenio Conchez, Mariano Oliveto, Rosario Pascual Battista y, en especial, a mi compañera de cátedra, María Pía Bruno.

- A los catedráticos españoles Joaquín Rubio Tovar y Fernando Larraz Elorriaga, por su generosidad y disposición para colaborar con mi trabajo.

- A los bibliotecarios de diversos centros, públicos y privados, por su disposición y su eficiencia, sin las cuales gran parte de este trabajo no hubiera sido posible.

Y a mi familia, por todo. 
Avatares del Hispanismo: canon y estudios literarios en la Argentina (1949-1973)

\section{Dedicatoria}

Dedico este trabajo a la memoria de mi padre, que hace setenta años eligió los claustros de la Facultad de Humanidades de la Universidad Nacional de La Plata para formarse, recorrió sus corredores en el edificio señorial, frecuentó sus bibliotecas y moldeó su compromiso con el conocimiento. Hoy regreso a esta misma Universidad para renovar ese compromiso, como homenaje a su pasión por el saber. 


\section{INTRODUCCIÓN}

\section{Hispanismo(s): derroteros de un concepto}

Al abordar el estudio acerca de la génesis y la conformación del hispanismo en la Argentina es necesario realizar algunos deslindes conceptuales. El término hispanismo ha ido adquiriendo diferentes matices teóricos e ideológicos a lo largo del último siglo, tanto dentro de la Península Ibérica como fuera de ella. Si bien a priori identifica al estudio de la lengua y la cultura hispánicas — según las definiciones ofrecidas, por ejemplo, por la Real Academia Española ${ }^{1}$-, en el abordaje teórico resulta un concepto más problemático, en el que se entrecruzan dimensiones lingüísticas, políticas, sociales y culturales, de allí cierta "imprecisión” de su objeto (Romanos 2004: 77). Este carácter laxo puede vincularse con las modulaciones que la noción ha sufrido a lo largo de las décadas y que ha posibilitado que bajo esa denominación se incluyan perspectivas más o menos amplias al momento de abordar el objeto de estudio. Entre las acepciones que el término ha presentado, se encuentran algunas que podrían considerarse de extensión máxima, como aquellas que identifican al hispanismo con el estudio de la lengua y la cultura hispánicas, sin precisar la procedencia geográfica de dichos estudios (Zuleta 1992), hasta aquellas que se centran en caracterizar al hispanismo como el conjunto de indagaciones sobre la lengua y la cultura hispánicas realizado fuera de España, o también las que distinguen entre un hispanismo stricto sensu —es decir, aquel que comprenda sólo el acercamiento a la lengua y la cultura españolas (excluyendo las manifestaciones gestadas en otros ámbitos de raigambre cultural hispánica, como América) — y otro más abarcador que incluya lo producido en países hispanoparlantes.

\footnotetext{
${ }^{1}$ En la edición on line del Diccionario de la Real Academia Español, la última de las acepciones brindadas define al hispanismo como "Afición al estudio de las lenguas, literaturas o cultura hispánicas", en el que el término "afición" parece desdibujar el carácter propio de una disciplina científica. (Consultado el 10/09/2014).
} 
Estas consideraciones permiten pensar al hispanismo como un concepto "abierto", tanto desde la delimitación de su objeto de estudio como desde los enfoques metodológicos y hermenéuticos propuestos, así como en la conformación de un canon (Morales Moya 2011: 167).

La fundación en 1962 de la Asociación Internacional de Hispanistas - cuyo primer congreso se realizó en la ciudad de Oxford, Inglaterra, ese mismo año- dio estatuto institucional a la trayectoria de investigación y a la labor crítica de un número importante de investigadores alrededor del mundo vinculados con los estudios hispánicos, al tiempo que proponía un espacio para la difusión y el intercambio de aportes e ideas acerca de este campo de estudio. De este modo se conformaba una red internacional que establecía lazos entre investigadores pertenecientes a diversos centros académicos y universitarios, unidos por el interés común en la lengua y la cultura hispánicas.

La realización del Primer Congreso de la Asociación Internacional de Hispanistas reviste algunos datos significativos. En primer lugar, la elección de una ciudad inglesa de dilatada historia universitaria y de sólido prestigio académico sitúa al hispanismo en un ámbito fuera de los límites geográficos de la Península —en ese momento bajo el régimen franquista - lo cual permite otorgarle una particular visibilidad en el ámbito académico mundial. En segundo lugar, la designación de Ramón Menéndez Pidal como presidente honorario del congreso representa el reconocimiento a su figura y su trayectoria en el campo de los estudios hispánicos ${ }^{2}$, en especial en la filología, concretada a través de numerosas publicaciones y de la

\footnotetext{
${ }^{2}$ Es de destacar que al momento de realizarse el congreso, el filólogo contaba con 93 años, por lo cual esta designación significa un verdadero homenaje a una figura eminente e ilustre del hispanismo. Consciente de su lugar privilegiado, Menéndez Pidal aboga al comienzo de su Comunicación Plenaria por la consolidación del hispanismo y por la continuación de los caminos trazados: "Todo ello hace ver que este Primer Congreso Internacional de Hispanistas no será mero augurio, sino primera piedra de un edificio cuya necesidad antes no era sentida [...] (Actas 1964: 14).
} 
formación de una pléyade de estudiosos y filólogos que desde España se diseminarían por Europa y América durante las primeras décadas del siglo XX, forjando una extensa red de centros de estudios hispánicos. Para inicios de la década de 1960, el hispanismo ha consolidado un estatus particular en el seno de las humanidades y la creación de la Asociación Internacional de Hispanistas pone de relieve el reconocimiento de un colectivo "hispanistas" con el que se designan y se (re)conocen los investigadores dedicados al estudio de la lengua y la cultura hispánicas. Así, el término "hispanistas" distingue a quienes se ocupan de temas hispánicos o, dicho de otro modo, a quienes hacen del hispanismo el ámbito de sus indagaciones ${ }^{3}$.

Sin embargo, la génesis de lo que se conoce como hispanismo puede ubicarse unas décadas antes de que se creara de la Asociación, vinculada con el paulatino interés que los temas hispánicos despertaron en intelectuales europeos primero e hispanoamericanos más tarde, desde finales del siglo XIX y comienzos del siglo $\mathrm{XX}^{4}$. Para el abordaje propuesto en esta investigación, consideraremos al hispanismo en un sentido acotado, siguiendo lo señalado por Emilia de Zuleta (1992), cuando deslinda el alcance que el término ofrece en el ámbito hispanoamericano: "Sin embargo, desde Hispanoamérica, el término hispanismo sigue nombrando - preferentemente y sin desconocer otras connotaciones-, tanto la presencia de lo español en obras americanas

\footnotetext{
${ }^{3}$ Un recorrido por los nombres de quienes participaron en el primer congreso de la AIH pone de manifiesto la relevancia que los estudios hispánicos habían alcanzado a nivel mundial, y al mismo tiempo, permite analizar la mayor o menor presencia de algunos centros, así como el prestigio alcanzado por algunos de los investigadores. Además de Menéndez Pidal, fueron expositores los españoles Dámaso Alonso, Guillermo de Torre, Gerardo Diego y Emilio Orozco, y otros destacados hispanistas europeos y norteamericanos, como Marcel Bataillon, Helmut Hatzfeld, Otis Green y Elias Rivers, entre los de mayor renombre. Las Actas publicadas (Oxford, 1964) incluyen los textos de las diez conferencias plenarias y de cuarenta comunicaciones presentadas en el congreso, entre las que se encuentran las de los argentinos Ana María Barrenechea, María Rosa Lida — fallecida el mismo año de la realización del congresoGermán Orduna, Emma S. Speratti Piñero, Carlos Nállim, Rodolfo Borello y Juan Bautista Avalle Arce, lo que expresa ya la significativa presencia de hispanistas argentinos en el concierto de hispanismo internacional, como se analizará más adelante en este estudio.

${ }^{4}$ Según indica el historiador español Antonio Niño (1988: 5), halló la primera referencia al término hispaniste acuñada por el estudioso francés Alfred Morel-Fatio (1850-1924) en un artículo publicado en el Bulletin Historique. Espagne. «Revue Historique», XIX (enero-abril 1879).
} 
como el estudio de la lengua, la literatura y la cultura españolas" (en cursiva en el original, 73) y por Gloria Chicote (2013), quien afirma en un sentido análogo “[...] en Argentina, como en otros países hispanoamericanos, el término hispanismo nombra la presencia de lo español en la cultura americana y el estudio de la lengua, literatura y cultura españolas" (34). Esta conceptualización puede aplicarse al hispanismo en la Argentina, como matriz ideológico-conceptual que permita dar cuenta de la índole de las relaciones culturales e intelectuales entre España y Argentina ${ }^{5}$. Dichas relaciones estuvieron signadas por tensiones más o menos explícitas y atravesaron momentos de fuertes polémicas, que condujeron en algunos casos a componer una "imagen negativa secular arraigada en nuestra tradición intelectual", al decir de José Luis de Diego (2004: 93).

La creación en 1986 de la Asociación Argentina de Hispanistas constituyó otro paso importante en el proceso de institucionalización de los estudios hispanistas en el país, proceso iniciado en las primeras décadas del siglo XX y que fue consolidando un ámbito de estudio e investigación diferenciado, principalmente en universidades e instituciones académicas. Las actividades desarrolladas por la Asociación en sus tres décadas de vida ponen de manifiesto el interés y el fortalecimiento del hispanismo en el concierto de las humanidades, así como permiten dar cuenta de los debates, ajustes y ampliaciones del canon hispánico y sus apropiaciones en el campo académico argentino.

Las disquisiciones en torno al hispanismo continúan siendo objeto de debate en los círculos académicos argentinos: en el año 2004, la revista Olivar, editada por la Universidad Nacional de La Plata, dedica un dossier completo a trabajos vinculados con el análisis de la situación del hispanismo. En ellos es posible apreciar, por un lado, la

\footnotetext{
${ }^{5}$ En ese artículo, Gloria Chicote se refiere al proceso de expansión y afianzamiento de la identidad hispana a partir de la noción de "hispanización", que derivó en conceptos que encierran las diferentes variaciones semánticas que este vínculo ha generado en América Hispana y en la Argentina: "hispanismo, hispanidad, panhispanismo, hispanoamericanismo" (2013: 34), lo cual reafirma el carácter complejo de las relaciones entre España e Hispanoamérica.
} 
ubicación del hispanismo como centro de interés académico, y por otro, la insistencia en resaltar el carácter conflictivo que atravesaron $-\mathrm{y}$ atraviesan — las relaciones entre el hispanismo y la tradición intelectual argentina. Al respecto, Melchora Romanos señala en esa publicación que "el concepto de hispanismo se resemantiza o se matiza en función de intereses locales o interiores frente a los internacionales o exteriores" (83). Por su parte, la contribución brindada por de Diego en ese dossier sitúa el "antihispanismo" como el "grado cero" de las relaciones entre la tradición intelectual argentina y la española. Revisa las principales posiciones antihispanistas de los intelectuales argentinos de los siglos XIX y XX y culmina su derrotero en el análisis de la situación del hispanismo a partir de la década del 60 del siglo pasado, cuando, según su perspectiva, se produce un estancamiento en la incorporación de nuevas tendencias críticas en auge en ese momento, lo que tiene su correlato en un atraso metodológico y crítico. Este desfasaje entre actualización teórica y enfoques críticos tradicionales es el rasgo que pareciera caracterizar los estudios hispánicos de esa época. En un trabajo posterior, Raquel Macciuci (2006) retoma la tesis expresada por de Diego y le adiciona otros aspectos que, a su criterio, coadyuvan en esta postura antihispanista: la condición de "otredad" que reviste la literatura española para nuestro país y el desconocimiento existente en sectores intelectuales sobre los aportes de investigadores argentinos a los estudios hispánicos en el nivel internacional. Esta construcción antinómica hispanismo/antihispanismo parece ser un factor clave en la revisión crítica del hispanismo en la Argentina y evidencia las tensiones que marcaron $-\mathrm{y}$ marcan aúnestos estudios.

Se trata, entonces, de un proceso complejo en el que se entrelazan cuestiones vinculadas con las prácticas culturales y con los debates ideológicos desde una mirada 
situada en el campo cultural argentino durante los siglos XIX y parte del siglo XX, que habría de repercutir en la configuración global del hispanismo.

\section{El hispanismo en la Argentina: alcances de esta investigación}

Desde esos antecedentes, este trabajo se propone contribuir a la reconstrucción de los procesos de conformación del hispanismo en la Argentina y dar cuenta de los debates y tensiones que atravesaron este proceso, a partir del análisis de los modos de apropiación y resignificación del canon hispánico por parte de los intelectuales argentinos vinculados primordialmente con centros universitarios - durante la segunda mitad del siglo XX. De allí que el título formulado para esta investigación condensa, por un lado, el carácter dinámico del proceso ("Avatares del hispanismo”), y por otro, centra su objeto de estudio en el concepto de “canon" y su relación con la consolidación disciplinar de los estudios literarios vinculados con la literatura española en la Argentina. El recorte temporal propuesto (1949-1973) delimita un periodo de intensa producción intelectual y académica que fue otorgando al hispanismo estatus de campo de estudio particular y conformando una tradición en el ámbito académico argentino; sin embargo, el análisis de estos procesos implica necesariamente indagar en los antecedentes y en los agentes intelectuales, culturales y sociales involucrados, de allí que en algunos acercamientos a los temas propuestos se exceda este límite en pos de privilegiar ciertos aspectos considerados relevantes para la investigación.

Una de las hipótesis que orienta este trabajo asume que el hispanismo argentino —entendido provisoriamente como conjunto de intelectuales y producciones vinculados con los estudios de la lengua y la cultura españolas - se presenta como un concepto definido a partir de tensiones en, al menos, dos sentidos: uno, en las relaciones con España, como parte de un proceso en "la búsqueda de la identidad y la expresión propia 
de nuestro continente" (de Zuleta 1992: 950), proceso no exento de discrepancias; y otro, en el seno del campo intelectual argentino, donde las visiones críticas de las posiciones antihispanistas, de larga trayectoria en nuestro país, evidencian un entramado ideológico, político, histórico y literario de múltiples aristas.

En ese sentido, el primer capítulo "Antecedentes y conformación del Hispanismo en la Argentina" propone un recorrido por los antecedentes históricos y culturales que signaron las relaciones entre España e Hispanoamérica - y la Argentina en particular- durante el siglo XIX y las primeras décadas del siglo XX, en el marco de los debates identitarios que signaron el panorama ideológico y cultural, en el cual los debates por la cuestión de la lengua ocuparon un lugar central. Así, se examinan las modulaciones que el hispanismo fue adquiriendo, desde las posiciones antagónicas y radicales hacia España del periodo post independentista, hasta las revisiones que sufre el concepto a comienzos del siglo $\mathrm{XX}$, a partir los cambios y transformaciones del contexto sociocultural argentino debido, entre otros factores, a los efectos del fenómeno inmigratorio en el tejido social. Paralelamente a la reactivación de las querellas lingüísticas, se asiste a una nueva mirada sobre el hispanismo, concebido como un sustrato común que enlaza a una comunidad inserta en una tradición considerada como prestigiosa.

Las celebraciones de aniversarios de fechas clave del devenir histórico tanto de España como de la Argentina (el del cuarto centenario del descubrimiento de América en 1892 o el centenario de la Revolución de Mayo en 1910, por citar dos relevantes) se ofrecen como hitos para indagar en las representaciones de lo hispánico tanto en España como en las ex colonias. Asimismo, estos desplazamientos y redefiniciones del concepto de hispanismo en el contexto argentino tienen su correlato en un cambio dentro de las políticas científicas de España, que impulsará la concreción de relaciones 
intelectuales con los países hispanoamericanos. En tal sentido, se reseña el papel que los viajes de intelectuales y académicos desde y hacia la Península tendrán en el proceso de redefinición de los vínculos y sus repercusiones en el ámbito académico argentino, en particular en las universidades y centros de investigación, en los que comenzará a gestarse un hispanismo de cuño académico. La creación de centros e institutos de investigación vinculados con los estudios hispánicos será uno de los hitos clave en este proceso, de allí que en esta parte se focalice en los orígenes y trayectorias de los primeros núcleos de investigación enmarcados en las universidades argentinas y en los modos en que se comienza a delimitar un incipiente hispanismo de cuño argentino. En ese contexto, se reseña la génesis y primeros años del Instituto de Filología de la Universidad de Buenos Aires, sus principales figuras y los aportes realizados al campo de los estudios filológicos, lingüísticos y literarios y su impronta española.

El capítulo 2 "El Hispanismo y la vida académica argentina a partir de 1940" continúa y profundiza el proceso de institucionalización del hispanismo en el ámbito académico, a partir de reconstruir las trayectorias de algunos de los principales institutos y centros de investigación diseminados a lo largo de la Argentina. El recorte propuesto para esta investigación - que aspira a ofrecer una muestra relevante debido a su vinculación con los estudios hispánicos - incluye centros e institutos de las universidades de La Plata, Tucumán, Bahía Blanca y Mendoza, así como la Academia Argentina de Letras y su papel en estos procesos de consolidación del hispanismo y de un canon hispánico, en consonancia con otra de las hipótesis que sustenta este trabajo. Dicha hipótesis postula que en la Argentina, el hispanismo constituye un ámbito de producción e investigación fuertemente vinculado con la vida académica, cuyos principales aportes se visibilizaron en publicaciones científicas, revistas literarias y culturales, ediciones críticas de obras destinadas no sólo al estudio, sino a un público 
cada vez más amplio, así como en otros discursos que dan cuenta de las apropiaciones críticas del canon hispánico (reseñas, comentarios críticos, boletines de instituciones, etc.). Este proceso se acelera a partir de finales de la década de 1950, en conjunción con las transformaciones políticas y sociales del campo cultural argentino. Para ello, se contextualiza en este capítulo el panorama de la vida universitaria argentina, en particular a partir de la década de 1930, cuando se acentúan las crisis políticas cuyos efectos se sienten en el sistema universitario y derivan en ajustes y reformulaciones tanto institucionales como disciplinares y metodológicos. En el caso de los estudios hispanistas, su conformación y desarrollo estuvieron fuertemente vinculados a ciertas figuras relevantes, que dejaron su impronta en el ámbito académico y que contribuyeron a consolidar el hispanismo a lo largo del país. Junto con estas figuras, otro de los elementos que fortalecieron el establecimiento del hispanismo como un espacio particular fueron las publicaciones, que permitieron la visibilización de las producciones de los investigadores vinculados con esa área del conocimiento. En ese sentido, las publicaciones académicas (periódicas y no periódicas) constituyen un dispositivo clave para analizar los procesos de conformación del hispanismo, así como sus relaciones con las instituciones y con los procesos de conformación de un canon hispánico en la Argentina. Un recorrido por los institutos y centros académicos seleccionados para esta investigación y sus órganos de difusión más representativos ofrecerá un panorama de la presencia de los estudios hispánicos en la agenda investigativa de la Argentina desde mediados del siglo XX.

Finalmente, el capítulo 3 "El Hispanismo y la industria editorial en la Argentina (1940-1973)" se propone aportar otra dimensión a estos procesos, vinculada con el papel de la industria y las políticas editoriales en la consolidación del canon hispanista en la Argentina. En tal sentido, se aborda el panorama de dicha industria en el país y sus 
vínculos con España, de modo de poner de manifiesto el rol de ciertos sellos editoriales en la difusión y apropiación de obras y autores españoles en el contexto argentino. En este capítulo se retoman las cuestiones vinculadas a la conformación del canon y de las tensiones que implica, en términos de lo que es puesto en circulación en un contexto determinado, así como los factores de índole política, cultural y económica que se conjugan en estos procesos. Asimismo, se examina la noción de "clásico" que suele subyacer en los criterios de definición de las colecciones diseñadas por las editoriales y se procura ponerla en relación con los corpus de la literatura española incluidos en ellas y con la noción de "tradición hispánica" que se materializa en las obras consideradas insoslayables en el canon propuesto por el mercado editorial. Desde esta perspectiva, los catálogos editoriales constituyen un corpus significativo para indagar en estas tensiones, de allí que se analicen los listados de las empresas seleccionadas a fin de dar cuenta de la presencia de textos españoles y de su gravitación en las colecciones de los sellos editores entre las décadas de 1930 y 1970. Estas constataciones también permiten evidenciar los lazos entre la investigación académica y las formas de difusión del mercado editorial, así como las imbricaciones entre políticas, instituciones y ampliación del público lector.

El itinerario descripto procura dar cuenta de los matices y contornos que el hispanismo ha ido adquiriendo en el campo cultural argentino, definido en un primer momento por los matices de las relaciones con España, y en ese marco, el papel que ciertas figuras intelectuales desempeñaron en la forja de un incipiente hispanismo de corte académico e institucional. El derrotero planteado delinea una cartografía del hispanismo en la Argentina a partir de su inserción institucional en universidades y centros de investigación y sus vínculos con las publicaciones académicas desde las primeras décadas del siglo XX. Dichas publicaciones, junto con las propuestas del 
mercado editorial, van configurando un canon hispánico que es legitimado por los estudios críticos y literarios generados desde los centros académicos y a la vez, "legible" desde las propuestas editoriales. Esta conjunción de elementos y agentes otorga al hispanismo argentino una particular conformación que habilita abordajes desde diversas perspectivas y le confiere una matriz teórica para pensar las relaciones de este ámbito disciplinar con el amplio campo de las humanidades y sus dimensiones formativas, culturales e ideológicas en el contexto argentino de mediados del siglo XX. 


\section{CAPÍTULO 1: Antecedentes y conformación del Hispanismo en la Argentina}

\subsection{Relaciones intelectuales entre España y la Argentina en el siglo XIX}

El proceso de construcción del hispanismo argentino —entendido provisoriamente como conjunto de intelectuales y producciones vinculados con los estudios de la lengua y la cultura españolas ${ }^{6}$ - debe incluirse en el marco más amplio de las relaciones con España y de las tensiones y conflictos que éstas determinaron en el ámbito letrado y cultural de nuestro país desde el siglo XIX y que, con distintas modulaciones, atravesaron gran parte del siglo XX.

El siglo XIX fue, para la historia del continente americano, un periodo clave en la conformación de los Estados nacionales surgidos a partir de la desintegración del sistema colonial. La crisis e inestabilidad provocadas por los cambios políticos y sociales acarrearon debates y disputas en torno de las nuevas estructuras de poder y de las conformaciones identitarias de un colectivo que se definió, en un primer momento de este proceso, como americano y luego, ya avanzado el siglo, adquirió ribetes de índole nacional. Esta búsqueda de una redefinición de las formas de identidad estuvo signada en gran medida durante las primeras décadas post independentistas por su carácter de oposición o antagonismo con respecto a España y se centró, fundamentalmente, en un debate por la cuestión de la lengua (Di Tullio 2006, 2010; Rama 1982) ${ }^{7}$. Esta polémica lingüística involucró a la mayoría de los pensadores

\footnotetext{
${ }^{6}$ Tal como se ha señalado, el concepto de hispanismo ha ido moldeando su significado en el último siglo, de allí que para esta primera parte de la investigación se proponga una definición provisoria que se irá ajustando en la medida en que se incorporen elementos para su abordaje.

${ }^{7}$ La cuestión del idioma se convirtió en uno de los debates más significativos durante gran parte del siglo XIX. Al respecto, Carlos Rama (1982) reconoce dos momentos en los que denomina "la batalla del idioma": el que se extiende desde 1810 hasta 1866, caracterizado por la alta conflictividad, los debates más encendidos y la búsqueda de soluciones locales, y otro que se inicia a partir de 1866, en el que se produce un giro en las relaciones entre intelectuales españoles y americanos en pos de un acercamiento de posiciones (117-118).
} 
hispanoamericanos a lo largo del siglo y se convirtió en figura clave de la emancipación política y cultural ${ }^{8}$. De este modo, las reformas ortográficas formuladas por Domingo F. Sarmiento o Andrés Bello ${ }^{9}$, con sus matices diferenciales, constituyen gestos concretos de ruptura de los lazos con las formas de la autoridad española representadas por la normativa lingüística. En este sentido, ambas propuestas deben ser entendidas en el marco de un proceso de conformación identitaria de las incipientes naciones americanas y de los debates por la modernización de la cultura hispanoamericana, entre los cuales la lengua ocupa un papel fundamental (Narvaja de Arnoux 2008).

En el Río de La Plata, la gestación de núcleos letrados en la década de 1830 bajo el influjo del ideario del Romanticismo europeo asumió entre sus debates la cuestión del idioma en términos de emancipación y con ella, de la literatura española ${ }^{10}$. Conocidas son las opiniones de los principales representantes de estos grupos intelectuales, como Esteban Echeverría, Juan Bautista Alberdi y Juan María Gutiérrez respecto de la necesidad de buscar nuevas formas de expresión lingüística acordes con los nuevos

\footnotetext{
${ }^{8} \mathrm{Si}$ bien excede los límites temporales y territoriales de este trabajo, resulta ineludible mencionar las contribuciones de Andrés Bello en Chile, Rufino José Cuervo y Miguel A. Caro en Colombia, por citar los más relevantes.

${ }^{9}$ La reforma ortográfica de Bello, ya anunciada en una serie de textos escritos durante su estadía en Londres en 1823, se plasmó en la Gramática de la lengua castellana destinada al uso de los americanos, publicada en Santiago de Chile en 1847 y tuvo vigencia durante unas décadas. Por su parte, la propuesta de Sarmiento se concretó en la disertación "Memoria sobre la ortografía americana" que expuso en la recientemente creada Universidad de Chile en 1843, de la cual era rector fundador Andrés Bello (Alfón 2011, Jakšic 2001).

Las lecturas de los últimos años acerca de la célebre polémica entre ambos intelectuales han matizado las aparentes diferencias irreconciliables y se han focalizado en los aspectos compartidos, esto es, el proyecto educativo como base de la consolidación de un estado-nación moderno (Ennis 2008, Alfón 2011). Así, las diferencias entre ambas propuestas son más de grado que de fondo y se vinculan con los modos en que Bello y Sarmiento disputaban las querellas en el ámbito público -más batallador y polémico el argentino y más conciliador y unificador el venezolano- respecto del idioma español.

${ }^{10}$ El rechazo por la herencia lingüística española -incluida su literatura- está presente en la mayoría de los discursos de los intelectuales rioplatenses desde la gesta independentista, tal como lo afirma con cierta mirada crítica Rafael A. Arrieta: "Los adalides de la generación literaria de 1830 sintieron que la lengua en la que se expresaban les asfixiaba el pensamiento, e intentaron desgarrar esa túnica de Neso. Lengua y literatura son términos que se confunden continuamente en su prédica libertadora, sin que alcancen a distinguir entre el instrumento y la obra" (1957: 91).
} 
tiempos, que dejaran atrás todo lazo de dependencia con la Península ${ }^{11}$. Una postura crítica análoga a este pensamiento es la que sostendrá Sarmiento una década más tarde, al rechazar el carácter modélico de las obras españolas para expresar las nuevas ideas. En 1842, en su estadía en Chile, Sarmiento expresa:

¿Por qué motivo de interés general y de aplicación práctica a nuestras necesidades actuales se requiere que vayan a exhumarse esas antiguallas del padre Isla y Santa Teresa y fray Luis de León y el de Granada, y todos esos modelos tan decantados que se proponen a la juventud? ¿Para adquirir las formas? ¿Y quién suministra el fondo de las ideas, la materia prima en que han de ensayarse?" (citado en Rama 1982, 120-121).

A partir de la década de 1860 se produce un giro en las relaciones culturales entre España y América, motivado, entre otras razones, por el interés de la Real Academia Española en crear instituciones correspondientes en el continente americano $^{12}$. Esta iniciativa tuvo repercusiones variadas dentro y fuera de la Península, y en el ámbito hispanoamericano suscitó adhesiones y también rechazos, como el emblemático del argentino Juan María Gutiérrez, designado en 1875 miembro correspondiente de la Real Academia, cargo que declinó con argumentos que retoman los expresados décadas atrás en el Salón Literario respecto de la necesidad de romper

\footnotetext{
${ }^{11}$ Juan María Gutiérrez (1809-1878) fue una de las voces más virulentas a favor de una emancipación de España en todos los aspectos -en particular los culturales, considerados caducos- y formas de sujeción. En el discurso pronunciado en 1837 en la apertura del Salón Literario, expresó con ardor: "Nula, pues, la ciencia y la literatura españolas, debemos nosotros divorciarnos de completamente con ellas y emanciparnos a este respecto de las tradiciones peninsulares, como supimos hacerlo en política cuando nos proclamamos libres". Más adelante ratifica aún más la necesidad de romper los vínculos idiomáticos, tal vez los más arraigados, al afirmar: "Quedamos aún ligados por el vínculo fuerte y estrecho del idioma, pero éste debe aflojarse de día en día, a medida que vayamos entrando en el movimiento intelectual de los pueblos adelantados de la Europa [...] Y si hemos de tener una literatura, hagamos que sea nacional, que represente nuestras costumbres y nuestras naturaleza" (Citado en El Salón Literario 1958: 145).

${ }^{12}$ La Real Academia de Española fue creada en 1713 y su objeto principal está enunciado en su Estatuto: "Siendo el fin principal de la Fundación de esta Academia cultivár y fijár la puréza, y elegancia de la lengua Castellana (sic)", que en 1715 se cristalizará en el lema insignia de la Institución: "Limpia, fija y da esplendor". En la reforma del Estatuto de 1859 se define la figura del "académico correspondiente", que será la utilizada por los representantes americanos ante la Academia. (Consultado en http://www.rae.es/la-institucion/organizacion/estatutos el 14/06/ 2014).
} 
toda forma de sumisión a la corona española y reivindicar la libertad de expresión ${ }^{13}$. A pesar de ciertas posturas críticas contra el avance academicista en América, durante las siguientes décadas se crearon Academias correspondientes en varios países hispanoamericanos y que tuvieron como miembros a algunos intelectuales relevantes de la época, como Andrés Bello, el uruguayo Juan Zorrilla de San Martín o el peruano Ricardo Palma (Rama 1982) ${ }^{14}$.

En el ámbito argentino, desde la década de 1870 la Real Academia Española contaba con miembros correspondientes entre los que se encontraban polígrafos de renombre en los círculos intelectuales de la época, como señala Pedro Luis Barcia (2013): “Aceptaron su designación Bartolomé Mitre, Vicente Fidel López, don Ángel Justiniano Carranza, Luis Domínguez, Carlos Guido Spano, Vicente Quesada, Pastor Obligado, Ernesto Quesada y Carlos María Ocantos"15. Asimismo, en el año 1873 se creó en Buenos Aires, por iniciativa de un grupo de intelectuales, la Academia Argentina de Ciencias y Letras. Según se desprende de su Estatuto, dictado en 1877, las tareas propuestas por la institución excedían el ámbito lingüístico —aunque éste era parte de sus objetivos - según lo establecido en el Artículo 1: "La Academia Argentina tiene por objeto estudiar, proteger y difundir en la República las ciencias, las letras y las artes [...].” (Lauria 2012, 172). Entre sus tareas estuvo la edición de un Diccionario de argentinismos, proyecto que no llegó a concretarse a causa de la disolución de la

\footnotetext{
${ }^{13}$ Según Rama (1982), la actitud de Gutiérrez será saludada por otros intelectuales hispanoamericanos como el cubano José Martí y el peruano Manuel González Prada y manifiesta las tensiones que continuaban atravesando las relaciones entre la Península y los países hispanoamericanos a finales del siglo XIX. Asimismo, Moure (2008) indica que Gutiérrez sumó más rechazos que adhesiones, debido al giro en el modo en que se percibía a España a fines del siglo XIX.

${ }^{14}$ La Academia Colombiana de la Lengua, fundada en 1871 fue la primera, y durante las décadas de 1870 y 1880, se crearon otras en el ámbito hispanoamericano. Resulta significativo que en la Argentina recién se concretó la creación de la Academia Argentina de Letras en 1931, sesenta años después de la primera en suelo americano.

15 En su "Brevísima historia de la Academia Argentina de Letras" (2013), Barcia, en ese entonces su Director, menciona los nombres de los intelectuales argentinos designados miembros correspondientes. En http://www.aal.edu.ar/?q=node/181 (Consultado el 18/06/2014).
} 
Academia en $1879^{16}$. A pesar de su efímera vida, la Academia Argentina de Letras y

Ciencias constituye un hito en la reformulación de las relaciones culturales con España, luego de décadas marcadas por las posturas antagónicas y antihispánicas de los grupos intelectuales argentinos ya que, a diferencia de éstos, "la Academia se instaló en una posición prohispanista, que cristalizó la noción de argentinismo como peculiaridad o particularidad en relación con la lengua común. Esta concepción de la lengua nacional aboga por la unidad de la lengua y la filiación con la norma erigida en España" (Lauria 2012: 173-174).

La nueva generación de intelectuales, que constituirá la llamada Generación del $80^{17}$ —entre los que se puede mencionar a Miguel Cané, Eduardo Wilde, Eugenio Cambaceres y Lucio V. Mansilla—, volverá sobre la cuestión del idioma a partir de los cambios sociales y culturales que el aluvión inmigratorio produjo en la sociedad argentina desde finales del siglo XIX. Mientras que para la élite intelectual del 80 cierto poliglotismo era signo de pertenencia a un grupo letrado ${ }^{18}$, la diversidad lingüística que acarreó la incorporación masiva de inmigrantes provenientes de otros países, en especial de Italia, encendió las alarmas entre la élite nacional respecto de la posible disolución

\footnotetext{
${ }^{16}$ En su artículo "La Academia Argentina de Letras y Ciencias y su posición sobre la lengua nacional (1873-1875)", Daniela Lauria (2012:172) reseña la vida de la institución, sus objetivos y los postulados ideológicos que la sustentaban. Señala que: "Entre sus miembros se hallaban destacados polígrafos: Martín Coronado, Eduardo L. Holmberg, Ernesto Quesada, Miguel Cané, Pedro Goyena, Olegario Andrade, Atanasio Quiroga, Eduardo Gutiérrez, Clemente Fregeiro, Carlos Guido y Spano, Pastor Obligado y Martín García Mérou". Nótese que varios de los nombres de los miembros de esta institución coinciden con los de los académicos correspondientes designados por la RAE.
}

${ }^{17}$ El concepto "Generación del 80" ha sido sometido a diversas revisiones, según analiza Paula Bruno (2012) a lo largo del siglo XX; sin embargo su funcionalidad para el abordaje cultural y literario de las últimas décadas del siglo XIX sigue vigente y engloba a los escritores estrechamente vinculados con la vida política y social de la época y a sus producciones.

${ }^{18}$ Véase al respecto los guiños en lengua francesa hacia el propio grupo de pertenencia de Lucio V. Mansilla en los textos incluidos en Entre nos: causeries de los jueves, publicados entre 1889 y 1890 . En un sentido análogo, resultan significativas las "ventajas" que invoca Vicente F. López en el Prefacio a su obra de índole antropológica, titulada Les races aryennes du Pérou, editado en 1871. Dichas "ventajas" se refieren a la mayor experiencia de las imprentas francesas en publicar textos con caracteres ajenos al occidental -tal como aparecían en su libro-, y también debido a que "El idioma francés es además el vehículo más generalmente conocido en el mundo para los trabajos científicos, y en nuestro mismo país [la Argentina] es entendido por todos cuantos habrían podido estudiar mi libro en español" (1871: 3, el destacado es nuestro). 
del idioma (Di Tullio 2003; Bertoni 2001). Se reaviva entonces el debate por el "idioma nacional", no ya bajo la matriz de diferenciación de España como se había planteado en los hombres de la Generación de 37, sino como una estrategia para afianzar la idea de una nación y para combatir, desde el plano ideológico, los peligros que encerraba la dispersión lingüística. Asimismo, la crisis política, social y económica que afectó a nuestro país en la década de 1890 fue ocasión propicia para repensar la construcción de una "cultura nacional", inscripta en el marco más amplio de los conflictivos debates por la identidad nacional, donde la lengua — junto con nociones como raza o tradiciónocuparía un lugar central. En ese marco, comienzan las impugnaciones al materialismo de la Generación anterior, y se asiste a un proceso de reformulación de la figura del "escritor moderno", construida en torno de las tensiones entre tradición/modernismo, junto con una incipiente forma de profesionalización y de redefinición de las relaciones del intelectual con el Estado ${ }^{19}$.

\subsection{2 (Re)formulaciones y (re)visiones: en torno al IV Centenario del}

\section{Descubrimiento de América}

El clima intelectual de las relaciones entre España e Hispanoamérica adquiere singular preponderancia en torno a los festejos por el IV Centenario del Descubrimiento de América en 1892. A ambos lados del Atlántico se suceden los homenajes y celebraciones, que se plasman en una sucesión de congresos, certámenes y exposiciones

\footnotetext{
${ }^{19}$ El Ateneo de Buenos Aires (1892-1902) fue una institución que cristalizó las nuevas formas de sociabilidad de los intelectuales y contribuyó a la consolidación de ese nuevo estatuto del escritor "moderno". De sus inicios informales, bajo la figura de tertulias o reuniones, se conforma como institución y se propone ser "un espacio institucional de resguardo de una cultura nacional" (Bibbo 2012). La primera Comisión Directiva, organizada en 1892, estuvo presidida por Carlos Guido y Spano. Entre sus miembros se destaca la figura de Joaquín V. González como condensador del ideario cultural que aglutinó a los hombres del Ateneo a lo largo de diez años, junto con Rafael Obligado.
} 
conmemorativos $^{20}$. En ese marco, dos eventos resultan de gran significación para revisar los lazos culturales entre la metrópoli y los países hispanoamericanos: por un lado, la realización ese año del Congreso Literario Hispano-americano en Madrid, y por otro, la publicación de la Antología de poetas hispanoamericanos de Marcelino Menéndez Pelayo, preparada por encargo de la Real Academia Española. A este periodo de acercamiento entre España y América, Emilia de Zuleta (1992) lo incluye dentro de los que denomina "hispanismo práctico", cuyos orígenes pueden situarse en la década de 1880, en particular con la creación de la Unión Iberoamericana, que contó con el patrocinio de políticos y funcionarios, reunió a intelectuales españoles y generó un afianzamiento de las relaciones entre la metrópoli y las ex colonias, en términos diplomáticos y culturales (Rama 1982).

Organizado por la Asociación de Escritores y Artistas Españoles, el Congreso Literario Hispano-americano contó con la presencia de intelectuales fundamentalmente españoles $y$, en menor medida, provenientes del continente americano. El Congreso incluyó tres secciones: Filología — que ocupó la mayoría de las intervenciones-, Relaciones Internacionales y Librería ${ }^{21}$. Las intervenciones del área de Filología giraron básicamente en torno de los debates por la unidad de la lengua y su valor en el contexto de las relaciones entre España y los países hispanoamericanos, y se inscribieron en el ideario vigente en la metrópoli según el cual ambos territorios estaban unidos por las

\footnotetext{
${ }^{20}$ La práctica de celebrar los centenarios se consolida en Europa durante el siglo XIX, en consonancia con una laicización de las celebraciones, que buscan reemplazar las antiguas de índole religiosa. De allí la proliferación de festejos por los centenarios no sólo de hechos históricos, sino de autores o figuras literarias e intelectuales (Gutiérrez Cuadrado y Pascual Rodríguez 1992: 2). Por su parte, Díaz Quiñones destaca el papel de las exposiciones mundiales que se realizaron a finales del siglo XIX como una forma de concebir a la historia "como escenografía y como pastiche [...] es decir, las culturas convertidas en objetos de museo, con sus representaciones simbólicas del orden cultural y colonial" (1995: 476). Asimismo, la funcionalidad de las conmemoraciones como lieux de mémoire, noción propuesta por el historiador francés Pierre Nora para designar a aquellos elementos "destinados a desentrañar la dimensión rememoradora de los objetos, que pueden ser materiales, pero sobre todo, inmateriales" (1998: 32).

${ }^{21}$ Parte de este proceso y su vinculación con la edición de obras españolas en la Argentina de mediados del siglo XX se abordará en el Capítulo 3 de esta investigación.
} 
ideas de raza, religión, lengua e historia, en un constructo ideológico que intentaba reforzar el vínculo existente. En ese sentido, una de las metáforas recurrentes en referencia al tipo de lazo entre la Península y las ex colonias es la de "familia", en la cual España ocupa el lugar de "madre" y los países hispanoamericanos serían los “hijos” y, por lo tanto, “hermanos” entre sí (Rizzo 2011)². Así, España recupera en el discurso el lugar de la "Madre Patria", figura que seguirá presente en los discursos de españoles e hispanoamericanos ya iniciado el siglo XX.

La Real Academia Española también tuvo presencia en la conmemoración del IV Centenario, y en muestra de ello encargó a Marcelino Menéndez y Pelayo, ya reconocida figura de los estudios hispánicos ${ }^{23}$, la confección de una Antología de poetas hispanoamericanos, publicada en cuatro volúmenes entre 1893 y 1895, como "nueva prenda del espíritu de fraternidad hispanoamericana" (citado en Degiovanni 2007) ${ }^{24}$. El gesto político de la Academia era claro: la legitimación de la literatura hispanoamericana debía provenir desde la metrópoli, y el trabajo de Menéndez y Pelayo

\footnotetext{
${ }^{22}$ En relación con la retórica exhibida en nuestro país durante este periodo para caracterizar las relaciones con España resulta significativo el debate acerca del Himno Nacional, cuyas estrofas en las que se presentaba a España como la "metrópoli tiránica", fueron eliminadas en 1900 de la versión oficial por un decreto del entonces presidente Julio Argentino Roca. Ya años antes, en consonancia con el clima de acercamiento generado por la celebración del IV Centenario del Descubrimiento de América, se habían producido intentos de modificaciones (Bertoni 2001: 180-184). [Véanse en la letra original de Vicente López y Planes, de 1813, las imágenes que presentan a España como "fiera", en una clara animalización: "En los fieros tiranos la envidia/escupió su pestífera hiel”, “¿No los veis sobre México y Quito/arrojarse con saña tenaz? [...] ¿No los veis devorando cual fieras/todo pueblo que logran rendir?", "A estos tigres sedientos de sangre/fuertes pechos sabrán oponer", entre otras de similar tenor].

${ }^{23}$ Marcelino Menéndez y Pelayo (1856-1912) fue sin dudas una de las figuras clave del pensamiento español de la segunda mitad del siglo XIX. Su extensísima producción intelectual le valió el reconocimiento y la incorporación a las principales academias e instituciones culturales. En 1881 ingresó a la Real Academia de la Lengua y ocupó un lugar preponderante en el ámbito intelectual español, no exento de polémicas y debates. España, su historia, su tradición, su lengua y su cultura fueron las principales preocupaciones de su pensamiento, plasmadas en una ingente bibliografía que sirvió de base para la consolidación de un modelo de historiografía literaria y de los procesos de consolidación del canon hispánico. Una revisión de la figura de Menéndez y Pelayo y su lugar en estos procesos de construcción de una tradición crítica hispánica es desarrollada en los últimos años por Florencia Calvo y un grupo de investigadores de la Universidad de Buenos Aires, plasmada en numerosos trabajos (2011, 2013, 2014).

${ }^{24}$ Si bien la Antología fue publicada como tal entre esas fechas, en 1911 el propio Menéndez y Pelayo revisó y reeditó la obra bajo el nombre de Historia de la poesía hispanoamericana, en dos volúmenes que incluyen los prólogos y estudios que acompañaban la selección realizada.
} 
refuerza esta idea, a partir de pensar a la literatura colonial como un hilo conductor que expresa el vínculo nunca extinguido entre España y las ex colonias ${ }^{25}$. El argumento central de Menéndez y Pelayo era de índole lingüística, y reemplazaba al criterio político vigente durante el siglo XIX, el cual se intentó erradicar. Esto se verifica en la exclusión de la Antología de casi todos los poemas celebratorios de la época de la emancipación y de oposición a España ${ }^{26}$ (Degiovanni 2007, 56-60).

A pesar de las críticas que suscitó desde diferentes sectores nacionalistas a causa de su carácter predominantemente hispánico, la Antología de Menéndez y Pelayo constituyó un hito insoslayable en la conformación de un canon literario hispanoamericano y argentino, como lo demuestran las colecciones propuestas en los años siguientes, como la fundamental Historia de la literatura argentina (1917-1922), de Ricardo Rojas, donde éste reconoce el papel que le cupo a la Antología de Menéndez y Pelayo en el proceso de conformación de un canon literario hispanoamericano, a través de una genealogía que reconoce a la obra de Juan María Gutiérrez como antecedente $^{27} \mathrm{y}$, asimismo, en el proceso de construcción de un discurso hispánico que

\footnotetext{
${ }^{25}$ La organización interna de la Antología respondía a criterios geográficos y regionales. Así, en el primer tomo se abordaban producciones de México y América Central, en el segundo de Cuba, Santo Domingo y Puerto Rico, el tercero incluía textos y autores de Colombia, Ecuador, Perú y Bolivia y el cuarto y último, de Chile, Argentina y Uruguay. En el caso de la Argentina, la Antología menciona a Juan Cruz Varela, Florencio Varela, Ventura de la Vega, Esteban Echeverría, Juan María Gutiérrez, José Mármol, Olegario V. Andrade y Carlos Encina, de quienes incluye una selección de poemas. De entre ellos, el mayor número de textos incluidos corresponde a Echeverría, lo cual de algún modo anticipa el lugar canónico que el escritor ocuparía en las letras argentinas.
}

${ }^{26}$ Un antecedente clave de la Antología de Menéndez y Pelayo es la preparada por Juan María Gutiérrez entre 1846 y 1847. De alguna manera, la Antología del santanderino entabla un diálogo crítico con su antecesora a la vez que sugiere nuevos criterios de índole lingüística, en sintonía con los discursos de la época que le otorgan a la lengua un papel preponderante en la conformación de las identidades nacionales. Una lectura acerca de las modulaciones de dicho diálogo la ofrece Patricio Fontana (2014) a partir del análisis de los modos en que Menéndez Pelayo "lee" a Gutiérrez y, desde allí, a la literatura hispanoamericana y en especial, la argentina y sus implicancias ideológicas en la construcción de un canon literario.

${ }^{27}$ Al mismo tiempo, Rojas reconoce las tensiones implícitas en esa relación: "don Marcelino Menéndez y Pelayo inició su famosa Antología de poetas americanos, que señala un fasto en nuestra cronología, porque ella indicó que el voto de Sarmiento empezaba a realizarse y España reconocía con esa obra nuestra personería literaria: la audaz tentativa de Gutiérrez encontraba, medio siglo más tarde, imitador ilustre en la propia academia de sus recelos" (Cuarta parte, I: 258). A continuación, Rojas señala las 
incluyera a América como parte de su tradición. Al respecto señala Arcadio Díaz Quiñones: “América aparece de nuevo como proyección europea; España era apta para servir de canon y de punto de referencia, para incluir y excluir. La relación entre lenguaje y poder era explícita" (1995: 483)”. Esta cita pone de relieve la imbricación entre lengua y política, tal como se ha venido señalando en el contexto finisecular a ambos lados del Atlántico ${ }^{28}$.

Desde esta perspectiva, el año 1892 — a partir de la oportunidad que ofrece la conmemoración del IV Centenario del Descubrimiento de América- actúa como cifra no sólo de los procesos de reformulación de las relaciones entre España y América, sino también de una revisión de la idea de "nación", a partir de las nociones de "raza" y "lengua" que atravesaron los discursos a ambos lados del Atlántico. En nuestro país, estas revisiones tuvieron su correlato con los debates en torno a la construcción de la identidad nacional que comienzan a gestarse y que alcanzarán su apogeo en las primeras décadas del siglo XX.

\subsubsection{Nuevo siglo, nuevas fluctuaciones: el "giro hispanista" (1900 - 1920)}

Los estudios acerca del periodo de entresiglos en la cultura argentina —en particular en el Río de La Plata - coinciden en reconocer una suerte de "retorno a España" 29 en los discursos intelectuales que atraviesan esta época, muchos de ellos vinculados con la

compilaciones de Juan de la Cruz Puig, de 1910, la de Ernesto Barreda de 1914 y la de E. Morales y D. Novillo Quiroga de 1917.

${ }^{28}$ En dicho trabajo, Díaz Quiñones realiza una lectura del IV Centenario en clave de discurso colonial. Allí analiza el papel de la Antología de Menéndez y Pelayo en la construcción de un discurso hegemónico español que incluyera a la América Hispánica como parte de su tradición.

${ }^{29}$ Así titula Alfredo Rubione su trabajo incluido en la Historia crítica de la literatura argentina, Vol. 5 La crisis de las formas, sintagma que condensa la índole de los procesos ideológicos del periodo en relación con España. 
cuestión del "idioma nacional", que adquiere un nuevo vigor a partir de las profundas transformaciones sociales derivadas del impacto inmigratorio (Bertoni 2001; Di Tullio 2003; Rubione 2006; Ennis 2008).

La publicación en París del libro Idioma nacional de los argentinos del lingüista francés Lucien Abeille inaugura el siglo y con él una amplia polémica en el medio intelectual argentino. La tesis de Abeille, impregnada de los principios de la lingüística europea de corte histórico-comparativo, se presenta como un estudio basado en métodos y modelos científicos y promueve la tesis controversial de la evolución del español hacia un "idioma argentino", resultado de las transformaciones que había sufrido el país y que, a la vez que se alejaba del español peninsular, culminaría por integrar los aportes populares y de otras lenguas como rasgos distintivos e identificatorios de esa nueva cultura $^{30}$. El texto de Abeille suscitó una reacción casi unánime en los intelectuales argentinos en rechazo de sus hipótesis ${ }^{31}$, básicamente por el lugar que le otorgaba a lo popular en la conformación del "idioma argentino", lo cual fue leído como una reivindicación de aquello que desde la élite letrada se veía como amenazante en el proceso de construcción de una identidad nacional en el que dicha élite ocupaba una posición hegemónica ${ }^{32}$. En este contexto, los discursos se articularon en torno a la idea

\footnotetext{
${ }^{30}$ Según Paul Verdevoye (2001), la tesis formulada por Abeille se inscribe en una línea de análisis ya expresada en el ideario de Alberdi y de Gutiérrez respecto de la necesidad de un nuevo idioma para una nueva nación, en la que se recuperan aspectos de la noción herderiana de la lengua como "visión del mundo". Para un análisis exhaustivo del texto de Abeille y de sus principales aspectos, véanse Oviedo 2005, Di Tullio 2003 y Ennis 2008.

${ }^{31}$ Frente a las mayoritarias repercusiones en contra de las tesis expuestas por Abeille en su libro, algunas pocas voces acordaron con sus ideas, entre ellos Carlos Pellegrini y Carlos Olivera (Di Tullio 2003: 111) y Vicente Rossi, quien años después, al reavivarse las polémicas lingüísticas en la década de 1920, retomaría los argumentos de Abeille en su Folletos lenguaraces (Ennis 2008: 162-163).

${ }^{32}$ Alfredo Rubione caracteriza esta vinculación entre la clase letrada y los discursos hegemónicos que se consolidaron en la época: "Aquel sector de hombres de letras, políticos y funcionarios contribuyó decididamente a configurar el discurso homogeneizante en el que se delimitó con precisión el 'nosotros' sobre la base de una comunidad natural preexistente (la hispano-criolla)- fuente de argumentos nacionalistas y matriz autorreferencial de legitimación del propio sector social y de la cultura oficial" (2006: 20).
} 
de una postura prohispanista, de cuño integrador, que habilitara la construcción de una tradición en la cual insertarse y que diera respuesta a las crisis provocadas por el aluvión inmigratorio.

Esta postura prohispanista de sectores de la élite letrada — si bien tuvo sus más fuertes expresiones en los debates por la lengua - también se manifestó en otras prácticas y producciones, que dejaron su huella en el panorama social y cultural argentino de entresiglos ${ }^{33}$. De allí que sea necesario, en este punto, ajustar la noción de hispanismo presentada al comienzo de este capítulo, para considerarlo como el conjunto de posturas, discursos y lazos intelectuales y literarios, construidos en torno a una reivindicación de la tradición hispánica, de su lengua, su raza, su cultura y su religión, que se conforman en el marco de un contexto signado por la necesidad de afianzar una identidad propia. Así entendido, el hispanismo argentino de comienzos del siglo XX se convierte en "piedra angular" para pensar la identidad argentina, no ya en términos de una férrea oposición a todo aquello proveniente de España, sino como sustrato común que le otorga legitimidad y le permite inscribirse en una tradición percibida como $\operatorname{prestigiosa}^{34}$.

Este "giro hispanista" es el resultado de un doble movimiento: por un lado, tal como se ha señalado, de una búsqueda por parte de ciertos sectores de la élite argentina de una tradición común que enlace a la incipiente idea de nación con una tradición más vasta y abarcadora que la incluya y la resignifique, y por otro, del acercamiento que desde España comienza a delinearse hacia América Hispánica en pos de una redefinición del lugar que ésta debe ocupar en el concierto de una "comunidad

\footnotetext{
${ }^{33}$ En ese mismo trabajo, Rubione señala que la presencia de lo hispánico excedió los debates lingüísticos y se manifestó en el arte, el teatro, la arquitectura y la enseñanza (Ibídem 21).

34 En su artículo "El dispositivo hispanista" (1992), Oscar Terán postula la existencia de mecanismos discursivos que dan cuenta de los modos en que se articularon "esos mensajes [las traducciones del hispanismo] con la tradición, y a las particulares vinculaciones de los intelectuales con la sociedad, la política, el Estado y con su mismo campo intelectual" (129).
} 
hispánica" (Zuleta 1992, 951). Los intelectuales españoles nucleados en la denominada Generación del 98 —entre los que se ha ubicado a Miguel de Unamuno, Azorín [José Martínez Ruiz], Ángel Ganivet, Pío Baroja, Antonio y Manuel Machado, Ramiro de Maeztu, Jacinto Benavente y Ramón del Valle Inclán- ${ }^{35}$ propugnan una nueva forma de relación entre la metrópoli y los nuevos Estados americanos, entre ellos la Argentina, donde se forjarán vínculos intelectuales y culturales relevantes, en el marco de lo que Oscar Terán denomina "un auténtico operativo rehispanizante" $(1992,131)^{36}$. Dicho movimiento debe encuadrarse en un contexto internacional complejo para España, debido al avance norteamericano no sólo en el plano político — dentro del cual debe ubicarse el episodio de la Guerra de Cuba en 1898 y las implicancias ideológicas que acarreó en el campo intelectual español ${ }^{37}$ - sino también en el cultural, ya que se veía con recelo y alarma el avance de la cultura norteamericana, incluido su idioma, con su consecuente bagaje de materialismo y pragmatismo ${ }^{38}$. El impacto de la derrota entre los

\footnotetext{
${ }^{35} \mathrm{Al}$ igual que ocurre con otros marbetes similares, el concepto "Generación del 98" para referirse a un grupo de escritores españoles finiseculares ha sido sujeto a revisión en tanto forma de periodización literaria que se gestó como tal a comienzos del siglo XX (Mainer 1980). Desde los textos inaugurales de Azorín de 1913, se va corporeizando la idea de un conjunto de rasgos compartido por los literatos españoles en tanto respuesta intelectual y estética al denominado "problema español", entendido como conciencia de crisis ante la situación política y cultural de España, profundizada luego de la derrota de la Guerra de Cuba en 1898.

${ }^{36} \mathrm{El}$ interés por las producciones literarias hispanoamericanas está presente en los críticos e intelectuales españoles de fines de siglo XIX, tal como se ha visto con la intervención de Menéndez y Pelayo en la constitución de un canon literario hispanoamericano, y también en las lecturas críticas que acerca de obras gestadas en la América Hispana, entre la que resulta paradigmática —al menos para la literatura argentina- el juicio valorativo realizado por Miguel de Unamuno sobre el Martín Fierro de José Hernández, publicado en la Revista Española en 1894. En ese artículo inserta al poema gauchesco en la tradición española, cuestionando de este modo los argumentos lingüísticos que propugnaban la existencia de una "lengua nacional argentina", cuestión que Unamuno rechaza de plano (Obras Completas VIII: 55).

${ }^{37}$ La Guerra de Cuba o Guerra Hispano-Estadounidense fue un conflicto bélico que enfrentó a ambos países en el año 1898 y que culminó con la derrota de España y la pérdida de las últimas colonias de ultramar (Cuba, Puerto Rico y Filipinas). Las consecuencias de esta guerra excedieron el plano político y se expandieron en el imaginario hispánico como signo de la "decadencia" española en todos los planos, en especial el moral. El año 1898 quedó registrado como "el año del desastre", lo que condensa la percepción del hecho en la historiografía española.
}

38 La construcción discursiva de rechazo a la postura norteamericana en términos de materialismo/espiritualismo tuvo especial repercusión en América Hispánica, donde las voces de los intelectuales se alzaron en contra de lo que se percibía como un avance del imperialismo del norte. Entre ellas se pueden destacar las obras del uruguayo José Enrique Rodó (Ariel, 1900), del nicaragüense Rubén 
intelectuales españoles dio origen a una serie de revisiones acerca de la historia, el devenir y el destino de España, plasmadas en múltiples respuestas al denominado “problema de España”. Según el historiador Pedro Laín Entralgo, se trata del "conflicto entre la hispanidad tradicional y la europeidad moderna [que] es resuelto en su mente por la doble vía del interiorismo o «casticismo intrahistórico» y de la ejemplaridad espiritual" (1948). Estos rasgos podrían sintetizar la mirada particular que los escritores tuvieron respecto de la situación de su país y de su compromiso intelectual para con él y también el lugar que las antiguas colonias ocupaban en el imaginario hispánico de fines del siglo XIX.

Asimismo, este acontecimiento histórico generó en América Hispana $-\mathrm{y}$ en particular en el Río de la Plata - una reacción de apoyo y solidaridad con España, lo cual contribuyó de algún modo a reforzar las actitudes prohispanistas de algunos sectores de la intelectualidad y del gobierno ${ }^{39}$. En este sentido, el conflicto bélico actuó como un catalizador de dichas posiciones, ya presentes en los discursos de los grupos dirigentes por las condiciones sociales y culturales que atravesaba la Argentina debido al impacto de la inmigración masiva, y permitió articularlas con el contexto americano, en el que el avance de los Estados Unidos era visto como amenazador tanto en el plano político y económico como cultural.

Este entorno particular posibilitó el acercamiento y el refuerzo de las relaciones con la metrópoli, que se plasmaron, como se indicó, en discursos a ambos lados del Atlántico y también a través de gestos más concretos, entre los cuales se destacan los viajes de los intelectuales. La época de entresiglos fue un momento particular para los

Darío (“Oda a Roosevelt", 1904) y del argentino Calixto Oyuela (“Oda a España”, 1898) (Rubione 2006: 34-35).

${ }^{39}$ Ignacio García señala dos razones fundamentales para explicar el cambio de actitud de la sociedad rioplatense frente a España a fines del siglo XIX: el rechazo a la intervención norteamericana en Cuba y la importante presencia de inmigrantes españoles en nuestro país, ya organizados en sociedades y centros y con órganos de difusión propios (2002: 50-51). 
desplazamientos territoriales en ambas direcciones — desde el Río de la Plata a España y de España a nuestras tierras - de pensadores, escritores, periodistas y catedráticos, a través de cuyos discursos es posible reconstruir las modulaciones que fueron adquiriendo las relaciones entre ambos países. Entre los intelectuales españoles que llegaron a la Argentina, muchos de ellos emigrados debido a cuestiones políticas, y donde desarrollaron actividades culturales de variada y diversa índole, pueden citarse — sin pretensiones de exhaustividad - al catalán Ricardo Monner Sans ${ }^{40}$, al navarro Juan José García Velloso ${ }^{41}$, al burgalés Eustaquio Pellicer ${ }^{42}$, al valenciano Rafael Altamira $^{43}$ y al asturiano Adolfo González Posada ${ }^{44}$, estos últimos catedráticos españoles que fueron enviados a nuestro país en un intento de reforzar las relaciones

\footnotetext{
${ }^{40}$ Ricardo José Vicente Monner Sans (1853-1927) nació en Cataluña y llegó a la Argentina en 1889. Su actividad estuvo vinculada con la enseñanza -fue docente en el Colegio Nacional de Buenos Aires-, el periodismo y la crítica literaria. Fue reconocido por su cruzada a favor del purismo idiomático.

Las referencias biobibliográficas que se incluyen a continuación apuntan a destacar aquellas figuras que contribuyeron, desde sus producciones intelectuales y sus actividades, a cimentar las relaciones entre España y la Argentina y, fundamentalmente, a forjar una visión renovada del país y de su cultura, en el marco de los discursos de fortalecimiento de los lazos culturales que comenzaron a circular en esa época.

${ }^{41}$ Juan José García Velloso (1849-1907) fue un escritor y periodista español que llegó a la Argentina en la década de 1880 y entre otras actividades, se desempeñó como docente en la Universidad de Buenos Aires. Escribió libros de texto destinados a la enseñanza de la lengua y la literatura. Fue el padre de Enrique García Velloso, precursor del teatro criollo en nuestro país.

${ }^{42}$ Eustaquio Pellicer (1859-1937), periodista y fundador de revistas y publicaciones periódicas, nació en Burgos y en 1892 llegó a Buenos Aires. Colaboró en el diario La Nación y fue el creador de las míticas revistas Caras y Caretas (1898) y PBT (1904).

${ }^{43}$ Rafael Altamira (1866-1951) fue un intelectual prolífico, dedicado a la investigación en varias disciplinas humanísticas. Viajó a la Argentina y a otros países americanos entre 1909 y 1910 e, invitado por el entonces presidente de la Universidad Nacional de La Plata, Joaquín V. González, dictó en esa casa de estudios una serie de conferencias y cursos y fue designado Profesor Honoris Causa en 1909. Regresó a España en 1910 y su experiencia americana quedó registrada en su obra Mi viaje a América (1911).

${ }^{44}$ Adolfo González Posada (1860-1944), jurista y catedrático de la Universidad de Oviedo, viajó a la Argentina en 1910, en el marco del afianzamiento de las relaciones científicas entre España y América Hispana que promovía la Junta para Ampliación de Estudios. Fue disertante en la Universidad Nacional de La Plata y, al igual que otros especialistas que visitaron América, dejó registro de sus impresiones en una serie de obras, entre las que se destacan Para América desde España (1910), La república del Paraguay. Impresiones y comentarios (1911), En América. Una campaña: relaciones científicas con América, Chile, Paraguay y Uruguay (1911) y La República Argentina. Impresiones y Comentarios, publicada en Madrid, a su regreso del periplo americano (1912).
} 
científicas y académicas entre España y América ${ }^{45}$. La presencia de los catedráticos españoles en América — y en particular en la Argentina— está en estrecha relación con las actividades de la recientemente creada Junta para Ampliación de Estudios e Investigaciones Científicas de Madrid (JAE) en 1907, destinada a organizar y modernizar la ciencia y la cultura en España. Entre sus objetivos se encontraba la formación de estudiosos en el extranjero y la creación de instituciones dedicadas a la investigación, entre los cuales se destaca el Centro de Estudios Históricos en 1910, con sede en Madrid, cuyo primer director fue el filólogo Ramón Menéndez Pidal. En ese contexto, los viajes de los profesores de universidades españolas a América Hispana fueron una muestra del espíritu de integración entre la metrópoli y las ex colonias y la creación de nuevos lazos basados en condiciones de igualdad.

Otros referentes de la cultura española visitaron nuestro país en este periodo: escritores como Jacinto Benavente, en 1906, Vicente Blasco Ibáñez ${ }^{46}$ y José María Salaverría ${ }^{47}$ en 1909 (Zuleta 1999) y Ramón del Valle-Inclán, en 1910, quien llegó como director de una compañía teatral (Giaccio 2011, 2013) ${ }^{48}$. Al mismo tiempo, se

\footnotetext{
${ }^{45}$ Esta voluntad se expresa en las opiniones de Rafael Altamira, quien en su informe a la Junta recomendará: "Emprender estas primeras misiones como por vía de tanteo y ensayo, sin darles mayores proporciones que las que les correspondan, ni rodear la acción de la Junta de manifestaciones desmedidas: no se trata, no debe tratarse, de ninguna empresa de descubrimientos, de penetraciones, sino sencillamente de estudio y de intimidad intelectual con aquellos países". Citado en García, Ignacio "El institucionismo en los krausistas argentinos" (2001). Disponible en http://www.ensayistas.org/filosofos/argentina/roig/homenaje/garcia.htm. (Consultado 10/09/2014).
}

${ }^{46}$ Resultado de la visita del escritor español a nuestro país será la publicación de su obra La Argentina y sus grandezas en Madrid en 1910 y presentada en Buenos Aires con motivo de las celebraciones por el Centenario. Según Zuleta, el libro constituye "una verdadera suma histórico-geográfica de casi ochocientas páginas escritas con el propósito de «desvanecer preocupaciones, falsedades e ignorancias»" (1999: 18).

${ }^{47}$ El escritor vasco José María Salaverría (1873-1940), que formó parte de los escritores del 98, emigró a la Argentina en 1911, donde permaneció hasta 1913 y allí desarrolló parte de su vocación como escritor. Fue colaborador del diario La Nación y a su regreso a España publicó sus impresiones acerca de su experiencia en el país en su obra, A lo lejos España vista desde América (1914), así como un ensayo referido a la literatura argentina titulado El poema de la pampa. "Martín Fierro" y el criollismo español (1918).

${ }^{48}$ La visita de Valle-Inclán a la Argentina ha sido objeto de una detallada revisión en el número especial que Cuadrante. Revista Semestral de Estudios Valleinclanianos e Históricos, donde un grupo de 
establecieron en el país empresarios libreros que contribuirán al afianzamiento de la actividad editorial, una de las más sólidas en el ámbito hispánico fuera de la Península, tal como se analizará más adelante.

También es de destacar la actuación en la Argentina del catalán Luis Ricardo Fors, quien llegó al país a fines del siglo XIX y fue el primer director de la Biblioteca Pública de la Universidad Nacional de La Plata, recientemente fundada ${ }^{49}$. Desde esa función, impulsó la profesionalización de las tareas bibliotecológicas y organizó la Colección Cervantina en 1905 - en consonancia con el tercer centenario de la publicación de El ingenioso hidalgo Don Quijote de La Mancha - que constituyó uno de los repertorios de la obra de Cervantes más importantes fuera de España, a partir de la adquisición de ejemplares antiguos y valiosos que pasaron a formar parte de la colección. También Fors fue el responsable de una edición de El ingenioso hidalgo Don Quijote de la Mancha en 1904 la cual, según declara el propio Fors, era la "primera edición sudamericana" ${ }^{, 50}$. Si bien no se trata de una edición crítica, reviste un valor

investigadores argentinos se dedica a presentar las diferentes aristas de ese viaje y sus repercusiones en el espacio cultural argentino en el marco de los festejos por el Centenario (Especial "Valle en la Argentina", $\mathrm{N}^{\circ} 29$, diciembre 2014).

49 La Biblioteca Pública de la Universidad Nacional de La Plata tiene sus orígenes en la Biblioteca Pública Provincial de Buenos Aires, creada en 1887. Con la fundación de la Universidad en 1905, los fondos de la Biblioteca Pública se integran a la Biblioteca de la Universidad Nacional de la Plata. Luis Fors era el director de la Biblioteca Pública y continuó en el cargo al pasar a depender de la Universidad (Chicote 2005).

${ }^{50}$ La edición conmemorativa de 1904 ofrece, junto con el texto cervantino, ilustraciones y un estudio sobre la vida de Cervantes realizado por el propio Fors. Su portada exhibe la siguiente inscripción: " $E l$ ingenioso hidalgo Don Quijote de La Mancha. Primera edición sud-americana, ilustrada y precedida de la Vida de Cervantes. Dada á luz en homenaje a este inmortal escritor al celebrarse en la ciudad de La Plata el tercer centenario de la impresión y publicación del Quijote, La Plata, Tall. Gráf. de Sesé y Larrañaga, 1904". La obra incluye grabados de los ilustradores Ricardo Balaca y Canseco y de José Luis Pellicer y Fener.

Respecto de su condición de primera edición sudamericana de la obra de Cervantes - ya que la primera del continente americano corresponde a una edición realizada en México en 1833 - , es necesario señalar que en el año 1880 se publicó en Montevideo, Uruguay, por la Imprenta de La Colonia Española, una edición de El ingenioso hidalgo Don Quijote de La Mancha como obsequio a los suscriptores del periódico La Colonia Española fundado por el español Antonio Aguayo en 1877 (Garabedian 2012: 174). Según reza en la portada del libro, se trata de una "edición conforme á la última corregida por la Academia Española de la Lengua, con la vida del autor y notas para la buena inteligencia del texto". Uno de los ejemplares conservados de esta edición uruguaya está incluida en la Colección Cervantina "Arturo 
particular debido al carácter inaugural atribuido a ella — más allá de las polémicas en torno a este hecho - por tratarse de una publicación de la novela cervantina realizada en el Cono Sur, y más particularmente, en la ciudad bonaerense de La Plata. La ciudad, que apenas contaba con dos décadas de vida — había sido fundada por el gobernador Dardo Rocha en 1882 - ya evidenciaba inquietudes culturales e intelectuales (Cf. Nota $n^{\circ} 49$ ) y, a partir de la creación de la Universidad Nacional de La Plata, forjará un centro intelectual de renombre, que irá completando el mapa universitario argentino ${ }^{51}$.

Entre las visitas destacadas de esta primera década del siglo XX se encuentra la que realizó Ramón Menéndez Pidal a la Argentina en 1905, en el marco de una misión diplomática a América ${ }^{52}$. Su interés por la investigación y la recopilación de romances hispánicos en el territorio americano lo impulsó a conectarse con estudiosos locales en los países que visitó en su periplo. Durante su estadía en Buenos Aires, se contactó, entre otros, con Ricardo Rojas y Robert Lehmann-Nitsche en busca de materiales para su investigación sobre el romancero (Chicote 2009). En el caso de Rojas, estos contactos iniciales serán fundamentales para el desarrollo y afianzamiento de las relaciones intelectuales entre ambos y se mantendrán a lo largo de las décadas siguientes y tendrán una importancia crucial en la conformación de centros académicos.

La presencia de intelectuales y de empresarios españoles en nuestro país dejó su impronta en los vínculos que se fueron consolidando y en el intercambio de ideas y de

E. Xalambrí”, que forma parte del acervo bibliográfico de la Biblioteca y Centro de Documentación de la Universidad de Montevideo (Vairo Botta, 2012).

${ }^{51}$ La fundación de la Universidad Nacional de La Plata se sumó a las ya existentes Universidad Nacional de Córdoba (1613) y Universidad de Buenos Aires (1821).

${ }^{52}$ Menéndez Pidal fue comisionado por el rey Alfonso XIII en 1905 para actuar en la disputa limítrofe que mantenían los países de Ecuador y Perú, de la cual la corona española era árbitro. Este viaje le permitió a Menéndez Pidal contactarse con investigadores americanos en busca de materiales para su proyecto sobre el Romancero hispánico. 
visiones acerca de las realidades de cada país ${ }^{53}$. Asimismo, estos lazos no se establecieron en el vacío, ya que la presencia de emigrantes españoles en la Argentina fue muy significativa desde finales del siglo XIX y comienzos del XX y generó modos de socialización y de organización particulares, concretadas en instituciones, entre las que pueden mencionarse el Club Español de Buenos Aires, creado en 1857, la Asociación Patriótica Española, surgida en 1896 al calor de la Guerra de Cuba, y más adelante la Institución Cultural Española, de 1912, centrada en promover las relaciones culturales y académicas entre España y la Argentina, así como instituciones similares creadas en el interior del país. Junto con las instituciones vinculadas con el fomento de relaciones políticas o culturales, ya desde mediados del siglo XIX habían aparecido asociaciones mutuales que atendían las necesidades básicas de atención de las comunidades de colonos en la Argentina ${ }^{54}$.

El contacto directo y vivencial de estos emigrantes españoles con la sociedad argentina y los modos en que se insertaron en el contexto cultural e intelectual de la época se reflejaron en numerosas producciones (libros, memorias, cartas, crónicas de viajes, informes, conferencias) que dan cuenta de los procesos de revisión de la mirada española sobre las ex colonias del Río de la Plata, en la mayoría de los casos con un afán integrador y conciliador, lejos de las disputas políticas o ideológicas, con excepción, como se ha visto, de los debates lingüísticos que siguieron atravesando los discursos tanto de los argentinos como de los españoles hasta entrado el siglo XX.

\footnotetext{
${ }^{53}$ También tuvo un rol destacado la prensa, a través de los periódicos impulsados por la colectividad española, como el diario El Correo Español, de 1872, la revista cultural España, de 1903, El Diario Español, de 1906, órganos de difusión de las ideas que aglutinaban al colectivo español residente en la Argentina. Para un análisis de las formas y los discursos del patriotismo español en la Argentina, véanse los trabajos de Marcela García Sebastiani (2006, 2013).

54 En el caso de la colectividad española, en 1857 se fundó la Asociación Española de Socorros Mutuos de Buenos Aires, que fue señera en el mutualismo argentino y que se multiplicará en los barrios porteños primero y luego en las localidades del interior del país en las que hubiera presencia de inmigrantes españoles.
} 
Desde esta orilla también partieron intelectuales hacia España en busca de ciertas formas de interpretar y de configurar las nuevas formas de relaciones que se establecían entre España y nuestro país. El clima post Guerra de Cuba y de los festejos por el Centenario fueron un ámbito propicio para emprender este "regreso a España" e indagar en la tradición hispánica. Por su significación y la influencia que tuvieron en la consolidación del hispanismo en las primeras décadas del siglo XX nos detendremos en las figuras de Ricardo Rojas y Manuel Gálvez, que realizaron estadías en España y dejaron sus registros en una multiplicidad de escritos literarios, ensayísticos y periodísticos ${ }^{55}$

Ambos escritores comparten posturas ideológicas que han permitido ubicarlos en la denominada "Generación del Centenario" y en la conformación del primer nacionalismo argentino, aunque con diferencias relevantes. Payá y Cárdenas (1978) incluyen a ambas figuras en ese grupo intelectual debido a ciertos rasgos compartidos tanto en el plano ideológico como estético. En el primer caso, si bien estos escritores reconocen y valoran los logros de la denominada Generación del 80, cuestionan su excesivo materialismo, la pérdida de ideales y el avance del cosmopolitismo indiscriminado. En el plano estético, adscriben al modernismo y de este modo enfrentan a las corrientes naturalistas y cientificistas de finales del siglo $\mathrm{XIX}^{56}$. De la conjunción de ambos planos puede apreciarse un giro hacia formas de un espiritualismo impresionista y subjetivo. Las coincidencias estéticas e ideológicas entre ambos escritores se plasmó en la participación que tuvieron en la creación de la revista Ideas

\footnotetext{
${ }^{55}$ Las primeras décadas del siglo XX fueron un momento de fluidos viajes, tal como se ha señalado. Además de las travesías de Gálvez y de Rojas, otros escritores e intelectuales argentinos se desplazaron hacia el Viejo Continente, como Manuel Ugarte y Leopoldo Lugones.

${ }^{56}$ La tesis de la adhesión de Gálvez al movimiento modernista planteada por Payá y Cárdenas en su libro puede matizarse con los aportes de María Teresa Gramuglio (2002: 146), quien ubica su producción poética temprana dentro de los "iniciadores de la poesía realista". El devenir de Gálvez hacia la prosa novelística permitió incluirlo dentro de las corrientes realistas de las primeras décadas del siglo XX.
} 
(1903-1905), publicación dirigida por Manuel Gálvez, que reunió a escritores e intelectuales que se representaban a sí mismos como miembros de una nueva "generación" que tenía entre sus principales postulados la especificidad de la producción literaria, en particular de la crítica, como modo de intervención en el incipiente campo cultural argentino, y la profesionalización de la actividad del escritor $^{57}$. En este cambio se advierte en ambos las influencias de las líneas de pensamiento español de Miguel de Unamuno y de Ángel Ganivet, quienes habían reflexionado, en el marco de las reformulaciones intelectuales de la España post Guerra de Cuba, acerca de la necesidad de postular una "restauración de la vida entera de España" (Ganivet 1896) y de una vuelta hacia formulaciones de la tradición. Estas ideas se conjugaron en Rojas y Gálvez con una particular visión de la historia argentina y del interior del país y se articularon con una visión positiva de España y su cultura, a la que refieren en sus escritos, visión que fueron construyendo a partir de sus lecturas y de sus experiencias en tierras españolas. Los viajes al viejo continente, y en particular a España, revistieron un carácter iniciático para ambos jóvenes, a la vez que contribuyeron a consolidar sus ideas respecto de la trascendencia y relevancia de la cultura española para repensar la propia historia y la formación de un proyecto naciona $1^{58}$. Además de proporcionar la experiencia directa con la vida social y cultural de la Península, los viajes permitieron el establecimiento de lazos con figuras relevantes del campo intelectual español, que reforzaría los vínculos ideológicos.

\footnotetext{
${ }^{57}$ Formaron parte de ella, además de los mencionados Gálvez y Rojas, Alberto Gerchunoff, Juan Pablo Echagüe, Emilio Becher, Ricardo Olivera, Emilio Ortiz Grognet, entre otros. Según expresa Bendahan (2009), "El grupo fundador de Ideas se constituyó al pensarse a sí mismo como la primera generación de escritores que se conformó en la Argentina en el siglo XX" (68).

${ }^{58}$ En su análisis de la obra de Manuel Gálvez, María Teresa Gramuglio sintetiza los tópicos que articulan la figura del "escritor nacionalista": "el linaje criollo prestigioso, el viaje a Europa, el descubrimiento de la patria desde el extranjero, el redescubrimiento de la hispanidad, la conversión al catolicismo, el viaje a las provincias interiores, el conocimiento de la tradición" (2001: 49). Como puede observarse, la mayoría de estas ideas están presentes en las obras de Gálvez y Rojas, entre las cuales se destacan el viaje como forma de (re)conocimiento y la matriz hispanizante.
} 
En 1905, recién recibido de abogado, Manuel Gálvez realizó su primer viaje al viejo continente que se iniciaría, como en el caso de muchos viajeros de esa época, en Francia. La capital francesa revestía para la clase letrada argentina un halo de prestigio cultural de larga data, su idioma era signo de distinción entre la elite ilustrada (Cf. Nota $\left.\mathrm{n}^{\circ} 18\right)$ y en ella Gálvez se nutrió de la vida intelectual parisina de principios de siglo. Tuvo contactos con argentinos residentes allí, como Manuel Ugarte y un Leopoldo Lugones de paso y pudo, a través del crítico chileno Francisco Contreras, encontrarse con Rubén Darío, faro literario de esta generación. Luego de su estadía en Francia, Gálvez llegó a España, que, si bien no representaba un centro irradiador de cultura, encarnaba el regreso a la tierra de sus antepasados ${ }^{59}$. Allí, del mismo modo en que lo había hecho en París, frecuenta a escritores y se vincula con el mundo literario español de la época y en particular con los pertenecientes a la Generación del 98, cuya influencia se podrá percibir en su obra y también en la de Ricardo Rojas, no sólo en el plano ideológico sino también en el estético, tal como había ocurrido con el modernismo en sus años de formación.

A su regreso de Europa, Gálvez publica en 1913 un texto emblemático acerca de la significación de la cultura española en el contexto de la búsqueda de la identidad nacional que ocupaba los debates de entresiglos: El solar de la raza. El libro, escrito bajo la forma de un ensayo, resume las principales ideas de Gálvez respecto de la necesidad de recuperar, en el plano del discurso, la relevancia de la tradición hispánica para afianzar el modelo identitario nacional. En la mirada de Gálvez, España se erige como modelo ideal y resguardo de la espiritualidad necesarios para la conformación de

\footnotetext{
${ }^{59}$ Parte importante de sus experiencias de esta época está registrada en sus memorias, publicadas bajo el nombre Amigos y maestros de mi juventud, en 1944, el primero de los cuatro volúmenes que componen su obras Recuerdos de la vida literaria. Citado en Payá y Cárdenas (1978: 67).
} 
la propia nacionalidad ${ }^{60}$. El viaje, como forma de conocimiento, es la matriz desde la cual Gálvez construye su tesis acerca del "alma española" y de la necesidad de revelarla para obtener, a partir de ella, la fuerza espiritual necesaria para la construcción de una nación que se inscriba en la tradición hispánica en primer lugar y en la latina en definitiva, retomando así las ideas de un panlatinismo vigente en el pensamiento de intelectuales de la época. El denominado "panlatinismo" refiere al conjunto de ideas surgido a fines del siglo XIX en respuesta al avance anglosajón en el campo de la cultura y la política y que reivindica la pertenencia de los pueblos de raíces latinas a una comunidad supranacional, basada en la tradición grecolatina y en la exaltación de valores comunes como el espiritualismo y el idealismo. Si bien su origen se sitúa en Francia, en la América Hispana, el panlatinismo constituirá una matriz ideológica para pensar las relaciones tanto con España como con el creciente imperialismo norteamericano, en especial luego de la derrota española en la Guerra de Cuba. El arielismo de José E. Rodó es una de las manifestaciones de esta idea en el contexto americano, que compartirá Rubén Darío y que tendrá predicamento en las élites letradas del continente (Véase Bonfiglio 2010). En el caso de Gálvez, Franco Quinziano (2002: 89-90) expresa que su adhesión al ideario latinista adquiere rasgos particulares, a partir de la reelaboración de la tradición grecolatina a través de los “componentes hispánicos” por lo cual las ideas de latinidad e hispanidad están indisolublemente unidas en la concepción de Gálvez.

\footnotetext{
${ }^{60} \mathrm{Ya}$ en la dedicatoria de su libro, Gálvez traza una genealogía que lo incluye, en tanto argentino, en una continuidad hispánica que se propone como atemporal y permanente: "A la memoria de mis antepasados españoles; a los hijos de Hispania que contribuyen con su trabajo a edificar la grandeza de mi patria, y a mi abuelo materno, nacido en la entrañas mismas de Castilla la Vieja, consagro este libro a modo de concreto homenaje hacia la España admirable: la España donde todavía perdura una intensa vida espiritual; la España profunda y maravillosa; la España que es para nosotros, los argentinos, la casa solariega y blasonada que debemos amar". De este modo, la genealogía familiar y la experiencia personal se integran en una única herencia que vincula a los dos países, y el homenaje deviene en deber patriótico.
} 
El recorrido por las viejas ciudades españolas, que en la mirada del autor son el último baluarte de la vida espiritual disipada por la vida moderna, permite articular las reflexiones respecto de la Argentina y su destino como nación, tal como proclama al final del libro: "Pero antes de penetrar en la raza era preciso conocer su solar. ¡Saber de dónde venimos, sin lo cual nunca sabremos adónde vamos, lector!” (262). En tal sentido, Enrique Zuleta Álvarez afirma que: "la España de Gálvez era el modelo de un ideal, la forma poética que revestía su sueño de una regeneración espiritual de la Argentina" (1995: 189).

Las coincidencias con el ideario de Rojas son significativas — tal como se analizará más adelante - en cuanto al carácter espiritualista del enfoque, la idea de "comunidad" hispánica unida a través de la raza y, fundamentalmente, del idioma común, que enlaza a los pueblos y los incluye en una tradición compartida, y también en la necesidad de indagar en el "alma española" los principios de la propia nacionalidad. Este ejercicio retórico, cuyo locus enuntiationis es el "argentino", en tanto portador de una raza y un idioma que lo equipara con el español, refuerza un afán universalizador: "Y es que nosotros, a pesar de las aparentes diferencias, somos en el fondo españoles [...] Somos españoles porque hablamos el idioma español, como los españoles eran latinos sólo porque hablaban el latín. El idioma es quizás el único elemento caracterizador de las razas" (Gálvez 1913: 19). El "alma” como símbolo de esa búsqueda de espiritualidad vertebra las reflexiones de ambos escritores y los inserta en el pensamiento espiritualista y atemporal de una corriente del nacionalismo ${ }^{61}$.

\footnotetext{
61 Algunos autores denominan a esta corriente del pensamiento "nacionalismo espiritualista" 0 "espiritualismo nacionalista", en referencia a dos vertientes que confluyen en ciertas formulaciones que se concretan alrededor del Centenario y que se caracterizan básicamente por conjugar una visión centrada en el rescate de una serie de valores espirituales, que se consideran propios de la nación y a los cuales se puede captar intuitivamente, con los debates por la búsqueda de una identidad nacional a comienzos del siglo XX (Ramaglia 1998). Al respecto Oscar Terán (1992) incluye a Gálvez y a Rojas en lo que denomina un "nacionalismo espiritualista", formulado en oposición al avance de ciertas formas del materialismo, y que puede vincularse con algunos de los aspectos del panlatinismo.
} 
Ricardo Rojas viajó por primera vez a España en 1907, previo recorrido por Francia, Inglaterra y Alemania, a donde había ido enviado por el gobierno argentino para estudiar aspectos de la enseñanza de la historia en los centros universitarios de esos países. Dichas experiencias dieron origen a su obra La restauración nacionalista. Informe sobre la educación (1909), texto clave para analizar las concepciones educativas en el marco del Centenario y sus propias ideas respecto de la conformación de la nación. En tal sentido, el título del libro condensa las líneas de pensamiento de Rojas y lo pone en relación con el ideario nacionalista, tal como afirma en el Prólogo de la primera edición: "El actual momento nos aconseja, con patriótico apremio, el adoptar un ideal semejante [al de las naciones europeas] para que sea nuestra escuela el hogar de la ciudadanía donde se fundan y armonicen los elementos cosmopolitas que constituyen la nación" (1909: 10).

Durante su estancia en España trabó relación con Miguel de Unamuno, cuya influencia sería clave para la formulación de sus ideas respecto de la nación y la historia. Ambos intelectuales - el joven Rojas y el maduro Unamuno- mantuvieron una nutrida correspondencia, que se había iniciado en 1903, cuando Rojas le envió al salamantino un ejemplar de su primera obra poética. Durante los años siguientes, este intercambio continuó y además se enriqueció con los comentarios críticos y reseñas que Unamuno realizó sobre los textos de Rojas, en un ejercicio de legitimación que el argentino reivindicara años después ${ }^{62}$. Además de sus vínculos con Unamuno, Rojas se contacta en Madrid con Marcelino Menéndez y Pelayo, Ramón Menéndez Pidal (quien ya había visitado la Argentina en 1905) y también con hombres de letras, como el

\footnotetext{
62 En el Prólogo a la segunda edición de La restauración nacionalista de 1922, Rojas lamenta el poco eco que tuvo su obra al momento de su aparición y destaca los auspiciosos juicios que despertó en intelectuales como Unamuno, en sus artículos publicados en el diario La Nación en 1910 y de Ramiro de Maeztu aparecidos en La Prensa. Las referencias a los destacados escritores españoles funciona en el texto de Rojas como estrategia legitimadora y, a la vez, permite inscribir su producción en una línea filosófica compartida.
} 
novelista Benito Pérez Galdós; es decir, se comienza a delinear una red de relaciones entre intelectuales de ambos lados del Atlántico que perdurarán en el tiempo y que derivarán en la concreción de proyectos académicos de diversa índole.

En forma paralela a la investigación para la que había sido enviado a España, Rojas aprovechará su estadía en España para publicar una colección de reseñas sobre obras de autores españoles, que fue editada en 1907 en Valencia, a la que tituló El alma española (Ensayo sobre la moderna literatura castellana). Ya desde el título, la obra se inscribe en el pensamiento de Rojas en relación con ciertas vertientes del espiritualismo, presente en su ideario y en el de otros autores de la época. En la Dedicatoria: "A la memoria de los primeros conquistadores de América y a la obra de los nuevos escritores de España dedícales el autor R.R.” se cifra el programa ideológico de Rojas, al poner en una misma línea las armas y las letras, como un gesto de reconocimiento a la gesta hispana y a su literatura. Luego, en la Advertencia Preliminar, dirigida al lector, Rojas refiere al "alma" de las diferentes regiones de España y destaca la supremacía de "el alma castellana", ya que "Ésta esparció su tinte gris sobre las otras, asimilándolas por influencia de la centralización monárquica, de la tradición religiosa y de la comunidad espiritual del idioma" (1907, VII). Corona, religión e idioma conforman una unidad que reafirma la idea de "comunidad hispánica", idea que se corrobora cuando justifica su lectura de las obras españolas en el deseo de "[haber] contribuido a acercar hombres distantes de una misma habla española, y si estas páginas removiesen en ti, lector de mi raza, altas ideas y dudas fecundas, haciéndote pensar, pensar en contra o a favor de mis opiniones, pues el color de tu divisa no puede inquietar a quien no lleva ninguna" (VIII, el destacado es nuestro). La obra incluye comentarios críticos sobre ocho autores españoles y cierra con un extenso ensayo sobre Rubén Darío, al cual incluye en la "moderna literatura castellana" anticipada en el título, y del que afirma: "Nada más 
natural, pues si Darío pertenece a la América por su nacimiento, pertenece por su obra a todos los pueblos de habla española" $(203)^{63}$. Y al final del ensayo, cierra su argumentación: "Él [Darío] ha dado lugar a que por primera vez se reconociese la existencia de una ciudadanía intelectual común a todos los hijos de Hispano-América, por la tradición del alma castellana y el vínculo del idioma. Nicaragua lo ha parido, la República Argentina lo ha revelado; España lo adopta” (234). La figura de Darío viene así a encarnar "la unidad espiritual de esta raza", vehiculizada a través de un idioma y una tradición comunes y pone en un plano de igualdad a América y España en esa comunidad hispánica, a la vez que destaca el papel de la literatura como fuerza capaz de lograr esa unidad espiritual.

Fruto de ese viaje a España también es el libro Retablo español, en el que Rojas reúne una serie de crónicas escritas durante su permanencia en ese país y que publicará treinta años después, en $1938^{64}$. A pesar del tiempo transcurrido, estas "aguafuertes" permiten a Rojas volver a pensar lo español, que en ese momento atravesaba un contexto complejo ${ }^{65}$, tal como declara en la Explicación Preliminar: "Los americanos necesitamos entenderla [a España], porque su historia es parte de la nuestra. La caída o el ascenso de los valores españoles en la política del mundo interesa a nuestro propio destino, puesto que hablamos un mismo idioma” (9). Se recupera en estas líneas el pensamiento de Rojas respecto de la "unidad espiritual" de España y América desde una

\footnotetext{
${ }^{63}$ Las obras de los escritores españoles de las que se ocupa Rojas en el libro corresponden a Gaspar Núñez de Arce, Vicente Blasco Ibáñez, Pompeyo Gener, Benito Pérez Galdós, Pío Baroja, José Echegaray, Salvador Rueda y Joaquín Dicenta, es decir, autores contemporáneos o cercanos al momento en que Rojas escribió sus ensayos.

${ }^{64}$ El libro de Rojas fue publicado en la colección Panoramas de la Editorial Losada, que había sido recientemente creada por el español Gonzalo Losada. Dicha colección estaba a cargo de Guillermo de Torre, uno de los socios fundadores de la editorial, empresa que ocupará un lugar relevante en el mercado editorial argentino de medio siglo, tal como se analizará más adelante.

${ }^{65}$ En el momento de la publicación del libro, España estaba sumida en la Guerra Civil (1936-1939), conflicto que generó disputas ideológicas entre los intelectuales del ámbito hispánico y además provocó el exilio de intelectuales españoles, muchos de los cuales eligieron la Argentina, donde establecieron vínculos con los círculos locales.
} 
perspectiva americana y al mismo tiempo, traza su propia trayectoria intelectual como estudioso de la cultura española: "Desde entonces [1908] he estudiado a España en la cátedra universitaria, a la que llegué cuando volví de Europa ${ }^{66}$, y en obras que van desde El alma española (1908) hasta mi Cervantes (1935)” (8). En este caso, Rojas se posiciona en un lugar consolidado como docente e investigador, y, por ende, autorizado para reflexionar acerca de las complejas relaciones entre España y la Argentina.

Para 1938 el contexto político y social de la Argentina ya no es el del Centenario ni lo son sus debates, pero persiste en Rojas un interés por la cultura española, que, tal como él mismo lo declara, ha sido un eje que atravesó sus indagaciones a lo largo de las décadas $^{67}$. Muestra de ello es su estudio sobre Cervantes — que menciona en la cita anterior - resultado de una profundización de su trabajo de 1916, Poesías de Cervantes, antología lírica del escritor español, realizada por encargo de la Universidad Nacional de La Plata al conmemorarse el tercer centenario del fallecimiento del autor de Don Quijote de La Mancha. Las circunstancias de escritura de esta obra son particulares, ya que fue realizada durante el exilio forzoso que Rojas sufrió en la cárcel de Ushuaia en 1934, a causa de cuestiones políticas, tal como Rojas declara en el Apéndice que agregó a la edición de 1935: "escribí mi Cervantes en Ushuaia, durante un largo confinamiento político, que por ser arbitrario y por realizarse en el extremo austral de nuestra América,

\footnotetext{
${ }^{66}$ Ricardo Rojas fue designado para organizar lo que sería la Facultad de Humanidades de la Universidad Nacional de La Plata en 1909, definida como Sección de Historia, Filosofía y Letras y allí se desempeñó como profesor de Literatura durante más de una década. En 1913 es electo profesor titular de Literatura Argentina en la Facultad de Filosofía y Letras de la Universidad de Buenos Aires, cargo que ocupó por más de treinta años.

${ }^{67}$ Recuérdese, como dato, que ese año fue el del suicidio de Leopoldo Lugones, que había integrado, junto con Rojas y Gálvez, la corriente nacionalista del Centenario, aunque en el caso del escritor cordobés, sus devenires ideológicos lo ubicaron en un nacionalismo de corte conservador al final de su vida, en particular a partir del giro hacia la expresión política más contundente que realiza en la década de 1920 que desembocaría en "la orientación cada vez más política y menos poética" de su carrera como escritor (Dalmaroni 2006: 214). Este derrotero termina por distorsionar la imagen del escritor al servicio de la nación, tal como se delineaba en las intervenciones nacionalistas del Centenario, para devenir en una figura vinculada con los fascismos en ascenso en el país y en el mundo.
} 
resultó un episodio doblemente sudamericano" ${ }^{\text {68 }}$. De este modo, Rojas se inscribe en el linaje de cultores americanos de la obra cervantina: "En América, Cervantes tuvo siempre sinceros devotos: lo estudió Bello, lo imitó Montalvo, lo cantó Darío; pero en este caso actual hubo primores nuevos, porque jamás habíale ocurrido al maestro que le rindieran culto en aquel confín del continente" ${ }^{, 69}$. Rojas se reconoce no sólo como un declarado admirador de la obra cervantina, sino como partícipe del proceso de reconocimiento que desde América, y en particular desde finis terrae, con toda la impronta simbólica que este gesto presenta, se estaba realizando: “De allá [de Ushuaia] lo traje redivivo".

Otro elemento se agrega a las condiciones de producción de la obra: el impacto que la noticia sobre la reclusión de Rojas tuvo en el mundo intelectual español, que derivó en una misiva que iba a ser entregada al gobierno argentino para solicitarle la liberación del escritor ${ }^{70}$. Entre las razones esgrimidas en la nota, se destaca el espíritu de respaldo mutuo entre un colectivo identificado "trabajadores intelectuales", en el que se incluye a Rojas: "no nos mueve otro estímulo para tal petición que el deber de solidaridad entre trabajadores intelectuales que han servido todos de uno u otro modo a sus patrias en largos años de consagración a la labor intelectual". Este reconocimiento

\footnotetext{
${ }^{68}$ En 1934 Ricardo Rojas, de declarada militancia en la Unión Cívica Radical, fue confinado a Ushuaia junto con otras figuras políticas, luego de un fallido intento de derrocamiento del gobierno del general Agustín P. Justo y permaneció allí durante unos meses, hasta que fue liberado en mayo de ese año. Durante ese periodo dio forma al trabajo sobre Cervantes, que publicaría unos años después.

${ }^{69}$ Las citas corresponden a la versión del texto de Rojas que se encuentra disponible en el Centro Virtual Cervantes http://cvc.cervantes.es/literatura/quijote america/argentina/rojas.htm. El libro se publicó más tarde bajo el sello de la editorial Losada en 1948, con el título de Cervantes. En el prólogo, Rojas refiere a su exilio y las condiciones de escritura.

${ }^{70}$ En la semblanza de Ricardo Rojas que realiza su discípulo Ismael Moya (1961), se refiere a la reclusión de Rojas en Ushuaia y se adjudica el envío de una carta a Ramón Menéndez Pidal en la que informa de la situación. Según Moya, la respuesta del filólogo español fue la misiva firmada por "todos los grandes de la intelectualidad hispana" (52-53). Asimismo, Moya señala que, si bien la carta no llegó a ser enviada al gobierno, sí se le hizo llegar a Rojas como testimonio de la solidaridad que su caso había despertado entre los intelectuales. Los fragmentos de la nota enviada a Rojas figuran en el Apéndice a la edición de su obra Cervantes de 1935(disponible en http://cvc.cervantes.es/literatura/quijote_america/argentina/rojas.htm).
} 
pone de manifiesto la existencia de una conciencia de grupo, más allá de las fronteras geográficas, que incluye a los intelectuales "hispánicos", como se afirma en otro fragmento: “¡Y cuánto más obligatorio no es este sentimiento de fraternidad cuando se trata de dos países que como la República Argentina y España han de sentirse en más entrañable contacto, en más estrecho deber de hermandad que otros cualesquiera!”. La nota lleva la firma, entre otros, de Ramón Menéndez Pidal — con quien Rojas tenía una relación de varios años-, Armando Palacio Valdés, Gregorio Marañón, Pedro Salinas, Américo Castro — quien había estado en la Argentina como primer director del Instituto de Filología como se verá más adelante- y Juan Ramón Jiménez.

Más allá del carácter anecdótico del hecho, éste permite visibilizar los lazos entre intelectuales hispánicos que se fueron conformando desde principios del siglo XX y que contribuyeron a la consolidación de redes intelectuales sólidas que resultarán clave en el panorama académico y cultural de medio siglo.

El periplo hacia y en tierras españolas efectuado por Manuel Gálvez y Ricardo Rojas describe un momento en el proceso de conformación y consolidación de una corriente hispanizante de la intelectualidad argentina en el contexto de las revisiones y debates ideológicos que atravesaron los años del Centenario. Las experiencias de ambos escritores en contacto con la vida intelectual española de la primera década del siglo XX habilitaron un conjunto de reflexiones acerca de la realidad argentina, su historia y sus tradiciones. El ideario de la Generación del 98 español ofreció un paradigma para pensar las cuestiones nacionales bajo la óptica de la "restauración", es decir, de búsqueda en la propia tradición — opacada y desdibujada bajo el aluvión cosmopolita— de los principios "espirituales" que permitirán construir la nación. Esta visión de corte espiritualista tendrá en España un símbolo de lo perenne y duradero, del resguardo de ciertos valores y de la pertenencia a una "raza" común, unida por el vehículo 
invalorable del idioma. En un momento en el que el campo intelectual argentino se encuentra en pleno proceso de construcción, con la emergencia de la figura del escritor como un rol diferenciado en dicho campo (Altamirano y Sarlo 1997), tal como puede observarse en los escritos de los autores analizados, y, además, donde se plantea una nueva forma de relación entre los escritores y el Estado, en tanto agentes de una modernización literaria y representantes de las nuevas funciones atribuidas al escritor en ese proceso $^{71}$, el "retorno a España" constituye una matriz ideológica para concebir un proyecto nacional. Al mismo tiempo, a partir del fortalecimiento de las relaciones intelectuales entre españoles y argentinos, se va conformando una red intelectual vigorosa, que incluye intercambios, contribuciones y lecturas críticas a ambos lados del Atlántico, y que será clave para la consolidación de los estudios humanísticos en la Argentina de las décadas siguientes.

El periodo de entresiglos — que se extiende hasta el Centenario— se caracterizó por una serie de debates y polémicas en torno a la identidad nacional, en los que la lengua, como se ha observado, ocupó un lugar central, y se generó una corriente de pensamiento que puede englobarse bajo el rótulo de "nacionalismo". En las indagaciones acerca de la identidad nacional, el acercamiento con España originó una serie de discursos que permearon los debates que ocuparon a los escritores argentinos, en un momento en el que la figura del escritor se encontraba en plena reformulación, desde el letrado decimonónico ${ }^{72}$ hacia la del escritor "moderno", que se concebía a sí

\footnotetext{
${ }^{71}$ Para las relaciones entre escritores y Estado en la época del Centenario y la construcción de la figura del escritor como motor de la modernización estatal y del discurso literario como organizador y articulador de dicho proceso, véase Miguel Dalmaroni (2006).

${ }^{72}$ David Viñas se refiere a este grupo de escritores de finales del siglo XIX como los "gentlemenescritores", para los cuales el ejercicio de la literatura constituye "una ocupación lateral, imprescindible casi siempre, pero de manera alguna necesaria" (1996: 10). También señala el hecho de que ya en el periodo de entresiglos esta figura aristocrática comienza su ocaso y será reemplazada paulatinamente por la figura del escritor profesional. El tema de la profesionalización del escritor y los nuevos modos de socialización literaria aparece desarrollado en Altamirano y Sarlo 1997 [1983]: 161-199.
} 
mismo como parte relevante del proceso modernizador del Estado y de la construcción de la nación.

Junto con las nuevas configuraciones del escritor, también se advierte en la época una fuerte intervención de los intelectuales en la construcción de un canon nacional, en consonancia con los debates en torno a la identidad nacional. En este sentido, las colecciones impulsadas por Rojas (La Biblioteca Argentina) y José Ingenieros (La Cultura Argentina), ambas iniciadas en 1915, constituyen gestos concretos de estas formas de intervención en el campo cultural. Asimismo, señalan la importancia que la edición y circulación de textos, junto con la ampliación del público lector, adquieren en las primeras décadas del siglo XX, tal como lo demuestra el crecimiento del mercado editorial y la multiplicación de emprendimientos editoriales ${ }^{73}$.

En este contexto, el hispanismo se presenta como una de las respuestas ideológicas que los intelectuales argentinos ofrecieron ante la cuestión de la identidad nacional, en el marco más amplio de las relaciones con España, en particular luego de la Guerra de Cuba, y de la emergencia de un incipiente campo intelectual y académico. El fortalecimiento de las relaciones intelectuales con la Península — que se incrementará vertiginosamente a partir de los primeros años del siglo $\mathrm{XX}$ - tendrá un impacto decisivo no sólo en el campo intelectual y literario, sino en el ámbito académico, donde las redes conformadas entre ambos países irán configurando un hispanismo de corte académico, que permitirá el desarrollo de un "hispanismo científico" (Zuleta 1992), a partir de la década de 1920, en consonancia con la expansión de los estudios sobre la lengua y la literatura, la profesionalización de la actividad científica y la investigación en el campo académico, en particular, el universitario.

\footnotetext{
${ }^{73}$ Como ejemplo de estas imbricaciones entre la figura del escritor y del editor, Manuel Gálvez estará al frente de la Cooperativa de Ediciones Limitada Buenos Aires desde 1917 (de Diego 2006). Estas ideas se retomarán en para su análisis en el apartado dedicado a la conformación del mercado editorial en la Argentina a mediados del siglo XX.
} 


\subsubsection{Las figuras intelectuales y el rol de los centros culturales y académicos en la constitución del Hispanismo (1910- 1940)}

Durante las primeras décadas del siglo XX se asiste, desde la Argentina, a un proceso de (re)visión de las relaciones culturales con España. Este proceso —como se ha analizado - debe enmarcarse en otros más amplios que atraviesan ambos países, como consecuencia de las transformaciones políticas y sociales. Así, España se encuentra en un momento de replanteo de su situación en el contexto internacional, luego de la derrota de la Guerra de Cuba y de los efectos que la pérdida de los últimos territorios ultramarinos tuvo en su clase política y en sus intelectuales, concretados en los discursos que circulan en ese momento ${ }^{74}$. En ese proceso, las relaciones con la América hispana adquieren una relevancia particular, tal como puede observarse en las tentativas por afianzar los vínculos culturales, no ya desde una perspectiva de metrópoli centralista, sino en busca de afinidades y $\operatorname{contactos}^{75}$.

Por su parte, la Argentina está experimentando en las primeras décadas del siglo un acelerado proceso de cambios sociales, derivados fundamentalmente del fenómeno inmigratorio y de la formación de un incipiente campo intelectual en el que la figura del escritor ocupa un lugar central. Las vertiginosas transformaciones sociales, el crecimiento demográfico, la diversidad lingüística, las polémicas por el estatuto de la "lengua nacional", la modernización del campo cultural y de las prácticas de escritura, las complejas relaciones entre intelectuales y Estado, interpelan a las clases gobernantes y a sus intelectuales y promueven un extendido debate por la identidad nacional que se articulará bajo diversas formulaciones teóricas e ideológicas que pueden sintetizarse —

\footnotetext{
${ }^{74}$ Se ha denominado "hispanoamericanismo" — en consonancia con los "ismos" que caracterizan a los movimientos o corrientes - al conjunto de pensamientos políticos, ideológicos y culturales que tiene a la América hispana como objeto de análisis o de campo de aplicación (Rivadulla Barrientos 1992).

${ }^{75}$ En tal sentido, las visitas que académicos españoles realizaron en los primeros años del siglo constituirían un gesto de estos intentos de aproximación cultural y a la vez, de modernización de los estudios científicos (Cf. Capítulo 1 ).
} 
con la necesaria simplificación que implica - bajo el concepto de "nacionalismo". En el marco de dichos debates, las relaciones con España, su estatuto y su valor adquieren particular relevancia y se convierten en el punto de convergencias y divergencias ideológicas de largo alcance.

De la confluencia de estos procesos a ambos lados del Atlántico resultará la conformación de lazos intelectuales que se irán consolidando y ramificando en las décadas siguientes. Es posible reconstruir parte de este complejo entramado a partir de ciertos hitos que delinean las imbricaciones entre el campo intelectual español y el argentino, en particular a partir de la segunda década del siglo XX.

La creación en España de la Junta para Ampliación de Estudios e Investigaciones Científicas (JAE) en 1907 constituyó un paso clave para el impulso de la investigación científica en ese país, en un momento en que Europa asistía a una modernización e institucionalización del conocimiento científico ${ }^{76}$. Uno de los principios de dicha institución fue el fomento de las relaciones con otros centros académicos fuera de España, en busca de la apertura de la ciencia española hacia el exterior, con una clara vocación europeísta (Puig-Samper Mulero 2007: 23-26). Esta apertura se materializará en el otorgamiento de becas y estancias de investigadores en el exterior para su formación y también, en un gesto inverso, en el envío de académicos a América para afianzar los lazos que favorecieran el intercambio. Es de destacar que tempranamente la JAE demostró un interés por incentivar las relaciones con la América hispana, en particular luego del viaje de Rafael Altamira a tierras americanas (1910-

\footnotetext{
${ }^{76}$ La creación de la Junta para Ampliación de Estudios se inscribe en el proceso "regeneracionista" iniciado por un grupo de intelectuales españoles a finales del siglo XIX, que había dado como resultado la fundación en 1876 de la Institución de Libre Enseñanza, cuyo proyecto pedagógico, de raigambre krausista, fue pionero en el proceso de modernización de la educación en España. Fue fundada por un grupo de catedráticos, entre los que se encontraban Francisco Giner de los Ríos, quien fue su primer director, Gumersindo de Azcárate y Nicolás Salmerón y su impronta marcaría la vida cultural española en las primeras décadas del siglo XX.
} 
1911), quien fue un impulsor de acciones tendientes a consolidar los vínculos académicos y científicos con los países hispanohablantes.

En el ámbito de estas políticas, resultó clave la creación en 1910, en el seno de la JAE, del Centro de Estudios Históricos (CEH), que llegará a ocupar un lugar destacado en la investigación en la Península, no sólo por su prolífica trayectoria, sino porque en él se formaron varias de las figuras más preeminentes de la filología y los estudios históricos españoles de la primera mitad del siglo XX. Su primer director fue Ramón Menéndez Pidal, ya para entonces un filólogo reconocido, cuya impronta otorgará a la filología — disciplina en ese momento en gestación en el ámbito hispánico, aunque con una importante trayectoria en Europa - una centralidad indiscutible entre los programas y objetivos del Centro, junto con la historiografía y el derecho ${ }^{77}$. Asimismo, el Centro de Estudios Históricos desarrollará una política de acercamiento hacia América hispana, que se concretará a través de las visitas de académicos españoles con la finalidad de conocer la realidad americana, interesarse en su cultura y, además, difundir los avances de la ciencia española fuera de sus fronteras. Esto hizo que, en la práctica, la índole de las relaciones fuera unidireccional, ya que no se propiciaba desde la JAE un programa de intercambio, sino más bien una suerte de "embajada" cultural española en el continente (Bernabeu Albert y Naranjo Ogrovio 2007: 129-130). Según señalan estos autores, "En estos primeros años de la JAE y del Centro de Estudios Históricos, la Historia, la Filología o el Arte sirvieron de forma indistinta para acercarse a América Latina. Sus cátedras, aquí y allá, fueron semillas del americanismo que, de forma oficial, no logró una sección, una institucionalización dentro de la Junta, hasta 1933"

\footnotetext{
${ }^{77}$ Para una completa semblanza del Centro de Estudios Históricos y su rol en la profesionalización y actualización científica de España a comienzos de siglo XX, véase el capítulo "El Centro de Estudios Históricos y los orígenes de un modernos sistema científico español" de José María López Sánchez (en Puig Sánchez- Mulero, ed., 2007).
} 
$(130)^{78}$. De todos modos, estos contactos iniciales fueron tejiendo una red de relaciones científicas que fructificaron a ambos lados del Atlántico y que llegarían hasta Estados Unidos, donde se gestaría un importante núcleo académico relacionado con los estudios hispánicos ${ }^{79}$.

Desde esta orilla también las visiones de y sobre España a comienzos del siglo XX empezaban a adquirir nuevas dimensiones. Los viajes de intelectuales argentinos a la Península y sus correspondientes registros escritos ofrecieron miradas renovadas sobre la España de la época, en un intento por apartarse de la idea de una España vetusta, en ruinas y carente de savia vital, y colocarla como lugar de resguardo de ciertas tradiciones compartidas. De allí que, en muchos casos, los viajes devinieron en "redescubrimientos" de la Madre Patria como sede de la hispanidad desde donde proyectar la propia identidad (Cf. el apartado referido a los viajes de Manuel Gálvez y Ricardo Rojas). Estos "redescubrimientos" mutuos entre españoles y argentinos facilitaron la generación de lazos culturales que se plasmaron a través de las personalidades que visitaron la Argentina, pero también ocuparon un lugar destacado las instituciones, no sólo académicas o universitarias, sino otras de índole social y cultural, como fue el caso en la Argentina de la creación en 1912 de la Institución Cultural

\footnotetext{
${ }^{78}$ Ese año se crea oficialmente en el seno del CEH la Sección Hispanoamericana, cuyo primer director fue Américo Castro, discípulo de Ramón Menéndez Pidal, razón por la cual los primeros cursos de esta sección estuvieron orientados hacia los estudios de cuño lingüístico y filológico, aunque luego se fueron ampliando (Bernabéu Albert 2006). La figura de Castro será relevante en el ámbito del hispanismo en la Argentina, tal como se analizará más adelante. Uno de los proyectos llevados adelante por esta Sección fue la publicación de la revista Tierra Firme (1935-1936), de vida efimera debido a la irrupción de la Guerra Civil.

${ }^{79}$ Entre los filólogos que se formaron en el CEH, Federico de Onís (1885-1966) fue quien impulsó, a partir de su estancia en la Columbia University en 1916, los estudios hispánicos en el ámbito norteamericano. En 1920 fundó en esa universidad el Instituto de las Españas, cuyo órgano de difusión será la Revista Hispánica Moderna, creada en 1934. La larga y fructífera trayectoria de Onís en Estados Unidos continuará luego en Puerto Rico, durante las décadas de 1950 y 1960, donde dirigió el Departamento de Estudios Hispánicos de la Universidad de Puerto Rico (Montero Reguera 2005: 2-3).
} 
Española de Buenos Aires ${ }^{80}$. Según afirma Pilar García Mouton "Estas Instituciones [las

de Buenos Aires y de Uruguay, creada en 1919], y otras similares que vinieron después, resultaron fundamentales para desarrollar la vocación americanista de la Escuela de Filología Española, porque a través de ellas se canalizó su actividad docente y sus investigaciones americanas" $(2007: 172)^{81}$.

La creación de la Institución Cultural Española de Buenos Aires fue el resultado de las gestiones realizadas por la comunidad española residente en Buenos Aires y su impulsor principal fue Avelino Gutiérrez, un médico español radicado en la Argentina ${ }^{82}$. En efecto, ya para ese momento la JAE propulsaba la conformación de un vínculo académico más fluido con América y daba forma a las políticas de intercambio y colaboración que, en un principio, estuvieron teñidas de cierto "paternalismo", dado que fueron concebidas más como proyecto de extensión y difusión de la ciencia española que como un intercambio en pie de igualdad entre académicos de ambos países (López

\footnotetext{
${ }^{80}$ Un rasgo de la colectividad española de Buenos Aires fue su patriotismo en relación con España, el cual se plasmó en numerosos discursos. Según señala García Sebastiani, "el patriotismo de los españoles emigrantes movilizó activos, conmovió a colectivos, generó solidaridades en contextos de frenética movilidad social y de alternativos proyectos nacionalizadores con los que compitió, fue utilizado con fines políticos y, finalmente, forjó memoria" (2013: 471). En ese marco se fundaron instituciones que capitalizaron las acciones en pos de reivindicar el sentimiento patriótico respecto de España, como fueron el Club Español y la Asociación Patriótica Española (Cf. Nota ${ }^{\circ}$ 54). Esta última tuvo un papel relevante en el impulso de la celebración en la Argentina del "Día de la Raza" el 12 de octubre, declarado por el decreto 7112 del presidente Hipólito Yrigoyen en el año 1917. En el Visto del texto normativo se menciona específicamente el "memorial presentado por la Asociación Patriótica Argentina a la que se han adherido todas las demás sociedades españolas y diversas instituciones argentinas, científicas y literarias".

${ }^{81}$ La de Buenos Aires fue la primera de las instituciones de este tipo creadas fuera de España, a la que siguieron cronológicamente la de Uruguay, en 1919 y el ya mencionado Instituto de las Españas de Estados Unidos en 1920 (Cf. Nota $n^{\circ}$ 79). A partir de la segunda década del siglo se continuaría con la creación de instituciones similares en América.

${ }^{82}$ Avelino Gutiérrez del Arroyo (1864-1945) nació en España pero se trasladó joven a la Argentina, donde realizó sus estudios universitarios en la Facultad de Medicina de la Universidad de Buenos Aires. Allí se destacó no sólo como docente universitario, sino por su voluntariosa vocación por afianzar los vínculos académicos con España. Como gesto cabal de esa voluntad, en 1912 y 1913 efectuó donaciones de dinero a la JAE, que posibilitaron la concreción de tres estancias de investigación de becarios españoles en el exterior. Tales actitudes de Gutiérrez le merecieron el reconocimiento de las autoridades de la JAE, tal como puede leerse en la Memoria correspondiente a los años 1912-1913: "Cuantos han visitado la República Argentina en misión de cultura, conocen el cariño del donante [Avelino Gutiérrez] á su patria de origen y su ferviente anhelo de que ella sea hogar espiritual para las nacionalidades hispanoamericanas" (JAE 1914: 167).
} 
Sánchez 2007, García Mouton 2007). En este proceso resultó clave el apoyo de las colectividades españolas en el continente, el que, junto con el prestigio que había ido adquiriendo la ciencia española y la lengua compartida, favorecieron e impulsaron los emprendimientos culturales españoles a este lado del Atlántico, en particular, en la Argentina, país en el que la comunidad hispánica era una de las más numerosas (Formentín Ibáñez y Villegas Sanz 1992: 91-92).

Así, en 1914 — el mismo año que en el CEH de Madrid se fundaba la Revista de Filología Hispánica - la vocación por constituir un espacio institucional de acercamiento entre intelectuales españoles y argentinos se corporeiza en la Institución Cultural Española $(\mathrm{ICE})^{83}$. Su base estaba asentada en la creación y sostén de una cátedra en la que participarían académicos y científicos españoles y en el fomento de toda clase de actividades culturales entre España y la Argentina (López Sánchez 2007: 88). La vinculación con la Junta para Ampliación de Estudios quedó plasmada desde los inicios, ya que, según se establece, la selección y designación de los académicos que ocuparían la cátedra recae en dicho organismo, y también la Universidad de Buenos Aires participa de este proyecto, ya que es la que la que ofrece el espacio para la cátedra. De este modo se configura un ámbito en el que confluyen las políticas de extensión españolas hacia América y la voluntad de consolidar la presencia española en el incipiente campo cultural argentino a través de instituciones culturales y académicas.

Desde su inicio en 1914, las cátedras patrocinadas por la ICE estuvieron a cargo de relevantes figuras de la ciencia y la investigación españolas de la época. La cátedra inaugural convocó a Ramón Menéndez Pidal, director del CEH de Madrid, quien dedicó las conferencias a homenajear a la figura de Marcelino Menéndez y Pelayo, fallecido

\footnotetext{
${ }^{83}$ A diferencia de la JAE y de los institutos que la conformaban, la ICE de Buenos Aires no era un organismo dependiente del Estado, sino que su sustento eran las contribuciones de los socios a través de las asociaciones de españoles radicadas en Buenos Aires.
} 
dos años antes ${ }^{84}$. La presencia del filólogo español en la apertura de las actividades académicas de la recientemente creada Institución Cultural Española pone de relieve, por un lado, el carácter destacado que la disciplina filológica estaba adquiriendo en el seno del desarrollo científico español, y por el otro, ya anticipa la centralidad que Menéndez Pidal, y con él el Centro de Estudios Históricos, ocuparía en relación con el afianzamiento de los estudios hispánicos en la Argentina en la década siguiente. Asimismo, a partir de la creación de la ICE, Buenos Aires comienza a erigirse como uno de los principales centros de expansión de actividades culturales españolas y de este modo, la institución se convierte en "modelo" de las acciones españolas en América (García Mouton 2007: 173). Esto determinó que en los años siguientes las relaciones entre la JAE y América Latina estuvieran en gran medida mediatizadas por la ICE de Buenos Aires, desde donde se proponían los nombres de los profesores españoles visitantes y a donde llegaban las solicitudes de otras instituciones similares del resto de América; además, Buenos Aires era el primer destino de los académicos peninsulares, quienes en ocasiones, luego de su estadía en la ciudad, se dirigían a Uruguay, Chile u otros países americanos ${ }^{85}$. Estas visitas tuvieron muy buena acogida en el ámbito cultural rioplatense y fueron fortaleciendo el clima de acercamiento entre España y la

\footnotetext{
${ }^{84}$ Un dato significativo obtenido durante esta investigación: los textos de las conferencias que Menéndez Pidal ofreció en el marco de la cátedra de la ICE permanecen inéditas y se supone formaban parte de un programa de mayor alcance en el que el filólogo iba a encarar un exhaustivo estudio de la vida y la obra de Menéndez y Pelayo, el cual no llegó a concretar. Una parte importante de estos manuscritos se encuentran en la Fundación Menéndez Pidal de Madrid y existe actualmente un proyecto para editarlos, según afirma Sara Sánchez Bellido (2014), en un artículo en el que presenta el estado del material y de los problemas en torno a la edición.

${ }^{85}$ Como dato ilustrativo de estas prácticas puede citarse el viaje de Menéndez Pidal a Chile luego de su gira por Buenos Aires en 1914; en 1916 llega a la Argentina el filósofo José Ortega y Gasset, cuyas conferencias despertaron un gran interés en la comunidad y después se desplaza al interior, donde recorre varias provincias y finalmente recala en Montevideo. Un derrotero similar realiza en 1917 Julio Rey Pastor, científico español que da sus conferencias primero en Buenos Aires y La Plata y luego en Montevideo. Del registro de las actividades de los profesores invitados se desprende que formaban parte de la estadía en América la visita a otros centros académicos y las disertaciones destinadas al público. Desde su creación hasta el estallido de la Guerra Civil en 1936 visitaron el país veinte profesores de diversas disciplinas y todos tuvieron buenas recepciones (Formentín Ibáñez y Villegas Sanz 1992: 104107).
} 
Argentina, a la vez que este país ocupaba un lugar cada vez más relevante en este concierto. El viaje de Avelino Gutiérrez a España en 1920 constituyó un momento clave para este proceso de afianzamiento de vínculos entre ambos países y puso de manifiesto la entidad que la ICE de Buenos Aires tenía en ese proceso.

En forma paralela a estas acciones impulsadas desde la ICE y sus vínculos con la JAE, el ámbito universitario argentino también está atravesando un periodo de cambios y transformaciones, intensificados por la Reforma Universitaria de 1918 y los debates que impulsó respecto del papel de la institución universitaria en la sociedad argentina ${ }^{86}$. Originado en la Universidad Nacional de Córdoba, el movimiento reformista se difundió por todo el país y acarreó cambios importantes en el sistema universitario, entre los cuales se cuenta la actualización de la formación científica y académica, lo que se verá plasmado en la creación de institutos en el seno de la universidades, destinados a fomentar la investigación científica en el país.

En ese marco de revisión, el estudio de las humanidades adquiere relevancia y se inserta en los proyectos de reforma educativa que el Estado argentino venía implementando desde principios del siglo para otorgar un sesgo nacional a los programas de formación de los ciudadanos, en consonancia con el clima de creciente nacionalismo movilizado por los debates por la identidad nacional en torno al Centenario (Cf. apartado anterior). La propuesta de Ricardo Rojas, formulada en La restauración nacionalista de 1909, confería a la historia un lugar preponderante entre las disciplinas humanísticas —en un sentido análogo a los criterios adoptados por la JAE al momento de crear el Centro de Estudios Históricos en 1910 (Toscano y García

\footnotetext{
${ }^{86}$ La denominada Reforma Universitaria fue un movimiento estudiantil originado en la Universidad de Córdoba en 1918 que abogaba en contra del autoritarismo vigente en el sistema de educación universitaria en la Argentina. Sus reivindicaciones incluían la participación de los estudiantes en el gobierno universitario, la autonomía universitaria, la renovación de los planes de estudio de las carreras y el acceso y permanencia de los docentes a través de concursos. Las repercusiones nacionales e internacionales de este evento fueron notorias y el movimiento reformista se expandió por América Latina.
} 
2009: 115)—, y a la filología una particular importancia para la educación, ya que se enraizaba con los estudios sobre la lengua y los textos, vehículos privilegiados para acceder al conocimiento del "espíritu nacional". Esta postura de Rojas ya desarrollada en sus obras tempranas, se complementará con iniciativas tendientes a dar estatuto institucional a los estudios filológicos. La filología española había adquirido, a partir de la impronta de las investigaciones de Ramón Menéndez Pidal, un relieve particular y gozaba ya de prestigio académico (García Mouton 2007: 167-168) ${ }^{87}$. La creación de la Revista de Filología Española en 1914 dio visibilidad internacional a los estudios filológicos hispánicos que, si bien en un comienzo estuvieron abocados fundamentalmente a relevar la fuentes históricas, lingüísticas y literarias de España, con el correr de las décadas y con el avance de las relaciones entre la Península y América hispana, los temas americanos empiezan a despertar el interés de los filólogos españoles, tal como lo demuestran los contactos que a principios del siglo XX mantuvo Menéndez Pidal con intelectuales hispanoamericanos en busca de la presencia del romancero español fuera de la Península, entre ellos con el propio Rojas (Cf. Nota $n^{\circ}$ 52). De estos contactos iniciales comienzan a forjarse lazos que se acrecentarán en las décadas siguientes, y la figura de Menéndez Pidal tendrá particular importancia para la consolidación de los estudios filológicos en la Argentina.

El ideario de Rojas respecto de la preeminencia de los estudios humanísticos en el proyecto educativo nacional, y en particular los vinculados con la lengua y sus manifestaciones culturales, se había ido concretando a través de sus publicaciones pero también - y éste es un aspecto que nos interesa destacar - a partir de la incorporación

\footnotetext{
${ }^{87}$ La impronta de los estudios de Menéndez Pidal marcó las características que esta disciplina adquirió en España y que marcaron los derroteros que siguió durante gran parte del siglo XX. Según señala Rubio Tovar, "Menéndez Pidal desarrolló la filología en sus dos ramas básicas: la literaria y la lingüística, y sentó las bases de campos diversos: la dialectología, la edición de textos, la etimología, la gramática histórica y el estudio de obras literarias. [...] El haber mantenido esta unidad es un hecho singular que caracteriza los estudios de la escuela de filología española frente a la de otros países" (2004: 26).
} 
de las disciplinas humanísticas con un mayor estatuto en el ámbito académico. En este sentido, su presencia fundadora en la Sección de Historia, Filosofía y Letras de la Universidad Nacional de La Plata en 1909, la creación de la cátedra de Literatura Argentina que inauguró en 1913 en la Universidad de Buenos Aires, su tarea docente en ambas universidades y su posterior actuación como decano de la Facultad de Filosofía y Letras de la Universidad de Buenos Aires, estuvieron signadas por los intereses en pos de cimentar una "escuela argentina" en la que las humanidades desempeñaran un rol central e iniciar una escuela filológica argentina, a fin de profundizar el estudio sobre el idioma y el patrimonio cultural (Rodríguez Temperley 2008: 234 y ss.). Para Rojas, la fuente en la que abrevar para el desarrollo de los estudios filológicos argentinos estaba en España, donde la disciplina ya exhibía una trayectoria sólida y, además, compartía el acervo común de la lengua, "la llave mágica para entrar en el secreto de nuestros propios corazones", tal como afirma en el discurso en la inauguración del Instituto de Filología (1923: 10-13). La inclusión de la Argentina en el desenvolvimiento de una filología hispánica y universal era uno de los objetivos que Rojas se planteaba al proponer la creación del Instituto.

El proyecto de creación del Instituto de Filología en el ámbito de la Facultad de Filosofía y Letras debe encuadrarse en las coordenadas políticas y académicas de la vida universitaria del momento, atravesadas por las transformaciones post reformistas de 1918 en relación con la actividad científica en la universidad. Según señala Pablo Buchbinder, "en Filosofía y Letras, entre 1921 y 1942, fueron creados dieciséis institutos a través de los cuales la Facultad se proponía canalizar la investigación y la producción científica" (1997: 131). Concebidos como centros en los cuales se articulaba la docencia con la investigación, una de las funciones que caracterizaba a las actividades de los institutos era la edición y publicación de trabajos, traducciones y fuentes 
documentales como una contribución a la enseñanza. Esto les otorgó una impronta especial y en algunos casos, llegaron a alcanzar prestigio propio aún fuera de los claustros universitarios.

\subsection{Hispanismo y universidad.}

\subsubsection{El Instituto de Filología de la Universidad de Buenos Aires: génesis y primeros años (1922 -1927)}

La historiografía en torno a la génesis del Instituto de Filología parece haberse desarrollado en torno a dos líneas: la primera destaca la continuidad entre las acciones del CEH de Madrid en relación con la consolidación de la filología, mediatizada por el papel que desempeñó la ICE de Buenos Aires, y la creación del Instituto, es decir que su fundación sería entendida como parte del programa implantado por las instituciones españolas para América. Otra línea le confiere a Rojas una actuación fundante en el marco de su proyecto nacionalista y oblitera un tanto la presencia de las instituciones peninsulares en la fundación del Instituto ${ }^{88}$. A pesar de las diferencias de enfoque, investigaciones recientes acerca de este centro han puesto en entredicho ciertas afirmaciones cristalizadas y han revisado críticamente los procesos que llevaron a la creación del Instituto de Filología en 1923. En este sentido, Toscano y García señala que "la creación del IF [Instituto de Filología] resulta de la integración conflictiva de los proyectos diferentes: el nacionalismo reformista de Ricardo Rojas y el programa de modernización científica desarrollado en España por la JAE (y difundido en la Argentina por la Institución Cultural Española)" (2009: 113-114). Esta tensión

\footnotetext{
${ }^{88}$ En un trabajo reciente, Florencia Calvo (2009) hace referencia a esta mirada divergente de la historiografía acerca de los orígenes del Instituto y de sus filiaciones. También Toscano y García, en sus investigaciones sobre la historia del Instituto, revisa las versiones consagradas y da cuenta de las tensiones no siempre explicitadas alrededor de este proyecto $(2009 ; 2011)$.
} 
inaugural atraviesa los primeros años del Instituto y marca los avatares $\mathrm{y}$ las inestabilidades que caracterizaron ese periodo.

La vocación de Rojas por consolidar en la Argentina una disciplina casi desconocida y sin tradición en el campo académico nacional estaba en estrecha relación con su proyecto nacionalista, de allí que si bien reconoce la necesidad de buscar en España los referentes idóneos para llevar adelante el proyecto de desarrollo de la filología en el país, su idea no era que el Instituto de Filología se convirtiera en una filial del centro madrileño, sino que tuviera su propia idiosincrasia y se dedicara a estudiar temas vinculados con la lengua nacional y sus derivaciones, y que la relación con España fuera de colaboración mutua y no de dependencia (Rodríguez Temperley 2008: 240-241). Así, el proyecto de Rojas suponía líneas de investigación en cuatro direcciones: filología general, romance, americana e indígena (Romanos 2013: 38), lo cual anticipa el carácter integrador que se pretendía para el Instituto y la impronta americana de los estudios.

De lo expuesto se desprende que los inicios del Instituto de Filología son el resultado de un entramado complejo que resulta de la conjunción — no siempre desprovista de conflictos - del plan impulsado por Rojas para fundar en la Argentina una escuela filológica de impronta nacional con las políticas expansivas del campo científico español encarnadas en el CEH de Madrid y del creciente prestigio que las instituciones hispánicas y sus representantes habían logrado en el ámbito cultural argentino de las primeras décadas del siglo XX.

A principios de la década de 1920 comienza a cristalizarse el proyecto de creación de un Instituto que impulsara las investigaciones en materia lingüística y filológica, área que aún estaba vacante en el ámbito universitario. Finalmente, en junio de 1922 el Consejo Directivo de la Facultad de Filosofía y Letras, presidido por el 
entonces decano Ricardo Rojas, aprobó la creación de un instituto que inicialmente se denominará Instituto de Lingüística, aunque el nombre con el que se lo identifica desde su fundación sea "Instituto de Filología" 89 . Las gestiones de Rojas continúan en pos de hallar un especialista para la dirección del recientemente creado instituto, dado que se trata de una disciplina sin tradición en el país, para lo cual escribe a Menéndez Pidal — con quien ya había tenido contactos anteriores tanto epistolares como personales, durante su estancia en España a comienzos de siglo — a fin de solicitarle, en su carácter de director del $\mathrm{CEH}$, la sugerencia de una figura que estuviera en condiciones de organizar y poner en marcha el instituto. El filólogo español propone a uno de sus discípulos que se desempeñaban con él en el CEH: Américo Castro. La inauguración oficial del Instituto se hará efectiva en junio de 1923, con la presencia de autoridades académicas y diplomáticas ${ }^{90}$, lo que de algún modo resaltaba el interés que la creación del instituto despertaba no sólo en el ámbito universitario, sino también en la sociedad, tal como puede verse el eco que la llegada de Castro a Buenos Aires tuvo en la prensa local ${ }^{91}$.

La gestión de Castro al frente del Instituto duró unos pocos meses, ya que finalizó a fines de 1923, pero por su carácter inaugural permite analizar algunos

\footnotetext{
${ }^{89}$ En una detallada investigación, Toscano y García (2009) releva los vericuetos administrativos que sufrieron los proyectos de creación del Instituto, las lagunas informativas, las fluctuaciones de denominación, las diferencias reglamentarias referidas a remuneraciones y los términos de contratación de los directores, lo que expresa las discusiones en torno a su organización y sus objetivos. En lo referido al nombre oficial del Instituto, recién en 1940 una ordenanza propulsada por Amado Alonso reemplazará el nombre original por el de Instituto de Filología. Con el correr de los años, a causa de las vicisitudes de la vida institucional, el instituto sufrirá cambios en su organización y su nombre, como se verá más adelante.

${ }^{90}$ La presencia del embajador español en la Argentina durante el acto inaugural puede ser leído como una muestra explícita de la vinculación entre la creación del Instituto y las acciones del CEH de Madrid a través de la mediación de la ICE de Buenos Aires (Toscano y García 2009: 122).

${ }^{91}$ El diario La Nación registra el arribo del filólogo y lo vincula explícitamente con las actividades del ICE, más que con su inminente función al frente del Instituto. Asimismo, el diario La Prensa también registra el acto de asunción de Castro y transcribe su discurso en forma completa (La Prensa, 7 de junio de 1923. Consultado en el Archivo de la Casa Museo Ricardo Rojas, octubre de 2014).
} 
aspectos que van delineando la trayectoria del centro y su relación con el ámbito académico nacional, y también los modos en que se fueron modulando los lazos con el CEH de Madrid. En primer lugar, los asuntos lingüísticos ocuparon un lugar central entre las acciones proyectadas por Castro, tal como lo expuso en el discurso de asunción de la dirección y que continuaría en los objetivos propuestos y también en las actividades de extensión que impulsó, en particular en las conferencias ofrecidas en diferentes ámbitos y en los artículos periodísticos publicados. Asimismo, inició una línea de trabajos de índole lingüístico-filológica, algunos de los cuales fueron editados y otros estaban en proceso de elaboración al final de su mandato. Al momento de dejar la dirección del Instituto, Castro elaboró un informe de lo actuado en esos meses iniciales, que permite observar ciertas desavenencias con el ideario original de Rojas en relación con la creación del centro, ya que los temas de lenguas indígenas o la confección de materiales gramaticales destinados a la enseñanza no estuvieron presentes en este periodo (Toscano y García 2009: 124-125). A pesar de estos desajustes primeros, el balance de la gestión de Castro al frente del Instituto redundó en la difusión de la filología no sólo en los claustros académicos, sino también ante un público más amplio, y permitió colocar al Instituto en la escena pública de un Buenos Aires ávido de novedades y de saberes. La figura de Castro estuvo presente en la vida social y cultural porteña en esos meses de 1923 y ejerció la representación de la vocación expansionista $\operatorname{del} \mathrm{CEH}^{92}$.

Sin embargo, en el contexto del campo intelectual argentino de la década de 1920, la creación de un centro universitario destinado a investigar cuestiones

\footnotetext{
92 Además de su desempeño en el Instituto de Filología, Castro dictó cursos en la Universidad Nacional de La Plata, donde trabó relación con jóvenes estudiosos como Arturo Marasso. En 1924, en ocasión de un homenaje que los profesores de la Facultad de Humanidades ofrecieron a Castro, éste destacó la figura de Marasso, al que definió como "una de las mayores esperanzas con que cuenta la universidad argentina en lo que atañe a los estudios de literatura española" (Revista Humanidades, Tomo VIII: 104105). La trayectoria posterior de Marasso ratifica la visión del filólogo español, a la vez que lo inserta en una tradición filológica compartida.
} 
lingüísticas a partir de la aplicación de métodos filológicos provenientes de la escuela española acarreó no pocos debates, que excedieron el ámbito académico y se dirimieron también en la arena periodística de la época ${ }^{93}$. El tema de la "lengua nacional", que había ocupado los discursos ideológicos desde el periodo postcolonial, adquiere en la década de 1920 nueva efervescencia, en parte impulsada por la decisión de formar un instituto que se ocupara específicamente y desde una perspectiva epistemológica particular del estudio de la lengua, cuestión que hasta ese momento había sido objeto de miradas diversas. A pesar de ello, a excepción del libro de Abeille, los debates en torno al idioma nacional estuvieron teñidos de aspectos más políticos e ideológicos que específicamente lingüísticos. De allí el cambio de perspectiva y los desplazamientos que provocan esta institucionalización de los estudios filológicos, tal como señalan Degiovanni y Toscano y García, “desde entonces [la creación del Instituto de Filología], los filólogos en la Argentina podrán hacer valer una autoridad disciplinaria que colocará inevitablemente al resto de los estudiosos en el terreno de los amateurs o en el de los aprendices" (2010: 7).

Este posicionamiento en el campo intelectual producirá una división en dos sectores diferenciados: los lingüistas o filólogos, con formación académica y científica por un lado, nucleados en el Instituto de Filología, y aquellos que abordaban el tema de la lengua desde perspectivas culturales, históricas o literarias ${ }^{94}$, cuya autoridad se definía por sus propuestas y sus intervenciones, muchas de ellas a través de publicaciones que circulaban entre diferentes círculos y también con diversas

\footnotetext{
${ }^{93}$ Para un detallado análisis de las diatribas entre los miembros del Instituto y algunas figuras del mundo intelectual de la época pueden consultarse los trabajos de Degiovanni y Toscano García (2010) y Miranda Lida (2012).

94 Las intervenciones de Jorge Luis Borges en las polémicas de la época acerca del lenguaje de los argentinos pueden incluirse en el marco de su propia afirmación en el campo literario. Al respecto, resulta esclarecedora la tesis que desarrollan Degiovanni y Toscano y García que presenta a las reflexiones de Borges acerca del lenguaje como posiciones estéticas antes que ideológicas (2010).
} 
repercusiones ${ }^{95}$. La prensa de la época se convirtió en la caja de resonancia de numerosas discusiones en torno de la legitimidad de los enfoques propiciados desde el Instituto, así como la de los filólogos españoles para abordar el estudio de la lengua en la Argentina. De este modo se reavivaron las polémicas respecto del lugar de España en relación con el conocimiento de la realidad americana y de su posición de árbitro y autoridad en cuestiones lingüísticas. Esto da cuenta de un estado del campo intelectual, de las pugnas por conformar tradiciones propias y por consolidar la identidad nacional y por otorgarle al lenguaje - y a través de él al discurso literario argentino - un lugar definido en el horizonte del mundo hispánico.

Asimismo, las tensiones originadas por la creación del Instituto de Filología y por las direcciones teóricas y metodológicas que la "nueva" disciplina generaba a propósito de la cuestión de la lengua en el ámbito cultural argentino signaron la gestión de Castro al frente de la institución, otorgándole a su figura y a la del centro una visibilidad inusitada en la vida cultural. Al mismo tiempo, la exposición pública y las líneas de trabajo delineadas por Castro durante su mandato también repercutieron en las relaciones con el CEH, tal como lo analizan Degiovanni y Toscano y García (2010), a partir de las cartas que Castro envió al centro durante su estadía en Buenos Aires. La lectura propuesta por los investigadores pone de manifiesto, por un lado, el desacuerdo de Castro respecto de los cambios en las designaciones de los directores — según lo pautado entre Rojas y Menéndez Pidal, a Castro debía sucederlo Tomás Navarro Tomás, pero éste desiste y Menéndez Pidal sugiere el nombre de Agustín Millares Carlo—, y por otro, el cuestionamiento a las observaciones críticas hechas sobre la orientación de

\footnotetext{
${ }^{95}$ Entre algunas de las figuras que participaron en las polémicas con el Instituto estuvieron Arturo Costa Álvarez, traductor y reconocido estudioso del lenguaje y autor del texto Nuestra tierra (1922), quien a través de la prensa fustigó las acciones del centro y a sus directores, y Vicente Rossi, autor de los célebres y difundidos Folletos lenguaraces, verdaderas diatribas en contra de cualquier forma de autoridad lingüística, entre las cuales el Instituto de Filología fue uno de los antagonistas destacados (Lida 2012).
} 
sus indagaciones, así como sobre sus actividades como expositor y conferencista en diferentes ámbitos, ya que considera que son modos de reforzar los lazos con España, y, por lo tanto, implican una dimensión política que no debería ser desdeñada. En definitiva, según demuestran los autores, la gestión inaugural de Castro en el Instituto de Filología evidenció las primeras divergencias con el proyecto original propulsado por Rojas, pero también con las aspiraciones del CEH en relación con la implementación de centros fuera de España, al tiempo que reactivó las querellas por el estatuto de la lengua nacional, de los estudios lingüísticos y su vinculación con la formación de los ciudadanos $\mathrm{y}$, fundamentalmente, por el papel que le correspondía a España, representada en la figura de los filólogos, en ese replanteo ${ }^{96}$.

Los primeros cuatro años de vida del Instituto estuvieron signados por la inestabilidad debida al cambio de directores y por los intentos por dar forma a un programa de trabajo ${ }^{97}$. A Castro lo sucedió en la dirección del Instituto el investigador canario Agustín Millares Carlo, quien estará en el cargo durante 1924. Millares Carlo pertenecía a la pléyade de filólogos formados en el CEH bajo la tutela de Menéndez Pidal. Especialista en paleografia ${ }^{98}$, latinista, historiador de la lengua, la formación académica de Millares Carlo lo acercaba más a los estudios y a la filología clásicos que a las líneas de investigación que Rojas propiciaba para el Instituto, más vinculadas con

\footnotetext{
96 Para mediados de la década de 1920 ya se había despertado en Castro una vocación "hispanoamericanista" en sus estudios, tal como se desprende del discurso que dio en ocasión de un homenaje en su honor en la Universidad Nacional de La Plata (Cf. Nota $n^{\circ}$ 92). El texto fue publicado en la revista Humanidades bajo el título "El verdadero hispano-americanismo" y esboza ya las principales líneas de su pensamiento, que desembocarán en la creación de la Sección Hispanoamericana del CEH de Madrid en la década siguiente (Cf. Nota $\left.{ }^{\circ} 78\right)$.

97 La historia del Instituto de Filología ha sido reseñada en trabajos relevantes, donde se encuentra información exhaustiva y detallada respecto de su trayectoria (Weber de Kurlat 1975, Buchbinder 1997, Toscano y García 2009, 2011). Asimismo, con motivo del $90^{\circ}$ aniversario de la inauguración del Instituto, Melchora Romanos publicó una semblanza de su historia en la revista Ínsula 793-794 (2013: 38-42).

${ }^{98}$ El interés de Rojas por la paleografía se relaciona con su voluntad de formar investigadores en esta disciplina para enseñar a transcribir manuscritos y documentos relacionados con la historia de América que estaban en repositorios y archivos (Cf. La restauración nacionalista).
} 
el estudio de las variedades lingüísticas del español de la Argentina y con la regulación de la norma culta. Las reseñas acerca de los primeros años del Instituto ubican a la gestión de Millares Carlo como una continuidad de la de Castro (Toscano y García 2009: 127) y, en general, sólo destacan como hecho relevante de los meses a cargo del centro la publicación del primer volumen de los Cuadernos del Instituto $^{99}$ y la continuación de algunas de las tareas iniciadas en la gestión anterior. La impronta de Menéndez Pidal en esta primera época del Instituto de Filología es decisiva, en especial en la autoridad que ejercía para la elección de los encargados de la dirección de este centro, tal como señala Moreiro González: “Acudió allí Millares como representante de la nueva escuela de filología española, comprometido con Menéndez Pidal para desarrollar una serie de labores [...]" $(1987: 60)^{100}$. Entre esas labores se destacará la continuación de la edición de una Biblia escurialense del siglo XIII, que finalmente aparecerá en $1926^{101}$, y la preparación de algunos trabajos de índole filológica española, todos ellos alejados de la investigación de temas vinculados con la Argentina o América (Toscano y García 2009: 127).

También constituye una continuación de la actuación de Castro el desempeño de Millares Carlo, tanto en el ámbito académico como en las presentaciones públicas, tal

\footnotetext{
99 Los Cuadernos del Instituto de Filología fueron la primera publicación periódica del Centro y aparecieron entre 1925 y 1926. Abarcan temas de filología, lingüística y ediciones de textos; los trabajos estuvieron a cargo de colaboradores del Instituto. El primer volumen incluye tres trabajos: "La lengua española", de Ramón Menéndez Pidal, "Concepto de la pronunciación correcta", de Tomás Navarro Tomás y "El español de América y el latín vulgar “, de Max Wagner.

${ }^{100}$ En una conversación mantenida entre Leonardo Romero Tobar y Millares Carlo en 1975, luego recogida en el libro Maestros amigos (2013), el filólogo expresa: "Posteriormente don Ramón Menéndez Pidal me envió a Buenos Aires para dirigir el Instituto de Filología, trabajo en el que me habían precedido Américo Castro y el inolvidable Amado Alonso [sic]. Allí permanecí un año simultaneando la dirección del Instituto y desarrollando un curso en la Universidad de La Plata" (49). El ascendiente de Menéndez Pidal sobre los enviados a la Argentina parece ser un rasgo en común de los primeros directores, más comprometidos con el director del CEH que con las autoridades locales.

101 Se trata de la edición del Tomo I de la Biblia Medieval Romanceada. Pentateuco (Según tres manuscritos de la Biblioteca del Escorial), con Prólogo de Amado Alonso y un Estudio crítico de los manuscritos utilizados, a cargo de Américo Castro. Como responsables de la edición figuran Américo Castro, Agustín Millares Carlo y Ángel Battistessa.
} 
como se manifiesta en el dictado de conferencias y en colaboraciones en los medios periodísticos, lo que le otorga al director del Instituto un lugar significativo en la vida cultural de Buenos Aires, lo cual parece reforzar la importancia que para los españoles tenía la difusión de los temas de interés para el CEH en la sociedad argentina y el lugar privilegiado que se le otorgaba a los investigadores españoles como referentes de los estudios filológicos de corte científico. Este carácter central de los catedráticos y de las instituciones españolas continuará en los años siguientes y será una marca distintiva de las relaciones entre la vida académica y la vida cultural que tenían a España como eje integrador $^{102}$.

La afirmación del Instituto como centro de referencia para los estudios lingüísticos fue ampliando la brecha entre los detractores de la influencia hispánica en temas de la lengua nacional y quienes abogaban por la constitución de una escuela disciplinar de cuño científico a la manera de la escuela filológica de Menéndez Pidal, así como también fue evidenciando la gravitación de su figura en el desarrollo inicial del Instituto, que no lograba definir unas políticas de investigación propias en el contexto argentino, ya que éstas parecían replicar los intereses del CEH. A fines de 1924 Millares Carlo regresó a España ${ }^{103}$ y en abril de 1925 asumió la dirección el tercer

\footnotetext{
${ }^{102}$ En el artículo "Aportaciones a la biobibliografía de Agustín Millares Carlo hasta su exilio en México" (2014), Francisco Chacón Gómez Monedero adjunta en los Apéndices que acompañan al texto la transcripción de cartas vinculadas con la trayectoria del filólogo español. Entre ellas se encuentra una enviada por Millares Carlo desde Buenos Aires en septiembre de 1924 al entonces decano de la Facultad de Letras de la Universidad de Madrid, Adolfo Bonilla y San Martín, en la que resume sus actividades en la Argentina, entre ellas las conferencias dictadas y destaca su repercusión en la prensa local: "Desde mi llegada a este país fui acogido con el mayor cariño. Mi esfuerzo principal se ha concentrado en las conferencias: de ellas han dado cuenta oportunamente los periódicos de aquí como La Nación, La Prensa y El Diario Español" (Apéndice 3: 87.) Allí expresa su decisión de regresar a Madrid a fin de ese año, a pesar de que en principio su estadía en la Argentina iba a ser por más tiempo. El texto de la misiva dedica gran espacio a hablar de las conferencias mientras que las referencias a sus tareas en el Instituto se limitan a mencionar las publicaciones en marcha.

103 Después de marcharse de la Argentina debido a razones personales, ya que su hija enfermó gravemente, Agustín Millares Carlo continuó su vida académica en España, y luego de 1938 se exilió en México, donde se desempeñó como vicecónsul de la Embajada de España y a partir de allí se relacionó con diversas instituciones, como la Casa de España, institución que derivaría en el Colegio de México, y trabó relación con Alfonso Reyes, a quien había conocido durante el exilio del mexicano en Madrid entre
} 
enviado por Menéndez Pidal: Manuel de Montoliu. El catedrático catalán exhibía una formación vinculada con la literatura y la filología hispánicas, y su trayectoria en la Península había estado relacionada con los estudios literarios, las traducciones y la crítica literaria, pero también con los estudios dialectológicos y gramaticales del español $^{104}$. De allí que su perfil difería del de su antecesor y esto le otorgó a su labor al frente del Instituto una impronta particular, programáticamente más cercana al ideario fundacional de Rojas. En primer lugar, su concepción gramatical se enraíza con la lingüística sincrónica y descriptiva, a diferencia de la mirada diacrónica propuesta por la línea menendezpidaliana, y además, introduce el modelo de la lingüística vossleriana de corte idealista a partir de sus trabajos, iniciando así una línea de análisis que será retomada por Amado Alonso más adelante con la consolidación de la Estilística como enfoque metodológico $^{105}$ (Toscano y García 2009; Battista 2010, 2011).

Además de esta novedad en la perspectiva de análisis y abordaje del fenómeno lingüístico, las actividades desplegadas por Montoliu abarcan la articulación entre investigación, docencia y extensión universitaria, a partir del curso de gramática y su enseñanza que dictó, destinado a profesores de escuelas secundarias (Toscano y García 2009). Asimismo, continúa con la publicación de los Cuadernos, iniciados por Millares Carlo, con la inclusión de trabajos de miembros del Instituto, algunos de los cuales abordan cuestiones vinculadas con las variedades del español ${ }^{106}$, así como la proyección

1914 y 1920. Además desarrolló una prolífica carrera en la Universidad Nacional Autónoma, donde ingresó parra desempeñarse en la Biblioteca y continuó como profesor hasta 1958 (Moreiro González 2001).

104 La Gramática castellana (1914) de Montoliu, destinada a la educación básica, tuvo gran difusión como material de estudio en España y en Hispanoamérica, con reediciones hasta 1935 (Battista 2011:2).

${ }^{105}$ Emiliano Battista (2010) rastrea los antecedentes de la incorporación de la Estilística a los modelos metodológicos impulsados desde el Instituto de Filología y reconoce a Montoliu como el iniciador de esta corriente en la Argentina.

106 Los Cuadernos, iniciados bajo la gestión de Millares Carlo, continuaron durante la dirección de Montoliu. En 1925 aparecieron el Cuaderno 2 "El supuesto andalucismo de América", de Pedro Henríquez Ureña, el Cuaderno 3 "La biblioteca de un jurisconsulto toledano del siglo XV”, de Ángel 
de un Diccionario del habla popular argentina. De este modo, se comenzaba a perfilar otra línea de acción del Instituto, más vinculada con el programa original, es decir, la investigación lingüística destinada a profesionalizar la enseñanza de la lengua en el país en el marco del proyecto de normalización lingüística, aunque persiste el enfoque normativo encuadrado en la norma del español peninsular.

Con la partida de Montoliu a España en marzo de 1926, luego de casi un año de gestión, culminan los tres primeros años de vida del Instituto de Filología, desarrollados bajo la impronta de una tríada de filólogos españoles que, en mayor o menor medida, impulsaron los cimientos de una formación filológica en el ámbito académico argentino. Las revisiones críticas sobre este primer periodo resaltan las fluctuaciones iniciales tanto en el plano epistemológico y metodológico — delimitación de las líneas de investigación a seguir, muchas veces en conexión con la formación e intereses de los directores - como en el plano político-institucional, ya que, a pesar de los esfuerzos de Rojas por consolidar un programa lingüístico de cuño nacional que abordara temas propios, las investigaciones preliminares del centro no se ajustaron a esos objetivos. Por otro lado, la fuerte intervención del $\mathrm{CEH}$, a través de las acciones de Menéndez Pidal en cuanto a la elección de los directores, marcó este tiempo inaugural, lo que, sumado a la brevedad de los mandatos de los tres directores primeros, obturó la posibilidad de consolidar un perfil académico definido para el Instituto, y que no deviniera en un sucedáneo del CEH de Madrid. Asimismo, la prolífica vida pública de los directores y su relación con instituciones públicas y privadas de la época, contribuyó a la difusión de los temas filológicos entre un público más amplio que el exclusivamente académico y

Battistessa, el Cuaderno 4 "Un diálogo toledano romanceado en el siglo XV", de Ana Julia Darnet, el Cuaderno 5 "La colocación del pronombre", de Mauricio Schneider y el Cuaderno 6 "Contribución al estudio del italianismo en la República Argentina”, de Renata Donghi de Halperin. El Cuaderno 7, último volumen de la serie, se publicó en 1926 y corresponde a "El lenguaje como fenómeno estético", a cargo del propio Montoliu. Como es posible observar, en estas publicaciones los temas apuntan a diferentes aspectos de los estudios filológicos, y a excepción de los trabajos de Henríquez Ureña y de Renata Donghi, no abordan estudios de cuestiones locales. 
otorgó a esta disciplina una visibilidad particular en el campo cultural de la década de 1920, con los consecuentes debates que se dieron dentro y fuera de la academia, actualizando las polémicas lingüísticas y culturales respecto del lugar de España en el entramado ideológico y que continuarían en los años siguientes con diversas formas de intervención pública.

En marzo de 1926 es designado director interino el antropólogo de origen alemán Robert Lehmann-Nitsche, docente de la Facultad de Filosofía y Letras. Durante su gestión se propusieron algunas acciones concretas para revitalizar las investigaciones acerca de temas locales, como fue la creación de la sección de lingüística indígena, ámbito en el que Lehmann-Nitsche tenía importante trayectoria ${ }^{107}$. A pesar de su brevedad y su carácter transitorio ${ }^{108}$, la gestión del antropólogo marcará un cambio de la índole de las líneas de trabajo del Instituto. A cargo de las publicaciones y de los aspectos administrativos quedó Ángel Battistessa, uno de los jóvenes miembros del Instituto, quien llevará adelante la edición de los dos primeros números del Boletín del Instituto de Filología (1926 y 1927). La publicación del Boletín, junto con la organización del material bibliográfico del Instituto y la concreción de algunos trabajos sobre temas diversos, resumen el balance de estos meses intermedios antes del advenimiento de otro filólogo formado bajo la órbita de Menéndez Pidal: el navarro Amado Alonso, quien llegará al país para hacerse cargo del Instituto en agosto de 1927.

La llegada de Alonso estuvo precedida por el compromiso asumido por parte de las autoridades de la Facultad respecto de la exigencia de que el director debía

\footnotetext{
${ }^{107}$ Robert Lehmann-Nitsche (1872-1938), originario de Radonitz (en ese momento parte del Imperio Alemán), había llegado a la Argentina en 1897 para hacerse cargo de la sección de Antropología del Museo de Ciencias Naturales de La Plata creado unos años antes. Desarrolló una extensa actividad de investigación en temas antropológicos, lingüísticos y etnológicos, fue docente de las universidades de Buenos Aires y de La Plata y autor de numerosos trabajos científicos (Chicote 2010).

${ }^{108}$ Según indica Toscano y García (2009: 131), existía la posibilidad de que Montoliu regresara a ocupar el cargo al año siguiente, de allí que continuara la supervisión de los investigadores por vía epistolar. Sin embargo, dicho regreso no se produjo, sino que en su reemplazo fue enviado Amado Alonso.
} 
permanecer tres años en el cargo, de modo de contrarrestar las inestabilidades iniciales del centro y poder definir políticas a mediano plazo. Esta condición se cumplirá sobradamente, ya que Alonso dirigirá el Instituto por casi veinte años, hasta 1946.

\subsubsection{El Instituto de Filología bajo la gestión de Amado Alonso (1927-1946): afianzamientos y proyecciones}

Las numerosas reseñas críticas acerca del periodo de la gestión de Alonso al frente del Instituto coinciden en atribuirle a esta etapa un carácter excepcional en cuanto a la producción intelectual, la formación de investigadores, las publicaciones y la consolidación de la filología como disciplina en el ámbito argentino, a la vez que destacan su proyección en el ámbito del hispanismo internacional (Weber de Kurlat 1975; Romanos 2013; Lida 2014). La identificación de estos años de vida del Instituto bajo la dirección de Alonso con conceptos como "Edad de Oro" (Romanos 2013) o “años dorados" (Lida 2014), resume la percepción de un periodo de extraordinario auge de la disciplina y de su impacto en la vida académica y cultural. El vórtice de ese notorio florecimiento lo constituye, desde esta perspectiva, la figura de Amado Alonso, quien es presentado como el factótum de esa situación privilegiada que alcanzó el Instituto de Filología durante casi veinte años.

Para los alcances de esta investigación nos detendremos en indagar acerca del papel que le cupo al Instituto de Filología y a sus integrantes en los procesos que condujeron a la consolidación de un hispanismo de cuño argentino, resultado de las múltiples interacciones entre las relaciones académicas y culturales con España y las transformaciones que operaban en el campo cultural e intelectual argentino, con los consecuentes convergencias y divergencias que éstas suscitaron. 
En este contexto, el año 1927 — cuando Alonso llega a la Argentina — resultó ser un año clave en el devenir de las relaciones culturales entre España y la Argentina y de los debates por una búsqueda de identidad cultural propia, entre los cuales la lengua — y con ella la literatura — vuelve a ocupar un lugar relevante.

El año se inicia con la aparición en Madrid de La Gaceta Literaria-ibérica, americana-internacional, publicación quincenal vinculada con las vanguardias literarias $\mathrm{y}$ artísticas ${ }^{109}$. Desde los primeros números se presenta como un espacio donde "acercar eficazmente autores, editores y lectores" (“Salutación”, Año I $n^{\circ} 1$ ), en un afán por modernizar la cultura española y sacarla de su "provincianismo", para lo cual se presenta como "ibérica, americana e internacional” (ibídem) ${ }^{110}$. La vocación de ubicar a España en el contexto europeo y americano se percibe en los artículos que aparecen publicados en los primeros números de ese año. El 15 de abril, en el número 8 de la revista, se publica el artículo "Madrid: meridiano intelectual de Hispanoamérica", cuyas lecturas reavivarán el debate — nunca extinguido del todo - acerca de la posición de España en relación con Hispanoamérica ${ }^{111}$. El planteo básico del artículo se vertebra en torno a disputar el lugar de París como referente cultural de los países hispanoamericanos y proponer en su lugar a Madrid como "meridiano cultural", teniendo en cuenta la historia y la lengua en común. Las reacciones al otro lado del Atlántico y en la misma España frente a las ideas expresadas en el editorial de la revista han sido profusamente estudiadas (Barchino Pérez 1993; Manzoni 1996; Marti

\footnotetext{
${ }^{109}$ La Gaceta Literaria aparecerá durante cinco años, hasta 1932. Su director y fundador fue Ernesto Giménez Caballero y Guillermo de Torre el secretario durante los primeros tiempos, hasta que se marchó a la Argentina.

${ }^{110}$ Este ideario es desarrollado por José Ortega y Gasset en ese primer número de la revista, en el que, a modo de Presentación, se publica un texto del filósofo denominado "Sobre un periódico de las letras", que abre la publicación y funciona como un manifiesto, a la vez que evidencia la filiación de los editores con la figura del filósofo y su relevancia en el campo intelectual de la época.
}

${ }^{111}$ Si bien el artículo no aparece firmado, Guillermo de Torre reconocerá su autoría (Manzoni 1996: 121). 
Monterde 2014), de allí que nos interese señalar la vinculación de estas polémicas con las transformaciones y desplazamientos que se estaban produciendo en el campo cultural argentino a mediados de la década de 1920 y su referencialidad con España. En el caso de la Argentina, las respuestas más visibles se expresaron a través de las páginas de la revista Martín Fierro, de carácter vanguardista, en la que se manifestaron acerca del tema varios de los escritores nucleados en ella ${ }^{112}$. En un momento en que las vanguardias habían provocado revisiones en el campo literario argentino y en que los escritores buscaban un afianzamiento de las propias voces, las ideas de de Torre impulsaron álgidas polémicas. Una de las más célebres — por el reconocimiento que su nombre ya estaba adquiriendo - fue la de Jorge Luis Borges, quien en junio de ese año publicó en la revista el trabajo "Sobre el meridiano de una gaceta", en donde responde críticamente al planteo del español, con el tono mordaz e irónico propio de la actitud vanguardista $^{113}$. En definitiva, lo que la polémica dejó como balance fue el destiempo de la propuesta realizada por de Torre: en el momento de plena efervescencia acerca de la indagación de una identidad propia en América Hispana y de la construcción de sus tradiciones, de la búsqueda de un lenguaje expresivo, la idea de que Madrid pudiera

\footnotetext{
${ }^{112}$ La revista Martín Fierro había sido creada en 1924 - hubo un intento fugaz en 1919, que no prosperó- y, paradójicamente, se cerraría ese mismo año de 1927. Desde su manifiesto inicial, la publicación se presenta como portavoz de las tendencias vanguardistas argentinas en busca de una identidad propia, con una clara conciencia de novedad, de iconoclasia y de carácter americano, y por lo tanto, alejada de la tutela española: "'MARTÍN FIERRO" cree en la importancia del aporte intelectual de América, previo tijeretazo a todo cordón umbilical" ("Manifiesto", 15/05/1924:1-2). Su fundador y director fue Evar Méndez y en ella participaron, entre otros, Jorge Luis Borges, Eduardo González Lanuza, Leopoldo Marechal, Pablo Rojas Paz y Raúl González Tuñón.

${ }^{113}$ Además de dicho artículo, Borges publicó junto con Carlos Mastronardi otro aún más satírico en la revista Martín Fierro, bajo el seudónimo Ortelli y Gasset, titulado "A un meridiano encontrao en una fiambrera". Allí acentúan el tono satírico e irreverente y recurren a una jerga lunfarda para cuestionar las ideas de de Torre, como se advierte en el cierre del artículo: "Espiracusen con plumero y todo, antes que los faje. Che meridiano: hacete a un lao que voy a escupir". Ambos artículos aparecidos en la revista Martín Fierro fueron reproducidos en la edición de los Textos recobrados 1919-1929 de Jorge Luis Borges (2011:311-313).
} 
erigirse como "vórtice" cultural generó reacciones intensas, que pueden entenderse en el marco de estas reformulaciones del campo cultural ${ }^{114}$.

Una de las características de este campo cultural fue, sin duda, el papel de la prensa en los debates más relevantes que atravesaron las primeras décadas del siglo. La emergencia de diarios, revistas y publicaciones periódicas da cuenta de la consolidación de la prensa como dispositivo desde el cual plantear cuestiones vinculadas con la sociedad, la cultura y la política ${ }^{115}$. En ese contexto, el lanzamiento de la encuesta promovida por el diario Crítica en junio de 1927 en la que se preguntaba “¿Llegaremos [los argentinos] a tener un idioma propio?” reactivó las polémicas por el estatuto de una lengua "nacional", insertas en una genealogía de larga data, cuyos inicios se ubican en la etapa post independentista, atraviesan el siglo XIX, se agitan en los años del Centenario y reaparecen en esta década. Ya se había observado de qué modo la intervención de los filólogos españoles en el ámbito académico había despertado las polémicas locales a principios de la década de 1920, en concordancia con la creación del Instituto de Filología y su vinculación con el CEH y la escuela de Menéndez Pidal; en ese sentido, la pregunta formulada por el diario involucra a un "nosotros" entendido como "los argentinos", y cuyas respuestas estarán a cargo de algunos de los representantes de la intelectualidad nacional ${ }^{116}$. Si bien el resultado de esa encuesta

\footnotetext{
${ }^{114}$ La propuesta de erigir a Madrid como "meridiano cultural" del mundo hispánico abarcaba también aristas de índole económica y cultural, ya que en el artículo se hace referencia al mercado editorial y el lugar de España en ese contexto. Estos aspectos serán retomados en el Capítulo 3 de esta investigación.

115 Entre las publicaciones más destacadas pueden señalarse las revistas Nosotros. Revista mensual de Letras, Arte, Historia, Filosofia y Ciencias Sociales (que había sido fundada en 1907 por Alfredo A. Bianchi y Roberto F. Giusti y que ocupaba un lugar consolidado, al igual que Caras y Caretas, de 1898), y las creadas en la década de 1920, algunas de vida efímera como Prismas (1921), Proa (1922), Martín Fierro (1924-1927), Los Pensadores, y diarios, tanto los de larga trayectoria - como La Prensa (1869) o La Nación (1870) - y otros como La Razón (1905) y Crítica (1913), que atendían a un público cada vez más amplio.

${ }^{116}$ Algunos de los consultados por el diario fueron Ricardo Rojas, Jorge Luis Borges, José María Monner Sans, Roberto J. Payró, Manuel Gálvez, Arturo Costa Álvarez y Arturo Cancela, la mayoría de cuño conservador en cuestiones lingüísticas.
} 
ofrece un amplio consenso respecto de la inviabilidad de un "idioma argentino", la iniciativa del diario expresa que, ya avanzado el siglo XX, la cuestión del idioma no se hallaba definitivamente zanjada y pone en evidencia, además, cómo el tema de la "lengua nacional” interesaba a un diario masivo como Crítica y a un público más amplio que el de los académicos ${ }^{117}$.

En el mismo sentido puede inscribirse la intervención de Jorge Luis Borges en una conferencia ofrecida en el Instituto Popular de Conferencias en septiembre de 1927, titulada "Sobre el idioma de los argentinos". El ámbito en el que se desarrolló el evento también forma parte de la geografía urbana del Buenos Aires de las primeras décadas del siglo: el edificio del diario La Prensa, que se había convertido en uno de los centros principales de la vida pública de la época ${ }^{118}$. Allí funcionaba el Instituto Popular de Conferencias, institución creada en 1914 por el director del diario e hijo del fundador, Ezequiel Paz, con el objetivo de difundir la cultura y contribuir a la formación ciudadana $^{119}$. En ese marco, Borges es invitado a disertar y el texto de su conferencia

\footnotetext{
${ }^{117}$ En una tónica análoga pueden ubicarse las "aguafuertes" publicadas por Roberto Arlt en el diario $E l$ Mundo en la década de 1920. Una de ellas en particular, "El idioma de los argentinos", aparecida en 1930 (que lleva el mismo título que el texto de Jorge L. Borges), cuestiona la propuesta de Ricardo Monner Sans de "purificar" el idioma. Esto expresa el papel clave que tuvo la prensa escrita en los debates acerca de la lengua y sus valorizaciones, además de las disputas entre las posiciones más hispanizantes y las más localistas.

${ }^{118}$ Inaugurado en 1899, el edificio que albergaba al diario La Prensa constituía uno de los más lujosos de la ciudad. Su ubicación privilegiada sobre la Avenida de Mayo, ya para ese entonces una de las arterias más importantes de la ciudad, exhibía la relevancia que el medio había adquirido desde su fundación y también el poder económico y social de la empresa (Gómez 2008).

${ }^{119}$ En la Actas de fundación del Instituto Popular de Conferencias correspondientes al 18 de julio de 1914 se transcriben las palabras de Ezequiel Paz, impulsor del proyecto: "Es mi propósito, y para eso os he llamado y solicitado concurso, fundar un centro de difusión y cultura, que, a la par que atestigüe la potencia intelectual de nuestra raza, contribuya a fomentar la educación espiritual del pueblo en forma amena y sintética de conferencias selectas [...]". Se percibe en la alocución de Paz la conjunción, muy presente en los discursos de la época del Centenario, de la cultura y la raza, así como el carácter espiritual atribuido a la educación y la necesidad de fomentar la educación de la ciudadanía. [Disponible en http://archive.org/stream/analesdelinstitu00inst/analesdelinstitu00inst_djvu.txt]
} 
fue publicado al día siguiente en las páginas de La Prensa, lo que garantizaba una difusión muy extendida.

El panorama cultural que recibió a Amado Alonso en 1927 estaba atravesado entonces por debates que involucraban cuestiones lingüísticas, culturales y literarias y que, por su necesaria referencialidad, tenían a España y a sus representantes en el centro de la escena. De allí que, si bien la figura de Alonso no venía precedida de la reputación de sus antecesores (Lida 2012: 105), rápidamente buscó insertarse en el nuevo medio y armonizar las relaciones entre el Instituto y otros espacios culturales. Los registros referidos a las múltiples actividades llevadas adelante por Alonso durante su estadía en la Argentina, tanto en el plano académico como en el más amplio de la vida cultural porteña (Lida 2014), dan cuenta de su voluntad de convertir al Instituto de Filología en una sólida referencia en el campo del hispanismo internacional y al mismo tiempo consolidar a los estudios filológicos en el ámbito académico argentino, a partir de la rigurosidad metodológica de los enfoques y la formación sistemática de discípulos que convergerían en una generación de filólogos argentinos.

La figura de Alonso fue la impulsora de los diversos proyectos que se llevaron adelante desde el Instituto y que buscaron promover la investigación, la actualización bibliográfica, la difusión de los trabajos a través de las publicaciones, la intensificación de las relaciones con otros centros de estudios hispánicos, la vinculación con el mercado editorial en plena expansión en esos años; es decir, el rasgo que caracterizó a su gestión fue un gran dinamismo, lo que posibilitó un afianzamiento de la filología como disciplina, entendida en un sentido amplio y abarcador, y la conformación de un núcleo de investigadores que continuarían la línea trazada en pos de otorgar a los estudios hispánicos un lugar relevante en el ámbito académico argentino. 
Este dinamismo se reveló en varias aristas del trabajo emprendido en el Instituto, las cuales han sido profusamente analizadas (Weber de Kurlat 1975; Zuleta 1992; Barrenechea 1996; Lecea Yabar 1996; Buchbinder 1997; Toscano y García 2009, 2011; Lida 2014) y abarcan los proyectos de publicación (la Biblioteca de Dialectología Hispanoamericana, cuyos siete tomos aparecieron entre 1930 y 1949 y en la que colaboraron miembros del Instituto, la Colección de Estudios Indigenistas, cuyo único volumen se publicó en 1931, la Colección de Estudios Estilísticos, que incluyó traducciones y comentarios sobre textos clave de la Estilística, y la Revista de Filología Hispánica, que se publicó entre 1939 y 1947). Todos estos emprendimientos, sumados a los trabajos propios de Alonso publicados por el Instituto, hablan de la fuerte apuesta del filólogo por la investigación y la difusión de los resultados, así como del incentivo entre los miembros del Instituto para que publicaran sus trabajos, tanto en el país como en revistas internacionales, como se analizará más adelante. Los investigadores nucleados en el Instituto comienzan a formarse en la metodología científica propia de las disciplinas lingüísticas y literarias y a ampliar los temas de interés: a las cuestiones fonéticas, gramaticales y dialectológicas se le agregan el análisis literario —en particular a partir de la incorporación de la Estilística como matriz teórica-, las intervenciones en el ámbito de la enseñanza de la lengua en las escuelas y la divulgación hacia un público no especializado. Esta variedad de asuntos evidencia la ductilidad y la amplitud de las ideas y los objetivos de Alonso y constituye una de las razones por las cuales el Instituto de Filología adquiere una clara relevancia hacia dentro de la academia pero también —y quizás sea éste un rasgo distintivo del centroen el contexto de la vida cultural e intelectual porteña desde sus inicios y que continuaría en las décadas siguientes, además de su proyección internacional. 
De este modo, los objetivos iniciales del Instituto toman cuerpo y se empiezan a recoger los frutos de las líneas sembradas en los años iniciales: se define un perfil científico y académico para los estudios lingüísticos y literarios, se abreva en las teorías vigentes para actualizar los enfoques, se fomenta la formación de discípulos en la investigación, se concretan publicaciones periódicas, entre las que se destaca la creación de la Revista de Filología Hispánica, en $1939^{120}$, y no periódicas; en definitiva, se le otorga definitivamente a este centro de investigación un estatus especializado en el nivel de los más importantes del mundo hispánico.

Este relieve alcanzado por el Instituto puede explicarse por los factores internos mencionados, pero en el análisis no debe soslayarse el hecho de que, luego del estallido de la Guerra Civil en España, el CEH, que durante décadas había sido el referente internacional del hispanismo, es disuelto y muchos de los intelectuales allí reunidos emprenden el exilio ${ }^{121}$. Las consecuencias políticas, sociales y culturales del conflicto sumirán a España en un periodo de retracción tanto en el plano interno como en el internacional y esto provocará la emergencia de otros centros como referentes del hispanismo mundial. Entre ellos, la Argentina — junto con México y Puerto Ricoconstituirán los polos de irradiación de los estudios y de la difusión de las producciones en lengua española, debido al impulso que adquirieron las empresas editoriales fuera de la Península. Así, el desplazamiento del centro desde Madrid a las periferias americanas colocó en un lugar privilegiado a estas regiones y les otorgó relieve internacional.

\footnotetext{
${ }^{120}$ Para los alcances de esta investigación resulta relevante mencionar los dos Anejos que acompañaron la publicación de la revista, dedicados a temas de literatura española: el Anejo 1, de 1943, que contenía el trabajo "Sentido y forma de las Novelas Ejemplares", del catedrático español Joaquín Casalduero, y el Anejo 2, de 1946, con el artículo "América en el teatro de Lope de Vega", de Marcos Morínigo.

${ }^{121}$ Respecto de los efectos del conflicto en el campo de la ciencia y la investigación españolas expresa López Sánchez: "El estallido de la Guerra Civil supuso un paso atrás considerable en materia científica. La disolución de la Junta y los procesos de depuración conllevaron que la mayor parte del tejido científico que tanto le había costado construir desapareciera de un plumazo" (2007: 121). La JAE fue disuelta en 1938 y al año siguiente se creó el Consejo Superior de Investigaciones Científicas (CSIC), institución que continúa dirigiendo las políticas científicas españolas hasta la actualidad.
} 
En este contexto, el campo académico e intelectual argentino, en particular el universitario, se nutrirá con las incorporaciones de especialistas españoles que contribuirán a arraigar los estudios filológicos en el país ${ }^{122}$. Por su carácter precursor, el Instituto de Filología de la Universidad de Buenos Aires devendrá un referente significativo de los estudios hispánicos, y a partir de esta relevancia, un hispanismo argentino comenzará a consolidarse y se expandirá hacia el interior de la Argentina, conformando centros académicos en las principales universidades del país.

Junto con Amado Alonso, otra figura resulta clave en este proceso: la del dominicano Pedro Henríquez Ureña. Llegado a la Argentina en 1924, luego de un intenso periplo formativo por diversos países, aquí se afincó y desarrolló su vida intelectual hasta su muerte imprevista, en 1946. Sus intereses abarcaron un amplio abanico de disciplinas, tal como lo demuestran sus producciones: fue filólogo, educador, escritor, investigador e historiador, en especial de la cultura hispanoamericana ${ }^{123}$. Además de su reconocida labor docente en las Universidades de La Plata y Buenos Aires, así como en el Instituto Nacional del Profesorado y el Colegio Nacional de La Plata, y de su participación en la edición de obras literarias y de antologías, fue investigador en el Instituto de Filología, convocado por Alonso para trabajar en temas referidos al estudio de la lengua. La relación de Alonso con el dominicano fue de mutua

\footnotetext{
${ }^{122}$ La presencia de lingüistas españoles en la Argentina y su inserción en el ámbito universitario es analizado por Ana María Barrenechea y Elida Lois en su artículo "El exilio y la investigación lingüística en la Argentina" (1989) en el que se detienen en las figuras de Amado Alonso, Américo Castro - quien retornó al país en 1936 a causa de la Guerra Civil luego de su experiencia al frente del Instituto y permaneció hasta 1940 - Joan Corominas y Clemente Hernando Balmori, todos los cuales contribuyeron a diseminar los estudios lingüísticos y filológicos en el país.

${ }^{123}$ El interés de Henríquez Ureña por consolidar una cultura que excediera los límites nacionales para pensarla en términos continentales se plasma fundamentalmente en sus obras Seis ensayos en busca de nuestra expresión (Buenos Aires, 1928), Corrientes literarias de la América Hispánica (editada en 1945 por la Universidad de Harvard. La primera edición en español es de 1949 bajo el sello del Fondo de Cultura Económica) e Historia de la cultura en la América Hispánica, publicada luego de su muerte, en 1947 por el Fondo de Cultura Económica. Esta perspectiva integradora es descripta por Beatriz Garza Cuarón: "Es bien sabido que su intención — lograda - fue trabajar para que se consolidaran no culturas aisladas o nacionales, sino una cultura continental, que llamó cultura de la América Hispánica (de la que no excluye a Brasil)" (1988: 322).
} 
colaboración, y también participaron en la vida pública y social del Buenos Aires de la época, en especial a partir de sus vínculos con Alfonso Reyes, entonces embajador mexicano en la Argentina, quien contribuyó a la creación de círculos de sociabilidad con la sociedad porteña ${ }^{124}$. De este modo, estas tres figuras extranjeras se insertaron activamente en la vida cultural y así contribuyeron a aumentar el prestigio de la lengua española $-\mathrm{y}$ con ella su cultura — entre la élite ilustrada ${ }^{125}$.

En el ámbito académico, Alonso y Henríquez Ureña estimularon con sus actividades la producción intelectual del Instituto y el fortalecimiento de la perspectiva unificadora de los estudios lingüísticos y literarios. Asimismo, intervinieron en el campo de la enseñanza de la lengua a partir de la publicación de la Gramática castellana, en 1938, destinada al nivel secundario, que se propuso como modelo normativo inscripto en la tradición de los estudios lingüísticos de Andrés Bello ${ }^{126}$. Al decir de Emilia de Zuleta: "Este hispanismo integrador de ambas orillas, el rigor filológico, el enfoque metódico plural — lingüístico, cultural y literario - es el sello que estos primeros maestros [Alonso y Henríquez Ureña] imponen a sus discípulos, los cuales prolongarían luego esta orientación en niveles importantes del hispanismo internacional" (1992: 956).

La formación de discípulos en las metodologías y teorías vigentes y la consecución de un modo de trabajo de corte científico fueron otros de los baluartes del

\footnotetext{
${ }^{124}$ Alfonso Reyes vino a la Argentina como embajador de México en dos oportunidades: entre 1927 y 1930 y entre 1936 y 1938. Su misión fue consolidar las relaciones entre ambos países y su figura ya era reconocida en los ámbitos literarios y culturales. De allí que su gestión diplomática estuvo vinculada con las actividades culturales y con otras figuras e instituciones de la vida porteña.

125 Acerca de este proceso de acercamiento a la cultura española por parte de la élite argentina, señala Miranda Lida: "Ya sea a través de la música de Manuel de Falla — como le ocurrió a Victoria Ocampo-, o través del propio trato social con estas reputadas figuras [Alonso, Reyes y Henríquez Ureña], la lengua española y todo lo que ella traía consigo - la historia, la literatura - despertaron creciente interés por parte de unas elites cultas tradicionalmente muy francófilas” (2014: 80).

126 La Gramática castellana fue publicada por la recientemente creada editorial Losada y tuvo numerosas reediciones a lo largo de los años. Para 1971 había alcanzado la $26^{\circ}$ edición, lo que expresa la vigencia de este texto en la currícula escolar argentina.
} 
Instituto de Filología, según el modelo instaurado por el CEH de Madrid. Si bien esta práctica formativa había comenzado en los albores del Instituto, fue bajo la gestión de Alonso cuando terminó de consolidarse. Así, a partir de fines de la década de 1920 y en las siguientes, se fueron incorporando al Instituto jóvenes egresados de las carreras universitarias y de Institutos del Profesorado que iniciaban allí el camino de la investigación filológica y crítica. Debido a la relevancia que sus trabajos adquirieron en el contexto del hispanismo no sólo argentino sino internacional, nos detendremos en algunas de las figuras representativas de este periodo de la vida institucional del centro y sus proyecciones a fin de presentar los derroteros de estos primeros investigadores en filología y literaturas hispánicas nucleados en el Instituto ${ }^{127}$.

En los primeros años del centro se incorporó al recientemente creado Instituto Ángel Battistessa (1902-1993), quien desarrollaría una amplia y prolífica labor como investigador, crítico literario, traductor y docente en universidades argentinas, donde llegó a ocupar cargos de gestión, además de formar parte de instituciones académicas nacionales e internacionales. En lo referido a sus producciones durante la primera época del Instituto, se destaca la publicación, en conjunto con Américo Castro y Millares Carlo de la Biblia medieval romanceada según los manuscritos escurialenses (1927). Colaboró en los Cuadernos del Instituto y tuvo a su cargo la edición del Boletín del Instituto durante 1926 y 1927. A comienzos de la década de 1930 viajó becado a Europa para continuar su formación filológica. A su regreso al país, continuó sus tareas en la docencia, las traducciones y las publicaciones de libros y de artículos en revistas

\footnotetext{
${ }^{127}$ El listado de investigadores que se presenta no intenta ser completo, sino detenerse en aquellas figuras que se formaron en los años iniciales del Instituto y que lograron una trascendencia tanto local como internacional $\mathrm{y}$, al mismo tiempo, colaboraron para delinear un hispanismo argentino con identidad propia. Además de los aquí mencionados, pueden citarse, sin pretensión de exhaustividad, a Enrique Anderson Imbert, Berta Vidal de Battini, Daniel Devoto, Julio Caillet Bois, José Gatti y Juan Bautista Avalle Arce (Barrenechea 1989; Zuleta 1992).
} 
especializadas. Su extensa trayectoria continuará vinculada con los centros académicos argentinos a través de la docencia y la investigación en temas literarios ${ }^{128}$.

Ángel Rosenblat (1902-1984), nacido en Polonia y emigrado en su infancia a la Argentina, donde desarrolló sus estudios, se incorporará al Instituto en 1927, durante la gestión de Amado Alonso, quien lo convocará para colaborar con los trabajos de investigación en dialectología. Fue colaborador en la confección de la Biblioteca de Dialectología Hispanoamericana (1930), disciplina a la que dedicó sus mayores esfuerzos. Completó su formación en Alemania y en Madrid, donde se desempeñó en el CEH desde 1933 hasta 1937. Regresó a la Argentina y continuó desarrollando su trabajo hasta 1946, año en que se marcha a Venezuela, donde se radicará a partir de 1946 y donde fundará, en 1947, el Instituto de Filología Andrés Bello de la Facultad de Humanidades de la Universidad Central de Venezuela. Regresó por un tiempo a la Argentina, donde dirigió fugazmente el Instituto de Filología de la Universidad de Buenos Aires durante los meses de agosto y noviembre de 1962, y años más tarde, en 1973, fue designado miembro correspondiente de la Academia Argentina de Letras. Sus principales aportes se vinculan con el estudio y la sistematización de las lenguas americanas, las variedades del español americano y el habla de diferentes regiones del continente. Si bien su centro de interés estuvo en la lingüística, realizó una edición del Amadís de Gaula (1940) y publicó un trabajo sobre la lengua en Don Quijote de la Mancha $(1971)^{129}$. Su extensa y fructífera trayectoria académica, continuada en

\footnotetext{
${ }^{128}$ La dilatada trayectoria de Battistessa excede los límites de esta investigación, de allí que para una información más acabada de su vida y obra puede recurrirse al libro de Diego Pró Ángel Battistessa (1961) y el volumen especial de la revista Letras (Vol. VI y VII, dic. 1982-abril 1983), editada por la Universidad Católica Argentina en ocasión del octogésimo aniversario del escritor.

${ }^{129}$ La edición del Amadís fue publicada en 1940 por la editorial Losada, en la colección Los inmortales. El subtítulo de la edición reza: "Novela de caballerías refundida y modernizada por Ángel Rosenblat", y dado que se trataba de una versión acotada y actualizada, fue durante décadas de uso en las escuelas. Por su parte, el trabajo sobre la lengua literaria de Cervantes, titulado La lengua del Quijote fue publicado en Madrid por la editorial Gredos en 1971.
} 
Venezuela, tuvo el signo de sus años de formación en el Instituto de Filología de Buenos Aires (Moure 2004-2005) ${ }^{130}$.

El paraguayo Marcos Morínigo (1904-1987) llegó a Buenos Aires a mediados de la década de 1920 para seguir sus estudios en la Facultad de Filosofía y Letras de la Universidad de Buenos Aires. Allí conoció a Alonso, que se desempeñaba como profesor, y se incorporó al Instituto de Filología. Obtuvo una beca para continuar sus estudios en París y a su regreso retomó su trabajo en el Instituto y en la docencia. Sus indagaciones giraron alrededor del guaraní y de las influencias lingüísticas, que plasmó en sus escritos. Además, trabajó sobre el teatro de Lope de Vega. Entre 1956 y 1959 fue designado director del Instituto de Filología ${ }^{131}$.

El Instituto también fue el ámbito en el que desarrollaron su formación los hermanos Raimundo (1908-1979) y María Rosa Lida (1910-1962). Provenientes de una familia de ascendencia judía que llegó a la Argentina a comienzos del siglo XX desde el Imperio Austro Húngaro, los hermanos Lida estudiaron en la Facultad de Filosofía y Letras de la Universidad de Buenos Aires y luego se incorporaron al Instituto de Filología, donde iniciaron su formación bajo la tutela de Amado Alonso y Pedro Henríquez Ureña. Raimundo Lida fue un estrecho colaborador de Amado Alonso en sus proyectos y fue perfilando sus intereses en torno a la filosofía del lenguaje, la estilística

\footnotetext{
${ }^{130}$ Respecto de la filiación del Instituto creado por Rosenblat en Venezuela con el correspondiente argentino, él mismo la reconoce en una carta a Jimena Menéndez Pidal, hija del filólogo, en la que le solicita una contribución de Menéndez Pidal para incluirla en la revista que tenía previsto fundar. Allí declara: "Mi Instituto es una prolongación del Instituto de Buenos Aires que dirigía Amado Alonso y del Centro de Estudios Históricos. Me interesa que el artículo de Don Ramón, o la colaboración de Don Ramón, cualquiera que sea, represente el signo de esa filiación. Yo soy filológicamente nieto de Don Ramón, y me amparo en mi abuelo" (En Hernández 2007:191). Este gesto de reconocimiento de las relaciones entre los centros, así como de las genealogías maestro-discípulo están presentes en la configuración del hispanismo americano.

${ }^{131}$ Como dato particular, puede señalarse que presidió la Academia Porteña del Lunfardo, una institución privada que se creó en 1962 para promover los estudios del habla de Buenos Aires y sus particularidades. Han sido miembros de ella escritores y periodistas, como Nicolás Olivari y, José Barcia, además del propio Morínigo. También fue docente en la Universidad Nacional de Tucumán y en universidades extranjeras. Llegó a ser decano de la Facultad de Filosofía y Letras de la Universidad de Buenos Aires.
} 
y la crítica literaria. Colaboró como secretario en la Revista de Filología Hispánica, creada por Alonso en 1939 y además de sus trabajos académicos, participó activamente en la vida cultural de la época ${ }^{132}$. Luego de la ida de Alonso, se estableció en México donde continuó su tarea de investigación y de difusión, ya que participó en la edición de la Nueva Revista de Filología Hispánica, continuación del proyecto editorial de Alonso en México. Más adelante se trasladó a Harvard, donde se instaló definitivamente y completó su trayectoria como filólogo e hispanista de renombre.

Por su parte, el recorrido intelectual de María Rosa Lida, si bien tuvo puntos de contacto con el de su hermano, siguió itinerarios propios. A diferencia de Raimundo, sus inicios en la investigación tuvieron lugar en el Instituto de Literatura Clásica de la Universidad de Buenos Aires, desde su graduación en 1932 hasta 1935, cuando se incorporó al Instituto de Filología, centro que no abandonaría hasta su partida del país en 1947. Allí prosiguió su formación bajo la guía de Alonso y se contactó con algunas de las figuras relevantes de la cultura, como el caso de Alfonso Reyes ${ }^{133}$. Su matriz de formación clásica se evidencia en sus estudios, de corte clasicista, que abarcaron desde textos y autores de la antigüedad grecolatina hasta de la literatura española, en particular la medieval, y también fue traductora y crítica literaria. Por otro lado, mientras que Raimundo tuvo activa participación en la vida cultural y se relacionó con otros centros, la trayectoria de María Rosa se circunscribió al Instituto de Filología. En 1947 obtiene una beca de la Fundación Rockefeller y se marcha a Estados Unidos, donde se radicará

\footnotetext{
${ }^{132}$ Para una detallada semblanza de Raimundo Lida pueden consultarse los trabajos de Ana María Barrenechea "En memoria de Raimundo Lida" (1980), de Fernando y Clara Lida "Raimundo Lida: filólogo, humanista y peregrino" (2009) y de Miranda Lida Años dorados de la cultura argentina. Los hermanos María Rosa y Raimundo Lida y el Instituto de Filología antes del peronismo (2014).

${ }^{133}$ La relación entre María Rosa y Raimundo Lida y el escritor mexicano se inició en Buenos Aires y continuó luego de que éste regresara a México y los hermanos se marcharan a Estados Unidos. La correspondencia que mantuvieron durante más de diez años fue publicada por Sergei Zaïtzeff en 2009.
} 
definitivamente hasta su muerte y donde continuará su producción intelectual, que le otorgará un sitio relevante en el hispanismo internacional ${ }^{134}$.

Entre los discípulos formados bajo el influjo de Alonso en el Instituto de Filología se destacan algunas figuras femeninas que desarrollarán sus trayectorias académicas tanto en los claustros argentinos como en el extranjero, tal como se ha visto en el caso de María Rosa Lida. Otra de las discípulas de Alonso fue Ana María Barrenechea (1913-2010). Recibida de profesora en el Instituto Nacional del Profesorado, se incorporó al Instituto en 1938 y allí continúa su formación en el campo de la lingüística y los estudios literarios. Su labor docente la desarrolló en el Instituto del Profesorado y luego, a partir de 1958, en la Facultad de Filosofía y Letras de la Universidad de Buenos Aires, donde ocupó las cátedras de Gramática Castellana y de Introducción a la Literatura, lo cual resume las dos ramas de sus investigaciones y sus enfoques teóricos a lo largo de las décadas. Fue la primera mujer directora del Instituto de Filología, cargo que ocupó a inicios de la década de 1960. Sus aportes a los estudios gramaticales y lingüísticos se plasmaron en numerosas publicaciones, entre ellas textos destinados a la enseñanza de la lengua en las escuelas, así como artículos en revistas internacionales y obras de crítica literaria. Ejerció el magisterio formativo de discípulos, siguiendo la huella trazada por su maestro Amado Alonso. Su extensa trayectoria estuvo ligada a los estudios hispanistas, tanto lingüísticos como literarios, lo que le valió el reconocimiento internacional ${ }^{135}$.

Otra de las discípulas del filólogo navarro fue Frida Weber de Kurlat (19141981), egresada, al igual que varios de los investigadores del Instituto, del Instituto del

\footnotetext{
${ }^{134}$ La figura de María Rosa Lida ha sido objeto de numerosos estudios que abordan las diferentes facetas de su quehacer intelectual. Entre los más recientes pueden citarse el de Ángel Gómez Moreno (2011), Nora Catelli (2012) y el libro de Miranda Lida (2014).

${ }^{135}$ Como dato revelador del relieve que su figura alcanzó en el concierto del hispanismo internacional debe mencionarse que fue la primera mujer elegida para presidir la Asociación Internacional de Hispanistas (AIH) en 1977 (Romanos 2013: 2).
} 
Profesorado. Bajo la dirección de Alonso comenzó sus tareas de investigación y de docencia en la Facultad de Filosofía y Letras, donde fue profesora de Literatura Española Medieval y del Siglo de Oro. Sus trabajos sobre el teatro, en particular el prelopesco fueron la génesis de estudios señeros sobre los dramaturgos Sánchez de Badajoz y González de Eslava. En esa misma línea fueron sus investigaciones sobre la comedia de Lope de Vega, que fructificaron en artículos y estudios críticos. De este modo, su nombre ha quedado definitivamente ligado a los estudios de literatura española que sobrepasaron las fronteras y que aún hoy constituyen obras de insoslayable consulta. Además de la docencia y la investigación, dirigió el Instituto entre 1968 y 1973 y tuvo a su cargo la edición de la revista Filología.

Esta revisión de figuras de investigadoras del Instituto incluye también a Celina Sabor de Cortazar (1913-1985), cuya trayectoria en la docencia y la investigación ha quedado plasmada en numerosos trabajos sobre la literatura española. Tuvo a su cargo la cátedra de Literatura Española del Siglo de Oro en la Facultad de Filosofía y Letras, ámbito que le permitió profundizar sus indagaciones sobre textos y autores áureos. Sus contribuciones críticas acompañaron ediciones anotadas de obras canónicas del Siglo de Oro, entre la que se destaca la edición conjunta de El ingenioso hidalgo Don Quijote de La Mancha que elaboró con Isaías Lerner y que publicó Eudeba en 1968 (Cf. Capítulo 3). Asimismo, fue secretaria de redacción de la revista Filología y en 1984 fue designada académica de número en la Academia Argentina de Letras.

Las someras semblanzas presentadas ofrecen un acercamiento a los modos en que en el Instituto de Filología se forjaron las trayectorias y derroteros de figuras relevantes para el hispanismo no solo argentino, sino mundial. En ese ejercicio del magisterio, de la docencia, de la crítica y la investigación se fue consolidando una tradición de estudios y líneas de indagaciones vinculados con la lengua y la literatura 
españolas ${ }^{136}$. En ese sentido, el Instituto de Filología supo conjugar las diversas perspectivas teóricas y metodológicas y promover la formación crítica de sus integrantes. Así lo expresa Enrique Pezzoni, en un homenaje a Ana María Barrenechea: "Muchas son, pues, las perspectivas que se entrecruzan en el Instituto de Filología cuando Anita trabaja en él. Lingüística, estilística, filosofía del lenguaje, estética, estudios sobre la literatura latinoamericana y la española [...] De esa multiplicidad está hecho el discurso crítico del Instituto, con una riqueza que nada tiene que ver con el eclecticismo amorfo" (1984: 17). Asimismo, a través de sus líneas de investigación y de los aportes teóricos que impulsó, el Instituto de Filología reorganizó y sentó las bases de la crítica literaria en el ámbito académico durante las décadas siguientes.

El alejamiento de Amado Alonso de la dirección del Instituto de Filología en 1947 coincide con su ida del país hacia Estados Unidos, invitado por la Universidad de Harvard como Visiting Lecturer. Mucho se ha especulado sobre las razones del apartamiento del filólogo de su cargo, pero la mayoría de los trabajos al respecto coincide en atribuirle un carácter político por su oposición al gobierno peronista (Buchbinder 1997; Zuleta 1992; Lecea Yábar 1995; Venier 2002; Lida 2012, 2104) ${ }^{137}$, que remiten, en mayor o menor medida, a las desavenencias políticas con el gobierno nacional y con las designadas autoridades universitarias ${ }^{138}$. En los hechos, Alonso

\footnotetext{
${ }^{136}$ Las publicaciones específicas de los investigadores del Instituto de Filología acerca de temas de literatura española serán presentadas de manera más exhaustiva en el Capítulo 2 de este trabajo.

${ }^{137}$ En tal sentido, una nota de color la ofrece la necrológica sobre Alonso publicada en el Bulletin Hispanique en el año de su muerte, en la que se afirma que el alejamiento del filólogo se debió "à l' avènement d'un nouveau régime auquel les savants de l' Institut refusèrent de jurer fidélité" (Vol. LVI, 1952:450-452). La cita reafirma la idea que circuló en diferentes ámbitos respecto del cariz político del alejamiento.

${ }^{138}$ Frente a la cuasi unanimidad en las interpretaciones acerca de la jugada política para apartar a Alonso del cargo, aprovechando el cambio de autoridades, algunas, como la del escritor argentino Arturo Cambours Ocampo expresan que, sin quitarle el cariz político, hubo otros entretelones detrás de esa decisión. Cambours Ocampo se había opuesto críticamente a la injerencia del Instituto de Filología en cuestiones de la lengua. En un trabajo de 1952, titulado "El problema de nuestro lenguaje" plantea su posición crítica y, en una nota al pie, expresa:
} 
marchó hacia Estados Unidos y no regresó a la Argentina; continuó su carrera académica en el país del norte, donde falleció a los pocos años.

A partir de la idiosincrasia que Amado Alonso le imprimió a su labor al frente del Instituto ${ }^{139}$, éste logró producir importantes frutos que fueron conformando un foco de estudios hispanistas que, desde el Cono Sur y alejados de la metrópoli, adquirieron una relevancia distintiva. La labor de investigación y de divulgación del Instituto durante la gestión de Alonso lo llevaron a ocupar un lugar destacado en el mapa del hispanismo internacional, a la vez que se afirmaba en la Argentina una incipiente tradición de estudios hispánicos, cuya trayectoria iba a afianzarse en las décadas siguientes.

Terminado este trabajo, nos llega la noticia de la muerte de Amado Alonso en Arlington, Massachusetts, el 26 de mayo de este año. Lo conocí en 1930. Conversamos, muchas veces, del problema de la lengua en la Argentina. Su defensa de la unidad era lógica y respetable. Lógica y respetable para él. Mi posición no aceptaba sus puntos de vista; Alonso, en cambio, comprendió buena parte de nuestras razones y publicó, en 1930, el primer tomo de la Biblioteca de Dialectología Hispanoamericana (Estudios sobre el español de Nueva Méjico). A su lado trabajó un grupo, muy reducido, de alumnos y profesores que conservan del ex director del Instituto un recuerdo de profunda admiración, respeto y amistad. Es, precisamente, teniendo en cuenta esos sentimientos tan nobles, que no queremos que nuestras palabras -en estas horas de dolor- molesten, de ninguna manera, a los que fueron sus amigos. No le reprochamos al profesor Amado Alonso su actitud de filólogo hispano en Buenos Aires. Después de todo, cumplía con un mandato. Sí, le reprochamos su intromisión en la política: la universitaria y la otra. Esto es necesario que lo sepan los jóvenes españoles que hoy lo lloran. Amado Alonso jugó a la política en la Argentina y se equivocó. Por esta razón tuvo que abandonar Buenos Aires. Su condición de profesor extranjero y su postura beligerante eran incompatibles con la cátedra. Ahora descansa en paz en el cementerio de Mount Auburn. España ha perdido uno de sus más altos valores contemporáneos" (1952: 25).

${ }^{139}$ La adscripción de la figura de Amado Alonso con la de "maestro" está presente en las invocaciones de sus discípulos. Así Ma. Rosa Lida se refiere a él al despedirlo en 1947, cuando Alonso deja la Argentina: "Esto es lo que, ante todo, es aquel Amado Alonso: un maestro", Frida W. de Kurlat (1975), expresa: "Amado Alonso fue un maestro en el sentido más amplio y generoso del término". En sentido similar se manifiestan Morínigo y Rosenblat. Asimismo, a su muerte se publican homenajes en diversas revistas, entre las que se pueden citar Ínsula $\mathrm{N}^{\circ} 78$ (julio 1952), en donde escriben sobre la figura del filólogo Dámaso Alonso, María Rosa Lida y el mismo Ramón Menéndez Pidal. También la Revista de Filología Española de Madrid dedica un homenaje en el Tomo XXXVI (1952-1953) y en la Nueva Revista de Filología Hispánica, de la que fue fundador, se publica una nota necrológica a cargo de Raimundo Lida (Años VII-IX 1953-1954), en un volumen dedicado en su memoria. Lo mismo ocurre con el volumen del Año IV, N ${ }^{\circ}$ 1-2-3 (1952-1953) de la revista Filología, publicada por el Instituto de Filología de Buenos Aires, en donde se publica un homenaje a cargo de Guillermo Guitarte y los volúmenes correspondientes al Año V, N ${ }^{\circ} 1-2$ y 3 (1959), que exhiben en la tapa la leyenda "Homenaje a Amado Alonso", aunque en el interior no figuran textos sobre el filólogo ni su obra. En 1996, al cumplirse el centenario del nacimiento del filólogo navarro, la revista Ínsula dedica el $\mathrm{N}^{\circ} 599$ a su figura, bajo el título "Amado Alonso, español de dos mundos"; también Cauce. Revista de Filología, Comunicación y sus Didácticas destina el $\mathrm{N}^{\circ} 18-19$ (1995-1996) a recordar a Alonso, con contribuciones de discípulos y de reconocidos lingüistas y filólogos, e incluye un Apéndice y los registros sonoros de unas grabaciones realizadas por el propio Alonso con la lectura de textos de Federico García Lorca y de Don Quijote de La Mancha. 


\subsubsection{Proyecciones: hacia una cartografía del hispanismo argentino}

La centralidad que la ciudad de Buenos Aires y sus instituciones revistieron en la génesis y conformación de los estudios hispánicos ha quedado demostrada a través de la revisión de los procesos de constitución de núcleos de intelectuales nacionales y españoles que fueron cimentando una tradición de estudios lingüísticos, filológicos y literarios a partir de los diálogos y los vínculos que se fueron estableciendo desde el periodo de entresiglos y que, con los años, consolidaron y difundieron teorías, metodologías, saberes y lecturas.

Ese proceso de formación de un hispanismo de cuño argentino está fuertemente ligado con las instituciones académicas y educativas y con el relieve que adquirieron ciertas figuras intelectuales, cuyas trayectorias signaron los estudios hispanistas y que permitieron su arraigo y diseminación en diferentes centros del país. Así, es posible observar a partir de las primeras décadas del siglo $\mathrm{XX}-\mathrm{y}$ en correlato con el afianzamiento de la investigación en Argentina - la creación de institutos y centros de investigación vinculados con las Humanidades, en el marco de los cuales los estudios hispánicos ocuparon un lugar relevante, ya sea por las líneas de trabajo delineadas, por los temas objeto de indagación o por la impronta que ciertas figuras imprimieron a los perfiles de las instituciones y sus producciones. Esto permitirá trazar un mapa inicial del hispanismo argentino a través de la conformación de núcleos académicos que tuvieron entre sus intereses los estudios hispánicos a mediados del siglo XX, en estrecha relación con los cambios y transformaciones que fue sufriendo la vida universitaria argentina a partir de mediados de siglo y que incidieron en las configuraciones del campo académico.

Un primer hito en esta proyección del hispanismo en el campo académico argentino lo constituye la Universidad Nacional de La Plata que exhibe, junto con las 
instituciones académicas y culturales de Buenos Aires, una fértil trayectoria, iniciada tempranamente (Rodríguez Temperley 2008). Como se ha señalado, ya en 1909 se crea la Sección de de Historia, Filosofía y Letras, en la que se desempeñó Ricardo Rojas como profesor y en 1914, junto con la creación de la Facultad de Humanidades — hoy centenaria - se inicia la carrera de Profesorado en Filosofía y Letras, que contará entre sus docentes a profesores que compartía con la Universidad de Buenos Aires y con los Institutos del Profesorado, con lo cual se establecía una red de relaciones intelectuales y de fomento de los estudios e investigaciones entre ambas sedes. Asimismo, como se ha señalado, a comienzos del siglo XX, la Universidad Nacional de La Plata fue receptora de una parte importante de visitas de catedráticos españoles que establecieron lazos académicos con las instituciones argentinas, en particular con las universidades, como parte significativa del proyecto de expansión de los estudios científicos españoles desde la Península hacia los países hispanoamericanos en el marco de la actualización de los enfoques científicos cuyos resultados impactaron en el desenvolvimiento de ciertas disciplinas. Esto pone de manifiesto la temprana vocación de la Universidad por ocupar un lugar distinguido en el panorama académico nacional, en especial en el campo de los estudios humanísticos, consolidada a través del establecimiento de relaciones interinstitucionales tanto en el país como en el extranjero, particularmente con España, cuyo estatuto como referente cultural estaba en pleno estado de revisión durante este periodo $^{140}$.

Por otra parte, en los procesos de creación y organización de las instituciones, algunas figuras adquieren una relevancia particular por el carácter fundacional de sus

\footnotetext{
${ }^{140}$ Es de destacarse, como se ha señalado, que la Universidad Nacional de La Plata fue pionera en la recepción de académicos españoles que vinieron a dictar cursos y conferencias en sus claustros, como lo fue el convenio con la Universidad de Oviedo, por la cual llegaron a las tierras del Plata en la primera década del siglo XX Adolfo Posadas y Rafael Altamira, quienes fueron señeros en la consolidación de los vínculos intelectuales entre ambos países (Cf. Notas $n^{\circ} 43-45$ ).
} 
acciones; ya se ha observado el papel clave de Ricardo Rojas en la concreción de cátedras universitarias en la Universidad de Buenos Aires, su impulso para la formación del Instituto de Filología en esa misma casa de estudios, además de su desempeño en cargos de gestión en el Estado y en el mismo ámbito universitario. A esto debe sumarse la publicación de su libro Poesías de Cervantes, en 1916, que de algún modo inaugura los estudios cervantinos en nuestro país. En esa línea de investigaciones acerca de textos y autores hispánicos en la Universidad Nacional de La Plata pueden reconocerse figuras que fueron cimentando la consolidación de los estudios hispánicos; entre ellas deben destacarse las de Arturo Marasso y Augusto Cortina, ${ }^{141}$ quienes, en consonancia con las líneas propuestas desde la creación de la Sección de Historia, Filosofía y Letras, desarrollarán una sólida tarea de docencia e investigación literaria que permitirá ubicar a La Plata como uno de los centros reconocidos en el concierto del hispanismo nacional.

Así, se comienza a consolidar en el ámbito de la Facultad de Humanidades y Ciencias de la Educación una tradición de estudios y de análisis de textos literarios hispánicos, como también de investigaciones lingüísticas y filológicas que se concretarán en la creación de institutos y centros de investigación y en publicaciones de diversa índole que irán ampliando el mapa del hispanismo a nivel nacional.

El camino de la formación de una tradición argentina en el campo del hispanismo se había abierto; a partir de los núcleos de docentes e investigadores dedicados a los estudios hispánicos se iniciará una proyección hacia otros centros creados a lo largo del país, que fructificarán en publicaciones y aportes de relieve, y también en la formación de nuevas generaciones de investigadores. En ese proceso de

\footnotetext{
${ }^{141}$ Arturo Marasso (1890-1970) fue un escritor, profesor y crítico literario argentino, que desempeñó gran parte de su carrera académica en la Universidad Nacional de La Plata. Fue designado miembro de la Academia Argentina de Letras, cuyo Boletín dirigió durante décadas. Entre su producción crítica se destacan los estudios sobre literatura española.

Augusto Cortina Aravena (1902-1981) se graduó en la Universidad Nacional de la Plata y se doctoró en España. A su regreso ejerció la docencia y la investigación en la Universidad Nacional de La Plata. Fue el primer director del Instituto de Investigaciones Literarias, creado en 1937, cuyo Boletín, iniciado ese mismo año, tuvo a su cargo.
} 
irradiación, este aspecto formativo adquiere una significación particular, ya que la impronta de los vínculos entre maestros y discípulos marcará de algún modo la conformación de un "mapa" del hispanismo argentino, a partir de las trayectorias profesionales de sus integrantes y sus modos de inserción en el ámbito académico, a la vez que contribuirá a la conformación de un hispanismo de raigambre nacional gestado en el seno de las instituciones y academias a lo largo del país.

De este modo, la matriz formativa y la pertenencia institucional, así como una marcada vocación por la investigación y la difusión de los aportes que desde el ámbito académico argentino se fueron generando, constituyen los rasgos principales de este hispanismo argentino que a mediados del siglo $\mathrm{XX}$ se encontraba en proceso de consolidación. 


\section{CAPITULO 2: El Hispanismo y la vida académica argentina a partir de 1940}

\subsection{Cambios y transformaciones en el sistema universitario argentino (1930-1960)}

Como se ha señalado, una de las hipótesis que orienta este trabajo sostiene que en la Argentina, el hispanismo — considerado en tanto área de estudio e investigación de la lengua y la cultura españolas - constituye un ámbito de producción e investigación fuertemente vinculado con la vida académica, cuyos principales aportes se visibilizaron en publicaciones, revistas literarias y culturales, ediciones críticas de obras destinadas no sólo al estudio, sino a un público cada vez más amplio, así como en otros discursos que dan cuenta de las apropiaciones críticas del canon hispánico (reseñas, comentarios críticos, boletines de instituciones, etc.). Esta articulación entre hispanismo y vida académica requiere examinar las fluctuaciones que este ámbito experimentó desde mediados del siglo, en correlato con los cambios y movimientos políticos y sociales que atravesaron la historia argentina durante ese periodo y que repercutieron de manera más o menos directa en el ámbito académico y, en particular, en las universidades. Esto posibilitará analizar las modulaciones que el hispanismo —entendido como el estudio de la literatura y la cultura españolas - fue adquiriendo, junto con su consolidación como un espacio diferenciado en el campo académico argentino.

Desde las renovaciones impulsadas por la Reforma Universitaria de 1918, la universidad argentina continuó su desarrollo bajo esos principios, que incluían — junto con el cogobierno de docentes, graduados y estudiantes-, modificaciones en los planes de estudio y en los perfiles profesionales de los egresados, y el fortalecimiento de las otras dos funciones básicas de la universidad: la investigación y la extensión. La década de 1920 fue el momento de la orientación de las universidades nacionales a las posturas reformistas, tal como se ha podido observar en los derroteros de la Universidad de 
Buenos Aires y de La Plata, orientación que se extendía a los otros centros universitarios del país ${ }^{142}$. En ese contexto se inició en dichas universidades la institucionalización de la investigación, a partir de la creación de centros e institutos que cimentaron el desarrollo de los estudios en las diferentes disciplinas. Entre ellas, las humanísticas tuvieron un lugar destacado, tal como se observa en la creación del Instituto de Investigaciones Históricas en 1921, el Instituto de Literatura Argentina, en 1922 y el Instituto de Filología en 1923, de la Universidad de Buenos Aires (Buchbinder 1997), y el Instituto de Investigaciones Literarias de la Universidad Nacional de La Plata en 1937. Esto constituyó el punto de partida de una etapa de afianzamiento de la dimensión investigativa de las universidades, en consonancia con los principios reformistas.

A comienzos de la década de 1930 — y en relación con los cambios y vicisitudes de la vida política y social del país_ ${ }^{143}$, se observa en la universidad la emergencia de tensiones entre las posiciones reformistas y las de sectores más conservadores, que disputan el perfil y los fines de la universidad (Mangone y Warley 1984; Buchbinder 2005). De este modo, los acontecimientos que marcaron la política argentina se trasladaron al ámbito universitario, donde dejaron entrever las posturas y visiones contrapuestas acerca de la universidad como institución y su papel en la sociedad.

\footnotetext{
${ }^{142}$ Recuérdese que hasta inicios de la década de 1950 sólo existían en la Argentina seis universidades nacionales: la de Córdoba (1623), la de Buenos Aires (1821), la de La Plata (1905), la del Litoral (1919), la de Tucumán (1914, nacionalizada en 1921) y la de Cuyo (1939) (Buchbinder 2005).

${ }^{143}$ En septiembre de 1930 se produjo el golpe de estado, de carácter cívico-militar, que derrocó al presidente Yrigoyen. En su lugar asumió el general José Félix Uriburu, de tendencias corporativistas, lo que marcó el inicio de un periodo de alta inestabilidad política e institucional, así como del enfrentamiento de sectores que profesaban ideologías diversas, que termina con la llegada al poder del conservador General Agustín P. Justo en 1932. Esta época -que se extiende hasta 1943- es conocida como la "Década infame" rótulo que propone, en su condensación, una visión unívoca y sin fisuras que ha sido objeto de revisiones. La historiografía coincide en atribuir al escritor y periodista tucumano José Luis Torres (1901-1965) la acuñación del nombre a partir de la publicación de su libro La Década Infame (1930-1940). Apuntes históricos para el estudio del presente político, que apareció en 1945 bajo el sello Editorial Formación Patria. Este hecho también revela el poder ascendente de las Fuerzas Armadas como actores políticos, que se afianzará a lo largo de las décadas siguientes.
} 
Paralelamente a las crisis políticas e institucionales, los años treinta se presentan como una época de expansión de la vida cultural, impulsada entre otros factores por la modernización, la creciente urbanización ${ }^{144}$, el flujo de personalidades del arte y la cultura de diversos lugares del mundo, y el desarrollo de la industria editorial y de los medios de comunicación (en especial, la radiodifusión). Esta intensa actividad cultural se verá reflejada en la multiplicidad de conferencias, ciclos de charlas, representaciones teatrales, conciertos, publicaciones de revistas, libros y suplementos culturales de la prensa escrita que tendrán lugar en estos años (Lida 2014) ${ }^{145}$.

En el plano cultural, además, en 1928 se creó la Sociedad Argentina de Escritores (SADE), cuya finalidad era afianzar los lazos entre escritores y otorgarles cierta representatividad gremial $^{146}$; en 1931 se crea la Academia Argentina de Letras, que reunirá a figuras de destacada trayectoria en la filología y la literatura y otorgará carácter institucional a las acciones en pos de regular los usos lingüísticos, cuestión que había sido objeto de debates intensos desde comienzos de siglo. Al mismo tiempo, la industria editorial experimenta un periodo de expansión considerable, lo que amplía el mercado de lo impreso y el público lector (de Diego 2006), proceso en el cual los editores de origen español tendrán una incidencia considerable, tal como se analizará

\footnotetext{
${ }^{144}$ Uno de los rasgos salientes del gobierno del general Justo fue el impulso a la obra pública, que se concretó en edificios, puentes, carreteras, hospitales, etc. En el caso de las universidades, en la década de 1930 se erigen los edificios de las Facultades de Medicina de la Universidad de Buenos Aires (que antes había ocupado otro predio, donde luego se instalaría la Facultad de Ciencias Económicas) y la Biblioteca Pública de la Universidad Nacional de La Plata. Para una reseña de los edificios que ocupó la Universidad de Buenos Aires puede consultarse el sitio: http://www.uba.ar/institucional/uba/edificios/univ_inv.pdf

${ }^{145}$ Para contrarrestar la visión simplificadora que sobre esta época se ha gestado, Miranda Lida ofrece en su libro una mirada diferente y acentúa el lugar de Buenos Aires, que, desde su perspectiva, "llegó a ocupar una importante plaza vacante en el mundo, convirtiéndose en un centro productor de cultura de nivel internacional" (2014: 133). Como muestra de esta efervescencia cultural puede citarse las visitas del escritor español Federico García Lorca (1933) o del músico ruso Igor Stravinski (1936), que fueron un suceso de público y de gran repercusión en los medios. También puede mencionarse como un hito de la época la creación de la revista Sur, en 1933, cuya impronta en la ámbito cultural e intelectual argentino ha sido profusamente estudiado (King 1989; Gramuglio 1983, 1986, 2004; Wilson 2003, por citar algunos).

${ }^{146}$ Para profundizar en la historia y trayectoria de la SADE, en particular durante las décadas de 1940 y 1950, véanse Fiorucci 2001, 2011 y Nállim 2003.
} 
más adelante. Las revistas culturales también tuvieron un papel relevante en el proceso de conformación del campo cultural argentino, entre las cuales pueden mencionarse Nosotros, que había iniciado su vida en 1907 y que continuó hasta la década de 1940 y Sur, fundada por Victoria Ocampo en 1931. Ambas revistas también llevarían adelante proyectos editoriales de envergadura que completarían el panorama editorial de la época.

Esto pone de manifiesto la complejidad y densidad del periodo y las múltiples aristas que presenta, entre las cuales los vaivenes de la universidad serán una parte importante de los debates que lo atravesarán. Como se ha visto, durante estos años se va consolidando la investigación y la extensión en el ámbito académico, lo cual se traduce en la producción intelectual de los institutos y de los centros universitarios, así como en las acciones desarrolladas por academias y otras instituciones del quehacer cultural, en los cuales los estudios hispánicos tendrán un lugar relevante. En este panorama ocuparán también un rol destacado los exiliados europeos — fundamentalmente españoles - que se desempeñarán en las universidades argentinas y dejarán su impronta en los estudios humanísticos ${ }^{147}$, así como en el mercado editorial en expansión.

En ese contexto, el proceso de renovación y de autonomización de la universidad instaurado a partir de la Reforma Universitaria sufrirá un severo revés luego del golpe militar que en junio de 1943 puso fin al gobierno del presidente Ramón Castillo y con él a la denominada "Década infame". A diferencia de lo ocurrido en el periodo anterior, en que las universidades habían mantenido cierta autonomía respecto del poder político, el gobierno de facto instaurado, conformado por sectores pertenecientes al nacionalismo y al catolicismo conservador, avanzó sobre las universidades, cuyo efecto más relevante

\footnotetext{
${ }^{147}$ Entre los exiliados que llegaron a la Argentina y desarrollaron sus actividades académicas se pueden citar a los españoles Lorenzo Luzuriaga, pedagogo que se desempeñó en la Universidad Nacional de Tucumán, adonde también recalaron el filósofo español Manuel García Morente, y Claudio Sánchez Albornoz, historiador especializado en la Edad Media, quien ejerció la docencia y la investigación en las universidades de Cuyo y de Buenos Aires (Buchbinder 2005: 127-128).
} 
fue la intervención en la Universidad Nacional del Litoral, y acciones similares en la de Buenos Aires, Cuyo y La Plata. Junto con esto, se produce la cesantía de profesores y la movilización estudiantil en rechazo de esta injerencia gubernamental en la vida institucional (Mangone y Warley 1989; Buchbinder 2005, 2006). Como resultado de las presiones de diversos grupos, a mediados de 1945 se inicia una etapa de normalización de las universidades. Sin embargo, los sucesos políticos por venir obturaron tempranamente este proceso y comenzará así otro periodo convulsionado para las universidades argentinas. Las elecciones generales de febrero de 1946 llevaron al gobierno al Coronel Juan Domingo Perón, que había sido funcionario del régimen anterior, una de cuyas primeras acciones fue la de decretar la intervención de las universidades nacionales (Decreto $\left.\mathrm{N}^{\circ} 12.195 / 46\right)^{148}$, acción que acarreó expulsiones, cesantías, renuncias y jubilaciones anticipadas de docentes, en particular entre los últimos meses de 1946 y comienzos de 1947, junto con protestas y movilizaciones estudiantiles en repudio a las acciones del gobierno ${ }^{149}$. De este modo se produce una ruptura de la lógica de la carrera docente tal como había sido concebida desde la Reforma; los cargos dejados vacantes son cubiertos en su mayoría por docentes que ya

\footnotetext{
${ }^{148}$ El Decreto, firmado por el entonces presidente Edelmiro Farrell, señala la necesidad de intervenir las universidades nacionales a fin de adecuarlas al nuevo régimen legal y político. Así en el anteúltimo considerando, expresa: "Que las Universidades, en esta hora de grandes transformaciones en el orden jurídico, como en el económico-social, tanto en nuestro país como en todos aquellos que marchan a la cabeza de la civilización, deben responder, como fiel imagen del país, a este reclamo de conciencia nacional, aproximándose al pueblo como cosa propia e imprescindible para su progreso" (citado en Mangone y Warley 1984: 92-93).

${ }^{149}$ Uno de los casos resonados de profesores que fueron dejados fuera del sistema fue el de Amado Alonso, en ese entonces director del Instituto de Filología de la UBA (Cf. Capítulo 1). En la Facultad de Filosofía y Letras de esa universidad también dejaron sus cargos Emilio Ravignani y Ricardo Rojas. Lo mismo ocurrió en La Plata con Francisco Romero, Juan Mantovani y José María Monner Sans, profesores de la Facultad de Humanidades (Buchbinder 2005, 2006). En algunos casos, su distanciamiento se debió al giro que tomaron los acontecimientos y su discrepancia con las medidas tomadas por el gobierno.
} 
se desempeñaban en la misma universidad o en otras universidades nacionales, que de este modo acceden a las cátedras ${ }^{150}$.

Este proceso de reformulación de las relaciones entre gobierno y universidad culminará en 1947 con la sanción de la ley $13.031{ }^{151}$. En palabras de Buchbinder: "la irrupción del peronismo introdujo así una serie de cambios sustanciales en las formas de entender los vínculos entre la Universidad y el sistema político" (2005: 150). También según este autor, a diferencia del periodo 1943-1946, en el que las reformas apuntaban a una reorientación de la enseñanza según perspectivas ideológicas concretas, en los primeros años del peronismo no hubo modificaciones sustanciales en los modos y las prácticas universitarias; el cambio más notorio estuvo puesto en la reformulación de los principios y fines de la universidad respecto del ideario reformista, impulsada desde el gobierno para alinearla a las políticas gubernamentales que propició la ley de Régimen Universitario. Por otro lado, la sanción de la Constitución de 1949 profundizó el modelo que el gobierno peronista pretendía para las universidades (Mangone y Warley: 34$35)^{152}$. Esto acarreó la conformación de grupos que, desde fuera de los claustros,

\footnotetext{
${ }^{150}$ Como ejemplo de esta situación puede mencionarse, para la Facultad de Filosofía y Letras de la UBA, los casos de los profesores Ángel Battistessa, quien quedará a cargo de Literatura Castellana y de Ramón Albesa, en la cátedra de Latín. Una parte de la tradición universitaria ha homogeneizado a estos docentes que accedieron a las cátedras luego del proceso de expulsión de estos años bajo el rótulo "Flor de Ceibo", en directa alusión a la línea de productos de la industria nacional generados durante esa época y que llevaban el nombre la flor nacional argentina. En el plano del discurso, esta denominación conlleva la connotación de poca calidad y mediocridad, cuando en realidad, en muchos casos, los docentes que accedieron a las cátedras en este momento tenían una trayectoria destacada, como el caso del profesor Battistessa. Esto no hace más que expresar las visiones maniqueas que parte de la historiografía ha cristalizado acerca de las relaciones entre el gobierno peronista y la clases intelectuales, presentado en término de oposiciones insalvables ("alpargatas sí, libros no" es el lema que parece resumir estas visiones).

${ }^{151}$ Esta ley, promulgada el 9 de octubre de 1947, y conocida como la "Ley Guardo" debido al nombre del diputado justicialista que la propició, modificó el sistema universitario y su funcionamiento, así como el régimen de designación de docentes, las formas de gobierno universitario, entre otros aspectos. Se caracteriza básicamente por su índole reglamentarista y por promover una mayor sujeción de la universidad a los lineamientos del gobierno.

152 Haciendo una ajustada síntesis, puede afirmarse que el espíritu general que imbuía a la Constitución de 1949 apuntaba a modificar los fundamentos ideológicos de la Constitución de 1853, de corte más liberal, para adecuarlo al nuevo proyecto en el cual el Estado adquiría un rol más preponderante. En ese marco, las universidades, en tanto instituciones estatales, debían reformular sus funciones a fin de
} 
mantuvieron un programa intelectual paralelo, fundamentalmente aglutinado en torno a revistas o publicaciones que reunían las voces de los desplazados de la academia ${ }^{153}$. Entre las revistas que se fundaron en estos años y que nucleaban a los intelectuales desplazados puede citarse Imago Mundi, creada por José Luis Romero en 1953. Posteriormente a la caída del gobierno en 1955, Romero y otros intelectuales contribuyeron a consolidar el discurso acerca de la existencia de una "universidad en las sombras", o "la academia fuera de la academia" para referirse a estos proyectos intelectuales (Fiorucci 2011; Buchbinder 2005). Al mismo tiempo, en el ámbito de las universidades la vida académica continuó, más allá de los debates que la atravesaban, tal como puede observarse en el caso de las publicaciones académicas, que durante estos años, previos al golpe de 1955, siguieron con sus proyectos ${ }^{154}$.

Las investigaciones recientes sobre las políticas culturales del peronismo insisten en destacar que durante los primeros años del gobierno del general Perón no se logró articular un programa sistematizado de organización del campo intelectual y académico

otorgarles un sesgo marcadamente social y de formación política Así, el Artículo 37, III. 4 expresa: “El Estado encomienda a las universidades la enseñanza en el grado superior, que prepare a la juventud para el cultivo de las ciencias al servicio de los fines espirituales y del engrandecimiento de la Nación y para el ejercicio de las profesiones y de las artes técnicas en función del bien de la colectividad. Las universidades tienen el derecho de gobernarse con autonomía, dentro de los límites establecidos por una ley especial que reglamentará su organización y funcionamiento". Más adelante, el mismo apartado agrega: "Las universidades establecerán cursos obligatorios y comunes destinados a los estudiantes de todas las facultades para su formación política, con el propósito de que cada alumno conozca la esencia de lo argentino, la realidad espiritual, económica, social y política de su país, la evolución y la misión histórica de la República Argentina, y para que adquiera conciencia de la responsabilidad que debe asumir en la empresa de lograr y afianzar los fines reconocidos y fijados en esta Constitución". Estos principios habilitaron una mayor injerencia del Estado en la vida universitaria e intensificaron los debates en el mundo académico.

153 Otras revistas culturales editadas durante el gobierno peronista que expresaban ideologías contrarias al gobierno fueron Expresión (1946-1948), de tendencia de izquierda, Realidad (1947-1949), dirigida por Francisco Romero, Liberalis (1949-1961), de cuño liberal, además de Sur, que durante estos año continuó con su publicación y sus posturas antinómicas a las formas del nacionalismo cultural (Fiorucci 2011).

${ }^{154}$ Al respecto, véase el caso de la revista Filología, del Instituto de Filología de la UBA, creada en 1949, o el Boletín de la AAL, iniciado en 1933, que continuaron su publicación en esos años, a pesar de ciertas interrupciones producidas a partir de la década de 1950, a raíz del endurecimiento de las relaciones entre el gobierno y las universidades y otras instituciones del campo cultural. En el caso de Filología, la publicación vino a ocupar de algún modo el lugar de la Revista de Filología Hispánica creada por Amado Alonso y que él se llevó al ausentarse de Buenos Aires para continuarla en México. Estos aspectos se desarrollarán en el apartado destinado al Instituto de Filología y sus publicaciones. 
(Fiorucci 2011) y que las relaciones entre gobierno e intelectuales tuvieron diferentes momentos y avatares, por lo que no pueden ser simplificadas bajo lemas o rótulos que ofrezcan una perspectiva unívoca y totalizante ${ }^{155}$.

La convulsionada vida universitaria argentina tendrá otro hito relevante a partir de 1955, año en que el gobierno del general Perón es derrocado por un golpe militar conocido como la "Revolución Libertadora", que instauró un régimen cívico militar. Uno de los primeros objetivos del nuevo gobierno fue la intervención de las universidades nacionales y su reorganización según los principios de la autonomía. Una vez más, las universidades eran objeto de disputas ideológicas respecto de sus fines sociales y de su relación con el Estado, tal como queda plasmado en el decreto 6403 de diciembre de 1955 , cuyo artículo $28^{156}$ instalaría la discusión acerca de un sistema universitario mixto que diera cabida a la creación de universidades privadas, cuestión que finalmente fue aprobada por el presidente Arturo Frondizi en 1958 $8^{157}$. Según expresa Buchbinder, el gobierno de la Revolución Libertadora se propuso "construir sobre nuevas bases la relación entre el Estado y la Enseñanza Superior" (2005: 174), propuesta similar a la que habían alentado las reformas del gobierno peronista la década anterior. En ese marco, y a lo largo de la década que culminará con el golpe de 1966, se

${ }^{155}$ Como ejemplo de estos vaivenes puede citarse la presencia del general Perón en el acto de homenaje por el cuarto centenario de Cervantes realizado por la Academia Argentina de Letras en octubre de 1947, donde realizó una defensa de los ideales hispánicos, tal como se analizará más adelante.

${ }^{156}$ El texto del artículo 28 del Decreto-ley es escueto y expresa: "La iniciativa privada puede crear universidades libres que estarán capacitadas para expedir diplomas y títulos habilitantes siempre que se sometan a las condiciones expresadas por una reglamentación que se dictará oportunamente" (Extraído de https://www.boletinoficial.gob.ar/\#!DetalleNormaBusquedaAvanzada/10921348/null) Consultado el $2 / 2$ 12016). Con posterioridad fue modificado por el art. $1^{\circ}$ de la Ley $14557 / 58$, que ajusta los alcances de las universidades privadas y su relación con el Estado nacional.

157 El gobierno de facto establecido luego de la denominada "Revolución Libertadora" convocó a elecciones en 1958, en las cuales el peronismo estuvo proscripto como partido político. Asumió como presidente Arturo Frondizi, proveniente de la Unión Cívica Radical, quien fue destituido en 1962. Convocadas nuevamente las elecciones, y con el peronismo aún excluido de la participación, en 1963 es electo Arturo U. Illia, también de extracción radical, quien será depuesto en 1966. A pesar de la alternancia entre gobiernos militares y civiles, la década 1955-1966 está signada por el poder y el control de las Fuerzas Armadas en todos los ámbitos, lo cual se evidencia en la fragilidad de los gobiernos civiles electos en ese periodo, a lo que se suma la proscripción del Partido Justicialista. 
producen dos fenómenos paralelos, de impacto en el sistema universitario nacional: por un lado, la modernización funcional y de contenidos de las carreras universitarias y la expansión del sistema científico ${ }^{158}$, y por otro, la creación de nuevas universidades que dieran respuesta a la creciente masificación de la enseñanza superior ${ }^{159}$. Este crecimiento y ampliación del sistema universitario, sumado a la impronta renovadora que se le dio a los estudios y a la investigación han vinculado esta etapa de la vida universitaria con cierta "edad dorada", en especial en la Universidad de Buenos Aires, donde estos fenómenos se expresaron con más fuerza. Junto con ello, los protagonistas de este proceso comparten una conciencia de "refundación" de la universidad, que no implica retrotraerla a la universidad anterior al peronismo, sino inaugurar una "nueva época" ${ }^{160}$. También se asiste en estos años a la expansión del mercado editorial, y dentro de él, de las editoriales universitarias ${ }^{161}$, cuya producción crece de modo exponencial, tanto en lo referido a publicaciones periódicas como a obras de teoría y crítica, así como la incorporación de nuevos paradigmas teóricos y metodológicos de las disciplinas.

\footnotetext{
${ }^{158}$ Este proceso fue más evidente en las universidades más grandes, como el caso de la UBA, donde se crearon en la década de 1950 carreras como Psicología (1957), Sociología (1957) y Antropología (1958), que dan cuenta de la relevancia de estos estudios en el país, donde ya contaban con trayectorias desde cátedras e institutos, y de la demanda de profesionalización. En el ámbito científico, en 1951, por el decreto 9695/51 se creó el Consejo Nacional de Investigaciones Técnicas y Científicas (CONITYC), primer centro de investigaciones científicas a nivel nacional. En esta línea, en 1958, aún bajo el gobierno de facto del General Pedro Aramburu, se creó el Consejo Nacional de Investigaciones Científicas y Técnicas (CONICET) destinado a promover las actividades científicas y tecnológicas. Su primer director fue el doctor Bernardo Houssay, eminente científico argentino que obtuvo el Premio Nobel de Fisiología Medicina en 1947.
}

${ }^{159}$ Entre las universidades creadas en esos años pueden citarse la Universidad Nacional del Sur y la del Nordeste, en 1956. Asimismo puede mencionarse en este periodo la creación de universidades provinciales, como la de La Pampa en 1958, que fue nacionalizada en 1973.

${ }^{160}$ Afirma Beatriz Sarlo: "La revolución de 1955 interviene las universidades abriendo una nueva época. No se trata de una restauración del pasado preperonista sino de un proyecto novedoso que une las consignas de la reforma sobre el gobierno universitario al impulso modernizador que tendrá su centro en las Facultades de Ciencias Exactas y de Humanidades —en especial de la Universidad de Buenos Airesy en las estructuras, originales en Argentina, de las recién creadas universidades del Noreste y del Sur" (2001: 85).

${ }^{161}$ La creación de la Editorial de la Universidad de Buenos Aires (Eudeba) en 1958 marca un hito en el mercado editorial por la conjunción de academia y mercado y contribuye a las políticas de investigación y de extensión propiciadas por el clima intelectual de la época. Un análisis más detallado del papel de Eudeba en el campo editorial argentino se desarrollará más adelante. 
Estos aspectos impactarán en las disciplinas humanísticas, que experimentarán revisiones y ajustes acordes con las nuevas perspectivas.

En menos de dos décadas, las universidades argentinas experimentarán la tercera injerencia del gobierno en su vida institucional y política, luego del golpe de estado de 1966, autodenominado la "Revolución Argentina", que llevará a la presidencia al general Juan Carlos Onganía. A pocas semanas de establecido el gobierno de facto, se firma el Decreto-ley 16.912 que eliminaba el gobierno tripartito y lesionaba seriamente la autonomía universitaria, transformando a los rectores en interventores. La reacción de la comunidad universitaria no se hizo esperar y se expresó en los rechazos que suscitó la medida. La irrupción de las fuerzas de seguridad en la Facultad de Ciencias Exactas de la Universidad de Buenos Aires la noche misma de publicación del decreto, el 29 de julio de 1966, y la detención de profesores y alumnos — conocida como "la noche de los bastones largos" - ha quedado registrada como el momento culminante del enfrentamiento entre el gobierno de facto y la universidad. Luego de este violento episodio, se produjeron renuncias masivas de docentes y el éxodo de gran parte de ellos al extranjero, donde continuaron sus carreras académicas ${ }^{162}$. El efecto más contundente de estos hechos fue el desmantelamiento de los equipos de docencia e investigación y con ello, la reorganización de las cátedras y la suspensión de programas y proyectos. Según la mirada de los historiadores, esta intervención en la vida universitaria cercenó

\footnotetext{
${ }^{162}$ En el caso de las Humanidades, los sucesos de 1966 tuvieron un impacto decisivo en la Universidad de Buenos Aires, lo que provocó que se alejaran del país, entre otros, el historiador Tulio Halperin Donghi y el filósofo Risieri Frondizi (que había sido rector de la UBA entre 1957 y 1962). También dejó las aulas la lingüista Ana María Barrenechea, que continuó su vida académica en los Estados Unidos, donde dictaba un semestre de clases. De todos modos, no llegó nunca a radicarse en el país del norte y a su regreso al país, dirigió el grupo de investigación abocado al estudio del habla en la ciudad de Buenos Aires. El resultado de más de 20 años de investigaciones fue la publicación del texto El habla culta en la ciudad de Buenos Aires. Materiales para su estudio, en 1987, que formaba parte de un proyecto más abarcador que incluía el relevamiento a través de encuestas de los usos del habla culta en once ciudades hispanoparlantes de América y España, denominado "Proyecto de estudio coordinado de la norma lingüística culta de las principales ciudades de Iberoamérica y de la Península Ibérica". Esto expresa que, a pesar de su alejamiento de las aulas, la lingüista continuó vinculada a la investigación y la producción científica en el país.
} 
el proyecto modernizador y agudizó los conflictos intra y extrauniversitarios que serán característicos de las década siguiente.

Este sucinto panorama ofrecido sobre la vida universitaria y académica argentina desde 1940 hasta fines de la década de 1960 permite dar encuadre a las producciones intelectuales generadas durante estos años $\mathrm{y}$, a la vez, expresar las vicisitudes y alternancias de posiciones intelectuales y sus efectos en la conformación del campo académico. Junto con las transformaciones institucionales que experimentó desde mediados del siglo XX, la universidad también fue el espacio privilegiado en el que se afianzaron las corrientes teóricas y metodológicas que a partir de ese periodo se difundieron en la Argentina y que generaron una ampliación de enfoques y revisiones disciplinares. En el área de la lingüística y la literatura, desde los años 50, los aportes provenientes del estructuralismo fueron una matriz fértil para el desarrollo de los estudios literarios y lingüísticos, que se plasmaron en numerosas publicaciones e investigaciones. Un ejemplo de ello es la creación de la cátedra de Gramática en la Facultad de Filosofía y Letras de la Universidad de Buenos Aires en 1958, cuya primera docente a cargo fue Ana María Barrenechea, hecho que marca el inicio de la institucionalización de los estudios estructuralistas en el campo de la lingüística ${ }^{163}$. Las lecturas del existencialismo y del marxismo, así como las perspectivas psicoanalíticas también expandieron los horizontes teóricos y metodológicos en las disciplinas lingüísticas y literarias; de este modo se fue consolidando un campo de crítica e investigación especializado.

\footnotetext{
${ }^{163}$ Este enfoque se extenderá a la enseñanza de la lengua en el nivel medio, tal como lo atestiguan los manuales que comienzan a publicarse a partir de la década de 1960, entre los cuales pueden citarse Castellano 1, 2 y 3, de María Hortensia Lacau y Mabel Manacorda de Rosetti (1962), Castellano 1, 2 y 3 de Nicolás Bratosevich (1962) y Castellano 1, 2 y 3 de Ofelia Kovacci (1964) (Gianmatteo y Albano 2007: 114). La nomenclatura de la asignatura todavía remitía al criterio idiomático, pero el enfoque era estructuralista. Estos libros fueron utilizados para la enseñanza de la lengua durante las dos décadas siguientes. Asimismo, el modelo de análisis estructural aplicado a los textos literarios comienza a impregnar la crítica literaria y los abordajes de las obras, fundamentalmente a partir de la lectura de los textos de Ronald Barthes $(1966,1970)$, que fueron traducidos y puestos en circulación en esos años.
} 
En ese contexto, los estudios de hispanística constituyeron un ámbito particular permeado por las tensiones que atravesaron el campo intelectual. Por un lado, se observa que desde la creación de los primeros institutos de investigación en el marco de las universidades nacionales, el hispanismo comienza a consolidarse como un ámbito definido, a partir de la impronta de figuras relevantes que fueron conformando, a través de las investigaciones, ensayos críticos y formación de discípulos, una línea de estudios centrada en la literatura española, que comenzó a dar sus frutos a partir de los años 20 y 30 del siglo pasado. Por otro lado, los vaivenes y alternancias políticos de signo diferente que atravesaron las universidades fueron otorgando al hispanismo académico diferentes matices, en consonancia con las disputas ideológicas; sin embargo, un recorrido por las contribuciones críticas y la diseminación de los estudios hispánicos a lo largo del país pone de relieve que el hispanismo se fue afianzando como campo de estudio y de investigación a partir de la década de 1940 y llegó a constituir un núcleo significativo que aglutinó a un conjunto de investigadores y críticos literarios, sus producciones y aportes y ciertas matrices teóricas y metodológicas, a la vez que delineaba una red de relaciones interinstitucionales que expandía el mapa del hispanismo a nivel nacional.

\subsection{Vinculaciones entre los centros académicos y los estudios hispanistas: procesos} de configuración del hispanismo

Los institutos y centros de investigación gestados a partir de la década de 1920 surgieron como un modo de dar un encuadre académico e institucional a la investigación, hasta ese entonces diseminada en esfuerzos individuales o de pequeños grupos, y así otorgarle un estatuto particular, en consonancia con el afianzamiento de la investigación como una de las dimensiones clave de la vida universitaria. La conciencia 
de que los estudios acerca de temas autóctonos - como las variaciones lingüísticas del castellano, las vertientes folklóricas y populares, la incipiente literatura argentinadebían ocupar un lugar relevante en las líneas de trabajo marcó los orígenes de estos centros, dedicados fundamentalmente a la investigación, a la formación de estudiosos y también — como una actividad complementaria a la indagación-, a la publicación de trabajos de diversa índole (libros, artículos, recopilaciones, bibliografías razonadas, boletines, fuentes, diccionarios), que comenzaron a sistematizar el campo de las publicaciones académicas en la Argentina.

De forma paralela a este desarrollo de las líneas de investigación acerca de temas "argentinos" (la lengua, la literatura, la cultura tradicional y popular), se fue gestando un espacio dedicado a los estudios de la literatura y la cultura españolas, que se percibían vinculadas a la cultura nacional, tanto como modelos a seguir o como modelos refractarios para consolidar ciertas formas de identidad. Así, a partir de inicios del siglo XX, el hispanismo constituyó un espacio desde donde pensar las relaciones culturales con España y a la vez, a partir del cual pensar la propia identidad. En ese marco, las relaciones personales entre miembros de la clase letrada argentina con intelectuales españoles — piénsese en Ricardo Rojas y Ramón Menéndez Pidal, por ejemplo ${ }^{164}$ fueron uno de los caminos para empezar a diseñar un ámbito destinado a estudiar a la cultura española de modo excéntrico: no ya desde la metrópoli, sino desde las periferias, donde las definiciones y redefiniciones de las relaciones con España fueron moldeando ese objeto de estudio. Si durante el XIX los aportes de la intelectualidad hispanoamericana, y argentina en particular, al estudio de la cultura española se

\footnotetext{
${ }^{164}$ La relación entre ambos intelectuales a lo largo de las décadas ha quedado registrada en una profusa correspondencia. Las misivas y esquelas enviadas por Menéndez Pidal a su par argentino se conservan en la Casa Museo Ricardo Rojas de la ciudad de Buenos Aires y dan cuenta del contacto que ambos mantuvieron desde inicios del siglo XX hasta el fallecimiento de Rojas en 1957. Gracias a la generosa disposición del personal de la Casa, he podido acceder a esos materiales para su compulsa.
} 
centraron fundamentalmente en los aspectos lingüísticos (a partir de los trabajos de Bello, Cuervo, Sarmiento, Gutiérrez, Alberdi, por mencionar algunos de los nombres significativos), y también se destacaron ciertas intervenciones en el campo de la crítica literaria y de la difusión de autores y textos españoles contemporáneos — como es el caso de Calixto Oyuela ${ }^{165}$,- recién a partir de principios del siglo XX se observa un creciente interés en la Argentina por contribuir críticamente al estudio de la cultura española, y en particular, de su literatura.

La publicación en 1916 de Poesías de Cervantes, de Ricardo Rojas, constituye un hito relevante en la constitución de este incipiente hispanismo de cuño argentino. En las páginas preliminares del libro, editado en La Plata, Rojas postula su posicionamiento en el campo de los estudios cervantinos:

A este movimiento contemporáneo —que bien pudiéramos llamar neocervantismo - viene a sumarse, como humilde contribución americana, el presente volumen, donde intento aquilatar y documentar la verdadera significación de Cervantes considerado como poeta lírico (VIII).

También destaca su aporte original y cimenta su legitimidad como investigador, al afirmar:

Por eso al afrontar esta obra he debido primeramente recopilar todas las poesías líricas de Cervantes, las cuales — según mis noticias y las de las bibliografías especiales que he consultado - no han sido reunidas antes de la nuestra en edición especial [...] Tal es -me apresuro a decirlo- el justificativo y

\footnotetext{
${ }^{165}$ El cuño hispanista de Oyuela se manifiesta en varias de sus obras, en particular aquellas destinadas a la enseñanza secundaria, ámbito en con el cual Oyuela estuvo fuertemente vinculado. Un texto clave para la consolidación de un canon escolar de corte hispanista lo constituye su antología Trozos selectos de literatura castellana desde el siglo XIII hasta nuestros días (España y América), en cinco volúmenes. La primera edición de Ángel Estrada es de 1885 y a partir de entonces gozó de un amplio prestigio que contribuyó de manera cabal a fijar un corpus de materiales para la formación literaria de las generaciones de estudiantes argentinos. Ya en la "Advertencia", Oyuela expresa dos ideas relevantes acerca de su selección: la de la continuidad entre la literatura española y la americana a través de la lengua ("Era menester presentar un cuadro completo de aquella [la literatura castellana], desde sus comienzos en España hasta la presente en España y América (VI)") y la del carácter novedoso de la obra ("Una obra como la presente no tiene precedente alguno en nuestra lengua. Puedo afirmar, sin jactancia y sin riesgo, que es completamente nueva (VII)".
} 
predicamento de esta edición, que sale a la luz bajo los auspicios de la Universidad de La Plata, como tributo argentino a la gloria de Cervantes en el centenario de su muerte (IX).

Las ideas de "contribución" y "tributo" postulan la actitud del intelectual argentino y su posicionamiento en un campo de tan largo desarrollo como es el cervantismo, dentro y fuera de España, y ponen de manifiesto el gesto concreto de lograr un lugar en el concierto del hispanismo ${ }^{166}$. La senda inaugurada por Rojas continuará durante las décadas siguientes, y en ella se destacan la publicación de una obra medular para la contribución argentina a los estudios cervantinos como es Cervantes. La invención del Quijote, de Arturo Marasso, cuya primera edición es de $1943^{167}$, y la edición de Isaías Lerner y Celina Sabor de Cortazar de El ingenioso hidalgo Don Quijote de La Mancha, publicada por Eudeba en 1969 y que constituirá un hito no solo dentro del cervantismo argentino, sino entre las ediciones americanas de la obra cervantina, por citar algunos de los ejemplos más significativos. Los responsables de esta edición eran profesores e investigadores del Instituto de Filología y encararon la tarea a partir de su participación en un seminario dictado por Marcos Morínigo a comienzos de la década de 1960, y el trabajo de rastreo de fuentes, análisis léxico y filológico y cotejo de ediciones insumió varios años hasta plasmarlo en esta edición ${ }^{168}$.

\footnotetext{
${ }^{166}$ La publicación del estudio de Rojas sobre Cervantes fue elogiada por Menéndez Pidal en una carta enviada al autor, en la que agradece el envío de la obra. En ella, el filólogo español expresa: "Recibo con mucho interés su edición de las Poesías de Cervantes, en la cual el trabajo de compilación es muy valioso, y la selección más valiosa aún por venir de un escritor como Ud. La edición digna de la Universidad que la hace. Leí con sumo agrado el Prólogo, lleno de novedad y profundidad en ciertos juicios" (Madrid, 20/10/1916). La carta forma parte del acervo conservado en la Casa Museo Ricardo Rojas, de la ciudad de Buenos Aires, donde tuve oportunidad de consultarla y acceder a parte de la correspondencia entre ambos intelectuales en el mes de octubre de 2014.

${ }^{167}$ El estudio de Marasso será reeditado en 1947, en ocasión de la conmemoración del cuarto centenario del nacimiento de Cervantes por la Academia Argentina de Letras - de la cual Marasso era miembro fundador - bajo el título Cervantes, y posteriormente en 1953 por la editorial Hachette, con el título original de 1943.

${ }^{168}$ En un artículo sobre la figura de Celina Sabor de Cortazar, Melchora Romanos refiere a la magnitud de la tarea que emprendieron ambos investigadores: "Me detengo en la precisión de las fechas para
} 
Los aportes de la crítica literaria argentina al hispanismo se vinculan, como se ha venido señalando, con la institucionalización de los estudios e investigaciones a partir de las primeras décadas del siglo XX. Las redes intelectuales que se forjaron entre España y la Argentina fueron consolidando los estudios hispanistas como un campo diferenciado en el seno de las disciplinas humanísticas. Tal como se ha reseñado, la gestación de institutos y centros académicos en la Argentina, dedicados a fomentar las investigaciones sobre temas literarios, lingüísticos y filológicos, estuvo íntimamente relacionada con la gravitación de ciertas renombradas figuras del hispanismo tanto peninsular — como es el caso de Ramón Menéndez Pidal o de Amado Alonso, por mencionar algunas de las más representativas - como nacional, entre las que se destaca Ricardo Rojas, lo que determinó que la literatura y la cultura españolas estuvieran incluidas tempranamente entre las áreas de investigación de mayor relieve del campo académico argentino (Zuleta 1992, 1996; Romanos 2001, 2004; Chicote 2003, 2013). Este proceso de afianzamiento que se inició con la creación del Instituto de Filología de la Universidad de Buenos Aires, derivó en los años siguientes en la concreción de centros similares en otras universidades argentinas y de este modo, a partir de 1940, se fue ampliando el mapa del hispanismo nacional. Al mismo tiempo, la inclusión de la literatura española como asignatura en la currícula escolar del nivel medio y en los planes de estudio de las carreras de Letras contribuyó a otorgarle a esta disciplina un lugar relevante en la formación humanística y así comenzó a gestarse una tradición argentina de estudios hispanistas que fructificó en publicaciones, libros, artículos, manuales, ediciones críticas, prólogos y anotaciones. Este conjunto de contribuciones conforma un corpus destacado de los aportes argentinos a la consolidación de la

reflexionar sobre el tiempo que estos profesores e investigadores, que compartían la tarea con otras actividades docentes, le dedicaron a una tarea que sintieron muchas veces que era superior a sus fuerzas ya que la fijación de un texto supone la revisión de ediciones críticas anteriores y la dilucidación de posibles variantes, la determinación de los criterios a seguir, junto a la preparación de las 3330 notas que incorporaron al texto (2005: 62). 
disciplina y, al mismo tiempo, al establecimiento y difusión del canon hispánico tanto en el ámbito nacional como en el hispanoamericano. Dentro de ese corpus de producciones intelectuales, las revistas académicas constituyen un repertorio sumamente significativo para examinar las relaciones entre las instituciones, sus integrantes y los modos de difusión de los saberes vinculados con los estudios hispánicos.

\subsection{Los centros de investigación y académicos: líneas de trabajo y publicaciones vinculadas con el hispanismo}

\subsubsection{Las revistas y publicaciones académicas}

A partir de las primeras décadas del siglo $\mathrm{XX}-\mathrm{y}$ en coincidencia con la emergencia de la investigación en la Argentina-, las publicaciones académicas, junto con los estudios críticos sobre textos y autores españoles, fueron el vehículo principal para la difusión de los aportes de la investigación y de los estudios argentinos tanto de temas nacionales como de otras culturas, entre ellas particularmente la española, que es el objeto de esta investigación. De este modo se comienza a delinear el panorama de las publicaciones académicas en el país, que incluye revistas, boletines, suplementos y otros formatos similares. De allí que el análisis de estos órganos de difusión surgidos a partir del primer cuarto del siglo XX resulte un ámbito fértil para indagar en los procesos de definición de un hispanismo argentino.

La estrecha vinculación entre producción de conocimiento y divulgación de resultados constituye uno de los pilares clave en las fases de institucionalización de la investigación científica y académica, tal como queda demostrado en las políticas de publicaciones de los centros e institutos creados en la Argentina desde las primeras 
décadas del siglo XX en todos los ámbitos del saber. En el caso de los organismos dedicados a los estudios de las Humanidades, como se ha podido observar, una de las primeras tareas propuestas por los directivos de las instituciones académicas fue la de organizar las publicaciones a través de las cuales difundir y visibilizar los aportes críticos y metodológicos. En este sentido, es posible establecer algunos vínculos entre campo académico y publicaciones, en términos de analizar a estas últimas como espacios particulares para indagar en ese entramado que involucra aspectos culturales, sociales e ideológicos.

Asimismo, para el abordaje de este entramado, resultan productivas las contribuciones de la sociología de la cultura, en particular ciertos conceptos aportados por Pierre Bourdieu (1966, 1992), Raymond Williams (1980, 1994) y de los estudios postcoloniales desde la perspectiva de Edward Said ([1984] 2004), para pensar las relaciones entre los agentes del campo intelectual y académico y sus contribuciones. En primer lugar, las reflexiones de Bourdieu acerca de la constitución del campo intelectual —entendido como espacio social relativamente autónomo de producción de bienes simbólicos (1967) — permiten analizar los modos de legitimación de la creación intelectual y de la posición del intelectual en ese dominio. Para ello revisten particular interés algunas conceptualizaciones referidas a la dinámica de funcionamiento de dicho campo y de sus agentes, condicionada por las relaciones de poder dentro de ese campo y de las posiciones que ocupan dichos agentes. En tal sentido, las universidades y academias funcionan como legitimadoras de ciertas formas de prestigio para el sector; de allí que estas instituciones detenten un estatuto particular en el seno del campo intelectual. En el caso de la Argentina, la creación de universidades, academias y centros desde finales del siglo XIX pone de manifiesto el papel cada vez más preponderante de estas instituciones en la consolidación del campo intelectual y su 
función legitimadora ${ }^{169}$. En la medida en que éstas ejercen su poder de legitimación, sus producciones conllevan también este carácter, y las revistas científicas en particular, constituyen para Bourdieu “instancias de legitimación y transmisión” ([1967] 2002: 37).

Desde la perspectiva del materialismo cultural, Raymond Williams centra su atención en el análisis de la cultura y sus productos entendidos como prácticas sociales y por ende su objetivo es revelar las condiciones de dichas prácticas. Para el enfoque propuesto, nociones clásicas de la sociología como la de "instituciones" son abordadas bajo una nueva luz, que focaliza en las relaciones sociales de los productores culturales. También agrega al análisis el concepto de "formaciones", es decir, el modo de organización que pueden adoptar los productores culturales, por ejemplo, bajo la forma de escuelas o movimientos. Así, ambos conceptos se entrecruzan con la dimensión histórica y social de los procesos y prácticas $(1980,1994)$ y resultan relevantes para analizar las relaciones entre instituciones y agentes culturales.

Otro aporte significativo para pensar las relaciones entre intelectuales e instituciones lo constituyen las nociones de "filiación” y "afiliación" propuestas por el crítico Edward Said ([1984] 2004) para caracterizar la naturaleza de los vínculos entre el texto y el crítico. El intelectual palestino distingue ambas nociones en referencia a los modos en que pueden establecerse las relaciones entre textos; así, la noción de “filiación" pertenece al orden de lo natural y biológico, en tanto que "afiliación" corresponde con la esfera de la cultura y definiría las relaciones de adscripción a

\footnotetext{
169 Pierre Bourdieu distingue el papel de las universidades y de las academias como instituciones legitimadoras y consagradoras de los intelectuales: "Cada intelectual inserta en sus relaciones con los demás intelectuales una pretensión a la consagración cultural (o a la legitimidad) que depende, en su forma y en los derechos que invoca, de la posición que ocupa en el campo intelectual y en particular en relación con la universidad, detentadora en última instancia de los signos infalibles de la consagración: mientras la academia, que pretende el monopolio de la consagración de los creadores contemporáneos, contribuye a organizar el campo intelectual bajo la relación de la ortodoxia, por una jurisprudencia que combina la tradición y la innovación, la universidad pretende el monopolio de la transmisión de las obras consagradas del pasado, que consagra como "clásicas", y el monopolio de la legitimación y de la consagración (entre otras cosas con el diploma) de los consumidores culturales más conformes" ([1966] 2002: 40).
} 
modelos, esquemas y sistemas de creencias no basadas en lazos sociales, étnicos o sexuales. La cooperación entre ambas formas de relación está en la base de lo que

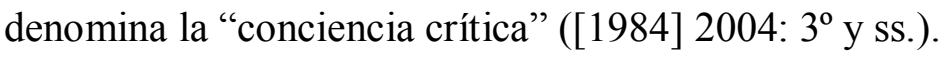

Extendidas a las interrelaciones en el campo académico, estas nociones pueden aplicarse para definir los modos en que las revistas académicas organizan y definen los lazos entre sus integrantes, con las instituciones a las que pertenecen, y con la/s tradición/es en las que se entroncan. Así, estas publicaciones evidencian mecanismos de afiliación y, a la vez, de consagración y legitimación, por lo que conforman dispositivos para analizar los posicionamientos y los (re)ligamientos entre sus integrantes en relación con el campo intelectual y académico. Por otra parte, Said focaliza los estudios humanísticos en el ámbito universitario como ejemplo del modo en que se modulan estas relaciones de (a)filiaciones y su vinculación con el canon, y en particular, los textos considerados "clásicos" para una cultura ${ }^{170}$.

De este modo, estas formulaciones teóricas devienen altamente productivas para abordar las interrelaciones entre docencia, crítica e investigación en el marco de las instituciones académicas y sus intersecciones con otros núcleos teóricos relevantes como el de "canon" y "tradición". Desde esta perspectiva, las revistas académicas se presentan como un territorio discursivo atravesado por esas tensiones, donde se pone de manifiesto la conformación de redes intelectuales y (a)filiaciones, los términos a partir de los cuales son construidas y, a la vez, su vinculación con ciertas tradiciones y con ciertas formaciones.

\footnotetext{
${ }^{170} \mathrm{Al}$ respecto de la estrecha relación entre universidad, canon y estudios humanísticos, señala Said: "Así vemos que la experiencia universitaria está más o menos oficialmente consagrada al pacto establecido entre un canon de obras, una banda de instructores iniciados y un grupo de miembros asociados más jóvenes; todo esto reproduce de un modo socialmente validado la disciplina filiativa supuestamente trascendida por el proceso educativo" (2004: 35-36).
} 
Por sus rasgos discursivos y genéricos, las revistas académicas constituyen un corpus particular en el universo de publicaciones periódicas que circularon en el campo cultural argentino a partir de la institucionalización de la vida académica, proceso que se inició con la fundación de universidades, centros de estudio y academias, los cuales, entre las primeras acciones que definieron, estuvo la de crear órganos de difusión de sus actividades. Más allá de los principios que les otorguen organicidad, las revistas académicas pugnan por lograr un espacio en el concierto de otras publicaciones, ya que su visibilidad opera como un signo de valorización y reconocimiento, conceptos en los que se ponen en juego las ideas de "prestigio" y "capital simbólico" analizados por Bourdieu (1983).

Su vinculación directa con las instituciones a las que pertenecen les confiere un carácter propio, que las diferencia de otros géneros de publicaciones periódicas como las revistas culturales o las revistas literarias ${ }^{171}$. Si bien comparten con éstas su carácter periódico y los aspectos materiales (formato, diseño, periodicidad, formas de difusión) e inmateriales (temas, contenidos, organización, estructura) (Pita González 2015), las revistas académicas exhiben ciertos rasgos que las distinguen de otras publicaciones análogas. En un trabajo reciente acerca de las revistas académicas de la Facultad de Filosofía y Letras de la Universidad de Buenos Aires, Gruber y Rodríguez (2011) señalan tres particularidades de las revistas académicas: en primer lugar, su dependencia de las instituciones, lo que determina una lógica de publicación diferente de la del

\footnotetext{
${ }^{171}$ En los últimos años han proliferado las investigaciones dedicadas a analizar este tipo de publicaciones, lo que ha posibilitado ir conformando un "mapa" de las revistas argentinas del siglo XX. Entre estos trabajos pueden citarse desde el germinal libro de Lafleur y Provenzano (1962), hasta los más recientes de Zuleta (1997) referido a las revistas literarias argentinas, Sosnowski (1999) sobre revistas latinoamericanas, Patiño (2006), que aborda las revistas literarias y culturales argentinas de la década de 1980, Maíz (2011), acerca de redes intelectuales y revistas culturales. También resultan un aporte de suma relevancia los cuatro tomos de La prensa literaria argentina (1890-1974) de Washington Pereyra, editados entre 1993 y 2008. Asimismo, para el caso de las revistas científicas del ámbito de las Humanidades, puede consultarse el estudio de Susana Romanos de Tiratel y colaboradores (2008). Por su parte, ciertas revistas individualmente han sido objeto de indagación, lo que da cuenta de un creciente interés por este tipo de dispositivos culturales.
} 
mercado editorial; en segundo lugar, al presentar aspectos sobre las disciplinas particulares, delinean sus propias agendas y, por lo tanto, tienden a trascender las coyunturas socio-culturales, y en tercer lugar, se presentan como espacios de legitimación y consagración para sus colaboradores, de allí que los criterios de prestigio y relevancia en el área del conocimiento sean los más ponderados, los cuales se miden en términos de periodicidad y calidad científica. A modo de conclusión afirman las autoras:

En suma, las revistas académicas se presentan como un mundo social de cierta complejidad donde se dan cita factores políticos, económicos y tecnológicos, entramados por la razón científica que se manifiesta en los aspectos sustantivos de sus páginas. Cierto carácter reflexivo acaso se revela en su capacidad de constituir y consagrar campos y arenas, temáticas e intereses, autores y colaboradores, produciendo agendas y al mismo tiempo la investidura misma de aquéllos encargados de concretarlas -i.e., investigadores y autoridades, nombres denostados y/u olvidados- (2011: 69).

Ideadas en primer lugar como órganos de difusión de las actividades de investigación de esos centros, los que les otorgan respaldo institucional y validación, estas publicaciones periódicas van adquiriendo perfiles propios, y en algunos casos logran alcanzar cierta forma de autonomía respecto de las instituciones. Su carácter de construcción colectiva conlleva la búsqueda de rasgos identitarios que posibiliten un (re)conocimiento en el ámbito en el que se insertan; así, además de ser un medio legitimado de difusión académica, las revistas procuran constituirse en un espacio prestigioso, a partir de su pertenencia institucional pero también basado en criterios de calidad de sus trabajos y de sus colaboradores, en una compleja dinámica no libre de tensiones.

Dichas tensiones también se vinculan con los vaivenes de la vida institucional de las universidades y centros académicos, signadas por los cambios políticos e ideológicos 
que atravesó la Argentina, en particular a partir de la década de 1940. Estos cambios y fluctuaciones se perciben en las irregularidades de la periodicidad de las revistas o en su suspensión por determinados periodos, así como en los reemplazos de los directores o miembros de los Consejos Editoriales, en las mudanzas de dependencia institucional, y en otros factores de similar índole que dan cuenta del modo en que estas publicaciones se hacen eco de las vicisitudes de las instituciones a las que pertenecen.

Dada su idiosincrasia institucional, un abordaje del estudio de las publicaciones académicas requiere presentar el panorama de los centros e institutos que se fueron creando a partir de 1920 a lo largo del país, vinculados tanto con el ámbito universitario, que contaron con medios de difusión de la producción de conocimiento, como de otras instituciones, como la Academia Argentina de Letras, fundada en 1931, cuyo Boletín también fue un órgano que contó entre sus colaboraciones con estudios y trabajos vinculados con la literatura y la cultura españolas. Estas publicaciones, en su mayoría, surgieron en el seno de estas instituciones y se constituyeron en uno de los principales modos de divulgación y difusión de las líneas de trabajo de sus integrantes. De este modo, los aportes críticos y metodológicos producidos en el marco de los institutos, academias y centros de investigación se articulan con las publicaciones y conforman así un corpus significativo para relevar las contribuciones de los investigadores argentinos a los estudios hispánicos, a la vez que evidencian las agendas temáticas, los perfiles y los intereses que definieron a cada publicación. 


\subsubsection{El Instituto de Filología de la Universidad de Buenos Aires y la revista} Filología $^{172}$

Desde sus inicios, el Instituto de Filología de la Universidad de Buenos Aires exhibió un marcado interés por la investigación, que se plasmó en las publicaciones que llevó adelante, así como en los trabajos del grupo de intelectuales nucleados en él ${ }^{173}$. Los sucesivos directores con que contó el Instituto fueron delineando una política editorial que adquiriría su madurez con la aparición de la Revista de Filología Hispánica (RFH), en 1939, gestada por Amado Alonso y que formaba parte de un proyecto editorial ya iniciado por el filólogo desde su asunción al frente del Instituto ${ }^{174}$. Ya desde el primer número, la revista se presenta como un órgano de difusión de los estudios hispánicos con vistas a ocupar un lugar relevante entre las publicaciones similares de la época. En tal sentido, es coeditada con la Revista Hispánica Moderna del Instituto de las Españas y con el Department of Hispanic Languages de la Universidad de Columbia, en Nueva York, ambas bajo la dirección de Amado Alonso y, según las palabras de su director: "complementarias en su objeto común de estudiar y difundir la cultura hispánica" (RFH Año $1 \mathrm{~N}^{\mathrm{o}} 1$, 1939). De este modo, la revista constituirá un espacio para la difusión de los trabajos de los investigadores del propio Instituto y también de colaboradores de otros países. Con la publicación de la $R F H$, el centro de estudios argentino busca un posicionamiento activo en el escenario del hispanismo internacional.

\footnotetext{
${ }^{172}$ Una versión de este apartado fue publicada como artículo en el $N^{\circ} 19$ (2013) de la revista Olivar, bajo el título "Lecturas hispánicas desde el Río de la Plata: la revista Filología (1949-1973)".

${ }^{173}$ A modo de ejemplo, tan solo un año después de su creación en 1923, el Instituto publica el Cuaderno 1, el primero de una serie de siete números que aparecerán hasta 1926. Ese año se edita también el primer número del Boletín del Instituto de Filología, que tendrá un segundo número en 1927, y además se publican trabajos de los investigadores, en especial sobre aspectos lingüísticos y filológicos, acorde con el espíritu original del Instituto y el sesgo otorgado por sus primeros directores. Un listado detallado de las publicaciones del Instituto en esos años se presentará más adelante.

${ }^{174}$ El primer proyecto de envergadura encarado por Alonso como director del centro fue la creación de la Biblioteca de Dialectología Hispánica, de la que se editarían siete tomos entre 1929 y 1949, que reunió los principales aportes de los investigadores del Instituto y que fue una obra señera para el estudio del español en América (Weber de Kurlat 1975).
} 
Con el alejamiento definitivo de Amado Alonso en 1946 y la posterior dispersión del grupo de investigadores, la publicación cesa en el ámbito argentino ${ }^{175}$. Sin embargo, la vocación por divulgar desde el Instituto los aportes a los estudios hispánicos se retoma en 1949 cuando, ya bajo la dirección del filólogo español Alonso Zamora Vicente, aparece el primer número de la revista Filología, cuya existencia con excepción de ciertos periodos— continúa hasta nuestros días ${ }^{176}$. El nuevo director del Instituto retomará la tarea de otorgarle a este centro un órgano de difusión de sus líneas de investigación, en consonancia con las prácticas editoriales de los principales centros académicos del mundo en esos años ${ }^{177}$.

\footnotetext{
${ }^{175}$ Si bien la $R F H$ deja de publicarse en la Argentina, debido a las razones mencionadas, Alonso retoma desde el extranjero la iniciativa de publicar una revista de características similares, para lo cual se contacta con El Colegio de México - donde estaba Alfonso Reyes - e inicia en 1947 la publicación de la Nueva Revista de Filología Hispánica, que contó desde 1949 con la colaboración de la Universidad de Harvard, donde se desempeñaba Alonso. El secretario de dicha revista fue Raimundo Lida, uno de los hispanistas que emigraron en esos años del país. Al igual que Filología, la NRFH fue consolidando su trayectoria en el marco de las publicaciones internacionales y continúa apareciendo hasta nuestros días.

${ }^{176}$ Filología apareció trimestralmente, con altibajos, hasta 1953. Después de un silencio de seis años, la revista reaparece en 1959 retomando el número de año que había quedado en suspenso. A partir de esta fecha, sufre ciertos cambios en su periodicidad: en 1960 se torna anual hasta 1972, año en que su publicación se ve suspendida por la intervención al Instituto de Filología. Tiene una aparición fugaz entre los años 1976 y 1977 y luego retoma su publicación en el año 1982 de forma ininterrumpida hasta la actualidad. Estas intermitencias y paréntesis pueden leerse en correlato con las fluctuaciones de la vida política argentina, que repercutían en la vida académica.

177 Es posible reconocer en el panorama de publicaciones internacionales de ese momento algunas que sin duda resultaron referentes insoslayables para el ámbito de los estudios literarios y filológicos. En el ámbito europeo pueden mencionarse Romania. Recueil trimestriel consacré a l'étude des langues et des littératures romaines consagrada a los estudios de las lenguas y literaturas romances, publicada en Francia desde 1872, cuyos editores eran Paul Meyer y Gaston Paris; Bulletin Hispanique, publicación de la Faculté des Lettres de Bordeaux, de carácter trimestral, iniciada en 1898-99, cuyo director era E. Merimée; la Revista de Filología Española, editada en Madrid por el Centro de Estudios Históricos desde 1914 (interrumpida durante la Guerra Civil), bajo la figura señera de Ramón Menéndez Pidal y la Nueva Revista de Filología Hispánica. En el ámbito norteamericano se destaca Hispanic Review, publicada por la University of Pennsylvania desde 1933. Esta somera enumeración da cuenta de la extensa tradición de publicaciones vinculadas con el hispanismo en diversos países de Europa y América desde finales del siglo XIX y que continuaron más allá de los vaivenes históricos.
} 


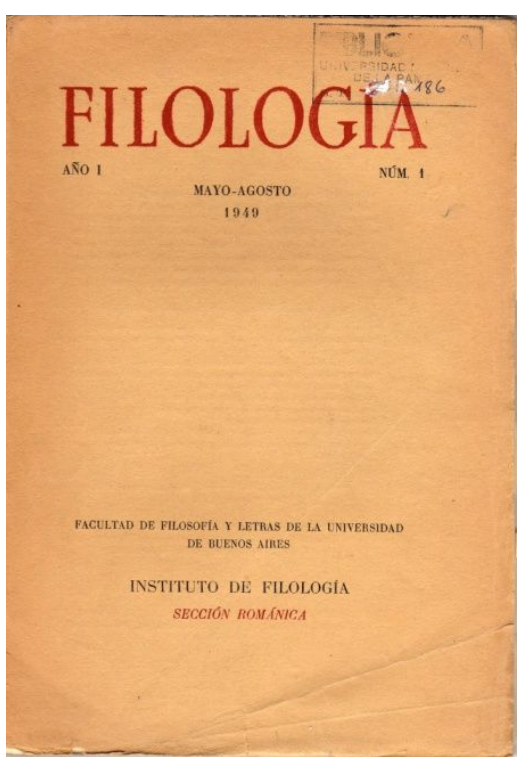

La adscripción de la revista a los modelos que ofrecían las publicaciones especializadas en temas de filología o estudios literarios hispánicos resulta evidente tanto desde lo formal (tamaño, diseño, diagramación externa e interna), como por las secciones en que organiza sus contribuciones (artículos, notas y reseñas son los géneros más recurrentes). Este afán por establecer lazos con publicaciones de similar tenor se evidencia en la reproducción de algunos rasgos configurativos propios, en particular en el aparato paratextual que, de alguna manera, funcionan como marcas identificadoras del género: la pertenencia institucional, el nombre del director, una breve caracterización de la revista y sus objetivos, la mención a otras publicaciones institucionales o el adelanto de próximas colaboraciones son elementos que, con escasas variantes, aparecen en las publicaciones académicas circulantes en la época y están presentes desde el primer número de Filología ${ }^{178}$.

Sin embargo, aún en la filiación con un modelo vigente, hay lugar para la diferenciación y la búsqueda de identidad propia: en este primer número aparece una presentación de la revista, a cargo de su director, en la que se expresan los propósitos de los responsables de la publicación y los temas que se abordarán ${ }^{179}$. Allí declara Zamora Vicente:

\footnotetext{
${ }^{178}$ Un examen de los aspectos paratextuales de las revistas mencionadas permite dar cuenta del afán por reproducir los rasgos formales y de diseño, lo que generaría una suerte de "estilo" propio del género. Al respecto, en el texto que aparece en la parte interior de las tapas de la revista a lo largo de los años analizados, se expresa: "Las colaboraciones se agruparán en las secciones acostumbradas de artículos, notas y reseñas" (la cursiva es nuestra). La elección del adjetivo indica un reconocimiento de ciertos géneros como característicos de este tipo de publicaciones académicas.

${ }^{179}$ De la revisión de los números de la revista del periodo señalado surge que este tipo de textos iniciales sólo aparecen en el $\mathrm{N}^{\circ} 1$ (1949) y en el volumen especial (1952-53). En el resto, cada número se abre directamente con el primer artículo, lo cual parece ser un rasgo propio de esta clase de publicaciones académicas (Cf. Romania, Bulletin Hispanique, NRFH, entre las más reconocidas).
} 
Filología, digámoslo de una vez, no pretende continuar revista alguna anterior, ni, muchísimo menos, suplantarla. No. Su afán es la comunidad del esfuerzo generoso por un laborar común, en este caso el idioma, y la carga, la maravillosa carga espiritual de la que es portador (Año I, $\mathrm{N}^{\circ} 1: 1$ ).

La velada mención a la Revista de Filología Hispánica fundada por Amado Alonso es clave para interpretar los modos en que una nueva publicación busca legitimar su espacio en el contexto institucional, a la vez que se reconoce parte de una comunidad que la incluye. Muestra de esto es, en el cierre de la presentación, la referencia a la figura de Menéndez Pidal:

Por último, queremos dejar aquí manifiesto un recuerdo de lealtad inalienable. En este año de 1949, en que Filología se asoma a la vida del trabajo, cumple sus ochenta años Ramón Menéndez Pidal, el maestro reconocido y admirado, bajo cuyos auspicios nació este Instituto en 1923 (Año I, N¹: 2-3).

En ambos párrafos se cifra este doble gesto de diferenciación y a la vez, de asimilación a una herencia compartida. De este modo, el Instituto de Filología de la Universidad de Buenos Aires vuelve a ocupar un lugar en el escenario del hispanismo $^{180}$. Si bien — como se ha explicitado — la revista no se plantea como la continuación de la publicación anterior, los lazos formales y estilísticos son evidentes, y se enmarcan en un afán homologador de la publicación con otras circulantes en el

180 La aparición del primer número de Filología en 1949 mereció un comentario en el Bulletin Hispanique, prestigiosa publicación del ámbito de la filología hispánica, en su sección "Revue des revues" del mismo año. Allí se señala: "Voici une nouvelle revue. Elle témoigne de l'interêt croissant en dépit de difficultés nombreuses, que porte le monde intellectuel argentin à sa langue et à sa culture [...] Parce-que ces contributions disent clairement l'école dont elles relèvent et qu'elles soulignent la solidarité de la culture argentine et de la culture espagnole. [...] Souhaitons longue vie à cette publication : elle participe à l'effort commun des revues hispaniques au nom d'une Argentine de plus en plus consciente de ses richesses spirituelles » $\left(B H\right.$, Vol. LI, $\left.\mathrm{n}^{\circ} 3: 347\right)$. La reseña está firmada por las iniciales C.V.A., que corresponden al profesor Charles V. Aubrun. Asimismo, en el No 284 de la revista Romania, de 1950, aparece en la sección "Periodiques" una reseña-resumen de los dos primeros números de Filología, a cargo de B. Poittier. El reconocimiento que estas referencias implican expresan la relevancia que rápidamente adquiere la revista en el conjunto de las publicaciones especializadas de la época. 
ámbito académico nacional e internacional. Así, como ya fuera señalado, su organización interna presenta las secciones reconocidas como características de este tipo de publicaciones: “Artículos", "Notas" y "Reseñas", tal como es posible observar en revistas de similar tenor, aunque a lo largo de los números esta división no siempre se mantiene, y a la vez se muestran variaciones en la cantidad y proporción entre las colaboraciones. Asimismo, estos vaivenes en la organización interna se trasladan a la periodicidad: del carácter cuatrimestral inicial, se pasa a la anualidad definitiva en 1960, con altibajos intermedios, lo que permite presuponer que estos cambios se relacionan con las transformaciones intrínsecas del Instituto ${ }^{181}$. A ello debe agregarse los cambios en la dirección de la revista: entre 1949 y 1951, estará bajo la dirección de Alonso Zamora Vicente; durante el bienio 1952-1953 —en el que solo se edita un único volumen que abarca tres números - el director es Arturo Berenguer; luego de la suspensión de la revista, en 1959 reaparece dirigida por Marcos Morínigo, quien continúa en el cargo en el $N^{\circ}$ correspondiente a 1960. A partir de 1961 y hasta 1964 la directora será Ana María Barrenechea, quien será sucedida por Frida Weber de Kurlat hasta la nueva interrupción de la publicación en 1973. Estos cambios en la gestión de la revista repercuten sin dudas tanto en los modos de presentación de los materiales como en la impronta de los trabajos y en las políticas de edición.

A las variaciones en la frecuencia y en la organización interna de la revista durante los primeros años se le suman oscilaciones en la cantidad y el tipo de

\footnotetext{
181 Las sucesivas nomenclaturas que recibe el Instituto permiten dar cuenta de estas transformaciones. En los números de 1949, aparece en la tapa la mención de la Facultad de Filosofía y Letras de la Universidad de Buenos Aires y a continuación "Instituto de Filología - Sección Románica". En los números del año siguiente se agrega, antes de la mención a la Facultad, "Ministerio de Educación" y ya el Instituto tiene el nombre de "Instituto de Filología Románica", denominación que se mantiene hasta 1952, en que se presenta como "Instituto de Filología Hispánica" y que seguirá así -excepto por el agregado del nombre de Amado Alonso en homenaje a su figura - hasta 1962, cuando se incorpora la referencia a la literatura y pasa a llamarse "Instituto de Filología y Literaturas Hispánicas Dr. Amado Alonso", nombre que mantiene hasta nuestros días.
} 
colaboraciones incluidas en los números, que en ocasiones están compuestos sólo por una exigua cantidad de artículos, sin notas o reseñas que los acompañen.

Paralelamente a estas transformaciones, se manifiestan otras en el contenido de la revista, vinculadas con el aumento de la presencia de artículos y notas referidos a temas y autores literarios, frente al claro predominio de los trabajos del área de lingüística y filología de los primeros tiempos.

Ahora bien, ante este incremento de temas literarios resulta válido preguntarse cuáles eran los textos y autores objeto de indagación por parte de los colaboradores de la revista, ya que de estas preferencias es posible inferir algunos modos de apropiación y de negociación con el canon hispánico. Un recorrido por los índices de la revista proporciona un primer itinerario para reconstruir la cartografía inicial del lugar que fueron ocupando los estudios sobre literatura española, a fin de indagar en las lecturas que se concretaron a partir de las operaciones críticas y su relación con los procesos de canonización de la literatura hispánica en el ámbito argentino. Al mismo tiempo, la reconstrucción de esas lecturas permite reconocer la formación de una tradición crítica ya consolidada en nuestro país que fue definiendo los perfiles de un hispanismo nacional. La posibilidad de inscribir la producción intelectual vinculada a la literatura española en el marco de una tradición de estudios de corte "científico", como postulaba la escuela de Menéndez Pidal, habilita a los colaboradores de la revista a participar en la construcción de nuevas tradiciones críticas, que, a pesar de su situación periférica en el mapa del hispanismo, bregan por ocupar un lugar relevante y por intervenir en la (re)definición del canon literario hispánico. Es por eso que resulta significativo indagar en las presencias - y las ausencias - que reflejan los trabajos publicados en la revista, en especial por su relevancia en el campo académico argentino de la época. 
El recorrido propuesto permite algunas constataciones iniciales: los trabajos sobre literatura española están presentes en todos los números, a excepción de los del primer año (1-2-3 1949), y del No 3 de 1959. Puede resultar un dato interesante analizar la cantidad de trabajos referidos a la literatura española en el conjunto de los publicados en la revista a lo largo de los años comprendidos entre 1949 y 1973: sobre un total de 192 trabajos (entre artículos y notas), 85 corresponden a temas y autores españoles, es decir, el $45 \%$ de las colaboraciones. En un análisis hacia el interior de ese corpus, (y siguiendo la tradicional división cronológica de los estudios literarios en "Medieval", "Siglo de Oro" y "Moderna y contemporánea"), se percibe la preeminencia de los escritos referidos a la literatura áurea (40 textos), seguidos por los que abordan la literatura del Medioevo español (27 textos) y en último término los dedicados a expresiones literarias del siglo XVIII en adelante $(18 \text { textos })^{182}$. A pesar de las diferencias cuantitativas, la presencia constante de temas de literatura española pone de manifiesto la marcada relevancia de los estudios literarios hispánicos y su afianzamiento frente a las contribuciones más estrictamente lingüísticas o gramaticales de los inicios, derivados de la impronta filológica de Alonso ${ }^{183}$.

Un dato adicional nos ofrecen las contratapas de Filología: a partir de 1963 aparece un apartado destinado a informar sobre las publicaciones no periódicas del

\footnotetext{
${ }^{182}$ Las cantidades consignadas no tienen pretensión de exhaustividad, dado que, en muchos casos, la inclusión dentro de una literatura en particular depende del criterio de clasificación. En nuestro caso, las cifras relevadas de los índices de las revistas tienen como objeto señalar la marcada presencia de temas de literatura española en el ámbito de la publicación.

${ }^{183}$ También es necesario mencionar que durante este periodo los institutos de investigación creados en el ámbito de la Facultad de Filosofía y Letras de la Universidad de Buenos Aires sufrieron transformaciones importantes y reestructuraciones derivadas de los cambios en la gestión. La intervención de 1946 reorganizó el plantel de los institutos, y su estructura interna. Así, el Instituto de Literatura fue estructurado en Secciones: Literatura Argentina, Literatura Americana, Literatura Española, Literatura Francesa e Italiana y Literatura de Europa Septentrional (Buchbinder 1997:175). Sucesivas reorganizaciones posibilitaron la creación del Instituto de Literatura Anglogermánica, el Instituto de Literatura Castellana y el Instituto de Literaturas Neolatinas. Esta diversificación y especialización no parece haber impactado en las producciones del Instituto de Filología concernientes a los estudios hispánicos, ya que la cantidad de colaboraciones se mantuvo y se consolidó a lo largo de los números.
} 
Instituto, bajo el título "Últimas publicaciones del Instituto". Allí se consignan otros trabajos y estudios de investigadores vinculados con temas literarios y lingüísticos, lo cual pone de manifiesto que las producciones intelectuales de ese centro se diversifican y amplían a la vez que consolidan algunas líneas de investigación. De la lectura de esos listados de obras se desprende el lugar que ocupa ya en ese momento la literatura española y en particular, algunos de esos títulos, que se transformarán en textos de referencia ineludible en el ámbito de los estudios hispánicos no solo de nuestro país, sino del continente ${ }^{184}$. Esta consolidación del Instituto como referente del hispanismo a nivel mundial se manifiesta en el hecho de que investigadores que habían continuado su vida académica fuera del país (como la mencionada María Rosa Lida de Malkiel) publican sus trabajos con el sello del Instituto. Así se va configurando una red de vínculos y filiaciones entre figuras y centros académicos que exceden la localización geográfica a la vez que refuerzan los lazos de pertenencia institucional y le otorgan al Instituto un rol clave en la formación de hispanistas de primer nivel.

Además de los temas abordados y de los textos publicados, otro aspecto significativo para analizar es el perfil de los colaboradores de la revista en estos años; en el listado de nombres hay alternancia entre los argentinos - fundamentalmente pertenecientes al Instituto o a la Facultad de Filosofía y Letras - y los extranjeros, con una destacada presencia de colaboraciones de hispanistas del ámbito anglosajón, en especial de universidades norteamericanas e inglesas, y de la Península. Aquí también cabe detenerse en los nombres que recorren los índices; junto con los miembros del Instituto se encuentran los de investigadores de renombre en el ámbito del hispanismo.

\footnotetext{
${ }^{184}$ A modo de ejemplo de los títulos publicados en esta década por el Instituto pueden citarse las ya clásicas obras de Ma. Rosa Lida Ensayos de literatura española y comparada (1966), reeditada más adelante por Losada, y Jerusalén: el tema de su cerco y destrucción por los romanos (1972), ambos publicados póstumamente, o los Estudios sobre versificación española de Pedro Henríquez Ureña (1961), que es una reedición ampliada de un trabajo de su juventud, La versificación irregular en la poesía castellana, publicada en el CEH de Madrid en 1920.
} 
Desde la presencia emblemática de María Goyri de Menéndez Pidal, esposa y compañera de trabajo inseparable del filólogo español, medievalistas como Edmund de Chasca o Alan Deyermond, por citar algunos, publicaron trabajos en la revista en el periodo analizado, lo que permite considerarla como un espacio legítimo para alcanzar visibilidad en el mundo académico de la época. Asimismo, si bien el número de colaboradores locales es inferior al de los extranjeros, la cantidad de trabajos de aquellos es mayor, ya que algunos publican a lo largo de varios números, mientras que los extranjeros sólo publican una vez, con algunas excepciones en las que han editado dos trabajos en la revista ${ }^{185}$. Esto expresa, por un lado, la vocación de los investigadores argentinos por divulgar sus trabajos en el ámbito académico a través de una revista que ya exhibía un nivel reconocido en los estudios de la lengua y la cultura españolas, y por otro, la plataforma que ésta ofrecía para los estudiosos extranjeros, así como también a los argentinos que habían migrado a otros países ${ }^{186}$.

Junto con la consolidación de las colaboraciones de investigadores locales en la revista, se destaca otro rasgo: la significativa presencia de mujeres entre ellos. De los veintisiete nombres correspondientes a autores argentinos, quince corresponden a mujeres, quienes además, en la mayoría de los casos, son autoras de dos o más trabajos. Además de las figuras de María Rosa Lida o de Ana María Barrenechea ${ }^{187}$, aparecen

\footnotetext{
${ }^{185}$ Los nombres que se reiteran son los de los mencionados de Chasca y Deyermond, quienes publicaron en 1966-67 y 1972 y en 1964 y 1968-69 respectivamente. El español Antonio Rodríguez Moñino publicó artículos en 1962 y $1968-69$.

${ }^{186}$ Entre los colaboradores argentinos que se radicaron en otros países podemos citar a Juan Bautista Avalle Arce, quien emigró a EEUU con Amado Alonso, al igual que Raimundo Lida, o Ángela Dellepiane de Martino, también radicada en el país del norte. En sentido inverso, hay colaboradores que provenían de otros países. En este grupo puede incluirse a Demetrio Gazdaru, de origen rumano, quien se radica en el país y se constituirá en una figura relevante del hispanismo, en particular de los estudios lingüísticos en el ámbito universitario, tal como se plasmaría en la fundación de la revista Románica, en la Universidad Nacional de La Plata (1968).

${ }^{187}$ A comienzos de la década de 1960 asume como directora Ana María Barrenechea, quien se hará cargo también de la dirección de Filología a partir de 1961. Su ubicación al frente del Instituto y de la revista sugiere también una nueva perspectiva, ya que por primera vez una mujer accede a dichos cargos y, a la vez, coincide con una mayor presencia de autoras en la publicación periódica.
} 
otras de docentes e investigadoras que ocuparían lugares relevantes en las aulas universitarias y en el Instituto y cuyas trayectorias ya fueron esbozadas en el capítulo anterior: Frida Weber de Kurlat y Celina Sabor de Cortazar, por nombrar las más destacadas, quienes además participarán en tareas de gestión. Weber de Kurlat dirigirá el Instituto desde mediados de la década del sesenta y Sabor de Cortazar será secretaria de la revista hasta el año 1973, momento del cese temporal de la publicación (Cf. Capítulo 1). Tal supremacía puede leerse al menos en dos sentidos; por un lado, el papel de la universidad en la formación de docentes, actividad en la cual la mujer ocupará un lugar preponderante desde finales del siglo XIX en la Argentina y que continúa afianzándose durante estas décadas, y por otro, la retroalimentación institucional que posibilitaba que, además de insertarse activamente en el ámbito académico, las integrantes del Instituto tuvieran presencia en el mundo editorial ${ }^{188}$.

La revisión de los nombres y filiaciones académicas de los colaboradores de Filología en estas décadas analizadas habilita también a pensar en las redes intelectuales que se conformaron a partir de las vinculaciones entre centros académicos situados en Hispanoamérica, Estados Unidos y Europa, en las interrelaciones que se construyeron y en las irradiaciones establecidas a partir del fuerte perfil de algunas figuras individuales, lo cual permite delinear un "mapa" del hispanismo en ese periodo y examinar el papel que las publicaciones académicas ocuparon en él. A la vez que órganos de difusión de

\footnotetext{
${ }^{188}$ Entre las colaboradoras de Filología que participaron en el ámbito editorial pueden mencionarse a Raquel Minian de Alfie, especialista en Lope de Vega y responsable de la edición de obras del dramaturgo para la colección GOLU (Grandes Obras de la Literatura Universal), de editorial Kapelusz, o Beatriz Entenza de Solare, quien tuvo a su cargo el texto sobre Fray Luis de León para la Enciclopedia Literaria del CEAL, además de otras ediciones destinadas a la divulgación o a la enseñanza. Tampoco puede dejar de mencionarse la ya citada edición crítica de El ingenioso hidalgo don Quijote de La Mancha preparada por Celina Sabor de Cortazar e Isaías Lerner, publicada en EUDEBA en 1969. Unos años después, en 1973, la colección GOLU publica la versión completa de Don Quijote de La Mancha, con un estudio preliminar de Sabor de Cortazar, que además reproduce las notas y cometarios de Martín de Riquer incluidos en la edición de las Obras Completas de Cervantes publicadas por la editorial Planeta en 1962. También en GOLU, la investigadora había publicado en 1972 una edición comentada de El casamiento engañoso y de El coloquio de los perros y en 1967 tuvo a su cargo la edición de El Lazarillo de Tormes en esa misma colección.
} 
análisis e investigaciones, las revistas constituían una faz inseparable de la vida de los centros académicos, que se organizaban en torno a la publicación que aglutinaba a sus integrantes y establecían conexiones con otros investigadores e instituciones a nivel mundial. Desde esta perspectiva, la revista Filología se reconoce en ese territorio como un espacio de difusión relevante, que se fue consolidando desde sus inicios hasta su afianzamiento en el campo de las publicaciones académicas no sólo argentinas sino mundiales, en correlato con el lugar que ocupó —y ocupa hoy en día — el Instituto de Filología y sus integrantes en el ámbito de los estudios hispánicos.

Los aportes críticos realizados por los colaboradores de la revista no se inscriben en el vacío: los precede una extensa y compleja serie de operaciones de conceptualización sobre la "literatura española" y sus vínculos con una "cultura española” (Zuleta 1992, 1996; Romanos 2004, 2006). Así, en la contraportada de todos los números de Filología del periodo analizado aparece una declaración que de algún modo cifra la inserción de la revista en el marco de los estudios hispánicos, formulados desde el campo académico argentino de mitad del siglo veinte: "Las páginas de Filología darán cabida a todo lo que pueda suponer una aportación al mejor conocimiento de la lengua y la cultura hispánica, tanto en su aspecto peninsular como —y especialmente - americano". El énfasis en la distinción entre ambas regiones sitúa esas aportaciones y permite a la vez su inclusión en el campo más vasto del hispanismo.

Desde esta perspectiva, el conjunto de textos y autores españoles analizados a lo largo de los volúmenes de la revista da cuenta de los modos y criterios de apropiación subyacentes, así como pone de manifiesto las tensiones intrínsecas a la noción de canon, concepto que si bien suele asociarse a ciertas formas de inmutabilidad y permanencia, está atravesado por variaciones y ajustes, tal como lo demuestran las revisiones más o menos periódicas que se formulan —explícita o implícitamente- desde el ámbito 
académico y también desde el mercado editorial. El siguiente cuadro registra las contribuciones críticas vinculadas con los estudios hispánicos en la revista Filología, ordenados cronológicamente:

Cuadro n 1: Artículos de literatura española en la revista Filología (1949-1972)

\begin{tabular}{|c|c|c|}
\hline Año, $\mathbf{N}^{\circ}$, Vol. & Autor/es & Título \\
\hline $\mathrm{I}, 1,1949$ & $\begin{array}{l}\text { Gatti, José } \\
\text { Francisco }\end{array}$ & $\begin{array}{l}\text { Las fuentes literarias de dos sainetes de Don } \\
\text { Ramón de la Cruz }\end{array}$ \\
\hline $\mathrm{I}, 2,1949$ & $\begin{array}{l}\text { Gatti, José } \\
\text { Francisco }\end{array}$ & Referencias a Feijoó en Inglaterra, \\
\hline \multirow[t]{3}{*}{ II, 1,1950} & $\begin{array}{l}\text { Ramos y } \\
\text { Loscertales, José } \\
\text { María }\end{array}$ & $\begin{array}{l}\text { Relatos poéticos en las crónicas medievales: } \\
\text { los hijos de Sancho III }\end{array}$ \\
\hline & $\begin{array}{l}\text { Zamora Vicente, } \\
\text { Alonso y María } \\
\text { Josefa Canellada de } \\
\text { Zamora }\end{array}$ & Una nota a El amor médico de Tirso \\
\hline & $\begin{array}{l}\text { Garasa, Delfín } \\
\text { Leocadio. }\end{array}$ & $\begin{array}{l}\text { Algunas notas a El criticón de Baltasar } \\
\text { Gracián }\end{array}$ \\
\hline II, 2,1950 & $\begin{array}{l}\text { Zamora Vicente, } \\
\text { Alonso }\end{array}$ & $\begin{array}{l}\text { El dialectalismo de José María Gabriel y } \\
\text { Galán }\end{array}$ \\
\hline \multirow[t]{2}{*}{ II, 3, 1950} & $\begin{array}{l}\text { Speratti Piñero, } \\
\text { Emma Susana }\end{array}$ & Los americanismos en Tirano Banderas \\
\hline & Devoto, Daniel & $\begin{array}{l}\text { Notas sobre el elemento tradicional en la obra } \\
\text { de García Lorca, }\end{array}$ \\
\hline $\begin{array}{l}\text { IV, 1-2-3, 1952- } \\
53\end{array}$ & $\begin{array}{l}\text { Dellepiane de } \\
\text { Martino, Ángela }\end{array}$ & $\begin{array}{l}\text { Ficción e historia en la Trilogía de los } \\
\text { Pizarros de Tirso }\end{array}$ \\
\hline $\mathrm{V}, 1-2,1959$ & $\begin{array}{l}\text { Avalle Arce, Juan } \\
\text { Bautista }\end{array}$ & Conocimiento y vida en Cervantes \\
\hline & Lida de Malkiel, & Para la génesis del Auto de la Sibila Casandra \\
\hline
\end{tabular}


Avatares del Hispanismo: canon y estudios literarios en la Argentina (1949-1973)

\begin{tabular}{|c|c|c|}
\hline Año, $N^{\circ}$, Vol. & Autor/es & Título \\
\hline & María Rosa & \\
\hline & Devoto, Daniel & Entre las siete y las ocho \\
\hline & $\begin{array}{l}\text { Anderson Imbert, } \\
\text { Enrique }\end{array}$ & La creación artística de Gabriel Miró \\
\hline \multirow[t]{3}{*}{ VI, 1960} & $\begin{array}{l}\text { Weber de Kurlat, } \\
\text { Frida }\end{array}$ & $\begin{array}{l}\text { El teatro anterior a Lope de Vega y la novela } \\
\text { picaresca }\end{array}$ \\
\hline & $\begin{array}{l}\text { Morreale, } \\
\text { Margherita }\end{array}$ & $\begin{array}{l}\text { Reflejos literarios de la moda femenina del } \\
\text { siglo quince }\end{array}$ \\
\hline & $\begin{array}{l}\text { Minian de Alfie, } \\
\text { Raquel }\end{array}$ & $\begin{array}{l}\text { Lope y Ricardo de Turia (A propósito de una } \\
\text { probable influencia) }\end{array}$ \\
\hline \multirow[t]{7}{*}{ VII, 1961} & $\begin{array}{l}\text { Barrenechea, Ana } \\
\text { María }\end{array}$ & $\begin{array}{l}\text { La ilustre fregona como ejemplo de estructura } \\
\text { novelesca cervantina }\end{array}$ \\
\hline & Cowes, Hugo W. & $\begin{array}{l}\text { Problema metodológico en un texto lírico de } \\
\text { Miguel de Unamuno, }\end{array}$ \\
\hline & Gazdaru, Demetrio & $\begin{array}{l}\text { La suerte en Provenza y Cataluña del tema } \\
\text { literario de "Fontefrida" }\end{array}$ \\
\hline & Hesse, Everett W & $\begin{array}{l}\text { Estructura e interpretación de una comedia de } \\
\text { Calderón: Eco y Narciso }\end{array}$ \\
\hline & $\begin{array}{l}\text { Kovacci, Ofelia y } \\
\text { Nélida Salvador }\end{array}$ & García Lorca y su "Leyenda del tiempo" \\
\hline & Orduna, Germán & $\begin{array}{l}\text { El fragmento P del Rimado de Palacio y un } \\
\text { continuador anónimo del Canciller Ayala }\end{array}$ \\
\hline & Whinnom, Keith & $\begin{array}{l}\text { MS. Escurialense K-III-7: el llamado } \\
\text { Cancionero de Fray Íñigo de Mendoza }\end{array}$ \\
\hline \multirow[t]{5}{*}{ VIII, 1-2, 1962} & $\begin{array}{l}\text { Avalle-Arce, Juan } \\
\text { Bautista }\end{array}$ & Dos notas de heterodoxia \\
\hline & $\begin{array}{l}\text { Blanco Aguinaga, } \\
\text { Carlos }\end{array}$ & $\begin{array}{l}\text { "Cerrar podrá mis ojos...": tradición y } \\
\text { originalidad }\end{array}$ \\
\hline & $\begin{array}{l}\text { Sabor de Cortazar, } \\
\text { Celina }\end{array}$ & $\begin{array}{l}\text { Notas para el estudio de la estructura del } \\
\text { Guzmán de Alfarache }\end{array}$ \\
\hline & Devoto, Daniel & Un ingrediente de Celestina, \\
\hline & Gatti, Francisco & El "Ubi sunt" en la prosa medieval española \\
\hline
\end{tabular}


Avatares del Hispanismo: canon y estudios literarios en la Argentina (1949-1973)

\begin{tabular}{|c|c|c|}
\hline Año, $\mathbf{N}^{\circ}$, Vol. & Autor/es & Título \\
\hline & $\begin{array}{l}\text { Weber de Kurlat, } \\
\text { Frida }\end{array}$ & $\begin{array}{l}\text { El tipo cómico del negro en el teatro } \\
\text { prelopesco. Fonética }\end{array}$ \\
\hline \multirow[t]{2}{*}{ VIII, 3, 1962} & Lida, Raimundo & Sobre Quevedo y su voluntad de leyenda \\
\hline & Alatorre, Antonio & $\begin{array}{l}\text { Dido y su defensa (Traductores españoles y } \\
\text { portugueses de dos epigramas atribuidos a } \\
\text { Ausonio }\end{array}$ \\
\hline \multirow[t]{5}{*}{ IX, 1963} & $\begin{array}{l}\text { Dutton, Brian y M. } \\
\text { Walker }\end{array}$ & $\begin{array}{l}\text { El Libro del cavallero Zifar y la lírica } \\
\text { castellana }\end{array}$ \\
\hline & Gazdaru, Demetrio & $\begin{array}{l}\text { La más antigua jarya mozárabe. Nueva } \\
\text { transcripción e interpretación }\end{array}$ \\
\hline & $\begin{array}{l}\text { Weber de Kurlat, } \\
\text { Frida }\end{array}$ & $\begin{array}{l}\text { Gil Vicente y Diego Sánchez de Badajoz. A } \\
\text { propósito del Auto da sebila Casandra y de la } \\
\text { Farsa del juego de cañas }\end{array}$ \\
\hline & Levisi, Margarita & $\begin{array}{l}\text { Hieronymus Bosch y los Sueños de Francisco } \\
\text { de Quevedo, }\end{array}$ \\
\hline & Riley, Edward C & $\begin{array}{l}\text { Sobre el arte de Sánchez Ferlosio: aspectos de } \\
\text { El Jarama }\end{array}$ \\
\hline \multirow[t]{7}{*}{$\mathrm{X}, 1964$} & Deyermond, Alan D & El hombre salvaje en la novela sentimental \\
\hline & Jones, Roy O & El perro del hortelano y la visión de Lope \\
\hline & $\begin{array}{l}\text { Ferrario de Orduna, } \\
\text { Lilia }\end{array}$ & La adoración de los pastores \\
\hline & Russell, Robert. H & $\begin{array}{l}\text { La óptica del novelista en La incógnita y } L a \\
\text { Realidad }\end{array}$ \\
\hline & $\begin{array}{l}\text { Sabor de Cortazar, } \\
\text { Celina e Isaías } \\
\text { Lerner }\end{array}$ & Notas al texto del Quijote, \\
\hline & $\begin{array}{l}\text { López Grigera, } \\
\text { Luisa }\end{array}$ & $\begin{array}{l}\text { Un problema bibliográfico en Quevedo: "La } \\
\text { cuna y la sepultura" }\end{array}$ \\
\hline & $\begin{array}{l}\text { Morínigo, Marcos } \\
\text { A. }\end{array}$ & $\begin{array}{l}\text { Una nota para la edición del } \\
\text { ¿Ladrillos "enrejados" } \\
\text { "enrelejados" }\end{array}$ \\
\hline \multirow[t]{2}{*}{ XI, 1965} & $\begin{array}{l}\text { Minian de Alfie, } \\
\text { Raquel }\end{array}$ & Lope, lector de cronistas de Indias \\
\hline & $\begin{array}{l}\text { Ferrario de Orduna, } \\
\text { Lilia }\end{array}$ & La adoración de los pastores \\
\hline
\end{tabular}


Avatares del Hispanismo: canon y estudios literarios en la Argentina (1949-1973)

\begin{tabular}{|c|c|c|}
\hline Año, $N^{\circ}$, Vol. & Autor/es & Título \\
\hline & $\begin{array}{l}\text { Entenza de Solare, } \\
\text { Beatriz }\end{array}$ & Fernando de Herrera ante el texto de Garcilaso \\
\hline & Fernández, Antonia & $\begin{array}{l}\text { Acerca de la fecha de composición de la Farsa } \\
o \text { cuasi comedia del soldado de Lucas } \\
\text { Fernández }\end{array}$ \\
\hline XII, 1966-1967 & Benítez, Rubén & $\begin{array}{l}\text { Bécquer en la Historia de los templos de } \\
\text { España }\end{array}$ \\
\hline & $\begin{array}{l}\text { Avalle-Arce, Juan } \\
\text { Bautista }\end{array}$ & $\begin{array}{l}\text { Dos relaciones inéditas de Ruy Díaz de } \\
\text { Guzmán }\end{array}$ \\
\hline & Chasca, Edmund de & $\begin{array}{l}\text { Composición escrita y oral en el Poema del } \\
\text { Cid }\end{array}$ \\
\hline & $\begin{array}{l}\text { Sabor de Cortazar, } \\
\text { Celina }\end{array}$ & $\begin{array}{l}\text { Lo cómico y lo grotesco en el Poema de } \\
\text { Orlando de Quevedo }\end{array}$ \\
\hline XII, 1968-1969 & Lapesa, Rafael & $\begin{array}{l}\text { Don Ramón Menéndez Pidal, ejemplo y } \\
\text { doctrina }\end{array}$ \\
\hline & Alvar, Manuel & $\begin{array}{l}\text { Una lección de Menéndez Pidal: las dos } \\
\text { ediciones del "Poema de Yuçuf" }\end{array}$ \\
\hline & Aubrun, Charles & $\begin{array}{l}\text { "Conversos del siglo XVI" (A propósito de } \\
\text { Antón de Montoro) }\end{array}$ \\
\hline & $\begin{array}{l}\text { Avalle-Arce, Juan } \\
\text { Bautista }\end{array}$ & $\begin{array}{l}\text { Las memorias de Gonzalo Fernández de } \\
\text { Oviedo, }\end{array}$ \\
\hline & Carilla, Emilio & El humor en el "Persiles" \\
\hline & Deyermond, Alan & $\begin{array}{l}\text { Motivos folklóricos y técnica estructural en el } \\
\text { Libro de Apolonio }\end{array}$ \\
\hline & $\begin{array}{l}\text { Entenza de Solare, } \\
\text { Beatriz Elena }\end{array}$ & Datos para la biografía de don Juan Coloma, \\
\hline & $\begin{array}{l}\text { Frenk Alatorre, } \\
\text { Margit }\end{array}$ & Problemas de antigua lírica popular \\
\hline & Lida, Raimundo & Hacia la "Política de Dios" \\
\hline & Mcgrady, Donald & $\begin{array}{l}\text { Tesis, réplica y contrarréplica en El Lazarillo, } \\
\text { el Guzmán y El Buscón }\end{array}$ \\
\hline & $\begin{array}{l}\text { Morreale, } \\
\text { Margherita }\end{array}$ & $\begin{array}{l}\text { El ms. } 10.288 \text { de la Biblioteca Nacional de } \\
\text { Madrid }\end{array}$ \\
\hline
\end{tabular}


Avatares del Hispanismo: canon y estudios literarios en la Argentina (1949-1973)

\begin{tabular}{|c|c|c|}
\hline \multirow[t]{2}{*}{ Año, $\mathbf{N}^{\circ}$, Vol. } & \multirow{2}{*}{$\begin{array}{l}\text { Autor/es } \\
\text { Orduna, Germán }\end{array}$} & \multirow{2}{*}{$\begin{array}{l}\text { Título } \\
\text { Observaciones al texto de la Tragicomedia de } \\
\text { Don Duardos }\end{array}$} \\
\hline & & \\
\hline & Ribbans, Geoffrey & $\begin{array}{l}\text { Nuevas precisiones sobre la influencia de } \\
\text { Verlaine en Antonio Machado }\end{array}$ \\
\hline & $\begin{array}{l}\text { Rodríguez-Moñino, } \\
\text { Antonio }\end{array}$ & $\begin{array}{l}\text { Las "poesías de autores andaluces" } \\
\text { (Manuscrito del siglo XVII) }\end{array}$ \\
\hline & $\begin{array}{l}\text { Sabor de Cortazar, } \\
\text { Celina }\end{array}$ & $\begin{array}{l}\text { La Farsa de la fortuna o hado de Diego } \\
\text { Sánchez de Badajoz y su sentido trascendente }\end{array}$ \\
\hline & $\begin{array}{l}\text { Weber de Kurlat, } \\
\text { Frida }\end{array}$ & $\begin{array}{l}\text { Sobre el portuguesismo de Diego Sánchez de } \\
\text { Badajoz }\end{array}$ \\
\hline & Whinnom, Keith & $\begin{array}{l}\text { Hacia una interpretación y apreciación de las } \\
\text { canciones del Cancionero General de } 1511\end{array}$ \\
\hline & $\begin{array}{l}\text { Zamora Vicente, } \\
\text { Alonso }\end{array}$ & $\begin{array}{l}\text { Tras las huellas de Alejandro Sawa (Notas a } \\
\text { Luces de bohemia.) }\end{array}$ \\
\hline & Zuleta, Emilia de & $\begin{array}{l}\text { La literatura nacional en las "Poéticas" } \\
\text { españolas }\end{array}$ \\
\hline \multirow[t]{6}{*}{ XIV, 1970} & Ferraresi de, Alicia & Sentido y unidad de "Razón de amor" \\
\hline & Guglielmi, Nilda & $\begin{array}{l}\text { Los elementos satíricos en las "Coplas de la } \\
\text { panadera" }\end{array}$ \\
\hline & $\begin{array}{l}\text { Rodríguez- } \\
\text { Puértolas, Julio }\end{array}$ & $\begin{array}{l}\text { La trasposición de la realidad en el Códice de } \\
\text { autos viejos }\end{array}$ \\
\hline & Amícola, José & El siglo XV y el teatro castellano \\
\hline & $\begin{array}{l}\text { Gatti, José } \\
\text { Francisco }\end{array}$ & $\begin{array}{l}\text { Le triomphe de Plutus de Marivaux y } \mathrm{El} \\
\text { triunfo del interés de Ramón de la Cruz }\end{array}$ \\
\hline & Schiavo, Leda & La parodia de Dante en Luces de bohemia \\
\hline \multirow[t]{4}{*}{$\mathrm{XV}, 1971$} & Amícola, José & $\begin{array}{l}\text { El Auto de la huida a Egipto, drama anónimo } \\
\text { del siglo XV }\end{array}$ \\
\hline & $\begin{array}{l}\text { Entenza de Solare. } \\
\text { Beatriz Elena }\end{array}$ & Notas sobre "El purgatorio de San Patricio" \\
\hline & $\begin{array}{l}\text { Minian de Alfie, } \\
\text { Raquel }\end{array}$ & $\begin{array}{l}\text { Algunas versiones del tema bíblico de Susana } \\
\text { en el teatro de los siglos XVI y XVII }\end{array}$ \\
\hline & Romanos, Melchora & Nuevos aportes al problema de las dos \\
\hline
\end{tabular}


Avatares del Hispanismo: canon y estudios literarios en la Argentina (1949-1973)

\begin{tabular}{|c|c|c|}
\hline \multirow[t]{2}{*}{ Año, No, Vol. } & \multirow[t]{2}{*}{ Autor/es } & Título \\
\hline & & versiones del "Antídoto" \\
\hline & $\begin{array}{l}\text { Sabor de Cortazar, } \\
\text { Celina }\end{array}$ & $\begin{array}{l}\text { Observaciones sobre la estructura de } L a \\
\text { Galatea }\end{array}$ \\
\hline & Delpy, María Silvia & $\begin{array}{l}\text { Serie y asonante en la subdivisión del "Cantar } \\
\text { de Rodrigo" }\end{array}$ \\
\hline & $\begin{array}{l}\text { Ferrario de Orduna, } \\
\text { Lilia }\end{array}$ & $\begin{array}{l}\text { Los estribillos de Tisbea y de la pescadora en } \\
\text { El burlador de Sevilla y Tan largo me lo fiáis }\end{array}$ \\
\hline & $\begin{array}{l}\text { Gatti, José } \\
\text { Francisco }\end{array}$ & $\begin{array}{l}\text { Una interpretación engañosa de Pérez de } \\
\text { Ayala }\end{array}$ \\
\hline & Schiavo, Leda & $\begin{array}{l}\text { Tradición literaria y nuevo sentido en } L a \\
\text { marquesa Rosalinda }\end{array}$ \\
\hline & Yahni, Roberto & $\begin{array}{l}\text { De las Sonatas al Ruedo Ibérico: rasgos de } \\
\text { estilo comunes }\end{array}$ \\
\hline XVI, 1972 & Chasca, Edmund de & $\begin{array}{l}\text { Registro comparativo de los números en el } \\
\text { Romancero del Cid y en el Poema de Mio Cid }\end{array}$ \\
\hline & $\begin{array}{l}\text { Ferrario de Orduna, } \\
\text { Lilia }\end{array}$ & $\begin{array}{l}\text { La Obra del Pecador según la edición de } \\
1611 .\end{array}$ \\
\hline & Forradellas, Joaquín & $\begin{array}{l}\text { Composiciones líricas en la Historia del } \\
\text { Monte Celia }\end{array}$ \\
\hline & $\begin{array}{l}\text { Minian de Alfie, } \\
\text { Raquel }\end{array}$ & La Elegía I de Garcilaso \\
\hline & $\begin{array}{l}\text { Uriarte Rebaudi, } \\
\text { Lía Noemí. }\end{array}$ & Un motivo folklórico en el Poema del Cid \\
\hline & $\begin{array}{l}\text { Morreale, } \\
\text { Margherita }\end{array}$ & $\begin{array}{l}\text { El libro del famoso e muy esforçado cavallero } \\
\text { Palmerín de Olivia. Testo crítico a cura di } \\
\text { Giuseppe di Stefano }\end{array}$ \\
\hline
\end{tabular}

Tal como se ha indicado, de los ochenta trabajos referidos a la literatura española en el periodo comprendido entre 1949 y 1973, casi la mitad abordan textos y autores del Siglo de Oro. Esta preeminencia parece replicar la que esta época tiene en el concierto de estudios hispánicos desde finales del siglo XIX y que se mantiene vigente durante el 
periodo analizado. Cervantes, Lope de Vega y Quevedo son los autores más estudiados: sobre cada uno de ellos hay seis contribuciones, lo que constituye la mitad de los trabajos sobre el Siglo de Oro. Les siguen en orden de presencia autores dramáticos como Tirso de Molina y Calderón de la Barca, y en menor medida, textos sobre la novela picaresca. En este repertorio, resulta significativa la inclusión de algunos autores menos visibles del canon, como Diego Sánchez de Badajoz o Gil Vicente; sin embargo, su inserción puede leerse desde la preeminencia de trabajos sobre el teatro español, género que ocupa una parte importante de las colaboraciones del periodo, frente a una presencia menor de la narrativa y de la poesía.

La literatura medieval, segunda en cantidad de trabajos publicados, exhibe una mayor variedad de temas y textos. El repertorio abordado incluye el género dramático, las crónicas, la épica (encabezada por el Cantar del Mio Cid) y la lírica tradicional. Si bien la literatura de este periodo ocupa un espacio significativo, no se evidencia la preeminencia de algún tema o texto en particular — a excepción del Cantar del Mio Cid, abordado en tres trabajos - sino más bien estudios sobre un género determinado u obras puntuales, algunas de las cuales como el Libro del caballero Zifar o el Libro de Apolonio conforman, al igual que el Cantar de Mio Cid, piezas clave del canon medieval español ya consolidado.

Los siglos XVIII y XIX apenas aparecen representados en la revista: dos trabajos sobre Ramón de la Cruz y uno sobre Benito Jerónimo de Feijoó, además de un estudio sobre preceptiva poética constituyen el corpus del siglo XVIII, mientras que del siglo XIX se destacan la figura de Bécquer, con dos contribuciones sobre su obra y un artículo en el que se aborda la obra poética de José M. Gabriel y Galán ${ }^{189}$.

\footnotetext{
${ }^{189}$ En este caso en particular, el enfoque del trabajo es filológico, ya que trata las formas dialectales presentes en los poemas del escritor siguiendo las líneas teóricas propuestas por Menéndez Pidal, es decir, que el acento está puesto en identificar y clasificar las variantes dialectales más que en una lectura crítica de la obra. Este tipo de trabajos expresa los puntos de contacto de las disciplinas que coexistían en el
} 
Ramón del Valle-Inclán y su teatro ocupan, con cuatro artículos, el primer lugar en la lista de autores correspondientes al siglo XX; lo siguen Federico García Lorca, abordado en dos estudios ${ }^{190}$. Ambos autores son figuras también relevantes en el canon contemporáneo, cuyas obras habían sido editadas en varios países de habla hispana y que era posible encontrar en catálogos de las colecciones editoriales, como es el caso de la Editorial Losada ${ }^{191}$. Luego aparecen los poetas Antonio Machado y Pedro Salinas y los novelistas Gabriel Miró y Ricardo Sánchez Ferlosio, con un artículo dedicado a cada uno de ellos.

La trayectoria analizada de la revista Filología en la década del cincuenta hasta inicios del los años setenta del siglo pasado demuestra así la fuerte tradición en estudios hispánicos que se enraíza con el campo académico e intelectual de nuestro país. Al mismo tiempo, sus intelectuales participan activamente en la forja de un hispanismo integrador cuya relevancia queda manifiesta en la perdurabilidad hasta nuestros días de sus nombres y de sus obras, signos renovados de una producción crítica inserta en el proceso dinámico de fijación y ampliación del canon hispánico que reedita las tensiones entre continuidades y rupturas, entre permanencia y actualización, intrínsecas de ese proceso cultural.

ámbito del Instituto y, a la vez, el afán integrador entre los aportes de las principales corrientes de investigación en boga en ese momento.

${ }^{190}$ El caso de Federico García Lorca es particular, ya que estuvo una temporada en Buenos Aires entre 1933 y 1934, a donde llegó invitado para dar conferencias por la Asociación Amigos del Arte. Durante su estancia se estrenaron algunas de sus obras, como Bodas de sangre, a cargo de la compañía teatral de Lola Membrives (1933), se repusieron otras, como La zapatera prodigiosa, que estuvo varias semanas en cartel, y Mariana Pineda, lo que pone de manifiesto la relación estrecha del poeta granadino con el mundo cultural porteño de la época.

191 La Editorial Losada (1938) tuvo un papel relevante en los procesos de ampliación y difusión del canon hispánico a partir de la concreción de colecciones y de la edición de obras de autores españoles contemporáneos. Entre ellas se destacan las Obras Completas de Federico García Lorca (1938) y las del poeta Miguel Hernández (1960). Estas vinculaciones con la industria editorial se desarrollarán en el Capítulo 3. 


\subsubsection{Otras publicaciones académicas del Instituto de Filología}

La reseña acerca de las líneas de investigación y de las publicaciones del Instituto de Filología realizada en la primera parte de este trabajo dio cuenta del lugar que la difusión de los estudios desarrollados por los miembros del Instituto, así como de colaboradores de otras universidades, tuvo entre las políticas institucionales. En este apartado se añadirán aquellas publicaciones periódicas o no vinculadas con la literatura española a partir de la década de $1940^{192}$. Entre ellas se destacan:

- Bibliografías de Literatura Española:

Benítez, Rubén. Ensayo de una bibliografía razonada de Gustavo Adolfo Bécquer. Buenos Aires, 1961.

- Monografías y Estudios De Literatura Española:

Henríquez Ureña, Pedro. Estudios de versificación española. Buenos Aires, 1961.

Spitzer, Leo. Sobre antigua poesía española. Buenos Aires, 1962.

Kurlat, Frida Weber de. Lo cómico en el teatro de Fernán González de Eslava. Buenos Aires, 1963.

Cowes, Hugo W. Relación Yo-Tú y trascendencia en la obra dramática de Pedro Salinas. Buenos Aires, 1965.

Malkiel, María Rosa Lida de. Jerusalén. El tema literario de su cerco y destrucción por los romanos. Buenos Aires, 1973.

- Textos: incluye ediciones críticas de textos españoles

Alfonso el Sabio. Setenario, Ed. e introducción de Keneth H. Vanderford. Buenos Aires, 1945.

\footnotetext{
${ }^{192}$ El listado de publicaciones del Instituto de Filología fue el resultado de la labor de inventario y fichaje realizada por Celina Sabor de Cortazar, de manera mecanografiada, a finales de la década de 1960, y que luego fue sistematizada y convertida en archivo digital durante la dirección de la Dra. Melchora Romanos, quien me facilitó gentilmente una versión.
} 
Tirso del Molina. Por el sótano y el torno. Ed., prólogo y notas de A. Zamora Vicente. Buenos Aires, 1949.

Sánchez de Badajoz, Diego. Recopilación en metro. (Sevilla, 1554). Trabajos de seminario bajo la dirección de Frida Weber de Kurlat. Buenos Aires, 1968.

De este modo, junto con la edición de la revista Filología, la lista de publicaciones referidas a temas y autores españoles pone de manifiesto la centralidad que estos estudios tuvieron entre las líneas de investigación del Instituto. Asimismo, entre los nombres de los autores se encuentran algunos de los que conformarían el núcleo del hispanismo nacional, en particular las investigadoras discípulas de Amado Alonso, María Rosa Lida, Frida Weber de Kurlat y Celina Sabor de Cortazar, cuyos itinerarios, aunque con derroteros diferentes, fueron señeros para la conformación y consolidación de un canon hispánico en el contexto de los estudios y la crítica literaria, así como en las proyecciones al campo de la enseñanza.

\subsubsection{La Facultad de Humanidades y Ciencias de la Educación de la Universidad Nacional de La Plata. La revista Humanidades}

Luego de unos inicios fuertemente vinculados con la impronta positivista de los primeros años de la universidad - marcados en particular por el desarrollo de la Pedagogía como disciplina-, la relevancia de las humanidades en el seno de la universidad platense se acentuará durante la gestión de Ricardo Levene, quien fue primero decano de la Facultad de Humanidades durante dos periodos (1920-1923 y 1926-1930) y luego rector de la Universidad entre los años 1930-1933. Su prolífica trayectoria como docente e investigador y también su desempeño como autoridad 
impulsaron el desarrollo de los estudios humanísticos en la Facultad, en consonancia con el ideario reformista que influyó en las reformas curriculares y académicas durante esas décadas. Una de las características primordiales que prevaleció en la formación académica de la Facultad fue un enfoque centrado en una visión humanística de corte idealista, propulsada por los principales docentes de la Facultad ${ }^{193}$. Entre las principales líneas del ideario humanista estaba el arielismo, expresado a través de una visión opositora al materialismo que encarnaban los Estados Unidos, y que proponía un regreso a los valores de un humanismo clásico y una revisión de la tradición hispana, a la vez que propiciaba un modelo formativo articulado en la figura del maestro-discípulo, según el modelo Próspero-Ariel de la obra de Rodó ${ }^{194}$. De este modo se concebía una matriz idealista que signaba los estudios y la formación de los estudiantes alejada de la impronta positivista de los primeros años y que se plasmó en las revistas estudiantiles que circularon en la Facultad durante la década de $1920^{195}$.

En ese marco, se creó la revista Humanidades, en 1921, órgano de publicación de trabajos vinculados con las áreas de la Facultad: Pedagogía, Filosofía y, en menor medida en los tiempos iniciales, Historia y Letras. A lo largo de cuatro décadas, esta publicación reunirá los trabajos de profesores, graduados e investigadores de la

${ }^{193}$ En un artículo referido al desarrollo de las Humanidades en el seno de la Facultad de Humanidades y Ciencias de la Educación de la UNLP, Osvaldo Graciano reconoce la impronta humanista en varios de los profesores que se desempeñaron en la década de 1920. Entre ellos menciona a Arturo Marasso, Carmelo Bonet, Arturo Capdevila, Rafael Alberto Arrieta, docentes de literatura que ejercieron su magisterio en la Facultad y además participaron en sus publicaciones (2014: 10-11).

194 En un artículo dedicado a analizar la presencia del humanismo idealista en la Universidad Nacional de La Plata, Gustavo Vallejo reconoce este modelo encarnado en las figuras de Arturo Marasso y Ezequiel Martínez Estrada, a quienes sus discípulos consideraban "maestros" y guías" para la formación humanística. También fue un difusor de las ideas arielistas Pedro Henríquez Ureña, docente de la Facultad. Asimismo, Vallejo destaca el viraje hacia una recuperación de la tradición hispánica a partir de las denominaciones que la UNLP recibió en ese tiempo, que indicarían ese cambio de rumbo: "La revalidación de la cultura hispana que en la década del "20 convirtió al "Oxford argentino" de la etapa gonzaliana [de Joaquín V. González] en la "Salamanca de Iberoamérica” (1999: 122-124).

195 En este mismo artículo, Vallejo menciona algunas de las revistas editadas por los estudiantes de la UNLP durante esa década: Valoraciones (1923-1925), Sagitario (1925-1927), Estudiantina (1925-1927) y Don Segundo Sombra (1928-1929), caracterizadas por sus miradas antipositivistas y el compromiso con las ideas reformistas (122). 


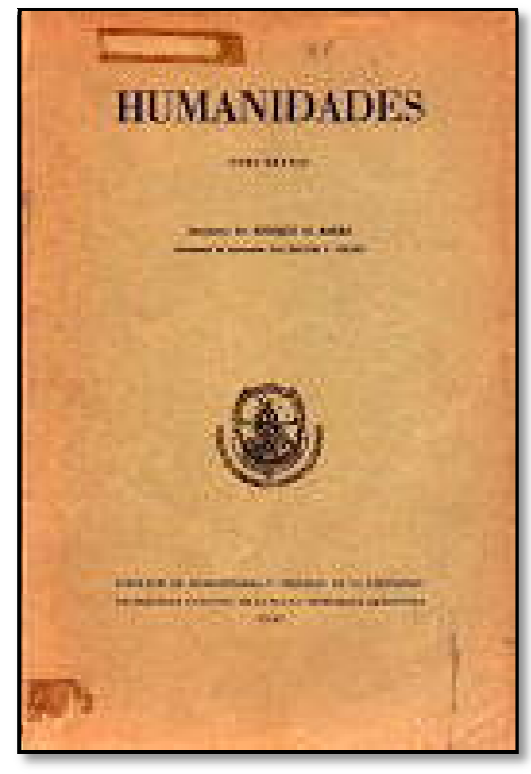

Facultad, así como de colaboradores de otras universidades, en un esfuerzo por difundir las principales líneas de indagación y los aportes teóricos generados en el ámbito de la Facultad ${ }^{196}$. Como es frecuente en la trayectoria de las publicaciones dependientes de las instituciones, su periodicidad suele presentar altibajos. En el caso de Humanidades, durante la primera década (1921-1930) publicó dos números por año; a partir de 1933 cambia a una frecuencia anual hasta 1940. Durante las décadas siguiente, la continuidad se torna irregular: tres números en la década de 1940 (1944, 1945 y 1948), en 1950 retoma el carácter semestral, con dos números publicados y reaparece en 1954 con una división en tres áreas: Filosofía, Letras e Historia. Luego de esa experiencia, no aparece hasta 1960, con dos volúmenes anuales y finaliza en 1961 con la publicación de los últimos cuatro números de la revista.

En su condición de portavoz de los trabajos de los miembros de la comunidad académica de la Facultad, la revista recogía contribuciones de variada índole, referidas a las áreas de estudio de la unidad académica; es decir, no tenía un perfil definido, sino que agrupaba artículos de las diferentes disciplinas que se dictaban en la Facultad ${ }^{197}$. De

\footnotetext{
196 Ya en el primer número de la revista $\left(\mathrm{N}^{\circ} 1,1921\right)$ aparece un trabajo de Carmelo Bonet, docente de la Facultad, referido a la enseñanza del castellano, cuestión que estaba en el centro de los debates por la lengua nacional en la década de 1920. En la misma tesitura, en el Nº3 (1922), Bonet publica "Apuntes sobre el arte de escribir", y también en ese número aparece un artículo de Arturo Marasso titulado "El castellano moderno". Estas intervenciones visibilizan los aportes de docentes e investigadores de la Facultad de Humanidades a los temas lingüísticos vinculados con el estatuto del castellano en el contexto de la enseñanza.

${ }^{197}$ La Facultad de Humanidades y Ciencias de la Educación de la Universidad Nacional de La Plata ha publicado recientemente en su Memoria Académica los cinco primeros volúmenes completos de la revista Humanidades. De ese repositorio se ha tomado la imagen que se incluye. Disponible en http://www.memoria.fahce.unlp.edu.ar/memoria/news/revista-humanidades-1921
} 
allí que - en especial en los primeros números - no se destaque la presencia de textos dedicados a los estudios literarios. Sin embargo, sí es de señalar la inclusión de algunas notas que dan cuenta del estado de los debates sobre la lengua nacional propios del periodo, tanto de profesores argentinos como colaboraciones de filólogos españoles, como Américo Castro (1923, 1924 y 19), Agustín Millares Carlo (1924), Manuel de Montoliu (1925) y Amado Alonso $(1928,1945)$ y hasta del mismo Ramón Menéndez Pidal, en $1930^{198}$.

En los números siguientes de la revista aparecen algunos artículos que abordan temas de la literatura española, de la pluma de los catedráticos que se desempeñaban en la Facultad: Arturo Marasso, Carmelo Bonet, el español Juan Millé y Giménez, Augusto Cortina y también de escritores, como Arturo Giménez Pastor ${ }^{199}$. Como nota de color, se destaca una contribución sobre Góngora de un joven Jorge Luis Borges, en el número de 1927. A partir de la década de 1930, se alternan con la participación de los profesores otros trabajos que corresponden a jóvenes en ese momento en formación en la universidad platense, lo que pone de manifiesto un espíritu de apertura y de fomento de la inserción de los noveles profesionales en el ámbito de las publicaciones ${ }^{200}$.

\footnotetext{
${ }^{198}$ Recuérdese que estos filólogos españoles —a excepción de Menéndez Pidal, aunque tuvo parte fundamental en su creación y en la elección de los directores- se desempeñaron como directores del Instituto de Filología de la Universidad de Buenos Aires y, en el caso de Américo Castro, también dictó cursos en la Universidad de La Plata. Sus colaboraciones en la revista evidencian los vínculos que ya se habían establecido entre el IF y la Facultad de Humanidades y Ciencias de la Educación.

${ }^{199}$ Resulta digno de destacar que un grupo importante de estos profesores que se desempeñaron en la Universidad Nacional de La Plata luego fueron designados miembros de la Academia Argentina de Letras, que se crea en 1931, entre ellos Arturo Marasso, Carmelo Bonet, Rafael Alberto Arrieta. Es decir, que su trayectoria como docentes e investigadores confluye años después en un sitio en la Academia y evidencia las relaciones entre la vida universitaria, la producción intelectual y el reconocimiento que otorga la pertenencia a la Academia, considerada una institución prestigiosa.

${ }^{200}$ Como ejemplo de esta colaboración entre profesores y estudiantes puede citarse la edición del Diálogo entr'el amor y un viejo, de Rodrigo de Cota, realizada por Augusto Cortina y anotada por un grupo de estudiantes de la Facultad de Humanidades (Editorial Coni, 1929). Tiempo después, fragmentos de este trabajo aparecerán publicados en el Boletín de la Academia Argentina de Letras (Cf. Cuadro $\mathrm{N}^{\circ}$ 7).
} 
Cuadro n 2: Artículos literatura española Revista Humanidades (UNLP) (19211961)

\begin{tabular}{|c|c|c|}
\hline $\begin{array}{l}\text { Año, } \quad \mathbf{N}^{\circ}, \\
\text { Vol. }\end{array}$ & Autor/es & Título \\
\hline $\mathrm{N}^{\circ} 4,1922$ & Martinenche, Ernesto & La Circe y los problemas mitológicos en Lope \\
\hline $\mathrm{N}^{\circ} 10,1925$ & Bonet, Carmelo & $\begin{array}{l}\text { Los amores de doña Endrina y don Melón de la } \\
\text { Huerta }\end{array}$ \\
\hline $\mathrm{N}^{\circ} 12,1926$ & Marasso, Arturo & Hesíodo en la literatura castellana \\
\hline \multirow[t]{4}{*}{$\mathrm{N}^{\circ} 15,1927$} & Farinelli, Arturo & Larra \\
\hline & $\begin{array}{l}\text { Millé y Giménez, } \\
\text { Juan }\end{array}$ & El horóscopo de Lope de Vega \\
\hline & $\begin{array}{l}\text { Giménez Pastor, } \\
\text { Arturo }\end{array}$ & El mundo de don Quijote \\
\hline & Borges, Jorge Luis & Gongorismo \\
\hline \multirow[t]{3}{*}{$\mathrm{N}^{\circ} 18,1928$} & Castro, Américo & Escepticismo y contradicción en Quevedo \\
\hline & Marasso, Arturo & Fray Luis de León \\
\hline & $\begin{array}{l}\text { Millé y Giménez, } \\
\text { Juan }\end{array}$ & Comentarios a dos sonetos de Góngora \\
\hline \multirow[t]{4}{*}{$\mathrm{N}^{\circ} 21,1930$} & $\begin{array}{l}\text { Menéndez Pidal, } \\
\text { Ramón }\end{array}$ & Realismo en la epopeya española \\
\hline & Marasso, Arturo & $\begin{array}{l}\text { Píndaro en la literatura castellana: notas para un } \\
\text { estudio }\end{array}$ \\
\hline & Cortina, Augusto & Rosalía Castro de Murgía \\
\hline & Bordato, Elisa Esther & Merinée y el Duque de Rivas \\
\hline \multirow[t]{3}{*}{$\mathrm{N}^{\circ} 24,1934$} & Marasso, Arturo & La antología griega en España \\
\hline & Oría, José A. & $\begin{array}{l}\text { La polémica de Menéndez y Pelayo con } \\
\text { Groussac sobre el 'Quijote' de Avellaneda }\end{array}$ \\
\hline & Bonet, Carmelo & 'La Dorotea' y la vida amorosa de Lope \\
\hline $\mathrm{N}^{\circ} 27,1939$ & Marasso, Arturo & El Lazarillo de Tormes \\
\hline $\mathrm{N}^{\circ} 29,1944$ & Marasso, Arturo & San Juan de la Cruz \\
\hline \multirow[t]{2}{*}{$\mathrm{N}^{\circ} 31,1948$} & $\begin{array}{l}\text { Nessi, Ángel } \\
\text { Osvaldo }\end{array}$ & La plástica del mito de Garcilaso \\
\hline & $\begin{array}{l}\text { Gallo de Amarilla, } \\
\text { Lidia }\end{array}$ & La sugestión lírica en Antonio Machado \\
\hline
\end{tabular}


Avatares del Hispanismo: canon y estudios literarios en la Argentina (1949-1973)

\begin{tabular}{|l|l|l|}
\hline $\begin{array}{l}\text { Año, } \\
\text { Vol. }\end{array}$ & Autor/es & Título \\
\hline $\begin{array}{l}\mathrm{N}^{\circ} 34,1954 \\
\text { (Letras) }\end{array}$ & Oteiza, Alberto & 'Arte Nuevo' de Lope de Vega \\
\hline $\mathrm{N}^{\circ} 36,1960$ & Yurkievich, Saúl & Antonio Machado: su poesía \\
\hline $\mathrm{N}^{\circ} 38,1961$ & Guglielmi, Nilda & Reflexiones sobre el Lazarillo de Tormes \\
\hline & Gazdaru, Demetrio & $\begin{array}{l}\text { Factores orientales, griegos y egipcios en la } \\
\text { elaboración del tema literario de 'Fonte Frida' }\end{array}$ \\
\hline
\end{tabular}

\section{- Addenda: Biblioteca Humanidades - Series monográficas ${ }^{201}$.}

Nº (1928) Millé y Giménez, Juan. Estudios de literatura española

En los cuarenta años que median entre el primero y el último número de la revista se publicaron veinticinco trabajos dedicados a la literatura española. Si bien se anticipa al recorte temporal de esta investigación, resulta pertinente incluir los números desde su creación, a fin de contar con un panorama más abarcador y completo del perfil de la revista. Respecto de las obras y autores abordados en estos artículos, el peso de los considerados "canónicos" por la tradición hispánica es evidente: Cervantes, Lope de Vega, Góngora, Quevedo, el Lazarillo de Tormes, Fray Luis de León. De los más modernos, unas pocas presencias: el Duque de Rivas, Mariano José de Larra y Rosalía de Castro, y entre los contemporáneos, Antonio Machado. Una vez más, los autores y textos consagrados por una tradición de estudios de literatura española conforman los repertorios de obras seleccionadas y, al mismo tiempo, retoman la noción de "clásico" o "canónico" atribuidas a estos textos y autores españoles.

\footnotetext{
201 Junto con la revista Humanidades, la Facultad publicó la Biblioteca Humanidades, constituida por volúmenes individuales dedicados a un asunto particular de las áreas disciplinares que se dictaban allí. Entre 1923 y 1960 se editaron treinta y dos números, con periodicidad irregular, y entre ellos aparece el $\mathrm{n}^{\circ} 7$, de 1928, cuyo autor es el profesor español Juan Millé y Giménez. Millé y Giménez fue profesor en la Universidad de Nacional de La Plata y autor de trabajos sobre literatura española del Siglo De Oro. Entre ellos se destaca la edición de las Obras completas de Luis de Góngora publicadas bajo el sello Aguilar en 1932 en Madrid, que tuvo numerosas reediciones. También fue colaborador en la editorial Espasa Calpe de Madrid.
} 
Aunque modestas, y en el marco de una publicación cuyo principal perfil era ser un órgano de difusión de una Facultad con diversas disciplinas humanísticas, las contribuciones acerca de la literatura española en la revista Humanidades dan cuenta de los incipientes esfuerzos de los estudiosos de temas hispánicos por buscar un espacio en el conjunto de las producciones académicas $\mathrm{y}$, de este modo, ir estableciendo perspectivas, enfoques y proyectos que permitirán trazar líneas de investigación en esta área del conocimiento y, a la vez, sus relaciones con la enseñanza y la formación de los estudiantes en el campo de las humanidades.

\subsubsection{EI Instituto de Investigaciones Literarias de la Facultad de Humanidades de}

\section{la UNLP y su Boletín}

A partir de la década de 1920 — y en consonancia con la dinámica de investigación y divulgación propugnada por la universidad post Reforma Universitaria - se produce la creación de centros de investigación en el seno de las universidades nacionales. En ese marco académico, como se ha indicado, en el año 1937 se funda el Instituto de Investigaciones Literarias en la Facultad de Humanidades de la Universidad Nacional de La Plata (Cf. Cap. I, Nota 141), bajo la dirección del profesor Augusto Cortina ${ }^{202}$. Con la creación del Instituto se sientan las bases en la Facultad de Humanidades y Ciencias de la Educación de la práctica de investigación literaria a partir del incentivo en la formación de los futuros profesores. Las actividades realizadas en el centro giran en torno a la investigación de temas literarios, tanto españoles como argentinos, que se plasman en la publicación de artículos y libros, así como la participación de estudiantes

\footnotetext{
${ }^{202}$ La Ordenanza que crea el Instituto lleva la firma del decano de la Facultad, José Rezzano y del secretario Marcelino Villar. En el artículo $2^{\circ}$ se establece el principal objetivo de dicha institución: "Dicho Instituto preparará un fichero bibliográfico de la producción literaria americana y española" (en Boletín del Instituto de Investigaciones Literarias $\left.\mathrm{N}^{\circ} 1\right)$.
} 
a través de conferencias y sesiones, lo que expresa una decidida vocación de desarrollar entre los alumnos el ejercicio de la investigación académica y de la crítica.

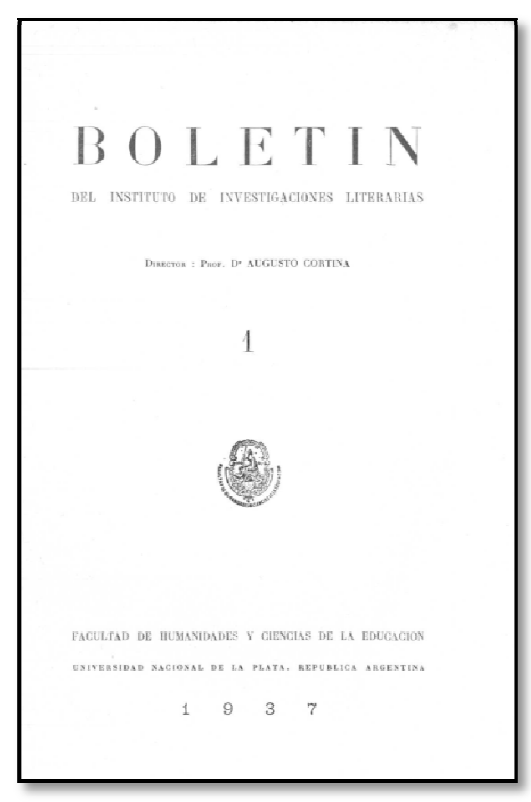

En ese mismo año, el Instituto publica el primer número de su Boletín, (BIIL) donde desde la Advertencia que abre el número, firmada por Augusto Cortina, su director, se dejan sentadas las bases programáticas de dicho centro: "Este Instituto se propone fomentar los estudios atinentes a su especialidad. Ha de contribuir, por tanto, en la medida de sus posibilidades, a formar investigadores convenientemente adiestrados en la técnica del trabajo intelectual" "(Advertencia", $\left.\mathrm{N}^{\circ} 1: \mathrm{VII}\right)$. El énfasis puesto en la investigación postula una revisión de los métodos de enseñanza basados en la repetición o en el razonamiento baldío, según expresa más adelante: 'Nunca podrá quien no estudia y aquilata los textos, ser otra cosa que reiterador impersonal de juicios extraños. Desmontemos la máquina y demos a los estudiantes las herramientas necesarias para que intenten construir otra mejor" (VIII). Estas ideas resumen el espíritu reformista que ya había calado en los claustros universitarios desde la década anterior y destacan la relevancia que la investigación literaria tendría en el marco de la formación de futuros docentes, así como el cuño pragmático que debiera tener dicha formación: "Es preciso impartir la enseñanza literaria, de una vez por todas, de modo absolutamente práctico” (VIII).

El acento en lo fáctico de la formación disciplinar se vincula, en esta perspectiva, con la publicación de los resultados alcanzados por los investigadores del Instituto, entre ellos, estudiantes avanzados, como modo de fomentar el trabajo intelectual. El Boletín, creado en forma simultánea con el Instituto, se presenta como el 
órgano para la difusión de los resultados de esas tareas intelectuales, y a la vez, como vehículo para la inserción del Instituto en el ámbito académico nacional e internacional. Este afán se expresa en la conformación del Instituto, cuyos miembros pertenecen tanto a la misma Facultad como a otras instituciones. La nómina de integrantes del Instituto está compuesta por profesores de la Facultad del área de Letras, muchos de ellos reconocidos catedráticos y escritores. Son ellos su director, Augusto Cortina, a la sazón docente de la cátedra Lectura y Comentario de Textos de la Facultad y miembro adscripto del Instituto de Literatura Latinoamericana de la Universidad de Buenos Aires; Rafael Alberto Arrieta, profesor de Literatura de Europa Septentrional y Meridional de la misma Facultad, también docente en la Facultad de Filosofía y Letras de la UBA y miembro de la Academia Argentina de Letras, creada recientemente; Carmelo M. Bonet, profesor del Seminario de Letras de la Facultad y también docente en la Facultad de Filosofía y Letras de la UBA; Arturo Capdevila, profesor de Literatura Argentina y de la América Española en la Facultad y académico correspondiente de la Academia Española; Américo Castro, quien luego de regresar a España finalizada su gestión al frente del Instituto de Filología de la Universidad Buenos Aires en 1924, retornó al país en la década de 1930, luego del estallido de la Guerra Civil, donde permaneció un tiempo y dictó clases en Buenos Aires y La Plata antes de emprender el exilio definitivo en los Estados Unidos ${ }^{203}$, y Arturo Marasso, quien, como se ha señalado, ya exhibía una importante trayectoria en la Facultad platense, de la que había sido vicedecano y también era miembro de la Academia Argentina de Letras ${ }^{204}$.

\footnotetext{
${ }^{203}$ La trayectoria de Américo Castro estuvo signada por los vaivenes de la vida política, tanto en España como fuera de ella. Luego de permanencias intermitentes en diferentes lugares de Hispanoamérica, entre ellos Buenos Aires en dos oportunidades, y Estados Unidos, Castro se radicó definitivamente allí en la década de 1940, donde continuó con sus estudios y con la formación de discípulos (Bernabeu Albert 2002).

${ }^{204}$ Como se podrá observar, todos los catedráticos que se nuclearon en el Instituto de Investigaciones Literarias habían formado parte de los colaboradores de la revista Humanidades editada por la Facultad de Humanidades y Ciencias de la Educación desde 1921: Cortina $\left(\mathrm{N}^{\circ} 10,1925 ; \mathrm{N}^{\circ} 21,1930\right)$, Arrieta $\left(\mathrm{N}^{\circ}\right.$
} 
Dos figuras relevantes del hispanismo revisten como miembros correspondientes del Instituto y cuyos itinerarios académicos e intelectuales estuvieron estrechamente vinculados con los ámbitos académicos y universitarios del país: Ricardo Rojas, fundador y organizador de la Facultad de Humanidades, y Ramón Menéndez Pidal, cuyo reconocimiento internacional en el campo del hispanismo era ya reconocido. La presencia de estos dos últimos refuerza las vinculaciones entre las universidades argentinas y España, a través de la mediación de la figura de Rojas. De este modo, el consejo del Boletín incluía entre sus miembros a figuras destacadas de la docencia y la investigación literarias, entre ellas, la literatura española.

Por la índole de la publicación, el Boletín es un género de publicación concebido en primer lugar como un órgano de difusión de las acciones, noticias y producciones de una institución determinada. De allí que presente un carácter diferente de las revistas académicas, definido más por su afán divulgativo. Esto se evidencia en el caso del Boletín del Instituto de Investigaciones Literarias, cuya Advertencia inicial concluye con la siguiente declaración: "El presente Boletín se propone sacar a la luz pública una parte de nuestra modesta labor" ( $\mathrm{N}^{\circ} 1$ : VIII).

Si bien la continuidad es un rasgo propio de las publicaciones periódicas, la trayectoria del BIIL presenta altibajos en este aspecto; se editó entre 1937 y 1953 , periodo en el cual sacó a la luz siete números, distribuidos de la siguiente manera: el $\mathrm{N}^{\circ}$ 1 en 1937, el Nº 2 en 1941 —cuatro años después—; los $N^{\circ} 3$, 4 y 5 salieron en 1949,

2, 1921; $\mathrm{N}^{\circ} 8,1924 ; \mathrm{N}^{\circ} 9,1924 ; \mathrm{N}^{\circ} 15,1927 ; \mathrm{N}^{\circ} 21,1930 ; \mathrm{N}^{\circ} 24,1934 ; \mathrm{N}^{\circ} 26,1938$ y No 27, 1939); Bonet ( $\mathrm{N}^{\circ} 1,1921 ; \mathrm{N}^{\circ} 3,1922 ; \mathrm{N}^{\circ} 5,1923 ; \mathrm{N}^{\circ} 10,1925 ; \mathrm{N}^{\circ} 15,1927 ; \mathrm{N}^{\circ} 21,1930 ; \mathrm{N}^{\circ} 24,1934 ; \mathrm{N}^{\circ} 27$, 1939); Capdevila ( $\left.\mathrm{N}^{\circ} 11,1925 ; \mathrm{N}^{\circ} 15,1927\right)$; A. Castro ( $\left.\mathrm{N}^{\circ} 6,1923 ; \mathrm{N}^{\circ} 8,1924 ; \mathrm{N}^{\circ} 18,1928\right)$ y Marasso $\left(\mathrm{N}^{\circ} 1,1921 ; \mathrm{N}^{\circ} 3,1922 ; \mathrm{N}^{\circ} 8,1924 ; \mathrm{N}^{\circ} 12,1926 ; \mathrm{N}^{\circ} 18,1928 ; \mathrm{N}^{\circ} 21,1930 ; \mathrm{N}^{\circ} 24,1934 ; \mathrm{N}^{\circ} 27,1939 ;\right.$ $\mathrm{N}^{\circ} 28$, 1944). Tal como puede apreciarse, Arrieta, Bonet y Marasso tuvieron una amplia presencia en la publicación, y luego continuaron su trayectoria como miembros de la Academia Argentina de Letras. 
luego de un interregno de ocho años, el № 6 es de 1951 y el 7 y último número apareció en $1953^{205}$.

En relación con la presencia de estudios sobre literatura española, todos los volúmenes del BIIL incluyen trabajos referidos a esta disciplina. Esto indica que las líneas de investigación relacionadas con esta literatura ocupaban un lugar significativo entre los intereses de sus colaboradores. Como se desprende del relevamiento realizado, entre ellos se encuentran tanto los docentes o miembros del BIIL, como otros nombres que pertenecen a estudiantes o investigadores noveles del Instituto. Esto se vincula con los propósitos declarados en el $\mathrm{N}^{\circ} 1$, referidos a la necesidad de interrelacionar la teoría y la praxis como parte de la formación académica de los estudiantes de Letras de la Facultad de Humanidades ${ }^{206}$.

Cuadro $\mathrm{n}^{\circ}$ 3: Artículos de literatura española en el Boletín del Instituto de Investigaciones literarias (1937 -1953)

\begin{tabular}{|l|l|l|}
\hline $\mathbf{N}^{\circ} /$ Año & Autor/es & Título del artículo \\
\hline $\mathrm{N}^{\circ} 1 / 1937$ & Marasso, Arturo & Fuentes virgilianas del Quijote \\
\hline & Panceira, Julio & Jorge Manrique y su tiempo \\
\hline $\mathrm{N}^{\circ} 2 / 1941$ & Ringuelet, Carlos & Garcilaso y su paisaje \\
\hline & Domínguez, Manuel A. & El ambiente arquitectónico en La Celestina \\
\hline & Disandro, Carlos & Los cantares de gesta y los romances viejos \\
\hline $\mathrm{N}^{\circ} 3 / 1949$ & Capdevila, Arturo & Guzmán de Alfarache o el pícaro moralista \\
\hline & Escalante, Miguel A. & Temperamento y estilo en Gabriel Miró \\
\hline
\end{tabular}

205 Como se ha visto en otros casos, el tema de la periodicidad en las publicaciones académicas es complejo, ya que dependen de avatares políticos, económicos e institucionales, que inciden de manera directa en la regularidad de las ediciones y a veces motivan su súbita interrupción o largos periodos de inactividad.

206 Entre los nombres de los autores de trabajos en el BIIL, se encuentran aquellos de los que en ese momento estaban en formación en las aulas de la Facultad de Humanidades y que luego se destacaron en el ámbito educativo, como por ejemplo Julio Panceira, quien sería rector del Colegio Nacional "Rafael Hernández", dependiente de la UNLP, Carlos Ringuelet, destacado poeta y docente y Alma Novella Mariani, nacida en Italia, egresada de la carrera de Letras, quien se desempeñaría como profesora de literatura italiana en la Facultad de Humanidades. 
Avatares del Hispanismo: canon y estudios literarios en la Argentina (1949-1973)

\begin{tabular}{|l|l|l|}
\hline $\mathbf{N}^{\circ} /$ Año & Autor/es & Título del artículo \\
\hline $\mathrm{N}^{\circ}$ 4/ 1949 & Nessi, Ángel Osvaldo & La variación poética en Herrera \\
\hline $\mathrm{N}^{\circ}$ 5/ 1949 & $\begin{array}{l}\text { Arregui y Olaechea, } \\
\text { Beatriz M. }\end{array}$ & $\begin{array}{l}\text { La frase del siglo XX en Flor de santidad de } \\
\text { Valle Inclán }\end{array}$ \\
\hline & Marani, Alma Novella & La lírica de Santa Teresa \\
\hline $\mathrm{N}^{\circ}$ 6/ 1951 & $\begin{array}{l}\text { Riveros Subizar, María } \\
\text { Irene }\end{array}$ & La justicia de Don Quijote \\
\hline $\mathrm{N}^{\circ} 7 / 1953$ & Carilla, Emilio & Cervantes, testimonios de épocas artísticas \\
\hline
\end{tabular}

Como signo de la relevancia que tenía la literatura española y, en particular la del Siglo de Oro, entre los temas de investigación, se observa que el primer artículo que abre las páginas del BIIL es uno de Arturo Marasso acerca del Quijote. Así, ese trabajo aúna al mismo tiempo dos figuras de valía: por un lado, la de Arturo Marasso, reconocido ya en el ámbito de la universidad platense y personalidad destacada del hispanismo argentino, y la de don Quijote, modelo canónico de las letras hispánicas y emblema del influjo de la literatura española en la literatura en lengua castellana ${ }^{207}$. Además de Cervantes — que aparece abordado en tres notas del BIIL—, otras obras y autores del canon hispánico son objeto de estudio en la publicación: Teresa de Ávila, Jorge Manrique, Garcilaso de la Vega, Fernando de Herrera entre los autores, y los cantares de gesta, los romances, La Celestina y el Guzmán de Alfarache entre las obras, y un par de autores españoles contemporáneos: Ramón del Valle-Inclán, y en dos ocasiones, Gabriel Miró. La preeminencia de estudios sobre textos y autores

\footnotetext{
${ }^{207} \mathrm{Al}$ respecto, recuérdese la colección cervantina que se encuentra en la Biblioteca Pública de la ciudad de La Plata, una de las más relevantes del mundo por la cantidad y el valor de los ejemplares que se conservan. Un catálogo comentado de dicha colección fue editado por la Universidad (2005), con un estudio de Gloria Chicote, quien además le dedicó otros trabajos a esta colección $(2006,2015)$. En el año 2015, con motivo de conmemorarse el $110^{\circ}$ aniversario de la Biblioteca Pública de la Universidad Nacional de La Plata, se organizó la Jornada "Entre anaqueles y tesoros" en la que disertaron especialistas en temas bibliográficos, entre ellos la Dra. Gloria Chicote, quien se refirió a la colección cervantina.
} 
consagrados por el canon marca de algún modo las tendencias críticas y teóricas del Instituto y evidencia la centralidad de aquel al momento de definir líneas de trabajo.

Asimismo, se resalta entre los autores la notoria presencia de mujeres como colaboradoras del BIIL, lo que, como se ha venido señalando, puede vincularse con la inserción cada vez más significativa de mujeres en los claustros universitarios y en los institutos dedicados a la formación docente. Resulta destacable la inclusión de jóvenes como participantes en la publicación, junto con nombres de consolidada trayectoria, lo cual manifiesta la voluntad de concretar los fines propuestos desde la creación del Instituto, concebido como ámbito de formación en el "trabajo intelectual" destinado a "estudiantes distinguidos" ( $\mathrm{N}^{\circ} 1$ : VII).

Si bien el BIIL tuvo una existencia relativamente breve y escasos números publicados, frente a otras publicaciones académicas similares, puede observarse, por un lado, el énfasis puesto desde el inicio en la investigación como disciplina intelectual, y por el otro, el espacio otorgado a los jóvenes estudiantes para que ejercitaran los primeros pasos en la vida académica junto a profesores prestigiosos. Este tipo de experiencias contribuyó a aquilatar y a fortalecer la investigación $-\mathrm{y}$ con ella la necesaria difusión de los saberes- como uno de los principios de la formación intelectual, en particular en el caso de las Humanidades. En ese contexto, la literatura española constituyó un ámbito particularmente fecundo para las investigaciones promovidas desde el Instituto de Investigaciones Literarias.

Para cerrar este recorrido por las publicaciones que, desde la Facultad de Humanidades y Ciencias de la Educación de la UNLP, hicieron aportes a los estudios de la literatura la cultura españolas, es necesario mencionar los volúmenes de la serie “Trabajos, comunicaciones y conferencias", editados por el Departamento de Letras de la Facultad. Estos textos, de índole monográfica, reúnen contribuciones referidas a un 
tema o a un autor. En el caso de los autores abordados, la selección tiene que ver con los aniversarios de sus nacimientos o muertes, ocasión que sirve para sacar a la luz un conjunto de trabajos de profesores y estudiantes avanzados referidos a dicho autor. Esta serie se publicó entre 1961 y 1977 y consta de diecinueve números. Entre ellos hay cuatro dedicados a autores españoles, publicados como homenajes en ocasión de celebrarse algunos de los centenarios: el $N^{\circ} 4$ (1963) a Lope de Vega, el Nº 5 (1965), a Fray Benito Jerónimo de Feijoó, el № 9 (1967), a Ramón del Valle Inclán y el ํo 12 (1971) a Gustavo Adolfo Bécquer, este último editado por el Instituto de Literaturas Neo-latinas ${ }^{208}$. Los trabajos allí recopilados abordan diferentes aspectos de la vida y la obra de los escritores y representan aportes genuinos del trabajo intelectual de los integrantes del Departamento de Letras, al tiempo que refuerzan la conformación de un canon hispánico, a partir de las figuras seleccionadas. Estos volúmenes monográficos incluyen artículos de investigadores de renombre, como Ángel Battistessa, Raúl Castagnino, Juan Carlos Ghiano, Arturo Berenguer Carisomo o Julio Caillet-Bois, con una destacada trayectoria en los estudios de crítica literaria dentro y fuera de los claustros universitarios.

A través de sus publicaciones, la Facultad de Humanidades y Ciencias de la Educación de la Universidad de La Plata continuará con la impronta de los estudios hispánicos en la Argentina, ya iniciada en Buenos Aires y cimentada en la obra de destacada figuras, y sentará en esa ciudad las bases de una tradición crítica de prestigio y solidez que trascenderá sus límites para alcanzar dimensión nacional e internacional.

\footnotetext{
${ }^{208}$ Los volúmenes de la serie presentan características de formato y tamaño similares, lo que les otorga uniformidad, al igual que los títulos, que responden a estructuras análogas. Los cuatro volúmenes aludidos son: Lope de Vega: Estudios reunidos en conmemoración del IV centenario de su nacimiento, que incluye catorce trabajos, Fray Jerónimo de Feijoo y Montenegro: Estudios reunidos en conmemoración del II centenario de su muerte (1764-1964), con veintiún trabajos, Ramón M. del ValleInclán: Estudios reunidos en conmemoración del centenario (1866-1966), que agrupa veintinueve notas y Gustavo Adolfo Bécquer: Estudios reunidos en conmemoración del centenario (1860-1970), con doce contribuciones.
} 


\subsubsection{La Facultad de Filosofía y Letras de la Universidad Nacional de Tucumán y}

\section{la revista Humanitas.}

La Universidad de Tucumán fue creada en 1914 y se constituyó en la cuarta universidad establecida en el territorio argentino. Su fundación amplió el panorama universitario en el país y se ofreció como una alternativa a la influencia de la tradicional Universidad Nacional de Córdoba y como una institución enraizada en la región y sus características. Fue nacionalizada en 1921, en pleno periodo de transformaciones derivadas de la Reforma Universitaria, y en los primeros años solo contó con dos Facultades: Ingeniería y Farmacia e Higiene, dos institutos científicos, un museo y una biblioteca (Vanella 2014:10). En la década de 1930 se expande la oferta de esta casa de estudios y para finales de esa década se habían creado la Facultad de Derecho y la de Filosofía y Letras (1939). Esta última tuvo sus antecedentes en el Departamento de Filosofía y Letras y con su creación se inauguran los estudios humanísticos en la Universidad Nacional de Tucumán. En este proceso se destaca la presencia de profesores extranjeros que llegaron a la Argentina en los años 30, algunos de ellos por razones políticas, y se establecieron en la Universidad, donde desarrollaron su tarea y de este modo fueron consolidando el perfil humanístico. Una de las figuras clave en esta etapa fue la del filósofo español Manuel García Morente, quien llegó a Tucumán en 1937 y fomentó la creación del Departamento de Filosofía, germen de la futura Facultad ${ }^{209}$. También llegó de España, convocado por la Universidad, el lingüista español Clemente Hernando Balmori, quien se dedicó al estudio de las lenguas indígenas, ámbito en el que realizó importantes investigaciones $^{210}$. De Italia arribó el filólogo y lingüista Benvenuto Terracini, quien

\footnotetext{
${ }^{209}$ Uno de los primeros directores del Departamento de Filosofía de la Universidad de Tucumán fue Risieri Frondizi, quien luego sería rector de la UBA. También se destacaron entre sus integrantes el pedagogo Lorenzo Luzuriaga y el filósofo italiano Rodolfo Mondolfo.

${ }^{210}$ Clemente Hernando Balmori llegó a la Argentina a comienzos de la década de 1940 y se instaló en Tucumán, donde desarrolló sus investigaciones, en especial sobre temas lingüísticos, dada su formación
} 
permaneció en la Universidad Nacional de Tucumán entre 1941 y 1946. La impronta de estos profesores estuvo marcada por la revalorización de la formación humanística y caracterizó la vida académica de la Universidad entre los años 30 y 40 (Vanella 2014).

Los estudios sobre literatura española tuvieron su representación en esta universidad en la figura del profesor Emilio Carilla. Doctorado en la Universidad de Buenos Aires bajo la tutela de Pedro Henríquez Ureña en 1942, se instala en los claustros tucumanos en 1947 y desarrolla allí su labor docente y de investigación, en particular sobre temas de literatura argentina y española. Desde allí mantiene vínculos con otros centros de investigación; en 1949 es convocado por Alonso Zamora Vicente, director del Instituto de Filología Hispánica de la UBA para participar con un artículo en la revista Filología iniciada ese año ${ }^{211}$.

Una de sus primeras publicaciones en la Universidad Nacional de Tucumán es el libro Quevedo (entre dos centenarios) que edita en 1949 y que se convierte en referencia obligada de los estudios sobre el escritor español ${ }^{212}$. En los años siguientes

\footnotetext{
filológica obtenida en España, donde fue becario de la JAE en las décadas de 1920 y 1930. Su trayectoria luego lo llevó a la Universidad Nacional de La Plata, donde dirigió el Instituto de Filología en 1955 (Cf. Capítulo 1) y también fue investigador del Conicet y docente en la Universidad de Buenos Aires en la década de 1960. Estos profesores llegaron a la Argentina debido a razones políticas que los obligaron a dejar sus países de origen (García Morente y Balmori lo hicieron a causa de la Guerra Civil española y Terracini fue exonerado de la Universidad en Italia por ser judío y comunista). (Cf. Nota n $\left.{ }^{\circ} 122\right)$.

${ }^{211}$ En el volumen correspondiente al Año 1, 2 (1949) de Filología aparece su artículo "El verso esdrújulo en América". En números posteriores aparecerán otras colaboraciones, lo cual evidencia las relaciones que Carilla seguía manteniendo con otros centros académicos. Asimismo, en 1946 había publicado en la Facultad de Filosofía y Letras de la Universidad de Buenos Aires El gongorismo en América y en 1949 saldrá a la luz un volumen dedicado a la figura de Pedro Henríquez Ureña, su mentor: Pedro Henríquez Ureña y otros estudios.

${ }^{212}$ Los ecos de la publicación de este estudio de Carilla pueden registrarse en la reseña que apareció en el Bulletin Hispanique (Vol. 51, $\mathrm{N}^{\circ}$ 51-1, 1949), el mismo año de su edición. Más relevante aún es el comentario elogioso de Dámaso Alonso en su obra Poesía española. Ensayo de métodos y límites estilísticos, donde afirma: "El libro de este joven profesor argentino es el mejor, de conjunto, que existe actualmente sobre nuestro autor." (1950: 534).
} 
continuará con sus publicaciones universitarias, en la serie Cuadernos de Humanitas, en la que aparecerán textos dedicados a los estudios de literatura argentina y española ${ }^{213}$.

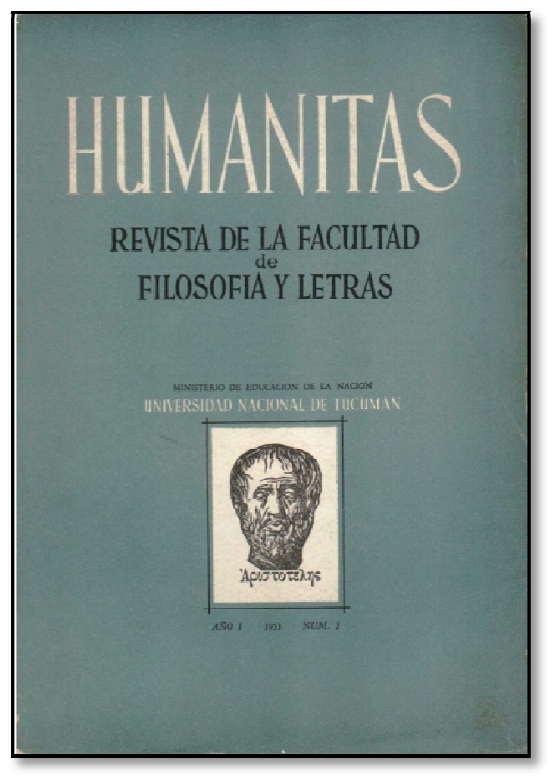

Esta colección forma parte del proyecto de publicaciones de la Facultad de Filosofía y Letras, entre las cuales se destaca la revista Humanitas, cuyo primer número apareció en 1953 y su fundador y primer director fue el filósofo Diego Pró. Si bien comparte los rasgos característicos de formato $\mathrm{y}$ estilo de revistas similares, llama la atención su volumen: el $\mathrm{N}^{\circ} 1$ está compuesto por 439 páginas, lo que la acerca más a un libro a que a una publicación periódica. Esta extensión permite la división interna en apartados o secciones diferenciados, que se mantendrá al menos hasta el $\mathrm{N}^{\circ} 6$ correspondiente a 1955.

El diseño de la tapa, sobrio y despejado, ofrece una imagen del filósofo Aristóteles, lo cual indica la filiación filosófica y humanística propuesta para la revista. Este carácter se retoma en la "Presentación" a cargo del director, Diego F. Pró; allí se hace mención explícita a las "disciplinas humanísticas" (Filosofía y Letras) "que establecen la capacidad estética y son vehículo de cultura y espiritualidad entre los pueblos" (11) e Historia. Se expresa luego: "la formación humanística universal no se logra ni tiene sentido si no se asienta y se nutre en el ambiente histórico, social y moral

\footnotetext{
${ }^{213}$ Cuadernos de Humanitas es una serie de textos destinados a divulgar aspectos y temas vinculados con las carreras de la Facultad de Filosofía y Letras de la Universidad Nacional de Tucumán. El ํㅜ 1, de 1954, corresponde a un trabajo de Emilio Carilla titulado Literatura argentina (1800-1950). Esquema generacional. Los números 6 (1961), 18 (1965), 25 (1968) y 29 (1968) también corresponden a estudios de Carilla sobre literatura argentina. En esa misma colección publicó sus Estudios de literatura española (Momentos, géneros, obras), en los números 36 (1971) y 40 (1972).
} 
de la Nación" (11). Aparece también en estas palabras iniciales una referencia concreta al contexto político-social del país: el Segundo Plan Quinquenal ${ }^{214}$.

Como ocurrió con otras universidades, la de Tucumán no estuvo al margen de los avatares políticos del país y sus efectos en los centros académicos; en 1946 sufrió la intervención del gobierno nacional, situación que se mantuvo hasta mediados de la década de 1950. En el primer número de Humanitas pueden observarse datos que remiten a dicha situación: en las "Palabras rectorales", a cargo del interventor Carlos F. Aguilar, se hace explícita referencia al gobierno nacional y en la sección "Noticias de la Facultad" se menciona la nueva organización de los Institutos, formalizada luego de la intervención. Entre ellos figura el de Letras, dirigido entonces por Emilio Carilla, que cuenta con tres secciones: Lengua y Literatura Española (bajo la dirección de María Delia Paladini), Lengua y Literatura Clásicas, y Literatura Argentina y Americana. Esta forma de organización es análoga a la que ya se estaba produciendo en otras universidades nacionales y se vincula con la institucionalización de la investigación en el ámbito académico y la parcelización y el mayor afán de especificidad de los estudios.

En sus comienzos, Humanitas se presenta como cuatrimestral, periodicidad habitual en publicaciones similares ${ }^{215}$, de allí que resulte llamativo la extensión de los volúmenes: todos superan las cuatrocientas páginas, lo que los acerca más al formato de libro. Esta extensión permite la subdivisión en secciones diferenciadas con títulos. Así, en el primer número, de 1953, aparecen mencionadas en el interior de la tapa nueve secciones, además de las "Palabras rectorales" y la "Presentación" (a cargo de la Dirección de la revista): "Artículos", "Notas y comentarios", "Textos", "Figuras del

\footnotetext{
${ }^{214}$ Los Planes Quinquenales fueron programas de gobierno implementados durante el gobierno de Juan Domingo Perón. El primero fue aprobado en 1947 y comprendía el balance y las acciones de gobierno proyectadas para el periodo 1947-1951 y el Segundo, aprobado en 1952, incluía los objetivos y acciones previstas para el siguiente quinquenio. La caída del gobierno en septiembre de 1955 dejó trunco este Plan.

${ }^{215}$ Ver Filología, Humanidades.
} 
pensamiento americano", "Bibliografía", "Revista de revistas", "Noticias", "Libros" y "Nuestros colaboradores", una forma de organización frecuente en las revistas académicas. En este caso particular, se destaca la sección "Figuras del pensamiento americano", ya que es un espacio destinado a recuperar nombres relacionados con la vida intelectual del continente ${ }^{216}$. En este primer número se abordan las semblanzas de Coriolano Alberini y de Alfonso Reyes, dos nombres vinculados con los estudios humanísticos $^{217}$. Si bien la literatura, y en particular la española, no tiene especial presencia en este número, sí aparece referida en las reseñas de la sección "Bibliografías", donde se abordan textos de Dámaso Alonso y Ramón Menéndez Pidal. El perfil de los colaboradores de la revista exhibe nombres de intelectuales extranjeros radicados en la Argentina y otros formados en las universidades nacionales que pertenecen a diferentes disciplinas humanísticas.

\footnotetext{
${ }^{216}$ En una entrevista realizada en 1994 , Diego Pró, fundador y primer director de la revista, expresaba la emergencia en el campo académico argentino de los estudios vinculados con el denominado "Pensamiento nacional", corriente que se materializó en la creación de cátedras en las universidades: "En julio de 1944, al asumir la Dirección Interna del Instituto de Filosofía de la Facultad de Filosofía y Letras de Cuyo, en su organización por secciones de estudios, en la filosofía práctica, no sólo preví los estudios del pensamiento y la cultura argentinos, sino que, con otros colegas, le dimos existencia real [...] Este rumbo de estudios lo prolongué durante mi actuación en la Facultad de Filosofía y Letras de Tucumán (1948-1955). Allí, en la revista Humanitas, por mí fundada, había una parte de la misma, dedicada al pensamiento y la cultura argentinos [...] Esta dirección de mis estudios, se vio afianzada en una reunión de decanos de la Facultad de Filosofia y Letras y de Humanidades, realizada en la Universidad de Córdoba en octubre de 1953. En ese encuentro, del que recuerdo la presencia del Profesor Rodolfo Agoglia, se estudiaron los planes de estudio de aquellas facultades y se resolvió aconsejar la introducción de una nueva asignatura: "Historia del Pensamiento y la Cultura Argentinos" (2000: 16). Esto pone de manifiesto la difusión de un campo específico destinado a revisar la cultura nacional, de la cual Humanitas resultaría uno de los órganos.

${ }^{217}$ Coriolano Alberini (1887-1960) fue un filósofo y profesor de las Universidades de Buenos Aires y La Plata. Además ejerció cargos de gestión (fue decano de la Facultad de Filosofía y Letras de la UBA en tres oportunidades: entre 1924 y 1928, 1931 y 1932 y 1936-1940; consejero superior y vicedecano durante la primera gestión de Ricardo Rojas en la Facultad). En el ejercicio de esos cargos tuvo una importante injerencia en la creación del Instituto de Filología de la Universidad de Bueno Aires y fue uno de los impulsores de las relaciones de la universidad con otros centros académicos del mundo. Asimismo, como filósofo tuvo una destacada trayectoria, de allí la relevancia que tuvo su figura para la revista Humanitas, de nítida impronta filosófica.

Por su parte, la figura de Alfonso Reyes estuvo muy vinculada con los círculos intelectuales de la Argentina durante su estadía como embajador de México en la década de 1930 (Cf. Nota ${ }^{\circ}{ }^{124}$ ) y luego continuó ligado a través de Amado Alonso cuando éste se estableció en los Estados Unidos y con los hermanos Lida, quienes también se afincaron en el país del norte (Cf. Capítulo 1). Sus trabajos literarios y ensayísticos se inscribieron en una corriente humanística de corte universalista.
} 
En los cinco números siguientes $\left(\mathrm{N}^{\circ} 2,1953, \mathrm{~N}^{\circ} 3,4\right.$ y 5,1954 y $\left.\mathrm{N}^{\circ} 6,1955\right)$ se mantienen los rasgos externos e internos de la revista. En ellos la presencia de textos sobre literatura es escasa, en relación con la filosofía o el pensamiento, pero sí se advierte la actividad de los Institutos, en especial el de Letras, donde se mencionan las contribuciones de Emilio Carilla en publicaciones nacionales y extranjeras, varias de ellas dedicadas a la literatura española, lo cual expresa la orientación de sus estudios y su divulgación dentro y fuera del país.

El $\mathrm{N}^{\circ} 7$ aparece en 1956 y presenta sustanciales modificaciones en formato y estructura: se reduce a la mitad la cantidad de páginas (214), desaparecen secciones (entre ellas "Figuras del pensamiento americano"), tiene nuevo director, el filósofo Arturo García Astrada, a la vez que se declara un cambio en la periodicidad de publicación. Estas transformaciones pueden ponerse en relación con los cambios políticos ocurridos a fines de 1955, que repercutieron en las universidades nacionales luego de la caída del gobierno peronista. En los números siguientes, se mantiene el predominio de los trabajos sobre filosofía y la literatura tiene su lugar entre las reseñas y las referencias bibliográficas. Entre ellas, la pluma de Emilio Carilla se destaca como reseñador de obras literarias, en especial de literatura americana y española ${ }^{218}$ y también hay alusiones a textos del autor publicados en el ámbito nacional, lo cual evidencia la centralidad de su figura en el desarrollo y difusión de estudios sobre literatura, en especial la española en el ámbito de la Universidad Nacional de Tucumán, donde ejerció la docencia y la investigación durante varios años, hasta 1966. Su carrera académica

\footnotetext{
${ }^{218}$ En el N ${ }^{\circ} 7$ de 1956, la sección "Bibliografia" está dividida por materias; en el caso de Letras, las tres reseñas son de Emilio Carilla y refieren a literatura latinoamericana, en el $\mathrm{N}^{\circ} 8$ de 1957 escribe una reseña sobre Ricardo Güiraldes, en el $\mathrm{N}^{\circ} 9$ de ese mismo año, reseña una obra sobre Alfonso Reyes, en el $\mathrm{N}^{\circ} 10$ de 1958 aparece una reseña sobre un libro de Menéndez Pelayo y en el $\mathrm{N}^{\circ} 11$, de 1959, otra referida a la obra del jesuita colombiano Hernando Domínguez Camargo acerca de San Ignacio de Loyola.
} 
continuó en el extranjero ${ }^{219}$ y en 1969 fue designado como académico correspondiente de la Academia Argentina de Letras, desde donde continuó realizando aportes en las áreas de su investigación.

El itinerario presentado revela el cuño humanista que signó la creación y desenvolvimiento de la Facultad de Filosofía y Letras de la Universidad Nacional de Tucumán a través de sus publicaciones y la impronta de sus profesores e investigadores. Entre ellos, en el ámbito de la literatura, especialmente la española y argentina, se destaca la figura de Emilio Carilla, quien, forjado en la Facultad de Filosofía y Letras de la Universidad de Buenos Aires, desplegó su actividad docente, crítica y de investigación en el centro de estudios tucumano y logró asentar las bases para proyectar al hispanismo a nivel nacional e internacional.

\subsubsection{El Instituto de Humanidades de la Universidad Nacional del Sur y la revista}

\section{Cuadernos del Sur}

El Instituto de Humanidades fue creado en 1956, año en que se fundó la Universidad Nacional del Sur, con sede en la ciudad de Bahía Blanca, y responde a la estructuración en Departamentos e Institutos en que se organizó dicha universidad, según el diseño de corte modernizador formulado que favorecía otras formas de organización institucional para las casas de altos estudios, entre ellas la departamentalización. Este sistema es una alternativa a la tradicional estructura de facultades, según el modelo europeo, y tiene su antecedente en el modelo académico norteamericano. Según expresa Buchbinder, "El objetivo era unir, por medio de éstos [los departamentos], a las mismas especialidades dentro de cada Universidad o Facultad, y articular en ellos, en forma estrecha, a la

\footnotetext{
${ }^{219}$ Luego de su partida del país, fue profesor en la Universidad Riverside, de California, en la Universidad de Colonia, Alemania y en la Universidad Pedro Henríquez Ureña de Santo Domingo.
} 
docencia con la investigación" (2005: 182). En el año 1958, dos años después de la creación del Instituto de Humanidades de la Universidad Nacional del Sur, se publican los primeros cuatro números de la revista Cuadernos del Sur.

Tanto en la creación del Instituto como en la gestación de la revista se destaca la figura del profesor Héctor Ciocchini, primer director del Instituto e impulsor, junto con otros intelectuales nucleados en él, del perfil humanístico e integral de los estudios. Formado en la Universidad Nacional de La Plata, bajo el magisterio de profesores renombrados de esa universidad como Arturo Marasso ${ }^{220}$ o Ezequiel Martínez Estrada, Ciocchini acompañará la creación de la Universidad Nacional del Sur y dedicará gran parte de su trayectoria académica a los estudios literarios, en particular de la literatura española del Siglo de Oro. La impronta humanista de los estudios realizados en La Plata, sumada a sus experiencias en el Warburg Institute de Londres, caracterizarán los perfiles y líneas de trabajo del Instituto bajo su dirección ${ }^{221}$. Asimismo, este recorrido vital e intelectual de Ciocchini permite pensar en el modo en que las filiaciones institucionales y personales participan en la conformación de redes o constelaciones intelectuales a lo largo de los centros universitarios en la Argentina, que resulta un dato relevante en el caso de la conformación del hispanismo a nivel nacional.

\footnotetext{
${ }^{220}$ La relación particular entre maestro y discípulo que entablaron Arturo Marasso y Ciocchini anima el libro que este último le dedicó a la figura de Marasso en 1967. Allí, en las palabras con que abre el texto, declara: "¿Qué decir de quien nos enseñó la admiración y el entusiasmo? [...] Es difícil decir algo de aquellos seres por los que sentimos veneración y a los que quisiéramos parecernos" (7). Convergen en esta declaración las ideas acerca de la imagen magistral y sus implicancias en la formación de los discípulos que caracteriza a varias figuras del hispanismo argentino.

${ }^{221}$ Como señala María de las Nieves Agesta en su exhaustiva reseña acerca de la creación del Instituto de Humanidades, en la génesis del centro puede advertirse la matriz ideológica del Warburg Institute, en el que Héctor Ciocchini había estado como investigador visitante. Los lineamientos que dieron origen al Instituto bahiense pueden ubicarse en las corrientes teóricas y metodológicas postuladas por el centro británico, aunque con un componente regional y local que le dio su particular impronta (2008: 158 y ss.). Por su parte, José E. Burucúa (2002) destaca la filiación entre los temas de investigación del Instituto de Humanidades y los principales ejes del pensamiento warbuguiano: las interrelaciones entre magia, religión y la pervivencia de la cultura clásica en la estética y la filosofía modernas. Estas matrices de pensamiento ya estaban presentes en las indagaciones de Marasso, Fatone y Martínez Estrada, a quienes Ciocchini reconoce como "maestros" (103-107).
} 
La articulación entre docencia e investigación que propiciaba el sistema departamental propuesto para la organización de la Universidad Nacional del Sur y la creación de institutos como centros en los cuales llevar adelante ese vínculo está presente en las publicaciones, y Cuadernos del Sur evidencia el énfasis puesto en el ensayo y la reflexión. Los primeros números de la publicación no exhiben aún los

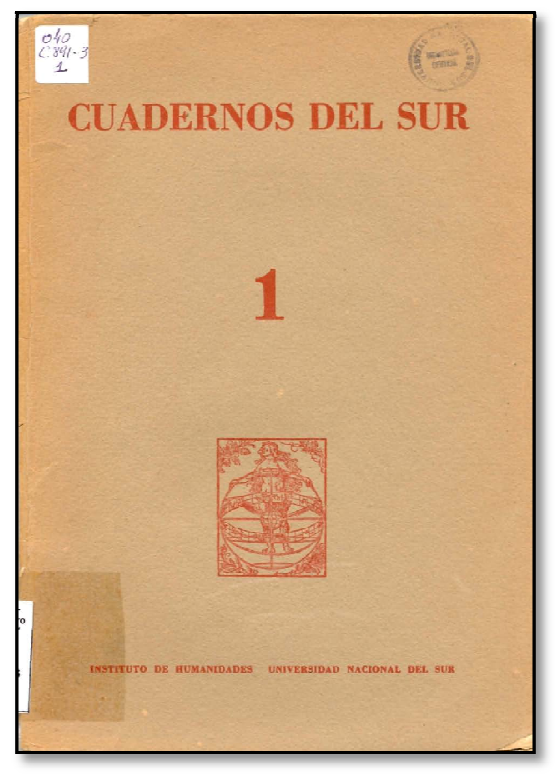

rasgos de una revista académica, en términos del formato que ya detentaban otras similares, tanto en el ámbito nacional como internacional: estos primeros volúmenes, editados entre mayo y junio de 1958, sólo contienen un artículo y se asemejan a una separata más que a una revista. Se trata de trabajos monográficos sobre un tema en particular, práctica que continuará en los años siguientes y que se agrupan bajo la denominación "Serie Cuadernos del Sur-Monografías”. Estas colaboraciones originales pertenecen a investigadores vinculados con el Instituto de Humanidades y abarcan temas de un amplio espectro relacionado con esas disciplinas ${ }^{222}$. En el mismo año de 1958, se editan dos Suplementos: el primero, aparecido en junio, se titula "Palabra y responsabilidad" e incluye cinco trabajos de autores extranjeros, a excepción del último, firmado por Arturo Marasso. En agosto de ese año se publica el segundo suplemento, bajo cuyo título, "Actualidad de los clásicos" se reúnen siete trabajos que abordan los estudios

\footnotetext{
${ }^{222}$ Los ensayos que componen estos primeros números son: "Misión del intelectual en la democracia argentina", de Hernán Zucchi ( $\mathrm{N}^{\circ} 1-$ mayo 1958), "El Escorial en el Barroco", de Dolly María Lucero Ontiveros ( $\mathrm{N}^{\circ} 2$ - mayo 1958), "Prestigio de la palabra" de Héctor Ciocchini ( $\mathrm{N}^{\circ} 3$ - mayo 1958) y "El mito de Narciso en la poesía de Lorca" ( $\mathrm{N}^{\circ}$ 4- junio de 1958) de Irma Cuña. Si bien a primera vista pueden percibirse como disímiles, los temas abordados están atravesados por una perspectiva humanista (Agesta 2008). Asimismo, la selecta de ensayos agrupados en los Suplementos 1 y 2, publicados ese mismo año, evidencian la preocupación por presentar temas vinculados con esa perspectiva: "Palabra y responsabilidad” ( $\left.\mathrm{N}^{\circ} 1\right)$ y “Acerca de los clásicos” $\left(\mathrm{N}^{\circ} 2\right)$.
} 
clásicos y pertenecen a intelectuales europeos, en particular franceses. A diferencia de los trabajos monográficos, que se editan sin paratextos, los suplementos incluyen unas palabras preliminares que presentan los escritos reunidos. A pesar de no estar firmados, en estos textos iniciales se expresan las ideas que sustentan las líneas de trabajo del Instituto: el lenguaje y su valor comunicativo y la reivindicación del estudio de la cultura clásica $^{223}$.

Junto con los temas y enfoque, otro elemento que se destaca en la presentación de las publicaciones es la iconografía que las acompaña. En la cubierta de los suplementos $\mathrm{n}^{\circ} 1$ y 2 aparece la reproducción de un grabado de Albert Durero del siglo XVI que representa la esfera armilar rodeada por los doce vientos ${ }^{224}$. La simbología de esta imagen apunta a resaltar, por un lado, las raíces clásicas y renacentistas de los estudios, y por otro, el carácter de unicidad e interdisciplinariedad a la que estos aspiraban. Los siguientes números de Cuadernos del Sur también presentaban imágenes provenientes de la iconografía renacentista y de alto contenido simbólico ${ }^{225}$, lo cual manifiesta la centralidad que las indagaciones acerca de las dimensiones humanísticas ocupaban en las líneas de trabajo propuestas desde el Instituto y su filiación con la tradición humanística del Renacimiento.

\footnotetext{
${ }^{223}$ En el texto que abre el primer suplemento se afirma: "Quizás es una aspiración de la moderna lingüística mostrar al hombre que su lenguaje lo revela en su integridad" (Suplemento $\mathrm{N}^{\circ} 1$, junio 1958, $\mathrm{s} / \mathrm{p}$ ), y en la presentación del segundo suplemento se subraya la carencia de formación clásica en el sistema educativo argentino: "Los otros fragmentos son dedicados a los estudiantes argentinos que quizá no ven claramente el valor formativo de las disciplinas clásicas. Son una nobilísima incitación a su estudio y marcan un camino que nuestro país no ha seguido y quizá ni siquiera comenzado" (Suplemento $\mathrm{N}^{\circ} 2$, agosto $1958, \mathrm{~s} / \mathrm{p}$ ).

${ }^{224}$ El grabado de Alberto Durero aparece en la edición de 1525 de Claudii Ptoelmaei Geographicae enarrationis libri octo, cuya edición digital se encuentra disponible en la Biblioteca Digital Hispánica [http://bdh.bne.es/bnesearch/detalle/bdh0000089080] (Consultada 20 de enero de 2015).

${ }^{225}$ En la portada de la revista aparecía la reproducción de otro grabado de Durero "El Alma del Mundo" [ca. 1498], de claras reminiscencias platónicas, y en la contratapa figuraba la imagen del dios del viento cálido del hemisferio norte, Noto (o Austro en la mitología romana). Un completo análisis de las connotaciones simbólicas de estas imágenes y su relación con el ideario del Instituto puede verse en Agesta 2008.
} 
Luego de una interrupción de casi ocho años ${ }^{226}$, en 1966 reaparece Cuadernos del Sur, con notables cambios en la estructura. Si bien en los aspectos externos conserva el diseño de la tapa y retoma la correlatividad de los números —el de ese año lleva el $\mathrm{N}^{\circ} 5$-, la organización interna expresa la voluntad de asimilarse al formato de las revistas académicas de la época: presenta una división en secciones diferenciadas, se mencionan los integrantes del Comité de Redacción y el sumario reúne el listado de trabajos publicados. Este cambio rotundo de imagen refleja a su vez una redefinición de los alcances y el perfil de la revista. Así, en la Memoria 1956-1969 del Instituto de Humanidades, se refiere a este cambio de situación: "Los Cuadernos del Sur se han venido editando en forma discontinua, asumiendo, a partir de 1966, el carácter de "Publicaciones estables" por Resolución X350/66 de la Universidad Nacional del Sur. La periodicidad y estabilidad de las mismas había sido solicitada para lograr la concreción de un plan ordenado y responsable" (25).

En forma paralela a este ordenamiento hacia el interior, se llevan a cabo acciones que apuntan a ubicar a la revista en el concierto de las publicaciones académicas del ámbito de las Humanidades. En octubre de 1966, Héctor Ciocchini, miembro del Comité de Redacción y virtual director de la revista, envía cartas a intelectuales del país y del exterior para solicitarles su incorporación como miembros del Comité Honorario de Cuadernos. Según se desprende del texto de las Memorias del Instituto, la convocatoria pretendía "lograr la constitución de un cuerpo de personalidades relevantes de nuestro país y eventualmente del extranjero que podrían darnos su colaboración, su apoyo moral e intelectual como así también hacernos llegar sus colaboraciones

\footnotetext{
${ }^{226}$ Como ya se hiciera referencia, la falta de periodicidad en la aparición de los números es una constante en la vida de las publicaciones académicas en nuestro país, ya que depende de las fluctuaciones políticas, académicas y económicas de las instituciones. Asimismo, el año de 1966 es clave en la historia argentina reciente, ya que en junio de ese año se produjo la denominada "Revolución Argentina" que derrocó al presidente constitucional Arturo U. Illia y designó como presidente de facto al general Juan Carlos Onganía. Los efectos nefastos de este régimen en el ámbito universitario se materializaron en la expulsión de docentes e investigadores, la intervención de la actividad estudiantil y la censura sobre contenidos y temas de enseñanza e investigación.
} 
personales y de estudiosos que quieran sumar a nuestra obra su tarea intelectual" (26). Queda así manifestada, por un lado, la voluntad de incluir un listado de nombres de relevancia en el ámbito de las Humanidades como modo de legitimación, y por otro, la ratificación del prestigio que ya la publicación había logrado y que se expresa en la positiva respuesta de los convocados ${ }^{227}$. Los nombres de estos intelectuales convocados por Ciocchini, y que responden afirmativamente a la convocatoria, permiten dar cuenta del sesgo "humanista" que se pretendía otorgar a la nueva etapa de la revista, más allá de los matices ideológicos y de las procedencias institucionales y las trayectorias de cada uno: Ana María Barrenechea, Ángel Battistessa, Jorge Bogliano, Marcelo Bórmida, Julio Caillet Bois, Ángel Rosenblat, Abraham Rosenvasser y Juan A. Vázquez conformarán el Comité Honorario de la revista ${ }^{228}$. Entre ellos se encuentran referentes de diversas disciplinas humanísticas: Barrenechea, Battistessa, Bogliano, Caillet Bois y Rosenblat provienen de la lingüística y la literatura, Rossenvaser de la historia, Bórmida de la antropología y Vázquez de la filosofía.

Además de la conformación del nuevo Comité Honorario, otro de los aspectos que se reformula a partir de 1966 es la división interna de la revista en secciones diferenciadas: "Estudios", "Panoramas", "Reseñas", "Textos y documentos", "Noticias" y "Publicaciones recibidas", lo cual expresa el afán por asimilarse a los formatos ya consagrados en el ámbito académico (Memoria 1956-1969: 25). A pesar de los cambios introducidos, persiste el espíritu integrador que animaba al Instituto como "centro de síntesis" (Memoria: 25), y que se había plasmado en el Reglamento del Instituto

\footnotetext{
${ }^{227}$ Una revisión de los textos de las cartas de respuesta de los intelectuales mencionados — conservadas en la Biblioteca de Humanidades de la UNS - pone en evidencia los vínculos entre personalidades e instituciones del mundo académico argentino a la vez que refuerza la idea de las redes intelectuales que se fueron conformando.

228 Tanto Rosenblat como Vázquez se desempeñaban para esas fechas en universidades extranjeras: Rosenblat en la Universidad Central de Venezuela y Vázquez en la Universidad de Pittsburgh. El resto de investigadores pertenecía a las universidades de Buenos Aires o de La Plata, lo cual también expresa la referencialidad que ambos centros académicos revestían.
} 
aprobado en 1963, donde se postula que dicho centro "agrupe en su seno las distintas ramas de las humanidades contemporáneas heredadas de la tradición clásica que se amplía y desarrolla en el humanismo científico y que advierte los puntos de analogía y de convergencia" (1).

Comienza así una nueva etapa para la revista Cuadernos del Sur, proyectada hacia otros ámbitos nacionales e internacionales y con una clara intencionalidad de ocupar un lugar entre las publicaciones dedicadas a los estudios humanísticos, y entre ellos, los dedicados a la literatura. Además de la reorganización interna de la revista a fin de adecuarla a los estándares vigentes de este tipo de publicaciones, de la conformación de un Comité Honorario con personalidades de prestigio académico, Cuadernos del Sur inició, a partir de esta segunda etapa de su vida institucional, la distribución en centros de investigación y el canje con otras publicaciones nacionales e internacionales. En la Memoria se citan las principales reseñas dedicadas a la revista en numerosas publicaciones, y se destaca, como nota relevante, la carta que Ramón Menéndez Pidal dirigió a la revista, fechada en abril de 1964, donde agradece el envío de "los variados trabajos publicados en Cuadernos del Sur"229.

Una revisión del índice del número 5 (1966) muestra los temas de interés de los investigadores y el lugar relevante que ocupa la literatura. La sección "Estudios" presenta seis trabajos, todos vinculados con la literatura, mientras que la sección "Panoramas" agrupa también seis colaboraciones sobre disciplinas diversas: la literatura, la arquitectura, la lingüística y el simbolismo. En los números siguientes la cantidad de trabajos es variada; un rasgo significativo es que comienzan a aparecer estudios sobre Hispanoamérica y Argentina, que no estaban presentes en los primeros

\footnotetext{
${ }^{229}$ La carta de Menéndez Pidal, así como las de varios de los miembros del Comité Honorario, se encuentran conservadas en el archivo de la Biblioteca de Humanidades de la UNS. Resulta significativo que en la Memoria se mencione especialmente esta misiva, lo cual pone de manifiesto la importancia de la figura del filólogo español y su prestigio vigente en el ámbito argentino durante más de cuarenta años.
} 
números, vinculados a aspectos más amplios de las humanidades de épocas distintas. Esta tendencia se consolida en el volumen que corresponde a los números 8-9 (1968), en cuya sección "Estudios" y "Panoramas" figuran seis estudios vinculados con la historia, la lengua y la literatura argentinas. En el número 10 (1969) se mantiene estable la cantidad de artículos en la sección "Estudios" y "Panoramas" — diez y seis respectivamente - y la preponderancia de temas literarios por sobre otras disciplinas. En este volumen, la literatura española tiene una mayor presencia, en especial en artículos referidos a autores y obras contemporáneos. Es posible observar que el afán inicial y proclamado de mantener una visión integral y multidisciplinaria se va diluyendo en pos de una mayor especialización de los trabajos y por ende una mayor dispersión temática y de enfoques.

El número 11 de la revista (1971) marca un cambio significativo en el aspecto material como en el contenido, ya que se trata de un volumen en homenaje al profesor Arturo Marasso, fallecido en 1970, quien había sido una figura relevante para la institución y miembro de su Comité Honorario ${ }^{230}$. El volumen es de mayor extensión que los anteriores (466 páginas) y difiere en el aspecto externo: la tapa es a dos colores (lacre y blanco) y se incorpora en la parte inferior de la tapa la referencia a la ciudad y el país ("Bahía Blanca-Rep. Argentina”). Se inicia con una semblanza del investigador fallecido, a cargo de Luis Alberto Sánchez, de la Universidad de San Marcos (Lima) para incluir al final cuatro trabajos sobre aspectos de la obra de Marasso.

A diferencia de los otros números analizados, este volumen 11 está compuesto por 32 artículos (no se señala la división en secciones "Estudios", "Panoramas" “Reseñas”). En ellos predominan claramente los destinados a los estudios literarios, entre los cuales se observa una preeminencia de la literatura española (en clara

\footnotetext{
${ }^{230}$ En el año de su fundación (1956), la Universidad de Sur había adquirido la biblioteca personal de Marasso, punto de partida para la creación de la Biblioteca de Humanidades de dicha universidad, que hoy lleva el nombre del destacado profesor y escritor riojano (Agesta 2008: 160).
} 
diferencia con los anteriores) ya que once abordan temas de literatura española: tres de contemporánea, cuatro medievales y cuatro del Siglo de Oro. Además, hay algunos que vinculan literatura española y latinoamericana. Es probable que este predominio temático conforme parte del homenaje a quien fuera un distinguido hispanista argentino, ya que, junto a nombres de investigadores del Instituto, puede verse los de Yakov Malkiel y Margherita Morreale — del ámbito internacional-y los de Emilio Carilla, Celina Sabor de Cortazar o Daniel Devoto, estudiosos de reconocida trayectoria en temas hispánicos. Cierran el volumen homenaje una "Selección del epistolario" de Arturo Marasso, con cartas recibidas de Alfonso Reyes, Raimundo Lida y otros intelectuales extranjeros, un artículo sobre la poesía de Marasso (de José Isaacson), otro sobre su biblioteca (de Nicolás Matijevic) y finalmente una bibliografía del poeta (de Horacio Becco).

Cuadro n 4: Artículos de literatura española en Cuadernos del Sur (1958-1971)

\begin{tabular}{|c|c|c|}
\hline Año, $\mathbf{N}^{\circ}$, Vol. & Autor/es & Título \\
\hline $\mathrm{N}^{\circ} 4$, junio 1958 & Cuña, Irma & El mito de Narciso en la poesía de Lorca \\
\hline \multirow[t]{3}{*}{$\mathrm{N}^{\circ} 5,1956$} & $\begin{array}{l}\text { Bermejo, Haydée } \\
\text { y Dinko } \\
\text { Cvitanovic }\end{array}$ & $\begin{array}{l}\text { La Danza de la Muerte: Antecedentes } \\
\text { iconográficos y literarios }\end{array}$ \\
\hline & $\begin{array}{l}\text { Zamudio de } \\
\text { Predán, Josefa }\end{array}$ & La metáfora del ‘teatro del mundo’ en Quevedo \\
\hline & $\begin{array}{l}\text { Cvitanovic, } \\
\text { Dinko }\end{array}$ & $\begin{array}{l}\text { Revisión de algunos estudios sobre la poesía de } \\
\text { los trovadores }\end{array}$ \\
\hline $\mathrm{N}^{\circ} 6-7,1967$ & $\begin{array}{l}\text { Cvitanovic, } \\
\text { Dinko }\end{array}$ & Ghelderode y la tradición bufonesca $^{231}$ \\
\hline $\mathrm{N}^{\circ} 10,1969$ & Virkel, Ana Ester & $\begin{array}{l}\text { El simbolismo de las aguas en la poesía de Luis } \\
\text { Cernuda }\end{array}$ \\
\hline
\end{tabular}

${ }^{231}$ Los trabajos de Dinko Cvitanovic son un ejemplo del enfoque propuesto desde el Instituto y en la revista para el abordaje de los temas, ya que proponen un estudio de las literaturas comparadas en torno a un tópico, y entre ellas aparece la literatura española. 
Avatares del Hispanismo: canon y estudios literarios en la Argentina (1949-1973)

\begin{tabular}{|c|c|c|}
\hline Año, $N^{\circ}$, Vol. & Autor/es & Título \\
\hline & $\begin{array}{l}\text { Frentzel Beyme, } \\
\text { Susana }\end{array}$ & $\begin{array}{l}\text { Interrelaciones plásticas y literarias según el } \\
\text { método de W. Sypher (Formas abiertas de } \\
\text { expresión y pensamiento en el Quijote) }\end{array}$ \\
\hline & Doerig, J.A. & $\begin{array}{l}\text { El concepto democrático de la literatura } \\
\text { española }\end{array}$ \\
\hline & $\begin{array}{l}\text { Pucciarelli, Ana } \\
\text { María }\end{array}$ & Rafael Sánchez Ferlosio: "El Jarama” \\
\hline \multirow{11}{*}{$\begin{array}{l}\mathrm{N}^{\circ} 11, \\
1971(\text { Homenaje a } \\
\text { Arturo Marasso) }\end{array}$} & $\begin{array}{l}\text { Cvitanovic, } \\
\text { Dinko }\end{array}$ & El tratadismo en Juan Rodríguez del Padrón \\
\hline & $\begin{array}{l}\text { Salazar, Abdón } \\
\text { M. }\end{array}$ & Los cinco mitos clásicos de Juan Luis Vives \\
\hline & Varela, José Luis & Artificio y ejemplaridad en el Siglo de Oro \\
\hline & Ciocchini, Héctor & Garcilaso, poeta europeo \\
\hline & $\begin{array}{l}\text { Navarro } \\
\text { González, } \\
\text { Alberto }\end{array}$ & Dulcinea y Galatea \\
\hline & $\begin{array}{l}\text { Cortazar, Celina } \\
\text { Sabor de }\end{array}$ & $\begin{array}{l}\text { Sobre los versos 202-202 del Polifemo de } \\
\text { Góngora: "el celestial humor recién cuajado" }\end{array}$ \\
\hline & Carilla, Emilio & Antonio Machado y Rubén Darío \\
\hline & $\begin{array}{l}\text { Glendinning, } \\
\text { Nigel }\end{array}$ & En torno a "Sonatina" \\
\hline & Mendizábal, Cruz & La sinceridad en Unamuno \\
\hline & $\begin{array}{l}\text { Selig, Karl- } \\
\text { Ludwig }\end{array}$ & $\begin{array}{l}\text { La monja gitana de García Lorca: ensayo de } \\
\text { análisis }\end{array}$ \\
\hline & $\begin{array}{l}\text { Sugden, Ana } \\
\text { María y Néstor } \\
\text { Otero }\end{array}$ & $\begin{array}{l}\text { Itinerario filosófico en la poesía de Jorge } \\
\text { Guillén }\end{array}$ \\
\hline
\end{tabular}

Como se ha señalado, el volumen dedicado a Marasso reviste características particulares, dada su índole de tributo a la figura del erudito riojano, cuya trayectoria estuvo vinculada estrechamente con la literatura española (Cf. apartado anterior). De allí que se destaquen, tal como se mencionó, numerosos artículos acerca de temas y autores 
de la literatura española medieval y áurea, así como de la época contemporánea. Junto con los nombres de reconocidos estudiosos del hispanismo, es necesario destacar el del mismo Ciocchini, alma mater de la revista y especializado en temas de la literatura española, y el de un investigador del centro bahiense cuya destacada trayectoria alcanzará renombre en el ámbito del hispanismo: Dinko Cvitanovic ${ }^{232}$. De este modo, el volumen ofrece un panorama de lecturas vinculadas con la literatura española, de manera análoga a la que es posible reconocer en los números de la revista Filología, del Instituto de Filología de la Universidad de Buenos Aires en homenaje a María Rosa Lida de Malkiel (Año VIII, 1-2 y 3, 1962) y a Ramón Menéndez Pidal (Año XIII, 19681969). Así, a través del homenaje a Marasso, la literatura española —que ya había exhibido una cierta presencia en los números anteriores de Cuadernos del Sur- ostenta una importante cantidad de trabajos: once en total, que abarcan desde temas de literatura medieval hasta contemporánea.

Por otro lado, este reconocimiento a la figura de Marasso pone de manifiesto su centralidad en el panorama de los estudios humanísticos y literarios y recupera a la vez su carácter magistral, a través de las referencias a su impronta en la formación de discípulos y en la consolidación del hispanismo como ámbito de estudio y reflexión al que contribuyó de manera significativa con sus trabajos diseminados en numerosas publicaciones.

Este volumen homenaje a Marasso fue también el último de la etapa de la revista reiniciada en 1966, ya que la publicación volverá a interrumpirse, debido a sucesivas

\footnotetext{
${ }^{232}$ El investigador y docente Dinko Cvitanovic (1938 -2003) había nacido en Croacia y llegó a temprana edad a la Argentina. Realizó sus estudios universitarios en la Universidad Nacional del Sur, donde se desempeñó como profesor en el Departamento de Humanidades. Fue miembro del Instituto de Humanidades y colaborador de la revista Cuadernos del Sur, de la que también fue editor. Su trayectoria como hispanista se plasmó en numerosas publicaciones académicas nacionales e internacionales. También creó en 1985 el Boletín de Estudios Hispánicos (BOEHI) de la Universidad del Sur, publicación que continuó hasta la muerte del profesor Cvitanovic en 2003. Fue uno de los miembros fundadores e incansable impulsor de la Asociación Argentina de Hispanistas, la cual presidió entre 1992 y 1995 y miembro correspondiente de la Academia Argentina de Letras.
} 
vicisitudes del Instituto y del Departamento de Humanidades durante los gobiernos de facto, hasta su reaparición en el año $1979^{233}$. Durante estos primeros años, la revista fue sufriendo cambios tanto a nivel material y estético como también en sus contenidos; el interés inicial en ofrecer una publicación centrada en las dimensiones humanísticas de los saberes, a partir de una visión integral del hombre y de la cultura, heredera del humanismo clásico — lo cual puede apreciarse no sólo en los temas abordados sino en la iconografía que acompaña los fascículos - fue paulatinamente cediendo en pos de la diversificación de los campos disciplinares, los intereses de los investigadores y las líneas de trabajo, de modo tal que algunas áreas del conocimiento fueron adquiriendo relevancia. Es el caso de la literatura, que a lo largo de los volúmenes fue ocupando mayor espacio, tanto la literatura universal, como la española, la hispanoamericana y la argentina.

Para la línea de análisis planteada en esta investigación resulta relevante la lectura del corpus de textos y autores abordados en los artículos en relación con los procesos de configuración y apropiación de un canon hispánico en al ámbito académico argentino de medio siglo. De allí que revisar los temas y autores españoles analizados en las colaboraciones aporte una mirada acerca de las conexiones entre canon y estudios literarios en el contexto de las publicaciones académicas argentinas, como es el caso de Cuadernos del Sur. Tal como se ha señalado, el espíritu inicial de la revista era brindar un panorama integral de las humanidades, relacionando cuestiones vinculadas con los principios de un humanismo renovado (Agesta 2008), por ende, las primeras

\footnotetext{
${ }^{233}$ Luego de la aparición del $\mathrm{N}^{\circ} 11$, correspondiente al periodo 1969-1971, la publicación es suspendida hasta el año 1979, cuando se reanuda con el № 12 y una frecuencia anual. En el año 1995 se produce la división en tres fascículos: Letras, Historia y Filosofía, que continúa hasta la actualidad. En el año 2014 se aprobó la designación de los miembros del Comité Editor de Cuadernos del Sur Ciencias de la Educación (http://www.cuadernosdelsur.uns.edu.ar/pages/Ed/Ed.htm.) De este modo queda evidenciado el giro de la revista desde su intención inicial de constituir un espacio destinado al estudio integral de las humanidades hacia la especialización disciplinar que el campo académico y científico argentino ha ido exigiendo en los últimos años y que se ha ido plasmando en el perfil de las publicaciones. Sin dudas a esto hay que agregarle el perfil de los directores y sus áreas de interés; en el caso de Cvitanovic, en los últimos años se orientó hacia temas de Literatura Latinoamericana.
} 
contribuciones publicadas evidencian esta mirada de corte holístico, como lo demuestran los trabajos de Cvitanovic que rastrean elementos simbólicos a través de diferentes discursos, no solo literarios, sino iconográficos. Con el correr de los números, comienza a aparecer una mayor focalización en temas o aspectos de una obra o un autor. Así, es posible reconocer la presencia de autores contemporáneos, en particular poetas, como Luis Cernuda, Jorge Guillén, Antonio Machado y Federico García Lorca y narradores como Rafael Sánchez Ferlosio y Miguel de Unamuno. También la literatura medieval tiene su espacio, con contribuciones acerca de ediciones de textos medievales y del temprano humanismo, y autores y obras del Siglo de Oro, como Cervantes, Quevedo, Garcilaso de la Vega y Góngora son abordados desde diferentes perspectivas en la revista.

Este recorrido permite algunas consideraciones: en primer lugar, reconocer el lugar que la literatura española ocupa en las indagaciones de los colaboradores, ya que son los textos y autores hispánicos objetos del abordaje desde el enfoque postulado por la revista: aspectos sobre el simbolismo, la metáfora, la mitología, las relaciones entre literatura y otros discursos son analizados en el corpus hispánico. Por otra parte, la selección de este corpus pone de manifiesto algunas preferencias por autores contemporáneos, cuyas producciones ofrecen un espacio para aplicar las perspectivas sustentadas por las líneas de investigación del centro y plasmadas en la revista y así procurar miradas renovadoras sobre éstos. Asimismo, la literatura del Siglo de Oro español, por su carácter canónico, también aparece analizada en los artículos publicados en la revista, en un afán por exponer otros puntos de vista sobre los autores y obras examinados.

En tanto órgano de difusión de las líneas de investigación del Instituto de Humanidades, la revista Cuadernos del Sur, en esta primera época de su existencia, 
evidencia el esfuerzo de su director, Héctor Ciocchini, y del grupo de colaboradores, fundamentalmente locales —aunque hay colaboraciones de investigadores extranjeros, en menor medida-, por abrir un espacio a una visión humanista integral, en la cual se integraran los aportes de diversas disciplinas para brindar una perspectiva propia, a partir de la inclusión en un paradigma humanista, situado en el contexto de la creación del Instituto de Humanidades de la Universidad Nacional del Sur. Este enfoque estuvo presente en los primeros números monográficos de la revista y luego de su reaparición en 1966, esta aspiración se mantuvo, tal como lo demuestra el espíritu expresado en Reglamento de Instituto (1963: 1); sin embargo, los avatares de la vida institucional, los cambios epistemológicos y metodológicos que atravesó el campo académico argentino, fueron desplazando este objetivo inicial hacia formas más especializadas de estudio. En ese movimiento, los estudios literarios $-\mathrm{y}$, entre ellos, los dedicados a la literatura española - fueron ocupando un lugar más relevante y de este modo, delinearon tradiciones críticas particulares que se insertarían productivamente en el campo del hispanismo argentino en franca consolidación.

\subsubsection{El Instituto de Lenguas y Literaturas Modernas de la Universidad Nacional de Cuyo y la Revista de Literaturas Modernas}

Para mediados de la década de 1950, la Facultad de Filosofía y Letras de la Universidad Nacional de Cuyo se encontraba en pleno proceso de consolidación de la actividad de investigación. Creada en 1939, junto con la Universidad Nacional de Cuyo, la Facultad había ido desarrollando tareas de docencia y formación bajo un perfil nítidamente humanista que se manifestó tanto en los diseños curriculares como en los fines 
institucionales ${ }^{234}$, y tempranamente organizó Institutos que nucleaban los estudios en diferentes disciplinas. En el caso de Letras, a comienzos de la década de 1940 se crearon Institutos dedicados a los estudios lingüísticos y literarios. En 1940 se inaugura el Instituto de Lingüística, cuyo primer director fue el lingüista y filólogo español Joan Corominas, en 1944 el de Lengua y Literatura Clásicas y finalmente el Instituto de Lenguas y Literaturas Modernas, fundado en 1947. Al igual que lo ocurrido en otros centros académicos del país, la presencia de investigadores extranjeros, en particular españoles, marcó la impronta de los estudios en el área de las humanidades ${ }^{235}$. Estos institutos adoptaron la organización en secciones, lo cual permitía desarrollar diversas líneas de trabajo. En el caso del Instituto de Lenguas y Literaturas Modernas, las

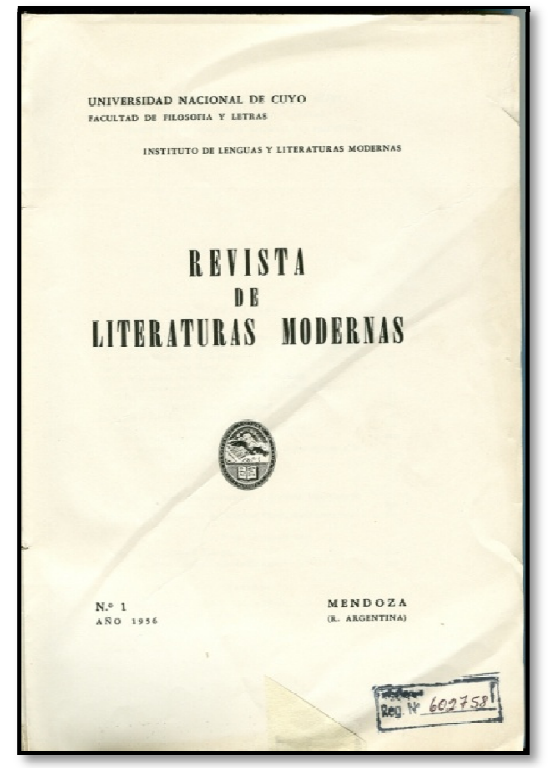
secciones, que abarcaban las áreas de las literaturas modernas, incluidas la española y la americana y argentina, concentraron los estudios literarios y en 1956 salió a la luz la Revista de Literaturas Modernas, donde se publicarían las contribuciones de los integrantes del Instituto y de otros colaboradores.

Con un formato mayor que el propio de las revistas académicas circulantes en la época —que se

\footnotetext{
${ }^{234}$ En una reseña de la historia de la Facultad de Filosofía y Letras de la Universidad de Cuyo, la profesora Gloria Videla de Rivero cita las palabras del filósofo Diego Pró, quien se desempeñó como docente en esa casa de estudios, quien en su trabajo "Orígenes e historia de la Facultad" (1965), expresa: "entre los designios de los fundadores y asesores de la Universidad estaba el de darle un decidido acento humanista, el de apoyar los estudios desinteresados y la formación no solo de profesionales y especialistas, sino ante todo, de hombres cultos" (Videla de Rivero 2009-2010: 32-33). Diego Pró fue también una figura relevante en la Universidad Nacional de Tucumán, donde el cuño humanista estuvo presente desde los orígenes de la Facultad de Filosofía y Letras. (Cf. apartado sobre la revista Humanitas).

${ }^{235}$ Además de Corominas, desarrollaron parte de su trayectoria en Mendoza el historiador Claudio Sánchez Albornoz, y los filólogos Antonio Tovar, Paul Bénichou y Rafael Benítez Claro, procedentes de España, y el lingüista alemán Fritz Kruger, quien sucedió a Corominas en la dirección del Instituto (Rodríguez Temperley 2008: 256-257).
} 
mantendrá en los cinco primeros números-, la Revista de Literaturas Modernas refleja las líneas de investigación de las secciones que componen el Instituto, de allí que haya en cada volumen trabajos correspondientes a diferentes literaturas ${ }^{236}$.

Tal como expresa en el "Preámbulo", firmado por "la Dirección" e incluido en el primer número de la revista, su principal objetivo era "reunir en una sola entrega anual una visión de conjunto del trabajo del Instituto de Lenguas y Literaturas Modernas de la Facultad de Filosofía y Letras, con comprensible acogida a colaboradores del exterior cuya obra armonice con la jerarquía de la publicación" ( $\left.\mathrm{N}^{\circ} 1,1956\right)$. Se destaca por un lado el carácter integrador de la revista y por otro, la búsqueda de un posicionamiento a partir de la idea de "jerarquía" atribuida a la publicación y por ende, a sus colaboradores. En ese marco, desde el primer número, la literatura española tendrá una destacada presencia, y comenzarán a perfilarse los nombres de los colaboradores que marcarán el camino de los estudios de hispanística en Cuyo: Carlos O. Nállim y Emilia Puceiro de Zuleta, docentes e investigadores de la Facultad. Ambos profesores desarrollarán una extensa trayectoria académica vinculada con el hispanismo en la Argentina. Carlos O. Nállim se desempeñó como profesor en la Facultad de Filosofía y Letras de Cuyo, tuvo activa participación en las revistas publicadas por los institutos y luego continuó su carrera académica en cargos de gestión ${ }^{237}$, mientras consolidaba su

\footnotetext{
${ }^{236}$ En la solapa de la revista se mencionan las siete secciones en que se organizaba el Instituto, que abarcaban un amplio espectro de literaturas. Estas eran, en orden alfabético, tal como aparecen: "Sección de Lengua y Literatura Alemanas", "Sección de Lengua y Literatura Argentinas e iberoamericanas", "Sección de Lengua y Literatura Españolas", "Sección de Lengua y Literatura Francesa", "Sección de Lengua y Literatura Inglesas", "Sección de Lengua y Literatura Italianas" y "Sección de Literatura General". A partir del $\mathrm{N}^{\circ} 3$, de 1964, se perciben algunos cambios en la organización interna: se dividen la sección de literatura argentina de la americana — denominada "iberoamericana" - y desaparece la palabra "lengua" en el nombre de las secciones, que pasarán a denominarse "Sección de literatura alemana (argentina, italiana, etc.)". Estas modificaciones son características de la vida institucional de estos centros académicos y se vinculan con los procesos de reorganización interna y de especialización disciplinar, que se profundizaron en la Argentina a partir de la década de 1960, en correlación con las transformaciones curriculares y científicas del campo académico nacional, tal como se ha venido señalando.
}

${ }^{237}$ Además de profesor, Nállim fue director del Instituto de Literaturas Modernas y luego decano de la Facultad de Filosofía y Letras de la UNCuyo. También fue ministro de Cultura y Educación de la 
perfil de investigador en temas de literatura, en especial la literatura española, a la cual le dedicó algunos trabajos señeros, como los dos tomos de Cervantes en las letras argentinas (1998, 2005), obra que se inscribe en la genealogía del cervantismo argentino.

Emilia Puceiro de Zuleta inició tempranamente su carrera docente y de investigación en la Universidad Nacional de Cuyo y orientó sus indagaciones tanto al estudio de la literatura española moderna y contemporánea, como a la crítica literaria, y en particular, a los aportes hispánicos a esa disciplina. Su profundo vínculo con el hispanismo atraviesa sus trabajos y sus publicaciones. Desde la cátedra y los institutos, encaminó sus investigaciones hacia la cultura española y sus nexos con la cultura argentina. De sus seminarios dictados surgieron algunos textos fundamentales acerca de las relaciones culturales entre España y la Argentina ${ }^{238}$.

Dado que el Instituto estaba orientado a las literaturas modernas, la mayoría de los artículos publicados en la Revista de Literaturas Modernas abordan textos y autores de la literatura española moderna y contemporánea, tal como puede verse en el cuadro que reúne las contribuciones de esos años. Sin embargo, tanto la literatura medieval como la renacentista tienen presencia a través de contribuciones de colaboradores invitados de otras universidades nacionales, como Adolfo Prieto, de la Universidad Nacional de Rosario, o Frida Weber de Kurlat, de la Universidad de Buenos Aires.

provincia de Mendoza. En 1988 fue designado académico correspondiente por Mendoza de la Academia Argentina de Letras, donde publicó algunos de sus trabajos más importantes vinculados con el hispanismo.

${ }^{238}$ Gloria Videla de Rivero rememora con calidez la formación ofrecida por la profesora de Zuleta tanto desde la cátedra como en los seminarios, así como el renombre que ya acompañaba a su figura: "Pero la influencia de Emilia de Zuleta no se agotaba en la cátedra: su prestigio la convertía en una de las directoras preferidas por los alumnos para realizar el Seminario de Literatura" (2009-2010: 47). Una vez más, el magisterio se destaca como una de las formas de relación intelectual en el campo del hispanismo argentino. La catedrática fue designada académica correspondiente en 1980 y luego académica de número de la Academia Argentina de Letras en 2001, donde ocupa el Sillón n 19 "Calixto Oyuela", destacado educador y precursor de los estudios hispanistas en la Argentina. También es miembro correspondiente de la Real Academia Española desde 1987 y referente del hispanismo en la Argentina. 
También es de destacar la participación de investigadores locales, con lo que se afirma la presencia de la literatura española como ámbito de indagación y estudio en los claustros mendocinos.

Cuadro ${ }^{\circ}$ 5: Artículos de literatura española en la Revista de Literaturas Modernas (UNCuyo) (1956 - 1967)

\begin{tabular}{|c|c|c|}
\hline Año, $\mathbf{N}^{\circ}$, Vol. & Autor/es & Título \\
\hline $\mathrm{N}^{\circ} 1,1956$ & Nállim, Carlos O. & Valle Inclán: "Tirano Banderas" \\
\hline \multirow[t]{4}{*}{$\mathrm{N}^{\circ} 2,1960$} & Bonet, Carmelo & Menéndez y Pelayo, crítico polifacético \\
\hline & Nállim, Carlos O. & Pío Baroja en perspectiva \\
\hline & $\begin{array}{l}\text { Zuleta, Emilia P. } \\
\text { de }\end{array}$ & La poesía de Miguel Hernández \\
\hline & Prieto, Adolfo & $\begin{array}{l}\text { El sentimiento de la muerte a través de la } \\
\text { literatura española (siglos XIV y XV) }\end{array}$ \\
\hline \multirow[t]{4}{*}{$\mathrm{N}^{\circ} 3,1964$} & $\begin{array}{l}\text { Zuleta, Emilia P. } \\
\text { de }\end{array}$ & "Azorín" como crítico literario \\
\hline & Nállim, Carlos O & Evocación de Pío Baroja \\
\hline & $\begin{array}{l}\text { López Estrada, } \\
\text { Francisco }\end{array}$ & $\begin{array}{l}\text { Epistolario de Menéndez Pelayo: sus cartas a } \\
\text { Servando Arbolí }\end{array}$ \\
\hline & Barbará, Esther & $\begin{array}{l}\text { El testimonio del artista en la obra de Gabriel } \\
\text { Miró }\end{array}$ \\
\hline \multirow[t]{2}{*}{$\mathrm{N}^{\circ} 4,1965$} & Nállim, Carlos O. & $\begin{array}{l}\text { El "Cisne de Apolo" de Carvallo y su inspiración } \\
\text { poética }\end{array}$ \\
\hline & $\begin{array}{l}\text { Zuleta, Emilia P. } \\
\text { de }\end{array}$ & $\begin{array}{l}\text { El escritor español en el último tercio del siglo } \\
\text { XIX }\end{array}$ \\
\hline \multirow[t]{2}{*}{$\mathrm{N}^{\circ} 5,1966$} & $\begin{array}{l}\text { Weber de Kurlat, } \\
\text { Frida }\end{array}$ & La estructura novelesca del Amadís de Gaula \\
\hline & $\begin{array}{l}\text { Zuleta, Emilia P. } \\
\text { de }\end{array}$ & $\begin{array}{l}\text { El concepto de España en la crítica española } \\
\text { contemporánea }\end{array}$ \\
\hline $\mathrm{N}^{\circ} 6,1967$ & $\begin{array}{l}\text { Zuleta, Emilia P. } \\
\text { de }\end{array}$ & La poética de Luis Cernuda \\
\hline
\end{tabular}


El año 1968 marcó un giro en el perfil de la revista, no sólo porque modificó su formato externo para adecuarlo a las nuevas normas ${ }^{239}$, sino porque se producen cambios en la organización del Instituto: ya no figura la sección de Literatura Española, debido a que en 1967 se había convertido en el Instituto de Lengua Española, que abarcaba las secciones de Filología Hispánica, Gramática Española, Literatura Española y Publicaciones. Esta división implicó, por un lado, que la Revista de Literaturas Modernas se orientara hacia las literaturas europeas y americanas, y por otro, puso de manifiesto la relevancia que los estudios hispanistas fueron adquiriendo en la Facultad, que determinaron la creación de un Instituto específico y la publicación de una revista propia: Cuadernos de Filología, cuyo primer número apareció en 1967 y se publicaría durante una década, hasta 1977.

Desde el punto de vista de su formato exterior, Cuadernos de Filología sigue el estilo de las publicaciones académicas tal como circulaban en la época; en este caso particular, la referencia a "cuadernos" del título se refleja en la factura, un poco menor que otras publicaciones similares. La "Presentación" que abre el primer número recupera las ideas de la Revista de Literaturas Modernas, en cuanto a "reflejar la labor de investigación que se realiza en el Instituto de Lengua Española” y también la noción de "jerarquía" asignada a la publicación $\left(\mathrm{N}^{\circ} 1,1967\right)$. Estas afirmaciones apuntan a una legitimación de las revistas en el concierto de las publicaciones nacionales vinculadas con los estudios hispánicos, desde un posicionamiento basado en la "jerarquía" de sus trabajos y de sus colaboradores.

\footnotetext{
${ }^{239}$ La referencia explícita al cambio de formato aparece en las primeras páginas de la revista, donde se lee: "La nueva forma de la Revista de Literaturas Modernas que puede observarse a partir del presente número está de acuerdo con lo prescripto por el Decreto $\mathrm{N}^{\circ}$ 969/66 del PEN, sobre la necesidad de normalizar los formatos de papeles, cartulina y cartones (Norma IRAM Oficial 3001 N10).”
} 
En su organización interna, Cuadernos de Filología presenta la división tradicional en secciones: "Artículos", "Notas" y "Reseñas". A diferencia de otras publicaciones similares, carece de Comité Editorial, o al menos no aparece mencionado en la revista. Sí figuran el nombre del director, Carlos Anastasi y del jefe de la sección publicaciones, Carlos O. Nállim. Por su factura, la revista apunta a ser fundamentalmente un órgano de difusión de los trabajos de los miembros del Instituto, un "cuaderno" a través del cual visibilizar las líneas

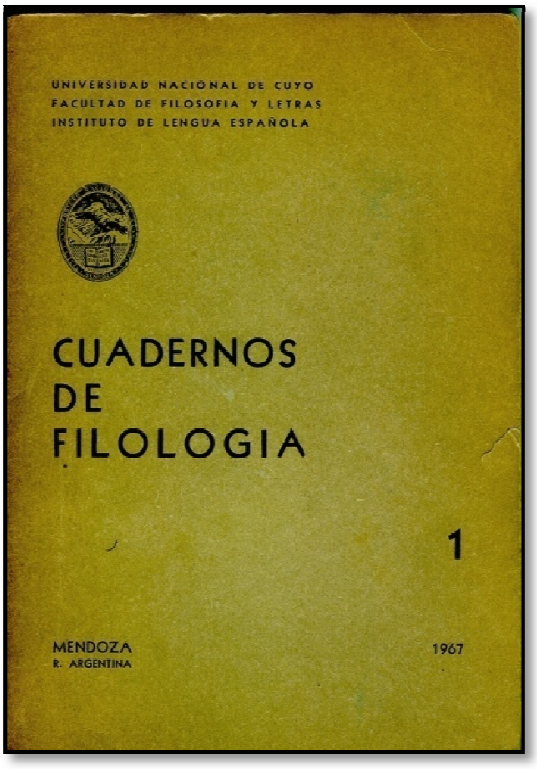

de trabajo de este Centro en el contexto de otras publicaciones de la Facultad de Filosofía y Letras de la Universidad Nacional de Cuyo ${ }^{240}$.

En los seis primeros números de la publicación (1967-1972) —que se corresponden con el periodo seleccionado para esta investigación-, la presencia de trabajos sobre la literatura española es significativa y sobrepasa a los dedicados a temas lingüísticos o gramaticales. Asimismo, se amplían las obras y autores hispánicos analizados, ya que a los trabajos sobre autores y obras españolas modernas y contemporáneas —que ocupan un lugar relevante en el conjunto- se incorporan estudios acerca de la literatura medieval o del Siglo de Oro, y también aumenta la participación de investigadores locales sobre aspectos de la literatura española.

\footnotetext{
${ }^{240}$ Además de las revistas reseñadas, los institutos de la Facultad de Filosofía y Letras de la UNCuyo contaban con publicaciones propias, como la Revista de Estudios Clásicos, del Instituto de Lenguas y Literaturas Clásicas, creada en 1944, los Anales del Instituto de Lingüística, del Instituto de Lingüística creado en 1941, o la Revista de Historia Americana y Argentina, publicación del Instituto de Historia Americana y Argentina, iniciada en 1956. Estas revistas continúan publicándose hasta el día de hoy, lo que señala la afincada trayectoria en la investigación y la difusión de los centros de la Facultad.
} 
Cuadro n 6: Artículos de literatura española en Cuadernos de Filología (UNCuyo)

(1967- 1972)

\begin{tabular}{|c|c|c|}
\hline Año, $N^{\circ}$, Vol. & Autor/es & Título \\
\hline \multirow[t]{3}{*}{$\mathrm{N}^{\circ} 1,1967$} & Nállim, Carlos O. & $\begin{array}{l}\text { La dignidad esencial en la poesía de Fray Luis } \\
\text { de León }\end{array}$ \\
\hline & Borello, Rodolfo & Las coplas de Manrique: estructura y fuentes \\
\hline & Gariano, Carmelo & El enfoque estilístico de la obra medieval \\
\hline \multirow[t]{4}{*}{$\mathrm{N}^{\circ} 2,1968$} & $\begin{array}{l}\text { Blanco González, } \\
\text { Bernardo }\end{array}$ & $\begin{array}{l}\text { La juventud de Don Diego Hurtado de } \\
\text { Mendoza y Pacheco }\end{array}$ \\
\hline & Zuleta, Emilia P. de & $\begin{array}{l}\text { La defensa del lenguaje en la literatura } \\
\text { española contemporánea }\end{array}$ \\
\hline & Vázquez Bigi, A. M & $\begin{array}{l}\text { La influencia de Baroja en Dos Passos y su } \\
\text { reflejo en la novelística contemporánea }\end{array}$ \\
\hline & $\begin{array}{l}\text { Videla de Rivero, } \\
\text { Gloria }\end{array}$ & $\begin{array}{l}\text { Captación artística del mundo moral en } \\
\text { "Nuestro padre san Daniel" y "El obispo } \\
\text { leproso" de Gabriel Miró }\end{array}$ \\
\hline \multirow[t]{4}{*}{$\mathrm{N}^{\circ} 3,1969$} & $\begin{array}{l}\text { Blanco González, } \\
\text { Bernardo }\end{array}$ & El Madrid de Larra \\
\hline & Zuleta, Emilia P. de & Los retornos en la poesía de Rafael Alberti \\
\hline & $\begin{array}{l}\text { Videla de Rivero, } \\
\text { Gloria }\end{array}$ & $\begin{array}{l}\text { "Las meninas" en el teatro de Antonio Buero } \\
\text { Vallejo }\end{array}$ \\
\hline & $\begin{array}{l}\text { Pauliello de } \\
\text { Choucholous, Hebe }\end{array}$ & $\begin{array}{l}\text { El procedimiento grotesco en "El concierto de } \\
\text { San Ovidio" }\end{array}$ \\
\hline \multirow[t]{5}{*}{$\mathrm{N}^{\circ} 4,1970$} & Carilla, Emilio & Naturaleza y retórica en Cervantes \\
\hline & Zuleta, Emilia P. de & Hacia una imagen de la literatura española \\
\hline & $\begin{array}{l}\text { Lucero de Padrón, } \\
\text { Nancy }\end{array}$ & Notas al "Aire del molinerillo nuevo" \\
\hline & $\begin{array}{l}\text { Videla de Rivero, } \\
\text { Gloria }\end{array}$ & Manuel Machado y su "Mal poema" \\
\hline & Fretes, Hilda Gladys & "El rey de la máscara" de Valle Inclán \\
\hline \multirow[t]{2}{*}{$\mathrm{N}^{\circ} 5,1971$} & Vázquez Bigi, A. M. & La formación francesa de Baroja \\
\hline & $\begin{array}{l}\text { Videla de Rivero, } \\
\text { Gloria }\end{array}$ & $\begin{array}{l}\text { La relación Hombre-dios en la poesía de } \\
\text { Dámaso Alonso }\end{array}$ \\
\hline
\end{tabular}


Avatares del Hispanismo: canon y estudios literarios en la Argentina (1949-1973)

\begin{tabular}{|l|l|l|}
\hline Año, No, Vol. & Autor/es & Título \\
\hline & Curia, Beatriz Elena & $\begin{array}{l}\text { Sobre el entremés "El retablo de las } \\
\text { maravillas" }\end{array}$ \\
\hline $\mathrm{N}^{\circ} 6,1972$ & Montes, Hugo & En torno a la poesía de San Juan de la Cruz \\
\hline & $\begin{array}{l}\text { Blanco González, } \\
\text { Bernardo }\end{array}$ & $\begin{array}{l}\text { Realismo y alegoría en el Cancionero de Juan } \\
\text { Alfonso de Baena }\end{array}$ \\
\hline & Borello, Rodolfo & El ubi sunt en la poesía española \\
\hline & Zapata, Celia & Fortunata y Jacinta \\
\hline & $\begin{array}{l}\text { Lucero, Dolly } \\
\text { Gidela de Rivero, } \\
\text { Gloria }\end{array}$ & $\begin{array}{l}\text { Estética y expresión en el teatro de Federico } \\
\text { García Lorca }\end{array}$ \\
\hline & Fretes, Hilda Gladys & Un relato de Pedro Salinas: "El desayuno" \\
\hline & $\begin{array}{l}\text { Badui de Zogbi, } \\
\text { María B. }\end{array}$ & $\begin{array}{l}\text { Sobre la intensificación idiomática en algunos } \\
\text { poemas de Quevedo }\end{array}$ \\
\hline
\end{tabular}

La lectura de los temas y nombres de los colaboradores de Cuadernos de Filología durante este periodo ratifica por un lado, la notoria presencia de investigadores locales y de otros que, con una formación en las universidades argentinas, continuaron sus carreras en el exterior, como el caso de Bernardo Blanco González o Carmelo Gariano, quienes siguieron las líneas de investigación ya delineadas en estos artículos y publicaron trabajos de mayor envergadura sobre temas de la literatura española. De este modo, la revista conjuga, de manera similar a otras de esta índole publicadas en el país, un núcleo de investigadores locales con otros que, formados en la Argentina, partieron al extranjero donde prosiguieron su vida académica. Así, las revistas se constituyen en espacios iniciales para la publicación de trabajos, muchos de los cuales luego fructificarán en obras relevantes, lo que les otorga un carácter seminal en las trayectorias de sus miembros. 


\subsubsection{La Academia Argentina de Letras y el Boletín}

Para cerrar este apartado dedicado a revisar las trayectorias de algunos institutos y centros de investigación vinculados con el hispanismo a lo largo de la Argentina, incluiremos a la Academia Argentina de Letras, institución cuya gravitación en los debates y los procesos de afianzamiento de los estudios hispanistas, tanto en lo referido a la lengua como a la literatura, resulta insoslayable. Desde una órbita distinta de la universitaria, signada por sus propias lógicas internas y externas, la Academia también atravesó vaivenes a lo largo de su historia y estos avatares fueron modulando un perfil particular que, en parte, se refleja en las publicaciones que realizó a través de los años.

Como se ha señalado, con la creación de la Academia Argentina de Letras en 1931 concluye un largo y complejo proceso que refleja de algún modo los avatares — no exentos de conflictos-de las relaciones culturales con España que atravesaron el periodo post independentista del siglo XIX y la conformación del estado nacional, junto con los debates generados durante el Centenario vinculados con la identidad nacional, el estatuto lingüístico y la existencia de un "idioma nacional”. En el marco de ese entramado de relaciones, los intentos por crear en la Argentina una institución que regulara las cuestiones lingüísticas y culturales constituyen hitos significativos para analizar los matices de estas relaciones y ponen de relieve las disputas y controversias que tuvieron lugar en el campo intelectual argentino (Cf. Capítulo 1).

El 13 de agosto de 1931 se crea la Academia Argentina de Letras, aunque no con carácter de correspondiente de la RAE, sino como una institución dependiente del Poder Ejecutivo nacional $^{241}$. Esta particularidad marca una diferencia con otras Academias del

\footnotetext{
${ }^{241}$ Esta dependencia del Poder Ejecutivo se expresa en el Artículo $2^{\circ}$ del Decreto-Ley: "La Academia de Letras redactará su propio Reglamento que someterá oportunamente a la aprobación del Poder Ejecutivo". Sin embargo, con el correr de los años, esta situación se modificó y desde 1999 cambió su situación de "Asociada" a la Real Academia Española por la de "Correspondiente", junto con las otras Academias de la Lengua Española (Consultado en http://www.aal.edu.ar/?q=node/181).
} 
ámbito hispanoamericano y le confirió una índole particular, ya expresada en los lineamientos del decreto presidencial, donde se fijaban los principios rectores de la institución y sus funciones $\left(\right.$ Art. $3^{\circ}$ ). Entre las funciones detalladas, la primera y la última tienen expresa relación con las cuestiones de la lengua: "Dar unidad y expresión al estudio de la lengua y de las producciones nacionales, para conservar y acrecentar el tesoro del idioma y las formas vivientes de nuestra cultura" y "Velar por la corrección y pureza del idioma, interviniendo por sí o asesorando a todas las reparticiones nacionales, provinciales o particulares que lo soliciten". Se vislumbran con claridad los fines propuestos para la Academia en lo referido al idioma: unificar, acrecentar, conservar y, en especial, controlar. Estos fines se constituyen en sintonía con las posturas a favor de la construcción de una tradición hispanista en la que insertarse sin descuidar las "peculiaridades" de la lengua y la cultura. Esta visión, de corte más integrador, pretende otorgar autoridad y legitimidad a las regulaciones acerca del idioma, a través de la creación de una institución que se erija como referente idóneo y legitimado en temas lingüísticos y culturales ${ }^{242}$.

Entre los proyectos iniciales de la Academia estuvo el de organizar las publicaciones que serían los órganos de difusión tanto de sus disposiciones como de los estudios lingüísticos, literarios y filológicos realizados por sus miembros. Así, en 1932 se trató en las sesiones el plan de publicaciones, presentado por el académico Arturo Marasso, que incluía, entre otras, la edición de un Boletín. Según lo dispuesto por la comisión respectiva y aprobado por la institución, “Cada número tendrá: colaboraciones

\footnotetext{
${ }^{242}$ Un análisis detallado de los alcances ideológicos del decreto de creación de la Academia es el realizado por Glozman (2013). Allí examina los principios que dieron origen a la institución y sus relaciones con el discurso político de la época desde una perspectiva glotopolítica.
} 
inéditas, notas filológicas y literarias, una sección bibliográfica y resoluciones de la Academia" ${ }^{243}$.

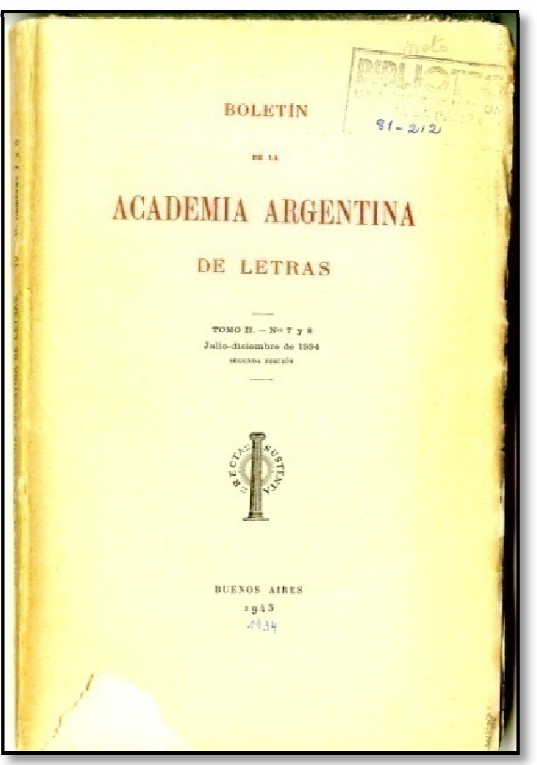

El primer número del Boletín (en adelante $B A A L)$, bajo la dirección el académico Juan Bautista Terán, apareció en abril de 1933 con una frecuencia trimestral, que mantendría, excepto por cortos periodos de tiempo, a lo largo de su existencia. En la "Advertencia" que abría el número, a cargo de su director, se expresa: "La creación de una Academia Argentina de Letras nada tiene que ver con el 'idioma de los argentinos' que ni existe ni es deseable. Es una fortuna pertenecer a la comunidad que habla la lengua castellana, en la que escribieron Cervantes y Quevedo" (6). La declaración inaugural del director del BAAL puede leerse como una afirmación de la búsqueda de la "unidad lingüística", a partir de la construcción de una tradición compartida en la cual enraizarse y desde la cual reafirmar la propia idiosincrasia lingüística y cultural ${ }^{244}$. Asimismo, estas afirmaciones intentarían zanjar de manera definitiva las polémicas lingüísticas que aún entrada la década de 1930 seguían agitando el panorama social ${ }^{245}$.

${ }^{243}$ Las citas corresponden al extracto recogido en "Creación y directores del Boletín", en BAAL, XXX, 1965: 131-133.

${ }^{244}$ Unas décadas después, en un artículo publicado en 1963 en el $B A A L$, Ángel Battistessa actualiza algunos de los puntos de debate sobre la unidad de la lengua castellana al afirmar: "es cierto que los argentinos nunca dejaremos de estimar, ni de agradecer, según se debe, este inestimable don del idioma que después del desgarrón revolucionario, España no dejó de confiar, preciosa herencia indivisa, sin hijuelas, a todos los americanos" (el subrayado es nuestro) (BAAL XXVIII, 1963, $\mathrm{n}^{\circ}$ 107-108: 51). Puede notarse como aún en la década de 1960 el tema de la unidad lingüística castellana seguía motivando reflexiones en consonancia con el ideario explicitado desde los primeros números del $B A A L$.

${ }^{245}$ La actualidad que los debates revestían aún en esta época lo evidencian las afirmaciones del académico Carlos Ibarguren, quien en su discurso publicado en el segundo número del $B A A L$, manifiesta: "La función primordial de una Academia de Letras es perfeccionar el lenguaje que mana del pueblo y es afinado por el ingenio de los escritores. En naciones de inmigración como la nuestra, la tarea tiene una importancia mayor que en los países tradicionales de población homogénea. El aluvión cosmopolita 
Por otra parte, en ese mismo número aparece publicada la carta que el presidente designado de la Academia, Calixto Oyuela, le escribe Ramón Menéndez Pidal, en ese momento director de la Academia Española de la Lengua, en donde expresa:

La cooperación y estrechos vínculos de nuestra Academia con la de Madrid, centro tradicional, universalmente reconocido y respetado de la cultura lingüística castellana, reviste, pues, la más alta importancia para la acción fecunda de la nueva institución argentina y para su unión y hermandad perennes con los propósitos de su ilustre antecesora española (82-83).

En las palabras de Oyuela se sintetizan los principios que plantean, desde el inicio, establecer una forma de filiación entre ambas instituciones, a la vez que ubican a la Academia española como centro desde el cual se irradian ciertos lineamientos que permiten dar unicidad y legitimidad a las acciones de la novel institución argentina, en estrecha vinculación con los fines expuestos en su creación, en particular con los referidos a "velar" por la unidad y pureza del castellano. En el mismo sentido, la referencia a los escritores canónicos de la literatura española en el texto de Terán reafirma esta vocación purista y recupera el carácter modélico atribuido a la prosa de ambos autores.

Entre los propósitos del $B A A L$ figuraba la inclusión de trabajos referidos a la literatura, en consonancia con los principios fundantes de la AAL de "infundir en el pueblo la noción de la importancia de la literatura", según expresan los considerandos del decreto, y además del énfasis puesto en el estudio de las "producciones nacionales" y "las formas vivientes de nuestra cultura", se desprendía de estas ideas la necesidad de

salpica la lengua de voces extrañas que ensucian y afean el idioma, lo que es menester combatir con ahínco para conservar acendrado el riquísimo patrimonio idiomático que nos dio España" (BAAL I, $\mathrm{N}^{\circ} 2$ y 3, Abril-septiembre 1933: 98). Es evidente en la postura de Ibarguren la actitud de rechazo a la convergencia y multiplicidad lingüística de la sociedad argentina y la filiación con una posición claramente hispanista. De todos modos, es de destacar que la mayoría de los académicos exhibieron posiciones más moderadas al respecto, en particular porque los momentos más álgidos de las disputas ya habían pasado. 
realizar aportes críticos al estudio de la literatura, en particular la argentina, cuya vida académica apenas contaba con un par de décadas ${ }^{246}$. Sin embargo, una revisión de las contribuciones que aparecieron a lo largo de los números del $B A A L$ da cuenta de una importante presencia de trabajos referidos a la literatura española, lo cual no se presenta a priori como problemático en el contexto de los intereses de la Academia ${ }^{247}$.

Así, a lo largo de los volúmenes del $B A A L$ convivirán las notas filológicas y lexicográficas acerca del castellano en América y en la Argentina, con estudios literarios de obras y autores hispanoamericanos, argentinos y un número significativo de ellos dedicados a la literatura española. El relevamiento de las contribuciones referidas a textos y autores españoles que aparecieron en los primeros cuarenta años de vida del $B A A L$ permitirá indagar acerca de los modos en que se relacionan los aportes realizados desde la Academia con la configuración y circulación de un canon hispánico en proceso de consolidación y, al mismo tiempo, reconocer las figuras más destacadas de un hispanismo de cuño argentino que también se encontraba en conformación vinculadas con la Academia, y así analizar los matices que adquiere ese campo de estudios en el marco de la institucionalización académica a mediados del siglo XX.

\footnotetext{
${ }^{246}$ Resulta significativa la elección del concepto "Letras" para nombrar a la Academia argentina, ya que otras análogas creadas dentro y fuera del continente americano habían adoptado la denominación "Academia de la Lengua". En la sección Noticias del primer número del $B A A L$ se define la extensión de ese término: "La Academia interpreta el vocablo 'Letras' que integra su denominación como comprensivo de Idioma, Filología, Literatura; y consideradas desde el punto de vista de la forma, las obras históricas y sociológicas" (BAAL $\left.\mathrm{N}^{\circ} 1: 7\right)$.

${ }^{247}$ Respecto los estudios literarios y culturales previstos por la AAL, la lectura realizada por Glozman le otorga a la referencia al carácter "nacional" de los temas un sesgo restrictivo, al señalar: "este aspecto [la construcción 'formas vivientes de nuestra cultura'] señala que, en cuanto a la cultura, la AAL debía restringirse a la cultura considerada nacional, evitando incorporar entre sus fines el estudio de la tradición literaria español (2013: 466).
} 
Cuadro $n^{\circ}$ 7. Artículos de literatura española en el $B A A L(1933-1973)$

\begin{tabular}{|c|c|c|}
\hline Tomo, $N^{\circ}$, Año & Autor & Título del artículo \\
\hline $\mathrm{I}, \mathrm{N}^{\circ} 1,1933$ & Marasso, Arturo & Fray Luis de León \\
\hline $\mathrm{I}, \mathrm{N}^{\circ} 4,1933$ & Cortina, Augusto & El 'Diálogo entr' el Amor y un Viejo (I) \\
\hline III, $N^{\circ} 11-12,1935$ & Alfonso, Luis & Acerca de un pasaje de Berceo \\
\hline \multirow[t]{2}{*}{$\mathrm{IV}, \mathrm{N}^{\circ} 13,1936$} & Marasso, Arturo & Humanismo en Lope de Vega \\
\hline & Marasso, Arturo & Bécquer y Grünn \\
\hline $\mathrm{IV}, \mathrm{N}^{\circ} 14,1936$ & Cortina, Augusto & Diálogo entr' el Amor y un Viejo (IV) \\
\hline \multirow[t]{3}{*}{$\mathrm{IV}, \mathrm{N}^{\circ} 15,1936$} & Marasso, Arturo & Una nota sobre las Soledades de Góngora \\
\hline & Marasso, Arturo & Lope de Vega y la pintura \\
\hline & Sordelli, Virgilio & $\begin{array}{l}\text { La noche primera en el Criticón de } \\
\text { Gracián }\end{array}$ \\
\hline $\mathrm{V}, \mathrm{N}^{\circ} 17,1937$ & $\begin{array}{l}\text { García Santillán, } \\
\text { Juan Carlos }\end{array}$ & En el centenario de la muerte de Larra \\
\hline $\mathrm{V}, \mathrm{N}^{\circ} 18,1937$ & Marasso, Arturo & Notas cervantinas \\
\hline \multirow[t]{2}{*}{$\mathrm{V}, \mathrm{N}^{\circ} 19,1937$} & Ramos, Juan Pablo & Santa Teresa de Jesús \\
\hline & Reyes, Alfonso & $\begin{array}{l}\text { Los autos sacramentales en España y } \\
\text { América }\end{array}$ \\
\hline $\mathrm{V}, \mathrm{N}^{\circ} 20,1937$ & Reyes, Alfonso & El peregrino en su patria de Lope de Vega \\
\hline VI, $N^{\circ} 21-22,1938$ & Reyes, Alfonso & $\begin{array}{l}\text { Influencia del ciclo artúrico en la literatura } \\
\text { castellana }\end{array}$ \\
\hline VI, $N^{\circ} 23-24,1938$ & $\begin{array}{l}\text { Martínez Zubiría, } \\
\text { Gustavo y Herrera, } \\
\text { Ataliva }\end{array}$ & Sobre el endecasílabo \\
\hline \multirow[t]{3}{*}{$\begin{array}{l}\text { VII, } \mathrm{N}^{\circ} \quad 25-26, \\
1939\end{array}$} & Marasso, Arturo & Ensayo sobre el verso alejandrino \\
\hline & Lida, María Rosa & $\begin{array}{l}\text { Las imágenes de la Cámara Maravillosa } \\
\text { (Historia troyana) }\end{array}$ \\
\hline & $\begin{array}{l}\text { Miranda, Edelmira } \\
\text { E. }\end{array}$ & $\begin{array}{l}\text { Safo en La Celestina y en la Imitación de } \\
\text { diversos de Fray Luis de León }\end{array}$ \\
\hline VIII, $N^{\circ} 29,1940$ & Krebs, Ernesto & $\begin{array}{l}\text { El Cortesano de Castiglione en España. La } \\
\text { disputa del lenguaje }\end{array}$ \\
\hline
\end{tabular}




\begin{tabular}{|c|c|c|}
\hline Tomo, $N^{\circ}$, Año & Autor & Título del artículo \\
\hline VIII, $\mathrm{N}^{\circ} 30,1940$ & Marasso, Arturo & Nota sobre Garcilaso \\
\hline \multirow[t]{2}{*}{ VIII, N 31,1940} & & $\begin{array}{l}\text { El Cortesano de Castiglione en España. } \\
\text { Del caballero y la dama. I) Del linaje }\end{array}$ \\
\hline & Marasso, Arturo & $\begin{array}{l}\text { Fernando de Herrera y El Cortesano de } \\
\text { Castiglione }\end{array}$ \\
\hline \multirow[t]{3}{*}{$\mathrm{IX}, \mathrm{N}^{\circ} 33,1941$} & Ramos, Juan Pablo & Don Diego de Saavedra Fajardo \\
\hline & Bonet, Carmelo & En torno al estilo de Saavedra Fajardo \\
\hline & Krebs, Ernesto & $\begin{array}{l}\text { El Cortesano de Castiglione en España. } \\
\text { Del caballero y la dama. II) De las partes } \\
\text { físicas }\end{array}$ \\
\hline IX, $\mathrm{N}^{\circ} 35,1941$ & & $\begin{array}{l}\text { El Cortesano de Castiglione en España. } \\
\text { Del caballero y la dama. III) Las armas }\end{array}$ \\
\hline IX, No 36,1941 & Marasso, Arturo & La elaboración del Lazarillo de Tormes \\
\hline \multirow[t]{2}{*}{$\mathrm{X}, \mathrm{N}^{\circ} 37,1942$} & Krebs, Ernesto & $\begin{array}{l}\text { El Cortesano de Castiglione en España. } \\
\text { Del caballero y la dama }\end{array}$ \\
\hline & Mazzei, Ángel & Cervantes en Italia \\
\hline $\mathrm{X}, \mathrm{N}^{\circ} 38,1942$ & Mazzei, Ángel & El agua en la poesía de Boscán y Garcilaso \\
\hline \multirow[t]{2}{*}{$\mathrm{X}, \mathrm{N}^{\circ} 40,1942$} & Krebs, Ernesto & $\begin{array}{l}\text { El Cortesano de Castiglione en España. } \\
\text { Del amor }\end{array}$ \\
\hline & Bassagoda, Roger & Gil Vicente \\
\hline $\mathrm{XI}, \mathrm{N}^{\circ} 41,1943$ & Marasso, Arturo & Góngora y el gongorismo \\
\hline $\mathrm{XI}, \mathrm{N}^{\circ} 43,1943$ & $\begin{array}{l}\text { Conde Montero, } \\
\text { Manuel }\end{array}$ & Dos notas sobre el Quijote \\
\hline $\mathrm{XI}, \mathrm{N}^{\circ} 44,1943$ & Marasso, Arturo & Juan Boscán \\
\hline XII, $N^{\circ} 45,1943$ & Giusti, Roberto & $\begin{array}{l}\text { Fernando de Rojas. Su obra de humanidad } \\
\text { española y de arte renacentista }\end{array}$ \\
\hline XIII, N 49,1944 & $\begin{array}{l}\text { Henríquez Ureña, } \\
\text { Pedro }\end{array}$ & El endecasílabo castellano \\
\hline $\mathrm{XIV}, \mathrm{N}^{\circ} 52,1945$ & Bonet, Carmelo & Quevedo prosista \\
\hline \multirow[t]{2}{*}{$\mathrm{XIV}, \mathrm{N}^{\circ} 53,1945$} & Marasso, Arturo & $\begin{array}{l}\text { Aspectos del lirismo de San Juan de la } \\
\text { Cruz }\end{array}$ \\
\hline & Cárpena, Elías & $\begin{array}{l}\text { Dos nuevas versiones del romance de } \\
\text { Delgadina }\end{array}$ \\
\hline
\end{tabular}




\begin{tabular}{|c|c|c|}
\hline Tomo, $N^{\circ}$, Año & Autor & Título del artículo \\
\hline & Mazzei, Ángel & El domingo en la poesía española \\
\hline $\mathrm{XV}, \mathrm{N}^{\circ} 54,1946$ & Marasso, Arturo & Píndaro en la poesía castellana \\
\hline $\mathrm{XV}, \mathrm{N}^{\circ} 55,1946$ & $\begin{array}{l}\text { Monner Sans, José } \\
\text { María }\end{array}$ & Notas sobre Gustavo A. Bécquer \\
\hline \multirow[t]{2}{*}{$\mathrm{XV}, \mathrm{N}^{\circ} 56,1946$} & $\begin{array}{l}\text { Monner Sans, José } \\
\text { María }\end{array}$ & Las fuentes de las 'Rimas' becquerianas \\
\hline & $\begin{array}{l}\text { Díaz- Plaja, } \\
\text { Guillermo }\end{array}$ & Conmemoración de Bretón de los Herreros \\
\hline $\mathrm{XV}, \mathrm{N}^{\circ} 57,1946$ & Marasso, Arturo & La 'Antología griega' en España \\
\hline XVI, N ${ }^{\circ} 58,1947$ & Marasso, Arturo & Hesíodo en la literatura castellana \\
\hline XVI, N 60,1947 & $\begin{array}{l}\text { Díaz-Plaja, } \\
\text { Guillermo }\end{array}$ & $\begin{array}{l}\text { Garcilaso de la Vega: prosopografía y } \\
\text { etopeya }\end{array}$ \\
\hline \multirow[t]{10}{*}{$\begin{array}{l}\text { XVI, N } N^{\circ} 61,1947 \\
\text { (Número homenaje } \\
\text { a Cervantes) }\end{array}$} & de Ibarguren, Carlos & $\begin{array}{l}\text { Discurso de homenaje a Miguel de } \\
\text { Cervantes }\end{array}$ \\
\hline & Marasso, Arturo & $\begin{array}{l}\text { Discurso de homenaje a Miguel de } \\
\text { Cervantes }\end{array}$ \\
\hline & $\begin{array}{l}\text { Perón, Juan } \\
\text { Domingo }\end{array}$ & Discurso en el Día de la Raza \\
\hline & Ramos, Juan P. & Cervantes \\
\hline & $\begin{array}{l}\text { Alonso Cortés, } \\
\text { Narciso }\end{array}$ & $\begin{array}{l}\text { Cervantes y la 'Relación' del bautismo de } \\
\text { Felipe IV }\end{array}$ \\
\hline & Farinelli, Arturo & $\begin{array}{l}\text { Cervantes: con ocasión del cuarto } \\
\text { centenario de su nacimiento }\end{array}$ \\
\hline & $\begin{array}{l}\text { De Macedo Soares, } \\
\text { José C. }\end{array}$ & Cervantes en Brasil \\
\hline & Ragucci, Rodolfo & Cervantes en la portada del 'Quijote' \\
\hline & Silva, Juan B. & La gramática y el Quijote \\
\hline & $\begin{array}{l}\text { Zaldumbide, } \\
\text { Gonzalo }\end{array}$ & $\begin{array}{l}\text { El Don Quijote de América o 'Capítulos } \\
\text { que se le olvidaron a Cervantes' }\end{array}$ \\
\hline XVII, Nº 63,1948 & Mazzei, Ángel & Un ejemplo de El conde Lucanor \\
\hline XVII, N 65,1948 & Arrieta, Rafael A. & $\begin{array}{l}\text { En torno a nuestros vínculos literarios con } \\
\text { España }\end{array}$ \\
\hline
\end{tabular}




\begin{tabular}{|c|c|c|}
\hline Tomo, $N^{\circ}$, Año & Autor & Título del artículo \\
\hline & Carilla, Emilio & Quevedo y el 'Parnaso Español' \\
\hline XVIII, $N^{\circ} 69,1949$ & Lida, María Rosa & La poesía de Juan de Mena \\
\hline XXII, N 83, 1957 & Krebs, Enrique & $\begin{array}{l}\text { Boscán, traductor de 'El Cortesano' de } \\
\text { Castiglione }\left(1^{\circ} \text { parte }\right)\end{array}$ \\
\hline XXII, N 84, 1957 & Krebs, Enrique & $\begin{array}{l}\text { Boscán, traductor de 'El Cortesano' de } \\
\text { Castiglione (continuación) }\end{array}$ \\
\hline XXII, N 84, 1957 & $\begin{array}{l}\text { Melián Lafinur, } \\
\text { Álvaro }\end{array}$ & Varela novelista \\
\hline XXII, N 86,1957 & Krebs, Enrique & $\begin{array}{l}\text { Boscán, traductor de 'El Cortesano’ de } \\
\text { Castiglione (conclusión) }\end{array}$ \\
\hline XXIII, $N^{\circ} 87,1958$ & Battistessa, Ángel & Acotaciones a un comentario crítico \\
\hline XXIII, $N^{\circ} 89,1958$ & Rhode, Jorge Max & $\begin{array}{l}\text { Menéndez Pelayo y don Juan Valera en su } \\
\text { epistolario }\end{array}$ \\
\hline XXIII, $N^{\circ} 90,1958$ & $\begin{array}{l}\text { Bernárdez, Francisco } \\
\text { Luis }\end{array}$ & Paridad de Cervantes y don Quijote \\
\hline $\mathrm{XXV}, \mathrm{N}^{\circ} 96,1960$ & $\begin{array}{l}\text { Garasa, Delfín } \\
\text { Leocadio }\end{array}$ & $\begin{array}{l}\text { Ángeles y demonios en el teatro de Lope } \\
\text { de Vega }\end{array}$ \\
\hline \multirow[t]{6}{*}{$\begin{array}{l}\text { XXVI, N } 101- \\
102,1961 \\
\text { (Homenaje a Luis } \\
\text { de Góngora) }\end{array}$} & Lida, María Rosa & El hilo narrativo de las Soledades \\
\hline & Marasso, Arturo & Nuevos aspectos de Góngora \\
\hline & Battistessa, Ángel & Tradición temática y revolución expresiva \\
\hline & Borges, Jorge Luis & Discurso \\
\hline & $\begin{array}{l}\text { Estrella Gutiérrez, } \\
\text { Fermín }\end{array}$ & Un soneto de Góngora \\
\hline & $\begin{array}{l}\text { Sánchez Hayes, } \\
\text { Ricardo }\end{array}$ & Evocación de Unamuno \\
\hline $\begin{array}{l}\text { XXVII, } N^{\circ} 103, \\
1962\end{array}$ & Cárpena, Elías & Las soledades de los poetas líricos \\
\hline $\begin{array}{l}\text { XXVIII, } N^{\circ} 107- \\
108,1963\end{array}$ & Navas Ruiz, Ricardo & Tres novelas españolas sobre América \\
\hline $\begin{array}{l}\text { XXIX, } \quad N^{\circ} \quad 112- \\
113,1964\end{array}$ & $\begin{array}{l}\text { Estrella Gutiérrez, } \\
\text { Fermín }\end{array}$ & $\begin{array}{l}\text { Unamuno y Maragall. Historia de una } \\
\text { amistad ejemplar }\end{array}$ \\
\hline
\end{tabular}




\begin{tabular}{|c|c|c|}
\hline Tomo, $N^{\circ}$, Año & Autor & Título del artículo \\
\hline & $\begin{array}{l}\text { Garasa, Delfín } \\
\text { Leocadio }\end{array}$ & $\begin{array}{l}\text { Circe en la literatura española del Siglo de } \\
\text { Oro }\end{array}$ \\
\hline $\begin{array}{l}\text { XXXI, } \mathrm{N}^{\circ} 119, \\
1966\end{array}$ & $\begin{array}{l}\text { Sánchez Hayes, } \\
\text { Ricardo }\end{array}$ & La España de Ganivet \\
\hline $\begin{array}{l}\text { XXXI, } \quad \mathrm{N}^{\circ} 120, \\
1966\end{array}$ & Bonet, Carmelo & En el año centenario de Valle Inclán \\
\hline $\begin{array}{l}\mathrm{XXXV}, \mathrm{N}^{\circ} 137- \\
138,1970\end{array}$ & $\begin{array}{l}\text { de la Guardia, } \\
\text { Alfredo }\end{array}$ & Gloria póstuma de Gustavo A. Bécquer \\
\hline $\begin{array}{l}\text { XXXVI, } N^{\circ} 141- \\
142,1971\end{array}$ & $\begin{array}{l}\text { de la Guardia, } \\
\text { Alfredo }\end{array}$ & Gustavo A. Bécquer, autor teatral \\
\hline
\end{tabular}

Sin dudas, la vida de las publicaciones periódicas académicas está estrechamente enlazada tanto con las instituciones o centros de las que dependen como con el perfil de sus directores. El caso del $B A A L$ no escapa a esa norma: por un lado, desde los inicios se presenta como el órgano portavoz de las resoluciones y actos propios de la Academia y además va delineando el carácter de las contribuciones que lo integran. Así, junto con los trabajos dedicados a cuestiones lingüísticas y filológicas, en todos los volúmenes se advierte la presencia de artículos y notas acerca de temas de literatura, acorde con el carácter integrador atribuido a la Academia desde la elección misma del nombre (Cf. Nota $\mathrm{n}^{\circ}$ 246). Como se ha señalado, el primer director del $B A A L$ fue el académico Juan Bautista Terán, pero sólo ocupó el cargo para ese número, ya que a partir del segundo número, el $B A A L$ estará bajo la dirección de Arturo Marasso - excepto un breve interregno entre 1934 y 1935 - hasta la suspensión de la publicación por cuestiones políticas en $1951^{248}$. Marasso formaba parte de los académicos designados desde la

\footnotetext{
${ }^{248}$ En concordancia con el giro que las relaciones entre el gobierno del General Perón y el campo académico evidenciaron a partir de 1950, en septiembre de ese año se promulgó la ley 14.007 que se proponía regular el funcionamiento de las academias, cuyo decreto reglamentario fue aprobado en 1952 (Decreto 7500/52). Al respecto, en el № 79 (enero-mayo) de 1956, aparece una “Advertencia", en la que solo se menciona que el $B A A L$ "reaparece después de algunos años de obligado silencio con el mismo espíritu que lo animó desde el primer número" (7). A continuación se incluye el texto del discurso del
} 
creación de la AAL y contaba para ese entonces con una dilatada trayectoria en el campo de los estudios de la literatura, en particular la española y la hispanoamericana y había publicado algunas obras relevantes tanto de poesía como de crítica literaria ${ }^{249}$. A partir de su incorporación a la AAL, muchos de sus trabajos aparecerán en el $B A A L$, algunos de los cuales serán la génesis de obras de mayor envergadura ${ }^{250}$.

Si se hace un relevamiento de los artículos dedicados a la literatura española a lo largo de los números dirigidos por Marasso, puede constatarse una notoria presencia, en particular con contribuciones de su propia autoría. Así, el primer número se inaugura con una nota sobre Fray Luis de León (Tomo I $\mathrm{N}^{\circ}$ 1) y en los volúmenes correspondientes a 1936, 1937, 1939, 1941, 1943, 1945 y 1947 aparecerán trabajos acerca de temas y autores españoles. Además de Marasso, en este periodo de la vida del $B A A L$ publican textos referidos a la literatura española catedráticos e investigadores pertenecientes a la Academia o bien colaboradores especiales, lo que da cuenta de la relevancia que los escritos sobre esta literatura tuvieron en los primeros años del $B A A L$. Esto parece corroborar la afirmación incluida en la Advertencia que abría el Tomo XII, de 1943, con motivo del décimo aniversario de la publicación del Boletín: "vínculo de

ministro de Educación de la Nación, el Dr. Atilio Dell’Oro Maini pronunciado en el acto de reinstalación de las academias nacionales y el texto completo del Decreto. Ley 4362/55). La velada referencia al "obligado silencio" es la única indicación en el $B A A L$ del interregno en que no hubo actividad.

Por su parte, en la reseña histórica que figura en el sitio web de la AAL aparece un clara referencia a estas medidas y su impacto en la vida institucional: "[ambas regulaciones], medidas antidemocráticas en las que se cercenan la independencia y libertad de las academias nacionales, quitándoles su derecho de elegir a sus miembros y constituir sus autoridades, al otorgar atribuciones al Gobierno Nacional para vetar las decisiones e intervenir en su funcionamiento. Se abre así un interregno que, felizmente, durará pocos años" ( http://www.aal.edu.ar/?q=node/181). Ambas observaciones expresan las huellas que estas prescripciones tuvieron en la institución.

${ }^{249}$ Las primeras publicaciones de Arturo Marasso fueron obras de poesía pero también tempranamente comenzó su tarea como crítico literario, que cristalizó en textos sobre la figura de Joaquín V. González (1915), una colección de estudios sobre literatura argentina e hispanoamericana (Estudios literarios, 1920) y una serie de artículos publicados en la revista Humanidades de la Universidad Nacional de La Plata, en la que fue profesor durante varios años (Cf. Cuadro $\mathrm{N}^{\circ} 2$ ). En la mayor parte de su producción se destacan las indagaciones sobre temas de literatura española, que constituyen el núcleo central de sus textos críticos.

250 En 1955 Marasso publica el libro Estudios de literatura castellana que reúne trece artículos, la mayoría de los cuales habían aparecido en los números del $B A A L$. 
una tradición esencial que compartimos con tantas naciones, la lengua no puede desintegrarse de esa unidad literaria que le dio estructura y la incorporó a la civilización entera" (VII-VIII). Se retoman aquí las ideas de "tradición" y de "unidad", a la que se aspiraba desde la creación de la Academia, en la cual la literatura —y, en particular la española- adquieren una importancia fundamental para garantizar esos anhelos.

Un año clave para las reflexiones acerca del hispanismo y su impronta en la cultura nacional fue 1947, cuando se celebraron los cuatrocientos años del nacimiento de Miguel de Cervantes ${ }^{251}$. El número 61 del $B A A L$, de octubre de ese año, estuvo dedicado al autor español e incluía, junto con contribuciones críticas y culturales de la obra cervantina $^{252}$, los discursos pronunciados en ocasión del 12 de octubre, día en que junto con la conmemoración del día de la $\operatorname{Raza}^{253}$, la Academia realizó una sesión especial en homenaje a Cervantes. En esa oportunidad actuaron como oradores el entonces presidente de la AAL, Carlos Ibarguren, el académico Arturo Marasso y el Presidente de la Nación, el General Juan Domingo Perón. Excedería los límites de este trabajo el análisis exhaustivo de cada uno de los discursos, pero sí es menester detenerse en algunos rasgos compartidos en los conceptos expresados por los oradores, y que se vinculan con ciertas ideas acerca del lugar que ocupaba España en el imaginario cultural

\footnotetext{
${ }^{251}$ Aunque las revistas culturales o literarias no son objeto de esta investigación, resulta significativo mencionar que, en consonancia con las conmemoraciones del cuarto centenario del nacimiento de Cervantes, la revista Realidad dedicó su número de septiembre-octubre de 1947 a un "Homenaje a Cervantes", en el que participaron destacados cervantistas, tanto argentinos como extranjeros: Américo Castro, Marcel Bataillon, Joaquín Casalduero, Harry Levin, Max Singleton, así como miembros de la revista, como Francisco Romero y Francisco Ayala y otras figuras como Jorge Luis Borges, Julio Caillet Bois, Guillermo de Torre y Jaime Romero Brest. Esto expresa no sólo la filiación intelectual de sus colaboradores, sino que coloca a Cervantes y su obra en esa línea de pensamiento. Se declara al final del volumen: "Mediante el presente número extraordinario contribuimos de nuestro lado a perfilar la reacción colectiva ante una obra de imaginación poética y de pensamiento que ha tenido y sigue teniendo poder conformador sobre nuestra personalidad histórica" ( $\mathrm{N}^{\circ} 5$, Vol. $\left.2^{\circ}: 320\right)$.

${ }^{252}$ Además de los discursos pronunciados, el número incluye notas de Juan P. Ramos, del español Narciso Alonso Cortés, del italiano Arturo Farinelli, del brasileño José C. de Macedo Soares, de Rodolfo Ragucci, de Juan B. Silva y del ecuatoriano Gonzalo Zaldumbide referidas a distintos aspectos de la vida y obra de Cervantes.

${ }^{253}$ La celebración del 12 de octubre como "Día de la Raza" había sido instituida en la Argentina en 1917 por un decreto del entonces presidente Hipólito Yrigoyen, a instancias, entro otras instituciones, de las asociaciones españolas establecidas en Buenos Aires (Cf. Nota $\left.n^{\circ} 80\right)$.
} 
argentino de la época y ponen de manifiesto el marco ideológico que sustentaba dichas relaciones. Las alocuciones de Ibarguren y Marasso apuntan a destacar la figura y la obra cervantinas; en el caso del primero, hay un regreso a las posiciones puristas respecto del idioma que ya había manifestado en otras ocasiones (Cf. Nota $\left.\mathrm{n}^{\circ} 245\right)$. Las palabras de Marasso se detienen en recuperar una lectura crítico-literaria de la obra de Cervantes, en particular del Quijote, a partir del rastreo de fuentes y tradiciones literarias y en historiar la crítica cervantina; es decir, se trata de una disertación claramente académica. Sin embargo, al igual que en el discurso de Ibarguren, hay en su alocución una clara referencia a la "unidad espiritual" que aúna a la Argentina y a España, asentada en la lengua común:

[...] respetuosamente le consideramos [al Quijote] en nuestras sosegadas lecturas como artífice de la lengua, autoridad de su advertido uso, fuente común, con tantos otros escritores ilustres de la familia del habla castellana que se dilata sobre las fronteras para formar una patria, espiritualmente nuestra, el hogar común del idioma (BAAL Tomo XVI, $\left.\mathrm{n}^{\circ} 61: 20\right)$.

El extenso discurso del general Perón tiene un tinte político e ideológico más nítido; la primera parte se articula sobre el concepto de "comunidad hispánica” que vertebra las ideas referidas a las nociones de "espiritualidad hispánica", "raza", "comunidad cultural hispanoamericana", "Patria madre", que por un lado, recuperan y resignifican en el contexto político y cultural de la época el ideario ya expresado por Ricardo Rojas a comienzos del siglo ${ }^{254}$, y por el otro, manifiesta cierto posicionamiento político del gobierno nacional en una línea ideológica de cuño hispanista y conservador asociado a las del régimen franquista en España ${ }^{255}$.

\footnotetext{
${ }^{254}$ Estas ideas que vinculan la raza, el idioma y la cultura bajo un signo espiritualista ya están presentes en el discurso de Ricardo Rojas (Cf. Capítulo 1).

${ }^{255}$ Un análisis en detalle de las relaciones entre el gobierno peronista y el de Franco excedería los alcances de esta investigación. Sin embargo es necesario destacar las afinidades que articularon los
} 
Al analizar el discurso del general Perón ante la AAL, Marina Glozman señala: "Por consiguiente, la unidad cultural - uno de los objetivos del gobierno peronista- se realizaba sobre y con las posiciones hispanistas" (2009:134). En la segunda parte de su discurso desarrolla las posturas políticas de su gobierno acerca del panorama mundial delineado luego de finalizada la Segunda Guerra Mundial y la situación argentina en ese contexto. Allí vuelve a apelar a la "unidad espiritual y cultural" que enlaza a los pueblos hispanoamericanos con España como modo de afirmar un posicionamiento en el nuevo escenario mundial. Como síntesis de la postura del gobierno argentino encabezado por el general Perón respecto de la filiación hispánica del continente americano puede destacarse este fragmento del discurso:

Los pueblos de la hispanidad también constituimos una unidad y también vivimos dominados por la pasión patriótica. Tenemos mucho en común que defender: unidad de origen, unidad de cultura y unidad de destino. Vivimos hermanados por vínculos de idioma, de religión, de cultura, de historia. Estas identidades deben impulsarnos a una empresa universal, desbordando los límites geográficos que, aislados, integre la verdadera unidad espiritual de los pueblos hispanos (BAAL Tomo XVI, $\left.\mathrm{n}^{\circ} 61: 50\right)^{256}$.

discursos en torno a la idea de "hispanidad" en el nuevo concierto internacional post Segunda Guerra Mundial. Al respecto, también en ese artículo Glozman expresa las vinculaciones ideológicas entre los gobiernos de Franco y de Perón en estos primeros años, articuladas en torno a esta idea de "unidad hispánica". Afirma la autora: "El término Hispanidad en torno al cual se configura el discurso de Perón no es, pues, inocente: refleja de manera clara el cercano vínculo entre el gobierno de Perón y del dictador Franco" (134). En un orden análogo se expresa Ranaan Rein (1991) al referirse a los ecos en España del discurso de Perón ante la AAL: "El discurso de Perón fue recibido con entusiasmo en la España franquista, donde se apresuraron a aprovecharlo para promover sus intereses políticos. En pocas semanas, los españoles hicieron nada menos que cien mil copias del discurso, que fueron distribuidas por toda América Latina en un intento por modificar en pro de la dictadura franquista la atmósfera que regía en el continente" (61).

${ }^{256}$ Esa misma línea de afiliación con España y su cultura fue retomada en el discurso que el General Perón dio ese mismo año en ocasión de recibir el título de Doctor Honoris Causa de las Universidades Argentinas. Allí afirma: "Nosotros, los argentinos, tus hijos predilectos [de España], hemos labrado en el frontispicio de nuestras Universidades una leyenda de imperial resonancia, una leyenda de filial gratitud y de sabor hogareño, una leyenda que dice: No se pondrá jamás el sol de nuestra cultura hispánica" (disponible en http://www.bnm.me.gov.ar/giga1/documentos/EL000062.pdf . Consultado el 10/2/2016). 
Leídas en conjunto, las tres disertaciones comparten la mirada respecto del lugar reconocido a España en la conformación de la identidad nacional y continental, a partir del reconocimiento de una serie de valores "espirituales" compartidos —idioma, raza, religión, cultura - que de algún modo darían carnadura a la hispanidad, representada en su máxima expresión por la figura del Quijote, tal como lo expresa en el cierre de su discurso el general Perón: "Hoy, más que nunca, debe resucitar don Quijote” (56). Asimismo, expresan el cenit de la convergencia ideológica entre el gobierno nacional y la Academia, convergencia que poco tiempo después se disolvería a partir de las acciones llevadas a cabo por el gobierno en materia de políticas culturales y educativas (Glozman 2009).

En los años siguientes, previos a la suspensión de la publicación del $B A A L$ en 1951, hay notas referidas a la literatura española en los volúmenes de 1948 y 1949. En el correspondiente al Tomo XVIII de ese año, María Rosa Lida publica un artículo sobre la poesía de Juan de Mena; ya para entonces la filóloga estaba radicada en los Estados Unidos, pero continuaba vinculada con la vida académica argentina ${ }^{257}$.

Luego de un silencio de cinco años, en 1956 reaparece el $B A A L$, y Arturo Marasso fue reelecto como su director. Comienza entonces el segundo periodo de vida de la publicación —ininterrumpida hasta nuestros días - y con él se retoma la difusión de las actividades académicas y las contribuciones críticas. Entre ellas, continúan apareciendo trabajos referidos a la literatura española, con la incorporación de nuevos colaboradores. Entre estos volúmenes, se destaca el correspondiente a 1961, cuyos números 101 y 102 incluyen un homenaje a Luis de Góngora en el cuarto centenario de

\footnotetext{
${ }^{257}$ La segunda mitad de la década de 1940 fue en cierta manera turbulenta para la vida académica argentina, a partir del advenimiento del gobierno de Juan Domingo Perón. En 1946 se había alejado del Instituto de Filología de la Universidad de Buenos Aires su director, Amado Alonso, y en 1947 María Rosa Lida, una de sus discípulas, se marcha del país con una beca y ya no regresará a él sino esporádicamente. Situaciones similares se vivieron con otros filólogos e investigadores del Instituto (Cf. Capítulo 1).
} 
su nacimiento, tal como había ocurrido en ocasión del homenaje a Miguel de Cervantes. En este caso, las contribuciones están a cargo de los académicos María Rosa Lida ${ }^{258}$, Arturo Marasso, Ángel Battistessa, Fermín Estrella Gutiérrez y del escritor Jorge Luis Borges, quien un año después sería designado académico. No hay, como en 1947, intervenciones del ámbito político, sino que se trata de un homenaje estrictamente académico. En este sentido puede señalarse que la figura de Cervantes, a diferencia de Góngora, estaba imbuida de un carácter más "universal" y ligado a la idea de "hispanidad", y sus personajes más famosos habían alcanzado ya la categoría de arquetipos, por lo que admitían múltiples apropiaciones y resignificaciones. En contrapartida, la figura del poeta cordobés estuvo siempre más cercana a la idea de una poesía "culta", y asociada a la noción de complejidad, erudición y dificultad, de allí la diferencia entre la índole de ambos homenajes; uno de corte más político y cultural y el otro más estrictamente académico.

En los años siguientes, las contribuciones sobre literatura española continuaron publicándose en el $B A A L$, ya con frecuencia más esporádica. Como se ha señalado, la impronta de los directores resulta un factor decisivo en el perfil de las publicaciones. Durante el periodo seleccionado para este trabajo, además de Arturo Marasso, quien en 1958 dejó el cargo de director del $B A A L$, fueron designados para el cargo directivo Rafael A. Arrieta, quien fallece en 1968 y a quien sucederán Roberto Giusti (19681970) y Fermín Estrella Gutiérrez, desde 1970, año en que también fallece Arturo

\footnotetext{
${ }^{258}$ En 1959 María Rosa Lida había sido designada académica correspondiente, ya que residía en los Estados Unidos y fue la primera mujer en ingresar a la AAL. En 1962, con motivo de su fallecimiento, se publica en el $\mathrm{n}^{\circ}$ 105-106 del BAAL una nota necrológica a cargo del académico Ricardo Giusti, quien refiere a la marcha de la filóloga del país por cuestiones políticas, lo cual también evidencia el cambio radical en las relaciones de la institución con el gobierno destituido en 1955: "[Lida] se sintió moralmente obligada a expatriarse al comienzo de la dictadura caída en 1955" (BAAL Tomo XXVII, n 105-106, julio-dic. 1962: 347).
} 
$\operatorname{Marasso}^{259}$. Es posible hipotetizar que la mayor presencia de artículos y notas relacionados con la literatura española publicados en el $B A A L$ esté vinculada con la impronta de Marasso como director de la publicación, ya que su formación y trayectoria académica estuvieron ligadas a la literatura española y se plasmaron en estudios críticos, algunos de ellos hitos insoslayables en el hispanismo argentino como el trabajo sobre la obra de Cervantes (Cf. Capítulo 1). Bajo este sesgo, los primeros cuarenta años de vida del $B A A L$ incluyeron en sus páginas un número significativo de trabajos acerca de obras y autores españoles en el marco de una revista que si bien estaba destinada a una circulación acotada a los ámbitos académicos, contaba con el prestigio de la institución a la que pertenecía y con el relieve alcanzado por sus colaboradores.

Ahora bien, un aspecto significativo para este análisis lo constituye el relevamiento del corpus de obras y autores españoles abordados en los estudios publicados en el $B A A L$ a lo largo de estas cuatro décadas, ya que permite indagar en las elecciones, las persistencias y las revisiones de la literatura española realizadas por los colaboradores, y de este modo poner en relación estos procesos con la consolidación de un canon hispánico desde el ámbito académico argentino.

En primer lugar, tal como se ha señalado, la huella de Arturo Marasso impregna las páginas del $B A A L$ dedicadas a la literatura española; junto con ellas, se destaca la presencia de otros colaboradores que con sus escritos, realizaron aportes a los estudios hispánicos. Como se ha venido comprobando en el análisis de otras publicaciones periódicas de la época, la gravitación de los autores del denominado Siglo de Oro español en el canon resulta manifiesta en las elecciones de los temas. La centralidad de

\footnotetext{
${ }^{259}$ La relevancia de la figura de Arturo Marasso en la vida institucional de la AAL quedó plasmada en el

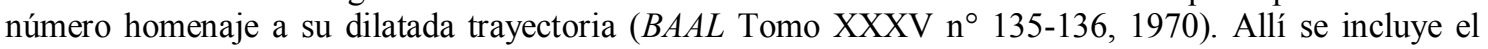
discurso expresado por el entonces director de la publicación, Fermín Estrella Gutiérrez, como homenaje de la Universidad Nacional de La Plata a quien fuera docente e investigador de esa casa de estudios. En ese discurso, pronunciado en la Universidad Nacional del Sur, Estrella Gutiérrez hace alusión a la biblioteca personal de Marasso que se incorporó como acervo inicial de la Biblioteca Humanidades de dicha Universidad (Cf. Nota ${ }^{\circ} 230$ ).
} 
Cervantes y de Góngora entre los autores elegidos se destaca en los volúmenes de homenaje, así como otras obras y escritores del periodo áureo, debido fundamentalmente a la conmemoración de los centenarios de estos autores, ocasiones en que proliferan los homenajes y los trabajos acerca de sus figuras. En tanto, de los autores modernos y contemporáneos, hay artículos sobre Gustavo A. Bécquer, Juan Valera, Miguel de Unamuno y Ángel Ganivet.

Esta preponderancia de los escritores del Siglo de Oro puede ponerse en correlación con las definiciones que en materia lingüística sostuvo la AAL a lo largo de su historia. Si se revisan los fines propuestos desde su creación, las declaraciones expresadas en el primer número del $B A A L$ acerca de la lengua literaria, así como en el volumen publicado con motivo del décimo aniversario de la publicación y en los discursos de los académicos en recepciones, aniversarios y celebraciones, podrá advertirse el sesgo de afiliación con la cultura española, en particular con su literatura, expresión cabal y acabada de la lengua “en la que escribieron Cervantes y Quevedo”, al decir de Juan Bautista Terán en la presentación de primer número del $B A A L$. En esa frase se cifra la aspirada unión entre lengua y literatura en el marco de una herencia compartida.

Por otro lado, la afirmación de la existencia de lazos históricos y culturales con España es más nítida en la primera parte de la existencia del $B A A L$, en la que se concentran la mayor cantidad de trabajos referidos a la literatura española y en la que hay más referencias a las relaciones culturales con la Península. Luego de la reaparición del Boletín a mediados de la década de 1950, la presencia de textos sobre esta literatura es más esporádica y puntual; como se ha señalado, posiblemente esto pueda explicarse por el perfil de su director durante casi veinte años, Arturo Marasso, y por la índole de los debates acerca del estatuto de la lengua que siguieron agitando el panorama cultural 
aún avanzado el siglo. A partir de la década de 1960 estos debates fueron apaciguándose $\mathrm{y}$, a excepción de alguna manifestación puntual —recuérdense las declaraciones de Battistessa de 1963 - no hay ya espacio para la polémica.

Junto con estos aspectos, la profesionalización de la actividad académica y de investigación, que empezó a consolidarse en la Argentina a mediados de la década de 1950, más vinculada con las universidades y con los centros de investigación, generó una multiplicación de publicaciones periódicas académicas en diferentes instituciones con perfiles más definidos, y, en el caso de los estudios literarios y lingüísticos, se acrecienta el número de revistas y publicaciones destinadas específicamente a la divulgación de estudios críticos, de cuestiones metodológicas y de avances de investigación. Asimismo, el perfil de los colaboradores y de los académicos que se fueron incorporando a la institución necesariamente le fue otorgando un cariz particular a la publicación. En ese contexto, puede entenderse que la presencia de trabajos referidos a la literatura española haya disminuido en el $B A A L$ en la segunda etapa de su vida institucional.

Con estos matices señalados, la presencia de la literatura española en el $B A A L$ resulta significativa, no sólo por el volumen de las artículos y notas publicados en los primeros cuarenta años, sino por la relevancia de los nombres de los colaboradores, muchos de ellos representantes del hispanismo argentino dentro y fuera del país, quienes, desde las páginas de una publicación perteneciente a una institución con un prestigio consolidado a través de los años y de los devenires políticos y culturales, hicieron sus aportes a la conformación de los estudios hispánicos. En muchos casos, estos trabajos fueron la génesis de obras críticas o de estudios destinados a la enseñanza o a la difusión de textos o autores, pero en todos los casos, resultaron $-\mathrm{y}$ resultan hoy en día - una contribución a la proyección y afianzamiento del canon hispánico, así 
como un testimonio de las modulaciones que adquirieron a lo largo de las décadas, las filiaciones y afiliaciones entre la institución argentina y el hispanismo, expresadas a través de sus posicionamientos en materia lingüística y también por las aproximaciones a la literatura española. Esa conjunción de intereses literarios e idiomáticos colaboró en el afianzamiento de los vínculos — no siempre libres de tensiones — entre el hispanismo argentino y la Academia, a la cual, ya desde el momento mismo de su creación, se le atribuía un papel fundamental en la forja de una unidad cultural que trascendiera las fronteras y cuyo basamento estuviera cifrado en la lengua y con ella, sus manifestaciones literarias y culturales:

[...] ningún pensamiento podrá llegar a fijarse en lo esencial sin el dominio del léxico, de la riqueza de la lengua literaria; que es patrimonio común de las naciones hispano-americanas este admirable instrumento de labor espiritual, cuyo porvenir es inmenso y cuya conservación es de innegable trascendencia (Acta de Constitución de la AAL) $^{260}$.

Así confluyen las ideas de unidad, permanencia y también de inserción en una tradición compartida, en la cual la literatura y la cultura españolas tendrán un lugar relevante, reafirmando de algún modo las (a)filiaciones de la AAL con sus pares hispanoamericanas y con la española, al menos desde el trazado de los temas y los enfoques.

\footnotetext{
${ }^{260}$ Disponible en http://www.aal.edu.ar/?q=node/131 (Consultado el 27/07/2015).
} 


\subsection{Constelaciones intelectuales en el hispanismo argentino}

El itinerario recorrido en este capítulo ha posibilitado reconstruir en parte los procesos de forja y consolidación de un hispanismo de cuño argentino, a partir de la creación de centros e instituciones que, tanto en el campo académico como en el universitario propiamente dicho, fueron sembrando a lo largo del país las simientes de lo que, con el correr de los años, se convertiría en un ámbito de estudio definido y prestigioso. A la vez, este recorrido permitió delinear un "mapa" o una cartografía del hispanismo argentino, definido tanto por la ubicación geográfica como por la red de relaciones intelectuales que se construyeron y que componen un entramado particular.

La creación de centros, institutos, departamentos e instituciones académicas vinculados con los estudios de las Humanidades a partir de la segunda década del siglo XX en la Argentina expresó, por un lado, el afianzamiento de la investigación como un aspecto ineludible de la vida académica, en especial la universitaria, y por otro, la conformación de espacios en los que nuclear la docencia y la formación de discípulos con la indagación y la difusión de conocimientos. En ese contexto, el interés y la gravitación que fueron adquiriendo los estudios de la literatura y la cultura españolas se recorta con nitidez.

Como se ha señalado, este recorrido habilita algunas consideraciones. En primer lugar, como todo itinerario, presenta una dimensión geográfica y una serie de trayectorias, con algunos hitos significativos. En la génesis de lo que serían los estudios hispanistas están los viajes y los desplazamientos: los de Ricardo Rojas a España a comienzos del siglo XX y sus contactos con la intelectualidad española, los de los catedráticos peninsulares que visitaron la Argentina en las primeras décadas del siglo y dejaron su impronta en diversas disciplinas, los de los filólogos españoles, formados en el Centro de Estudios Históricos de Madrid, que llegaron a Buenos Aires en los años 20 
para sentar las bases de la filología en el país, y años más tarde los de los profesores que, formados en las instituciones terciarias y universitarias de las principales ciudades, se trasladaron al interior del país y gestaron nuevos centros donde continuar expandiendo los estudios hispánicos ${ }^{261}$.

A esta dimensión geográfica se le agrega la de las trayectorias personales y las relaciones entabladas entre ciertas figuras relevantes, por el lugar que ocuparon en la conformación y consolidación del hispanismo, así como los particulares vínculos entre maestros y discípulos, que constituyen un rasgo particular en estos procesos y que fueron consolidando y expandiendo el hispanismo a lo largo del país. Asimismo, es posible develar la formación de una constelación de relaciones entre figuras e instituciones que compartieron espacios y fomentaron lazos personales e institucionales. En una mirada sobre estas relaciones se pueden reconocer ciertos focos de irradiación del hispanismo hacia dentro y hacia fuera de las fronteras; en primer lugar, el Instituto de Filología fue un centro en el cual se formó una camada de hispanistas ilustres, a partir del magisterio de Amado Alonso, algunos de los cuales, como se ha visto, continuaron sus trayectorias en el extranjero (María Rosa y Raimundo Lida, Ángel Rosenblat) y otros se insertaron en otras instituciones del país, como Ángel Battistessa en La Plata. También esta universidad contó con la labor de Arturo Marasso, quien se constituyó en una figura referente de los estudios literarios y fue maestro de Ángel Mazzei, que continuará su tarea en dicha universidad, y de Héctor Ciocchini, quien a su vez llevaría los estudios hispánicos a la Universidad Nacional del Sur, cuya revista, Cuadernos del Sur, contaría entre los miembros de su Consejo Editorial a Ana María Barrenechea y a Battistessa, del Instituto de Filología. Otra figura señera de la

\footnotetext{
${ }^{261}$ No pueden dejar de mencionarse los otros viajes, motivados por razones políticas o ideológicas, que llevaron a investigadores hispanistas argentinos a otros destinos extranjeros, donde continuaron sus carreras. Estos "hispanistas en el exilio" dejaron su huella en la diseminación de los estudios hispánicos en otros países americanos, incluidos los Estados Unidos (Cf. Capítulo 1).
} 
Universidad Nacional de La Plata y miembro del Instituto de Filología de Buenos Aires fue Pedro Henríquez Ureña, bajo cuya dirección Emilio Carilla se doctoró y llevó la simiente de los estudios hispánicos a Tucumán.

Otro elemento aglutinante fue la Academia Argentina de Letras, que tuvo - y tiene hoy en día - a destacados hispanistas entre sus miembros, tal como se ha señalado. Esto da cuenta del entramado particular que el hispanismo fue consolidando a lo largo del país y sus fuertes vínculos con la vida académica y asimismo permite reconstruir ciertas figuraciones de los profesores ligados a la literatura y la cultura españolas, cuyo sesgo estuvo marcada a partir de la consolidación del campo académico por una conjunción de erudición e investigación, que devino en una clara vinculación entre las cátedras, los institutos y las publicaciones periódicas y no periódicas.

Finalmente, una nueva dimensión de este recorrido abarca las publicaciones académicas, que acompañaron desde los inicios las actividades de los centros e instituciones, y que devienen en dispositivos fundamentales para examinar los modos en que se fue conformando y definiendo el hispanismo a partir de las contribuciones de sus colaboradores, a la vez que participan en los procesos de formación de un canon hispánico en el ámbito argentino a partir de la labor de profesores que sostienen y desarrollan la investigación especializada. Así, las publicaciones académicas analizadas se presentan como portavoces de las producciones locales referidas a temas de literatura y cultura españolas, a partir de la idiosincrasia que les otorgan a cada una su pertenencia institucional, su historia, los avatares de su trayectoria, el perfil de sus directores y de sus colaboradores. Desde esta perspectiva, cada revista ha contribuido con sus aportes, su multiplicidad de enfoques y de obras y autores abordados, las interrelaciones entre sus miembros y el prestigio adquirido dentro y fuera de las instituciones, a la proyección del hispanismo en la Argentina y la configuración del canon hispánico, ya que 
constituyen un núcleo fuerte de contribuciones a este ámbito de estudios, en particular a partir de la década de 1940 y que se irá afianzando en las décadas siguientes.

Pero al mismo tiempo, las revistas —en tanto espacio de visibilidad y de socialización - ponen de manifiesto su carácter de punto de encuentro de itinerarios individuales. En el caso de las revistas relevadas, esta dimensión aparece con nitidez, a partir de observar las presencias de ciertas figuras en más de una publicación, ya sea como colaborador o como miembro del consejo editorial. Es decir, esta red de relaciones que se teje alrededor de las revistas devela las (a)filiaciones y las convergencias, las tradiciones en las que se insertan y también las formas de legitimación a las que apelan.

Consideradas en su conjunto, las publicaciones analizadas se presentan como un corpus consistente que ofrece diferentes aristas para pensarlas en relación con los procesos de consolidación del hispanismo en Argentina: constituyen un documento que registra el desarrollo de los estudios hispanistas en los distintos centros que se fueron conformando, dan cuenta de la trama de relaciones que implican, en términos de fines, objetivos, enfoques teóricos y metodológicos, y a la vez, permiten establecer un "mapa de relaciones intelectuales", en palabras de Beatriz Sarlo (1992: 9-16). Esta trama particular se va integrando a partir de las relaciones entre maestros y discípulos, que se organiza como continuidad y pertenencia a una tradición compartida, y también a través de la relevancia de ciertas figuras que, vistas en perspectiva diacrónica, se erigieron en referentes del hispanismo argentino y señalaron los rumbos de estos estudios. Las múltiples religaciones que es posible reconstruir desde las páginas de las revistas muestran los itinerarios personales e institucionales en el marco del proceso de afianzamiento del hispanismo y dan cuenta de las apropiaciones y (re)apropiaciones del canon de la literatura española en el campo académico argentino, visibilizado en las 
publicaciones periódicas aparecidas desde las primeras décadas del siglo XX. Al mismo tiempo, este recorrido por las contribuciones publicadas en las revistas devela la incorporación de enfoques teóricos y metodológicos para el abordaje de obras y autores hispánicos, con lo cual este ámbito constituyó un espacio de convergencias entre las nuevas orientaciones críticas y el canon hispánico consolidado, lo cual produjo una revitalización de estos estudios y su afirmación en el campo académico argentino.

Más allá de los vaivenes intrínsecos de la vida universitaria argentina, este entramado deja vislumbrar asimismo, las inflexiones que fue adoptando el hispanismo, las tensiones entre posicionamientos anti y prohispanistas —que provenían de los debates decimonónicos y que continuaron atravesando el terreno intelectual durante el siglo XX-, junto con ciertos "usos" ideológicos de este concepto, así como determinadas connotaciones atribuidas al término "hispanismo",262, permiten reconocer la construcción de una "tradición hispanista" (en términos de Raymond Williams), en relación con el contexto cultural argentino, y los modos en que se fue delineando y afianzando una "agenda hispanista" en el ámbito académico nacional y sus relaciones con los procesos de conformación de un canon hispánico a partir de los aportes del campo académico argentino.

\footnotetext{
${ }^{262}$ La vinculación del hispanismo con las ideas de conservadurismo, nacionalismo o posturas recalcitrantes atraviesa parte de los debates en el campo cultural argentino, tal como lo reconoce expresamente Melchora Romanos en un artículo incluido en el dossier "El hispanismo hoy: estereotipos culturales y construcciones identitarias" publicado por la revista Olivar (Vol. $5 \mathrm{~N}^{\circ}$ 5, 2004): "se han disipado ciertas connotaciones de arcaísmo recalcitrante, conservadurismo y catolicismo a ultranza con que se configuraba a los hispanistas argentinos, por cierto no de modo totalmente injustificado en algunos casos, en el imaginario de los intelectuales progresistas" (84). En un sentido análogo se expresa José Luis de Diego, en un trabajo incluido en dicho dossier: "Lo mismo ocurría en el ámbito de nuestra disciplina [los estudios literarios] [...] lo español era rápidamente identificado con una filología atravesada por criterios de autoridad harto discutibles y con análisis de estilo que desembocaban con frecuencia en paráfrasis elegantes y en el regodeo de una prosa más atenta a su propia construcción que al rigor metodológico que exigían los nuevos tiempos" (93). Estas declaraciones ponen de manifiesto el matiz negativo que acompañó en los debates intelectuales y académicos al hispanismo como ámbito de estudio $\mathrm{y}$, a la vez, dan cuenta del giro que, a partir de los últimos años, ha tenido esta visión en el campo académico, del cual los numerosos trabajos, así como los eventos científicos, publicaciones, proyectos de investigación, etc. —incluido el mencionado dossier — vinculados con el hispanismo en la Argentina, son una clara muestra.
} 


\section{CAPITULO 3: El Hispanismo y la industria editorial en la Argentina (1940-1973)}

El desarrollo de las hipótesis que sustentan esta investigación implica considerar los procesos de configuración, apropiación y resignificación del canon hispánico en el contexto argentino de mediados del siglo $\mathrm{XX}$ y de sus repercusiones en el ámbito académico y de la formación docente, así como su presencia en las ofertas editoriales destinadas a públicos diferenciados. A la vez, este análisis deja entrever las tensiones y las operaciones de selección y de omisión, así como los textos y autores hispánicos de mayor presencia en los estudios críticos y en los catálogos editoriales del periodo. Se trata, entonces, de procesos complejos en los que se entrelazan cuestiones vinculadas con las prácticas culturales y académicas, las políticas editoriales y los debates ideológicos, que permiten postular una relectura del canon hispánico desde una mirada situada en el campo cultural argentino de la época.

En ese contexto, una de las dimensiones desde la cual abordar este entramado la constituye la relación entre canon hispánico e industria editorial, ya que las propuestas de ediciones de textos literarios conforman un corpus significativo para cartografiar la permanencia y las fluctuaciones de la tradición hispanista en el ámbito argentino.

\subsection{Panorama de la industria editorial argentina en las primeras décadas del siglo} XX (1900-1930)

\subsubsection{La impronta española}

En los últimos años se ha producido un auge de los estudios dedicados a reconstruir el panorama editorial en la Argentina y, en particular, sus articulaciones con España desde finales del siglo XIX y su desarrollo durante el siglo XX (Larraz 2007, 2010, 2011, 2014; de Diego 2006, 2015; Espósito 2010; Falcón 2011). Estos trabajos ponen en 
evidencia la relevante presencia de la industria española y de sus agentes en la conformación y expansión de un mercado editorial en la Argentina y de las redes de índole no sólo comercial y económica, sino cultural y política que subyacen en ese proceso, y su papel en el establecimiento de relaciones culturales y comerciales entre ambos países, en las que el libro — en tanto objeto material y simbólico- ocuparía un lugar central.

La celebración del IV Centenario del Descubrimiento de América en 1892 fue un momento propicio para repensar las relaciones entre España y las ex colonias americanas, entre las cuales los aspectos vinculados con la expansión del mercado editorial español en el continente tuvieron particular importancia. En el Congreso Literario Hispano-americano realizado en Madrid ese año, una de las secciones, denominada "Librería", estuvo especialmente dedicada a abordar cuestiones ligadas a la industria del libro y sus problemáticas (Cf. Capítulo 1). Una lectura de los temas formulados para las sesiones del Congreso de dicha sección pone de manifiesto las preocupaciones económicas, comerciales y legales de los empresarios libreros y otros agentes españoles vinculados con la comercialización de libros en América, lo cual anticipa las relaciones entre editores y libreros españoles y su proyección a América, en particular a México y Argentina, en las primeras décadas del siglo $\mathrm{XX}^{263}$. En el contexto del "ímpetu americanista" (Larraz 2007: 131) que impregnaba el clima intelectual de la época y las relaciones entre España y los países hispanoamericanos, el mercado del libro español ocupaba un lugar central y formaba parte de los discursos que apelaban a la

\footnotetext{
${ }^{263}$ La sección "Librería" era la $3^{\circ}$ de las secciones en que se organizó el Congreso de 1892 y sus temas giraban en torno de los "Medios prácticos conducentes al desarrollo y progreso del comercio de libros españoles en América y libros americanos en España, así como del de obras artísticas, organizando empresas editoriales, Bibliotecas, giro consular y representaciones recíprocas entre todos los países de origen español" (1892:14). La inclusión de este eje en el marco del Congreso expresa la importancia que revestía para los editores españoles la posibilidad de ampliar sus mercados a América, para entonces dominada por empresas alemanas, francesas e inglesas. Disponible en http://cvc.cervantes.es/lengua/congreso_literario/pdf/CVC_congreso_011.pdf
} 
"unidad" a través de la lengua, la raza y la tradición común y a la necesidad de refundar los lazos culturales (Cf. Capítulo 1).

El balance final de las deliberaciones acerca del libro español y su situación en el Congreso de 1892 evidenció, por un lado, las dificultades de orden estratégico y logístico que exhibía la industria editorial española para desarrollarse en América y, como consecuencia de ello, la creciente preocupación de los libreros españoles por insertarse activamente en el mercado hispanoamericano y recuperar el terreno que habían cedido en manos de editoriales europeas. De este modo, la evaluación acerca del estado de la industria editorial en América se inserta en el discurso de afianzamiento de lazos y de fortalecimiento de la "comunidad intelectual" que imperaba en la época (Larraz 2007: 131) ${ }^{264}$. De estos pronunciamientos surgirá un nuevo modelo de expansión del mercado editorial español en tierras americanas que sentará sus bases en un sistema de estrategias diferenciadas para la inserción del libro español en América, que incluirán nuevas formas de representación de las editoriales, la publicación de catálogos y boletines, conexiones con instituciones comerciales, culturales y educativas, entre otras ${ }^{265}$. Esto posibilitó la construcción de una red de comercialización compleja que cimentará el posterior desarrollo de la industria editorial en el continente (Larraz 2007; Espósito 2010).

\footnotetext{
${ }^{264}$ Tal como señala Fernando Larraz en su artículo, los análisis respecto de la situación de la industria y distribución del libro en América señalaban las falencias de tipo empresariales que aquejaban a la industria editorial española y a partir de ello se instaló la necesidad de recuperar ese espacio para ampliar los horizontes de las empresas españolas dedicadas al libro en el contexto de este reanudamiento de los lazos culturales y comerciales, bajo una clara consigna económica (2007).

${ }^{265}$ Un texto fundamental de la época es el folleto La producción literaria en España y el comercio de exportación de libros a América de Rafael Gutiérrez Jiménez, publicado en Madrid en 1893, que reunía las expresiones formuladas por el autor en el Congreso de 1892 y que resulta un eficaz diagnóstico de la situación de la industria editorial española a fines del siglo XIX y una síntesis de propuestas para revertir ese escenario poco ventajoso que incluye varias acciones concretas. Entre los argumentos esgrimidos por Gutiérrez Jiménez figuran la unidad lingüística y la pertenencia a una tradición literaria compartida: "Cervantes, Quevedo, Fr. Luis, Calderón y Lope, son escritores del siglo de oro de la literatura española; pero son además los escritores del siglo de oro de la literatura hispanoamericana" (1893: XIII), lo cual sintetiza de algún modo la consolidación de un "canon" compartido cuya persistencia se hará visible en las propuestas editoriales del siglo XX en el continente y en especial, en la Argentina.
} 
El inicio del siglo XX coincide con la expansión de la industria editorial en la Península ${ }^{266}$, hecho que, sin embargo, se encontró con las limitaciones que ofrecía el mercado interno y comenzó entonces una búsqueda de ampliación de mercados orientada a proyectarse en terreno americano. A pesar de los escollos que presentaba el comercio de ultramar (competencia extranjera, dificultades de distribución, altos costos de los libros, catálogos poco acordes al gusto del público, entre otros), con el correr del tiempo este desarrollo transatlántico se fue consolidando, y el estallido de la Primera Guerra Mundial ofreció una oportunidad a los editores españoles para afianzarse en América (Larraz 2007, 2010; Espósito 2010). Asimismo, como se ha desarrollado anteriormente, en las primeras décadas del siglo se llevan a cabo visitas de catedráticos españoles a América, en un afán por establecer vínculos científicos y académicos con sus pares americanos, lo cual comportó una revisión del rol del libro español en esta empresa cultural que buscaba afianzar los lazos y desarrollar la "vocación americanista" ya presente en el ideario español de la época ${ }^{267}$.

A pesar de los esfuerzos de reorganización empresarial y de desarrollo y puesta en marcha de nuevas estrategias de comercialización y distribución, a comienzos de la década de 1920 las editoriales españolas aún no lograban un despegue significativo. Los debates en torno a las falencias y las dificultades halladas pusieron el foco en un aspecto hasta el momento poco ponderado: los lectores hispanoamericanos. El "descubrimiento" del público lector americano tuvo consecuencias relevantes en las políticas editoriales

\footnotetext{
266 Fernández Moya (2009) menciona algunas de las editoriales españolas que se fundaron desde mediados del siglo XIX hasta las primeras décadas del XX: Espasa, 1860; Hernando, 1828; BaillyBaillière, 1848; Reus, 1852; Montaner y Simón, 1868; Calleja, 1875; Sopena, 1896; Salvat, 1897; Gustavo Gili, 1902; Seix Barral, 1911; Labor, 1915; Biblioteca Nueva, 1917; Ediciones Morata, 1920, entre otras. Esto pone de relieve el crecimiento sostenido del sector y su afianzamiento. Asimismo, algunas de ellas continuaron su labor en el siglo XX y fueron adalides de la industria a ambos lados del Atlántico.

${ }^{267}$ Como se ha señalado en la primera parte de este trabajo, uno de los profesores españoles que visitó el continente americano y que luego difundió el ideario americanista en la Península fue Rafael Altamira, en cuyos escritos hay referencias concretas a la necesidad de reforzar la presencia editorial española como modo de unificación cultural (Espósito 2010: 524-525).
} 
de las empresas y condujo a la idea de concebir un "libro hispánico", es decir, aquel destinado tanto a lectores españoles como hispanoamericanos (Espósito 2010) ${ }^{268}$. Esto repercutió en los criterios de confección de los catálogos de las editoriales y en una progresiva incorporación de obras y autores americanos que se ajustaran a la consigna de "hispánicos", con la consecuente ampliación de la oferta y la puesta en práctica de criterios de selección e inclusión que repercutirían en la conformación de nuevos repertorios.

Los trabajos que abordan el panorama de la industria editorial española y su expansión al continente americano durante las primeras décadas del siglo XX hacen especial referencia a las aristas ideológicas que - junto con las comerciales y políticas- presentaba este afán expansivo, en términos de captación del mercado editorial en lengua española. Durante la década de 1920, las editoriales españolas experimentaron un crecimiento significativo en la Península, tal como se desprende de los numerosos proyectos editoriales que se forjaron en esos años ${ }^{269}$, lo cual fomentó la idea de convertir a España en el nuevo centro cultural del mundo hispánico, lugar hasta entonces ocupado por otras ciudades europeas. Uno de los puntos álgidos de este debate por la reubicación de España en el mapa cultural hispánico fue el derivado de la publicación en el primer número de la revista La Gaceta Literaria de Madrid (abril de 1927) del artículo "Madrid, meridiano intelectual de Hispanoamérica", firmado por Guillermo de Torre. No nos detendremos aquí a revisar nuevamente dicho texto -que

\footnotetext{
${ }^{268}$ En su trabajo, Espósito menciona a José Venegas (1931) como uno de los impulsores de esta idea de ofrecer un corpus de obras que pudiera atraer a los lectores a ambos lados del Atlántico, idea que recupera las aspiraciones de los editores españoles desde finales del siglo XIX de ampliar sus horizontes a partir de expandir la oferta de libros (2010: 530-531).

${ }^{269}$ En el artículo mencionado, Fernández Moya enumera algunas de las empresas editoriales que se crearon en España en la década de 1920: Aguilar, 1923; Juventud, 1923; Calpe, 1918; Espasa-Calpe, 1925 y la Compañía Iberoamericana de Publicaciones, CIAP, 1925; Ediciones Oriente, 1928; Historia Nueva, 1928; Post-Guerra, 1927; Cenit, 1928; Ulises, 1929; Jasón, 1929; Zeus, 1930 y Ediciones Hoy, 1931. Si bien algunas tuvieron una vida efímera, otras se fueron consolidando y alcanzaron un lugar relevante en el ámbito editorial (2009: 66-67).
} 
generó ásperas polémicas en ambas orillas - ${ }^{270}$ sino en tanto se hace eco de las posiciones españolas respecto de su lugar en la industria editorial en el mundo hispánico. A pesar de las declaraciones en pos de un hispanoamericanismo ideal, “absolutamente puro y generoso y no implica hegemonía política o intelectual de ninguna clase" (1), estas expresiones fueron leídas desde América como un intento de apropiación del mercado editorial por parte de empresas españolas en desmedro de las americanas y de la cooptación de sus producciones intelectuales (Larraz 2007; Espósito 2010; Falcón 2011). Entre las estrategias para consolidar la presencia española en el mercado editorial hispánico se encontraba la de la ampliación de los catálogos con la incorporación de autores hispanoamericanos, estrategia que estuvo acompañada por un renovado interés de la crítica por las nuevas voces literarias del continente, lo cual afianzó los lazos entre los escritores americanos y los editores españoles, que vieron en ello la posibilidad de dar a conocer sus obras en un contexto más amplio (Larraz 2007).

Además de estas acciones, la expansión ultramarina de las editoriales españolas se articuló a través de una compleja red comercial, política y cultural que incluía viajes de exploración de las posibilidades de los mercados, contactos con editores americanos $\mathrm{y}$ con instituciones culturales, y finalmente la instalación de sucursales o representaciones de las principales empresas españolas. Por lo tanto, a pesar de los rechazos que suscitó entre parte de la intelectualidad americana el avance español en el ámbito del mercado del libro, a principios de la década de 1930 éstos se habían ido consolidando en América, particularmente en México y en la Argentina ${ }^{271}$. Asimismo,

\footnotetext{
${ }^{270}$ Un análisis vinculado con las repercusiones que tuvo esta nota editorial, escrita por Guillermo de Torre aunque aparecida sin firma, en el ámbito argentino, en especial en los aspectos lingüísticos, se encuentra en el Capítulo 1 de este trabajo.

${ }^{271}$ Si bien es cierto que para comienzos de la década de 1930 el mercado editorial hispanoamericano mostraba signos de crecimiento, parece perdurar en el imaginario de algunos intelectuales españoles la idea de que Madrid continuaba siendo el centro editor por excelencia del mundo hispánico. Por ejemplo, en una carta que Amado Alonso le escribe en 1935 a Alfonso Reyes - en ese momento en México- le expresa: "Algunas veces pienso que debiera V. buscar un editor madrileño (son montañas y hay que hacer
} 
las editoriales devendrán no solo en empresas comerciales, sino que conformarán un entramado de redes intelectuales, económicas y culturales en las que intervendrán diferentes agentes. En el caso de la Argentina, las condiciones preexistentes del mercado editorial local y el paulatino crecimiento de los emprendimientos españoles en ese ámbito, tuvieron su efecto sobre las editoriales. Al respecto señala Espósito:

[las editoriales] se transformaron en espacios privilegiados de intervención pública, en los que los intereses económicos del editor aparecían como mediadores de la relación entre el escritor y los lectores, y al mismo tiempo, se consolidaron como un medio de vida para quienes pretendían hacer de su afición a las letras una profesión (2010: 535-36).

En el mismo sentido se expresa Falcón (2011), al señalar "la consecuente conversión del espacio editorial en un espacio de sociabilidad intelectual y de supervivencia económica, paralelo o sustitutivo de espacios institucionales específicos del campo intelectual, tanto español como argentino" (110, en cursiva en el original).

El estallido de la Guerra Civil Española en 1936 puso fin al auge de la industria editorial en la Península y con él, a la pretensión declarada de convertir a Madrid en el nuevo "meridiano intelectual"272. A partir de este momento, ese eje se trasladará a América, y en particular, a México y a Buenos Aires, centros que ya contaban con un campo editorial desarrollado a partir de la convergencia de diversos factores que habían

de Mahoma) para sus versos. Desde Madrid van los libros a todas partes. Y el valor reconocido" (Carta de Amado Alonso a Alfonso Reyes, 9/4/1935, en Venier 2008: 96. El destacado es nuestro).

${ }^{272}$ En un sentido análogo se expresa el Arzobispo de Toledo y Primado de España, Isidro Gomá Tomás, en ocasión de la celebración del Día de la Raza de 1934, cuando en su discurso "Apología de la Hispanidad", pronunciado en el Teatro Colón de Buenos Aires y luego publicado en la revista madrileña Acción Española, afirma: "Un gran centro de cultura hispanoamericana en España, en comunicación con otros análogos en las naciones de habla española en América, podría ser el foco que recogiera e irradiara la luz homogénea del pensamiento de aquende los mares" (Tomo XI, № 64-65, 1934: 193-230). 
producido un crecimiento del público lector y una modernización de la industria editorial desde las primeras décadas del siglo $\mathrm{XX}^{273}$.

\subsubsection{La impronta argentina}

El panorama trazado hasta ahora pretende dar cuenta de los procesos culturales, económicos y comerciales que llevaron a empresas editoriales españolas a buscar insertarse en el mercado americano, de modo de ampliar sus horizontes y expandir sus posibilidades comerciales. Es indudable que desde fines del siglo XIX la industria editorial peninsular comenzó un proyecto expansionista que le permitiría recuperar un lugar relevante en el continente, proyecto que se articuló con el discurso proamericanista de la época, que buscaba restaurar lazos con las antiguas colonias basado en la idea de cierta "comunidad hispánica", fundada en valores tales como la lengua, la raza y la cultura en común. Esta empresa se llevó adelante a través de diversas estrategias y logró que para las primeras décadas del siglo XX la presencia de editoriales españolas en América estuviera consolidada.

Uno de los países hispanoamericanos que recibió una importante afluencia de representantes y delegados de las empresas editoriales españolas fue la Argentina, que para ese entonces ya contaba con antecedentes editoriales significativos y con una población en creciente proceso de alfabetización, lo que se tradujo en una ampliación del público lector y con él, de las demandas.

\footnotetext{
${ }^{273}$ En el caso de México, en 1934 se funda la editorial Fondo de Cultura Económica, cuyo impulsor fue el intelectual Daniel Cosío Villegas. El sello alcanzó un notable prestigio como editor de obras en el campo de las ciencias sociales y, tal como ocurrió con otros emprendimientos similares, constituyó un espacio para la socialización de figuras del mundo intelectual hispanoamericano. Según ha quedado registro en las cartas intercambiadas entre Alfonso Reyes y Amado Alonso, el mexicano medió para procurar que la editorial distribuyera la Revista de Filología Hispánica, proyectada por Alonso desde el Instituto de Filología de la Universidad de Buenos Aires (en Venier 2008 110-112). Más allá de los resultados de estas gestiones, quedan en evidencia las redes intelectuales y los vínculos editoriales entre figuras del hispanismo del continente.
} 
En su revisión del desarrollo del campo editorial en la Argentina, Margarita Merbilháa (2006) señala que para inicios del siglo XX, dicho espacio se encontraba en pleno proceso de diversificación $\mathrm{y}$ de ampliación de estrategias, debido fundamentalmente a la mayor demanda del público lector, a las mejoras de las condiciones técnicas de producción editorial y a la emergencia de la profesionalización de la actividad intelectual, en particular del periodismo y la literatura. Junto con ello, el clima intelectual creado alrededor del Centenario, atravesado por los debates en torno a la cuestión de la identidad nacional, propició la concreción de proyectos editoriales tendientes a atender las demandas del nuevo perfil del público lector y a afianzar los idearios nacionalistas. Entre las propuestas que vieron la luz en este periodo pueden citarse la Biblioteca La Nación, impulsada por el diario homónimo, cuyo editor responsable fue Roberto J. Payró ${ }^{274}$, iniciada en 1901 y que se constituyó rápidamente en un éxito editorial inédito que puso a disposición del público una colección de textos y autores de diversa procedencia. Otras dos colecciones marcaron el panorama editorial de la época: la Biblioteca Argentina, dirigida por Ricardo Rojas (1915-1928) y La Cultura Argentina, fundada por José Ingenieros, que apareció entre 1915 y 1925. Más allá de las diferencias que presentan ambas colecciones, constituyen intentos concretos de instaurar un corpus de textos y autores sobre los cuales cimentar una tradición nacional a partir de textos considerados fundantes para la cultura ${ }^{275}$.

\footnotetext{
${ }^{274}$ El diario La Nación fue fundado por Bartolomé Mitre en 1870 y ocupaba para inicios del siglo XX un lugar destacado, junto con La Prensa, en el ámbito periodístico nacional. La colección de libros conocida como La Biblioteca La Nación se extendió desde 1901 hasta 1920, con un voluminoso catálogo misceláneo que da cuenta de las aspiraciones de alcanzar a un público amplio. Esta práctica editorial gestada por diarios y periódicos se mantuvo vigente a lo largo del siglo, tal como lo demuestran otras colecciones impulsadas por diarios como Clarín, Página 12 y el mismo La Nación en décadas posteriores, lo cual pone de manifiesto los estrechos vínculos entre periodismo y modos de circulación de la literatura.

${ }^{275}$ Un análisis exhaustivo de ambas colecciones y de su valor fundante del pensamiento nacional es el realizado por Fernando Degiovanni (2007). También Margarita Merbilháa, en su capítulo referido al panorama editorial en la Argentina en las primeras décadas del siglo XX indaga en las características y alcances de estas colecciones (2006).
} 
Las tres colecciones citadas tenían en común el hecho de ofrecer materiales a bajo costo, de manera de llegar al público amplio, aunque con matices diferenciados: más orientada a la variedad y al entretenimiento la del diario, con un perfil más pedagógico y formativo las otras dos. En lo referido a la presencia de literatura española, dado su carácter, ésta sólo está presente en el catálogo de la Biblioteca La Nación, aunque menguada frente a la cantidad de volúmenes que correspondían a textos traducidos de otras literaturas ${ }^{276}$. La escasa presencia de obras y autores españoles puede deberse, entre otras razones, a cierto "antihispanismo" vigente en el periodo de entresiglos, y a la poca relación con las novedades gestadas en España en ese momento. Sin embargo, no deja de ser significativo que la colección se inicie con la publicación de un volumen que incluía obras de la picaresca española: Tres novelas picarescas: Lazarillo de Tormes, sus fortunas y adversidades; Rinconete y Cortadillo y La historia $y$ vida del gran tacaño. En el prólogo que inaugura el volumen $-\mathrm{y}$ con él, la colección- se afirma:

Con el presente volumen, que, como debido homenaje a la pureza del idioma, contiene tres novelas clásicas [...] inauguramos la BIBLIOTECA DE LA NACIÓN, destinada a vulgarizar las mejores obras de entretenimiento que ha producido la literatura universal, tanto antigua como moderna (en Wilson 2005: 246).

La referencia a la "pureza del idioma" puede vincularse con los debates en torno a la "lengua nacional" vigentes en la época y en la necesidad de fijar ciertos usos de la lengua, para lo cual los autores y obras clásicos de la literatura española funcionaban como modelos. De este modo, se conjuga la noción de "canon" con una impronta

\footnotetext{
${ }^{276} \mathrm{Al}$ respecto, Patricia Wilson señala que de los 872 volúmenes que integran la colección completa, 761 corresponden a obras pertenecientes a tradiciones en lengua no española (francesas, inglesas, rusas, italianas, etc.), mediatizadas por las traducciones (2008: 30).
} 
pedagógica y modélica, vínculo que suele aparecer reflejado en las colecciones, combinada en esta propuesta con la idea de "entretenimiento".

En este proceso de afianzamiento de las prácticas de edición en la Argentina se percibe la conjunción de diversos factores de índole económica, técnica y cultural y, en particular, se destaca la emergencia de la figura del editor en el campo intelectual, en tanto mediador entre las nuevas prácticas, el mercado y los agentes de ese espacio cultural (escritores y lectores), con rasgos diferentes de los que presentaba esta figura en las décadas anteriores (Delgado y Espósito 2006). Este "editor moderno" ocupará un lugar central en las redefiniciones del campo editorial y en las articulaciones entre escritores, oferta editorial, público y mercado.

Como se ha señalado, el periodo de entreguerras coincide con un auge de la industria editorial, tanto en España como en América. En la Argentina, en esta época se fundan casas editoriales que intentarán responder a las demandas del público a partir de políticas editoriales diferenciadas. Algunas de ellas corresponden a emprendimientos de inmigrantes, que vieron en esta industria un futuro promisorio basado en la publicación de colecciones populares, de bajo costo, destinadas a un público amplio y diverso ${ }^{277}$. Así verán la luz en el periodo 1910-1930 varias ofertas editoriales con estas características, que expandieron de manera significativa el mercado editorial y moldearon las prácticas de lectura del público, a las que deben sumarse las que editaban libros para lectores letrados, en ediciones de mejor calidad y con una selección más cuidada; las imprentas y librerías que también se ocupaban de publicar materiales

\footnotetext{
${ }^{277}$ Delgado y Espósito (2006) mencionan algunas de las editoriales y colecciones surgidas en esta época, desde la célebre Tor, fundada por el mallorquín Juan Torrendell en 1916, hasta los proyectos de Samuel y Leonardo Glusberg (Ediciones Selectas-América, 1919) y Bernard y Durán (Joyas Literarias, 1922). También se destaca la Cooperativa Editorial Claridad, creada por Antonio Zamora en 1922 y que será una de las empresas editoriales más importantes hasta mediados de 1940. Estas se caracterizaron por orientarse a un público popular y masivo, con ediciones baratas y de periodicidad frecuente.
} 
$\operatorname{diversos}^{278}$, y los proyectos editoriales vinculados con las revistas culturales, órganos de divulgación muy frecuentes en la época, entre los cuales se destacan el de la revista Nosotros, cuya editorial se crea en 1907 conjuntamente con el lanzamiento de la publicación periódica, el de la revista Proa, en 1924 y el de Sur, que se inicia en 1933. Todo esto da cuenta de un complejo entramado de circulación y difusión de libros en diversos formatos, de los criterios editoriales para la confección de las colecciones, de los modos de apropiación de los lectores, de las prácticas de lectura, de la creciente profesionalización y autonomización de la figura del escritor, de la modernización del editor y su rol de mediador; en definitiva, de la conformación de un espacio diferenciado dentro del campo cultural argentino.

Este somero panorama aquí esbozado procura evidenciar la creciente importancia que la industria editorial había adquirido en la Argentina desde comienzos del siglo XX y el papel de los editores y libreros en la conformación de un nuevo público y en la formación literaria de las generaciones de lectores, de modo de contextualizar los proyectos editoriales y las múltiples relaciones entre editores, intelectuales y lectores y, a partir de ellas, las que se establecieron entre editoriales, instituciones y mercado, marco en el cual será posible insertar al hispanismo como ámbito de producción intelectual.

\footnotetext{
${ }^{278}$ Una de las empresas que fue señera en la industria gráfica y editorial argentina fue la Librería Peuser, fundada por un inmigrante alemán, Jacobo Peuser, en 1867. A lo largo de las décadas fue ampliando su negocio inicial de librería y papelería, para convertirse en una empresa gráfica completa. Como dato de color, Miranda Lida refiere que allí trabajó como obrero calificado en encuadernación Mauricio Lida, padre de Raimundo y María Rosa, quien había inmigrado a la Argentina con su familia a comienzos del siglo XX. De este modo, los niños desde pequeños tuvieron acceso al mundo del libro. Más adelante, el padre intentó crear su propia empresa de encuadernación, que si bien no prosperó, puso a sus hijos en contacto directo con los libros, "una selva enmarañada donde los temas, los títulos, los autores, los colores y los idiomas eran difíciles de desentrañar", lo cual marcó el inicio de su formación lectora (2014: 36-38). Más allá de la referencia personal, el dato aporta una mirada sobre los modos de acceso a la lectura de las generaciones hijas de inmigrantes y su inserción en una tradición literaria que se proyectaría en sus trayectorias intelectuales posteriores.
} 


\subsection{El exilio republicano español en la Argentina: articulaciones intelectuales y} culturales (1936- 1950)

La década de 1930 en la Argentina se caracterizó por ser un periodo de convulsionada vida política, que se inició con el derrocamiento del presidente Hipólito Yrigoyen en 1930 y que derivó en un giro conservador de la política. Dicho periodo de la vida política y social argentina se conoce como la "Década infame", durante la cual se intensifican los debates y tensiones entre facciones nacionalistas y antifascistas, en concordancia con los acontecimientos mundiales que también signaron la época.

Uno de los rasgos salientes del periodo es el contraste entre el auge cultural y los procesos de modernización que caracterizan la vida social y cultural argentina, que ha llevado a caracterizarla como los "años dorados" de la cultura (Lida 2014) (Cf. Capítulo 2), y el giro conservador producido en el ámbito político. Así, durante estos agitados años, la Argentina experimentará intensos debates entre posturas ideológicas encontradas; asimismo, el ascenso del nacionalismo, con sus diversas variantes, y las amenazas que suponía para un sector importante de la sociedad el avance del fascismo y del comunismo a nivel mundial, generaban reacciones y polémicas. En ese contexto, se reavivan las posiciones a favor de un hispanismo de cuño conservador, tendiente a reconstruir una tradición común hispánica basada en la lengua, la raza, la religión y la cultura, tal como se desprende de ciertos discursos de la época ${ }^{279}$. En el marco de ese panorama conflictivo, la proclamación de la Segunda República Española en 1931 y el

\footnotetext{
279 La historiografía ha señalado el incremento de discursos prohispánicos asociados con el conservadurismo y ciertas formas del nacionalismo durante la década de 1930 en la Argentina. En tal sentido pueden citarse los discursos de Ramiro de Maeztu, embajador español en la Argentina entre 1928 y 1930, cuyo texto "Defensa de la Hispanidad" influyó en los intelectuales nacionalistas argentinos y latinoamericanos (González Calleja 2007: 618); el discurso pronunciado por el arzobispo Gomá Tomás en ocasión del Día de la Raza en 1934 (Cf. Nota n 80), así como revistas y publicaciones que expresaban posturas prohispanistas (Criterio o Sol y Luna, por citar algunas de las más difundidas). También estos discursos están presentes en algunos de los miembros de la Academia Argentina de Letras, tal como aparecen publicados en su Boletín (Cf. Capítulo 2). Recuérdese asimismo la polémica desatada por la publicación del artículo de Guillermo de Torre "Madrid, meridiano cultural", en 1927 (Cf. Notas n 111$113)$.
} 
estallido de la Guerra Civil en 1936 ubicaron a España y su situación política en el centro de los debates en el campo sociocultural argentino ${ }^{280}$.

En el plano político, el gobierno de cuño conservador del periodo había comenzado a aplicar medidas restrictivas para el ingreso de inmigrantes, que se fueron endureciendo durante esos años (Schwarsztein 2001; Ortuño Martínez 2012). Desde inicios de la década de 1930 se habían incrementado las medidas gubernamentales tendientes a restringir el ingreso de inmigrantes (Domenech 2011). El estallido de la Guerra Civil Española, junto con los cambios en el panorama mundial, determina que el gobierno argentino llevara adelante una política restrictiva respecto de la inmigración. A partir de 1936 se produce un cambio significativo en el perfil de la inmigración de origen español, que dejó de ser casi exclusivamente de carácter socioeconómico, es decir, aquella que había llegado al país desde finales del siglo XIX para incorporarse al mercado laboral como mano de obra, y fue sustituida por la figura del "exiliado político", derivada del conflicto español ${ }^{281}$. Este cambio en la figura del emigrante generó tensiones que se traslucieron en las políticas inmigratorias restringidas que se aplicaron en la época (Ortuño Martínez 2012), entre las cuales puede citarse el Decreto

\footnotetext{
${ }^{280}$ En 2012 se publicó en Madrid una colección que aborda el impacto de la Guerra Civil Española en el campo intelectual hispanoamericano, coordinada por Niall Binns. En el caso de la Argentina, el autor señala que el conflicto no dejó indiferente a ningún sector del campo intelectual, ya sea a favor de la República o del bando fascista. Entre los ejemplos de escritores argentinos que expresaron a través de sus producciones sus posturas respecto de la situación española se pueden citar a Elías Castelnuovo, quien en 1938 publicó en la editorial Claridad su novela Resurrección: impresiones de una conciencia libre sobre la epopeya heroica del pueblo español, considerada una de las primeras referencias literarias a la guerra civil escrita en Hispanoamérica, de claro signo republicano, o la traducción que realiza Leopoldo Marechal del poema de Paul Claudel "Aux martyrs espagnols" (1937), el mismo año de su publicación, una suerte de elegía a las víctimas católicas del conflicto. Ambas posturas pueden funcionar como ejemplo de la movilización ideológica que el conflicto generó en los intelectuales argentinos.

${ }^{281}$ En su investigación, Ortuño Martínez distingue, a fines metodológicos, los conceptos de "exiliado" del "emigrante político", en tanto el primero es obligado a marcharse del país a causa de sus ideas o actividades políticas, mientras que el segundo elige marcharse por no compartir la situación política o social, a lo que suelen sumarse factores económicos. Según su perspectiva, en el conjunto de inmigrantes españoles llegados al país en esta época confluyen ambas categorías (2012: 22-25).
} 
92.621, de octubre de 1936, en el que se fijaban nuevas normas para el ingreso de inmigrantes al país ${ }^{282}$.

A pesar de esas limitaciones impuestas por el gobierno - a diferencia de las posturas de otros países hispanoamericanos, como México, Chile y República Dominicana, que favorecieron la inmigración de españoles durante la conflagración-, la Argentina fue uno de los países más elegidos por los emigrantes españoles. Los estudios acerca del exilio español de la década de 1930 coinciden en algunos aspectos que fueron determinantes para esta elección, y que pueden sintetizarse en la importancia de la comunidad española asentada en la Argentina desde finales del siglo XIX, organizada a través de asociaciones e instituciones sociales y culturales de consolidada trayectoria, la presencia de importantes redes intelectuales, culturales y económicas hispano-argentinas establecidas desde décadas anteriores y también la existencia de microrredes familiares, que funcionaban como agentes convocantes para aquellos que se veían compelidos a abandonar su tierra (Schwarsztein 1991; de Zuleta 1992, 1999; Falcón 2011; Ortuño Martínez 2012). Este flujo inmigratorio se inició en 1936, apenas comenzado el conflicto, y se extendió hasta la década de 1950, con intermitencias. Dadas las restricciones de la política inmigratoria vigentes, un número importante de exiliados logró instalarse en la Argentina a través de medios ilegales o de artimañas, lo cual parece ratificar el interés que este país revestía para los emigrantes ${ }^{283}$.

\footnotetext{
${ }^{282}$ El Decreto mencionado, proveniente del Ministerio de Agricultura, promulgado bajo el gobierno del General Agustín P. Justo, ponía el foco en el perfil de los inmigrantes que a los que debía negarse el ingreso: "extremar las medidas de control y vigilancia del movimiento de pasajeros con destino al país, tendientes a evitar in-filtraciones en el mismo de elementos que puedan constituir un peligro para la salud física o moral de nuestra población o conspiren contra la estabilidad de las instituciones creadas por la Constitución Nacional" (citado en Domenech 2011: 38). Durante los años siguientes, estas medidas fueron intensificándose, en correlación con el aguzamiento de los conflictos a nivel mundial.

283 Entre los artilugios a los que recurrían los emigrantes que no contaban con la documentación necesaria pueden citarse las "cartas de llamada", enviadas por residentes argentinos a familiares españoles, las "visas de turista" o las "visas de tránsito", los pases a través de países limítrofes, el uso de documentación de otras personas, que muchas veces eran apócrifas o adulteradas (Ortuño Martínez 9698).
} 
En su análisis del proceso de emigración española a la Argentina iniciado en 1936, Ortuño Martínez indica que los inmigrantes que llegaron a tierras argentinas pertenecían a extracciones sociales diversas, muchos de ellos comerciantes o trabajadores manuales o agrícolas, lo cual matiza un poco el estereotipo consolidado que equipara al exiliado político con el intelectual. Si bien es cierto que un grupo importante de arribados contaban con antecedentes de profesiones u oficios vinculados con la cultura (catedráticos, maestros, periodistas, escritores, actores y directores teatrales), estos no conforman el núcleo más significativo (88-92), aunque es menester reconocer que este grupo de exiliados fue el que tuvo mayor visibilidad a partir de su inserción en el campo cultural argentino.

\subsubsection{Exiliados españoles en el campo cultural y académico}

Para los objetivos de este trabajo, nos interesa especialmente revisar los modos en que se articuló la inserción de los intelectuales españoles exiliados en el campo cultural argentino, con especial énfasis en aquellos que dejaron su impronta en el ámbito académico y el editorial.

Uno de los grupos de intelectuales que arribaron a la Argentina y lograron una incorporarse al campo académico argentino fueron los profesores y catedráticos que contaban con una trayectoria en España y que pudieron continuar con sus actividades en el país, fundamentalmente gracias a las gestiones de residentes o por invitaciones de universidades o institutos. En el ámbito de las Humanidades, algunas figuras resultaron señeras en sus disciplinas y dejaron su huella en las instituciones en las que se desempeñaron. Si bien un número importante se afincó en Buenos Aires o La Plata, que contaban con universidades establecidas y de prestigio, otros lo hicieron en 
universidades del interior del país, donde desarrollaron sus carreras ${ }^{284}$. Dentro de los estudios hispanistas, la figura de Américo Castro, quien había sido el primer director del Instituto de Filología de la Universidad de Buenos Aires en 1923, también está asociada al exilio español, ya que por motivos de discrepancias ideológicas, Castro regresó a la Argentina en 1937 y retomó sus tareas como docente e investigador y participó de actividades culturales hasta su exilio definitivo en los Estados Unidos en 1942.

Otro conjunto de exiliados del ámbito intelectual fueron los escritores, quienes desarrollaron una ingente producción tanto literaria como periodística en la Argentina. Emilia de Zuleta $(1992,1999)$ ha indagado en la presencia de exiliados españoles en este ámbito y destaca las intervenciones en los diarios y revistas de la época, que contaron entre sus colaboradores con importantes figuras de intelectuales españoles. En el caso de los diarios, dos de los de mayor circulación en la época concentraron las contribuciones de los emigrados: La Nación y La Prensa ${ }^{285}$. También las páginas de las revistas de la época, algunas de ellas de gran difusión popular, fueron un espacio para la participación de los intelectuales españoles: El Hogar, Leoplán, Atlántida, así como aquellas de origen español.

Un capítulo aparte en la conformación de las redes intelectuales entre exiliados y el campo cultural argentino lo constituyen las revistas culturales, espacios en los que convergieron tanto intelectuales argentinos como extranjeros, entre los cuales los

\footnotetext{
${ }^{284}$ En el Capítulo 2 de esta tesis se revisa la presencia de profesores extranjeros en la génesis y desarrollo de algunos centros e institutos importantes del país vinculados con las Humanidades. Entre los españoles mencionados se encuentran algunos que llegaron en la década de 1930, impulsados por los acontecimientos políticos de su país, como Lorenzo Luzuriaga y Manuel García Morente, que se desempeñaron en la Universidad Nacional de Tucumán, Claudio Sánchez Albornoz y Joan Corominas, en la Universidad Nacional de Cuyo, Nicolás Sánchez Albornoz — hijo de Claudio- y Manuel Lamana, en la Universidad Nacional del Sur, entre otros. Para el caso puntual de la Universidad Nacional del Sur, resulta esclarecedor el trabajo de Federico Vitelli (2014).

${ }^{285}$ Entre los colaboradores españoles del diario La Nación, Emilia de Zuleta menciona a Ramón Gómez de la Serna, Guillermo de Torre, Francisco Ayala, José Ortega y Gasset, Rafael Alberti y Rosa Chacel. También enviaron sus textos, desde Estados Unidos, Jorge Guillén y Juan Ramón Jiménez. En el caso de La Prensa, allí escribieron, entre otros, Azorín, expatriado en Francia, Ramón Pérez de Ayala y María de Maeztu.
} 
españoles tuvieron una destacada presencia. Las revistas culturales, por su particular idiosincrasia, se definen y (re)definen a partir del perfil de su programa y de sus colaboradores. Horacio Tarcus (2007), al referirse a las revistas culturales afirma:

[...] las revistas han sido (y siguen siendo) los vehículos privilegiados a través de los cuales se expresan los colectivos humanos, ya sean políticos, literarios, artísticos, científicos o filosóficos. Las revistas expresan a un grupo, les dan cohesión y contribuyen a forjar su identidad [...] Y a través de los debates frecuentes entre las revistas - porque las revistas son los vehículos privilegiados del debate cultural - se configura un campo de fuerzas donde los distintos colectivos luchan por la hegemonía cultural y reconfiguran incesantemente sus identidades (1).

En ese sentido, la presencia de escritores españoles en revistas culturales que ya gozaban de prestigio en el campo cultural argentino, como Nosotros o Sur - aunque con programas y estéticas diferenciados - deviene en modos de legitimación o de consagración y se articula con los debates estéticos e ideológicos que se expresan en las publicaciones. Así, mientras que la presencia de escritores españoles del periodo del exilio en relativamente escasa en Nosotros, en Sur la impronta española es notable, no sólo por el número de colaboraciones, sino por los lugares que ocuparon algunos de ellos, como el caso de Guillermo de Torre, que fue secretario de la revista ${ }^{286}$.

Además de la participación en los medios gráficos y revistas, la vocación por generar ámbitos propios para la expresión genuina del ideario español llevó a la creación de revistas que de Zuleta menciona como el momento de "la dominante española", iniciado a partir de 1942. En esta línea incluye las revistas en las que

\footnotetext{
${ }^{286}$ Gran parte de los colaboradores de Sur aparecen también en los suplementos culturales de los diarios de la época, como se ha señalado, lo cual pone de manifiesto la conformación de redes que incluyen a medios periodísticos, culturales y también a empresas editoriales, como se verá más adelante. Esto permite dar cuenta de la impronta que un grupo de intelectuales españoles tuvo en el campo cultural argentino.
} 
predominaron las contribuciones españolas sobre temas del contexto cultural del momento, como De mar a mar (1942), Correo Literario (1943) o Realidad (1947) 287.

También fue significativa la llegada a la Argentina de exiliados vinculados con el mundo teatral: directores, autores, actores y músicos se instalaron en Buenos Aires y en otras ciudades de interior, donde continuaron desarrollando sus actividades artísticas y llegaron a ocupar un lugar destacado en la escena nacional ${ }^{288}$.

La sucinta reseña realizada intenta dar cuenta de las múltiples articulaciones que se fueron tramando entre el grupo de intelectuales españoles que emprendió el viaje del exilio a la Argentina y las instituciones y formaciones locales —en términos de Raymond Williams [1977] (1980) — lo cual dio como resultado una particular conjunción que dejó su impronta en el campo cultural argentino de medio siglo. En ese contexto, resulta de interés para esta investigación indagar en los modos en que esta impronta española signada por la experiencia del exilio repercutió en la configuración del hispanismo argentino. Una parte de esos aportes se vincula con la presencia de figuras intelectuales de relieve que se insertaron en el campo académico y cultural, y otra parte significativa la constituyen las relaciones entre la industria editorial y las condiciones ideológicas, materiales y culturales que posibilitaron esas convergencias y que condujeron a la expansión del mercado del libro y con él, a los procesos de conformación de un “canon hispánico” en la Argentina.

\footnotetext{
287 La revista Realidad, en la que hubo una notable inclusión de intelectuales españoles, ha sido considerada también como uno de los órganos de expresión de un grupo de figuras del ámbito intelectual que se oponía a las políticas del gobierno peronista electo en 1946, junto con otras publicaciones de la época (Cf. Nota $\left.\mathrm{n}^{\circ} 153\right)$.

${ }^{288}$ Aunque excede los fines de este trabajo, resulta significativo mencionar que en los últimos tiempos se ha renovado el interés de investigadores argentinos por estudiar las relaciones entre el exilio de la posguerra española y la escena teatral argentina. A modo de somerísimo panorama, pueden mencionarse el libro de Osvaldo Pelletieri Dos escenarios: intercambio teatral entre España y Argentina (2006), y los trabajos de Marcela Arpes (2008) y de Paula Simón (2014).
} 


\subsubsection{Exiliados españoles en la industria editorial}

Otro de los tópicos que se ha cristalizado en relación con el exilio español en la Argentina - junto con el de la preeminencia del "exiliado intelectual" - es el que asocia este fenómeno con la expansión de la industria editorial en el país. Es sin dudas incuestionable que la llegada de editores y libreros y otros profesionales del ámbito editorial provenientes de España y su inserción activa en el campo editorial impulsó el crecimiento y expansión de esa industria; sin embargo, es necesario poner en relación esa construcción con otros factores que incidieron en ese proceso (Falcón 2011). Al respecto, la autora declara:

[...] en el plano simbólico, en el plano de las representaciones compartidas [...] el vínculo entre "exilio español" y "mundo editorial" se extiende al auge editorial en su conjunto [...] A este vínculo obligado, se suma un supuesto carácter fundacional. En efecto, la imagen de una tierra yerma en materia editorial aún es recurrente (111).

Estas reflexiones no se proponen desconocer o minimizar el impacto de la incorporación de agentes del mundo editorial español en el ámbito argentino, sino moderar o matizar ciertas afirmaciones que han instalado la necesaria relación de causalidad entre exilio español y expansión de la industria editorial argentina.

Algunos de los factores que propiciaron esa relación ya han sido mencionados: la magnitud de la presencia de la comunidad española en el país y de sus instituciones, los lazos comerciales y culturales ya existentes, a los que se le suma, para el caso de la industria editorial, el progresivo afianzamiento de este sector en el ámbito argentino, como se ha visto previamente. Esto posibilitó que la incorporación de profesionales del área de la edición y comercialización del libro no se hiciera en una "tierra yerma", sino en un terreno ya consolidado desde finales del siglo XIX, a lo que se agrega la ampliación de las demandas del público lector, que en los primeros años del siglo XX 
experimentó en Argentina - por los efectos de la difusión de las políticas de alfabetización impulsadas desde el Estado, entre otras causas- y que ofrecía un mercado ávido de materiales de lectura. De la conjunción de estos elementos, junto con causas económicas y políticas derivadas del conflicto armado en España, emergerá un panorama particularmente fértil para la expansión del mercado editorial, en el que la Argentina pasará a ocupar ese "centro" que se había reclamado años antes para Madrid. Dicho desplazamiento tendrá efectos decisivos sobre la industria editorial argentina en las siguientes dos décadas, que se conocen con el nombre de "época de oro" (de Diego 2006), rótulo que condensa no sólo el auge económico del sector, sino fundamentalmente sus efectos en el campo cultural tanto argentino como hispanoamericano $^{289}$.

Este nuevo "giro hispanista" del campo intelectual argentino puede explicarse a partir del cambio en la visión acerca de España, asociada no ya con cierto atraso y conservadurismo, sino con un ideario democrático y liberal, y además, con la apertura que esta industria editorial ofrecía a los escritores locales, quienes de este modo entreveían las posibilidades de acceder a un mercado más amplio (Falcón 2011: 120). De esta manera, se entrecruzan cuestiones de índole cultural, económica y de políticas editoriales y lingüísticas, que se articulan con las condiciones preexistentes favorables para la industria del libro y con los cambios y transformaciones del panorama español de la época, en el cual la figura del emigrado tendrá un relieve particular.

Los estudios realizados en los últimos tiempos acerca de las relaciones entre emigrados españoles y empresas editoriales han focalizado particularmente en ciertas

\footnotetext{
${ }^{289}$ Entre estos efectos se destaca el tema de la lengua, cuyo debate de larga data en el campo cultural argentino incidió también en las políticas lingüísticas de las editoriales. Así, como señala Falcón, el predominio de la Argentina en el mercado editorial hispánico a partir de la década de 1940 no se tradujo en la adopción de rasgos propios de las variedades locales - como el uso del "voseo"- sino que la perspectiva lingüística adoptada será de corte "elitista y universalista", situación que puede explicarse por el prestigio de los editores españoles en dicho campo (2011: 115).
} 
figuras de editores y su vinculación con la creación o el afianzamiento de casas editoriales, muchos de ellos de origen español que llegaron a la Argentina antes o después de la contienda civil (de Sagastizábal 1995; de Zuleta 1999; de Diego 2006, 2015; Lago Carballo y López Villegas 2007). De allí que en la reconstrucción del escenario editorial del periodo — que coincide con el auge de este sector- aparezcan asociados los nombres propios de los editores con las empresas editoriales, en una suerte de expresión metonímica que resume esta conexión, a la vez que contribuye a su consolidación en el plano simbólico, plano en el que la vinculación entre emigración española y auge del campo editorial se presenta como determinante.

Asimismo, la expansión y la complejización del sector editorial durante el primer cuarto del siglo condujeron a la búsqueda de marcos legales y de representación de los actores involucrados; así, en 1938 se realizó en Buenos Aires el Primer Congreso de Editores, y ese mismo año se constituye la Sociedad Argentina de Editores, base de lo que constituiría en 1941 la Cámara Argentina del Libro. De este modo, para comienzos de la década de 1940, la industria editorial había alcanzado un alto grado de desarrollo y la asociación posibilitó el afianzamiento del sector y una mayor incidencia —al menos desde el plano simbólico — en el campo cultural ${ }^{290}$.

\footnotetext{
290 Según señala de Sagastizábal (1995), los objetivos fijados en el estatuto de la organización apuntaban a resguardar la industria, fomentar la capacitación profesional y lograr protección por parte del Estado. También el autor destaca la "clara convicción de defensa del libro de origen argentino" implícita en los objetivos institucionales (123). Si bien la Cámara estaba conformada por diversos agentes del campo editorial, los editores ocuparon un lugar relevante en la gestión de la organización. Uno de sus presidentes fue Gonzalo Losada quien ejerció el cargo durante dos periodos, lo cual manifiesta la gravitación del editor español en el sector a la vez que contribuye a afianzar en el ideario la impronta española en el ámbito argentino y su preeminencia durante estas décadas.
} 


\subsection{Los catálogos editoriales y la conformación de colecciones: canon hispánico y políticas editoriales (1940-1970)}

En los últimos tiempos, como se ha venido señalando, son numerosos los trabajos que han recuperado las historias de las editoriales fundadas durante las décadas de $1920 \mathrm{y}$ 1930, con particular énfasis en aquellas creadas a partir de la llegada a la Argentina de profesionales y libreros españoles que coinciden con el periodo del exilio republicano, y también se han recobrado las trayectorias vitales de ciertas figuras señeras en el campo editorial. Estos estudios realizados ponen de manifiesto la relevancia de este campo de investigación y han permitido reconstruir el derrotero de las casas editoriales y de sus impulsores. De allí que los objetivos de esta investigación se focalicen en indagar en los perfiles propios que algunas de esas editoriales fueron delineando a partir de las colecciones diseñadas e impulsadas y su relación con los procesos de conformación y difusión de un canon hispánico en el ámbito argentino. El recorte sugerido incluye a las editoriales que publicaron colecciones en las que la presencia de libros y autores españoles resulta significativa y ello implica incluir empresas con fuerte impronta española y otras de origen argentino, de modo de analizar los criterios que subyacen en su confección, sus variantes particulares, los principios de selección y exclusión que las organizan, y así proyectar sus vinculaciones con la construcción de un hispanismo de cuño argentino.

Para ello, se han seleccionado aquellos sellos editoriales que impulsaron colecciones en las que la inclusión de textos y autores españoles resulta significativa en términos no solo cuantitativos sino cualitativos, dada su relación con nociones como "clásico" o "canónico" que atraviesan los procesos de conformación de los repertorios ofrecidos y que permiten reconocer variaciones y permanencias. Asimismo, la presencia en dichos proyectos editoriales de figuras relevantes del ámbito académico e intelectual 
posibilita reconstruir las redes que se fueron tejiendo en torno a las editoriales y sus integrantes y otros espacios del campo intelectual argentino. Esto implica considerar a las editoriales no solo como empresas comerciales, sino como espacio de sociabilidad intelectual, tal como las define Falcón (2011).

Desde la perspectiva de la sociología cultural, las editoriales también pueden pensarse como una forma de intersección entre las nociones de "instituciones" y "formaciones", en conceptos de Raymond Williams (1980), en tanto funcionan como moldeadoras de prácticas culturales y como agentes activos en la construcción y legitimación de tradiciones literarias. Así, las estrategias desarrolladas por las editoriales configuran un espacio delimitado en el campo cultural y operan como mecanismos de inserción de los autores y los textos en dicho campo (Bourdieu 2012). En ese sentido, las empresas editoriales ocupan un lugar particular, atravesado por variables de valor no solo económico, sino fundamentalmente simbólico, que les confieren un estatuto propio en el ámbito de las instituciones culturales.

Así entendidas, las editoriales, sus políticas y sus estrategias ofrecen una perspectiva de análisis productiva para reflexionar acerca de las relaciones entre mercado editorial, público lector, canon y prácticas de lectura en el contexto argentino de mediados del siglo XX, a partir del examen de las colecciones que dichas empresas llevaron adelante, de las principales figuras involucradas en los proyectos, de los propósitos y alcances fijados y del corpus delimitado para cada propuesta editorial.

El diseño de colecciones es una de las estrategias utilizadas por las editoriales para articular sus ofertas con el mercado y con el público lector al que se aspira llegar y permiten a la vez organizar sus políticas editoriales según criterios económicos, culturales, estéticos y también ideológicos, y otorgarle permanencia y previsibilidad a la 
oferta. Esta funcionalidad de la organización en colecciones es reconocida por de Sagastizábal (1995: 162-163):

[las colecciones] tienen un doble objetivo: por un lado, constituirse en una propuesta orgánica sobre determinados temas, ya sea porque se refieren a un mismo aspecto del conocimiento, ya sea porque están pensadas para un público determinado; por otro lado, generar un mercado que se continúe y que incluso facilite cierta previsibilidad en cuanto a la cantidad de ejemplares a editar, precios que el mercado acepta, etc.

Para cumplir con este objetivo, en esta parte de la investigación se revisarán las trayectorias de algunas de las empresas editoriales más relevantes del campo editorial argentino y se propondrá una lectura analítica de sus catálogos, repertorios que manifiestan las tensiones entre los procesos de selección y exclusión, de jerarquización y clasificación de obras y autores destinados al público lector, en los cuales la noción de “canon" subyace de manera más o menos implícita.

Sánchez Vigil define a los catálogos editoriales como

Memoria o inventario de los fondos de una editorial con descripción de sus contenidos, cuya finalidad es su presentación y difusión [...] Los catálogos se constituyen así en el referente identificador de las editoriales, su contenido es la carta de presentación, el resumen científico e incluso ideológico (2006: 263).

Por su carácter identitario, dicho autor considera que estos repertorios constituyen "documentos imprescindibles en el estudio de la edición desde todos los puntos de vista: histórico, cultural, socioeconómico, etc.” (2008: 115). En tanto instrumento para la difusión de las obras publicadas por una entidad (pública o privada), el catálogo excede su carácter de lista o inventario, ya que es una forma concreta de intervención en el campo editorial a través del material ofrecido y su modo de organización. Desde esta perspectiva, es posible leer el catálogo como un corpus 
particular que condensa facetas de índole cultural, económica e ideológica y que se presenta como un conjunto cohesivo de obras y autores organizados según criterios más o menos explícitos. Su valor como documento resulta clave para otorgarle densidad histórica y cultural a los proyectos editoriales, tal como lo señala Judith Gociol (2012: 20):

Leídos con distancia histórica, los catálogos de los fondos editoriales pueden dar cuenta de una experiencia y dejar registro del modo de concepción de un proyecto y de un discurso; permiten entrever los criterios de lectura y de pensamiento de una época, los actores sociales que se entienden relevantes, los valores culturales estimados prioritarios, los modelos económico-políticos impuestos; cómo es mirada la tradición y cómo las innovaciones y las rupturas $[\ldots]$.

Desde el punto de vista de su conformación, los catálogos ofrecen una mirada puntual acerca de las editoriales, de sus políticas de publicación y también de los lectores a los que van dirigidos. En este sentido, realizar un análisis de algunos de estos dispositivos permite examinar ciertos aspectos referidos a los criterios de conformación de las colecciones, las elecciones explícitas e implícitas, los perfiles propuestos, y ponerlos en relación con el objeto de esta investigación.

Desde esta perspectiva, este acercamiento planteado permitirá indagar en las modulaciones que fue adquiriendo la conformación de un canon hispánico en el campo editorial argentino de mediados del siglo XX.

\subsubsection{Espasa Calpe: la literatura española de "Clásicos Castellanos" a "Austral"}

El nombre de la editorial Espasa Calpe ha estado ligado al mercado editorial español e hispanoamericano desde finales del siglo XIX. No es esta la ocasión para reseñar la historia de la empresa; baste con señalar algunos momentos clave que permitan delinear 
su impronta en el panorama editorial dentro y fuera de la Península. Creada en 1925 a partir de la fusión de dos compañías españolas dedicadas a la edición —Espasa, que lleva el nombre de su fundador, con una dilatada trayectoria en la publicación de obras de referencia y enciclopedias desde la segunda mitad del siglo XIX, y el grupo CALPE (Compañía Anónima de Librería, Publicaciones y Ediciones ${ }^{291}$ ), fundado en 1918 bajo la impronta de Nicolás Urgoiti, que aglutinaba un conjunto de empresas papeleras y editoriales españolas - pronto adquirió un lugar destacado en el ámbito editorial de la Península $^{292}$. Como se ha señalado profusamente, el periodo de entreguerras en España coincidió con la expansión del mercado editorial, la ampliación del público lector a partir de la puesta en práctica de estrategias editoriales destinadas a la difusión masiva de textos y a la modernización de la industria editorial. En ese contexto, Espasa-Calpe ocupará un lugar relevante en particular a partir de dos líneas editoriales definidas: por un lado, la continuación de la publicación de la renombrada Enciclopedia EspasaCalpe, iniciada en 1907, obra de referencia indiscutida para generaciones de hispanoparlantes, y por otro, la edición de colecciones especializadas, destinadas a poner al alcance de un público más amplio un conjunto de obras seleccionadas según diversos criterios y en las cuales tendrán injerencia figuras del mundo intelectual de la época. Una de las figuras centrales en la vida de la empresa editorial fue el filósofo español José Ortega y Gasset, quien había iniciado su relación con el mundo editorial

\footnotetext{
${ }^{291}$ Respecto del significado de la sigla que da nombre a la empresa, se han hallado variantes en los textos consultados: en algunos aparece como se ha consignado (López Cobo 2013, Olarra Jiménez 2003, Sánchez Vigil 2006) y en otros del mismo Sánchez Vigil, por ejemplo (2004) figura como "Compañía Anónima de Librería y Publicaciones Españolas".

${ }^{292}$ Para una revisión de la historia de las casas editoras Espasa y CALPE y su posterior fusión pueden consultarse Olarra Jiménez (2003) y Sánchez Vigil (2004; 2006). En el caso particular de la empresa CALPE, a pesar de su corta existencia (1919-1925) logró publicar una ingente cantidad de obras de diferentes disciplinas — entre las cuales la literatura tuvo un lugar central — que ampliaron notablemente la oferta editorial en España, parte de la cual luego se extenderá al continente americano. A título informativo, Sánchez Vigil (2006) enumera 46 series y colecciones publicadas por CALPE según figuran en el Catálogo de 1923.
} 
junto con Urgoiti en los inicios de $\mathrm{CALPE}^{293}$. Ortega no sólo fue asesor editorial y director de colecciones, sino que publicó en ella gran parte de su obra y dejó su impronta en la trayectoria de la editorial a lo largo de más de veinte años ${ }^{294}$.

Entre las colecciones más renombradas de la empresa pueden citarse, además de la Enciclopedia, la "Colección Universal", iniciada por CALPE en 1919, que fue pionera en Europa de las colecciones llamadas "de bolsillo", destinadas a llegar a un público amplio. Esta colección se editó hasta 1935 e incluyó más de mil volúmenes y sería el antecedente inmediato de la "Colección Austral", creada pocos años después en el ámbito argentino. Otra de las colecciones de más larga duración publicadas por Espasa-Calpe fue "Clásicos Castellanos", originada en una serie anterior editada por La Lectura en 1910, cuyos fondos fueron adquiridos luego de la fusión de la empresa ${ }^{295}$. De este modo, la colección nace de la unión entre el proyecto intelectual de los discípulos de Menéndez Pidal, destinado a brindar un repertorio de textos considerados "clásicos" de la literatura castellana fijados con rigor filológico, según las premisas de trabajo delineadas por el Centro de Estudios Históricos de Madrid, y una empresa editorial que ya contaba con inserción en el mercado de la época. A lo largo del siglo XX, esta

\footnotetext{
${ }^{293}$ En el caso del proyecto editorial de CALPE (1918-1925) participaron, además de Ortega, intelectuales relevantes como Gregorio Marañón, Manuel García Morente o Ramón Menéndez Pidal, entre otros, lo cual expresa el carácter cultural que impulsaba el programa editorial.
}

${ }^{294}$ En el caso de Ortega y Gasset, éste continuará vinculado activamente con la editorial luego de su fusión con Espasa, aunque su influencia dentro de las decisiones de la empresa fue menguando a partir de 1940. Una muestra del peso de Ortega en las decisiones editoriales puede rescatarse en una carta de 1932 que el escritor mexicano Alfonso Reyes le envía desde México a Amado Alonso, en ese momento en la Argentina, donde se queja de la actitud de Ortega para con sus obras: "me entristeció para siempre la mala voluntad de José Ortega y Gasset, que me dejó rechazar cortésmente por CALPE [...] acudí después a él para publicar unos libros y no me ayudó" (en Venier 2008: 67).

Respecto de los avatares de la relación entre Ortega y Gasset y la empresa editorial a lo largo de más de veinte años, resulta iluminador el trabajo de López Cobo (2013).

${ }^{295}$ Los orígenes de la colección se ubican en 1910, cuando un grupo de intelectuales nucleados en el Centro de Estudios Históricos de Madrid inicia la empresa de editar una colección que reuniera las obras y autores considerados "clásicos" de la literatura en lengua castellana bajo la impronta filológica impulsada por el entonces director del Centro, Ramón Menéndez Pidal. Dicho proyecto se materializó a partir de la relación con una empresa española de reconocida trayectoria: la editorial La Lectura, fundada a principios de siglo por Francisco Acébal y que contaba con experiencia en ediciones de prestigio (Cf. "Nota preliminar" en el Catálogo de 1980). 
colección mantuvo los principios sostenidos desde su creación: rigor metodológico y precisión crítica y filológica (García 1989: 95), lo que la ubicó en un lugar destacado en el conjunto de las ediciones de obras españolas y le otorgó permanencia en el tiempo, lo cual manifiesta la relevancia de la literatura española, y en particular de los considerados "clásicos", en el concierto de las publicaciones editoriales de la empresa $^{296}$. De este modo, Espasa-Calpe se constituye desde los comienzos como una sólida empresa editorial, con un amplio y variado catálogo y un prestigio consolidado en el sector, lo cual le permitió al sello posicionarse activamente en el mercado del libro hispano y condujo a proyectarla en el territorio hispanoamericano, a fin de expandir sus mercados y ampliar la distribución de su ingente producción editorial ${ }^{297}$.

El advenimiento de los sucesos políticos y sociales que atravesó España durante la década de 1930 impulsó la decisión de los directivos de Espasa-Calpe de convertir a la filial argentina en una sociedad anónima en 1937, al frente de la cual fue nombrado gerente el español Manuel Olarra, con una extendida trayectoria en la editorial CALPE primero, y en su fusión con Espasa más tarde. Respecto de los propósitos declarados de esta iniciativa, señala López Cobo:

Espasa-Calpe Argentina nacía para garantizar la producción y distribución de los fondos Espasa- Calpe de Madrid en Iberoamérica, para ampliar la nómina de dichos fondos con nuevos proyectos, bibliotecas y colecciones, y para dar salida

\footnotetext{
${ }^{296}$ En 1980 Espasa Calpe S.A. de Madrid publicó un completo catálogo de los títulos publicados desde los inicios de la colección a principios del siglo XX, que incluye diferentes índices (temáticos, de autores, de títulos y de los colaboradores). Para ese momento, la colección reunía 223 títulos, algunos de los cuales habían sido reeditados en varias oportunidades. Además, el catálogo — concebido como un material informativo pero también estético - cuenta en cada sección con imágenes que acompañan los datos. El conjunto resulta un compendio no sólo de los libros que fueron editados y reeditados a lo largo de las décadas, sino una muestra del valor y la estimación que dichos textos han mantenido y su lugar privilegiado en ámbito literario y en la formación de los lectores.

${ }^{297}$ En el marco de ese proceso de expansión empresarial, CALPE había enviado en 1923 a Julián Urgoiti - familiar del fundador - a un viaje por América, cuyo resultado fue la apertura de una delegación de la editorial en Buenos Aires, con lo cual se consolida el lugar de la editorial española en el mercado americano y en la difusión de sus publicaciones. Posteriormente, ya creada Espasa-Calpe, llegará al país en 1928 para desempeñarse en la delegación local de la firma Gonzalo Losada, figura clave del desarrollo editorial argentino a partir de finales de la década de 1930.
} 
en el subcontinente americano a los títulos que sufrían la censura por las autoridades españolas (2013: 48).

Aparecen así resumidos los objetivos empresariales para la sucursal argentina: insertar en el mercado americano los fondos de la editorial madrileña, ampliar dichos fondos y evadir la censura impuesta. Este será el origen de uno de los emprendimientos editoriales más importantes del campo argentino durante las décadas siguientes, en particular a partir de las políticas editoriales puestas en práctica.

Uno de esos "nuevos proyectos" desarrollados por la nueva sucursal fue el de la “Colección Austral”, que saldrá a la luz el mismo año de la creación de la sede argentina. Esta colección se convertirá en una de las más importantes del mercado editorial hispánico, no sólo por el volumen de obras publicadas a lo largo de su vida, sino por el impacto que tuvo en el público lector y en la difusión de obras de variada índole a bajo costo, conjunción que dio como resultado uno de los proyectos más exitosos de la historia editorial en lengua castellana ${ }^{298}$.

En la génesis de la colección, además de Gonzalo Losada, quien se desempeñaba al frente de la editorial desde 1928, estuvo el crítico y escritor Guillermo de Torre, quien había regresado de España unos años antes y se hallaba ya instalado e inserto en la vida cultural de la Argentina. Ambos diseñaron la colección en base a unos criterios definidos: formato pequeño, bajo costo y variedad temática, lo cual evidencia el propósito de llegar a un público amplio ${ }^{299}$. Estos criterios que sustentaban la colección se encuentran explícitos en las palabras dirigidas "Al lector", a la manera de los

\footnotetext{
${ }^{298}$ En 2012, en ocasión de celebrarse el $75^{\circ}$ aniversario de la colección Austral, Sánchez Vigil y Olivera Zaldua repasan la historia de la colección a lo largo del siglo XX y muestran los vaivenes que acompañaron este itinerario.

${ }^{299}$ Entre los elementos distintivos de la colección se destaca el logotipo que la identificará a lo largo de las décadas. Se trata de una imagen que remite a la constelación de Capricornio y fue diseñado por el artista Atilio Rossi, quien también tuvo a su cargo el diseño de las tapas y cubiertas. Según la tradición y los testimonios recogidos, el boceto inicial de Rossi consistía en un oso polar y fue Jorge Luis Borges quien la objetó, argumentando que no era un animal propio de la Antártida y propuso la imagen que se convirtió en signo inseparable de la colección (Sánchez Vigil 2009, 2012).
} 
prólogos clásicos, que inaugura el catálogo publicado en 1945, en ocasión de haber alcanzado la publicación del volumen $\mathrm{n}^{\circ} 500$, en apenas ocho años:

[...] Espasa Calpe Argentina SA lleva adelante la publicación de su ya extensa y difundida Colección Austral, formada básicamente con producciones de los primeros escritores de nuestros días, intercaladas con las obras cumbres clásicas que consagraron el prestigio de los más famosos autores de todos los tiempos. Seleccionadas con criterio práctico y ecléctico, pone al alcance de la gran masa del público que se hallaba imposibilitado de leerlas — porque las ediciones eran raras o incompletas - ediciones íntegras, autorizadas, bellamente presentadas, muy económicas y en traducciones correctas cuando se trata de autores extranjeros (1945).

La cita resume los criterios que la sustentan: divulgación masiva, seriedad y rigor editorial, junto con valores estéticos y literarios; no se trata, como en el caso de la colección "Clásicos Castellanos" de ediciones acompañadas de aparato crítico, sino que

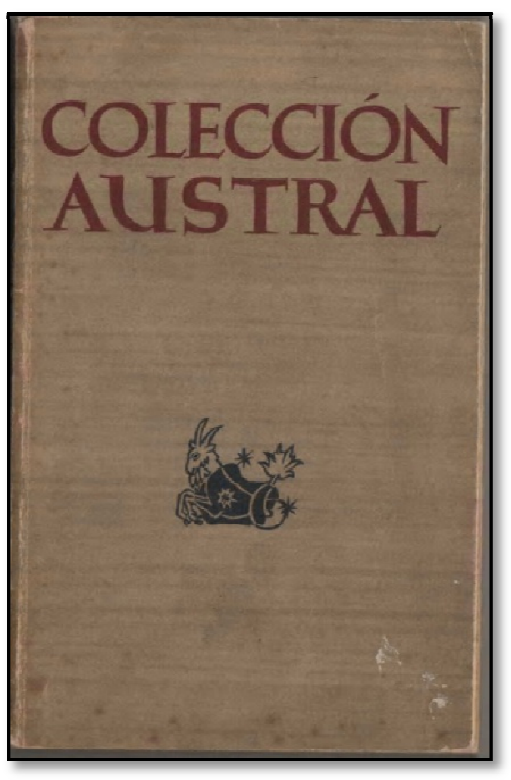
apuntan a la divulgación. Y también se delinean en esa presentación un tipo de libro y un tipo de lector: "libros para todos los lectores y un libro para el gusto de cada lector”. Así, el lector deviene en una pieza clave del proyecto y se acentúa el rol cada vez más importante del mercado y de la difusión masiva ${ }^{300}$.

Un rasgo significativo de la "Colección Austral", como se ha destacado, es su carácter "ecléctico", tal como reza en la presentación del catálogo de 1945. Ese aspecto fue clave en el perfil de la colección y se plasmó en el

\footnotetext{
${ }^{300}$ Según señalan Sánchez Vigil y Olivera Zaldua (2012) en su revisión de la trayectoria de la colección Austral con motivo de celebrar los 75 años de su creación, en los dos primeros años se editaban tres títulos al mes, con una tirada promedio de doce mil ejemplares, además de las reimpresiones. Una parte significativa se exportaba a España, debido a los costos inferiores de publicar en la Argentina. Esto expresa la importante producción editorial de la empresa, así como la demanda del público lector tanto argentino como español.
} 
diseño de nueve "series" —identificadas con los colores de las cubiertas de los volúmenes, que serían un signo distintivo del repertorio editorial- en las que se organizó la publicación de las obras a lo largo de los años. Estas eran: Serie Azul (Novelas y cuentos en general), Serie Verde (Ensayos y filosofia), Serie Anaranjada (Biografías y vidas novelescas), Serie Negra (Viajes y reportajes), Serie Amarilla (Libros políticos y documentos del tiempo), Serie Violeta (Teatro y poesía), Serie Gris (Clásicos), Serie Roja (Novelas policíacas, de aventuras y femeninas) y a partir de 1941 se incorpora a la colección la Serie Marrón (Ciencia y técnica. Clásicos de la ciencia). Como es posible observar, en los criterios que subyacen a la distinción parecen primar los de índole genérica (novela, cuento, biografía, ensayo) y temática (libros políticos, filosofía, ciencia y técnica), aunque éstas pueden resultar algo ambiguas desde criterios actuales $^{301}$.

El catálogo de la colección editado en 1945 constituye en sí mismo un signo del valor que la editorial otorgaba a dicha colección. Como señalan Sánchez Vigil et al. (2008), durante los periodos de expansión y auge de la industria editorial, los catálogos experimentan rediseños y se configuran como muestra de dicho florecimiento. Esto puede observarse en el catálogo referido, ya que desde su factura es un ejemplo de esas “joyas" que evidencian el rol que el libro como objeto cultural revestía para las editoriales y también para el público lector. Hojear este catálogo es encontrar no sólo el listado de los títulos publicados, sino ilustraciones, fotografías y mapas que los acompañan, y a la vez, recorrer una suerte de antología de textos literarios de autores en

\footnotetext{
${ }^{301}$ En un repaso por los títulos que integran las series, se advierten algunas peculiaridades, como por ejemplo la conjunción que propone la serie destinada a "novelas policíacas, de aventura y femeninas", en la que se homologa un género de larga tradición como el "aventuras" con otro más moderno como el policial y se presenta como género a la literatura "femenina", aunque para un lector contemporáneo esto puede resultar paradójico, ya que de los 23 títulos de esta serie publicados hasta ese momento, ninguno era de autora mujer. También se expresan otras categorías al momento de definir las series, como por ejemplo, la de "clásicos", que tiene una serie propia, o denominaciones como "documentos del tiempo", que resultan un tanto ambiguas para un lector actual.
} 
lengua española y, al final, encontrar una selección de opiniones de intelectuales de ambos lados del océano respecto de la colección ${ }^{302}$. Así, la publicación constituye mucho más que un listado de libros, autores y fechas; representa un modo de concebir al libro, a la lectura y a las prácticas de circulación y difusión que atravesaban el campo cultural argentino e hispanoamericano a mediados del siglo XX.

\subsubsection{Literatura española en la Colección Austral (1937-1945)}

Uno de los ejes que se plantean para esta investigación se relaciona con la presencia de textos y autores de la literatura española en el marco de la oferta editorial que circulaba en la Argentina a mediados del siglo XX, a fin de poder establecer vínculos con la conformación de un hispanismo nacional y con los procesos de canonización de esa literatura en el campo cultural argentino. De allí que la revisión de los títulos que integran los catálogos constituye un primer acercamiento a estas relaciones. Para ello, en primer lugar se examinará el catálogo de 1945 a fin de analizar la selección de obras y autores españoles en relación con las series en las que se organiza la colección, con su perfil y con el tipo de lector al que apunta y su relación con los procesos de canonización, su relación con la idea de "clásico" y con la reconfiguración de un nuevo perfil de público lector.

\footnotetext{
302 Entre los autores cuyos textos literarios figuran en las páginas del catálogo, que actúan como complemento de los listados de las colecciones y también como muestras de los contenidos que el lector podría encontrar en los volúmenes, pueden citarse los españoles Antonio Machado, Azorín, Jacinto Benavente, Ramón Menéndez Pidal y los americanos Gabriela Mistral, Juana de Ibarbourou, Enrique Larreta y Baldomero Fernández Moreno. Asimismo, al final de la publicación se anexan cerca de setenta opiniones y juicios de intelectuales de diversas procedencias - aunque con preponderancia de argentinos - acerca de la colección, lo cual funciona como estrategia legitimizadora de la propuesta. Entre los argentinos pueden citarse intelectuales y escritores como Rafael Alberto Arrieta, Arturo Capdevila, Arturo Cancela, Manuel Gálvez, Ricardo Levene, Eduardo Mallea, Ignacio Anzoátegui, Augusto Cortina o Julio Rey Pastor. Asimismo aparecen las voces de escritores del ámbito europeo, como André Maurois, Jules Romains, Bernard Shaw o H. G. Wells.
} 
Cuadro No 8: Resumen cuantitativo de la Colección Austral (1937-1945) ${ }^{303}$

\begin{tabular}{|c|c|c|c|}
\hline Serie & $\begin{array}{l}\text { Total de } \\
\text { volúmenes } \\
\text { publicados }\end{array}$ & $\begin{array}{l}\text { Cantidad de volúmenes } \\
\text { correspondientes a obras y } \\
\text { autores españoles }\end{array}$ & Porcentaje \\
\hline $\begin{array}{l}\text { AZUL (Novelas y } \\
\text { cuentos en general }\end{array}$ & 163 & 74 & $45 \%$ \\
\hline $\begin{array}{l}\text { VERDE (Ensayos y } \\
\text { Filosofía) }\end{array}$ & 98 & 65 & $66 \%$ \\
\hline $\begin{array}{l}\text { ANARANJADA } \\
\text { (Biografias y vidas } \\
\text { novelescas) }\end{array}$ & 39 & 16 & $41 \%$ \\
\hline $\begin{array}{l}\text { AMARILLA (Libros } \\
\text { políticos y documentos } \\
\text { del tiempo) }\end{array}$ & 19 & 3 & $15 \%$ \\
\hline $\begin{array}{l}\text { NEGRA (Viajes y } \\
\text { reportajes) }\end{array}$ & 26 & 9 & $39 \%$ \\
\hline $\begin{array}{l}\text { ROJA (Novelas } \\
\text { policíacas, de aventuras } \\
\text { y femeninas) }\end{array}$ & 23 & 5 & $21,7 \%$ \\
\hline GRIS (Clásicos) & 51 & 37 & $72 \%$ \\
\hline $\begin{array}{l}\text { VIOLETA (Teatro y } \\
\text { poesía) }\end{array}$ & 71 & 35 & $49 \%$ \\
\hline \multirow[t]{2}{*}{$\begin{array}{l}\text { MARRÓN (Ciencia y } \\
\text { Técnica. Clásicos de la } \\
\text { ciencia) }\end{array}$} & 11 & 2 & $18 \%$ \\
\hline & 500 & 246 & $49 \%$ \\
\hline
\end{tabular}

Esta síntesis, aun en su carácter sucinto, habilita algunas consideraciones. En primer lugar, como se expresa en la presentación del catálogo, el objetivo principal de la colección es poner al alcance del público una amplia selección de textos y autores

\footnotetext{
${ }^{303}$ Dado el volumen de títulos publicados solamente en los primeros siete años de la colección y de la organización en series que agrupan los textos según criterios de género o temático, se optó por sistematizar la información en un cuadro. En el caso de otras colecciones en los que la cantidad de títulos es significativamente menor, se incluyen en el texto.
} 
considerados fundamentales, es decir, "los libros que marcan una fecha capital en la historia de la literatura y del pensamiento y de los que ninguna persona culta puede prescindir" (2). Partiendo de esa declaración, es necesario detenerse en la composición de cada serie. Como se observa en el cuadro, la que reunió la mayor cantidad de volúmenes publicados en los primeros ocho años fue la serie "Azul", dedicada a las formas de la narrativa literaria (cuentos y novelas). Sin embargo, si se le suman a esta serie los volúmenes de la serie "Roja" (novelas policíacas, de aventuras y femeninas), el número aumenta y se acentúa la presencia del género narrativo ${ }^{304}$. Le siguen en volumen los títulos destinados al ensayo y a la filosofía, incluidos en la serie "Verde". Si se atiene a lo declarado en la presentación, este conjunto correspondería a las obras relevantes del "pensamiento" propuestas en la presentación $\mathrm{y}$, en el caso de esta colección, dicha relevancia puede asociarse, entre otras posibles razones, a la injerencia de la figura de José Ortega y Gasset en el Consejo Editorial de Espasa-Calpe, cuya obra La rebelión de las masas abrió la colección en 1937. Este gesto señala la relevancia del filósofo en las políticas editoriales del sello y también su centralidad en el campo intelectual hispánico, lugar que venía ocupando desde las primeras décadas del siglo.

El teatro y la poesía, en la serie "Violeta", ocupan el siguiente lugar en cuanto a la cantidad de volúmenes, seguidos por una categoría que amerita un examen particular: la de "Clásicos", a la que se dedica la serie "Gris" de la colección. Su inclusión ya altera los criterios genéricos que caracterizan a las otras series, con algunas variaciones, ya que introduce una categoría que implica, al mismo tiempo, un juicio de valor sobre las obras elegidas. La noción de "clásico", de larga data en Occidente, ha ido cargándose de

\footnotetext{
304 Escapa a los objetivos de este trabajo, pero resulta significativa esta división en dos series diferenciadas de textos pertenecientes al mismo género, como es el caso de la categoría "novela" incluida en ambas series. Es posible hipotetizar que los subgéneros incluidos en la serie "Roja" no contaran en esa época aún con un estatuto definido en el discurso literario, lo cual parece evidenciarse en la selección de obras, bastante difusa, en la que conviven las novelas de caballería medievales con obras de Robert Stevenson o Gastón Léroux, lo que habla de las vacilaciones en los criterios seguidos.
} 
connotaciones a lo largo de los siglos que la vinculan con ciertas ideas: excelencia, permanencia en el tiempo, inmutabilidad, carácter modélico, universalidad. Tal como señala Claudia Fernández, "se observa que en la ponderación de los clásicos las cualidades estéticas suelen confundirse con las éticas: por regla general, los autores y textos llamados clásicos son portadores de virtudes morales, como la madurez, la serenidad, la compostura, el control de sí, el orden y el dominio de las pasiones" (2008: 24). Este carácter moral asociado a los clásicos parece ser el que prima en la presentación de la serie Austral incluida en el catálogo:

Leer a los clásicos es olvidarse un poco de las inquietudes del presente y lograr un descanso que nos de lucidez para contemplar con mayor serenidad los graves problemas de las horas inciertas [...] nadie que se precie de poseer una cultura literaria bien cimentada puede desconocer esos valores inmutables que son los clásicos, símbolo de lo inmarcesible frente al destino perecedero de la vida $(1945 \mathrm{~s} / \mathrm{p})$.

Así, frente a un presente incierto, el clásico ofrece estabilidad y permanencia, a la vez que se asimila a la pertenencia a una cierta "cultura",305. Ahora bien, esta declaración universalista e imperecedera de lo clásico se concretará en un repertorio de textos y autores correspondientes fundamentalmente a la literatura española, con lo cual en el catálogo se homologa la noción de "clásico" a la de "clásico castellano", poniendo de relieve el valor lingüístico: "Y tratándose particularmente de los clásicos castellanos, su lectura es indispensable para aquilatar plenamente el tesoro de nuestra lengua, enriquecida y cincelada por ellos [...].” De este modo se retoman en esta presentación

\footnotetext{
${ }^{305}$ Unas décadas después, el escritor italiano Italo Calvino regresa sobre el tema de la lectura de los clásicos en la época actual y expresa: "Los clásicos son esos libros que nos llegan trayendo impresa la huella de las lecturas que han precedido a la nuestra, y tras de sí, la huella que han dejado en la cultura o en las culturas que han atravesado [...]"; "Es clásico lo que tiende a relegar la actualidad a la categoría de ruido de fondo, pero al mismo tiempo, no puede prescindir de ese ruido de fondo. Es clásico lo que persiste como ruido de fondo incluso allí donde la actualidad más incompatible se impone" [1981] (1992: 15-18). En estas citas reaparece la idea de los clásicos como persistencia cultural y como "antídoto" frente a la realidad insatisfactoria.
} 
la idea de una supremacía ética y estética de ciertas obras y autores españoles, cuya validación se vincula con una lengua prestigiosa: la lengua castellana peninsular, a la que además se menciona como "nuestra", en un afán por incluir al ámbito hispanoamericano, cuyos autores no ocupan un lugar en la colección ${ }^{306}$. Así entre las cincuenta y una obras listadas para esta serie en el catálogo, treinta y siete corresponden a autores españoles, fundamentalmente del Siglo de Oro, lo cual otorga a la noción de clásico un valor adicional: la de pertenecer a un periodo considerado ya por la tradición literaria como excepcional, por la valía de sus escritores y de sus producciones. Desde esta perspectiva, la presencia de autores como Miguel de Cervantes, Lope de Vega, Calderón de la Barca o Teresa de Ávila, metonímicamente, parece resumir la tradición clásica española cuya permanencia debe ser sostenida a través del tiempo a fin de ponerla a disposición de los lectores del siglo XX. El resto del listado está conformado por autores griegos, las tragedias de Shakespeare, un par de comedias de Molière y una obra filosófica, como es El discurso del método de René Descartes ${ }^{307}$, lo cual expresa la idea de "clásico" que subyace a la selección, ligado a lo consagrado y prestigioso de la cultura europea.

La centralidad otorgada a la literatura española en esta serie es análoga a la que aparece, con matices, en las otras series de la colección. Así, la serie "Anaranjada" dedicada al género biográfico, ya sea ficcional o no, exhibe una importante presencia de obras españolas, al igual que la serie "Negra", que incluye el género de relatos de viajes. Solamente dos series no muestran una significativa presencia de autores españoles: la

\footnotetext{
${ }^{306}$ Con excepción del Inca Garcilaso de la Vega, los textos y autores de habla castellana incluidos en la serie son españoles, desde El Cantar del Mio Cid hasta el Duque de Rivas, con lo cual queda en evidencia lo ecléctico de la selección, aunque sustentado en la idea de "clásico" que puede equipararse con "canónico", dado que se trata de autores y textos consagrados.

${ }^{307}$ La inclusión de esta obra en esta serie y no, como podría esperarse, en la serie "Verde", dedicada a los ensayos y textos filosóficos, puede entenderse en relación con una de las funciones atribuidas a los clásicos: la de ofrecer una mirada que permita "contemplar con mayor serenidad los graves problemas de las horas inciertas", como se expresa en la presentación de la serie.
} 
"Amarilla", dedicada a los libros políticos y la "Marrón", destinada a publicar textos científicos, pero también es evidente que estas series no fueron las más relevantes de la colección, ya que, en conjunto, solo se publicaron en ellas cuarenta volúmenes sobre quinientos que abarca la totalidad editada hasta 1945, tendencia que continuó en los años posteriores.

La lista de los autores españoles que integran la selección incluida en la colección puede también examinarse desde el punto de vista ideológico, tal como lo esboza Fernando Larraz (2009). En su trabajo, el investigador español pasa revista a los autores españoles comprendidos, en especial a los contemporáneos, y reconoce la presencia de algunos identificados con el régimen franquista - a los cuales se intentaba elevar a la categoría de "clásicos"-, otros provenientes de las vertientes católicas y algunos intelectuales conservadores que, luego de la instauración del régimen, fueron admitidos y comenzaron a publicar en España. Por su parte, los escritores de la Generación del 98 tuvieron buena acogida en la colección, a pesar de sus divergencias ideológicas con el ideario franquista. Esta lectura muestra el sesgo de corte conservador, tanto en lo literario como en lo ideológico que subyacía a la selección.

Este análisis propuesto pone de manifiesto, por un lado, los ambiciosos objetivos que animaron la creación de la "Colección Austral", el primer proyecto de envergadura de Espasa-Calpe Argentina, apenas creada. Por otro lado, la respuesta del público afianzó la idea de la necesidad de ampliar la oferta editorial para satisfacer las demandas no solo locales, sino del resto del mundo hispanoparlante, incluida la Península, atravesada por la Guerra Civil primero y bajo el régimen franquista desde 1939. De allí que la selección de textos y autores esté claramente orientada a difundir textos y autores ya consagrados por la tradición literaria y académica, aun de aquellos no tan conocidos, pero alejados de la novedad y — si se adhiere a la hipótesis ideológica- que no 
representaran una clara oposición al régimen instalado en España ${ }^{308}$. Austral no fue una colección que se haya propuesto como finalidad difundir autores contemporáneos — con la salvedad de las obras de Ortega y Gasset, cuya relación con la empresa ya se ha subrayado y de algunas otras figuras menores coetáneas españolas así como nombres consagrados de ciertas literaturas europeas-, ni españoles ni hispanoamericanos, con algunas excepciones. La noción de "libros actuales", que aparece en la presentación, tiene que ver más con su carácter de permanencia, de valor adquirido y de consagración; eso resume la expresión con la que se refiere a los libros de la colección: "Libros que son actuales, ayer, hoy y siempre”. Esta afirmación se aproxima más a la noción de "clásico", tal como se ha observado, que a la de "actual", que en el caso de la propuesta editorial de la colección Austral, aparecen equiparados. En ese contexto, la fuerte presencia de textos y autores españoles en las series que integran la colección (casi el $50 \%$ del total de obras publicadas en los primeros ocho años) ratifica la centralidad atribuida a la literatura y la cultura españolas en el campo cultural argentino.

La "Colección Austral" continuó editándose durante las décadas siguientes a un ritmo similar, lo que llevó a que en 1951 —apenas catorce años después de su creación - se publicara el número 1000, que correspondió a El Cid Campeador, de Ramón Menéndez Pidal. Para finales de la década de 1950 se habían editado casi 1300 volúmenes, lo cual pone de manifiesto el éxito de la colección. Esta expansión coincide con el auge de la industria editorial argentina en el periodo, que de Diego $(2006,2015)$ ha denominado "época de oro". A partir de mediados de la década de 1950 comienza un declive de esta industria en el país, debido a cuestiones económicas que dificultan mantener el ritmo de producción, y, además, a la lenta pero progresiva recuperación del

\footnotetext{
${ }^{308}$ Larraz Elorriaga (2009) ilustra a través del caso de la publicación en la Colección Austral de las Poesías Completas de Antonio Machado, en 1941, escritor comprometido con la causa republicana, las tensiones en la confección del catálogo de la serie. La edición de su poemario - incompleto- estuvo mediada por la inclusión de un prólogo a cargo de Dionisio Ridruejo, Director General de Propaganda del régimen. En dicho apartado, Ridruejo propone "rescatar" la figura del poeta de la influencia republicana.
} 
sector editorial en España, lo cual repercutirá en el campo editorial argentino, del cual la trayectoria posterior de la Colección Austral resulta un claro ejemplo ${ }^{309}$.

En ese contexto de expansión y retracción, la "Colección Austral" continuó manteniendo los principios que orientaron su creación y de este modo la oferta se amplió y las reediciones de las obras más exitosas se sucedieron. De modo similar a lo ocurrido durante los primeros años de vida de la colección, la literatura española mantuvo su lugar privilegiado y contribuyó a consolidar un dilatado corpus de textos y autores en el que convivían los clásicos ya consagrados por la tradición académica y escolar con los nombres menos relevantes de obras y autores hispanos, en un particular entramado que circuló profusamente tanto en el campo ámbito argentino e hispanoamericano como en España, donde la recuperación de la industria editorial a mediados del siglo XX reubicó a Espasa Calpe entre las principales empresas del sector y con ella a sus colecciones consagradas. Así, la "Colección Austral”, nacida bajo el auge editorial que experimentó la Argentina a finales de la década de 1930, continuará su periplo en la Península, con un ritmo menor según los vaivenes de la empresa y del mercado editorial, hasta los albores del siglo XXI, pero manteniendo los principios que la hicieron uno de los proyectos editoriales de más largo aliento a lo largo del siglo en el mundo hispanoparlante ${ }^{310}$.

\footnotetext{
${ }^{309}$ Sánchez Vigil y Olivera Zaldua indican que a partir de la segunda mitad de la década de 1960 se produce en España un despegue económico y un giro de la política exterior que posibilitó una apertura de España hacia el contexto internacional con las consiguientes mejoras en el plano económico. Esto acarreó un cambio en las políticas editoriales de Espasa Calpe, que comenzó a editar en Madrid, aunque el volumen de números editados disminuyó sensiblemente (2012: 36).

310 Como muestra de los cambios que experimentaron las políticas editoriales a lo largo de las décadas, en 1993 la Colección Austral lanza al mercado argentino la Biblioteca de Literatura Hispanoamericana destinada a la enseñanza secundaria. Dicha Biblioteca está compuesta por 30 títulos correspondientes a autores americanos y españoles, repartidos del siguiente modo: nueve argentinos, seis hispanoamericanos y los quince restantes españoles, desde medievales hasta contemporáneos. Esta distribución muestra la preponderancia de la literatura española, aun en una colección propuesta para la Argentina a finales del siglo XX. Otro rasgo distintivo de la serie es la inclusión de estudios preliminares o introducciones a cargo de especialistas destacados tanto de España como de Hispanoamérica y el acompañamiento de una "Guía de lectura" para cada volumen de la colección.
} 


\subsubsection{La Editorial Losada: colecciones y políticas editoriales}

La editorial Espasa Calpe y su filial argentina ocuparon rápidamente un lugar central en el campo editorial, a partir de sus políticas empresariales y de la gestión de sus responsables, que provenían de España y que contaban con experiencia en este sector. Esto impulsó su desarrollo y permitió que en poco tiempo la editorial lograra una expansión significativa.

Los nombres que aparecen vinculados con la creación de la sucursal argentina son los de Manuel Olarra, Julián Urgoiti y Gonzalo Losada. Este último había llegado a la Argentina para desempeñarse en la delegación local en 1928 y permaneció en ella cuando se convirtió en una Sociedad Anónima. Sin embargo, un año después deja la firma y crea su propio sello editorial, la editorial Losada, que será una de las más importantes del mundo hispánico durante las décadas siguientes ${ }^{311}$.

Los trabajos referidos a los orígenes y desarrollo de la editorial coinciden en atribuirle ciertos rasgos característicos: la importante presencia de intelectuales españoles y argentinos en el grupo fundador, la nítida orientación hacia los textos y autores contemporáneos, tanto españoles como hispanoamericanos y extranjeros, las estrategias de legitimación en el campo editorial vinculadas, por un lado, con los nombres que la integraban y también por las relaciones con el público lector y con la prensa. Esto le confirió a la editorial un perfil propio como "guía cultural” o "formadora del público" (Santiago de Chitarrini 1992: 530), es decir, no sólo se destacó como empresa exitosa desde el punto de vista comercial, sino cultural ${ }^{312}$.

\footnotetext{
${ }^{311}$ Las razones del alejamiento de Losada de Espasa Calpe han sido interpretadas ideológicamente, por las afinidades del editor con el bando republicano y sus consecuentes desavenencias con Olarra (de Diego 2006, Larraz 2009). Otros autores mencionan la marcha de Losada pero soslayan los motivos (Lago Carballo 2007; Olarra Jiménez 2003; de Zuleta 1999).

${ }^{312}$ Una de las estrategias innovadoras que propulsó la editorial fue la de instaurar un premio literario, iniciativa que ya contaba con trayectoria en Europa y que funcionó también como mecanismo legitimador para los escritores (Santiago de Chitarrini 1992).
} 
Uno de los aspectos más relevantes de la editorial fue la incorporación de un grupo importante de intelectuales que le dieron un sesgo particular al emprendimiento de Losada. Entre ellos se encontraban los españoles Guillermo de Torre — quien también se alejó de Espasa-Calpe junto con Gonzalo Losada-, Amado Alonso, quien en ese momento se desempeñaba como director del Instituto de Filología de la Universidad de Buenos Aires, el pedagogo Lorenzo Luzuriaga, el catedrático Luis Jiménez de Asúa, junto con el dominicano Pedro Henríquez Ureña y los argentinos Francisco Romero y Ricardo Rojas y el diseñador Atilio Rossi, entre otros. Esta particular conjunción de intelectuales convirtió a la editorial en un "microcosmos en el que se dio una intensa convivencia entre la intelectualidad argentina y la española que residía en la Argentina antes de la guerra y el exilio republicano" (Ortuño Martínez 2012: 117). La presencia de intelectuales llegados durante la década de 1930 a la Argentina, sumada a las simpatías ideológicas de Gonzalo Losada hacia el bando republicano, asociaron a la editorial con el exilio republicano español, de allí que se la mencione como "la editorial de los exiliados", aunque este marbete no se ajuste totalmente a la realidad ${ }^{313}$. Lo cierto es que los desencuentros de algunos intelectuales con las líneas editoriales de Espasa-Calpe por motivos ideológicos quedaron expresados en testimonios de los involucrados, como la carta que Pedro Henríquez Ureña le envía a Alfonso Reyes, donde le manifiesta:

Espasa Calpe Argentina, bajo la presión del franquismo, se ha reducido a poca cosa [...] Los que allí estábamos — Guillermo de Torre, el pintor Atilio Rossi y yo [...] — nos hemos ido con Gonzalo Losada, ex gerente de Calpe (sic) que ha fundado una casa editora" (citado en Larraz 2009: 4).

\footnotetext{
${ }^{313}$ Así aparece mencionada en textos y artículos periodísticos (Cf. La Nación, 20/7/1986, en Dabusti de Muñoz 1999-2000).
} 
Por su parte, José Ortega y Gasset, que permanecía ligado a Espasa Calpe en España, le escribe a Gregorio Marañón en 1938:

He tenido algunas noticias -todas procedentes de la Argentina- sobre la situación de Espasa-Calpe. En efecto, Losada se ha separado con algunos muchachos de izquierda y ha creado una editorial, cuyo capital, de cuantía desconocida, no tiene un origen todavía notorio. Es resueltamente una editorial roja" (citada en López Cobo 2013: 47-48).

Ambos testimonios, desde perspectivas distintas, acentúan la visión que se formó alrededor de la gestación de la editorial, que quedó de este modo asociada a un sector ideológico y le otorgó un sesgo particular en el plano simbólico.

El programa editorial diseñado por Losada y sus colaboradores fue ambicioso: desde el inicio se planificaron diferentes colecciones que abarcaran un universo variado de textos, en procura de instalarse en el campo editorial e ir definiendo un perfil propio. En el catálogo publicado al año siguiente de su creación aparecen las cinco primeras colecciones, entre las cuales se destaca la "Biblioteca Clásica y Contemporánea" —inicialmente denominada solo "Biblioteca Contemporánea"- que se convertiría en la colección más difundida de la editorial y que, de algún modo, competiría con la "Colección Austral" de Espasa Calpe. Ambas colecciones compartían formato, bajo costo, gran volumen de publicación, carácter ecléctico y misceláneo, periodicidad en las apariciones, por lo que "las convertía [a las colecciones] en repertorios representativos de los diversos niveles de la cultura nacional y universal, renunciando expresamente a cualquier concepto elitista de la cultura escrita" (Larraz 2009: 5).

En este proyecto inicial tuvieron un papel clave algunas de las figuras que integraban la editorial, como Guillermo de Torre, responsable de la "Biblioteca Contemporánea", de la colección "Panoramas" y de la edición de las Obras Completas de Federico García Lorca, la primera de su tipo publicada en el ámbito hispano; Pedro 
Henríquez Ureña, quien dirigió otra de las colecciones señeras de Losada: "Las cien obras maestras de la literatura y el pensamiento universal", que quedará trunca luego de la muerte del dominicano en 1943; Francisco Romero, que tuvo a su cargo la colección "Biblioteca Filosófica" y Amado Alonso, que iniciaría la colección "Filosofía y Teoría del Lenguaje", donde se editaron obras de Ferdinand de Saussure, Charles Bally y Karl Vossler $^{314}$. También Alonso propuso la creación de otra colección, que no llegó a concretarse, que incluiría unos tomos destinados a semblanzas de escritores y pensadores del mundo hispánico ${ }^{315}$.

El panorama presentado evidencia el perfil buscado por la editorial desde sus comienzos: aunar masividad y calidad, novedad y clasicismo, diversidad $\mathrm{y}$ especialización. Este carácter de corte integrador se sustentaba en el prestigio de los intelectuales que participaban de la empresa, que actuaba como mecanismo legitimador de las propuestas y a la vez, en la impronta amplia y abarcadora que las caracterizaba. En ese marco, resulta significativo examinar los modos en que se incluye la literatura española en algunos de los repertorios editoriales, a fin de analizar sus articulaciones

\footnotetext{
314 Amado Alonso tuvo una participación activa en los inicios de Losada, tal como puede apreciarse en la correspondencia que mantiene en esos años con Alfonso Reyes, residente en México. En una carta de diciembre de 1939, a un año de creada la editorial, Alonso le escribe a Reyes: "En la Casa Losada (sic) voy a emprender la publicación de unos diez o doce libros fundamentales de la Lingüística. [...] Ya tengo los permisos de A. Meilet, Bally, de Saussure, Jespersen, Schuchardt, Vossler, Príncipe Trubetzkoy y tramito otros" (en Venier 2008: 106). Si bien no todos ellos pudieron concretarse, la enumeración evidencia las expectativas de Alonso respecto de crear una colección que reuniera por primera vez en castellano las principales obras de una disciplina de reciente creación.

${ }^{315}$ Según se desprende de la correspondencia con Reyes, este proyecto Alonso lo mantuvo al menos hasta 1940. Su idea era confeccionar unos volúmenes breves - "tomitos", los llama - destinados a un público no especialista, según expresa en la carta fechada en diciembre de 1939, a solo un año de la fundación de la editorial: "Son libros destinados a profesores secundarios, alumnos universitarios, periodistas y escritores, etc." [...] Queremos hacer tomitos baratos, para vender muchos" (en Venier 2008: 104). Esta declaración expresa la clara conciencia de Alonso del perfil esperado para la editorial, así como su progresiva instalación en el medio: "La Losada (sic) va tomando importancia" (ibídem). También allí menciona los posibles encargados de la redacción de esos volúmenes (Américo Castro, Arturo Capdevila, Rafael A. Arrieta, Agustín Millares Carlo, Henríquez Ureña y el propio Reyes, a quien Alonso le solicita se ocupe de Góngora), lo que habla también de esta interrelación entre intelectuales del ámbito hispánico como uno de los perfiles propios de la editorial.
} 
con la noción de "canon" y con la consolidación de los estudios hispánicos en la Argentina.

De acuerdo con los objetivos de esta investigación, se focalizará en aquellas colecciones publicadas por la Losada entre las décadas de 1940 y 1970 en las que la literatura española tuvo particular relevancia, a partir del relevamiento de títulos y autores presentes en los catálogos seleccionados, así como en los avatares de las políticas editoriales, con sus convergencias y divergencias, que dichos catálogos ponen de manifiesto. Para el caso de la editorial Losada se analizarán los catálogos de 1947, 1966 y el editado en 1998 al cumplirse los 60 años de la fundación.

\subsubsection{La "Biblioteca Contemporánea" y "Las Cien Obras Maestras del pensamiento y la literatura universal": "los mejores libros del mundo"}

La creación en 1938 de la denominada "Biblioteca Contemporánea" de Losada fue uno de los puntos más salientes de su programa inicial para insertarse en el mercado local. Desde su factura, la colección se homologaba con otras similares, como la "Colección Austral" en cuanto a formato y precio ${ }^{316}$, pero también en cuanto a su carácter misceláneo y variado y a su afán de calidad editorial. En un principio, la colección se tituló "Biblioteca Contemporánea", lo cual marcaba un recorte temporal en la selección de las obras y autores. Su afán por llegar a un público amplio se evidencia en el texto que acompañaba en las solapas a los libros, que a la vez que resalta los criterios de la colección, está impregnado de un carácter publicitario:

Editorial Losada S.A. publica la Biblioteca Contemporánea que comprende los mejores libros del mundo, aquellos que responden verdaderamente a las

\footnotetext{
${ }^{316}$ En su análisis comparado de los catálogos de ambas colecciones, Fernando Larraz (2007, 2010) destaca estas similitudes entre ambas ofertas editoriales en cuanto al precio y las características externas de los volúmenes.
} 
curiosidades y a las necesidades culturales de los lectores, elegido con arreglo a su puro y alto significado literario e ideológico, sin alteraciones tendenciosas. Aparecen en la Biblioteca Contemporánea el libro ya famoso y el que lo será mañana, el libro de la alta cultura y el libro de ameno esparcimiento, el libro exquisito y el libro popular. Cada libro de la Biblioteca Contemporánea es, siempre, su edición legítima, debidamente autorizada por los autores, sus herederos o representantes; es su edición escrupulosamente impresa y corregida; es su edición mejor presentada. Todas las literaturas, todos los géneros.

Esta presentación de la colección amerita algunas consideraciones. En primer lugar, la calificación de "los mejores libros del mundo" vinculada con las preferencias de los lectores, junto con la explicitación de los criterios de esta selección: "elegido con arreglo a su puro y alto significado literario e ideológico, sin alteraciones tendenciosas". Esto expresa una doble apreciación: la primacía del supuesto valor estético o de las ideas vertidas por sobre las cuestiones ideológicas, aquí entendidas como expresión de un cierto ideario. Esta tal vez sea una sutil diferencia con la propuesta de la "Colección Austral", en la que no hay referencias a este aspecto, tal como señala Larraz (2007, 2010). En segundo lugar, la selección opera sobre un corpus heterogéneo en el que se combinan nociones provenientes de campos diversos: cultura alta y cultura popular, libros de entretenimiento y libros "exquisitos", lo que implica también una valoración respecto de la literatura y de los lectores. Por otro lado, la idea de "canon" campea en esta presentación: "el libro famoso y el que lo será mañana", donde la idea de "fama" puede atribuirse al rol que juegan en esta consagración las empresas editoriales. En otras palabras, la "fama" del libro depende en gran medida de su puesta en circulación ante un público amplio, antes que por su valor en sí. Así, en esta enumeración que intenta ser abarcadora, aparecen representadas diversas visiones sobre los valores atribuidos a los libros: cultos y populares, de entretenimiento y selectos y, como una categoría aparte pero no menos significativa, el éxito y el reconocimiento. Mientras que en las primeras 
categorías priman nociones del ámbito cultural, la última apela a la cuestión de mercado editorial y su incidencia en la consagración de obras y autores.

Finalmente, la referencia a la calidad de la edición y a su legalidad parece dialogar con uno de las problemáticas más significativas que enfrentaba la industria del libro: las ediciones ilegales, práctica que había proliferado a lo largo del siglo XX y que había sido objeto de debates en el seno de las instituciones que nucleaban a los libreros y editores ${ }^{317}$. Una ausencia en esta presentación es la traducción, que en el caso de la "Colección Austral" se presentaba como uno de los baluartes de su calidad; no hay referencia a esta dimensión, aunque es sabido que, conjuntamente con el auge editorial, la traducción creció y se consolidó como actividad en el campo cultural argentino y fue adquiriendo un perfil propio.

Esos principios expresados en la presentación de la colección acompañaron la aparición de los títulos durante los primeros años, a un ritmo sostenido, lo cual la erigió en la serie más importante de la editorial y en la cual la presencia de obras de autores españoles es significativa, aunque su gravitación en el repertorio no es tan importante como en el de la "Colección Austral", donde se ha observado la fuerte presencia de textos y autores españoles, en especial del Siglo de Oro y anteriores al siglo XX. La "Biblioteca Contemporánea" se proponía poner al alcance del público un conjunto de obras y autores modernos, pertenecientes a diversas tradiciones literarias, entre las cuales la española está representada en un primer momento por autores del siglo XX. La colección se inicia con La agonía del Cristianismo, de Miguel de Unamuno, en 1938 cuya primera edición había aparecido en Madrid en 1930 - y de algún modo señala el

\footnotetext{
${ }^{317}$ El tema de las ediciones fraudulentas había ocupado la agenda de los libreros desde finales del siglo XX y se había agudizado en las primeras décadas del siglo. Tal como lo analiza Larraz (2010), la falta de amparo legal propiciaba estas prácticas que perjudicaban notablemente al sector.
} 
límite temporal que abarca la selección, siempre bajo la impronta de lo

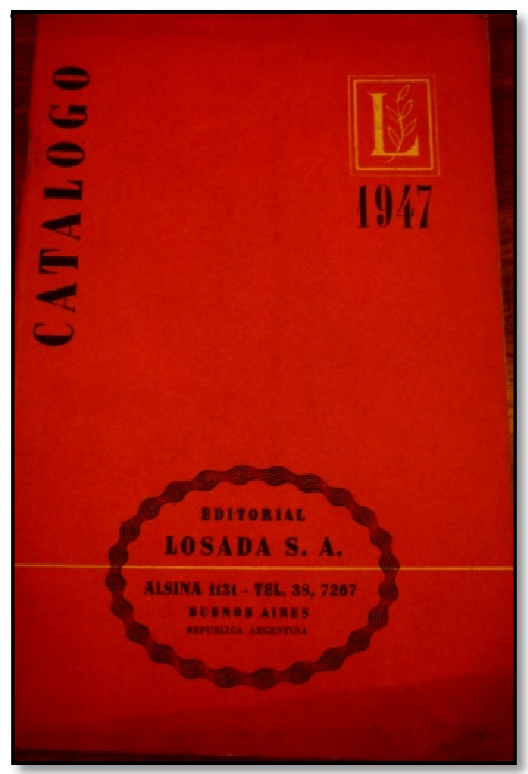
“contemporáneo" 318 .

El catálogo publicado por Losada en 1947, a menos de diez años de su fundación, permite dar cuenta de la expansión significativa de la oferta editorial de la empresa, concretada en la multiplicidad de colecciones iniciadas. A los efectos de esta investigación, nos detendremos únicamente en aquellas vinculadas con la literatura: a las tres iniciales, entre las que se encuentran la ya mencionada "Biblioteca Contemporánea", que inicia el volumen, "Las cien obras maestras de la literatura y el pensamiento universal”, las "Obras completas de Federico García Lorca”, se le agregan "Los Inmortales", "Biografías históricas y novelescas", "Las grandes novelas de nuestra época", "La Pajarita de papel”, "Poetas de España y América", "Prosistas de España y América", "Novelistas de España y América", "Grandes escritores de América”, “Azul y Blanco”, “Libros de Juan Ramón Jiménez” y “Obras de Ricardo Rojas", es decir, once colecciones dedicadas a la literatura. Como es posible observar de la enumeración, es manifiesta la preocupación por mostrar un equilibrio entre producciones españolas y americanas, así como la relevancia de algunas figuras de ambos lados del Atlántico, como el argentino Ricardo Rojas y los españoles Federico García Lorca y Juan Ramón Jiménez ${ }^{319}$.

\footnotetext{
${ }^{318}$ En el diseño artístico de la colección trabajó Atilio Rossi, quien se había incorporado al equipo editorial de Losada desde sus inicios y fue el responsable del logotipo de la letra L con el laurel que identifica a la editorial. La trayectoria del artista italiano estuvo vinculada a la industria editorial, ya que trabajó en la diagramación de revistas como De mar a mar, Cabalgata y Saber Vivir (publicación aparecida entre 1940 y 1956, de la que formaron parte algunos de los colaboradores de la revista Sur). Se desempeñó también como crítico de arte en la revista dirigida por Victoria Ocampo.
}

${ }^{319}$ Además de las colecciones literarias el catálogo exhibe otras dedicadas a diversos asuntos, que suman en total 47 series agrupadas por temas. La enumeración de todas las series excedería los límites de este 
De estas colecciones mencionadas, nos interesa detenernos en aquellas dos que resultan más relevantes para indagar en la presencia de textos y autores españoles: la ya referida "Biblioteca Contemporánea" — que en la década de 1950 pasará a denominarse "Biblioteca Clásica y Contemporánea" - y "Las cien obras maestras de la literatura y el pensamiento universal". Como se ha señalado, la primera serie se propuso incluir obras contemporáneas, entre las cuales las españolas ocuparon un lugar importante, y la segunda ofrecer ediciones cuidadas de obras clásicas de la literatura y el pensamiento occidental. Esta división permitió, en un primer momento, atender a criterios diferenciados: mientras que la "Biblioteca Contemporánea" reuniría obras de autores modernos, principalmente literarios, la dirigida por Henríquez Ureña apuntaba a confeccionar una biblioteca de obras ya consideradas clásicas por la tradición, alejadas del presente y cuya valía ya estuviera consagrada por su calidad y por el renombre de los autores. La referencia a la noción de "obra maestra" que figura en el título de la colección puede homologarse con la de "clásico" que agrupaba en la "Colección Austral" a aquellos textos imperecederos que la tradición ha aquilatado; en ambos subyace también la idea de "modelo" atribuido también a estas obras, más allá de su contenido. También desde el punto de vista de su formato y precio, ambas colecciones se dirigen a lectores diferenciados: mientras que la "Biblioteca Contemporánea" se caracterizaba por su formato en rústica, de tamaño pequeño y bajo precio $(\$ 1,50$ el volumen común, Larraz 2009), destinada a un público masivo, la colección dirigida por Henríquez Ureña se presentaba, según reza en el catálogo de 1947, como "Hermosos

trabajo, pero sí resulta significativo mencionar los títulos bajo los cuales se agrupan las colecciones o series que evidencian esta variedad; además de las "Colecciones literarias" ya mencionadas, figuran en el catálogo "Antologías, Crítica, Textos, Manuales", "Ensayos, Panoramas, Historia", "Arte”, "Filosofía”, "Sociología y Ciencias Económicas", "Publicaciones Pedagógicas", "Ciencias", "Libros en Administración" (donde se incluyen las colecciones pertenecientes a la Editorial Pleamar), "Publicaciones de las Universidades Argentinas" (incluye publicaciones de la Universidad de Buenos Aires, de Córdoba, de Tucumán y del Litoral) y "Otras Publicaciones". Si bien algunas de estas series incluyen pocos títulos, la diversidad de temas señala la búsqueda de un público lector amplio y la expansión de la oferta (1947: $3-5)$. 
volúmenes de unas 300 páginas, encuadernados en tela, con inscripciones doradas y cantos pintados: sobrecubierta en colores", cuyo precio era de $\$ 5$ (22). De este modo, vistas en conjunto, las dos colecciones de Losada apuntan a ofrecer un repertorio de obras que equilibre la novedad y la permanencia, lo contemporáneo y lo clásico, la masividad y la selectividad, que pudiera atraer a los lectores con diversos intereses.

Según lo expresa el catálogo publicado en 1947, ya la "Biblioteca Contemporánea" había editado para esa fecha casi doscientos títulos, entre los cuales los autores españoles tenían una importante presencia, fundamentalmente los poetas contemporáneos y escritores de la denominada "Generación del 98". Esto puede explicarse en parte por el recorte temporal que ofrecía la colección desde el título, pero también por una deliberada inclusión de autores que no hallaban espacio de publicación en el ámbito español por diferencias ideológicas y que a partir de su aparición en esta colección tuvieron difusión en el mundo hispánico ${ }^{320}$.

En el mismo catálogo editorial aparece el listado de los títulos correspondientes a las "Cien obras maestras..." y en él la presencia de autores españoles también resulta significativa, en especial porque la colección se postula con afán universalista; a pesar de ello, de los 43 volúmenes editados hasta esa fecha, 15 pertenecen a autores españoles considerados "clásicos", es decir, casi la tercera parte de la colección. Abre este repertorio el Poema del Cid, texto indiscutido de las obras canónicas españolas, en una edición versificada por Pedro Salinas, lo cual también implica un posicionamiento respecto de lo considerado "obra maestra", y se incluyen además obras de Cervantes, Quevedo, Góngora, Lope de Vega, Fernando de Rojas, Tirso de Molina, Baltasar

\footnotetext{
${ }^{320}$ Sin ánimo de exhaustividad, se pueden mencionar entre los escritores incluidos en los primeros números de la "Biblioteca Contemporánea", además de Unamuno, a Azorín, Pío Baroja, Juan Valera, José María de Pereda y Armando Palacio Valdés, entre los noventayochistas, y los poetas Antonio Machado, Miguel Hernández, León Felipe, Rafael Alberti —exiliado en la Argentina-, además de las ya referidas obras de Federico García Lorca y del dramaturgo Alejandro Casona, pertenecientes a las nuevas generaciones literarias.
} 
Gracián y Teresa de Ávila, con lo cual la supremacía de la literatura del Siglo de Oro queda evidenciada y ratifica su condición de "clásica"321. Otro dato significativo de esta colección es que el propio Henríquez Ureña prologó las obras, en un ejercicio de crítica literaria que el dominicano venía desarrollando desde su llegada a la Argentina. Así, las lecturas críticas de obras y autores relevantes se diseminaron no sólo en sus libros, sino que los prólogos también fueron espacios para delinear modelos de interpretación y además pueden vincularse con las prácticas docentes, que manifiestan los entramados intelectuales y sus lazos con la industria editorial ${ }^{322}$.

La colección dirigida por Henríquez Ureña no sobrevive mucho a la muerte de su director, en 1943, y es suspendida a finales de la década de 1940. Sin embargo, la mayoría de las ediciones de los autores españoles incluidas en "Las Cien obras maestras..." fueron incorporadas a partir de la década de 1950 en la "Biblioteca Contemporánea", que ya para ese momento había cambiado su denominación a "Biblioteca Clásica y Contemporánea", con la que continuaría su trayectoria hasta nuestros días. De este modo, el acervo de las obras clásicas españolas incrementó la presencia de la literatura española en la colección, aunque, como señala Larraz, no fue excluyente, sino que uno de los rasgos característicos de la propuesta de Losada fue dar cabida a escritores modernos no sólo españoles sino americanos, lo cual amplió de manera considerable la oferta de títulos de la colección. Al respecto expresa Larraz: “es apreciable, en el caso de la 'Biblioteca Contemporánea', la pretensión de integrar la literatura y la cultura hispanoamericanas en el repertorio de la literatura universal,

\footnotetext{
${ }^{321}$ Para ratificar aún más el carácter de "clásico" atribuido a estos textos y autores, el resto del listado incluye a autores grecolatinos (Homero, Esquilo, Plutarco, Aristófanes) y a europeos consagrados: William Shakespeare, Michel de Montaigne, Molière y Jean Racine. Un dato llamativo resulta la aparición del Facundo de Domingo F. Sarmiento, como segundo volumen de la colección, único americano de la lista, lo cual también expresa una vocación de incluir a escritores nacionales en un listado que se pretende "universal" y equipararlo a las "obras maestras" occidentales.

${ }^{322}$ En la editorial Losada Henríquez Ureña publicó, además de las ediciones críticas de obras, el libro Plenitud de España. Estudios de la historia de la cultura en 1941.
} 
intención que se acentúa a medida que Losada va incorporando a su catálogo a relevantes autores americanos" (2009: 8).

La lectura del catálogo de 1947 también ofrece información acerca de la presencia de la literatura y la cultura españolas en otras publicaciones distribuidas por la empresa: junto con las ya mencionadas colecciones "Poetas de España y América", "Prosistas de España y América" y "Novelistas de España y América", en la que aparecen nombres de autores españoles modernos y contemporáneos, el catálogo exhibe el listado de los títulos publicados de los Cuadernos de Cultura Española, editados por el Patronato Hispánico Argentino de Cultura, que abordan temas vinculados con la cultura española, y también las publicaciones de las universidades nacionales, entre las cuales se destacan las del Instituto de Filología de la Universidad de Buenos Aires, en ese momento bajo la dirección de Amado Alonso ${ }^{323}$. Esto da cuenta de las redes que se fueron conformando entre el ámbito académico —al cual pertenecían Alonso y el propio

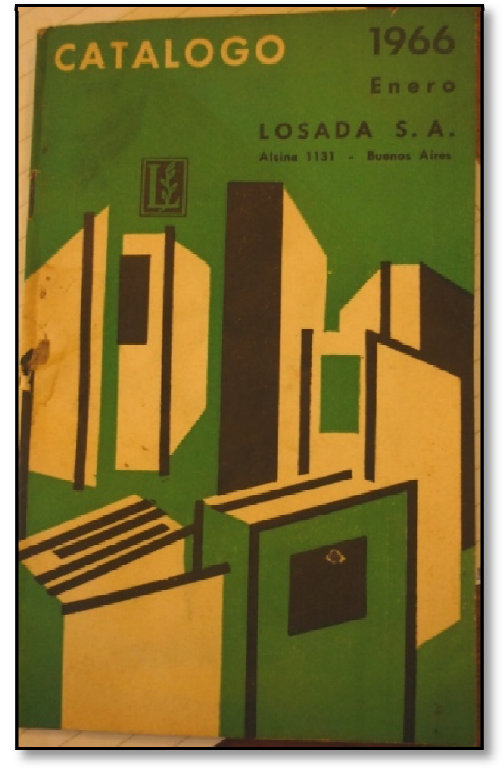

Henríquez Ureña-, y el editorial, lo cual contribuyó a la consolidación y difusión de los estudios hispánicos.

Otro momento en la trayectoria de la editorial Losada se refleja en el catálogo publicado en 1966, casi treinta años después de su creación. De la lectura de este material surgen algunas consideraciones. En primer lugar, para mediados de la década de 1960 la cantidad de colecciones ha disminuido y algunas se han reformulado, lo cual expresa las variaciones de las políticas editoriales

\footnotetext{
${ }^{323}$ En el catálogo de 1947 analizado figuran los títulos publicados en "Anejos de la Revista de Filología Hispánica", la "Colección de estudios estilísticos", la "Biblioteca de Dialectología Hispanoamericana" y la "Colección de Estudios indigenistas", todas publicaciones del Instituto de Filología. También aparecen publicaciones de los Institutos de Cultura Latino-Americana y de Historia de la Cultura Española Medieval y Moderna de la Universidad de Buenos Aires.
} 
de la empresa. En segundo lugar, la "Biblioteca Clásica y Contemporánea" — ya con la nueva denominación - sigue siendo la principal colección, que para este momento ha alcanzado los 316 títulos.

En su confección se mantienen los criterios presentes desde el inicio: inclusión de autores contemporáneos, entre ellos un número importante de españoles, hispanoamericanos y de otras literaturas, formato accesible y costos bajos. Se han reeditado títulos y se han incorporado las ediciones que formaban la colección dirigida por Henríquez Ureña y en algunos volúmenes se han agregado estudios preliminares ${ }^{324}$. Finalmente, continúan presentes en el catálogo las Obras Completas de Federico García Lorca y se agregan las del chileno Pablo Neruda. En definitiva, la literatura $-\mathrm{y}$ en particular la poesía - y los estudios vinculados con ella ocupan una parte significativa del catálogo. Ya no hay mención a otras publicaciones del ámbito universitario o cultural, sino que se trata de un catálogo que expresa las líneas editoriales que Losada proponía para el mercado editorial a mediados de la década de 1960. Este periodo de la industria editorial argentina ya evidencia signos claros de una crisis derivada de los vaivenes económicos y políticos que caracterizaron las décadas de 1950 y 1960 y ello se refleja en las políticas editoriales que asumieron las empresas (de Diego 2006), de las cuales la trayectoria de Losada constituye un claro ejemplo ${ }^{325}$.

\footnotetext{
${ }^{324}$ Además del cambio de denominación, se modificó el logotipo que acompaña a la colección. Durante el periodo correspondiente a "Biblioteca Contemporánea", la imagen apuntaba a la modernidad: una cabeza humana inserta en dos edificios de departamentos, mientras que el logo que identifica a la "Biblioteca Clásica y Contemporánea" abandona lo figurativo y exhibe solo las letras de la colección.

${ }^{325}$ Al respecto, cabe señalar que para mediados de la década de 1960 Espasa Calpe había trasladado la impresión de sus colecciones a España, debido por un lado, a la recuperación de la industria española y por otro, por las difíciles condiciones que presentaba el mercado argentino (Sánchez Vigil 2012).
} 


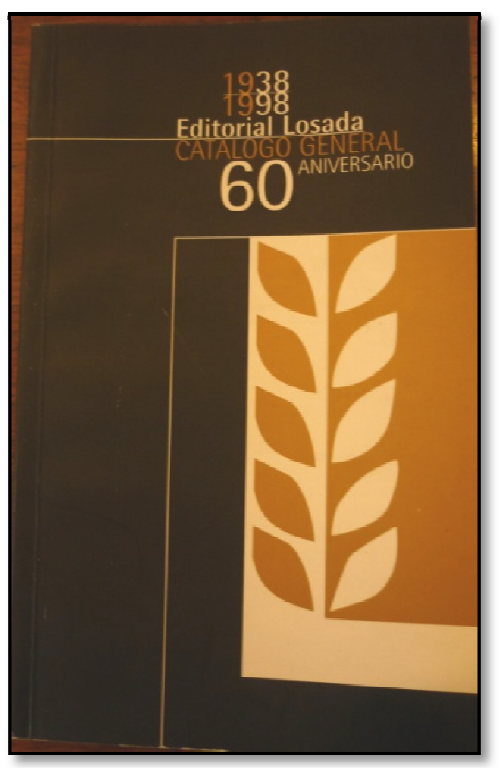

Para cerrar este recorrido por los itinerarios de la editorial Losada a lo largo de sus primeras décadas e indagar en la presencia de la literatura española entre sus publicaciones, nos detendremos en el catálogo que la editorial publicó en 1998, con motivo de celebrar el $60^{\circ}$ aniversario de su creación. En las 193 páginas que lo componen se condensan las principales líneas de su política editorial y los avatares de su trayectoria, en la cual puede corroborarse la relevancia de la "Biblioteca Clásica y Contemporánea", que exhibía ya 630 títulos publicados, entre los cuales hasta finales de la década de 1960 — periodo que abarca esta investigación — se habían editado 92 títulos correspondientes a obras y autores españoles, muchos de los cuales ya contaban con varias reediciones $^{326}$. Esto pone de manifiesto que el criterio mantenido por Losada de ofrecer una colección que incluyera un repertorio de autores selectos tanto del ámbito español como americano, de obras modernas y de clásicos permanentes, resultó una política editorial exitosa que se sostuvo en el tiempo y de la que aún hoy en día, a pesar de que la colección está cerrada, sus títulos continúan circulando. Como corolario de esta trayectoria de la Biblioteca Clásica y Contemporánea puede citarse la presentación que de ella realiza el Catálogo General $60^{\circ}$ aniversario (1938-1968):

La Biblioteca Clásica y Contemporánea a lo largo de estos años acompañó el crecimiento de Editorial Losada. Desde su origen la colección se dimensionó hasta alcanzar un número superior a los seiscientos títulos, pertenecientes a los

\footnotetext{
${ }^{326}$ A título ilustrativo de la permanencia y reediciones de algunas obras de esta colección, el catálogo de 1998 informa que del Poema del Cid (incorporado a la Biblioteca desde la colección de Henríquez Ureña) se habían realizado 23 ediciones, de La dama del alba, de Alejandro Casona, 27 ediciones, y del Romancero Gitano de García Lorca, 24 ediciones. Esto expresa la demanda que algunos títulos de autores españoles - y no exclusivamente contemporáneos - continuaron teniendo durante las décadas siguientes. Es posible que esta persistencia se vincule con su inclusión en la currícula escolar y universitaria.
} 
más variados géneros y tradiciones culturales. El carácter de su estructura se va redefiniendo en función de la importancia que adquieren ciertas obras con el paso del tiempo. La colección ofrece, entre otras cualidades destacables: célebres traducciones de obras clásicas que se mantienen en su versión original; ediciones cuidadas con estudios preliminares; antologías referentes en torno a autores o temas. El formato de libro de bolsillo contribuye a facilitar la maniobrabilidad del material y lo torna accesible (1998: s/p).

La revisión de las propuestas editoriales de Losada durante los primeros treinta años de vida — que coinciden con los momentos de esplendor y de recesión de la industria editorial en Argentina - expresadas en los catálogos seleccionados, permitió examinar los modos en que dichas propuestas asumieron la inclusión de la literatura española, a partir de las colecciones que se impulsaron desde el inicio de la empresa, y los criterios de selección que las sustentaron, en relación con sus propias políticas y con las estrategias de inserción en un mercado que se encontraba en plena expansión. De este modo, las colecciones analizadas en este trabajo dan cuenta del corpus de obras de autores españoles que la editorial ofreció al público tanto hispanoamericano como español —más allá de las vicisitudes que tuvieron las relaciones comerciales con la Península - en el que primaron criterios de variedad (en géneros y autores), modernidad (notable preferencia por los autores y obras contemporáneas), permanencia (a través de la colección "Las cien obras maestras...") y accesibilidad (formato y precio). Asimismo, los vínculos entre los intelectuales que estuvieron presentes en la gestación y desarrollo de la empresa en los primeros años se plasmaron en la publicación bajo este sello editorial, de obras hoy ya clásicas de los estudios lingüísticos y literarios, varios de ellos relacionados con la literatura española ${ }^{327}$, que le otorgaron a

\footnotetext{
327 Entre las obras destacadas en la colección "Estudios Literarios", creada por Amado Alonso que publicó Losada pueden citarse las de la filóloga María Rosa Lida: Libro del Buen amor. Selección (1941) e Introducción al teatro de Sófocles (1944). Más adelante, luego de la muerte de la investigadora, la editorial publicaría Estudios de literatura española y comparada (1966) y El cuento popular y otros
} 
la casa editorial un perfil destacado en el conjunto de las editoriales argentinas desde mediados del siglo XX y en los procesos de consolidación del canon hispánico.

\subsubsection{Editorial Emecé: de la impronta gallega a la "Biblioteca Emecé de Obras Universales"}

El panorama delineado en los apartados anteriores ha pasado revista por los proyectos editoriales de dos de los sellos que tuvieron una destacada presencia en el campo editorial argentino a partir de la década de 1930, ambos a su vez vinculados con la impronta española: Espasa-Calpe, de origen peninsular, que luego se convertirá en una empresa argentina, aunque con fuertes lazos con la casa matriz española, y Losada, fundada por un ex gerente de Espasa Calpe y que iniciará una trayectoria importante no solo como editora sino como "guía cultural" a partir del prestigio adquirido (Santiago de Chitarrini 1992: 531). Ambas empresas, unidas por orígenes en común, exhibirán desde sus comienzos las políticas editoriales con las cuales buscarán insertarse en el mercado y definir el perfil de sus colecciones y con ellas, el de los lectores.

En este panorama marcado por la impronta de los editores españoles, se fue delineando un campo específico en el ámbito cultural argentino a partir de la profesionalización de la industria, hasta ese momento en manos de libreros o imprenteros con cierta vocación y visión de mercado. En palabras de Hugo Levin, "La gran aportación de los editores españoles en la Argentina ha sido su profesionalismo" (en Lago Carballo y López Villegas 2007: 115). De este modo, la inserción de editores españoles en el campo editorial argentino provocó una renovación y modernización del sector y una ampliación de la oferta, en concordancia con el crecimiento de las demandas del público.

ensayos (1976), así como la reedición de Dos obras maestras españolas: El Libro del Buen Amor y La Celestina, editado originalmente por Eudeba en 1966. 
A los nombres de Espasa-Calpe y de Losada puede agregarse otra empresa editorial de origen español que tuvo una trayectoria relevante en el ámbito argentino: la editorial Emecé. Fue fundada en 1939 — y por lo tanto contemporánea de Losada y de la creación de la filial argentina de Espasa-Calpe - por un emigrante de origen gallego, Mariano Medina del Río, quien se asoció a Álvaro de las Casas y juntos dieron inicio a la empresa editorial, cuyo nombre reúne las iniciales de ambos apellidos (de Sagastizábal 2005). El origen gallego de sus fundadores marcó los comienzos de la editorial, que se propuso publicar obras y autores de esa región de España; al año siguiente se incorporan dos editores provenientes también de Galicia: Luis Seoane y Antonio Cuadrado, y se editan los primeros libros tanto en castellano como en gallego, incluidos en dos colecciones: "Dorna"328, dedicada a la poesía, y "Hórreo", de carácter más misceláneo, que abarcaba obras literarias y de otras índoles, como ensayos o filosofía. Ambas colecciones tuvieron repertorios acotados y una existencia breve, pero constituyen - junto con otros emprendimientos y publicaciones- un corpus significativo para examinar la presencia de la cultura gallega en el ámbito argentino ${ }^{329}$ (Gerhardt 2013, 2015).

Si bien el carácter inicial estuvo signado por la impronta cultural gallega, la incorporación de empresarios argentinos en la casa editora fue modificando este carácter primigenio y delineando un nuevo perfil editorial para Emecé. En efecto, el capital comercial lo procuraron los Braun Menéndez, empresarios argentinos vinculados

\footnotetext{
${ }^{328}$ En el caso particular de "Dorna" esta colección fue concebida para ofrecer libros de factura cuidada desde los aspectos materiales y el diseño, con ilustraciones y láminas, que hacían de cada volumen un ejemplar destacado (De Zuleta 1999: 67).

${ }^{329}$ Como dato adicional, al poco tiempo de creada la editorial Emecé, Seoane y Cuadrado se alejaron de ella y fundaron un nuevo sello editorial que continuó con la política de publicar obras de la cultura gallega: la editorial Nova, en 1942. Allí continuaron con esta línea editorial en dos colecciones: "Pomba" y "Camino de Santiago", pero luego ampliaron la oferta hacia otras manifestaciones literarias y culturales (de Diego 2006: 100). Tampoco este proyecto editorial perduró y en 1947 la editorial Nova cerró sus puertas, aunque sus impulsores continuaron vinculados a la industria editorial (Gerhardt 2015).
} 
con el sector agroexportador, que formaron parte del directorio de la editorial y le otorgaron un sesgo particular. Según señala de Sagastizábal: "Fundada por empresarios poderosos, Emecé tuvo desde el inicio un proyecto comercial que la diferenció de la mayoría de las editoriales argentinas, surgidas de emprendimientos individuales casi artesanales" (1995:85). De este modo, el carácter marcadamente comercial que le imprimieron los directores argentinos determinó las políticas editoriales que la empresa diseñó a partir de mediados de 1940. Entre otras, pueden destacarse la publicidad por medio de folletos y boletines que se distribuían entre los libreros, la publicación de avisos comerciales y también las conexiones con la prensa, en particular los suplementos culturales de los diarios de mayor circulación, práctica que empezaba a gestarse en este periodo ${ }^{330}$. Esto expresa los principios netamente comerciales que orientaron las políticas de la casa editora, aunque sin descuidar — al menos desde el plano discursivo - el costado cultural, lo cual escenifica de algún modo las tensiones siempre presentes en el campo editorial entre el libro como portador de cultura y como objeto de mercado (de Sagastizábal 1995: 89).

El giro desde un criterio inicial vinculado con la difusión de la cultura gallega hacia una propuesta que abarcara un público más amplio comienza a gestarse a mediados de la década de 1940, primero, con la concreción de otras colecciones como “Clásicos Emecé” y "Biblioteca Emecé de Obras Universales”, que comparten rasgos con proyectos similares de otros sellos, y luego con el lanzamiento en 1948 de la colección "Grandes Novelistas", donde se editaría un ingente número de novelas de autores contemporáneos de diversas literaturas, muchos de los cuales se convertirían en verdaderos éxitos comerciales. También fueron pioneros en la consolidación de un

\footnotetext{
${ }^{330}$ En el caso de Emecé, el nexo entre la editorial y la prensa lo encarnó el escritor Eduardo Mallea, quien además de participar activamente en las decisiones editoriales de la empresa, dirigió el suplemento cultural del diario La Nación durante casi un cuarto de siglo, entre 1931 y 1955 (de Sagastizábal 2005: 87).
} 
género que hasta ese momento no contaba con una tradición sólida en la Argentina: el policial. En 1944 se inaugura la colección "El Séptimo Círculo", bajo la dirección de Jorge Luis Borges y Adolfo Bioy Casares, que reuniría lo más destacado del género, en particular en lengua inglesa ${ }^{331}$. De allí que pueda apreciarse a partir de la década de 1950 una oferta más relacionada con la literatura de entretenimiento que apuntara a lectores masivos (de Sagastizábal 2005).

Para los objetivos de este trabajo nos interesa detenernos en dos de las colecciones que actuaron como punto de inflexión entre el espíritu inicial de ofrecer un espacio para la difusión de la cultura gallega y la búsqueda de nuevos públicos: "Clásicos Emecé” y "Biblioteca Emecé de Obras Universales". Ambas colecciones, iniciadas a comienzos de 1940, comparten algunos rasgos entre sí y con otras análogas que circulaban en la época ${ }^{332}$. Las diferencias entre las propuestas de cada editorial giran en torno de la factura del material ofrecido: en general, aunque la mayoría privilegia el bajo costo para asegurar la masividad, algunas ediciones se ofrecen a precio diferenciado según el formato material que publican ${ }^{333}$.

En primer lugar, la noción de "clásico" aparece en el nombre mismo de la primera colección mencionada, rasgo que comparte con otras colecciones analizadas. La apelación a lo "clásico" asegura un público que desea nutrir su biblioteca con obras

\footnotetext{
${ }^{331}$ La colección "El Séptimo Círculo" tuvo una extensa y exitosa trayectoria: entre 1945 y 1983 se publicaron en ella 366 títulos, la mayoría de obras traducidas del inglés. Borges y Bioy Casares la dirigieron desde su creación hasta 1956.

${ }^{332}$ En la presentación que acompaña a los volúmenes, incluida en la sobrecubierta, se hace referencia a estos rasgos compartidos con otras ofertas similares, tanto en los aspectos "intrínsecos" (calidad, integridad, seriedad) como "materiales" (comodidad, estética y resistencia). Asimismo, se menciona la composición interna de la colección en once series: I. Biografias y memorias, literatura epistolar y oratoria; II. Ciencias (Ciencias Naturales, Físicas y Matemáticas, Políticas y Morales, etc.); III. Poesía y teatro; IV. Ensayo y crítica; V. Ficción (novela y cuento); VI. Filosofía y religión; VII. Clásicos castellanos; VIII. Clásicos griegos y latinos; IX. Viajes y exploración; X. Historia y arqueología; XI. Referencia y varios. Nótese la semejanza con el modo de presentación de las series de la "Colección Austral", tanto en su forma de agrupamiento como en el carácter misceláneo.

${ }^{333}$ A modo de ejemplo, en el catálogo de la editorial Losada de 1947 se promocionan las obras de la colección "Las Cien Obras maestras..." con precio diferenciado según se trate de la edición en rústica (\$ $2,50)$ o en tela $(\$ 5)$.
} 
juzgadas como ineludibles en el acervo cultural para un sector de lectores que se configuraba a sí mismo como "ilustrado" o que aspiraba a serlo. Al respecto se expresa en la presentación de la colección que acompaña a cada volumen:

Las obras escogidas abarcarán todo el panorama de la cultura humana en el tiempo y en el espacio, pero si abundarán los libros de información y de estudio, aún abundarán más los de literatura pura: poesía, drama, novela, ensayo, etc., pues la verdadera cultura no es un inerte almacenaje de conocimientos, sino la formación viva del entendimiento y de la conciencia, y la función esencial de la creación literaria como de la obra de arte es ennoblecer el alma y avivar su fuego interior.

Se evidencia en esta declaración la preeminencia de la literatura por sobre otros discursos en la composición del corpus de la colección, lo cual tiene su correlato en las series que lo conforman, entre las que aparece una específica destinada a la literatura española: la Serie VII "Clásicos castellanos". Una vez más, el recorte operado en la selección de las obras y autores conjuga dos líneas: la noción de "clásico" atribuida a ciertas producciones o figuras del pensamiento, y el lugar central de la literatura española en la propuesta editorial que se autorrepresenta como "universal".

En ese amplio abanico que ofrece el concepto de "clásico", es de destacar la nítida presencia de autores y textos españoles, en particular del Medioevo y del Siglo de Oro, cuyo prestigio está garantizado por los proceso de canonización que operaron sobre esta literatura desde el siglo XVIII, pero también aparecen figuras más contemporáneas, como Marcelino Menéndez y Pelayo o Ramón Menéndez Pidal.

Así, en segundo lugar, la referencia al carácter "universal" de las colecciones y la noción de "biblioteca" que las vertebra es un rasgo compartido por las colecciones analizadas y que se retoma en el título que da nombre a la segunda colección de Emecé: "Biblioteca Emecé de Obras Universales". La idea de "biblioteca" resume en sí conceptos como selección y orden en base a criterios estéticos y de calidad. Se ofrece 
como un corpus completo que incluye aquellos textos que reúnen ciertos elementos compartidos, lo que, desde el nombre, apunta a un conjunto definido por cierta idea de unidad o de totalidad. Por su parte, el carácter "universal" atribuido a algunas de las colecciones brinda una matriz amplia que permita abarcar no solo obras y autores de diversas procedencias, sino también de épocas variadas, lo que habilita un diseño de las colecciones no restrictivo y con límites más laxos que otras denominaciones - de hecho, la inclusión del adjetivo "clásica" en el nombre de la "Biblioteca Contemporánea" de Losada puede leerse como un modo de incrementar el repertorio de textos y de reformular algunas de las líneas editoriales-.

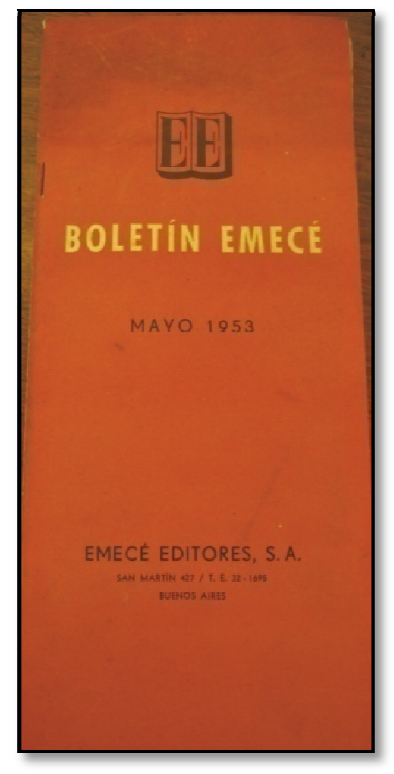

Una vez más los catálogos y boletines editoriales brindan información sustancial acerca de las líneas de publicación y también de los perfiles que se van configurando a través del tiempo. En el caso de Emecé, contamos con el Boletín que publicó la empresa en 1953, a casi quince años de fundada, y donde ya figuran las principales colecciones que conformarían el acervo editorial de este sello. La colección que abre el Boletín es la "Biblioteca Emecé de Obras Universales" que para ese momento lleva publicados 109 títulos, una cifra relativamente importante.

Una lectura del listado de las obras publicadas pone de manifiesto el carácter ecléctico de la propuesta y la ausencia de un criterio definido para la selección de los volúmenes. En él coinciden obras de autores españoles pertenecientes a épocas y géneros diversos (la colección se abre con Sotileza, de José María de Pereda y entre los primeros números se encuentran una obra teatral de Pedro Antonio de Alarcón y los ocho tomos de Historia de los heterodoxos españoles, de Menéndez y Pelayo) con 
escritores del romanticismo francés e inglés, novelistas rusos, autores norteamericanos y portugueses y también una obra de Cicerón, tragedias de Shakespeare y lo que puede resultar más llamativo, obras que pertenecen a géneros no literarios, como los diez volúmenes de Recuerdos entomológicos de Jean-Henri Favre, un tratado sobre esta disciplina. Esta variedad de géneros, épocas, temas y autores, en la que se hallan obras y autores consagrados de la tradición literaria mundial junto con textos de diferentes disciplinas (psicología, música, matemática) y otros de escaso renombre en el ámbito argentino, como el norteamericano Francis Bret Harte o el francés Frédéric Mistral, evidencian el carácter ecléctico de la serie. Llama la atención la ausencia de autores hispanoamericanos o argentinos en la colección, lo cual parece ratificar la idea de que lo "universal" se homologa con "extranjero".

En ese contexto misceláneo, la literatura española ocupa un lugar importante: de los 109 títulos incluidos, 39 corresponden a libros y autores de esa procedencia, es decir, más de la tercera parte. Un examen más en detalle de este corpus da cuenta de que el carácter ecléctico que impera en la colección en general se replica en la selección de obras y autores incluida. En orden histórico cronológico, aparecen obras de escritores del siglo XVI (Juan Luis Vives, Juan de Timoneda, Teresa de Ávila, Miguel de Cervantes, Lope de Vega) junto con autores de los siglos XIX y XX (Gustavo A. Bécquer, Pedro A. de Alarcón, Emilia Pardo Bazán, Luis de Coloma, Leopoldo Alas, el ya citado Pereda, Ángel Ganivet, Juan Valera, Jacinto Benavente, Ramiro de Maeztu). Entre ellos se destaca la figura de Menéndez y Pelayo, del cual aparecen publicados 14 volúmenes, con lo cual se le otorga al santanderino un lugar preeminente no solo entre los autores españoles, sino en el concierto de las "obras universales". Por otro lado, al igual que lo observado en la selección de obras y autores españoles de la "Colección Austral", los criterios de inclusión giran en torno a autores consagrados del canon 
hispánico, en el que el Siglo de Oro aparece de manera recurrente, y también un núcleo fuerte de escritores finiseculares, con lo cual la selección se clausura con estos autores y quedan excluidas las producciones literarias modernistas y contemporáneas. Esto evidencia una idea de canon de cuño conservador, en el que la literatura española comparte lugar con textos provenientes no sólo de otras literaturas en lengua no española, sino pertenecientes a géneros no exclusivamente literarios, tal como se desprende de la organización interna de la colección y de los objetivos postulados en la presentación.

De este modo, la revisión del listado de libros publicados en la colección "Biblioteca Emecé de Obras Universales" muestra un repertorio heterogéneo que no se presenta orientado por un criterio unívoco, en el que la noción de "universal" parece dar cuenta de este carácter misceláneo más que de un afán de ofrecer un panorama extendido de la literatura mundial, en el que conviven textos de la antigüedad clásica, tratados científicos contemporáneos junto con la prosa ensayística de Menéndez y Pelayo. En ese sentido, la propuesta de Emecé no se aparta significativamente de otras similares que circulaban en el campo editorial argentino de medio siglo, de allí la necesidad de postular una diferencia que le permita atraer a los lectores, basada en la relación calidad-precio que ofrecía, tal como queda plasmado en las consideraciones que la empresa impartía a sus distribuidores y donde brinda una definición de "buen libro", es decir, un libro "clásico y universal" cuya factura es correlativa de su calidad:

La Biblioteca Emecé de Obras Universales [...] está realizando el esfuerzo más serio y vigoroso en pro del buen libro a precio local [...] Los elementos inseparables del "buen libro" - texto, limpieza de erratas, calidad del papel, tipología, legibilidad, duración, etc. - son ampliamente superados por la Biblioteca Emecé en igualdad de precio (citado en de Sagastizábal 1995: 87). 
La otra colección publicada por Emecé que examinaremos es “Clásicos Emecé”. En este caso, el énfasis está puesto en el carácter de "clásico" atribuido a las obras que la conforman. Como se ha señalado, tanto la noción de "clásico", como la de "universal" que suelen acompañar el nombre de las colecciones es un rasgo compartido por las propuestas editoriales de este periodo, con un afán abarcador. Asimismo, se trata de nociones que, si bien se presentan a priori como naturalizadas, en realidad proyectan un conjunto de rasgos que desde el enunciador — en este caso el sello editorial— se le asignan a las obras y autores incluidos en ellas. Esto implica que la atribución de ambos adjetivos supone una concepción fijada y que se traslada al corpus seleccionado en un momento determinado sin problematizarse acerca de sus alcances.

En el caso de esta colección — que para la fecha de publicación del Boletín contaba con 20 volúmenes editados - el criterio que parece subyacer debajo del nombre “clásico" es la referencia a la antigüedad grecolatina, aunque no de forma excluyente. De la totalidad de obras editadas, nueve corresponden a textos históricos o filosóficos grecolatinos, y los restantes se reparten entre crónicas de la Conquista (tres volúmenes), un tratado político, un libro de aforismos, un texto de Boecio y finalmente, tres volúmenes dedicados a textos literarios del Siglo de Oro: La Araucana, de Alonso de Ercilla, la Política de Dios de Francisco de Quevedo y La Dorotea de Lope de Vega. Cierra el listado una selección de obras en prosa y verso de Quevedo, a cargo de Jorge Luis Borges y Adolfo Bioy Casares ${ }^{334}$. Una vez más, el criterio de inclusión de los textos resulta, al menos, diluido, ya que la preeminencia de textos de índole histórica o filosófica se ve matizada por la presencia de obras literarias que solo parecen compartir

\footnotetext{
${ }^{334}$ La colaboración de ambos escritores está presente desde los inicios de la editorial, donde además de participar en la dirección de la colección "El Séptimo Círculo", una de las más exitosas del sello, Borges publicó sus obras a lo largo de las décadas siguientes en exclusividad, lo que permitió asociar el nombre del escritor con el de la editorial para el público argentino.
} 
la idea de "clásico" debido a la consagración canónica con la que Lope de Vega o Quevedo ya cuentan.

Este examen de los títulos y autores incluidos en ambas colecciones publicadas por Emecé en sus primeros años —en un periodo que abarca la década de 1940 y comienzos de 1950 - habilita algunas consideraciones, en relación con los objetivos planteados. En primer lugar, luego de unos inicios vinculados a la difusión de la literatura gallega, la incorporación de empresarios con una visión claramente comercial modificó las políticas editoriales de la firma, lo cual se plasmó en la creación de colecciones afines a las demandas del mercado de la época, marcada por la expansión de la industria y por ende, de la necesidad de diversificar y ampliar la oferta. Así surgen contemporáneamente la "Biblioteca Emecé de Obras Universales" y los "Clásicos Emecé”, que se insertan en una tradición de publicación de series destinadas a un público amplio que contaba ya con importantes antecedentes, no solo en el ámbito argentino sino mundial. El carácter ecléctico y heterogéneo signa ambas colecciones, respaldadas por las ideas de "clásico" y "universal" —que en ocasiones pueden funcionar como sinónimos- que las equipara a otras propuestas similares, tal como se ha analizado y que define a varias de dichas propuestas editoriales: recuérdese la serie "Gris", destinada específicamente a los libros considerados "clásicos" de la "Colección Austral" de Espasa Calpe; la "Biblioteca Contemporánea", que luego se convertirá en "Clásica y Contemporánea", y las "Cien Obras Maestras de la literatura y el pensamiento universales", ambas publicadas en Losada, lo cual expresa una voluntad de poner a disposición del público versiones de obras consideradas fundamentales y perennes de la cultura, concebida como universal.

En segundo lugar, entre estas obras que integran las colecciones bajo dichos rótulos, la literatura española, y en particular la considerada canónica, tiene un lugar 
destacado. Así, ambos listados, ya sea que apunten a un repertorio más misceláneo o más conservador, incluyen textos de la literatura española, lo cual ratifica la gravitación de esta literatura en los corpora ofrecidos por la editorial y su relación con las nociones de "clásico" y "universal" que las vertebran. De este modo es posible examinar los criterios que subyacen en la conformación de repertorios a partir de nociones totalizantes, como "clásicos" o "universales" y el valor de la literatura española en esos repertorios destinados en primer lugar al mercado local, y también para públicos del continente y de la Península.

Bajo esos títulos abarcadores, las editoriales pueden ir delineando el perfil de las colecciones según los criterios asumidos por los directores o responsables, pero también funcionan como estrategias para adecuar la oferta a las demandas del público y a los intereses de la firma. Así entendidas, las ideas de "clásico" y "universal" no solo se complementan, sino que, por su índole abarcadora y flexible, autorizan inclusiones y ajustes de acuerdo con las necesidades y vaivenes del mercado y de las propias políticas de las editoriales y permitieron su permanencia en el tiempo sin mayores altibajos, como ha podido observarse en el caso de "Austral" y de la "Biblioteca Clásica y Contemporánea" de Losada, que perduraron hasta fines de siglo.

\subsubsection{Editorial Estrada y los “Clásicos Castellanos": obras españolas para lectores americanos}

Como se ha señalado, el surgimiento de empresas editoriales en este periodo coincide con la expansión de esta industria en la Argentina, que alcanzó en pocos años un crecimiento significativo, que se reflejó no solo en la creación de casas editoras, sino en la multiplicidad de materiales ofrecidos al público, en procura de atender a las crecientes demandas. Al mismo tiempo, las empresas argentinas que contaban para ese 
entonces con una trayectoria en el ámbito editorial, también participaron en la ampliación y diversificación de la oferta y sumaron sus aportes a este proceso, como es el caso de la Editorial Estrada, inserta en el mercado local desde mediados del siglo XIX. Esto implicó para las empresas la búsqueda de una identidad propia y de diferenciación en las propuestas que se pusieron en circulación fundamentalmente a partir de la década de 1940, momento del mayor auge de la industria en la Argentina (de Diego 2006, 2015). Se trataba, pues, no sólo de articular y diseñar líneas de publicación, sino de otorgarles un perfil propio. Así, las estrategias de conformación de la identidad de las colecciones se basaban en dos aspectos: los criterios de selección de las obras y autores a publicarse en ellas (permanencia/novedad, erudición/solaz, difusión/formación, etc.) y el tipo de lector al que iban dirigidas, tal como se ha podido observar en el análisis de las colecciones de Espasa-Calpe, de Losada y de Emecé, todas ellas vinculadas de un modo u otro a la impronta española en la industria, que se publicaron en el ámbito argentino a partir de 1940.

En ese contexto, la editorial Estrada, un sello de dilatada estirpe argentina, ya que había sido fundada en el último tercio del siglo XIX, intervendrá en este proceso de crecimiento del sector a partir de la concreción de colecciones que también participarán de la oferta editorial destinada a un público amplio ${ }^{335}$.

\footnotetext{
${ }^{335}$ La empresa comercial que luego se convertiría en la editorial fue fundada en 1869 por Ángel Estrada, perteneciente a una destacada familia argentina de origen español. Sus actividades iniciales estuvieron vinculadas a la impresión de materiales gráficos y a la industria papelera. En la década de 1870, a partir de la relación de su fundador con el entonces presidente Domingo F. Sarmiento, la empresa tendrá una creciente injerencia en el mercado de materiales destinados a la enseñanza, en particular libros y manuales escolares, que le otorgarían una impronta particular que persiste hasta nuestros días (Buonocuore 1974). Para una mayor información acerca de los orígenes y el desarrollo de la empresa, véase la publicación "Centenario Estrada 1869-1969" (1969) que la casa editorial sacó a la luz en ocasión del centenario de la fundación. Allí se incluyen, además de información acerca del fundador y de la historia de la empresa, trabajos monográficos de José Babini, Juan Carlos Ghiano, Adelmo Montenegro y Gustavo Cirigliano sobre literatura y educación.
} 
Si bien el nombre de la editorial Estrada estuvo — y está aún— asociado casi de manera exclusiva a la edición de materiales destinados a la enseñanza, tarea que ha desarrollado desde las postrimerías del siglo $\mathrm{XIX}^{336}$, a fines de la década de 1930, y en consonancia con la ampliación del mercado, diseñó tres colecciones dedicadas a obras literarias. Así, en 1938 se inaugura la "Colección Estrada", dirigida por el crítico Julio Noé ${ }^{337}$, quien también tendrá a su cargo la colección "Biblioteca de Clásicos Argentinos", iniciada en 1939. Ambas series tuvieron una extensa trayectoria, en especial la "Colección Estrada", cuyos ejemplares de formato de bolsillo, con cuidadas

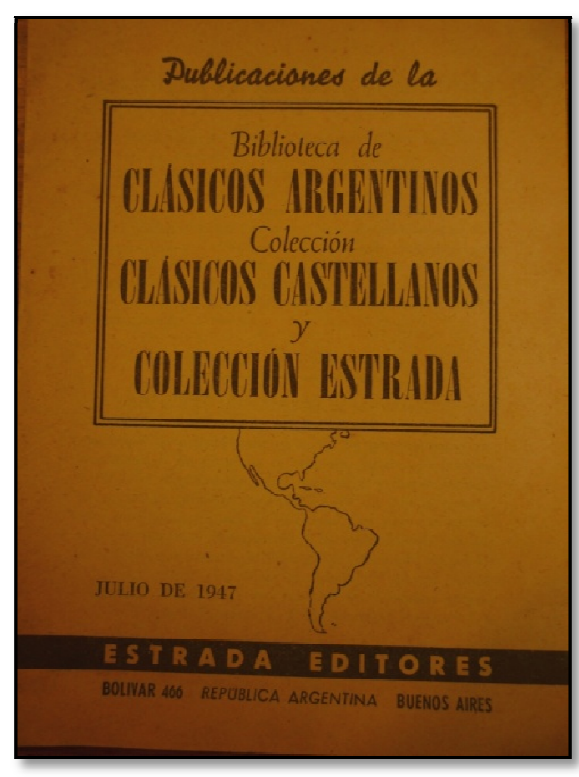
selecciones de obras, y prologados por figuras destacadas del ámbito intelectual, junto con el prestigio del que gozaba la editorial, permitieron alcanzar más de setenta volúmenes, conformando así una destacada colección en el ámbito argentino. A estas dos colecciones se le añadirá en 1943 “Clásicos Castellanos”, que completa este proyecto editorial referido a la literatura y al pensamiento.

En la presentación que acompaña a cada volumen se expresan los objetivos y aspiraciones de la colección y dan cuenta del afán de búsqueda de una identidad propia en el concierto de colecciones similares que, como se ha observado, fueron una

\footnotetext{
${ }^{336}$ El catálogo de la editorial Estada referido a textos didácticos y manuales de enseñanza pone de manifiesto la dilatada actividad que la empresa desarrolló a lo largo del siglo y las transformaciones que la enseñanza, desde el punto de vista de enfoques metodológicos y disciplinares, ha experimentado a través de las décadas. Un estudio exhaustivo de esos materiales permitiría historiar una parte importante de los modelos de enseñanza en la Argentina.

337 Julio Noé (1893- 1983) fue un abogado, historiador y crítico argentino, colaborador de la revista Nosotros, dirigida por Roberto Giusti y Alfredo Bianchi, y conocido por la publicación de la Antología de la poesía argentina moderna (1926). En la editorial Estrada trabajó como antólogo y prologuista de varios volúmenes y también publicó Curso y antología de la Literatura Hispanoamericana, manual destinado a la enseñanza secundaria.
} 
modalidad frecuente en el ámbito editorial de la denominada "época de oro". Allí se afirma:

La Colección Estrada, como otras similares que circulan con autoridad indiscutida en países de avanzada cultura, será una biblioteca de síntesis y orientación, de significación indudable. En cien volúmenes livianos, elegantes, económicos, impresos en nítidos caracteres, revisados y comentados en prólogos y acotaciones por profesores y críticos de probado saber y reconocida competencia docente [...] La Colección Estrada se publica para lectores amigos de las buenas letras y para estudiantes de enseñanza media, del profesorado y de la universidad [...] La autoridad de sus colaboradores y la jerarquía de la Editorial que la ha proyectado y publica bajo su contralor, convierten a la Colección Estrada en una expurgada e insuperable biblioteca de difusión cultural y de consulta para todo lector que desee conocer las obras más calificadas de los ingenios clásicos y las más afamadas, típicas y atrayentes de la literatura americana y vernacular [...] No atribuye esta Editorial originalidad a su iniciativa, pero tiene la convicción de que introduce nuevos valores y modalidades en este género de publicaciones, manteniendo siempre el más alto nivel intelectual y artístico (en cursiva en el original).

La extensión de la cita se justifica por los elementos que presenta para el análisis propuesto. Iniciada en 1938, la "Colección Estrada" ingresaba al mercado editorial al mismo tiempo que otras dos de similares características: la "Colección Austral" (1937) de Espasa Calpe y la "Biblioteca Clásica y Contemporánea" (1938), lanzada por Losada. Ello implica que Estrada debía hacer un esfuerzo por insertar su propuesta y ofrecer rasgos distintivos. En primer lugar, nótese la ausencia de referencia a otras colecciones locales, sino solo a "otras similares que circulan con autoridad indiscutida en países de avanzada cultura", con lo cual establece una genealogía con colecciones análogas de otras culturas y no con las del ámbito nacional; desde el principio, se propone como una "biblioteca de síntesis y orientación", que incluiría cien volúmenes (un número importante, aunque más acotado que las otras series, de allí la mención al 
carácter de "síntesis") cuyos rasgos materiales y formales son compartidos por los de las otras colecciones aludidas (tamaño, precio, factura), a los que se le agrega el plus de los prólogos, a cargo de "profesores y críticos de probado saber y reconocida competencia docente", que remitiría a la idea de la "orientación" pretendida. Asimismo, al igual que se ha observado en la presentación de las otras colecciones, el lector implícito aparece designado como "lectores amigos de las buenas letras" y "estudiantes", con lo cual el sesgo didáctico queda expresado. Esta idea se retoma al señalar que la colección se define como una "biblioteca de difusión cultural y de consulta", en la que se recupera la noción de "biblioteca" atribuida a este tipo de repertorios. Con respecto al contenido, no hay referencia a géneros o temas, pero sí figura la idea de "clásico", que parece ser un rasgo ineludible para las ofertas editoriales, así como a las literaturas "americana y vernacular". Es esta expresión, "clásico" y "americana y vernacular" no son homologables: los "clásicos" necesariamente refieren a textos de otras tradiciones. Finalmente, el reconocimiento de la existencia de colecciones análogas aparece velado hacia el final: su significación no radica en la "originalidad", sino en los modos de configuración, en los valores a los que apunta y en la calidad de la propuesta.

Desde el punto de vista de los textos incluidos, al igual que la colección "Las Cien Obras maestras...” dirigida por Henríquez Ureña, ésta se inicia con una obra de Domingo F. Sarmiento, lo que expresa el carácter inaugural de este autor para la tradición argentina. Y si bien entre los primeros números se hallan obras de la cultura grecolatina, la colección se destaca por una notable presencia de obras y autores americanos y argentinos. Sin embargo, los autores considerados "clásicos" de la literatura española no podían estar ausentes en una biblioteca que se presentaba a sí misma como "de difusión cultural y de consulta". Así, entre los primeros veinte títulos 
editados, cuatro corresponden a autores de los siglos XVII y XIX españoles, presencia que se mantendrá a lo largo de las publicaciones posteriores.

Un año después de lanzar la "Colección Estrada", en 1939, la editorial inaugura la "Biblioteca de Clásicos Argentinos", una serie que viene a "complementar" la colección anterior y que se plantea "dar a nuestro público, en ediciones sucesivas, los libros fundamentales de la literatura, la historia y el derecho argentinos", según reza la presentación que acompaña a cada volumen. También aquí se expresa la necesidad de diferenciación frente a propuestas similares; esta vez, los aspectos que la identifican son "los criterios de selección, el cuidado de los textos, la anotación de los mismos y la presentación gráfica de los diversos volúmenes", cuya "cuidada presentación [...] realza la atracción e interés de la Biblioteca". Un dato significativo cierra la presentación de la colección: la mención a la "misión principal de todo editor argentino: servir a la cultura de nuestro pueblo mediante la difusión de las obras en las que ha culminado el talento de sus grandes escritores". La referencia al "editor argentino" marca una perspectiva singular que tiñe las políticas de la empresa: la conciencia de su carácter nacional y por ende, del sesgo impreso a sus colecciones, que funcionará como rasgo distintivo en el

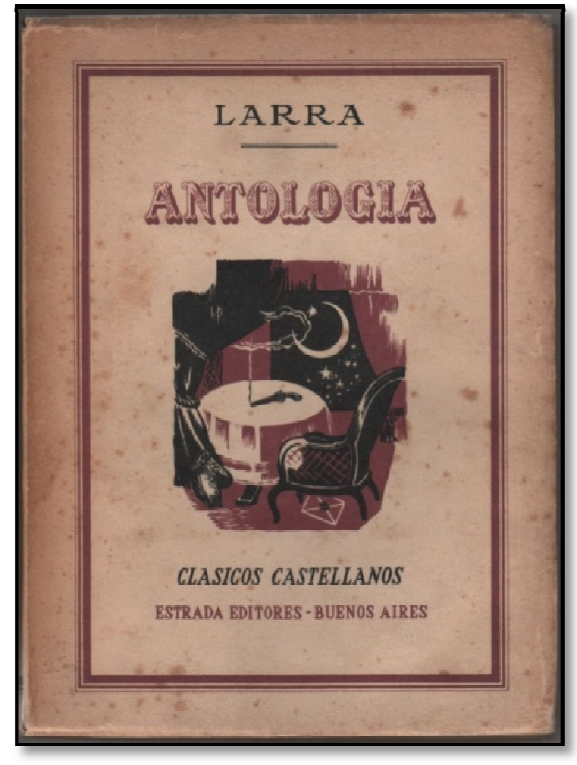
conjunto de propuestas análogas impulsadas en esa época por otros sellos editoriales.

En 1943, la editorial Estrada amplía su oferta con una colección particular, que resulta un claro ejemplo de la impronta nacional que el sello quería otorgar a sus productos: la biblioteca “Clásicos Castellanos", bajo la dirección del escritor Manuel Mujica Lainez. El título replica el de la emblemática serie editada por Espasa Calpe desde 
comienzos del siglo XX; sin embargo, tanto desde lo formal como desde el espíritu de la colección se presentan diferencias relevantes. En el aspecto del formato, los volúmenes poseen un tamaño mayor al de los libros "de bolsillo", y están acompañados tanto en la tapa como en las páginas iniciales, por diseños de un artista nacional de reconocida trayectoria: Alfredo Guido ${ }^{338}$. Es decir, desde su factura revelan un afán estético que reúne la calidad del papel, la tipografía y el diseño y conforman un objeto en el que se aúnan lo literario y lo artístico.

Por otro lado, el espíritu que orienta a la colección se manifiesta en la presentación que acompaña a los volúmenes: se trata de un proyecto que dé cuenta del "enlace" entre la cultura española y la cultura argentina. Esos lazos se fundarían en una tradición común gestada alrededor de la lengua heredada de la Península y desarrollada en el continente americano, lo cual recupera el discurso presente en la época acerca de la "unidad lingüística" y del papel aglutinador de la lengua en la conformación de una comunidad hispánica, junto con nociones como "raza” o "religión”. Resulta interesante que en el proyecto de Estrada la colección referida a la literatura española se anuncie como complementaria de la "Biblioteca de Clásicos Argentinos", en tanto que ambas “están destinadas a formar un solo conjunto armonioso, al que vincula una tradición común"339. De este modo, las producciones argentinas y las españolas se aúnan en un esfuerzo por "enriquecer con igual empeño tan suntuoso tesoro espiritual", al referir a la lengua.

\footnotetext{
${ }^{338}$ Alfredo Guido (1892- 1967) fue un destacado artista rosarino. Fue director de la Escuela Superior de Bellas Artes entre 1932 y 1955. Desarrolló una extensa trayectoria, que incluyó premios y distinciones y fue designado miembro de la Academia Nacional de Bellas Artes en 1941. Se destacó como ilustrador de libros desde la década de 1920. Además de las ilustraciones que acompañan las obras de la colección de Estrada, fue ilustrador de la editorial Kraft, entre las que sobresalen los diseños incluidos en la edición del Martín Fierro, de 1959.

${ }^{339}$ Las citas textuales están tomadas de las presentaciones que acompañaban a cada ejemplar de la colección en las páginas finales, junto con los títulos publicados y los anuncios de los por venir.
} 
La distinción se basa, entonces, por un lado, en la idea de continuidad cultural entre las letras argentinas y las españolas asentada en la lengua común, y por otro, en el "original criterio" en que se sustenta la colección, tal como se expresa en la presentación que se acompaña en las paginas finales de cada volumen: "Casa Estrada ofrece al lector, por primera vez, una biblioteca de autores hispanos en la que cada obra estará precedida por un estudio o prólogo de un autor argentino contemporáneo". Es decir, el sesgo argentino de la colección estará no solo en el aporte crítico que escritores argentinos puedan hacer de obras españolas consideradas "clásicas", sino $-\mathrm{y}$ allí se cifra la diferencia fundamental— en la lectura sugerida: "el punto de vista de un poeta o prosista argentino prestigioso ante ese texto y ese autor: observaciones, crítica y emoción que constituyen, precisamente, los elementos del buscado enlace espiritual a que aludimos". Cada obra española tendrá su lector privilegiado argentino: un hombre de letras que lee a otros hombres de letras a través de un diálogo que busca lograr ese enlace espiritual a través de la lengua compartida. No se trata entonces, de reemplazar la lectura erudita o de rigor filológico realizada por especialistas españoles por otra hecha por argentinos, sino de ofrecer a los lectores una mirada de los clásicos desde la perspectiva del escritor contemporáneo. Según se plantea también en dicha presentación, la idea era abrir el espectro de colaboradores a intelectuales americanos, cuestión que finalmente no llegó a concretarse ${ }^{340}$; de allí la afirmación final: "Una biblioteca de Clásicos Castellanos para lectores de nuestro continente".

Asimismo, en los Boletines publicados por la editorial correspondientes a eneroabril de 1945 y a julio de 1947, donde se informan las "Publicaciones de la Biblioteca de Clásicos Argentinos, Colección Clásicos Castellanos y Colección Estrada”, además de mencionar los títulos ya publicados y los por venir, se retoman estas ideas acerca del

\footnotetext{
${ }^{340}$ Según lo investigado, la colección se publicó, con algunos altibajos, entre 1943 y 1955 y luego se interrumpió, aun cuando restaban títulos anunciados para su aparición.
} 
valor de la colección dedicada a la literatura española y se señala: "Afirma esta colección, a nuestro juicio, una continuidad espiritual que, nacida bajo el cielo de España, se prolonga fervorosamente hasta nuestro país al amparo del idioma común y de su fluir permanente" (1945 s/p).

En un trabajo reciente (2008), Mercedes Rodríguez Temperley analiza en detalle algunos rasgos de esta colección. En primer lugar destaca el carácter netamente argentino y diferenciador de otras similares que se le imprime a la propuesta, en consonancia con un resurgimiento del hispanismo en diferentes esferas de la cultura (Cf. Capítulo 2). Por otra parte, enumera los títulos de obras publicados (doce en total, uno doble dedicado a El ingenioso hidalgo don Quijote de La Mancha) entre 1943 y 1955 y sus correspondientes prologuistas. Según se desprende del listado, las publicaciones fueron sostenidas hasta finales de los años 1940 y luego se discontinúan entre 1949 y 1955, periodo en el que solo se editan tres volúmenes y a partir de esa fecha la colección cesa, aun cuando estaban previstos nueve títulos más, según detalla la autora. A continuación se detiene en examinar especialmente dos de los prólogos: el de Adolfo Bioy Casares a la edición de La Celestina (1949) y el de Carlos Alberto Leumann a Poesías de amor y otras de Jorge Manrique (1952). De esta lectura propuesta se destacan algunos aspectos relevantes de la colección puestos de relieve por la investigadora: su afán diferenciador, el enfoque crítico delineado por los prologuistas argentinos, el valor del prólogo como espacio para ejercer la crítica literaria y la propia escritura y también el esfuerzo por ubicar a esta colección en una tradición hispanista.

Para la perspectiva de esta investigación resulta significativo relevar los títulos de las "obras maestras de la literatura española" que integran la colección — tal como se las denomina en el Boletín - a fin de analizar las convergencias y divergencias con los otros proyectos editoriales examinados. 
Como se ha señalado, el título de la serie se inscribe en una genealogía de otras similares publicadas tanto en España como en la Argentina desde comienzos del siglo, en las cuales la idea de "clásico" se asimila a la de obras y autores consagrados por la tradición canónica. En ese aspecto, esta colección no se aparta de los criterios de selección ya acreditados e incluye a autores y obras del Siglo de Oro: las Églogas de Garcilaso de la Vega, el Cántico Espiritual, de San Juan de la Cruz, las Soledades de Luis de Góngora, La vida del Lazarillo de Tormes, las Poesías de Fray Luis de León y — casi necesariamente - El ingenioso hidalgo don Quijote de La Mancha de Cervantes, en dos volúmenes, que fueron los últimos de la colección que vieron la luz en 1955. Es decir, los títulos dedicados a la literatura española áurea abarcan la mitad de los publicados. El resto se distribuye entre obras medievales: Trovadores castellanos. Cantigas de amor y religiosas, La Celestina, de Fernando de Rojas y las Poesías de amor y otras, de Jorge Manrique, y del siglo XIX: Las Rimas y otras páginas, de Gustavo A. Bécquer, y dos Antologías, una de Mariano de Larra y otra del Duque de Rivas.

Este corpus reseñado expresa con nitidez la noción de "clásico" que organiza la colección; todos los autores u obras incluidos en él han recibido la consagración de la tradición crítica hispánica. Ahora bien, una revisión del listado de títulos propuestos para la continuación de la serie sugiere algunas consideraciones: de los nueve proyectados que no llegaron a editarse, algunos revisten un indiscutido carácter "clásico": las Novelas Ejemplares de Miguel de Cervantes, Las Moradas, de Santa Teresa, El Criticón de Baltasar Gracián. A estos podría sumarse el nombre de Francisco de Quevedo, de quien se plantea publicar El Parnaso. Estos cuatro autores corresponden al Siglo de Oro, con lo cual se refuerza la presencia de la literatura áurea en el conjunto de los denominados "clásicos castellanos". Tampoco resulta discutible la inclusión de 
las Obras de Gonzalo de Berceo, autor medieval cuyas producciones formaban parte ya del canon hispánico del Medioevo. Sin embargo, otros títulos resultan más ajenos a la noción de "clásico" que parece operar en la selección, más atenida a los textos canónicos de la literatura española: la Historia verdadera de la conquista de la Nueva España, de Bernal Díaz del Castillo, una crónica del siglo XVI o La historia del famoso predicador Fray Gerundio de Campazas, alias 'Zotes', del Padre José F. de Islas, una obra satírica del siglo XVIII, junto con una novela del siglo XIX: Los trabajos del infatigable creador Pio Cid, de Ángel Ganivet. Si los dos primeros mencionados, más allá de sus diferencias y de sus trayectorias en el canon hispánico, pueden presentarse como obras insertas en una cierta tradición canónica, la del autor granadino resulta sugestiva en el conjunto de la colección que permite interrogarse acerca de los criterios para tal inclusión. Una posible hipótesis al respecto puede formularse en relación con la aparición de esta misma obra en otra colección contemporánea: la Biblioteca Emecé, que la publicó en 1945 con un estudio preliminar del escritor Eduardo Mallea. Según consta en el listado de títulos por aparecer, el mismo Mallea sería el responsable de la edición para Estrada, con lo cual puede suponerse que se trató de anteponer el prologuista a la obra seleccionada.

El perfil de los prologuistas fue el rasgo distintivo que se propuso la colección como modo de recortarse en el panorama de series similares, tanto en la Argentina como en la Península. De allí que resulte relevante detenerse en examinar dichos perfiles a fin de dar cuenta de la impronta que le imponen a la colección. Como se ha señalado, el director de esta serie editorial fue el escritor Manuel Mujica Lainez, quien no llegó a prologar la obra de Gonzalo de Berceo que estaba prevista para publicarse; sin embargo es factible conjeturar que tuvo cierta injerencia en la elección de los encargados de prologar las obras, quienes, según lo expresado en la presentación de la 
colección, eran "poetas o prosistas prestigiosos". Así, los responsables de cumplir con esta tarea fueron (en orden de aparición de los títulos): Ignacio B. Anzoátegui (Églogas de Garcilaso de la Vega), Leopoldo Marechal (Cántico Espiritual de San Juan de la Cruz), Eduardo González Lanuza (Soledades, de Luis de Góngora), Adolfo Mitre (Antología de Mariano José de Larra), Álvaro Melián Lafinur (Obras selectas del Duque de Rivas), Roberto F. Giusti (Trovadores castellanos. Cantigas de amor y religiosas), Arturo Marasso (Poesía de Fray Luis de León y los dos volúmenes del El ingenioso hidalgo don Quijote de La Mancha), José María Monner Sans (Las Rimas y otras páginas de Gustavo A. Bécquer), Augusto M. Delfino (La vida del Lazarillo de Tormes), Adolfo Bioy Casares (La Celestina de Fernando de Rojas) y Carlos Alberto Leumann (Poesías de amor y otras, de Jorge Manrique) ${ }^{341}$.

Más allá de la condición de "prestigioso" atribuida a los prologuistas, algunos datos permiten reconstruir ciertos lazos y relaciones entre ellos. En primer lugar, se destaca la confluencia de varios de ellos como colaboradores del diario La Nación, en ese momento bajo la dirección de Eduardo Mallea (Cf. Nota $n^{\circ} 330$ ) y donde se desempeñaba desde finales de la década de 1930 el propio Mujica Láinez: Ignacio B. Anzoátegui, Eduardo González Lanuza, Adolfo Mitre, Augusto Delfino y Carlos A. Leumann formaron parte de los colaboradores del suplemento literario del diario en diferentes momentos. Asimismo, algunos de ellos participaron en otras publicaciones culturales de la época: así, González Lanuza fue fundador junto con Jorge Luis Borges — quien estaba previsto que prologara la obra de Quevedo, nunca editada — de la revista Prisma en 1922; Roberto Giusti fue cofundador de la revista Nosotros junto con Alfredo

\footnotetext{
${ }^{341}$ Los prologuistas previstos para las obras que no llegaron a salir a la luz eran los escritores Pilar de Lusarreta, Arturo Cancela, el historiador Enrique de Gandía, Jorge L. Borges, Roberto Giusti, Manuel Mujica Láinez, Juan P. Ramos, Ángel Battistessa y Eduardo Mallea. El listado muestra que la idea era no reiterar el nombre de los colaboradores, con la excepción de Arturo Marasso, cuya inclusión en dos obras del Siglo de Oro puede deberse a la reconocida trayectoria de Marasso en ese ámbito, ya sea desde la docencia como desde su posición de académico. Asimismo, puede observarse la preeminencia de escritores por sobre eruditos o críticos provenientes del ámbito académico, en consonancia con lo propuesto para la colección.
} 
Bianchi; Mallea estuvo en los inicios de la revista Sur, donde también fue colaborador González Lanuza. Esto pone de manifiesto el rol que cumplieron los medios de difusión culturales en los procesos de sociabilidad de los escritores y en el establecimiento de redes intelectuales.

Otro elemento destacable del perfil de los prologuistas de la colección es su pertenencia a instituciones vinculadas con la cultura: Álvaro Melián Lafinur, Roberto Giusti y Arturo Marasso fueron miembros de la Academia Argentina de Letras; por su parte, Melián Lafinur también fue miembro de la Sociedad Argentina de Escritores (SADE), al igual que Leopoldo Marechal. Este último también compartió la función pública con Ignacio B. Anzoátegui en la Secretaría Nacional de Cultura que fuera creada en 1944.

Finalmente, los ámbitos de publicación de las obras de los escritoresprologuistas también evidencian ciertas conexiones: Augusto M. Delfino publicó algunas de su obras en la "Colección Austral", de Espasa Calpe y también en Losada, donde también publicaron Melián Lafinur y González Lanuza ${ }^{342}$. Otra casa editorial que congregó a varios de los autores aquí citados es Sudamericana donde publicaron Marechal, González Lanuza y Carlos A. Leumann ${ }^{343}$.

\footnotetext{
${ }^{342}$ A modo de ejemplo, Augusto M. Delfino publicó en la "Serie Azul" de la Colección Austral su libro de cuentos Fin de siglo (1944) y en la editorial Losada Cuentos de Nochebuena (1946). Eduardo González Lanuza publicó en la colección "Poetas de España y América" de Losada su poemario Oda a la alegría y otros poemas (1949). Carlos A. Leumann también formó parte de la "Serie Azul" de Austral con su libro La vida victoriosa (1944), cuya primera edición fue en 1922. Por su parte, Álvaro Melián Lafinur editó en la colección "Azul y Blanco" de Losada Buenos Aires. Imágenes y semblanzas (1939); asimismo, bajo el sello de la Institución Cultural Española publicó su libro de ensayos Temas hispánicos (1943), donde aborda la producción de Góngora, Lope de Vega, Vicente Blasco Ibáñez y del argentino Enrique Larreta. Este acotado relevamiento pone de manifiesto las interrelaciones forjadas entre los hombres de letras y las casas editoriales, tanto como ámbito de publicación como de participación en su condición de colaboradores.

${ }^{343}$ La editorial Sudamericana constituye otro ejemplo de la presencia de editores españoles en el campo argentino. Su origen comparte algunos rasgos con el de la editorial Losada, ya que su iniciador, Julián Urgoiti, pertenecía a la editorial Espasa Calpe y se aleja de ella en 1938 para crear su propio sello, la editorial Sudamericana, que junto con Losada y Emecé, constituyen la tríada de editoriales "grandes" de origen español arraigadas en suelo argentino casi contemporáneamente (de Zuleta 1999: 55). En los comienzos de la empresa figuran Victoria Ocampo, Oliverio Girondo y Enrique García Merou, entre
} 
El panorama de relaciones aquí esbozado intenta describir el entramado intelectual que subyace en la colección lanzada por Estrada, de clara impronta argentina, y al mismo tiempo permite reconocer los vínculos entre la tradición cultural hispánica y la argentina, a través de los modos en que nuestros escritores se (re)apropian de dicha tradición en los prólogos. Según expresa Rodríguez Temperley, el carácter diferenciador de estos prólogos se manifiesta en especial en el afán por apartarse de los modelos de la crítica académica o universitaria y acercarse más al del lector privilegiado que intenta transmitir el gozo estético que los “clásicos castellanos" le suscitan, actitud que toma, en palabras de la investigadora, la forma de una "velada militancia" (2008).

El cese de la colección en 1955 dejó inconclusa la propuesta de Estrada de ofrecer al público argentino e hispanoamericano una selección de obras y autores considerados "clásicos" de la literatura española a partir de un proyecto que se enraizaba en la idea de la tradición compartida entre España y América, concebida como un continuum cultural. La apuesta radicaba, entonces, en dos elementos: la perspectiva desde la cual se presentaban los textos, esto es, la mirada del hombre de letras situada en el campo cultural argentino de mediados del siglo XX, como forma de establecer un diálogo enriquecedor con los exponentes de esa tradición consagrada, y la factura de los libros como objetos culturales, en la cual lo estético es el aspecto subrayado. De este modo, la colección se inscribía en la tradición hispánica, de la cual la cultura argentina e hispanoamericana formaban parte indiscutida debido a los lazos forjados por el idioma, y a la vez, se apartaba de otras propuestas similares que circulaban en la época para otorgarle una impronta argentina.

otros, y luego se le sumará el editor catalán Antonio López Llausás, quien le imprimirá a la editorial un perfil propio (de Sagastizábal 1995, de Diego 2006). 


\subsection{Algunas consideraciones finales}

El itinerario trazado en esta primera parte, delineado a partir de las editoriales y de algunas de las principales colecciones que llevaron adelante entre fines de la década de 1930 y mediados de la década de 1950 —época que coincide con el periodo de mayor expansión y consolidación de esta industria- posibilita realizar algunas consideraciones. Tal como se ha señalado, para esta investigación se focalizó en la presencia de obras y autores de la literatura española incluidos en dichas colecciones, de modo de analizar la relevancia de dicha literatura en los proyectos editoriales y su relación con la conformación y consolidación del canon hispánico de mediados de siglo en el campo cultural argentino.

Del recorrido realizado por los catálogos y los listados de las colecciones, surge con nitidez que la literatura española ocupó un lugar destacado en el conjunto de los títulos publicados, a partir de al menos dos líneas definidas: por un lado, la asociación más o menos explícita entre "clásico" y un corpus de obras u autores ya consagrados por la tradición crítica y filológica hispánica de cuño menendezpidaliano; en este grupo se incluirían los textos del Siglo de Oro y del Medioevo y ciertos autores del siglo XIX, hasta la denominada "Generación del 98", revestidos de cierto carácter modélico y universalizante. Por otro lado, la apertura del canon hispánico hacia textos y autores modernos y contemporáneos, que permitió la visibilización temprana de un conjunto importante de autores españoles en el ámbito hispanoamericano. Estas operaciones de selección, jerarquización e inclusión expandieron el corpus "legible" y difundieron nuevas voces junto con los clásicos perennes. De este modo, la presencia de la literatura española daba cuenta de la tensión entre tradición e innovación, entre lo consagrado y lo novedoso, en una dinámica atravesada por las demandas del mercado y también por el perfil ideológico de las líneas editoriales que impulsaban las colecciones. 


\subsection{Afianzamiento y crisis de la industria editorial (1958-1973). Canon y nuevos}

\section{lectores}

El panorama presentado hasta ahora ha intentado dar cuenta de los procesos que acompañaron el crecimiento y expansión de la industria editorial en la Argentina desde finales de la década de 1930, que siguieron un desarrollo sostenido hasta mediados de la década de 1950. Dicho periodo es conocido como la "época de oro" del sector y se caracterizó básicamente por el aumento de la producción de libros, la diversificación de las ofertas y su consecuente ampliación del público lector. Durante este lapso se fundaron casas editoriales, se impulsaron otras existentes y se lanzaron al mercado propuestas editoriales variadas que apuntaban a cubrir las demandas de un público ávido y diverso. Entre ellas se han examinado aquellas colecciones más relevantes para los objetivos de esta investigación, es decir, aquellas que tuvieron una importante presencia en sus repertorios de autores y obras de la literatura española, y sus vinculaciones con la conformación de un canon hispánico "legible” para el ámbito hispanoparlante.

Esta etapa de auge y crecimiento tuvo su punto culminante en 1947, cuando se exportaron más de veinticuatro millones de ejemplares con destino a los mercados $\operatorname{hispanos}^{344}$, cifra que disminuiría drásticamente en los años siguientes. Los trabajos al respecto coinciden en ubicar en 1953 el año en que la crisis se hizo más notoria y marcó el inicio de un periodo de inestabilidad y de zozobra para la industria en el país, que luego se iría estabilizando hacia inicios de la década de 1960.

Tal como ocurriera con el proceso de expansión, las causas de esta declinación y reacomodamiento son de índole variada, pero pueden sintetizarse en dos planos; por un lado, el externo, entre los que pueden citarse los cambios respecto de la política editorial

\footnotetext{
${ }^{344}$ Un análisis detallado de los procesos de evolución de la industria editorial y de los mercados del libro en la Argentina en la primera mitad del siglo XX lo ofrece Raúl Bottaro (1964). Allí se encuentran datos y registros de la actividad, así como una evaluación de la situación del sector en ese momento, de sus causas y también la propuesta de ciertas líneas de acción para revertirla.
} 
impulsados por España desde finales de la década de 1940, que permitieron la recuperación del sector en la Península, con las consiguientes consecuencias para la producción de libros en otros territorios; y el interno, que encuentra a la Argentina en un momento de crisis económica y política que culminará con el derrocamiento del gobierno del General Juan Domingo Perón en el año 1955 y el advenimiento de la denominada Revolución Libertadora. (Cf. Capítulo 2).

Entre las consecuencias de este cambio político, una de las más significativas para este trabajo fue el impacto en el ámbito universitario nacional, que venía de sufrir intervenciones de signo diverso desde los años '30. Con el fin del gobierno peronista, las nuevas autoridades impulsaron una normalización de las universidades, en el marco de un proceso "que no fue sencillo ni estuvo exento de dificultades externas e internas en ese ámbito dividido entre humanistas y reformistas" (Gociol 2012: 24). A pesar de las dificultades y tensiones, el modelo universitario propuesto en esta época fue el que perduraría hasta entrado el siglo XXI, basado en la modernización de los saberes y disciplinas, la institucionalización de la investigación científica, la profesionalización y promoción de la docencia universitaria, la creación de nuevas universidades públicas y $\operatorname{privadas}^{345}$, lo que se conjugó con un aumento de la matrícula universitaria en todo el país. Esto posibilitó un redimensionamiento de la universidad y de su posición en el campo cultural argentino como uno de sus actores relevantes.

\subsubsection{Eudeba y la ampliación del público lector: "libros para todos"}

En este proceso de transformación universitaria, uno de los aspectos que adquirirá importancia es la incorporación de la universidad al ámbito editorial, situación que en la

${ }^{345}$ Los cambios y reformas del sistema universitario desde el peronismo en adelante han sido objeto de análisis en el Capítulo 2 de este trabajo. Aquí solo se retoman los aspectos relevantes para el enfoque propuesto. 
Argentina no contaba con demasiada trayectoria. De allí que la creación de la Editorial Universitaria de Buenos Aires (Eudeba) en 1958 fuera un punto de inflexión en las relaciones entre universidad y sociedad ${ }^{346}$. En ese contexto de cambios y de redefiniciones del rol que le cabía a la universidad en él, la Universidad de Buenos Aires ocupó un lugar destacado y se constituyó en la caja de resonancia de los cambios y revisiones que se llevaron a cabo, tanto en el plano ideológico como teórico y metodológico en el campo de las disciplinas. Así, la vinculación con la actividad editorial ofreció la posibilidad realizar aportes desde los campos de conocimiento específicos pero desde una perspectiva particular. Al respecto señala de Sagastizábal: "Eudeba mediatizaba, como toda editorial, la relación autor/lector, pero con el agregado de una preocupación cultural” (2005: 139).

La vida de la editorial ha sido ya reseñada en profundidad (de Sagastizábal 1995, 2008; de Diego 2006; Gociol 2012), de allí que para el enfoque sugerido para este trabajo nos atengamos a aquellos datos relevantes para nuestras indagaciones, relacionadas con las colecciones diseñadas y la presencia de la literatura española en las ofertas editoriales y su vinculación con la conformación del canon hispánico.

Los trabajos acerca de la historia de Eudeba coinciden en reconocer al menos dos etapas en su vida institucional: una primera que se extiende desde su creación en 1958 hasta 1966, en que se produce una nueva intervención a las universidades por el golpe de estado acaecido ese año, y una segunda que llegaría hasta 1976, en que ocurrirá otra interrupción del orden constitucional en el país ${ }^{347}$. De esas dos etapas, la primera se recorta con nitidez ya que se caracterizó por estar bajo la impronta de su

\footnotetext{
${ }^{346}$ Si bien Eudeba, por su proyección nacional y por la dimensión de su oferta, ocupará un lugar central entre las editoriales universitarias, a lo largo de las décadas siguientes surgieron editoriales en el seno de universidades nacionales, proceso que se intensificó a partir del retorno de la democracia en 1983.

${ }^{347}$ Una tercera etapa de la trayectoria de Eudeba es la iniciada con la recuperación de la democracia en 1983, que incluye una activación notoria de los proyectos editoriales pero que queda fuera del periodo abarcado en esta investigación.
} 
director, Boris Spivacow $^{348}$, mientras que la segunda estuvo signada por cambios y alternancias en la dirección, con sus efectos en las políticas editoriales.

A diferencia de las editoriales comerciales, Eudeba era una empresa dependiente de la Universidad de Buenos Aires, tanto en lo referido a la gestión — su directorio estaba integrado por docentes de la esa universidad- como a los aspectos presupuestarios. Esto implicó que para insertarse en un mercado ya consolidado y competitivo, fuera necesario plantear líneas editoriales que pudieran atender a demandas de públicos diferenciados, no exclusivamente universitarios.

Desde sus comienzos, las políticas fijadas apuntaban a ambos aspectos; de allí que se dirigiera tanto a editar libros para las cátedras o resultados de investigaciones académicas, como traducciones de obras que no circulaban en el mercado hispánico. Una de las decisiones editoriales planteadas desde los inicios fue la organización de colecciones, estrategia que permite la planificación y la continuidad de la oferta ${ }^{349}$. Las primeras colecciones lanzadas por la editorial fueron "Cuadernos" (1959), a la que le siguieron los "Manuales de Eudeba" y "Temas de Eudeba". La característica principal de estas colecciones es que ofrecían materiales de calidad tanto para el público universitario (docentes y estudiantes), como para los lectores interesados en esos temas. A pesar de su carácter académico, las colecciones de Eudeba lograron una muy buena recepción en el público, según se desprende de los volúmenes de producción que alcanzaron en los primeros años; las causas de esta situación favorable son atribuibles por un lado, a la ampliación de los perfiles de los potenciales lectores, pero también a

\footnotetext{
${ }^{348}$ La figura de Boris Spivacow (1951-1994) está asociada a dos de los mayores emprendimientos editoriales de la Argentina en ese periodo: cuando abandonó la dirección de Eudeba en 1966, creó el Centro Editor de América Latina (CEAL), que sería otra editorial señera del campo cultural argentino de las décadas de 1960 y 1970. Su fuerte impronta ha quedado vinculada a ambos sellos casi de manera metonímica y ha sido objeto de investigaciones acerca de su figura y su rol en la expansión de la industria en esos años (Maunás 1995; Gociol 2010).

${ }^{349}$ Según Oscar Fernández (2006), durante la gestión de Spivacow, Eudeba llegó a publicar treinta y dos colecciones, lo cual evidencia la diversidad y la multiplicidad de líneas concebidas para todos los públicos.
} 
las estrategias de difusión y comercialización que se implementaron. Además de las tradicionales de aunar bajo costo y accesibilidad, se le sumaron un diseño moderno y atractivo y una compleja red de comercialización, que incluyó la instalación de "quioscos" destinados a la venta de las publicaciones en lugares públicos, desde las facultades, hasta las calles y hospitales, y en los puestos de venta de diarios y revistas. Esto colocó a los materiales editados por Eudeba al alcance de todos los públicos.

En 1960, en consonancia con el $150^{\circ}$ aniversario de la Revolución de Mayo, Eudeba saca a la luz la "Serie del Siglo y Medio". El acta que aprueba la creación de la colección señala

Se trata de poner al alcance del estudiante y del hombre de la calle — no, en particular del lector habitual de libros sino de aquel que lee pocos libros o ninguno - un conjunto de obras que reflejaran la labor de nuestros grandes escritores, los hechos fundamentales, las costumbres de nuestro pueblo (citada en Gociol 2012, 31).

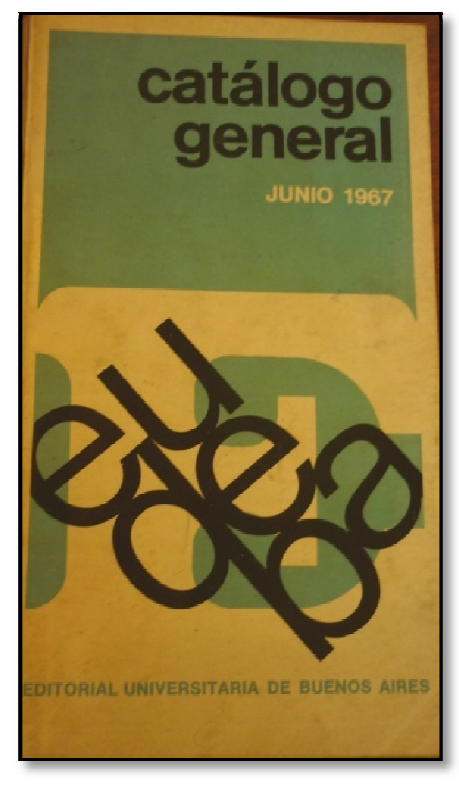

La colección supuso una revisión de los textos clave de la historia y la cultura nacionales desde una nueva mirada, diferente de aquella que signaba las colecciones de las décadas anteriores. Asimismo, desde la editorial se les otorgó un lugar importante al arte y al diseño, que se plasmó en la colección "Cuentistas y pintores" y también con la edición del Martín Fierro ilustrada por Juan Carlos Castagnino en 1962.

Estos ejemplos dan cuenta de las estrategias puestas en juego para posicionar a la editorial universitaria en un ámbito ya consolidado. La apuesta a la conjugación entre el prestigio de la institución universitaria y la modernización en el diseño y la distribución, así como la confección de colecciones 
amplias y de calidad a costos accesibles, le aseguraron un lugar relevante en el contexto editorial argentino y contribuyeron a definir una nueva relación entre la editorial y sus lectores. Así, en el Catálogo de 1967 — que reúne todos los materiales publicados bajo la gestión de Spivacow— se lee: "Eudeba quiere publicar el libro que usted necesita [...] El libro a usted le interesa, el libro que usted necesita, el libro que usted busca, lo tiene Eudeba". Esta forma de apelación directa a los lectores expresa la relevancia que el mercado potencial tenía para la gestión editorial. Asimismo, allí se refuerzan las características del sello que apuntaban en esa misma dirección:

Eudeba imprime sus obras en papel de primera calidad; Eudeba: libros de presentación cuidada, agradable y moderna; Eudeba: obras de jerarquía universal a precio económico; Eudeba: libros de todas las materias y de todos los niveles $(1967 \mathrm{~s} / \mathrm{p})$.

Como es posible observar, esta presentación recupera los principios que sustentaban las editoriales de la década de 1940: calidad, variedad, bajo costo y estética propia. A esto agrega la apelación al lector, que deviene así un elemento clave en el circuito editorial.

Estos rasgos reaparecen en la presentación que acompaña al Catálogo de 1972, que corresponde a otra etapa en la vida de la editorial. Allí se afirma:

Estimado lector: usted ya conoce a Eudeba y por ello es su amigo. Le proponemos continuar y estrechar esa amistad en lo futuro. Otórguele especial atención a este catálogo, analícelo y póngase en inmediato contacto con Eudeba. Lo recibiremos con la deferencia y, permítanos decirlo, con el aprecio con el que se atiende a un amigo. Sus sugerencias serán escuchadas y, en la medida de lo posible, puestas en práctica. Pues la capacidad, la formidable capacidad editora de Eudeba, está a su servicio, para alcanzarle amistosa y dignamente, cuando usted lo solicite, el mayor, el más importante fruto del espíritu humano: un buen libro (1972 s/p). 
Aquí la apelación al lector es más decidida, evidenciada tanto por la elección del formato epistolar, de larga data en la cultura occidental, como por el uso de los imperativos, combinados con la referencia a la amistad. Este modo de estrechar lazos con el lector se conecta también con otras ideas que ya estaban presentes en los catálogos analizados de décadas anteriores: el valor del libro como objeto cultural y simbólico.

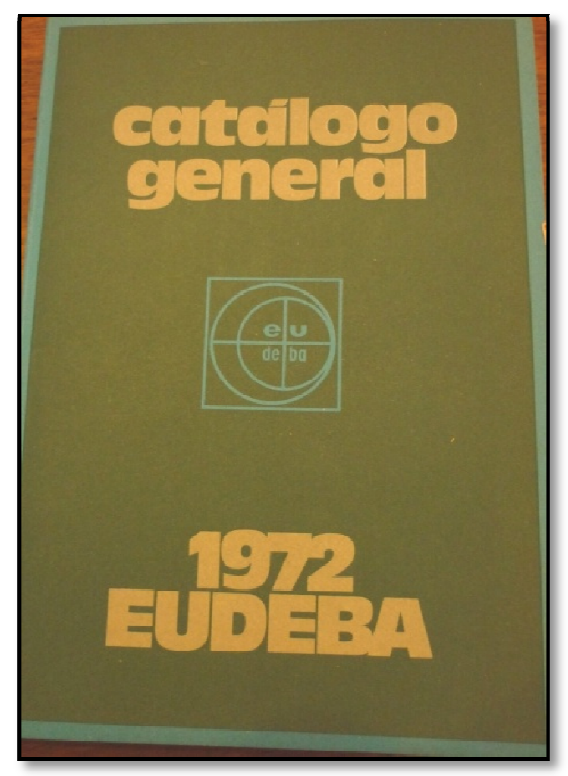

Los cambios producidos por los vaivenes políticos y sus efectos en la vida universitaria a partir de 1966 se sintieron también en el seno de la editorial, que no logró recuperar el impulso inicial que acompañó a sus primeros años. Si bien continuó con la edición de libros y de colecciones, las décadas posteriores, hasta el regreso de la democracia en 1983, estuvieron marcadas por fluctuaciones políticas, ideológicas y económicas que hicieron mella en la vida de la editorial. A pesar de ello, Eudeba ocupó - y ocupa hoy en día— un lugar destacado en el campo editorial argentino y dejó su impronta en un modo de concebir la relación con el público y de ampliar los horizontes de lecturas de toda una generación.

\subsubsection{La literatura española en las colecciones de Eudeba (1958-1973)}

La revisión de las principales colecciones editadas por Eudeba en el periodo seleccionado manifiesta la vocación de la empresa por alcanzar públicos más amplios, en un contexto de expansión del consumo de bienes culturales que se experimenta en la Argentina a partir de la década de 1960, derivado, entre otros aspectos, del incremento en la alfabetización y el mayor acceso al nivel universitario de más sectores de la 
población. Junto con estos factores se observan en la época otros que también permiten explicar el auge editorial y en particular, el de Eudeba: el creciente interés por temas nacionales y regionales y el papel de los medios masivos de comunicación en la formación de los lectores (Rivera 1980). En ese sentido, las ofertas editoriales de Eudeba apuntaron a satisfacer las demandas de los nuevos lectores acerca de esos temas, de allí la significatividad que adquirieron colecciones como la "Serie de Siglo y Medio", dedicada a obras argentinas, así como las reediciones de textos canónicos de la literatura y el pensamiento nacionales y continentales ${ }^{350}$.

En ese marco de renovación teórica y metodológica que se impulsaba desde la universidad, también los estudios literarios experimentaron revisiones y ajustes. Si bien la literatura argentina y la americana recibieron mayor atención en las propuestas editoriales de Eudeba, la literatura española tuvo una presencia si no numerosa, sí destacada, a través de textos que aún en nuestros días siguen siendo de consulta insoslayable. Así, durante la década de 1960 e inicios de 1970 se publicaron bajo este sello cuatro de los trabajos más importantes de la filóloga María Rosa Lida, investigadora del Instituto de Filología de la Universidad de Buenos Aires y afincada desde 1947 en los Estados Unidos, donde continuó su vida académica. A su muerte, ocurrida en 1962, Eudeba decidió publicar sus obras más relevantes referidas a la literatura española.

De este modo, en la colección "Teoría e investigación” se publica en 1962 La originalidad artística de "La Celestina", opera magna de la autora, en una edición

\footnotetext{
${ }^{350}$ En esta misma línea pueden citarse la colección "Genio y figura", que ofreció una semblanza de escritores argentinos desde la perspectiva de especialistas y escritores, con una selección de sus propios textos y la inclusión de fotografias e imágenes, que lograron así un producto que se apartaba de los modos tradicionales de presentación de las biografías y vidas, más vinculado a los modernos modos de publicación y difusión; la colección "La Escuela en el Tiempo", dirigida por Delia Echeverry, inserta en la renovación de la enseñanza de la época, destinada a los maestros, y "la Biblioteca de América", a cargo de Gregorio Selser, que incluyó materiales de diversos autores de Latinoamérica (Fernández 2006; Gociol 2012).
} 
revisada por ella misma, luego de una tarea que le insumió doce años de investigación; en 1966 aparece en la misma colección Estudios de literatura española y comparada, con una nota preliminar de Julio Caillet Bois fechada en enero de 1964; en esa edición, una nota advierte que se publica con la colaboración y el asesoramiento del Instituto de Filología y Literaturas Hispánicas ${ }^{351}$. Ese mismo año, en esa colección se publica Dos obras maestras españolas: "El libro de Buen amor" y "La Celestina", en cuya "Advertencia" se indica que estuvo al cuidado de Ana María Barrenechea ${ }^{352}$. Finalmente, en 1973 sale a la luz Juan Ruiz. Selección del "Libro de Buen Amor" y estudios críticos, en la colección "Biblioteca Cultural Los Fundamentales". Esta edición cuenta con un Prefacio de Yakov Malkiel, esposo de la filóloga fallecida, y un Prólogo de Alberto Várvaro. En el Prefacio, Malkiel agradece a Frida Weber de Kurlat, directora en ese momento del Instituto, la supervisión y la tarea de Silvia Delpy, que era entonces auxiliar de investigación.

Además de las obras de Lida de Malkiel, en la Colección “Ensayos” se publicó en 1962 El teatro de Lope de Vega. Artículos y estudios, una compilación realizada por José F. Gatti que incluye trabajos de distintos críticos sobre la dramaturgia del autor, entre ellos Charles Aubrun, José F. Montesinos, Edward Wilson, Geoffrey Ribbans, Leo Spitzer, Marcel Bataillon y Amado Alonso, con traducciones al español y que se convirtió en un libro muy reconocido por los especialistas en teatro.

En 1969 se publica en dos tomos la edición de Don Quijote de La Mancha, a cargo de Celina Sabor de Cortazar e Isaías Lerner, investigadores del Instituto de Filología y con ilustraciones del artista Roberto Páez en la colección "Biblioteca Básica

\footnotetext{
${ }^{351}$ En 1964 Losada publicó la primera versión de este conjunto de estudios críticos de Lida de Malkiel, lo cual también pone de manifiesto las vinculaciones entre editoriales y las formas de circulación de los materiales. En 1984, Losada lanza la segunda edición de esta obra.

${ }^{352}$ La obra de Lida de Malkiel había sido editada por primera vez en inglés, en 1966, bajo el sello de la University of Illinois.
} 
de la Lengua Española”, según figura en el catálogo de $1967^{353}$. Esta colección tendría como objetivo ofrecer "valiosas y cuidadas ediciones de libros fundamentales de las literaturas españolas e hispanoamericanas, con introducción, notas y apéndices a cargo de renombrados especialistas e ilustrados por prestigiosos pintores" (1967: 70). A pesar de estas intenciones, esta colección no tuvo desarrollo y solo llegó a publicarse esta obra, que se convirtió en la primera edición crítica de este tipo realizada en el continente americano y destinada a lectores hispanoparlantes y de la que se vendieron todos los ejemplares publicados ${ }^{354}$.

Si bien apareció en 1969, la edición sufrió demoras por los cambios suscitados por la intervención universitaria de 1966, ya que el prólogo a cargo de Marcos Morínigo está fechado en ese año. Luego de la intervención, tanto Morínigo como Lerner abandonaron sus cargos en la universidad y la preparación de la edición quedó a cargo de Sabor de Cortazar $^{355}$. Esto es una muestra de las vicisitudes que debió atravesar la editorial en esos años signados por cambios y desplazamientos.

La enumeración de los volúmenes dedicados a la literatura española publicados en Eudeba, muestra que, si bien no constituyen un corpus muy amplio, su relevancia radica en la impronta que dejaron en los estudios hispánicos no sólo en la Argentina, sino en el hispanismo internacional. Los trabajos de María Rosa Lida siguen siendo hoy en día material ineludible para la historiografía literaria de la literatura medieval, al

\footnotetext{
${ }^{353}$ En el Catálogo General de Eudeba editado en 1972 esta colección ya no figura y aparece como "Colección Clásicos Españoles", en la cual solo se halla la edición de Don Quijote, lo que expresa la falta de continuidad de esta propuesta. Nótese que el nombre previsto para la colección retoma las denominaciones clásicas para series de estos temas.

${ }^{354}$ En el año 2005, en coincidencia con el $4^{\circ}$ centenario de la publicación de la obra de Cervantes, Eudeba emprendió la reedición de esta obra, que se encontraba agotada desde hacía varios años, con la colaboración de investigadores del Instituto de Filología y Literaturas Hispánicas de la Universidad de Buenos Aires.

${ }^{355}$ Agradezco estos datos a la Dra. Melchora Romanos, quien estudió la figura de Celina Sabor de Cortazar, compartió con ella su labor en el Instituto de Filología en esos años y fue testigo privilegiado de la inmensa tarea realizada por los filólogos para esa edición anotada.
} 
igual que el libro sobre el teatro de Lope de Vega; la edición de Don Quijote de La Mancha señaló un punto de inflexión en los estudios cervantinos por décadas y ha sido reeditada y ampliada en los últimos años. De este modo, si bien las líneas editoriales de Eudeba no focalizaron específicamente en la literatura española, la envergadura de las obras vinculadas a ella publicadas le otorga un lugar significativo en el concierto de los aportes argentinos a la configuración del hispanismo nacional, sustentado en el prestigio y en el respaldo ofrecido por la Universidad.

De un modo análogo al que se presenta en las revistas académicas publicadas por universidades y centros de investigación, los trabajos aparecidos bajo el sello de una editorial universitaria contribuyeron a fortalecer el hispanismo como un ámbito particular dentro de los estudios de las Humanidades a partir del refuerzo de los lazos entre docencia, investigación y divulgación. El sesgo particular en el caso de Eudeba estuvo dado por su claro propósito de llegar a un público más amplio y de este modo reformular las relaciones entre universidad y sociedad.

\subsubsection{El Centro Editor de América Latina: expansión del canon y del público lector. "Más libros para más"}

El golpe de estado perpetrado en junio de 1966 tuvo implicancias directas en la vida universitaria y provocó una vez más cambios y desplazamientos, en especial de docentes e investigadores que abandonaron los claustros y, en muchos casos, el país. Se produjo entonces un desmantelamiento del sistema científico y académico, que tuvo su correlato en el seno de la Editorial Universitaria de la Universidad de Buenos Aires, la cual fue intervenida y designadas nuevas autoridades.

Una parte importante de los miembros apartados de Eudeba, con su gerente general Boris Spivacow a la cabeza, concreta poco tiempo después, en ese mismo año, 
un emprendimiento editorial que ocupará un espacio relevante en el sector y en el panorama cultural de la época: el Centro Editor de América Latina (CEAL).

Durante los años que ocupan a esta investigación, la editorial alcanzó un desarrollo extraordinario, evidenciado en la multiplicidad de colecciones en que organizó su oferta para llegar a la mayor cantidad de lectores. Ya no amparados por el capital y el apoyo estatal, como en el caso de Eudeba, los editores del CEAL debieron recurrir a estrategias de mercado para poder captar a un público cada vez más masivo y también, diversificado.

Desde su creación en 1966 hasta 1973 —periodo límite de esta investigaciónla editorial había diseñado y sacado a la luz treinta y ocho colecciones que abarcaban temáticas y enfoques diferentes, un número significativo si se piensa en los vaivenes económicos que asolaban al país y en el contexto de inestabilidad política que existía. Algunas de ellas tuvieron una vida efímera, pero otras llegaron a ocupar un sitio fundamental en la formación del público lector y en los modos de operar sobre el mercado: Capítulo. La historia de la literatura argentina y su Biblioteca Fundamental, iniciada apenas un año después de la creación de la editorial, que renovaría sustancialmente la historiografia literaria argentina; Capítulo Universal. La historia de literatura mundial, junto con la Biblioteca Básica Universal, que comenzó a publicarse en 1968 y que alcanzó los ciento cincuenta y ocho volúmenes; ese mismo año se comienza a publicar Siglomundo, la historia documental del siglo $X X$, dedicada a la historia contemporánea y que inauguró la publicación del fascículo acompañada por material documental.

Esta somera enumeración de algunas de las colecciones diseñadas por el CEAL intenta dar cuenta de una de las estrategias implementadas por la editorial que tendría un fuerte impacto en las políticas editoriales: la publicación de las colecciones en 
fascículos semanales coleccionables, junto con un libro de bolsillo, que modificó las formas de distribución y circulación de los materiales. La experiencia recupera algunos de los principios ya presentes en la propuestas de Eudeba: masividad, calidad, modernidad y bajo costo, para garantizar el acceso del público de todos los niveles a los materiales, pero le suma la práctica del fascículo, "forma híbrida entre el libro y el periódico" (Santos 2006), práctica que inaugura un nuevo modo de relación entre las publicaciones y el público. Al respecto afirma la autora, al referirse a la modalidad de presentación de la colección Capitulo. La historia de la literatura argentina:

Si su publicación [la de la colección] fue ideada de manera facsimilar [...] para su venta a mayor escala, también fue proyectada a una posterior encuadernación en volúmenes para conjurar el peligro de la duración efímera. Pero, principalmente, respondió a aun audaz proyecto de sustitución de ediciones especializadas sólo al restricto público culto — los mismos escritores, la Academia y algunos más - para establecer, en cambio, una comunicación con un circuito aún mayor [...] con un plus nada despreciable: la formalización de nuevas relaciones entre la producción cultural de la historia de la literatura y su público. (2006: 69-70).

El párrafo expresa estas modificaciones, no solo a nivel formal, sino, fundamentalmente, cultural: un nuevo pacto de lectura con el público y un nuevo modo de apropiación de los materiales.

Unos meses después del lanzamiento de la colección Capitulo dedicada a la literatura argentina, el CEAL pone en circulación una iniciativa que compartía los rasgos básicos de la anterior (organización en fascículos acompañados por un libro, frecuencia semanal, bajo costo), pero que se proponía historiar la literatura universal. Nace así en 1968, bajo la dirección de Luis Gregorich y el asesoramiento de Jaime Rest, Capitulo Universal. La historia de la literatura mundial, acompañada por los volúmenes que integrarían la Biblioteca básica universal, que a lo largo de ciento 
cincuenta y ocho entregas ofrecerá un ambicioso plan para abarcar las manifestaciones literarias de todas las épocas y todas las geografías. Este afán universalista está en sintonía con los principios rectores de las políticas de la editorial de llegar a públicos amplios con materiales también abundantes y variados, y también con cierta cosmovisión que impregnaba esos proyectos, según la cual "el mundo era plausible de ser asido, conocido y explicado" y que "todo ese conocimiento podía caber en una colección de libros" (Gociol 2008: 13), es decir, expresan la persistencia de cierta "utopía iluminista".

Para comprender un poco mejor el espíritu y los supuestos teóricos e ideológicos que sustentaban esta colección, resulta significativo detenerse en algunas ideas expresadas en las "Palabras preliminares" que abren la colección:

¿Cómo planear, pues, una historia de la literatura universal en la era de los

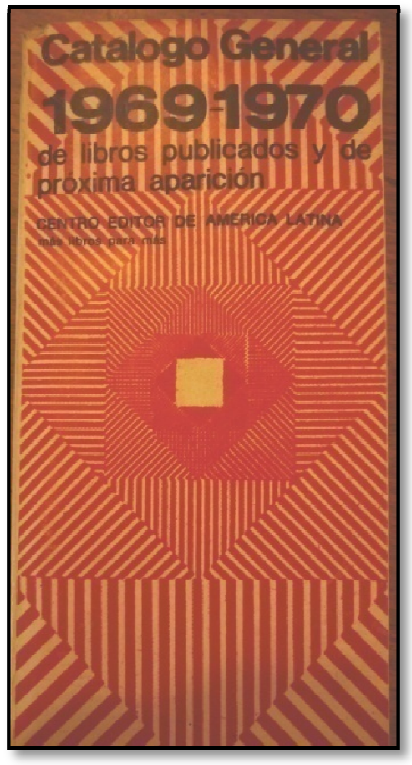
viajes espaciales, de la cultura de masas y de la reivindicación del mundo subdesarrollado? [...] la ambición sería ofrecer simultáneamente una historia de la literatura y una historia social y de la cultura que se enriquecieran y se complementaran mutuamente [...] con estas reservas teóricas, puede afirmarse que la historia de la literatura que iniciamos aquí tendrá un carácter eminentemente popular — no sólo por dirigirse a un sector de lectores muy vasto, sino también porque ha de prestar atención especial al papel desempeñado por las capas populares en la génesis de la cultura - y que su presentación tratará de estar en consonancia con una época fecunda en innovaciones en el terreno de las comunicaciones sociales y de los medios de difusión de masas. (“Capítulo Universal” 1: II).

Se percibe en estas palabras una clara conciencia del hic et nunc de la propuesta: una historia de la literatura situada en el momento contemporáneo, pensada para un tipo particular de lectores y que tuviera en cuenta la dimensión sociológica de los estudios literarios. El resultado fue una dilatada serie que incluyó no solo obras y autores de literaturas con afincada tradición sino también introdujo literaturas cuasi desconocidas 
para los públicos no especialistas, como la literatura asiática y la africana, así como de las culturas ágrafas ${ }^{356}$. Esta combinación de elementos consagrados y otros novedosos signó la iniciativa, que expresó la tensión entre modernidad y tradición y la voluntad de expandir el canon de lo legible en el contexto argentino.

En ese marco, resulta relevante para los fines de esta investigación dar cuenta de la presencia de autores y textos de la literatura española, de modo de analizar su gravitación en el concierto universalista de la propuesta.

Cuadro $N^{\circ}$ 9. Textos y autores españoles en la Capítulo Universal. Historia de la literatura mundial y la Biblioteca básica universal (1968-1973)

\begin{tabular}{|c|c|c|c|}
\hline $\begin{array}{l}\text { Fascículo } \\
\mathrm{N}^{\circ}\end{array}$ & Título del fascículo & Autor & $\begin{array}{l}\text { Obra literaria de } \\
\text { la } B B U\end{array}$ \\
\hline 1 & $\begin{array}{l}\text { Orígenes y desarrollo de la } \\
\text { novela }\end{array}$ & Jaime Rest & $\begin{array}{l}\text { Don Quijote de la } \\
\text { Mancha (I) }\end{array}$ \\
\hline 2 & Apogeo de la novela & Jaime Rest & $\begin{array}{l}\text { Don Quijote de la } \\
\text { Mancha (II) }\end{array}$ \\
\hline 11 & El Romanticismo español & Josefina Delgado & $\begin{array}{l}\text { Rimas y leyendas, } \\
\text { de G.A. Bécquer }\end{array}$ \\
\hline 38 & $\begin{array}{l}\text { Pérez Galdós y la narrativa } \\
\text { española }\end{array}$ & Eduardo Romano & $\begin{array}{l}\text { El sombrero de tres } \\
\text { picos, de Pedro A. } \\
\text { de Alarcón }\end{array}$ \\
\hline 42 & La Generación del 98 en España & Eduardo Romano & $\begin{array}{l}\text { Ensayos y artículos } \\
\text { (selec.), de M. de } \\
\text { Unamuno }\end{array}$ \\
\hline 47 & Desarrollo de la lírica española & Josefina Delgado & $\begin{array}{l}\text { La lírica española } \\
\text { (selec.) }\end{array}$ \\
\hline 48 & Los orígenes de la novela en & Isabel de Santa & La Celestina, de F. \\
\hline
\end{tabular}

${ }^{356}$ Según figura en la contratapa de los fascículos, el plan total de la colección incluía nueve secciones: Literaturas orales primitivas y de las sociedades sin escritura; Literaturas orientales; Literatura griega antigua; Literatura latina; Literatura medieval; Literatura del Renacimiento y de los Siglos de Oro; Literatura del siglo XVIII; Literatura del siglo XIX y Literatura del siglo XX. Como puede observarse, los criterios de organización conjugaban lo cronológico, con lo cultural y lingüístico. 
Avatares del Hispanismo: canon y estudios literarios en la Argentina (1949-1973)

\begin{tabular}{|c|c|c|c|}
\hline $\begin{array}{l}\text { Fascículo } \\
\mathrm{N}^{\circ}\end{array}$ & Título del fascículo & Autor & $\begin{array}{l}\text { Obra literaria de } \\
\text { la } B B U\end{array}$ \\
\hline & España & Catalina & de Rojas \\
\hline 49 & El apogeo del teatro español & $\begin{array}{l}\text { Osvaldo Blas } \\
\text { Dalmasso }\end{array}$ & $\begin{array}{l}\text { Fuenteovejuna, de } \\
\text { Lope de Vega }\end{array}$ \\
\hline 51 & $\begin{array}{l}\text { Cervantes y la madurez de la } \\
\text { novela }\end{array}$ & Estela Dos Santos & $\begin{array}{l}\text { Tres novelas } \\
\text { ejemplares, de M. } \\
\text { de Cervantes }\end{array}$ \\
\hline 53 & El barroco español & $\begin{array}{l}\text { Osvaldo Blas } \\
\text { Dalmasso }\end{array}$ & $\begin{array}{l}\text { Historia de la vida } \\
\text { del Buscón, de F. } \\
\text { de Quevedo }\end{array}$ \\
\hline 96 & $\begin{array}{l}\text { La lírica española de la Edad } \\
\text { Media }\end{array}$ & Rodolfo Borello & $\begin{array}{l}\text { La poesía medieval } \\
\text { española (selec.) }\end{array}$ \\
\hline 97 & La épica tradicional & $\begin{array}{l}\text { Sarah Josefina } \\
\text { Maurer }\end{array}$ & Cantar del Mio Cid \\
\hline 109 & $\begin{array}{l}\text { La renovación de la poesía en } \\
\text { España }\end{array}$ & Josefina Delgado & $\begin{array}{l}\text { Poesía española del } \\
\text { Siglo XX (selec.) }\end{array}$ \\
\hline 120 & La renovación del teatro español & Eduardo Romano & $\begin{array}{l}\text { La verbena de la } \\
\text { paloma, de Ricardo } \\
\text { de la Vega }\end{array}$ \\
\hline
\end{tabular}

Si se considera la totalidad de la colección, integrada por ciento cincuenta y ocho fascículos, la presencia de la literatura española puede parecer poco significativa, ya que aparece en once oportunidades; sin embargo, leído en términos cualitativos, el listado muestra la preeminencia del canon establecido para esta literatura. No faltan las obras consideradas centrales en dicho repertorio, con especial énfasis en las manifestaciones literarias del Siglo de Oro. En este sentido, la propuesta de la colección viene a reforzar la idea de un "canon fuerte" referido a la literatura española, que se fue consolidando a través de las décadas y del cual la serie Capítulo no parece apartarse ${ }^{357}$.

\footnotetext{
${ }^{357}$ La excepción podría verse en el Tomo N ${ }^{\circ} 109$ del año 1970, dedicado a la poesía española del siglo
} $\mathrm{XX}$, en la que se incluyen producciones de varios poetas, desde los de la Generación de 1927 hasta los de 
Estas constataciones manifiestan asimismo las tensiones que atravesaban el contexto cultural de la década de 1960, entendidas en términos de modernización (en los modos de circulación, en los formatos, en los sustentos ideológicos) y de tradición, que puede observarse en los criterios de selección de los materiales. De este modo, la particularidad de la propuesta editorial del CEAL para la literatura mundial estuvo puesta más en la ampliación del corpus de lo considerado "mundial" o "universal", al incluir literaturas o géneros considerados marginales desde una mirada etnocéntrica, como las literaturas africana y asiática, o los géneros populares, que en la revisión crítica del repertorio de obras asentadas por la tradición para las literaturas con una trayectoria de estudios literarios, en especial vinculados con el ámbito académico. Es posible hipotetizar que la extracción universitaria de los colaboradores de la colección haya contribuido a reforzar estos lazos al momento de la selección del corpus.

En el contexto de las múltiples colecciones que lanzó a lo largo de su existencia el CEAL, la literatura española también tuvo presencia en otras líneas editoriales, algunas de las cuales tuvieron una vida efímera. Tal es el caso de la Enciclopedia Literaria, que comenzó a publicarse en 1967 bajo la dirección de Aníbal Ford, organizada en dos líneas: una dedicada a trabajos de tipo monográfico sobre autores y obras de la lengua española y otra a temas de teoría y crítica literaria. En la primera se publicaron cuarenta y nueve volúmenes, de los cuales dieciséis corresponden a la literatura española, es decir, una tercera parte del total.

la posguerra y los denominados "contemporáneos", entre los cuales hay figuras poco conocidas o difundidas en el ámbito argentino, como Gloria Fuentes, Ángela Figuera Aymerich o Joaquín Marco. En un sentido similar puede leerse la inclusión de la obra de de la Vega, La verbena de la paloma, que pertenece a un género considerado "menor" por la crítica académica o especializada como es la zarzuela o el denominado "teatro por horas", de corte más popular. 
Cuadro $N^{\circ} 10$. Autores y obras de la literatura española en la serie "España e Hispanoamérica” de la Enciclopedia Literaria del CEAL (1967-1969)

\begin{tabular}{|c|c|c|}
\hline Vol. $\mathbf{N}^{\circ}$ & Título & Autor \\
\hline 1 & La poesía de Garcilaso de la Vega & Celina Sabor de Cortazar \\
\hline 5 & Benito Pérez Galdós & Beatriz Entenza de Solare \\
\hline 9 & El Mester de Clerecía & Pedro Luis Barcia \\
\hline 13 & Fray Luis de León & Beatriz Entenza de Solare \\
\hline 26 & Análisis de "El alcalde de Zalamea" & Eugenio Castelli \\
\hline 27 & Análisis de "El Conde Lucanor" & Pedro Luis Barcia \\
\hline 30 & La poesía de Quevedo & Celina Sabor de Cortazar \\
\hline 31 & Leandro Fernández de Moratín & Beatriz de Fiore \\
\hline 32 & Menéndez Pelayo & Emilia Puceiro de Zuleta Álvarez \\
\hline 33 & Gonzalo de Berceo 358 & Pedro Luis Barcia \\
\hline 34 & El teatro prelopesco & Oscar Dalmasso \\
\hline 37 & Bécquer & José Pedro Díaz \\
\hline 38 & Análisis de "Don Juan Tenorio" & Claude Cymerman \\
\hline 40 & Góngora & Oreste Fratoni \\
\hline 41 & El marqués de Santillana & Josefina Delgado \\
\hline 44 & Calderón de la Barca & Oscar Dalmasso \\
\hline
\end{tabular}

Una vez más es posible constatar la preferencia por textos y autores considerados canónicos de la literatura española. Asimismo, la relación con el ámbito académico, y en particular el universitario, se manifiesta en los nombres de los responsables de los títulos: Celina Sabor de Cortazar, Beatriz Entenza de Solare, Oreste

\footnotetext{
${ }^{358}$ Este volumen fue anunciado pero no llegó a publicarse.
} 
Fratoni, Emilia de Zuleta, Pedro Luis Barcia, Josefina Delgado y Oscar Dalmasso se desempeñaban en distintas universidades argentinas, lo cual reafirma el vínculo con los estudios literarios impulsados desde los centros académicos. Por su carácter de “enciclopedia", es probable que la colección estuviera más específicamente orientada hacia estudiantes y docentes, de allí la conexión con los textos y autores que tenían presencia en las currículas tanto universitarias como escolares.

Dos referencias más a la literatura española en las colecciones del CEAL: en la "Biblioteca de Literatura", dirigida también por Aníbal Ford y destinada al público universitario, se llegaron a publicar ocho volúmenes, entre 1968 y 1969, de los cuales dos corresponden a temas de literatura española: el $\mathrm{n}^{\circ} 4$, Introducción al Lazarillo de Tormes, de José Francisco Gatti y el n 5, El teatro español de la Edad de Oro, a cargo de Emilio Carilla. Y finalmente un proyecto que quedó trunco: la colección "Mío Cid. Biblioteca fundamental de la lengua española", de la cual solo llegaron a publicarse dos números, cuyo objetivo era editar "obras clásicas de la literatura en lengua española ilustradas en negro y color por destacados artistas y acompañadas por una breve presentación y notas básicas”. A pesar de que el título de la colección pareciera apuntar hacia la literatura española, las dos obras que salieron a la luz correspondieron a obras de la literatura hispanoamericana ${ }^{359}$.

Este recorrido realizado por algunas de las colecciones que lanzó al mercado el CEAL en los primeros años de su trayectoria posibilitó relevar la presencia de la literatura española, a través de la edición de obras y de estudios críticos. El afán modernizador de las propuestas editoriales de la empresa, tanto en lo técnico como en

\footnotetext{
${ }^{359}$ Las obras que llegaron a publicarse en ese año fueron Cantos de vida y esperanza. Los cisnes y otros poemas, de Rubén Darío y Martín Fierro, de José Hernández, con un estudio de Andrés Avellaneda. De esta obra hubo una reedición en 1972. Empero, entre las obras previstas figuran Rimas de Gustavo A. Bécquer, María, de Jorge Isaacs, El Lazarillo de Tormes, Tradiciones peruanas, de Ricardo Palma y Facundo, De Domingo F. Sarmiento. Esta selección evidencia la noción de "clásicos" atribuidos a la colección y su relación con el canon hispánico.
} 
los principios teóricos y metodológicos que las sustentaron, resultó innovador en el panorama editorial del periodo y continuó con el objetivo ya planteado en el proyecto de Eudeba de acercar al público la mayor cantidad y variedad de materiales de lectura de calidad acordes con los tiempos. En ese sentido, su oferta tuvo un cariz "pedagógico", entendido como formador del lector al que iba dirigido, al cual se le ponía a disposición un amplio abanico de lecturas desde una perspectiva novedosa, tanto en el plano formal y estético, como en los temas y abordajes.

En ese contexto modernizador, la literatura española ocupó un lugar significativo, no tanto en lo cuantitativo, como se ha señalado, sino en lo cualitativo, ya que la selección del repertorio incluido en las colecciones analizadas da cuenta de la impronta de un canon que ya estaba consolidado en el ámbito argentino, a la vez que refuerza, desde lo simbólico, las relaciones con el campo académico a través del perfil de los colaboradores y también con el campo educativo, dadas las orientaciones particulares de algunas de las colecciones. Se trata, en definitiva, de acercar materiales ya consagrados por la tradición académica y crítica a nuevos lectores desde una novedosa forma de divulgación y de presentación que genere otros modos de reapropiación de esas tradiciones y al mismo tiempo, contribuya a consolidarlas. Así, las propuestas del CEAL se inscriben en el proceso más amplio y complejo de configuración y resignificación del canon hispánico en el campo cultural argentino.

\subsection{Canon hispánico, mercado editorial y prácticas de lectura: intersecciones}

En consonancia con las líneas de investigación formuladas para este apartado, la revisión de un corpus de propuestas editoriales que circularon en el ámbito argentino en las décadas de 1940 y comienzos de $1970-$ y que incluyeron entre sus ofertas obras y autores pertenecientes a la literatura española — ha permitido, a partir de las hipótesis 
formuladas, exponer algunas consideraciones acerca del proceso de conformación y consolidación del canon hispánico en el contexto argentino de mediados del siglo XX y de las operaciones de apropiación y resignificación que éste involucra.

En primer lugar, es necesario atender a la creciente modernización de la industria editorial que experimenta el campo cultural argentino desde mediados de la década de 1920, a lo que se suma, ya entrada la década siguiente, el aporte sustancial de los editores y profesionales del ámbito editorial provenientes de España, donde dicho sector ya contaba con una importante trayectoria y consolidación. Estos aportes se concretarán en la creación de empresas editoriales cuyos orígenes están estrechamente ligados a España, ya sea porque la Argentina es elegida por casas editoras hispanas para abrir sucursales o crear delegaciones, o por la procedencia de los fundadores y sus lazos con la Península, como son los casos de Espasa Calpe, Losada, Emecé o Sudamericana. La conjunción entre el desarrollo sostenido de la industria en la Argentina desde inicios del siglo XX — del cual la editorial Estrada constituye un claro ejemplo—, sumado a la ampliación del público lector y por ende, de las demandas de materiales de lectura de variada índole, y la impronta que le otorgarán los editores españoles a esta esfera cultural, determinó un crecimiento sustancial de la industria en este periodo - en términos tanto cuantitativos como cualitativos - que ha llevado a calificarlo como la “época de oro" de la edición en la Argentina (de Diego 2006).

Por otro lado, el sesgo hispanista derivado de la impronta de origen de las empresas mencionadas se evidenciará en la confección de sus colecciones, que a partir de finales de la década de 1930 pondrán en circulación un repertorio de textos destinado a satisfacer las demandas del público lector, no solo argentino, sino hispánico. Estas colecciones compartirán ciertos rasgos en común: se trata de ediciones de bajo costo, con un formato "de bolsillo", de temas y géneros misceláneos, orientadas a atraer a un 
público amplio que encontrara en ellas calidad, variedad y la posibilidad de construir una "biblioteca" propia que incluyera obras y autores considerados clave para un lector que se autofigura como "culto".

La configuración del público lector es otro de los aspectos significativos en este proceso. Por un lado, se observa la preocupación por alcanzar a un universo de lectores cada vez más amplio apelando a sus gustos, preferencias y necesidades. Dichos objetivos estén en correlación con la idea de lector que se conforma desde las editoriales; así, según se desprende de los modos en que éste aparece representado en las presentaciones de las colecciones, las proyectos editoriales están diseñados para un lector con apetencias culturales, con curiosidad por las novedades y en constante busca de materiales de calidad tanto material como estética. Esta representación de los lectores que acompaña las propuestas de las décadas de 1940 y 1950 va a adquirir nuevos rasgos a partir de las transformaciones del campo cultural que se produce en la Argentina desde finales de la década de 1950 y durante los años siguientes, caracterizado por una innovación tecnológica, el avance de los medios masivos de difusión, las nuevas formas de circulación y por ende, del perfil de un nuevo lector, el "hombre de la calle", según manifiesta la presentación de la colección "Siglo y medio" de Eudeba, cuyos intereses se orientarán hacia otros temas y disciplinas que ocuparán los debates de la época. Junto con este giro hacia otros horizontes de lectura, perdura la idea de un núcleo fuerte de obras y autores consagrados por las tradiciones culturales y académicas, entre los cuales la literatura española ocupa un lugar relevante y contribuye a reforzar la pertenencia a cierta tradición cultural, a la cual se aspira a consolidar y resignificar desde el campo cultural argentino, con proyecciones al mundo hispánico.

De allí la significación que adquieren las ideas de "clásico" o "universal" con que se titulan las principales colecciones que circulan en este periodo; los libros 
ofrecidos al público lector apuntan a conformar un núcleo básico de la mejor literatura de todos los tiempos, ofrecida por primera vez en formatos accesibles, que se irán modificando de acuerdo con las necesidades y gustos del público.

En ese marco, también resulta revelador el lugar que el libro, en tanto objeto cultural, ha ocupado en las políticas editoriales y en conformación del público. A pesar de la modernización de los medios de difusión y de las prácticas culturales, en todas las propuestas editoriales analizadas se destaca el valor del libro, tanto material como simbólico.

Esta valoración se evidencia con nitidez en la confección de los catálogos o boletines con los que las editoriales ofrecías sus materiales. De su examen surgen ciertas concepciones acerca del libro, de la lectura y, como se ha señalado, del tipo de lector configurado. En el caso de los catálogos, en muchas ocasiones su propia factura lo asemeja al libro — como ha observado, por ejemplo, en el catálogo editado por EspasaCalpe para los primeros 500 títulos de la Colección Austral en 1945-, e incluye no solo los listados de títulos y autores, sino imágenes, antologías de trozos escogidos y hasta opiniones de intelectuales. En otros casos, en los que la elaboración del catálogo no ofrece tantos elementos, se destacan en las presentaciones las referencias al libro o al lector, en especial de textos literarios, aquellos que contribuyen a "ennoblecer el alma y avivar el fuego interior", según reza la presentación de la "Biblioteca Emecé de Obras Universales". Ese carácter formativo atribuido al libro está presente aún en las colecciones de finales del periodo, como puede observarse en la afirmación incluida en el catálogo de Eudeba de 1972: “el mayor, el más importante fruto del espíritu humano: un buen libro". Así, a través de las décadas y de las variaciones del ámbito social y cultural, el libro mantiene su papel de modelador de prácticas, de apropiaciones y (re)apropiaciones de un acervo que se presupone válido y fundante. 
Este haz de valorizaciones sobre el libro y su funcionalidad se entrelaza significativamente con la idea del "lector amigo" que propone Eudeba desde su catálogo de 1972, que puede vincularse también con el "público amigo de las buenas letras" que se propugnaba en la presentación de la "Colección Estrada" a comienzos de 1940. De este modo, se conforma un entramado conformado por las relaciones entre el lector, el libro y la editorial, como mediadora necesaria. Y asimismo, la referencia a las "buenas letras", a los "mejores libros del mundo, las "obras cumbres", o las "obras más calificadas de los ingenios clásicos" remiten indudablemente a cierta idea de canon que las colecciones intentan definir y resignificar. En ese contexto, la manifiesta presencia de un corpus de textos y autores de la literatura y la tradición españolas evidencia la gravitación que dicha tradición exhibía en el panorama cultural argentino de mediados del siglo y que, más allá de ciertas operaciones de ampliación y revisión de estos repertorios, el "canon fuerte" de la literatura hispánica se recorta con nitidez entre las propuestas editoriales, desde las de corte más universalista, hasta las más clásicas o modernizantes.

Concebido como un espacio atravesado por dichas tensiones, el canon hispánico adquiere nuevas aristas a partir de la relación entre los textos ya consolidados por la tradición y aquellos contemporáneos que llegaron a través de estas estrategias a un público amplio. Asimismo, ese canon también circulaba en el ámbito académico (Cf. el Capítulo 2 de esta investigación), con lo cual se genera una retroalimentación entre el corpus disponible para el mercado y aquel que forma parte de los estudios críticos y de los abordajes académicos. Una de las formas de intersección de estos espacios lo constituyen las figuras de los colaboradores, presentadores y prologuistas de los textos hispánicos incluidos en las colecciones analizadas, muchos de los cuales provenían del ámbito universitario o académico y, a su vez, se desempeñaban como colaboradores en 
revistas y publicaciones culturales. Así se conforma una red de interrelaciones entre diferentes esferas del campo cultural en la cual el canon hispánico se presenta como un espacio de debate y de negociaciones, a la vez que se va delineando la configuración de una tradición argentina de estudios hispánicos. 


\section{Conclusiones}

El itinerario propuesto en esta investigación permitió establecer algunas constataciones, a partir de las hipótesis delineadas en relación con los procesos que subyacen en la conformación del hispanismo en el campo intelectual y académico argentino y su impronta en la construcción de una tradición propia de estudios literarios y en la configuración de un canon hispánico situado en las coordenadas ideológico-culturales de mediados del siglo XX.

La primera constatación se relaciona con las modulaciones que fueron adquiriendo las relaciones con España desde el periodo post independentista en la América hispana y en la Argentina en particular. Las primeras décadas posteriores a los movimientos independentistas fueron momentos de fuertes debates en torno a la construcción de la identidad de los nuevos países y de la conformación de los estados nacionales. En ese contexto, en la Argentina de las primeras décadas del siglo XIX, el hispanismo se definió como una matriz ideológica a partir de / desde / contra la cual pensar la propia identidad cultural. Así, las posiciones antihispánicas definieron los discursos de los letrados como parte de los procesos de emancipación que, luego de su fase política, continuaron con la cultural, en la cual el tema de la lengua fue uno de los puntos clave de los debates. En ese marco, uno de los aspectos planteados y discutidos fue el de la necesidad de pensar en una lengua nacional y, a partir de ella, comenzar a diseñar una literatura propia. Desde esta perspectiva, el (anti)hispanismo fue la "piedra de toque" para reflexionar acerca de los vínculos con España y de los modos de construir una tradición nacional que necesariamente se definiría a partir de la tradición española, ya sea desde el rechazo o la aceptación. Durante este periodo de redefiniciones y búsquedas identitarias, los lazos con España se determinaron por oposición o por acercamiento, articulados en un conjunto de discursos en los cuales 
prevalecen la polémica o el contrapunto antes que el diálogo conciliador. Sin embargo, a partir de la segunda parte del siglo $-\mathrm{y}$ en concordancia con cambios en el panorama tanto peninsular como argentino e hispanoamericano - se advierten algunas variaciones en los discursos y en las valoraciones acerca de lo hispano. Como hitos pueden citarse la iniciativa de la Real Academia Española de crear academias correspondientes en el continente americano y la convocatoria a intelectuales para incorporarse como miembros correspondientes, gesto que fue recibido con beneplácito por la mayoría de los convocados. El paradigmático rechazo del argentino Juan María Gutiérrez pone de manifiesto la persistencia en el discurso de las posturas antihispanistas más radicales, aunque ya en franco retroceso. Otro hito lo constituye la publicación de la Antología de poetas hispanoamericanos, encargo de la Real Academia a Marcelino Menéndez y Pelayo como parte de los gestos celebratorios del IV Centenario del Descubrimiento de América, obra que sentó las bases para pensar un canon hispanoamericano.

La segunda constatación se vincula con las transformaciones socioculturales a las que se asiste en la Argentina en las últimas décadas del siglo XIX, debido a un fenómeno social que tendrá un fuerte impacto en los debates ideológicos: el aluvión inmigratorio. Ante esta nueva situación, reaparecen los discursos en pos de una "lengua nacional", no ya como modo de diferenciación con España, sino como estrategia discursiva para enfrentar los peligros de una posible disolución identitaria. Las celebraciones en torno al Centenario de la Revolución de Mayo ofrecen un escenario fértil para revisar las posturas hacia y contra España, momento en que se produce un "giro hispanista", a partir del cual las visiones acerca de España y su lugar en la tradición cultural adquieren nuevos tintes, permeados por el contexto. De este modo, las posiciones a favor o en contra de una vuelta al hispanismo se articulan en discursos que fluctúan entre el rechazo y la conciliación. 
Paralelamente, la modernización del sistema científico en la Península acarrea una apertura hacia el mundo, tanto europeo como americano, y la Argentina se convierte en uno de los destinos privilegiados para intelectuales y académicos españoles, que llegan a estas tierras en misión cultural y establecen vínculos con intelectuales de esta orilla, lo cual repercute en una incipiente institucionalización de los estudios tanto científicos como humanísticos en pos de generar conocimientos locales y situados. Asimismo, algunas figuras del campo intelectual argentino viajan a España, y en los discursos que plasman ese desplazamiento se entrevén también nuevas visiones de lo hispánico. Entre ellos, se destaca Ricardo Rojas, por el papel que desempeñó en la conformación de una tradición de estudios filológicos y lingüísticos en la Argentina, a partir de la institucionalización de estas disciplinas en el ámbito académico y universitario.

Estos procesos conducen a una tercera constatación: derivado de estas (re)visiones acerca de España y su cultura y de los nuevos lazos intelectuales que se establecen, el hispanismo deja de concebirse en tanto posición ideológica, definida en términos de oposición o adhesión, para empezar a pensarse como un ámbito de producción intelectual, como enfoque interpretativo y como campo de estudio. Una muestra de esta reformulación la constituye el temprano estudio de Rojas sobre Cervantes, que de algún modo inaugura una tradición de estudios acerca de la literatura española situada en el Cono Sur. De este modo, figuras como la de Rojas en la Universidad de Buenos Aires o Arturo Marasso en la Universidad Nacional de La Plata, junto con las primeras generaciones de filólogos formados en el Instituto de Filología y de otros centros académicos, fueron forjando un ámbito de estudios y de investigación que proponía lecturas críticas y apropiaciones de la tradición hispánica no ya desde la Península sino desde las periferias. Esto implicó un complejo proceso de legitimación, 
cuyas principales estrategias fueron la investigación rigurosa, la formación de discípulos, la asimilación de nuevos enfoques críticos y metodológicos y la divulgación de los resultados a través de publicaciones periódicas y no periódicas, que buscaron ocupar un lugar relevante en el contexto del hispanismo mundial. Se asiste así a la gestación de un hispanismo académico de cuño argentino, sólidamente vinculado a centros académicos, con proyecciones tanto nacionales — cristalizadas en la creación de institutos y centros en diversas universidades del país-, como internacionales. En este contexto, las relaciones con España no se plantean ya en términos opositivos — más allá del reverdecimiento de algunas polémicas lingüísticas ya avanzado el siglo $\mathrm{XX}$ - sino desde la legitimidad que otorga el reconocimiento temprano de los aportes argentinos a los estudios hispanistas. Así, desde mediados de siglo, el hispanismo se va consolidando como espacio autónomo en el ámbito académico a través de figuras que alcanzan renombre internacional (al respecto pueden citarse los nombres de los hermanos Raimundo y María Rosa Lida, Ángel Rosenblat, Arturo Marasso y Ana María Barrenechea, por mencionar algunos).

Las contribuciones y los estudios críticos generados desde el ámbito académico argentino habilitan una cuarta constatación, en tanto condujeron a operaciones de revisión, reformulación y/o apertura del canon hispánico, definido como un espacio de tensiones y negociaciones entre tradición e innovación. Estas tensiones se ven representadas en el corpus de aportes críticos y metodológicos producidos en el marco del hispanismo: por un lado se verifica una notoria presencia de trabajos sobre autores y textos considerados "clásicos" por la historiografía literaria hispánica, pero también revelan operaciones de intervención activa sobre dicho canon, a partir de intentos de apertura del repertorio tradicional, de relecturas de los clásicos desde nuevos enfoques, de inclusiones de obras y autores no consagrados o que ocupaban un lugar marginal en 
los estudios hispánicos. De esta manera se fue delineando un canon que resultara "legible" en el campo cultural argentino, con proyecciones hacia la investigación, la crítica y la enseñanza, tanto en el nivel universitario como secundario o terciario y atravesado por las tensiones intrínsecas a todo proceso de apropiación crítica.

Este derrotero señalado deriva en una constatación final, que pone en relación la circulación del canon "legible" no solo dentro del campo académico, vehiculizado fundamentalmente a través de las publicaciones periódicas y de obras teóricas y críticas, sino en el marco más amplio del público lector, en el que entran en juego las estrategias del sector editorial. Este sector experimentó a lo largo del siglo XX las fluctuaciones derivadas del contexto no sólo económico y político, sino cultural: la ampliación exponencial del público lector generada desde las primeras décadas del siglo conllevó una marcada transformación del campo editorial argentino. La conjugación de nuevas prácticas editoriales permeadas por el mercado y las prácticas de lectura con los aportes de la crítica académica y erudita actuó como instancia de legitimación de obras y autores de la tradición hispánica. Al mismo tiempo, tensiones análogas a las observadas en los procesos de apropiación crítica de un corpus hispánico por parte del ámbito académico se verifican en los repertorios confeccionados por las editoriales y puestos en circulación, así como en los criterios que subyacen a la confección de las colecciones editoriales, que condensan disputas acerca de los límites y alcances de la noción de canon en el campo cultural argentino de mediados de siglo XX.

Como cierre - provisorio, como el de toda investigación — es posible retomar las ideas expresadas en el título propuesto para este trabajo: los "avatares del hispanismo" refieren los procesos a través de los cuales el concepto de hispanismo fue adquiriendo modulaciones ideológicas particulares en distintos momentos del devenir intelectual en la Argentina, desde las posiciones ideológicas antagónicas iniciales del 
siglo XIX hasta su conformación como espacio disciplinar autónomo y sus estrategias de legitimación durante el siglo XX. En estos procesos, es posible reconocer la integración de redes intelectuales que involucraron a diversos agentes de este campo y que se diseminaron en los ámbitos estrictamente académicos, como institutos, cátedras o centros de investigación, y también hacia el campo editorial, lo que posibilitó una particular configuración del hispanismo argentino.

Este hispanismo argentino tuvo una decisiva intervención en la construcción de un canon literario contextualizado, atravesado por tensiones ideológicas y culturales, así como en la formación del gusto de los lectores, en la invención, selección y transformación de una educación literaria que se fue forjando a partir de sus aportes y en la reorganización de la crítica literaria. Se trata, en definitiva, de un proceso complejo en el que se entrelazan cuestiones vinculadas con las prácticas culturales y con los debates ideológicos, y que postulan una relectura del canon hispánico desde una mirada situada en el campo cultural argentino en la segunda mitad del siglo XX, que habría de repercutir en la configuración global del hispanismo.

Es de desear que algún día se escriba una historia global del hispanismo, intento que sin dudas auxiliaría a la comprensión de muchos fenómenos históricos, sociales y culturales (intercambios literarios, vinculaciones entre intelectuales, relaciones lingüísticas, estéticas, de pensamiento, etc.). En tal sentido, esperamos haber contribuido con un capítulo de dicha historia desde este lejano Cono Sur, ese "confín del continente" — en palabras de Ricardo Rojas - desde donde generaciones de hispanistas argentinos entablaron un diálogo fecundo con la tradición hispánica. 


\section{Bibliografía}

\section{Fuentes consultadas}

\subsection{Publicaciones periódicas}

Boletín del Instituto de Investigaciones Literarias. Instituto de Investigaciones

Literarias. Departamento de Letras. Facultad de Humanidades y Ciencias de la Educación. Universidad Nacional de La Plata. No 3 (1949) - 7 (1953).

Cuadernos de Filología. Facultad de Filosofía y Letras. Universidad Nacional de Cuyo. $\mathrm{N}^{\circ} 1(1966)-6(1972)$.

Cuadernos del Sur. Departamento de Humanidades. Universidad Nacional del Sur. No 1 (1958, junio) - 11 (1969-71).

Filología. Instituto de Filología y Literaturas Hispánicas “Amado Alonso”. Facultad de Filosofía y Letras. Universidad de Buenos Aires. No 1.1 (1949) - 16 (1972).

Revista de Literaturas Modernas. Facultad de Filosofía y Letras. Universidad Nacional de Cuyo. No 1 (1956) - 12 (1973).

Revista Humanitas. Facultad de Filosofia y Letras. Universidad Nacional de Tucumán. $\mathrm{N}^{\mathrm{o}} 1(1953)-17(1964)$

Series Monográficas. Trabajos, comunicaciones y conferencias. Departamento de Letras. Facultad de Humanidades y Ciencias de la Educación. Universidad Nacional de La Plata. No 4 (1963) - No 12 (1971).

\subsection{Boletines y publicaciones institucionales:}

Boletín de la Academia Argentina de Letras. No 1 (1933) - 38 (147-8) (1973).

\subsection{Catálogos editoriales}

Catálogo Colección Austral Espasa Calpe, 1945.

Catálogo Colección Clásicos Castellanos Espasa Calpe, 1980. 
Catálogo Losada, 1947.

Catálogo Losada, 1966.

Catálogo General 60 aniversario 1938-1998 Losada, 1998.

Boletín Emecé, 1953.

Publicaciones de la Biblioteca de Clásicos Argentinos, Colección Clásicos Castellanos y Colección Estrada, 1945.

Publicaciones de la Biblioteca de Clásicos Argentinos, Colección Clásicos Castellanos y Colección Estrada, 1947.

Catálogo General Eudeba, 1967.

Catálogo General Eudeba, 1972.

Catálogo General 1969-1970 de libros publicados y de próxima aparición CEAL, 1969.

\section{Referencias bibliográficas}

Abeille, Lucien. Idioma nacional de los argentinos. [1900]. Buenos Aires: Colihue, 2005.

Agesta, María de las Nieves. "Los trabajos de Anfión. Humanidades en la Universidad Nacional del Sur". Eadem utraque Europa [la misma y la otra Europa]. Revista de historia cultural e intelectual, Año 4, N 6, 2008: 157-182.

Alfieri, Teresa. "La identidad nacional en el banquillo". Historia crítica de la literatura argentina. Noé Jitrik, dir. Vol. 5. La crisis de las formas. Alfredo Rubione, dir. Buenos Aires: Emecé Editores, 2006: 515-541.

Alfón, Fernando. "La querella de la lengua en Argentina (1828-1928)". Tesis de Doctorado Universidad Nacional de La Plata, 2011 (online). Disponible en http://sedici.unlp.edu.ar/bitstream/handle/10915/20882/Documento completo pdf?sequence $=1$ 
"La Nación y los combates por la lengua". La Biblioteca, $\mathrm{N}^{\circ} 7$, primavera 2008: 402-430.

Altamirano, Carlos (ed.). Historia de los intelectuales en América latina. II. Los avatares de la "ciudad letrada" en el siglo XX. Buenos Aires: Katz Editores, 2010.

Altamirano, Carlos y Beatriz Sarlo. Ensayos argentinos. De Sarmiento a la vanguardia. Buenos Aires: Ariel, 1997.

Altamirano, Carlos. Bajo el signo de las masas (1943-1973). Biblioteca del pensamiento argentino VI. Buenos Aires: Emecé, 2001. Peronismo y cultura de izquierda. Buenos Aires: Temas, 2001.

Álvarez Barrientos, Joaquín (ed.). Memoria de hispanismo. Miradas sobre la cultura española. Madrid: Siglo XXI de España Editores, 2011.

Amícola, José y José Luis de Diego (dirs.). La teoría literaria hoy. Conceptos, enfoques, debates. La Plata: Al Margen, 2008.

Amor, Lidia, Florencia Calvo y Mariano Saba (coords.). El erudito frente al canon II. Por una filología de la historia literaria. Buenos Aires: el autor, 2014.

Ancos, Pablo e Ivy Corfis (eds). Two Spanish masterpieces: A celebration of the Life and Works of Maria Rosa Lida de Malkiel. Nueva York: Hispanic Seminary of Medieval Studies, 2013.

Arellano, Ignacio. "El Siglo de Oro en Austral". Ínsula 622, octubre 1998: 16-17.

Arpes, Marcela. “Teatro, exilio y crítica periférica [En línea]. $I^{\circ}$ Congreso Internacional de Literatura y Cultura Españolas Contemporáneas, 1 al 3 de octubre de 2008, La Plata. Los siglos XX y XXI. Disponible en: http://www.fuentesmemoria.fahce.unlp.edu.ar/trab_eventos/ev.295/ev.295.pdf 
Arrieta, Rafael Alberto. La literatura argentina y sus vínculos con España. Buenos Aires: Librería y Editorial Uruguay, 1957.

Aznar Soler, Manuel. "Historiografía y exilio teatral republicano de 1939". Iberoamericana, XII, 47 (2012): 129-141.

Barchino Pérez, Matías. "La polémica del meridiano intelectual de Hispanoamérica". Tema y variaciones de literatura. $\mathrm{N}^{\circ} 2,1993: 93-115$.

Barcia, Pedro Luis. "Brevísima historia de la Academia Argentina de Letras". 2013. Disponible en http://www.aal.edu.ar/?q=node/181

Barrenechea, Ana María. “Amado Alonso y el Instituto de Filología de la Argentina”. Cauce. Revista de Filología y su didáctica, º 18-19, 1995-96: 95-106. "En memoria de Raimundo Lida". Revista Iberoamericana. Vol. XLVI, Núm. 112-113, Julio-Diciembre 1980: 517-521. y Elida Lois. "El exilio y la investigación lingüística en la Argentina". Cuadernos Hispanoamericanos N 473-474, 1989: 81-91.

Battista, Emiliano. "La Gramática castellana (1914) de Manuel de Montolíu. Un análisis de sus concepciones gramaticales y lingüísticas". Revista argentina de historiografía lingüistica, III, 1, 2011: 1-28.

"Manuel de Montolíu y la incorporación de la Estilística en la etapa fundacional del Instituto de Filología". Víctor M. Castel y Liliana Cubo de Severino, (eds.) La renovación de la palabra en el bicentenario de la Argentina. Los colores de la mirada lingüistica. Mendoza: Editorial FFyL, UNCuyo, 2010. Bendahan, Mariana. "El incipiente nacionalismo cultural de la revista Ideas (19031905)”. Actas I Jornadas de Historia de la Crítica en la Argentina. Facultad de Filosofia y Letras, Universidad de Buenos Aires, 2009: 66-72. 
Berenguer Carisomo, Arturo. España en la Argentina (Ensayos sobre la contribución a la cultura nacional). Buenos Aires, s/e, 1953.

Bernabéu Albert, Salvador. "El americanismo en el Centro de Estudios Históricos: Américo Castro y la creación de la revista Tierra Firme (1935-1937)”. Dalla Corte, Gabriela, Ariadna Lluís i Vidal-Folch Ferran Camps, eds. De las independencias al Bicentenario. Barcelona: Casa Amèrica Catalunya, 2006: 4770.

“"Un señor que llegó del Brasil'. Américo Castro y la realidad histórica de América. Revista de Indias, Vol. LXII, N 226, 2002: 651674.

y Consuelo Naranjo Ogrovio. "Los estudios americanistas y la JAE”. Puig Samper Mulero, Miguel Ángel, coord. Tiempos de investigación: JAE-CSIC, cien años de ciencia en España. Madrid: CSIC, 2007: 129-134.

Bertoni, Lilia Ana. Patriotas, cosmopolitas y nacionalistas. La construcción de la nacionalidad argentina a fines del siglo XIX. Buenos Aires: Fondo de Cultura Económica, 2001.

Biagini, Hugo (comp.). La Universidad de La Plata y el movimiento estudiantil. Desde sus orígenes hasta 1930. La Plata: Editorial de la Universidad Nacional de la Plata, 1999.

Bibbo, Federico. "El Ateneo (1892-1902): Sincronías y afinidades". Prismas. Revista de historia intelectual [online]. 2012, Vol. 16, N² 2 [citado 2014-08-04]: 191-194. Disponible en: http://www.scielo.org.ar/scielo.php?script=sci_arttext\&pid=S185204992012000200009\&lng=es\&nrm=iso 
Binns, Niall (coord.). Argentina y la guerra civil española. La voz de los intelectuales. Madrid: Editorial Calambur, 2012.

Bloom, Harold. La angustia de las influencias. Caracas: Monte Ávila, 1991.

El canon occidental. Barcelona: Anagrama, 1995.

Bombini, Gustavo. "Reforma curricular y polémica: Amado Alonso y los programas de nivel secundario en Argentina”. Cauce. Revista de Filología y su didáctica, $\mathrm{N}^{\circ}$ 18-19, 1995-96: 215-224.

Los arrabales de la literatura. La historia de la enseñanza literaria en la escuela secundaria argentina (1860-1960). Buenos Aires, UBA / Miño \& Dávila, 2004.

Bonfiglio, Florencia. "Religaciones hispano-americanas en torno del 98: los usos de $L a$ Tempestad en el Modernismo (Darío y Rodó)”. Olivar. Revista de literatura y cultura españolas 11 (14), 2010: 71-91.

Borges, Jorge Luis. Textos recobrados 1919-1929. Buenos Aires: Sudamericana, 2011.

Bottaro, Raúl H. La edición de libros en Argentina. Buenos Aires: Ediciones Troquel, 1964.

Botto, Malena. “Canon”. Amícola, J. y José L. de Diego (dirs.). La teoría literaria hoy: conceptos, enfoques, debates (119-131). La Plata: Al Margen: 2008.

Bourdieu, Pierre. Campo del poder y campo intelectual. [1967]. Buenos Aires: Folios, 1983

Las reglas del arte. Génesis y estructura del campo literario.

Barcelona: Anagrama, 1995.

Homo academicus. Buenos Aires: Siglo XXI Editores, 2008. 
Bruno, Paula. "Vida intelectual de la Argentina de fines del siglo XIX y comienzos del XX. Un balance historiográfico". PolHis, Año 5, № 9, Primer semestre 2012: 69-91.

Buchbinder, Pablo. Historia de las universidades argentinas. Buenos Aires: Editorial Sudamericana, [2005] 2010 ( $2^{\circ}$ ed.).

Historia de la Facultad de Filosofía y Letras. Universidad de Buenos Aires. Buenos Aires: Eudeba, 1997.

Bueno, Mónica y Miguel Ángel Taroncher (coords). Centro Editor de América Latina. Capítulos para una historia. Buenos Aires: Siglo XXI Editores, 2006.

Buonocore, Domingo. Libreros, editores e impresores de Buenos Aires. Esbozo para una historia del libro argentino. Buenos Aires: Bowker Editores, 1974.

Burucúa, José Emilio. Historia, arte, cultura. De Aby Warburg a Carlo Ginzburg. Buenos Aires: Fondo de Cultura Económica, 2002.

Calvino, Italo. Por qué leer los clásicos [1981]. Barcelona: Tusquets, 1992.

Calvo, Florencia. "Maestros y discípulos en el Instituto de Filología. Unas anotaciones de Amado Alonso a la Historia de las ideas estéticas de Marcelino Menéndez y Pelayo". I Jornadas de la Crítica en la Argentina. Facultad de Filosofía y Letras, Universidad de Buenos Aires, 2009: 213-221.

Calvo, Florencia y Lidia Amor (coords). Historiografías literarias decimonónicas. La modernidad y sus cánones. Buenos Aires: Eudeba, 2011.

Cambours Ocampo, Arturo. Indagaciones sobre la literatura argentina. Buenos Aires: Editorial Albatros, 1952.

Carilla, Emilio. Quevedo: entre dos centenarios. Universidad Nacional de Tucumán, Instituto de Lengua y Literatura Española, 1949. 
Castro, Américo. "El verdadero hispano-americanismo". Revista Humanidades, Tomo VIII, 1924: 103-110.

Catelli, Nora. "María Rosa Lida: posición americana, filología y comparatismo". Filología. Revista del Instituto de Filología Dr. Amado Alonso. N XLIII (2011), 2013: 81-101.

Cella, Susana (comp.). Dominios de la literatura. Acerca del canon. Buenos Aires: Losada, 1998.

Chacón Gómez Monedero, Francisco A. “Aportaciones a la biobibliografía de Agustín Millares Carlo hasta su exilio en México”. Boletín Millares Carlo ํ 30, 2014: $51-90$.

Chartier, Roger. "La historia cultural redefinida: práctica, representaciones, apropiaciones." Punto de vista XIII, 39, 1990: 43-48.

El mundo como representación. Estudios sobre historia cultural. Barcelona: Gedisa, 1992.

Chicote, Gloria. "Cuatro postales del hispanismo argentino". Insula 793-794, enerofebrero 2013: 34-37.

. "Ramón Menéndez Pidal en Buenos Aires: dos cartas a Robert Lehmann-Nitsche después de su primer viaje ((Madrid, 28-09-1905 y Santander, 29-07-1909)". Olivar. Revista de literatura y cultura españolas 17, 2012: 145148.

. "Robert Lehmann-Nitsche: un viaje desde el centro a la periferia del conocimiento". Actas del Primer Simposio Internacional Interdisciplinario “Aduanas del Conocimiento". Córdoba, 2010. 
. "Ramón Menéndez Pidal en Buenos Aires: Carta a Robert Lehmann-

Nitsche (12-05-1905)". Olivar. Revista de literatura y cultura españolas 10 (13), 2009: 155-162.

“100 años de la colección cervantina de la Universidad Nacional de La

Plata: una historia de recepción quijotesca". Alicia Parodi, et al. (eds.). El Quijote en Buenos Aires. Lecturas cervantinas en el cuarto centenario. Buenos Aires: Instituto de Filología y Literaturas Hispánicas "Dr. Amado Alonso"Facultad de Filosofía y Letras (Univ. de Buenos Aires) - Asociación de Cervantistas, 2006: 337-343.

-. "La Colección Cervantina: historia de un proyecto institucional". Gloria Chicote y Norma Mangiaterra (coords.) Aventuras del Quijote en la UNLP. 75 Joyas de la Colección Cervantina de la Biblioteca Pública. Catálogo. La Plata, Universidad, 2005: 6-14.

. "Palabras introductorias". En Dossier "E1 Hispanismo hoy: estereotipos culturales y construcciones identitarias". Olivar. Revista de literatura y cultura españolas 5, 2004: 87-94.

"Saberes y conflictos en el hispanismo argentino". Boletín de la Fundación Federico García Lorca. Año XV, No 33-34, Madrid, 2003: 133-139.

Ciocchini, Héctor. Arturo Marasso. Buenos Aires: Ediciones Culturales Argentinas, 1967.

Clementi, Hebe (coord.). Inmigración española en Argentina (Seminario 1990). Buenos Aires: Oficina Cultural de la Embajada de España, 1991.

Corral, Rosa. "Ana María Barrenechea y su 'circunstancia mexicana"”. Cuadernos LIRICO [En línea], 9 2013. Disponible en: http://irico.revues.org/1081 
Costa, María Eugenia. "Edición y circulación de libros ilustrados en los años '60: Colección “Arte para todos" de EUDEBA". 2012. Disponible en http://sedici.unlp.edu.ar/bitstream/handle/10915/40742/Documento_completo.pd $\underline{\text { f?sequence }=1}$. Consultado el 30/09/2015.

Croce, Marcela (comp). Polémicas intelectuales en América Latina. Del "meridiano intelectual” al caso Padilla (1927-1971). Buenos Aires: Ediciones Simurg, 2006.

Dabusti de Muñoz, Teresa. "Trayectoria de Lorenzo Luzuriaga en Losada, una editorial del exilio". Revista de Historia contemporánea № 9-10, 1999-2000: 395-408.

Dalla Corte, Gabriela y Fabio Espósito. "Mercado del libro y empresas editoriales entre el Centenario de las Independencias y la Guerra Civil española: la editorial Sudamericana". Revista Complutense de Historia de América, Norteamérica, 36, dic. 2010. Disponible en:

http://revistas.ucm.es/index.php/RCHA/article/view/RCHA1010110257A/28376

Consultado el 28/09/2015.

Dalmaroni, Miguel. Una república de las letras. Lugones, Rojas, Payró. Escritores argentinos y Estado. Rosario: Beatriz Viterbo Editora, 2006.

de Diego, José Luis. La otra cara de Jano. Una mirada crítica sobre el libro y la edición. Buenos Aires: Ampersand, 2015.

(dir.). Editores y políticas editoriales en Argentina (1880-2000).

Buenos Aires: Fondo de Cultura Económica, 2006.

"El Hispanismo en Argentina". En Dossier "El Hispanismo hoy:

estereotipos culturales y construcciones identitarias". Olivar. Revista de literatura y cultura españolas 5, 2004: 87-94. 
de Sagastizábal, Leandro. "Editores españoles en el Río de la Plata”. Inmigración española en Argentina (Seminario 1990). Clementi, Hebe (coord.). Buenos Aires: Oficina Cultural de la Embajada de España, 1991: 259-272.

La edición de libros en Argentina: una empresa de cultura.

Buenos Aires: Eudeba, 1995.

50 años de libros para todos. Buenos Aires: Eudeba, 2008.

de Torre, Guillermo. "Madrid: meridano cultural de América". La Gaceta Literaria, Madrid, Año 1, $\mathrm{N}^{\circ} 1,27$ de abril de 1927. Disponible en http://www.filosofia.org/hem/dep/gac/gt00801a.htm . Consultado 10/11/2014.

Degiovanni, Fernando y Guillermo Toscano y García. "Disputas de origen: Américo Castro y la institucionalización de la filología en Argentina”. Nueva Revista de Filología Hispánica, Vol. LVIII, N 1, enero-junio, 2010: 191-213.

"Las alarmas del doctor Américo Castro":

institucionalización filológica y autoridad disciplinaria." Variaciones Borges $\mathrm{N}^{\circ}$ 30, Universidad de Pittsburgh, 2010: 3- 41.

Degiovanni, Fernando. Los textos de la patria. Nacionalismo, políticas culturales y canon en Argentina. Rosario: Beatriz Viterbo Editora, 2007.

Delgado, Verónica. "España en Nosotros (1907-1913)”. [En línea]. I Congreso Internacional de Literatura y Cultura Españolas Contemporáneas, 1 al 3 de octubre de 2008, La Plata. Los siglos XX y XXI. Disponible en: http://www.fuentesmemoria.fahce.unlp.edu.ar/trab_eventos/ev.374/ev.374.pdf

Díaz Sal, Braulio. Guía de los españoles en la Argentina. Madrid: Ediciones Iberoamericanas, 1975.

Díaz Quiñones, Arcadio. "1892. Los intelectuales y el discurso colonial”. Beatriz González Stephan, Javier Lasarte, Graciela Montaldo y María Julia Daroqui, 
comps. Esplendores y miserias del siglo XX. Cultura y sociedad en América

Latina. Caracas: Monte Ávila Editores, 1995: 473-498.

Di Tullio, Ángela. "El español de América y la tradición prescriptiva". Representaciones, Vol. XI, No 2 - Nov. 2015: 117-147.

"La construcción de la identidad lingüística argentina". Revista La

Biblioteca. Legados y porvenir en la Argentina del Centenario 9 (2010): 188208.

"Meridianos, polémicas e instituciones: el lugar del idioma".

Historia crítica de la literatura argentina. Noé Jitrik, dir. Vol.VII, Rupturas.

Celina Manzoni, ed. Buenos Aires: Emecé, 2009: 569-596.

" "Organizar la lengua, normalizar la escritura". Historia crítica de

la literatura argentina. Noé Jitrik, dir. Vol. 5 La crisis de las formas. Alfredo

Rubione, dir. Buenos Aires: Emecé, 2006: 543-580.

Políticas lingüisticas e inmigración. El caso argentino. Buenos

Aires: Eudeba, 2003.

Dittus, Rubén. "La revista cultural en el análisis semiótico: aproximación desde la obra de Pierre Bourdieu”. Comunicación y Medios № 26 (2012): 84-97.

Domenech, Eduardo. “Crónica de una 'amenaza' anunciada. Inmigración e 'ilegalidad': visiones de Estado en la Argentina contemporánea”. Feldman-Bianco, Bela, Liliana Rivera Sánchez, Carolina Stefoni, Marta Inés Villa Martínez, comps. La construcción social del sujeto migrante en América Latina Prácticas, representaciones y categorías. Quito: FLACSO, Sede Ecuador: Consejo Latinoamericano de Ciencias Sociales, CLACSO: Universidad Alberto Hurtado, 2011: 31-77. 
Egido, Aurora (coord.). "Mapa del Hispanismo". Boletín de la Fundación Federico García Lorca. Año XV, No 33-34, Madrid: 2003.

Ennis, Juan Antonio. Decir la lengua. Debates ideológico-lingüísticos en la Argentina desde 1837. Frankfurt/Bern/Bruxelles/Wien/Oxford/New York: Peter Lang, 2008

Espósito, Fabio. "Los editores españoles en Argentina: redes comerciales, políticas y culturales entre España y Argentina (1892-1938)". Historia de los intelectuales en América Latina. Carlos Altamirano (dir.) Buenos Aires: Katz Editores, 2010: 515-536.

Falcón, Alejandrina. “¿Un Meridiano que fue exilio? Presencia española en el campo cultural argentino (1938-1953)". Pagni, Andrea, ed. El exilio republicano español en México y Argentina. Historia cultural, instituciones literarias, medios. Estudios latinoamericanos $\mathrm{N}^{\circ}$ 51. Madrid: Iberoamericana- Vervuert, 2011: 107- 127 .

Fernández, Claudia. "Clasicismos”. Amícola, J. y José L. de Diego (dirs.), La teoría literaria hoy: conceptos, enfoques, debates. La Plata: Al Margen, 2008: 23-34.

Fernández, Oscar. "EUDEBA: El papel del Estado en la edición de libros en la Argentina (1958-1980)”. Bueno, Mónica y Miguel Ángel Taroncher, coords. Centro Editor de América Latina. Capítulos para una historia. Buenos Aires: Siglo XXI Editores, 2006: 39-61.

Fernández Moya, María. "Editoriales españolas en América Latina. Un proceso de internacionalización secular”. Revista de Economía ICE, $\mathrm{N}^{\circ} 849$, julio-agosto 2009: 65-77.

Ferrero de Sahab, Graciela et. al. "Historia de la Editorial Losada, 'voz' de los exiliados españoles". Actas del III Congreso Argentino de Hispanistas "España en 
América y América en España". Vol. II. Buenos Aires: Asociación Argentina de Hispanistas, Instituto de Filología y Literaturas Hispánicas “Amado Alonso”, Facultad de Filosofía y Letras, Universidad de Buenos Aires, 1992: 521-544.

Fiorucci, Flavia. Intelectuales y peronismo (1945- 1955). Buenos Aires: Editorial Biblos, 2011.

. "Los escritores y la SADE. Entre la supervivencia y el antiperonismo: los límites de la oposición (1946-1956)". Prismas. Revista de Historia intelectual, $\mathrm{N}^{\circ}$ 5, 2001: 101-125.

Fontana, Patricio. "Los lugares del crítico. Menéndez Pelayo, Juan María Gutiérrez y la Antología de poetas hispanoamericanos". Amor, Lidia y Florencia Calvo, coords. El erudito frente al canon II. Por una filología de la historia literaria. Buenos Aires: el autor, 2014: 119-150.

Formentín Ibáñez, Justo y María José Villegas Sanz. Relaciones culturales entre España y América: la Junta para Ampliación de Estudios. Madrid: Editorial Mapfre, 1992.

Gálvez, Manuel. El solar de la raza. Buenos Aires: Sociedad Cooperadora "Nosotros", 1913.

España y algunos españoles. Buenos Aires: Huarpes, 1945

Garabedian, Marcelo Hugo. "El Correo Español de Buenos Aires y la prensa española en el Río de La Plata. Nuevos enfoques para su estudio”. História: Questões \& Debates, Curitiba, N 56, jan. /jun. 2012: 159-177.

García, Ignacio. "Rubén Darío y Francisco Grandmontagne en el Buenos Aires de 1898. La redefinición de los conceptos de hispanismo en América y de americanismo en España”. Revista Iberoamericana, Vol. LXVIII, Nº 198, Enero-Marzo 2002: 49-66. 
"El institucionismo en los krausistas argentinos". Disponible en http://www.ensayistas.org/filosofos/argentina/roig/homenaje/garcia.htm

García Mouton, Pilar. "La vocación americanista de la Escuela de Filología Española”. Revista de Indias Vol. LXVII, No 239, 2007: 163-184.

García Sebastiani, Marcela. "España fuera de España. El patriotismo español en la emigración argentina: una aproximación”. Hispania, Vol. LXXIII, №. 244, mayo-agosto 2013: 469-500.

. "Prensa e identidad de los españoles inmigrantes en la Argentina:

el Diario Español de Buenos Aires en los comienzos del siglo XX". Congreso Internacional de la Asociación Española de Americanistas, XI, 2004. Murcia. El Mediterráneo y América, 2006, 1: 861-871.

Garza Cuarón, Beatriz. "La herencia filológica de Pedro Henríquez Ureña en El Colegio de México". Revista Iberoamericana 54 (142), 1988: 321-330.

Gerhardt, Federico. “Asociacionismo gallego y mercado del libro en la Buenos Aires de medio siglo: dos proyectos editoriales de Luis Seoane". Madrygal 18, 2015, N especial: $\quad 457-467 . \quad$ Disponible en http://revistas.ucm.es/index.php/MADR/article/view/48569. Consultado $12 / 11 / 2015$.

"Entre la prensa y el libro, entre España y la Argentina. Crítica literaria y mercado editorial en la revista De Mar a Mar". Actas del III Congreso Internacional Cuestiones Críticas. Rosario, Facultad de Humanidades y Artes abril de 2013. Disponible en Disponible en: http://www.celarg.org/int/arch publi/gerhardt federicocc.pdf 
Giaccio, Laura. "Panorama de la estadía de Valle-Inclán en Buenos Aires: sociabilidad y vida cultural". Cuadrante. Revista semestral de Estudios Valleinclanianos e Históricos. $\mathrm{N}^{\circ}$ 29, diciembre 2014: 163-182.

" Retratos e imagen de escritor de Ramón del Valle Inclán en la prensa porteña, (1899-1910)" (En línea). Trabajo presentado en VI Jornadas Internacionales de Filología y Lingüística, 7 al 9 de agosto de 2013, La Plata, Argentina.

en: http://www.memoria.fahce.unlp.edu.ar/trab eventos/ev.3857/ev.3857.pdf . "Las repercusiones de la visita de Valle Inclán a la Argentina del Centenario en la prensa periódica nacional: el caso de La Nación”. Teresa Basile y Enrique Foffani (dirs), Actas del VIII Congreso Internacional Orbis Tertius de Teoría y Crítica Literaria. La Plata, 2012. Disponible en: http://citclot.fahce.unlp.edu.ar/actas-2012

Gianmatteo, Mabel e Hilda Albano. "Los estudios lingüísticos en Argentina: un breve panorama”. Hispanic Issues Online, 2007: 113-120.

Giuliani, Alejandra. "La CAL y la historia de la edición: acerca de la organización de la primera Feria del Libro argentino”. Primer Coloquio Argentino de Estudios sobre el Libro y la Edición, La Plata, 31 de octubre al 2 de noviembre de 2012: 199-210.

Glozman, Mara. "Corporativismo, política cultural y regulación lingüística: la creación de la Academia Argentina de Letras". Lenguaje, 2013, 41 (2), 455-478.

"La Academia Argentina de Letras y el peronismo (1946-1956)". Anclajes Vol. XIII, N 13, dic. 2009: 129-144.

"Perón y las academias científicas y culturales. Política de intervención y proyectos culturales de estado entre 1944 y 1955”. Questión, Vol. 
Avatares del Hispanismo: canon y estudios literarios en la Argentina (1949-1973)

$1 \quad \mathrm{~N}^{\circ} \quad 10, \quad$ junio $2006 . \quad$ Disponible en http://perio.unlp.edu.ar/ojs/index.php/question/article/view/181

Gociol, Judith (coord.). Más libros para más. Colecciones del Centro Editor de América Latina. Buenos Aires: Biblioteca Nacional, 2008.

Libros para todos. Colecciones de Eudeba bajo la gestión de Boris Spivacow (1958-1966). Buenos Aires: Biblioteca Nacional, 2012.

Goloboff, Mario. "Cómo leímos, aquí y entonces, la literatura española". Olivar. Revista de literatura y cultura españolas, Vol. 11, Núm. 14 (2010): 179-186.

Gomá Tomás, Isidro. “Apología de la Hispanidad. Discurso pronunciado en el Teatro Colón de Buenos Aires, el día 12 de octubre de 1934, en la velada conmemorativa del Día de la Raza”. Acción Española, nov. 1934, Tomo XI, N 64-65: 193-230. $\quad$ Disponible en http://www.filosofia.org/hem/193/acc/e64193.htm

Gómez, Hernán. "Los diarios como espacios públicos. La Prensa en la vida social de Buenos Aires a comienzos del siglo XX”. Intersecciones en Antropología $\mathrm{N}^{\circ}$, ene. /dic. 2008: 261-264.

Gómez Moreno, Ángel. "En el centenario de María Rosa Lida de Malkiel”. Revista de Filología Española (RFE), XCI, 1, 2011: 171-188.

González, María de los Ángeles. "El tricentenario de Luis de Góngora en el Río de la Plata". Cuadernos Hispanoamericanos 651-652, septiembre-octubre 2004: 155170.

González Calleja, Eduardo. "El hispanismo autoritario español y el movimiento nacionalista argentino: balance de medio siglo de relaciones políticas e intelectuales (1898-1946)”. Hispania. Revista Española de Historia, 2007, Vol. LXVIII, No 226, mayo-agosto: 599-642. 
Graciano, Osvaldo. “Alejandro Korn y las humanidades en la Universidad Nacional de La Plata”. Archivos de Ciencias de la Educación, Año 8, № 8, 4 época, 2014. Recuperado de http://www.archivosdeciencias.fahce.unlp.edu.ar/article/view/Archivos08a04.

Gramuglio, María Teresa. "Posiciones de Sur en el espacio literario. Una política de la cultura". Historia crítica de la literatura argentina. Sylvia Saítta, comp. Vol. 9 El oficio que se afirma. Buenos Aires: Emecé Editores, 2004: 93-122.

"Novela y nación en el proyecto literario de Manuel Gálvez”.

Historia crítica de la literatura argentina. Noé Jitrik, dir. Vol. 6. El imperio realista. María Teresa Gramuglio, dir. Buenos Aires: Emecé Editores, 2002: 145-176.

"Estudio preliminar". El diario de Gabriel Quiroga. Opiniones sobre la vida argentina. Manuel Gálvez. Buenos Aires: Editorial Alfaguara, 2001: 11-52.

"Sur en la década del treinta: una revista política". Punto de vista 28, 1986: 32-39.

"Sur: constitución del grupo y proyecto cultural". Punto de vista 17, 1983: 7-10.

Gruber, Rosana y Mónica Rodríguez. "Vitrinas del mundo académico: las revistas de la Facultad de Filosofía y Letras de la Universidad de Buenos Aires entre 19461966”. Historiografías, 2 (Julio- Diciembre), 2011: 66-84.

Guardamagna, María Melina. "El rol de la universidad en la formación de cuadros políticos en la Constitución del 49”. POSTData 18, N¹, Abril 2013: 73-102.

Gudiño Kieffer, Eduardo. Losada. Gonzalo Losada, el editor que difundió el libro argentino en el mundo. Buenos Aires: Editorial Dunken, 2004. 
Gutiérrez Cuadrado, Juan y José A. Pascual Rodríguez. “A propósito de las actas del Congreso literario hispano-americano de 1892”. Prólogo a la edición facsímil de las Actas del Congreso literario Hispano-americano. Madrid, 1892. Disponible en http://cvc.cervantes.es/LENGUA/congreso_literario/prologo.htm [consultado 30 de junio de 2014].

Gutiérrez Giménez, Rafael. La producción literaria en España y el comercio de exportación de libros a América: documentos leídos en el Congreso Literario celebrado en Madrid en Noviembre de 1892. Madrid: Imprenta y fundición de Manuel Tello: $1893 . \quad$ Disponible en: http://www.galiciana.bibliotecadegalicia.xunta.es/es/consulta/registro.cmd?id=7 604. Consultado el 28 de septiembre de 2015.

Henríquez Salido, María do Carmo. "La gramática castellana de Amado Alonso y Pedro Henríquez Ureña”. Cauce. Revista de Filología y su didáctica $\mathrm{N}^{\circ} 20-21,1997-$ 98: 93-116.

Hernández, Esther. “Ángel Rosenblat y el español de América: influencia de la Escuela de Filología Española en su obra y cartas a Menéndez Pidal”. Revista de Indias, vol. LXVII, núm. 239, 2007: 185-220.

Inman Fox, Edward. "La invención de España: literatura y nacionalismo". Actas AIH 12, $1995 . \quad$ Disponible en http://cvc.cervantes.es/literatura/aih/pdf/12/aih_12_4 005.pdf

Jakšić, Iván Andrés. Bello: la pasión por el orden. Santiago de Chile: Editorial Universitaria, 2001.

Jalif de Bertranou, Clara Alicia. "En memoria de nuestro fundador: Diego F. Pró. Una entrevista inédita”. Cuyo. Anuario de Filosofía Argentina y Americana. № 17, 2000: 11-48. 
Junta para Ampliación de Estudios e Investigaciones Científicas (JAE). Memoria correspondiente á los años 1912 y 1913. Madrid: 1914.

King, John. Sur. Estudio de la revista argentina y de su papel en el desarrollo de una cultura (1931-1970). [1986]. México: Fondo de Cultura Económica, 1989.

Lafleur, Héctor, Sergio Provenzano y Fernando Alonso. Las revistas literarias argentinas: (1893-1960). Buenos Aires: Ediciones Culturales Argentinas: 1962.

Lago Carballo, Antonio y Nicanor Gómez Villegas (eds). Un viaje de ida y vuelta. La edición española e iberoamericana (1936-1975). Buenos Aires: Fondo de Cultura Económica/ Siruela, 2007.

Laín Entralgo, Pedro. "La Generación del 98 y el problema de España”. Arbor, 36 1948: 417-438. Disponible en http://www.cervantesvirtual.com/obra-visor/lageneracion-del-98-y-el-problema-de-espaa/html/ [Consultado 17 de septiembre de 2014]

Larraz Elorriaga, Fernando. “¿Un campo editorial? Cultura literaria, mercados y prácticas editoriales entre Argentina y España”. Cuadernos del CILHA, Año 15 $\mathrm{N}^{\circ} 21,2014: 123-136$.

Una historia trasatlántica del libro. Relaciones editoriales entre España y América Latina (1936-1950). Gijón: Ediciones Trea, 2010.

"Política y cultura. Biblioteca Contemporánea y Colección Austral, dos modelos de difusión cultural" [en línea]. Orbis Tertius 2009, XIV (15), Disponible en: $\quad$ http://www.orbistertius.unlp.edu.ar/numeros/numero15/01.\%20Larraz.pdf [Consultado 11/08/2015].

"Los editores españoles ante los mercados americanos (1900-1939)". Cuadernos Americanos N 119, 2007: 131-150. 
Lauria, Daniela. "La Academia Argentina de Ciencias y Letras y su posición sobre la lengua nacional (1873-1879)". Prismas. Revista de historia intelectual [online]. 2012, Vol. 16, $\mathrm{N}^{\circ} 2$ [citado 2014-06-17], 171-174. Disponible en: http://www.scielo.org.ar/scielo.php?

estado de la cuestión". Actas del Cuarto Congreso Internacional Celehis de literatura. Mar del Plata, 2011. Disponible en: http://www.mdp.edu.ar/humanidades/letras/celehis/congreso/2011/actas/ponenci $\underline{\text { as/giaccio.htm }}$

Lecea Yábar, Juan María. “Amado Alonso (1896-1952)”. Cauce. Revista de Filología y su didáctica, $\mathrm{N}^{\circ}$ 18-19, 1995-96: 17-70.

Lida, Clara E. y Fernando Lida-García. "Raimundo Lida, filólogo y humanista peregrino”. Prismas [online]. 2009, Vol.13, N 1 [citado 2014-10-16]: 115-134.

Disponible

en http://www.scielo.org.ar/scielo.php?script=sci_arttext\&pid=S1852$\underline{04992009000100005 \& \operatorname{lng}=\mathrm{es} \& \mathrm{nrm}=\mathrm{iso}}$

Lida, Miranda. "Una frágil edad de oro. Esplendor y ocaso del Instituto de Filología en tiempos de Amado Alonso (1927-1946)". Boca de sapo 19 [Era digital], Año XVI, abril 2015: 24-29.

Años dorados de la cultura argentina. Los hermanos María Rosa y Raimundo Lida y el Instituto de Filología antes del peronismo. Buenos Aires: Eudeba, 2014.

"Una lengua nacional aluvial para la Argentina. Jorge Luis Borges, Américo Castro y Amado Alonso en torno al idioma de los argentinos". Prismas. Revista de historia intelectual, № 16, 2012: 99-119. 
"Entre los despojos del peronismo. Esplendor y ocaso del Instituto de Filología de la Universidad de Buenos Aires (1927-1946)". Temas de historia argentina $y$ americana, $\quad \mathrm{N}^{\circ}$ 16, 2010: 189-217. Disponible en http://bibliotecadigital.uca.edu.ar/repositorio/revistas/despojos-peronismo.pdfLida, María Rosa. “Amado Alonso”. Cauce. Revista de Filología y su didáctica, N 1819. Apéndice: 902-905.

Lidgett, Esteban. "La correspondencia Monner Sans- Costa Álvarez (1920-1927). La definición de un programa de investigación filológica en Argentina” [en línea] VI Jornadas de Filología y Lingüística, La Plata, 2013. En Memoria Académica. Disponible en: www.memoria.fahce.unlp.edu.ar/trab_eventos/ev.3864/ev.3864.pdf

López, María Pía. Lugones: entre la aventura y la cruzada. Buenos Aires: Colihue, 2004.

López, Vicente Fidel. Les races aryennes du Pérou: leur langue, leur religion, leur histoire. Paris: Librairie A. Frank, 1871. Disponible en https://archive.org/details/lesracesaryennes00lopeiala

López Cobo, Azucena. 'Un proyecto cultural de Ortega con la editorial Espasa Calpe (1918-1942)". Revista de Estudios Orteguianos, № 26, 2013: 23-76.

López Sánchez, José María. “La Junta para Ampliación de Estudios y su proyección americanista: la Institución Cultural Española en Buenos Aires”. Revista de Indias, Vol. LXVII, N² 239, 2007: 81-102.

Macciuci Marta Raquel (ed.). La Plata lee a España. Literatura, cultura, memoria. La Plata: Ediciones del Lado de Acá, 2010. 
"Hispanismo y critica hispánica al sur. Sobre periferias, centros y

des-centramientos". Orbis Tertius, 2006 11(12). Disponible en: http://www.orbistertius.unlp.edu.ar/article/view/OTv11n12a13/3786

"Borges, Cortázar, el galache y la grupa sureña. Apostillas al debate sobre el (anti)hispanismo en Argentina." Olivar. Revista de literatura y cultura españolas $\mathrm{N}^{\mathrm{o}}$ 7, 2006: 125-145.

Maeztu, Ramiro de. "La Hispanidad”. Acción Española, Año 1, №1, Madrid, 15 de diciembre de 1931: 8-16. Disponible en http://www.filosofia.org/hem/193/acc/e01008.htm . Consultado el 20/11/2014. "El hispanismo de los sur-americanos". Nuevo Mundo, Año XXIV, número 1206, Madrid, 16 de febrero de 1917: 5. Disponible en http://www.filosofia.org/hem/191/9170216.htm . Consultado el 23/11/2104.

Mainer, José Carlos. "La crisis de fin de siglo: la nueva conciencia literaria". Historia y crítica de la literatura española. Francisco Rico, dir. Vol. 6 Modernismo y 98. José Carlos Mainer, dir. Madrid: Crítica, 1980.

Maíz, Claudio. "Las re(d)vistas latinoamericanas y las tramas culturales: redes de difusión en el romanticismo y el modernismo”. Cuadernos del CILHA - Vol. 12 $\mathrm{N}^{\circ}$ 14, 2011: 75-91.

Mangone, Carlos y Jorge Warley. Universidad y peronismo (1946-1955). Buenos Aires: Centro Editor de América Latina, 1984.

Manzoni, Celina. "La polémica del meridiano intelectual". Estudios. Revista de Investigaciones Literarias. Año 4, № 7, Caracas, ene-jun.1996: 121-132.

Marasso, Arturo. Cervantes. La invención del Quijote. Buenos Aires: Editorial Biblioteca Nueva, 1943. 
Marco García, Antonio. 'Propósitos filológicos de la colección 'Clásicos Castellanos' de la editorial La Lectura (1910-1935)". Actas del X Congreso de la AIH, Vol. 3, 1992: 81-96.

Martí Monterde, Antoni. “¿Dónde está el Meridiano? Guillermo de Torre y Agustí Calvet «Gaziel»: un diálogo frustrado" [artículo en línea], $452^{\circ} \mathrm{F}$. Revista electrónica de teoría de la literatura y literatura comparada, 11, 2014: 43-63 [Consultado 09 de octubre de 2014].

Martínez, María Victoria. "Los intelectuales españoles en el exilio en la Argentina y las condiciones de inserción en su nueva realidad. Los colaboradores españoles de La Nación de Buenos Aires en la década 1939-1949”. Disponible en http://www.unrc.edu.ar/publicar/borradores/Vol7/pdf

Martínez Del Sel, Valeria y Guido Riccono. "Las trayectorias académicas: una nueva mirada sobre los profesores de la Facultad de Filosofía y Letras durante el peronismo". Archivos de Ciencias de la Educación, 7 (7), 2013. Recuperado de: http://www.archivosdeciencias.fahce.unlp.edu.ar/article/view/Archivos07a13

Martínez Zuccardi, Victoria. "La Facultad de Filosofía y Letras y la consolidación de la literatura en Tucumán. Papel desplegado por Marcos A. Morínigo”. Disponible en http://www.archivo.unt.edu.ar/attachments/054_zucardi2.pdf. Consultado el $12 / 11 / 2015$.

Matamoros, Blas. "La emigración cultural española en Argentina durante la posguerra de 1939”. Cuadernos Hispanoamericanos № 384, junio 1982: 576-590.

Maunás, Delia. Boris Spivacow. Memorias de un sueño argentino. Buenos Aires: Editorial Colihue, 1995. 
Mendiola Oñate, Pedro. "El llanto de España: un episodio de las relaciones literarias entre España y Argentina". América sin nombre. № 3, Universidad de Alicante, 2002: 71-78.

Menéndez Pidal, Ramón. “Observaciones críticas sobre las biografías de Fray Bartolomé de las Casas". Actas del $1^{\circ}$ Congreso de la Asociación Internacional de Hispanistas. Oxford, 6 al 11 de septiembre de 1962. Disponible en http://cvc.cervantes.es/literatura/aih/pdf/01/aih_01_1_003.pdf

Menéndez y Pelayo, Marcelino. Historia de la poesía hispanoamericana. Madrid: CSIC, 1948.

Merbilhaá, Margarita. "La época de organización del espacio editorial”. de Diego, José Luis (dir.). Editores y politicas editoriales en Argentina (1880-2000). Buenos Aires: Fondo de Cultura Económica, 2006: 29-58.

Montero Reguera, José. "La huella cervantista americana de la Escuela Filológica Española". Olivar. Revista de literatura y cultura españolas 6 (6), 2005: 23-42. Morales Moya, Antonio. "Crisis de identidad española y situación del hispanismo". Álvarez Barrientos, Joaquín (ed.). Memoria de hispanismo. Miradas sobre la cultura española. Madrid: Siglo XXI de España Editores, 2011: 167-185.

Moreiro González, José Antonio. “Documentos administrativos sobre Agustín Millares Carlo en México. Datos complementarios para una biografia”. Boletín Millares Carlo $\mathrm{N}^{\circ} 20,2001: 35-49$. . "Comentarios a la bibliografía filológico-literaria de Millares Carlo". Boletín Millares Carlo No 9-10, 1987: 57-92.

Moure, José Luis. "Dos perspectivas decimonónicas en la construcción de una identidad lingüística americana: Rufino José Cuervo y Juan María Gutiérrez”. Boletín de la Academia Argentina de Letras, Vol. 73, № 297-298, 2008: 291-312. 

“Ángel Rosenblat. Una reivindicación filológica de América”. La Biblioteca, 1, Verano 2004-2005: 136-143.

"Norma lingüística y prescripción en la Argentina: una historia imperfecta”. Boletín de la Real Academia Española. Tomo LXXXIV, Cuaderno CCXC, julio-diciembre 2004: 255-279.

Moya, Ismael. Ricardo Rojas. Buenos Aires: Ediciones Culturales Argentinas, 1961.

Nállim, Julio. "De los intereses gremiales a la lucha política: la Sociedad Argentina de Escritores (SADE), 1928-1946”. Prismas. Revista de Historia intelectual, № 7 , 2003: 117-138.

Naranjo Orovio, Consuelo. "Los caminos de la JAE en América Latina: redes y lazos al servicio de los exiliados republicanos". Revista de Indias, Vol. LXVII, № 239, 2007: 283-306.

Narvaja de Arnoux, Elvira. Los discursos sobre la nación y el lenguaje en la formación del Estado (Chile, 1842-1862). Estudio glotopolítico. Buenos Aires: Santiago Arcos/SEMA, 2008.

Navarro, Federico. "Un índice crítico para la Revista de Filología Hispánica (19391946)". Milka Villayandre Manzanares (ed.) Actas del XXXV Simposio Internacional de la Sociedad Española de Lingüística. León: Universidad de León, 2006: 1383-1404.

Niño, Antonio. Cultura y diplomacia. Los hispanistas franceses y España 1875-1931. Madrid: Consejo Superior de Investigaciones Científicas y Técnicas, 1988.

Nora, Pierre. "La aventura de Les lieux de mémoire". Ayer 32 (1998): 17-34. Pierre Nora en Les lieux de mémoire. París: Gallimard, 1984. 
Núñez, Gabriel. "Las historias de la literatura y la canonización de autores y obras en el sistema educativo español". Revista de Literatura, enero-junio, vol. LXXVI, N ${ }^{\circ}$ 151, 2014: 39-55.

Olarra Jiménez, Rafael. Espasa. Calpe. Manuel Olarra, un editor con vocación hispanoamericana. Buenos Aires: Editorial Dunken, 2003.

Olguín, Manuel. "Menéndez Pelayo y la literatura latinoamericana". Revista Iberoamericana, Vol. XXII, Núm. 43, Enero-Junio 1957: 27-39.

Ortiz, Eduardo L. "Una alianza por la ciencia: relaciones científicas entre Argentina y España a principios de este siglo". Llull. Revista de la Sociedad Española de Historia de las Ciencias y de la Técnica. Vol. 11, 1988: 247-261.

Ortuño Martínez, Bárbara. El exilio y la emigración española de posguerra en Buenos Aires, 1936-1956. Tesis doctoral. Universidad de Alicante, 2010. Disponible en $\begin{array}{llll}\text { Biblioteca } & \text { Virtual }\end{array}$ http://www.cervantesvirtual.com/nd/ark:/59851/bmcs7611

Oviedo, Gerardo. "Lucien Abeille y el idioma nacional de los argentinos". Idioma nacional de los argentinos. Lucien Abeille. Buenos Aires: Colihue, 2005: 11-88.

Oyuela, Calixto. Trozos selectos de literatura castellana desde el siglo XIII hasta nuestros días (España y América). Buenos Aires: Estrada, 1885.

Pagni, Andrea, (ed.). El exilio republicano español en México y Argentina. Historia cultural, instituciones literarias, medios. Estudios latinoamericanos $\mathrm{N}^{\circ} 51$. Madrid: Iberoamericana- Vervuert, 2011.

Parada, Alejandro (dir.). Cruces y perspectivas de la cultura escrita en la Argentina. Historia de la edición, el libro y la lectura. Buenos Aires: Instituto de Investigaciones Bibliotecológicas, Facultad de Filosofía y Letras, Universidad de Buenos Aires, 2013. 
Bibliografía cervantina editada en la Argentina. Una primera aproximación. Buenos Aires: Academia Argentina de Letras, 2005.

Pas, Hernán. "La crítica editada. Juan María Gutiérrez y la América poética”. Orbis Tertius, 15 (16) (2010). En Memoria Académica. Disponible en: http://www.fuentesmemoria.fahce.unlp.edu.ar/art_revistas/pr.4238/p r.4238.pdf

Pascuaré, Andrea. "Del Hispanoamericanismo al Pan-hispanismo. Ideales y realidades en el encuentro de dos continentes". Revista Complutense de Historia de América, $\mathrm{N}^{\circ}$ 26, 2000: 281-306.

“Giusti y la revista Nosotros (1912-1930): crítica, política e intervenciones literarias en la formación del campo cultural argentino". Revista Eletrônica da ANPHLAC, $\mathrm{N}^{\circ}$ 12, jan./jun. 2012: 112-142. Disponible en http://revista.anphlac.org.br/index.php/revista

Patiño, Roxana. "Revistas literarias y culturales argentinas de los 80. Usinas para pensar una época”. Ínsula No 715-716, julio- agosto 2006: 2-5.

Payá, Carlos y Eduardo Cárdenas. El primer nacionalismo argentino en Manuel Gálvez y Ricardo Rojas. Buenos Aires: Peña Lillo Editor, 1978.

Pedrazuela Fuentes, Mario. “Amado Alonso y Alonso Zamora al frente del Instituto de Filología de Buenos Aires”. Filología XXXIV - XXXV, 2002-2003: 199-215.

Pelletieri, Osvaldo (dir.) Dos escenarios: intercambio teatral entre España y Argentina. Cuadernos del GETEA (Grupo de Estudio del Teatro Argentino e Iberoamericano). Buenos Aires: Galerna, 2006.

Petra, Adriana. "El pequeño mundo: revistas e historia intelectual. Apuntes para un estudio de Pasado y Presente (1963-1965)". Actas V Jornadas de Historia de las Izquierdas: "Prensa política, revistas culturales y emprendimientos editoriales de las izquierdas latinoamericanas". Buenos Aires, 2007: 2-8. 
Pérez-Villanueva Tovar, Isabel. "El significado y la labor de la Junta para Ampliación de Estudios e Investigaciones Científicas”. Revista de Educación № 299 (1992): 231-246.

Pereyra, Washington. La prensa literaria argentina (1890-1974). 4 Vols. Buenos Aires: Librería Colonial, 1993 - 1996 (Vols. 1 a 3); Fundación Bartolomé Hidalgo, 2008 (Vol. 4).

Pezzoni, Enrique. "Imagen de Ana María Barrenechea". Homenaje a Ana María Barrenechea. Ciclo de conferencias pronunciadas en el Centro Cultural General San Martín. Buenos Aires, 1984: 14-26.

Piaccenza, Paola. "Enseñanza de la literatura y procesos de canonización en la escuela media argentina (1966-1976)", Lulú Coquette. Revista de didáctica de la lengua y la literatura, Año 1, $\mathrm{N}^{\circ} 1$ (septiembre 2001), 86-96. Disponible en http://teorialiteraria2009. files.wordpress.com/2009/04/ensenanza-de-laliteratura-y-procesos-de-canonizacion-en-la-escuela-media-argentina-19661976.pdf. Consultado en noviembre de 2015.

Pita González, Alexandra. "Las revistas culturales como fuente de estudio de redes intelectuales”. Voces en papel. La prensa en Iberoamérica de 1792 a 1970. Del Palacio Montiel, Celia y Sarelly Martínez Mendoza, coord. México: Universidad Autónoma de Chiapas, 2008. Disponible en .http://www.cialc.unam.mx/Revistas literarias_y_culturales/PDF/Articulos/Las revistas_culturales_como fuente_de_estudio_de_redes_intelectuales.pdf

Pita González, Alexandra y María del Carmen Grillo. "Una propuesta de análisis para el estudio de revistas culturales". Revista Latinoamericana de Metodología de las Ciencias Sociales, 5 (1) (2015). Recuperado a partir de: http://www.relmecs.fahce.unlp.edu.ar/article/view/relmecsv05n01a06 
Polo, José. "Amado Alonso en el recuerdo. Inventario de trabajos, de carácter general, en torno a su figura, a su obra". Cauce. Revista de Filología y su didáctica, $\mathrm{N}^{\circ}$ 27, 2004: 349-363.

Pozuelo Yvancos, José María. “Razones para un canon hispánico”. Signa, N 18, Madrid: UNED, 2009: 87-97.

. “Canon: ¿estética o pedagogía?”. Insula 600, diciembre 1996: 3-4.

Pozuelo Yvancos, José María y Aradra Sánchez, María Rosa. Teoría del canon y literatura española. Madrid: Cátedra, 2000.

Pró, Diego F. Ángel J. Battistessa. Buenos Aires: Ediciones Culturales Argentinas, 1961.

. "Origen y desarrollo de la Facultad”. Memoria Histórica, 1939-1964. Mendoza: Facultad de Filosofía y Letras, 1965: 113-134.

Pronko, Marcela. El Peronismo en la Universidad. Buenos Aires: Libros del Rojas, 2000.

Puig Samper Mulero, Miguel Ángel, (coord.). Tiempos de investigación: JAE-CSIC, cien años de ciencia en España. Madrid: CSIC, 2007.

Quinziano, Franco. "Miradas rioplatenses en los albores del siglo XX. Manuel Gálvez, un viajero "espiritual"'. Cuadernos CANELA (Confederación Académica Nipona, Española y Latinoamericana), XVII, 2005: 79-99.

- "Manuel Gálvez: la Argentina del Centenario y la "nueva raza latina”. RILCE. Revista de Filología Hispánica 18. I, 2002: 87-96.

Rama, Carlos. Historia de las relaciones culturales entre España y la América Latina. Siglo XIX. México: Fondo de Cultura Económica, 1982. 
Ramaglia, Dante. "La formación del espiritualismo argentino. Proyecto y discurso en Ricardo Rojas". CUYO. Anuario de Filosofía Argentina y Americana, № 15, 1998: 23-60.

Rein, Ranaan. "Hispanidad y oportunismo político: el caso peronista”. Estudios interdisciplinarios de América Latina y el Caribe, Vol. 2, № 2, 1991: 51-68.

Rivadulla Barrientos, Daniel. La “amistad irreconciliable”. España y Argentina, 19001914. Madrid: Editorial Mapfre, 1992.

Rivera, Jorge B. "Apogeo y crisis de la industria del libro (1955-1970)". Capitulo. Historia de la literatura argentina. Buenos Aires: Centro Editor de América Latina, 1980.

Rizzo, María Florencia. "La configuración de imaginarios identitarios colectivos: del Congreso Literario Hispanoamericano (Madrid, 1892) al Congreso de la Lengua Española (Sevilla, 1992)". Tonos. Revista Electrónica de Estudios Filológicos $\mathrm{N}^{\circ} \quad$ 21, julio 2011. Disponible en http://www.um.es/tonosdigital/znum21/secciones/estudios-26-rizo.htm

[Consultado 30 de junio de 2014].

Rodríguez Martín, Bárbara. Juan María Gutiérrez y su contribución periodística (18331852) a la crítica cultural hispanoamericana. Tesis doctoral. Tenerife: Servicio de Publicaciones Universidad de La Laguna, 2005. Disponible en ftp://tesis.bbtk.ull.es/ccssyhum/cs215.pdf

Rodríguez Parada, Concepción. "Los catálogos e inventarios en la historia del libro y de las bibliotecas". BiD: textos universitaris de biblioteconomia i documentació, $\mathrm{N}^{\circ}$ 18 (juny). Disponible en http://bid.ub.edu/18rodri4.htm [Consulta: 25-02-2016]. 
Rodríguez Temperley, María Mercedes. "Prólogos argentinos a clásicos españoles (Editorial Estrada, 1943-1955)". Actas del Tercer Congreso Internacional Celehis de Literatura. Mar del Plata, 2008. (Versión en CD). "La Edad Media en las tierras del Plata. (A propósito del medievalismo en Argentina)", Revista de poética medieval, 21 (2008): 221-293.

Rojas, Ricardo. Poesías de Cervantes. La Plata, Universidad Nacional de La Plata, 1916.

La restauración nacionalista: crítica de la educación argentina y bases para una reforma en el estudio de las humanidades modernas. [2a. ed.]. Buenos Aires: La Facultad, 1922. Retablo español. Buenos Aires: Losada, 1938. El alma española: (ensayo sobre la moderna literatura castellana). Valencia: F. Sempere, 1907. Cervantes. Buenos Aires: Losada, 1948.

Romano, Aníbal Mario. La Universidad Nacional de Cuyo y la Revolución Argentina (1966-1973). Mendoza: Editorial de la Facultad de Filosofía y Letras de la Universidad Nacional de Cuyo, 2001.

Romanos, Melchora. "Filología e Hispanismo en el magisterio de Ana María Barrenechea”. Exlibris, Año 2, № 2, 2013: 10-16.

“El Instituto de Filología 'Dr. Amado Alonso' en sus noventa años”. Ínsula 793-794, enero-febrero 2013: 38-42.

"Contribución argentina a la historiografía de la crítica del teatro español áureo. Los trabajos de Frida Weber de Kurlat”. I Jornadas de la Crítica en la Argentina. Facultad de Filosofía y Letras, Universidad de Buenos Aires, 2009: $228-235$. 
"Estado actual de la enseñanza de la literatura española en las universidades argentinas". Actas del VII Congreso Nacional de Hispanistas. Hispanismo: discursos culturales, identidad y memoria. Vol. 1 Flawiá de Fernández, Nilda e Israilev, Silvia (coords.) Facultad de Filosofía y Letras, Universidad Nacional de Tucumán, 2006: 123-128.

"Celina Sabor de Cortazar: Vocación y docencia cervantina". Olivar.

Revista de literatura y cultura españolas. Vol. 6, $\mathrm{N}^{\circ}$ 6, 2005: 59-74.

"Procesos de construcción y evolución del concepto de

Hispanismo desde la perspectiva de los estudios de Literatura Española”. En Dossier "El Hispanismo hoy: estereotipos culturales y construcciones identitarias". Olivar. Revista de literatura y cultura españolas 5, 2004: 77-86. . "Los estudios hispánicos en algunos países de América del Sur:

Tendencias actuales de la investigación y perspectivas futuras." Arbor: Ciencia, pensamiento y cultura, $\mathrm{N}^{\mathrm{o}} 664,2001: 533-550$.

Romanos de Tiratel, Susana y colab., Revistas argentinas de Ciencias sociales y Humanidades: visibilidad en bases de datos internacionales. Buenos Aires: Instituto de Investigaciones Bibliotecológicas, Facultad de Filosofía y Letras, UBA, 2008.

Romero Tobar, Leonardo. Maestros amigos. Santander: Editorial de la Universidad de Cantabria, 2013.

Rosetti, Mariana. "La polémica del Meridiano Intelectual de 1927. La lucha por el cauce de las corrientes intelectuales”. Lexis Vol. XXXVI (1) 2012: 131-144.

Rubio Tovar, Joaquín. La vieja diosa. De la filología a la posmodernidad. Alcalá de Henares: Centro de Estudios Cervantinos, 2004. 
Rubione, Alfredo. "Retorno a España". Historia crítica de la literatura argentina. Noé Jitrik, dir. Vol. 5. La crisis de las formas. Alfredo Rubione, dir. Buenos Aires: Emecé Editores, 2006: 19-42.

Ruvituso, Clara. "Política universitaria y campo académico. Un estudio centrado en la trayectoria del área de filosofía de la Facultad de Humanidades y Ciencias de la Educación de la UNLP (1920-1955)". V Jornadas de Sociología de la UNLP. Universidad Nacional de La Plata. Facultad de Humanidades y Ciencias de la Educación. Departamento de Sociología, La Plata, 2008. Disponible en: www.memoria.fahce.unlp.edu.ar/tesis/te.610/te.610.pdf

Sabor de Cortazar, Celina. "Nota necrológica. Frida Weber de Kurlat". Filología, Año XIX, 1982-1984: 1-3.

Said, Edward. El mundo, el texto, el crítico. Buenos Aires: Debate, 2004.

Sánchez Bellido, Sara. "Proceso de edición de un manuscrito de Ramón Menéndez Pidal: Etapas en la vida y obra de Menéndez Pelayo”. Dicenda. Cuadernos de Filología Hispánica, 2014, Vol. 32, Núm. Especial: 45-55.

Sánchez Vigil, Juan Miguel. "Austral: un caleidoscopio de sueños y tentaciones". Ínsula, $\mathrm{N}^{\circ}$ 749, Mayo 2009: 3-4.

"La editorial CALPE y el Catálogo general de 1923". Documentación de las Ciencias de la Información, Vol. 29, 2006: 259-277. "La editorial CALPE en la Edad de Plata de la cultura española". Pliegos de bibliofilia $\mathrm{N}^{\circ} 28,2004:$ 9-24. y María Olivera Zaldúa. "La Colección Austral: 75 años de cultura en el bolsillo (1937-2012)". Palabra Clave (La Plata), Vol. 1, No 2, 2012: 29-47. Disponible en: http://www.palabraclave.fahce.unlp.edu.ar 
Sánchez Vigil, Juan Miguel, Juan Carlos Marcos Recio y Belén Fernández Fuentes. “Catálogos editoriales: características, funciones, tipología y análisis de contenido". Scire, № 14, 1, enero-junio 2008: 111-123.

Santiago de Chitarrini, Olga Beatriz. "Editorial Losada: trayectoria de legitimación". Actas del III Congreso Argentino de Hispanistas "España en América y América en España". Vol. II. Buenos Aires: Asociación Argentina de Hispanistas, Instituto de Filología y Literaturas Hispánicas “Amado Alonso”, Facultad de Filosofía y Letras, Universidad de Buenos Aires, 1992: 527-533.

Santos, Susana. "Historias de la historia. Simpatías y diferencias del proyecto de Capítulo en la historiografía de la literatura argentina (1917- 1979)”. Bueno, Mónica y Miguel Ángel Taroncher (coords). Centro Editor de América Latina. Capitulos para una historia. Buenos Aires: Siglo XXI Editores, 2006: 63-75.

Sarlo, Beatriz. "Intelectuales y revistas". América. Cahier du CRICCAL, No 9-10, 1992: 9-16.

La batalla de las ideas (1943-1973). Biblioteca del pensamiento argentino VII. Buenos Aires: Emecé, 2001.

Schwartz, Lía. "De hispanismos, los siglos XVI y XVII y el olvido de la historia". Ciberletras, 2, 2002. http://lehman.cuny.edu/ciberletras/v06/liaschwartz.html

Schwarsztein, Dora. "La conformación de la comunidad del exilio republicano en la Argentina”. Inmigración española en Argentina (Seminario 1990). Clementi, Hebe (coord.). Buenos Aires: Oficina Cultural de la Embajada de España, 1991: $221-231$

Sigal, Silvia. Intelectuales y poder en la década del sesenta. Buenos Aires: Puntosur, 1991. 
Simón, Paula. "Tres estrenos del exilio republicano en el teatro argentino vistos desde los programas de mano". Olivar. Revista de literatura y cultura españolas, 15 $(22)$, 2014. Recuperado

de: http://www.olivar.fahce.unlp.edu.ar/article/view/Olivar2014v15n22a11

Sosnowsky, Saúl (ed.). La cultura de un siglo. América Latina en sus revistas. Buenos Aires: Alianza Editorial, 1999.

Tarcus, Horacio (ed.). Catálogo de revistas culturales argentinas (1890-2006). Buenos Aires: CeDInC.I, 2007.

Terán. Oscar (coord.). Ideas en el siglo. Intelectuales y cultura en el siglo XX latinoamericano. Buenos Aires: Siglo XXI Editores Argentina, 2004. Historia de las ideas en Argentina. Diez lecciones iniciales 1810-1980. Buenos Aires: Siglo XXI, 2008. Vida intelectual en el Buenos Aires fin-de-siglo (1880-1910). Derivas de la “cultura científica”. Buenos Aires: Fondo de Cultura Económica, 2000. "El dispositivo hispanista". Actas del III Congreso Argentino de Hispanistas. España en América y América en España. Vol. 1. Martínez Cuitiño, Luis y Lois, Elida (editores), Buenos Aires: Instituto de Filología y Literaturas Hispánicas “Dr. Amado Alonso", Facultad de Filosofía y Letras UBA, 1993: 129-137.

Toscano y García, Guillermo. "La investigación lexicográfica en el Instituto de Filología de la Universidad de Buenos Aires (1923-1927)”. BSEHL 7, 2010: 185-205. "Materiales para una historia del Instituto de Filología de la Universidad de Buenos Aires (1920-1926)". Revista Internacional de Lingüística Iberoamericana (RILI) Vol. VII (2009), 1, (13): 113-135. 
Unamuno, Miguel de. "El gaucho Martín Fierro. Poema popular gauchesco de don José Hernández (argentino)”. Obras completas, Vol. VIII. Letras de América y otras lecturas. Barcelona: Editorial Vergara, 1958: 47:63.

Vairo Botta, Daniela Jessica. "La catalogación como instrumento para la investigación, difusión y preservación del patrimonio. Colección Cervantina 'Arturo E. Xalambrí"”. Proyecto presentado para obtener el título de Licenciada en Bibliotecología. Montevideo: Universidad de la República, 2012. Disponible en: http://eprints.rclis.org/19288/1/La\%20catalogaci $\% \mathrm{C} 3 \% \mathrm{~B} 3 \mathrm{n} \% 20$ como $\% 20 \mathrm{instru}$ mento $\% 20$ para $\% 201 \mathrm{a} \% 20$ investigaci $\% \mathrm{C} 3 \% \mathrm{~B} 3 \mathrm{n}, \% 20 \mathrm{difusi} \% \mathrm{C} 3 \% \mathrm{~B} 3 \mathrm{n} \% 20 \mathrm{y} \% 20$ preservaci\%C3\%B3n\%20del\%20patrimonio_Daniela\%20Vairo\%20Botta.pdf [consultado 11/09/2014].

Vallejo, Gustavo. “'El culto de lo bello': la universidad humanista en la década del 20". La Universidad de La Plata y el movimiento estudiantil. Desde sus orígenes hasta 1930. Biagini, Hugo, comp. La Plata: Editorial de la Universidad Nacional de La Plata, 1999: 113-152.

Vanella, Liliana María. "Humanistas y Reformistas: legados entre generaciones. La Universidad de Tucumán en 1930 y 1940”. Universidades, Vol. LXV, N 61, julio-septiembre, 2014: 7-18. Disponible en: http://www.redalyc.org/articulo.oa? $\mathrm{id}=37333039003$

Venier, Martha Elena (ed.). Crónica parcial. Cartas de Alfonso Reyes y Amado Alonso 1927-1952. México: El Colegio de México, 2008. ““Criatura migratoria' (NRFH, 1, 1947, num.1)”. Nueva Revista de Filología Hispánica, julio-diciembre 2002, año/vol. L, nº 002: 393-404.

Verdevoye, Paul. "Hace cien años, una bomba lingüística en Buenos Aires: el libro de Luciano Abeille”. Palabra y Persona, Año V, N 8, Mayo 2001: 6-24. 
Videla de Rivero, Gloria. "Algunos recuerdos de la Facultad de Filosofía y Letras en el setenta aniversario de su creación". Revista de Literaturas Modernas, №39-40, 2009-2010: 29-56.

Vila, Juan Diego (ed.). Número monográfico: “El cervantismo argentino: una historia tentativa". Olivar. Revista de literatura y cultura españolas $\mathrm{N}^{0}$ 6, 2005.

"Isaías Lerner, el fiel escucha de la voz cervantina", Olivar. Revista de literatura y cultura españolas $\mathrm{N}^{\circ}$ 6, 2005: 91-114.

Viñas, David. Literatura argentina y política II. De Lugones a Walsh. Buenos Aires: Editorial Sudamericana, 1996.

Vitelli, Federico Martín. "Los intelectuales y el exilio: la inserción de los profesores españoles republicanos en la Universidad Nacional del Sur (1956-1966)" [en línea]. II Jornadas de Trabajo sobre Exilios Políticos del Cono Sur en el siglo XX, Montevideo, 2014. En Memoria Académica. Disponible en http://www.memoria.fahce.unlp.edu.ar/trab eventos/ev.3983/ev.3983.pdf [consultado $11 / 08 / 2015]$.

Weber de Kurlat, Frida. "Para la historia del Instituto de Filología y literaturas hispánicas Dr. Amado Alonso”. Homenaje al Instituto de Filología y Literaturas hispánicas "Dr. Amado Alonso" en su cincuentenario 1923-1973. Buenos Aires: Artes Gráficas Bartolomé U. Chesino, 1975: 1-11.

Weinberg, Félix (ed.). El Salón literario. Buenos Aires: Hachette, 1958.

Williams, Raymond. Marxismo y literatura. Barcelona: Península, 1980. Sociología de la cultura. Buenos Aires: Paidós, 1994. El campo y la ciudad. Buenos Aires: Paidós, 2001. 
Wilson, Patricia. "El fin de una época: letrados-traductores en la primera colección de literatura traducida del siglo XX en la Argentina". Trans. Revista de traductología, $\mathrm{N}^{\circ} 12,2008:$ 29-42.

"Elite, traducción y público masivo". Estudios. Revista de Investigaciones Literarias y Culturales 25, 2005: 235-251.

La Constelación del Sur. Traductores y traducciones en la literatura argentina del siglo XX. Buenos Aires: Siglo XXI Editores, 2004.

Zaïtzeff, Sergei. Alfonso Reyes, Raimundo Lida y María Rosa Lida de Malkiel: correspondencia. México: El Colegio de México, 2009.

Zuleta Álvarez, Enrique. "España y la visión histórica de Manuel Gálvez". Investigaciones y Ensayos (Academia Nacional de la Historia), 45 (enerodiciembre 1995): 185-205.

“España y el nacionalismo argentino". Cuadernos del Sur N²3/24.

(1990-1991): 5-34.

Zuleta, Emilia Puceiro de. "La enseñanza de la literatura española en el nivel medio: un balance constructivo". Actas del VII Congreso Nacional de Hispanistas. Hispanismo: discursos culturales, identidad y memoria. Vol. 1, Flawiá de Fernández, Nilda e Israilev, Silvia (coords.) Facultad de Filosofía y Letras, Universidad Nacional de Tucumán, 2006: 111-115.

De mar a mar. Letras españolas desde la Argentina.

Mendoza: EDIUNC, 2004.

Españoles en Argentina. El exilio literario de 1936. Buenos

Aires: $\quad$ Editorial $\quad$ Atril, $1999 . \quad$ Disponible en:

http://www.cervantesvirtual.com/obra-visor-din/espanoles-en-la-argentina-el-

exilio-literario-de-1936--0/html/ 
"Hacia un mapa de las revistas literarias argentinas". Clío. Comité

Internacional, 4, 1997: 243-256.

"Contribuciones hispánicas al desarrollo de la crítica". Hispania

79, May 1996: 191-200.

. "Pasado y presente del hispanismo en Hispanoamérica". Martínez

Cuitiño, Luis y Lois, Elida (eds). Actas del III Congreso Argentino de

Hispanistas. España en América y América en España, Vol. 1. Buenos Aires:

Instituto de Filología y Literaturas Hispánicas "Dr. Amado Alonso", Facultad de Filosofía y Letras UBA, 1993: 17-32.

"El hispanismo de Hispanoamérica". Hispania 75, October

1992: 950-965.

(comp). Relaciones literarias entre España y la Argentina

(Seminario 1991). Buenos Aires: Embajada de España. Oficina Cultural, 1992. 


\section{Índice} 1

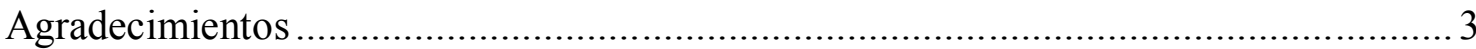

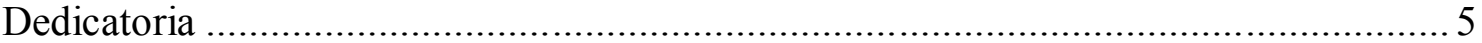

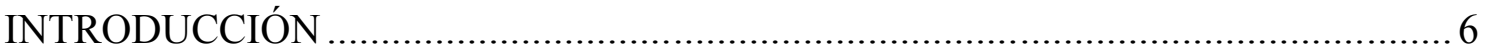

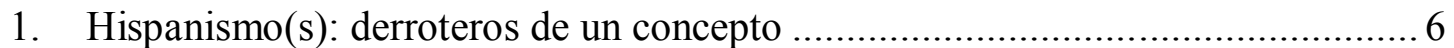

2. El hispanismo en la Argentina: alcances de esta investigación .......................... 11

CAPÍTULO 1: Antecedentes y conformación del Hispanismo en la Argentina............. 17

1.1 Relaciones intelectuales entre España y la Argentina en el siglo XIX ............ 17

1.1.2 (Re)formulaciones y (re)visiones: en torno al IV Centenario del Descubrimiento de América

1.1.3 Nuevo siglo, nuevas fluctuaciones: el "giro hispanista" (1900 - 1920). 26

1.1.4 Las figuras intelectuales y el rol de los centros culturales y académicos en la constitución del Hispanismo (1910- 1940)

1.2 Hispanismo y universidad.

1.2.1 El Instituto de Filología de la Universidad de Buenos Aires: génesis y primeros años (1922 -1927) 59

1.2.2 El Instituto de Filología bajo la gestión de Amado Alonso (1927-1946): afianzamientos y proyecciones .71

1.2.3 Proyecciones: hacia una cartografia del hispanismo argentino 89

CAPITULO 2: El Hispanismo y la vida académica argentina a partir de 1940 93

2.1 Cambios y transformaciones en el sistema universitario argentino (1930-1960). 93

2.2 Vinculaciones entre los centros académicos y los estudios hispanistas: procesos de configuración del hispanismo 104 
2.3 Los centros de investigación y académicos: líneas de trabajo y publicaciones vinculadas con el hispanismo 109

2.3.1 Las revistas y publicaciones académicas. 109

2.3.2 El Instituto de Filología de la Universidad de Buenos Aires y la revista Filología 116

2.3.2.1 Otras publicaciones académicas del Instituto de Filología 135

2.3.3 La Facultad de Humanidades y Ciencias de la Educación de la Universidad Nacional de La Plata. La revista Humanidades..... 136

2.3.4 El Instituto de Investigaciones Literarias de la Facultad de Humanidades de la UNLP y su Boletín 142

2.3.5 La Facultad de Filosofía y Letras de la Universidad Nacional de Tucumán y la revista Humanitas. 150

2.3.6 El Instituto de Humanidades de la Universidad Nacional del Sur y la revista Cuadernos del Sur 156

2.3.7 El Instituto de Lenguas y Literaturas Modernas de la Universidad Nacional de Cuyo y la Revista de Literaturas Modernas. 169

2.3.8 La Academia Argentina de Letras y el Boletín..... 178

2.4. Constelaciones intelectuales en el hispanismo argentino 198

CAPITULO 3: El Hispanismo y la industria editorial en la Argentina (1940-1973) ... 203

3.1 Panorama de la industria editorial argentina en las primeras décadas del siglo XX (1900-1930). 203

3.1.1 La impronta española 203

3.1.2 La impronta argentina 210

3.2 El exilio republicano español en la Argentina: articulaciones intelectuales y culturales (1936- 1950). 
3.2.1 Exiliados españoles en el campo cultural y académico 218

3.2.2 Exiliados españoles en la industria editorial 222

3.3. Los catálogos editoriales y la conformación de colecciones: canon hispánico y políticas editoriales (1940-1970). 225

3.3.1 Espasa Calpe: la literatura española de "Clásicos Castellanos" a "Austral” 228

3.3.1.1 Literatura española en la Colección Austral (1937-1945) 235

3.3.2 La Editorial Losada: colecciones y políticas editoriales 243

3.3.2.1 La "Biblioteca Contemporánea" y "Las Cien Obras Maestras del pensamiento y la literatura universal": "los mejores libros del mundo" 247

3.3.3 Editorial Emecé: de la impronta gallega a la "Biblioteca Emecé de Obras Universales" 258

3.3.4 Editorial Estrada y los "Clásicos Castellanos": obras españolas para lectores americanos 268

3.4 Algunas consideraciones finales 282

3.5 Afianzamiento y crisis de la industria editorial (1958-1973). Canon y nuevos lectores 283

3.5.1. Eudeba y la ampliación del público lector: "libros para todos" 284

3.5.1.1. La literatura española en las colecciones de Eudeba (1958-1973) 289

3.5.2. El Centro Editor de América Latina: expansión del canon y del público lector. "Más libros para más" 293

3.6 Canon hispánico, mercado editorial y prácticas de lectura: intersecciones ........ 302 Conclusiones 308

Bibliografía 314

1. Fuentes consultadas 314

1.1 Publicaciones periódicas 314 
Avatares del Hispanismo: canon y estudios literarios en la Argentina (1949-1973)

1.2. Boletines y publicaciones institucionales:

1.3 Catálogos editoriales

2. Referencias bibliográficas

Índice. 354 